UNIVERSIDADE DE SÃO PAULO

INSTITUTO DE GEOCIÊNCIAS

\title{
INFLUÊNCIA DA PETROTRAMA, TEXTURA E MINERALOGIA SOBRE PARÂMETROS GEOMECÂNICOS DE ARENITOS: \\ O CASO DA FORMAÇÃO PIRAMBOIA
}

\author{
PAULO FIORINI \\ Orientador: Prof. Dr. Paulo César Fonseca Giannini
}

Dissertação de Mestrado

Programa de Pós-Graduação em Geoquímica e Geotectônica

SÃO PAULO

2018 

UNIVERSIDADE DE SÃO PAULO

INSTITUTO DE GEOCIÊNCIAS

Influência da petrotrama, textura e mineralogia sobre parâmetros geomecânicos de arenitos: o caso da Formação Piramboia

\section{PAULO FIORINI}

Dissertação apresentada ao Programa de Geoquímica e Geotectônica para a obtenção do título de Mestre em Ciências.

Área de concentração: Geotectônica

Orientador: Prof. Dr. Paulo César Fonseca Giannini 
Autorizo a reprodução e divulgação total ou parcial deste trabalho, por qualquer meio convencional ou eletrônico, para fins de estudo e pesquisa, desde que citada a fonte.

Serviço de Biblioteca e Documentação do IGc/USP

Ficha catalográfica gerada automaticamente com dados fornecidos pelo(a) autor(a) via programa desenvolvido pela Seção Técnica de Informática do ICMC/USP

Bibliotecários responsáveis pela estrutura de catalogação da publicação: Sonia Regina Yole Guerra - CRB-8/4208 | Anderson de Santana - CRB-8/6658

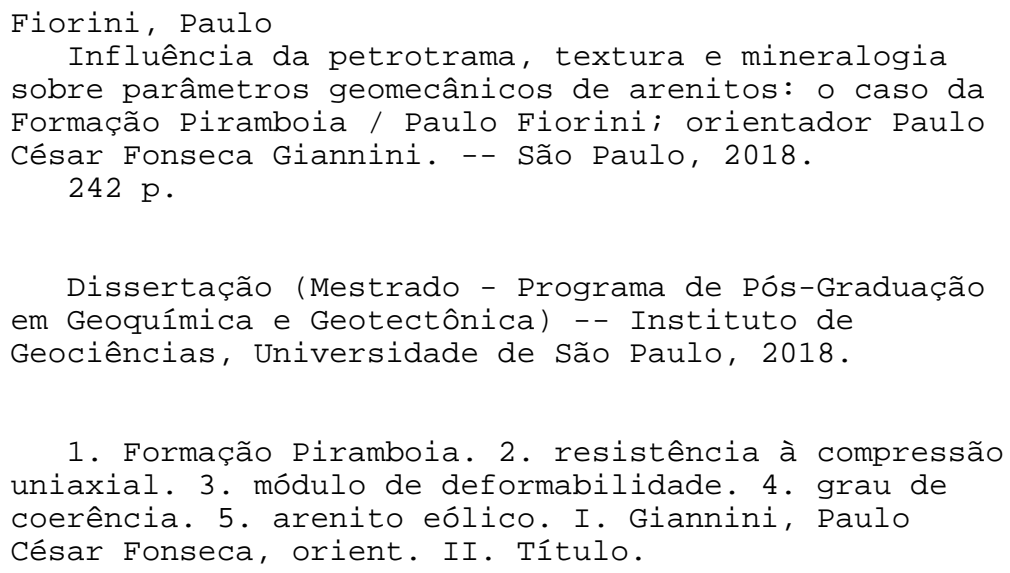

1. Formação Piramboia. 2. resistência à compressão uniaxial. 3. módulo de deformabilidade. 4. grau de coerência. 5. arenito eólico. I. Giannini, Paulo César Fonseca, orient. II. Título. 


$$
\begin{aligned}
& \text { UNIVERSIDADE DE SÃO PAULO } \\
& \text { INSTITUTO DE GEOCIÊNCIAS }
\end{aligned}
$$

\title{
INFLUÊNCIA DA PETROTRAMA, TEXTURA E MINERALOGIA SOBRE PARÂMETROS GEOMECÂNICOS DE ARENITOS: O CASO DA FORMAÇÃO PIRAMBOIA
}

\section{PAULO FIORINI}

Orientador: Prof. Dr. Paulo César Fonseca Giannini

Dissertação de Mestrado

№ 807

COMISSÃO JULGADORA

Dr. Paulo César Fonseca Giannini

Dra. Ana Lúcia Desenzi Gesicki

Dr. Alexandre Campane Vidal

Dr. Fernando Antônio Medeiros Marinho

\author{
SÃO PAULO \\ 2018
}


Aos meus pais, que sempre me apoiaram incondicionalmente e fizeram o possível e o impossível para estar ao meu lado, por quem sempre vou sentir enorme amor, admiração e gratidão. 



\section{AGRADECIMENTOS}

Agradeço primeiramente ao Professor Paulo César Fonseca Giannini, excelso orientador e amigo, por ter tornado possível e contribuído com a execução deste Projeto de Mestrado, do começo ao fim, em todas as etapas, de maneira admirável. Obrigado por toda a paciência em ensinar.

Às geólogas Marilda Tressoldi e Silvia Maria Kitahara e ao Eng. Luiz Morita, por intermediarem o diálogo junto ao Departamento Hidroviário de São Paulo (DH) e tornarem possível a realização deste Projeto de Mestrado.

Ao DH, por ceder o material de estudo, em especial aos Engs. Pedro Vitória, Marco Antônio Araujo, Marcelo F. Rodrigues, Evandro Torquato Sobrado e Jairo de Almeida Machado Júnior.

Ao Conselho Nacional de Desenvolvimento Científico e Tecnológico (CNPq), pelo auxílio financeiro.

À Themag Engenharia e Gerenciamento Ltda. e à Progeo Engenharia Ltda.

Ao pessoal dos laboratórios do Instituto de Geociências da Universidade de São Paulo (IGc-USP): Luciana Nogueira e Eng. Jordana Acuña Zampelli (LabPetro), Eng. Isaac Jamil Sayeg (LabMev), Marcos Mansueto (Laboratório de ME) e Renato Carvalho (Seção de Laminação).

Ao pessoal do Instituto de Pesquisas Tecnológicas (IPT), em especial aos geólogos Eduardo B. Quitete e Lúcio Flávio Maia Coelho e aos técnicos Nilson de Paula e Luiz Carlos Agostini, cujas contribuições foram cruciais para o desenvolvimento deste Projeto.

Ao pessoal do Centro de Pesquisa e Desenvolvimento Tecnológico em Construção Civil (CPqDCC) da Escola Politécnica (Poli-USP), em especial aos Profs. Rafael G. Pillegi e Renata Monte, por permitirem o uso da prensa e dos extensômetros, viabilizando a existência deste Projeto, e ao Eng. Pedro Cacciari, pelas sugestões valiosas.

Ao Eng. Paulo Aquino e ao Sr. Antônio Froza.

Aos colegas de profissão: Eng. Juliana Martins, geólogos Adinan Jarouche, Dailson Bertassoli, Danilo L. Vetorello, Helena A. A. Andrade, João C. V. Parizotto, Renato Contessotto, Rogério L. Araújo, Vinicius R. Mendes e, em especial, ao geólogo Marcelo T. Kawata. 
Às especialíssimas mulheres de minha família: minha esposa e companheira Roberta Brito de Oliveira, minha irmã Ana Maria Fiorini, e minha mãe Nadia Salhab Fiorini.

Por fim, um agradecimento especial a meu pai Marcos Antonio Fiorini, que nos deixou durante o desenvolvimento deste trabalho, mas que esteve e sempre estará presente no meu coração. Eu te amo, pai. 


\section{RESUMO}

Fiorini, P., 2018. Influência da petrotrama, textura e mineralogia sobre parâmetros geomecânicos de arenitos: o caso da Formação Piramboia [Dissertação de Mestrado], São Paulo, Instituto de Geociências, Universidade de São Paulo, 242 p.

A resistência à compressão uniaxial e o módulo de deformabilidade são parâmetros que descrevem o comportamento de materiais rochosos frente a solicitações por esforços. É prática corriqueira em investigações geológico-geotécnicas para projetos de engenharia estimar a resistência de maneira preliminar com base em propriedades de tenacidade, dureza e friabilidade, aferindo à rocha graus de coerência. Dados laboratoriais referentes a aspectos físicos, texturais e mineralógicos de arenitos da Formação Piramboia, Bacia do Paraná, amostrados via sondagens mistas na região de Anhembi e Santa Maria da Serra, Estado de São Paulo, foram correlacionados entre si e a parâmetros geomecânicos como resistência à compressão uniaxial, módulo de deformabilidade e graus de coerência. As fácies reconhecidas nos arenitos foram agrupadas em associações de dunas e interdunas e suas rochas classificadas como quartzo arenitos e arenitos feldspáticos ou subarcóseos, com cimentação principalmente de esmectita ou material argiloferruginoso. Encontraram-se correlações significativas da resistência à compressão uniaxial com tamanho médio dos grãos e densidade, inversa no primeiro caso e direta no segundo. Já o módulo de deformabilidade apresentou correlação significativa inversa com proporção de pelíticos, e direta com tamanho médio dos grãos, desvio padrão da distribuição granulométrica e grau de empacotamento. Arenitos característicos de inundações efêmeras em domínio de interdunas úmidas, com maiores teores de pelíticos, apresentaram módulos de deformabilidade baixos e resistências altas em comparação aos arenitos de demais fácies. Variações da composição mineralógica do arcabouço não se mostraram suficientes para influenciar significativamente o comportamento geomecânico dos arenitos.

Palavras chave: Formação Piramboia, resistência à compressão uniaxial, módulo de deformabilidade, grau de coerência, petrofísica, arenito eólico, Santa Maria da Serra. 


\section{ABSTRACT}

Fiorini, P., 2018. Influence of petrofabric, texture and mineralogy on geomechanical parameters of sandstones: the case of the Piramboia Formation [Master's Thesis], São Paulo, Instituto de Geociências, Universidade de São Paulo, 242 p.

The uniaxial compressive strength and the deformability modulus are parameters that describe the behavior of rock materials under stress. It is an everyday practice in geological and geotechnical investigations for engineering projects to estimate strength in a preliminary fashion, based on properties such as tenacity, toughness and friability, attributing to the rock a qualitative term describing its strength. Laboratorial data on physical, textural and mineralogical aspects of sandstones of the Piramboia Formation, Paraná Basin, obtained by core drillings in the region of Anhembi and Santa Maria da Serra, state of São Paulo, were correlated to each other and to geomechanical parameters such as uniaxial compressive strength, deformability modulus and qualitative terms describing their strength. The recognized sandstone facies were grouped in dune and interdune associations and their rocks were classified as quartz arenites and feldspathic arenites or subarkoses, whose cementation is mainly composed of smectite or ferruginous clay material. Significant correlations of uniaxial compressive strength with mean grain size and density were found, inverse in the first case and direct in the second. On the other hand, the deformability modulus showed a significant inverse correlation with the amount of pelitic material, and direct with mean grain size, standard deviation of grain size distribution and packing density. Sandstones characteristic of ephemeral floods in the domain of wet interdunes, with greater amounts of pelitic material, presented low values of deformability modulus and high strength values compared to the other facies. Variations in the mineral composition of the framework were not sufficient to significantly influence the geomechanical behavior of the sandstones.

Keywords: Piramboia Formation, uniaxial compressive strength, deformability modulus, rock strength, petrophysics, eolian sandstone, Santa Maria da Serra. 


\section{SUMÁRIO}

1. INTRODUÇÃO .................................................................................. 1

1.1 Meta e objetivos ..................................................................................... 3

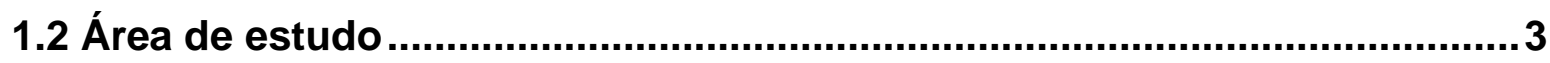

2. MATERIAIS E MÉTODOS.................................................................. 5

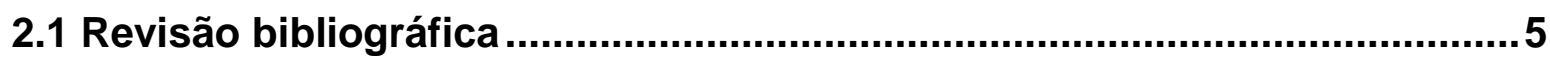

2.2 Amostragem .......................................................................................... 5

2.2.1 Fácies sedimentares reconhecidas em testemunhos e aferição dos graus de coerência ........................................................................................6

2.2.2 Coleta de amostras para realização de ensaios mecânicos .................8

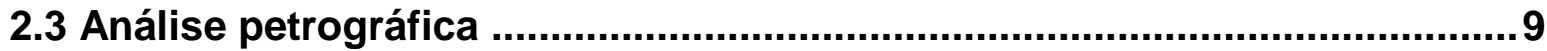

2.3.1 Preparação e confecção de seções delgadas........................................9

2.3.2 Quantificação dos componentes deposicionais e diagenéticos por meio de análise modal................................................................................. 10

2.3.3 Arcabouço .............................................................................................. 10

2.3.4 Matriz e cimento .............................................................................. 12

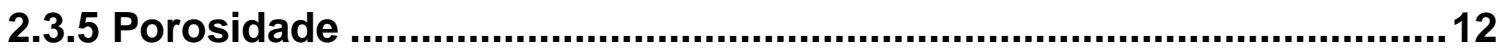

2.3.6 Individualização e nomenclatura de petrofácies ................................. 13

2.4 Análise via MEV-EDS ......................................................................... 14

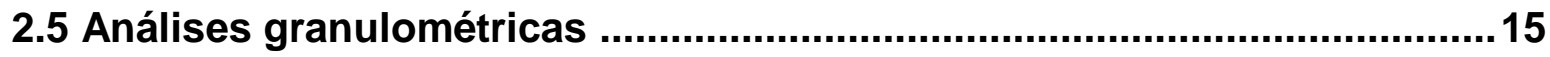

2.6 Determinação da densidade e porosidade aparentes ............................. 15

2.7 Ensaios mecânicos......................................................................................17

2.7.1 Moldagem dos corpos de prova..........................................................17

2.7.2 Determinação da resistência à compressão uniaxial e módulo de deformabilidade ......................................................................................... 19

2.8 Tratamento gráfico-estatístico de resultados ..........................................22

3. RESULTADOS ............................................................................... 27

3.1 Revisão bibliográfica .......................................................................... 27

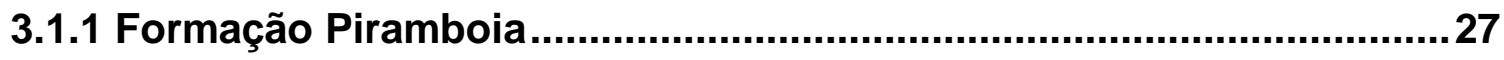

3.1.2 Correlação entre parâmetros petrográficos, físicos e mecânicos de

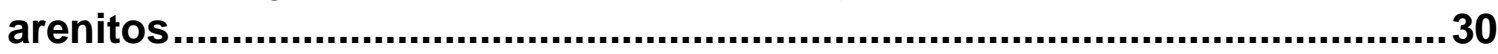

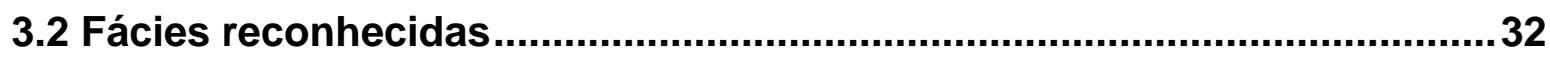

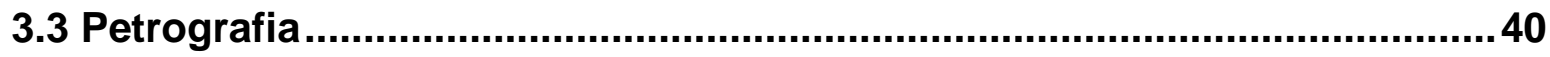


3.3.1 Componentes - arcabouço, matriz, cimento e poros ......................... 40

3.3.2 Arcabouço - mineralogia, textura e petrotrama ................................... 41

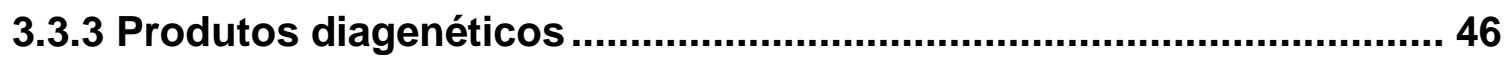

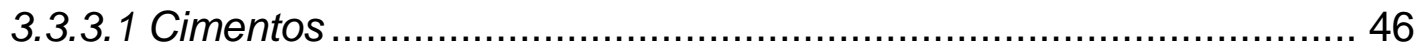

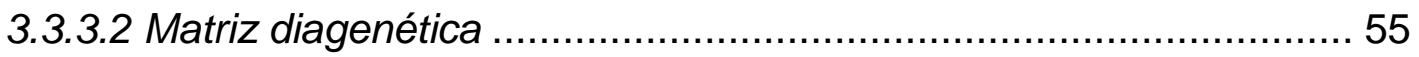

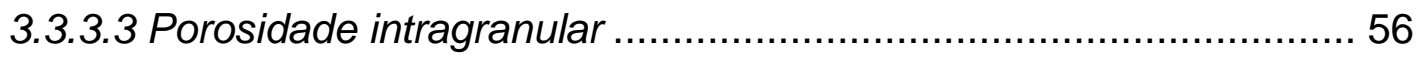

3.3.3.4 Compactação .................................................................... 57

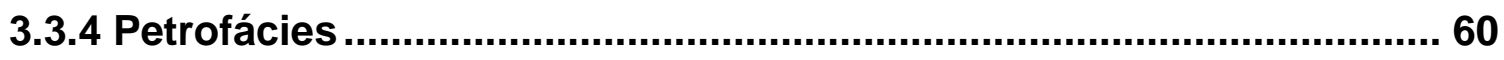

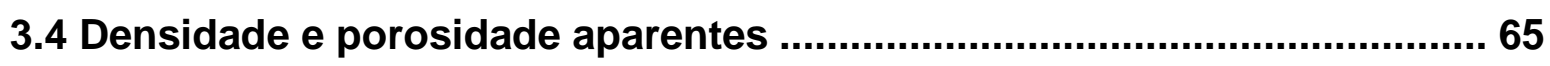

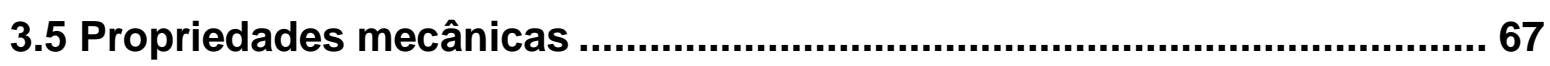

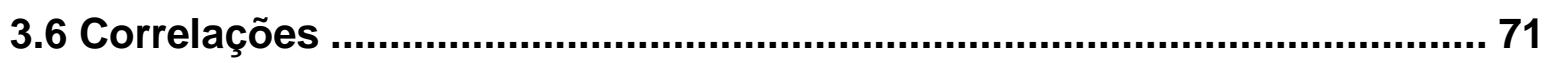

3.6.1 Correlações entre propriedades petrográficas ................................. 71

3.6.2 Correlações entre propriedades petrográficas e profundidade ......... 87

3.6.3 Correlações entre propriedades petrográficas e coerência ............... 91

3.6.4 Correlações entre propriedades petrográficas e resistência à

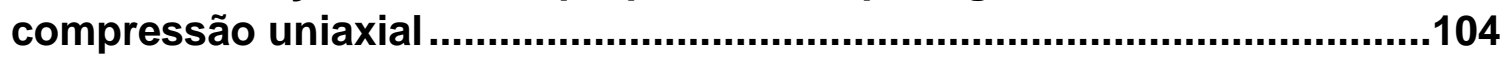

3.6.5 Correlações entre propriedades petrográficas e módulo de deformabilidade..........................................................................................112

\section{INTERPRETAÇÃO E DISCUSSÃO DOS RESULTADOS ................121}

4.1 Associação entre fácies reconhecidas em testemunhos e em afloramentos ........................................................................................121

4.2 Influência da petrotrama, textura e mineralogia sobre parâmetros geomecânicos ............................................................................................126

5. CONCLUSÕES .........................................................................133

REFERÊNCIAS BIBLIOGRÁFICAS ...............................................135

APÊNDICES ...................................................................................141 


\section{LISTA DE FIGURAS}

Figura 1.2.1 - Mapa geológico da região de estudo .......................................4

Figura 1.2.2 - Mapa de localização das sondagens cujos testemunhos foram amostrados ....................................................................... 4

Figura 2.3.1 - Representação esquemática de arenito observado ao microscópio petrográfico para quantificação da densidade e proximidade de empacotamento (Kahn, 1956) ................................................ 12

Figura 2.7.1 - Lixa para ferro e gabarito de tubo PVC utilizados na moldagem dos corpos de prova e corpo de prova em processo de moldagem .................................................................... 18

Figura 2.7.2 - Equipamentos utilizados nos ensaios de resistência à compressão uniaxial ........................................................................ 21

Figura 2.7.3 - Gráficos de determinação dos módulos de deformabilidade .......22

Figura 2.8.1 - Diagrama de caixa utilizado para representar a distribuição de dados por agrupamentos ...................................................24

Figura 3.2.1 - Fotografia dos testemunhos da sondagem SM-222 …................33

Figura 3.2.2 - Fotografias de amostras da fácies Ap ........................................34

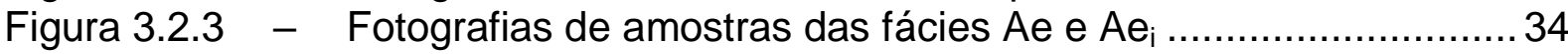

Figura 3.2.4 - Fotografias de amostras da fácies Am ......................................35

Figura 3.2.5 - Nódulos carbonáticos em arenito da fácies Ae ..........................36

Figura 3.2.6 - Manchas irregulares de cimento de óxi-hidróxido metálico de cor

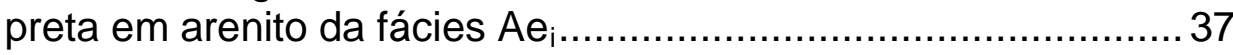

Figura 3.2.7 - Cavidades subcirculares de diâmetro milimétrico em amostra da

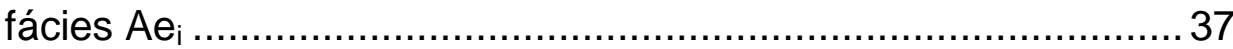

Figura 3.2.8 - Seção colunar estratigráfica da sondagem SM-222, com granulometria e graus de coerência ........................................39

Figura 3.3.1 - Seção estratigráfica colunar da sondagem SM-222 apresentando graus de coerência, proporção relativa entre os componentes petrográficos e porosidades modal e avaliada por meio de software analisador de imagens digitais...................................... 41

Figura 3.3.2 - Classificações de Dott (1964) e Folk (1968) para todos os arenitos

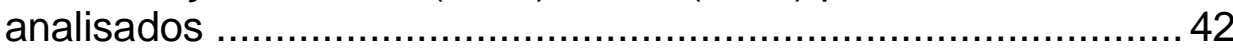

Figura 3.3.3 - Intraclastos argilosos ...................................................... 42

Figura 3.3.4 - Seção estratigráfica colunar da sondagem SM-222, com dados de grau de coerência e de textura e trama...................................... 45

Figura 3.3.5 - Cimento carbonático espático intersticial ..................................47

Figura 3.3.6 - Moldes de grãos do arcabouço, com preenchimento de carbonato espático, envoltos por cutícula de esmectita ...............................47

Figura 3.3.7 - Fotomicrografia do cimento carbonático obtida ao MEV por meio de detector de elétrons secundários ......................................... 48

Figura 3.3.8 - Espectrograma obtido pelo sistema MEV-EDS referente ao cimento carbonático ............................................................. 48

Figura 3.3.9 - Cutícula de esmectita e cimento esmectítico intergranular.......... 49

Figura 3.3.10 - Cimentos de esmectita .................................................... 49

Figura 3.3.11 - Imagens do cimento esmectítico obtidas ao MEV por meio de detector de elétrons secundários ..............................................50

Figura 3.3.12 - Espectrograma obtido pelo sistema MEV-EDS referente ao cimento esmectítico ...................................................................50 
Figura 3.3.13 - Cimento de óxi-hidróxido metálico avermelhado ........................51

Figura 3.3.14 - Espectrograma obtido pelo sistema MEV-EDS referente ao cimento constituído por óxi-hidróxido metálico em amostra da cota $454,7 \mathrm{~m}$ da sondagem SM-222 ...........................................51

Figura 3.3.15 - Cimento de óxi-hidróxido metálico opaco .................................51

Figura 3.3.16 - Espectrograma obtido pelo sistema MEV-EDS referente ao cimento constituído por óxi-hidróxido metálico em amostra da cota $451,5 \mathrm{~m}$ da sondagem SM-222 ….......................................52

Figura 3.3.17 - Cimento argilo-ferruginoso intersticial em amostras das cotas 454,3 e 451,2 m da sondagem SM-222..................................53

Figura 3.3.18 - Cimento argilo-ferruginoso intersticial em amostra coletada próximo à cota $454,7 \mathrm{~m}$ da sondagem SM-222 …....................53

Figura 3.3.19 - Imagens do cimento argilo-ferruginoso obtidas ao MEV por meio de detector de elétrons secundários...........................................53

Figura 3.3.20 - Espectrograma obtido pelo sistema MEV-EDS referente ao cimento argilo-ferruginoso observado na amostra da cota $454,7 \mathrm{~m}$ da sondagem SM-222 .....................................................54

Figura 3.3.21 - Espectrograma obtido pelo sistema MEV-EDS referente ao cimento argilo-ferruginoso observado na amostra da cota 448,2 m da sondagem SM-222 ........................................................54

Figura 3.3.22 - Microconcreção de óxi-hidróxido metálico envolvida por cimento argilo-ferruginoso ...............................................................54

Figura 3.3.23 - Epimatriz, formada pela alteração e recristalização de grão de feldspato do arcabouço para provável caulinita ...........................55

Figura 3.3.24 - Pseudomatriz (setas), constituída por intraclastos argilosos amolgados entre demais grãos do arcabouço ..............................56

Figura 3.3.25 - Porosidade intragranular e de dissolução parcial de cimento

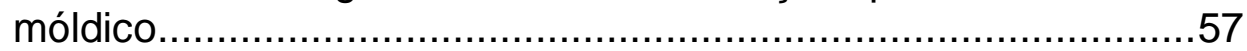

Figura 3.3.26 - Porosidade intragranular móldica .........................................57

Figura 3.3.27 - Grãos de filossilicatos leve a moderadamente deformados .........58

Figura 3.3.28 - Produtos diagenéticos e proporção de contatos intergranulares e contatos entre grãos e demais componentes petrográficos, das amostras analisadas na sondagem SM-222 ..............................59

Figura 3.4.1 - Gráficos do tipo boxplot representando a distribuição dos resultados de densidade e porosidade aparentes das amostras analisadas ................................................................................. 65

Figura 3.4.2 - Seção estratigráfica colunar da sondagem SM-222 apresentando graus de coerência e a densidade e porosidade aparentes ........66

Figura 3.4.3 - Diagrama de dispersão com os valores de densidade e porosidade aparentes das amostras das sondagens SM-201, SM208, SM-210, SM-216, SM-224 e SM-505................................66

Figura 3.5.1 - Diagrama de dispersão com valores de $\sigma_{50}$ versus $E_{s}$ para todos os corpos de prova submetidos a estes tipos de ensaio..............70

Figura 3.5.2 - Valores de $\sigma_{50}$ de cada unidade de arenito analisada comparados aos diferentes termos utilizados na designação da resistência das

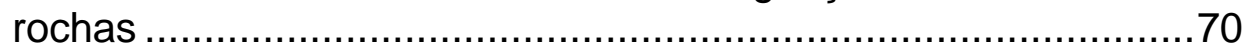

Figura 3.6.1 - Diagramas de dispersão entre teor de pelíticos obtido por elutriação e tamanho médio dos grãos......................................71

Figura 3.6.2 - Diagramas de dispersão entre proporção de porosidade intragranular e tamanho médio dos grãos ...................................72 
Figura 3.6.3 - Boxplot dos dados de porosidade intragranular .........................72

Figura 3.6.4 - Diagramas de dispersão entre densidade de empacotamento e tamanho médio dos grãos..................................................... 73

Figura 3.6.5 - Diagramas de dispersão entre porcentagem de grãos do arcabouço e tamanho médio dos grãos ......................................73

Figura 3.6.6 - Diagramas de dispersão entre proporção de cimento e tamanho médio dos grãos ................................................................... 74

Figura 3.6.7 - Diagramas de dispersão entre proporção de cimento constituído por óxi-hidróxido metálico e tamanho médio dos grãos ...............74

Figura 3.6.8 - Diagramas de dispersão entre proporção de cimento constituído por esmectita e tamanho médio dos grãos ............................... 75

Figura 3.6.9 - Diagramas de dispersão entre proporção de contatos entre grãos do arcabouço e cimento e tamanho médio dos grãos ..................75

Figura 3.6.10 - Diagramas de dispersão entre proporção de contatos dos grãos do arcabouço com vazios e tamanho médio dos grãos................76

Figura 3.6.11 - Diagramas de dispersão entre a forma dos grãos, avaliada pela razão média entre os eixos menor e maior, e o tamanho médio dos grãos ........................................................................... 76

Figura 3.6.12 - Diagramas de dispersão entre desvio padrão do tamanho dos grãos de areia e proporções de arcabouço e cimento total ..........77

Figura 3.6.13 - Diagramas de dispersão do teor de pelíticos com a porosidade total e com a porosidade intragranular ..................................... 77

Figura 3.6.14 - Diagramas de dispersão do teor de pelíticos com a densidade de empacotamento e com a proporção de arcabouço .......................77

Figura 3.6.15 - Diagramas de dispersão do teor de pelíticos com as proporções de contatos grão-cimento e grão-vazio ....................................... 78

Figura 3.6.16 - Diagrama de dispersão entre teor de pelíticos e proporções de arcabouço e cimento total .......................................................... 78

Figura 3.6.17 - Diagramas de dispersão do teor de pelíticos com as proporções de cimento esmectítico e cimento de óxi-hidróxido metálico ........79

Figura 3.6.18 - Diagramas de dispersão da porosidade total com as proporções de cimento e de contatos entre grãos do arcabouço e cimento .. 80

Figura 3.6.19 - Diagramas de dispersão entre porosidade total e proporção de cimento constituído por óxi-hidróxido metálico ............................. 80

Figura 3.6.20 - Diagrama de dispersão entre porosidade total e proporção de grãos subarredondados ......................................................... 80

Figura 3.6.21 - Diagramas de dispersão entre as proporções de grãos arredondados e de cimento esmectítico..................................... 81

Figura 3.6.22 - Diagramas de dispersão entre porosidade intragranular e proporção de cimento total..................................................... 81

Figura 3.6.23 - Diagramas de dispersão entre porosidade intragranular e proporção de contatos entre grãos do arcabouço e cimento........ 82

Figura 3.6.24 - Diagramas de dispersão entre porosidade intragranular e proporção de cimento constituído por óxi-hidróxido metálico ....... 82

Figura 3.6.25 - Diagramas de dispersão entre porosidade intragranular e proporção de cimento constituído por esmectita ............................ 82

Figura 3.6.26 - Diagramas de dispersão entre porosidade intragranular e proporção de arcabouço ......................................................... 83

Figura 3.6.27 - Diagramas de dispersão entre porosidade intragranular e proporção de contatos entre grãos do arcabouço e vazios .......... 83 
Figura 3.6.28 - Diagramas de dispersão da densidade de empacotamento com as proporções de arcabouço e cimento .........................................84

Figura 3.6.29 - Diagramas de dispersão da densidade de empacotamento com a proporção de cimento constituído por óxi-hidróxido metálico e com a proporção de contatos entre grãos do arcabouço e cimento ....84

Figura 3.6.30 - Diagramas de dispersão entre densidade de empacotamento e proporção de cimento esmectítico ...............................................85

Figura 3.6.31 - Diagrama de dispersão entre proporção de contatos retos e a média das razões entre os eixos menor e maior dos grãos do

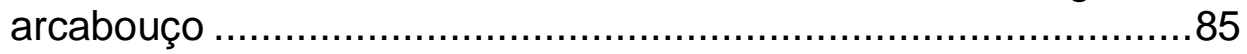

Figura 3.6.32 - Diagrama de dispersão entre proporção de contatos côncavoconvexos e proporção de arcabouço.........................................86

Figura 3.6.33 - Diagrama de dispersão entre proporção de contatos côncavoconvexos e a proporção total de cimento ...................................86

Figura 3.6.34 - Diagrama de dispersão entre proporção de grãos de feldspato e proporção de cimento esmectítico .............................................87

Figura 3.6.35 - Diagrama de dispersão entre proporção de grãos de feldspato e proporção de cimento constituído por óxi-hidróxido metálico .......87

Figura 3.6.36 - Diagramas de dispersão entre profundidade e tamanho médio dos grãos na fração areia ......................................................... 88

Figura 3.6.37 - Diagramas de dispersão da profundidade com o teor de pelíticos e com a proporção de cimento .................................................. 88

Figura 3.6.38 - Diagramas de dispersão entre profundidade e proporção de cimento argilo-ferruginoso ......................................................... 89

Figura 3.6.39 - Diagramas de dispersão entre profundidade e proporção de

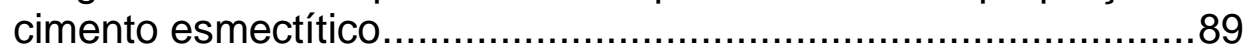

Figura 3.6.40 - Diagramas de dispersão entre profundidade e proporção de cimento constituído por óxi-hidróxido metálico .............................89

Figura 3.6.41 - Diagramas de dispersão da profundidade com a densidade de empacotamento e com a proporção de arcabouço .......................90

Figura 3.6.42 - Diagramas de dispersão da profundidade com a proporção total de feldspato e calculada em relação à somatória das proporções de quartzo, feldspato e fragmentos líticos ..................................90

Figura 3.6.43 - Diagramas de dispersão entre proporção de porosidade intragranular e profundidade ....................................................91

Figura 3.6.44 - Boxplots representando o tamanho médio dos grãos de cada grau de coerência .......................................................................92

Figura 3.6.45 - Boxplots representando o desvio padrão da distribuição granulométrica para cada grau de coerência ..............................92

Figura 3.6.46 - Boxplots representando o teor de pelíticos para cada grau de coerência ........................................................................93

Figura 3.6.47 - Boxplots representando as porosidades total e intragranular para os diferentes graus de coerência .............................................93

Figura 3.6.48 - Boxplots representando a densidade e porosidade aparentes agrupadas segundo o grau de coerência ...................................94

Figura 3.6.49 - Boxplots representando a densidade de empacotamento e a proximidade de empacotamento em arenitos com diferentes graus de coerência ....................................................................94 
Figura 3.6.50 - Boxplots representando as quantidades relativas dos diferentes tipos de contatos intergranulares em arenitos agrupados por grau de coerência

Figura 3.6.51 - Boxplots representando as proporções dos contatos entre grãos do arcabouço e cimentos e entre grãos do arcabouço e vazios por grau de coerência 96

Figura 3.6.52 - Boxplots representando as proporções de grãos subangulares, subarredondados e arredondados em arenitos agrupados de acordo com o grau de coerência............................................... 97

Figura 3.6.53 - Boxplots representando os valores médios das razões entre os eixos menor e maior dos arenitos com diferentes graus de coerência ......................................................................... 97

Figura 3.6.54 - Boxplots representando as proporções de grãos do arcabouço e de cimento nos arenitos com diferentes graus de coerência........98

Figura 3.6.55 - Boxplots representando as proporções de feldspato em relação à somatória entre grãos de quartzo, feldspato e fragmentos líticos e no total nos arenitos com diferentes graus de coerência 99

Figura 3.6.56 - Boxplots representando as proporções de cimentos constituídos por esmectita e óxi-hidróxido metálico nos diferentes graus de coerência ........................................................................... 100

Figura 3.6.57 - Número de amostras estratificadas ou com estrutura maciça/estratificação incipiente, agrupadas por grau de coerência ......................................................................... 101

Figura 3.6.58 - Número de amostras com diferentes graus de coerência, agrupadas por petrofácies ................................................... 102

Figura 3.6.59 - Boxplots representando as profundidades de ocorrência das diferentes petrofácies............................................................ 102

Figura 3.6.60 - Boxplots representando a relação entre os diferentes graus de coerência e a profundidade................................................... 103

Figura 3.6.61 - Diagramas de dispersão de valores medianos de $\sigma_{50}$ versus tamanho médio dos grãos e desvio padrão .............................. 104

Figura 3.6.62 - Diagrama de dispersão de $\sigma_{50}$ versus tamanho médio dos grãos, para cada corpo de prova .................................................... 105

Figura 3.6.63 - Diagrama de dispersão de $\sigma_{50}$ versus desvio padrão, para cada corpo de prova ................................................................... 105

Figura 3.6.64 - Diagrama de dispersão de teor de pelíticos versus a $\sigma_{50}$, para cada corpo de prova .......................................................... 106

Figura 3.6.65 - Diagrama de dispersão de $\sigma_{50}$ versus profundidade, para cada corpo de prova ................................................................. 106

Figura 3.6.66 - Boxplots representando a distribuição dos valores de $\sigma_{50}$ para os graus de coerência atribuídos aos 39 corpos de prova submetidos aos ensaios de resistência à compressão..................................107

Figura 3.6.67 - Diagramas de dispersão com medianas de $\sigma_{50}$ versus porosidade

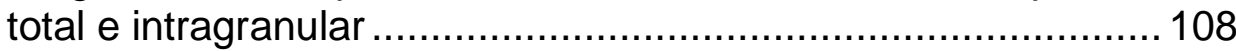

Figura 3.6.68 - Diagramas de dispersão das medianas de $\sigma_{50}$ versus densidade aparente e porosidade aparente ........................................... 108

Figura 3.6.69 - Diagramas de dispersão das medianas de $\sigma_{50}$ versus densidade de empacotamento e proximidade de empacotamento .............. 109 
Figura 3.6.70 - Diagramas de dispersão das medianas de $\sigma_{50}$ versus a porcentagem de contatos tangencias, retos e côncavoconvexos ........................................................................109

Figura 3.6.71 - Diagramas de dispersão entre as medianas de $\sigma_{50}$ e as proporções de contatos entre grãos do arcabouço e cimento e entre grãos do arcabouço e vazios.........................................110

Figura 3.6.72 - Diagramas de dispersão relacionando índices relativos ao formato dos grãos com as medianas de $\sigma_{50} \ldots \ldots \ldots \ldots \ldots \ldots \ldots \ldots \ldots \ldots \ldots \ldots \ldots \ldots . . .111$

Figura 3.6.73 - Diagrama de dispersão relacionando as medianas de $\sigma_{50}$ e as proporções relativas de arcabouço e cimento total...................111

Figura 3.6.74 - Diagrama de dispersão relacionando proporções de cimento constituída por esmectita e óxi-hidróxido metálico versus

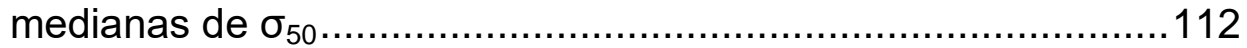

Figura 3.6.75 - Diagrama de dispersão entre profundidade e $E_{s}$, para os 27 corpos de prova submetidos ao ensaio de compressão uniaxial com medidas de deformação axial ........................................112

Figura 3.6.76 - Diagrama de dispersão entre tamanho médio dos grãos do arcabouço e $E_{s}$, para os 27 corpos de prova submetidos ao ensaio de compressão uniaxial com medidas de deformação axial .......113

Figura 3.6.77 - Diagramas de dispersão entre desvio padrão da distribuição granulométrica e $E_{s}$, para os 27 corpos de prova submetidos ao ensaio de compressão uniaxial com medidas de deformação axial ................................................................................113

Figura 3.6.78 - Diagrama de dispersão entre teor de pelíticos e $E_{s}$, para os 27 corpos de prova submetidos ao ensaio de compressão uniaxial com medidas de deformação axial ........................................114

Figura 3.6.79 - Diagramas de dispersão entre as medianas de $E_{s}$ e porosidades total e intragranular .........................................................114

Figura 3.6.80 - Diagramas de dispersão das medianas de $E_{s}$ versus medianas de densidade e porosidade aparentes ......................................115

Figura 3.6.81 - Diagramas de dispersão das medianas de $E_{s}$ com densidade de empacotamento e proximidade de empacotamento .................115

Figura 3.6.82 - Diagramas de dispersão relacionando as proporções de cada tipo de contato intergranular às medianas de $E_{s} \ldots \ldots \ldots \ldots \ldots \ldots \ldots \ldots \ldots \ldots . . .116$

Figura 3.6.83 - Diagramas de dispersão das medianas de $E_{s} c o m$ as proporções de contatos grão-cimento e grão-vazio ...................................116

Figura 3.6.84 - Diagramas de dispersão relacionando parâmetros relativos à forma dos grãos do arcabouço e as medianas de $E_{s}$...............117

Figura 3.6.85 - Diagramas de dispersão relacionando as medianas de $E_{s}$ às proporções de arcabouço e cimento total.................................117

Figura 3.6.86 - Diagramas de dispersão entre as medianas de $E_{s} e$ as concentrações de quartzo e feldspato no arcabouço ................118

Figura 3.6.87 - Diagramas de dispersão entre medianas de $E_{s}$ e proporções de cimento esmectítico e de óxi-hidróxido metálico........................118

Figura 3.6.88 - Boxplots representando a distribuição dos valores de $E_{s}$ para os graus de coerência atribuídos aos 27 corpos de prova submetidos aos ensaios de resistência à compressão com medidas de deformação axial ...............................................................119 


\section{LISTA DE QUADROS}

Quadro 2.2.1 - Graus de coerência................................................................

Quadro 2.3.1 - Significado das siglas utilizadas na nomenclatura das

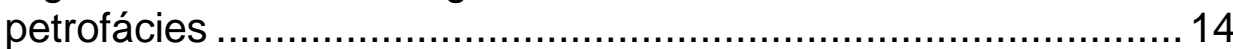

Quadro 2.7.1 - Descrição telegráfica do plano de carga utilizado na execução dos ensaios de compressão uiniaxial com determinação do módulo de deformabilidade

21

Quadro 3.1.1 - Unidades litoestratigráficas de arenitos estudadas em trabalhos de correlação entre propriedades petrográficas e geomecânicas ...................................................................... 32

Quadro 3.2.1 - Recorrências de fácies reconhecidas nos testemunhos da sondagem SM-222 ............................................................. 38

Quadro 3.2.2 - Fácies e graus de coerência atribuídos às amostras destinadas aos ensaios de compressão uniaxial ........................................39

Quadro 4.1.1 - Fácies sedimentares características do sistema eólico úmido Piramboia no Estado de São Paulo ...............................121, 122

Quadro 4.1.2 - Associação tentativa entre fácies reconhecidas em campo e fácies reconhecidas em testemunhos ....................................122, 123

Quadro 4.1.3 - Quadro comparativo entre os graus de coerência de Guidicini et al. (1972) e da ABGE (1983) ................................................. 128

\section{LISTA DE TABELAS}

Tabela 2.2.1 - Amostras coletadas nos testemunhos de sondagem da SM-222 ..8

Tabela 2.2.2 - Trechos de testemunhos amostrados para ensaios mecânicos ....8

Tabela 3.3.1 - Parâmetros estatísticos descritivos referentes aos componentes modais das amostras da sondagem SM-222 ….......................... 40

Tabela 3.3.2 - Dados granulométricos das amostras analisadas da sondagem SM-222 ......................................................................... 43

Tabela 3.3.3 - Dados granulométricos das amostras analisadas das sondagens SM-201, SM-208, SM-210, SM-216, SM-224 e SM-505 ............. 44

Tabela 3.3.4 - Estatísticas da distribuição granulométrica da fração areia obtidas pelo equipamento de difração de laser e teor de pelíticos em massa obtido por elutriação para as amostras da sondagem SM222 46

Tabela 3.3.5 - Valores medianos das estatísticas da distribuição granulométrica da fração areia obtidas pelo equipamento de difração de laser e teor de pelíticos em massa obtido por elutriação para as amostras destinadas aos ensaios de compressão uniaxial 46

Tabela 3.3.6 - Dados de granulometria, mineralogia de cimento e porosidade das amostras da petrofácies Efsx 60

Tabela 3.3.7 - Dados de granulometria, mineralogia de cimento e porosidade das amostras da petrofácies Ems 
Tabela 3.3.8 - Dados de granulometria, mineralogia de cimento e porosidade das amostras da petrofácies Epa...................................................62

Tabela 3.3.9 - Dados de granulometria, mineralogia de cimento e porosidade das amostras da petrofácies Mfsx.................................................63

Tabela 3.3.10 - Dados de granulometria, mineralogia de cimento e porosidade das amostras da petrofácies Mms .................................................64

Tabela 3.4.1 - Medianas das distribuições de densidade e porosidade aparentes das amostras das sondagens SM-201, SM-208, SM-210, SM-216, SM-224 e SM-505

Tabela 3.5.1 - Dados referentes aos corpos de prova da sondagem SM-208, petrofácies Efsx, submetidos aos ensaios geomecânicos ............68

Tabela 3.5.2 - Dados referentes aos corpos de prova da sondagem SM-210, petrofácies Efsx, submetidos aos ensaios geomecânicos ............68

Tabela 3.5.3 - Dados referentes aos corpos de prova da sondagem SM-210, petrofácies Ems, submetidos aos ensaios geomecânicos ............68

Tabela 3.5.4 - Dados referentes aos corpos de prova da sondagem SM-216, petrofácies Epa, submetidos aos ensaios geomecânicos.............68

Tabela 3.5.5 - Dados referentes aos corpos de prova da sondagem SM-224, petrofácies Mfsx, submetidos aos ensaios geomecânicos ..........69

Tabela 3.5.6 - Dados referentes aos corpos de prova da sondagem SM-505, petrofácies Mfsx, submetidos aos ensaios geomecânicos ...........69

Tabela 3.5.7 - Dados referentes aos corpos de prova da sondagem SM-201, petrofácies Mms, submetidos aos ensaios geomecânicos ...........69

Tabela 3.5.8 - Valores medianos de $\sigma_{50}$ e $E_{s}$, representativos de cada sondagem .........................................................................69

Tabela 3.6.1 - Teste de comparações múltiplas de Tukey para a razão entre os eixos menor e maior dos grãos, por grau de coerência ................97

Tabela 3.6.2 - Teste de comparações múltiplas de Tukey para as proporções de feldspato no total e na fração QFL, por grau de coerência ...........99

Tabela 3.6.3 - Teste de comparações múltiplas de Tukey para a profundidade das diferentes petrofácies 102

Tabela 3.6.4 - Teste de comparações múltiplas de Tukey para a profundidade, por grau de coerência ..........................................................103

Tabela 3.6.5 - Dados estatísticos de $\sigma_{50}$ por grau de coerência, para os 39 corpos de prova submetidos ao ensaio de compressão. $\mathrm{n}=$ número de amostras ...............................................................107

Tabela 3.6.6 - Teste de comparações múltiplas de Dunn para o $E_{s}$, por grau de coerência 119 


\section{LISTA DE SIGLAS}

ABGE Associação Brasileira de Geologia de Engenharia

ABNT Associação Brasileira de Normas Técnicas

Aca Fácies sedimentar característica do sistema eólico úmido Piramboia, constituída por arenito com estratificação cruzada de alto ângulo (Gesicki, 2007, com base em Giannini et al., 2004)

Acb Fácies sedimentar característica do sistema eólico úmido Piramboia, constituída por arenito com estratificação cruzada de baixo ângulo (Gesicki, 2007, com base em Giannini et al., 2004)

Acbl Fácies sedimentar característica do sistema eólico úmido Piramboia, constituída por arenito com estratificação horizontal ou de baixo ângulo e intercalação de lutitos (Gesicki, 2007, com base em Giannini et al., 2004)

Ae Fácies sedimentar reconhecida em testemunho, constituída por arenito muito fino a médio, estratificado

$\mathrm{Ae}_{\mathrm{i}} \quad$ Fácies sedimentar reconhecida em testemunho, constituída por arenito muito fino a médio, com estratificação incipiente ou parcialmente obliterada

Am Fácies sedimentar reconhecida em testemunho, constituída por arenito com bimodalidade granulométrica não segregada

ANOVA Análise de variância

Ap Fácies sedimentar reconhecida em testemunho, constituída por arenito muito fino a fino, estratificado, intercalações pelíticas

ASTM American Society for Testing and Materials

BGS British Geological Society

BS British Standard

C2 Arenito medianamente coerente

C3 Arenito pouco coerente

C4 Arenito incoerente

C2/C3 Arenito de coerência intermediária entre C2 e C3, com predomínio de C2 
C3/C2 Arenito de coerência intermediária entre C3 e C2, com predomínio de C3

C3/C4 Arenito de coerência intermediária entre C3 e C4, com predomínio de C3

C4/C3 Arenito de coerência intermediária entre C4 e C3, com predomínio de C4

CPRM Serviço Geológico do Brasil

DH Departamento Hidroviário da Secretaria de Logística e Transportes do Estado de São Paulo

EED Espectrômetro de Energia Dispersiva

EDS Energy Dispersive Spectroscopy

Efsx Petrofácies constituída por arenito fino estratificado rico em cimento de esmectita

Ems Petrofácies constituída por arenito médio a fino estratificado pobre em cimento de esmectita

Epa Petrofácies constituída por arenito fino estratificado rico em cimento argilo-ferruginoso

IAEG International Association for Engineering Geology and the Environment

ISRM International Society for Rock Mechanics

KW Teste de Kruskal-Wallis

MEV Microscopia Eletrônica de Varredura

Mfsx Petrofácies constituída por arenito fino maciço rico em cimento de esmectita

Mms Petrofácies constituída por arenito médio a fino maciço pobre em cimento de esmectita

NBR Norma Brasileira

Sirgas Sistema de Referência Geocêntrico para as Américas

SM Sondagem Mista

UTM Universal Transversa de Mercator 


\section{LISTA DE SÍMBOLOS}

$\begin{array}{ll}{ }^{\circ} \mathrm{C} & \text { Graus Celsius } \\ \mathrm{Ba} & \text { Bário } \\ \mathrm{Ca} & \text { Cálcio } \\ \mathrm{E} & \text { Módulo de deformabilidade } \\ \mathrm{E}_{\mathrm{s}} & \text { Módulo de deformabilidade secante } \\ \mathrm{Fe} & \text { Ferro } \\ \mathrm{H} & \text { Hidrogênio } \\ \mathrm{K} & \text { Potássio } \\ \mathrm{Mg} & \text { Magnésio } \\ \mathrm{Mn} & \text { Manganês } \\ \mathrm{O} & \text { Óxigênio } \\ p & \text { Nível de significância estatística } \\ P_{d} & \text { Densidade de empacotamento de Kahn (1956) } \\ P_{p} & \text { Proximidade de empacotamento de Kahn (1956) } \\ \mathrm{r} & \text { Coeficiente de correlação de Pearson } \\ \eta_{\mathrm{a}} & \text { Porosidade aparente } \\ \rho_{\mathrm{a}} & \text { Densidade aparente } \\ \sigma_{50} & \text { Resistência à compressão uniaxial ou simples padronizada conforme } \\ \sigma_{\mathrm{u}} & \text { equação proposta por Turk e Dearman (1986) } \\ \varphi & \text { Resistência à compressão uniaxial ou simples } \\ & \end{array}$




\section{INTRODUÇÃO}

A Formação Piramboia integra o Grupo São Bento, pertencente à Bacia do Paraná, sendo delimitada pela Formação Botucatu, no topo, e pelas formações Corumbataí e Teresina, pertencentes ao Grupo Passa Dois, na base. A unidade, composta predominantemente por arenitos com estratificação cruzada em séries de porte decimétrico a métrico (Assine et al., 2004; Giannini et al., 2004), estende-se continuamente pelo Estado de São Paulo, chegando a $270 \mathrm{~m}$ de espessura na região de São Pedro (Caetano-Chang, 1997). Sua idade não é consensual, devido à polêmica acerca do contato basal com o Grupo Passa Dois, se discordante ou não, situando-se entre o final do Permiano e o Eocretáceo (Giannini et al., 2004).

$\mathrm{Na}$ construção civil, os arenitos da Formação Piramboia são comumente desagregados mecanicamente para serem utilizados como material de empréstimo, havendo por isto pouca literatura sobre suas propriedades mecânicas enquanto rocha íntegra, in natura. A importância em estudar as propriedades petrográficas, físicas e mecânicas destes arenitos em termos de sua utilização na construção civil, não apenas como material de empréstimo, mas também como fundação, justifica-se pelo fato de que importantes obras foram construídas ou projetadas sobre a unidade. Trechos de obras viárias como as rodovias Castelo Branco (SP-280), Marechal Rondon (SP-300) e Washington Luís (SP-310), e as ferrovias das companhias Estrada de Ferro Sorocabana e Paulista de Estradas de Ferro, passam pela Formação Piramboia. As áreas diretamente afetadas pela construção de barragens, como parte da represa de Jurumirim e a maior parte da represa de Barra Bonita, encontram-se sobre arenitos da Formação Piramboia. O Aproveitamento Múltiplo Santa Maria da Serra, projeto não implantado, mas cujos primeiros estudos datam de 1975, tem suas fundações projetadas sobre arenitos desta unidade. Esse projeto visa, como objetivo principal, à extensão da Hidrovia Tietê-Paraná por $45 \mathrm{~km}$, através da construção de uma barragem nos municípios de Santa Maria da Serra e Anhembi, com finalidades secundárias como geração de energia e reserva hídrica.

Arenitos da Formação Piramboia, assim como todas as rochas consideradas brandas (segundo ISRM, 1981, rochas com resistência à compressão uniaxial inferior a $25 \mathrm{MPa}$ ), são problemáticos para a Geologia de Engenharia. Conforme apontado por Kanji (2014), quatro problemas principais vêm à tona quando se trata 
da utilização de rochas brandas para grandes obras de engenharia, como barragens, usinas hidrelétricas, túneis e rodovias: 1) por apresentarem uma série de comportamentos indesejáveis, como baixa resistência, desagregabilidade e suscetibilidade à erosão, estes tipos de rochas, e as áreas por elas dominadas, são muitas vezes evitadas na instalação destas obras; 2) por se tratar de material com resistência intermediária entre solo e rocha, os equipamentos para testes geomecânicos mostram-se frequentemente inadequados; 3) a amostragem é dificultada seja pela impenetrabilidade à sondagem à percussão, com valores de $\mathrm{N}_{\mathrm{SPT}}$ (número de golpes necessário para a cravação dos últimos $30 \mathrm{~cm}$ do barrilete amostrador no ensaio de penetração padronizado - standard penetration test) acima de 50, seja pela frequente desagregação completa da rocha pelas sondagens rotativas, o que resulta em índices elevados (até 70\%) de não recuperação; 4) os principais sistemas de classificação geomecânica foram desenvolvidos para rochas cristalinas fraturadas, fazendo-se necessária a adaptação destes sistemas, ou até mesmo o desenvolvimento de novos métodos de classificação específicos para rochas brandas.

A determinação de parâmetros relacionados ao comportamento mecânico das rochas, como a resistência à compressão uniaxial e o módulo de deformabilidade, requer corpos de prova de boa qualidade, especialmente difíceis de serem obtidos a partir de arenitos pouco coerentes e estratificados. Quando disponíveis, são escolhidos trechos mais resistentes da coluna sedimentar para a determinação destes índices, o que compromete a representatividade dos ensaios: a variação faciológica e geomecânica existente deixa de ser caracterizada em sua totalidade.

O presente trabalho pretende contribuir para a caracterização geológicogeotécnica da Formação Piramboia e verificar as possíveis relações da resistência à compressão uniaxial e do módulo de deformabilidade com as características mineralógicas e texturais de diferentes tipos de rocha desta unidade litoestratigráfica, identificados com base em aspectos sedimentológicos e diagenéticos macro e microscópicos.

Em âmbito mais geral, espera-se contribuir para os métodos de estudo e a compreensão do comportamento das rochas brandas frente às solicitações exigidas na construção civil. 


\subsection{Meta e objetivos}

A meta deste projeto de mestrado é contribuir para a caracterização geológico-geotécnica dos arenitos da Formação Piramboia por meio da verificação das possíveis correlações existentes entre propriedades petrográficas e geomecânicas.

Para atingir esta meta, estabeleceram-se os seguintes objetivos, focados em rochas de sub-superfície amostradas em testemunhos de sondagem no Estado de São Paulo:

- Fazer a análise e interpretação de fácies dos testemunhos e definir as diferentes unidades geológico-geotécnicas com base em características macroscópicas (textura e estrutura) e de coerência

- Caracterizar microscopicamente os produtos deposicionais e diagenéticos das diferentes unidades reconhecidas macroscopicamente e agrupá-los em petrofácies

- Obter a resistência à compressão uniaxial $\left(\sigma_{u}\right)$ e o módulo de deformabilidade (E) para diferentes unidades identificadas macroscopicamente

- Verificar correlações entre $\sigma_{u}$ e E, de um lado, e propriedades petrográficas específicas, de outro, tais como mineralogia e granulometria do arcabouço, tipos de contatos intergranulares, índice de fechamento do empacotamento, quantidade e mineralogia do cimento e proporção e tipo de porosidade

- De posse do conjunto de resultados, identificar quais parâmetros petrográficos, sejam de trama, textura ou mineralogia, influenciam o comportamento mecânico dos arenitos estudados.

\section{2 Área de estudo}

O principal material de estudo são testemunhos de sondagem mista (à percussão e rotativa) obtidos na região que compreende os municípios de Anhembi e Santa Maria da Serra, às margens do reservatório de Barra Bonita, no rio Piracicaba (figuras 1.2.1 e 1.2.2). Esta área situa-se na borda ocidental do compartimento geomorfológico da Depressão Periférica Paulista (Almeida, 1964; Ab'Saber, 1969), em seu limite com as cuestas basálticas do Planalto Ocidental. Uma das sondagens contempladas neste trabalho foi executada sobre lâmina de água do reservatório e, antes de chegar à Formação Piramboia, atravessou 
depósitos sedimentares aluvionares recentes, arenosos e argilosos, com cerca de $10 \mathrm{~m}$ de espessura. As demais sondagens foram executadas em terra, e atravessaram, logo sob a superfície, camadas de areia e de cascalho com espessuras entre 1 e $8 \mathrm{~m}$. Abaixo destes sedimentos inconsolidados, todas as sondagens penetraram apenas a Formação Piramboia.
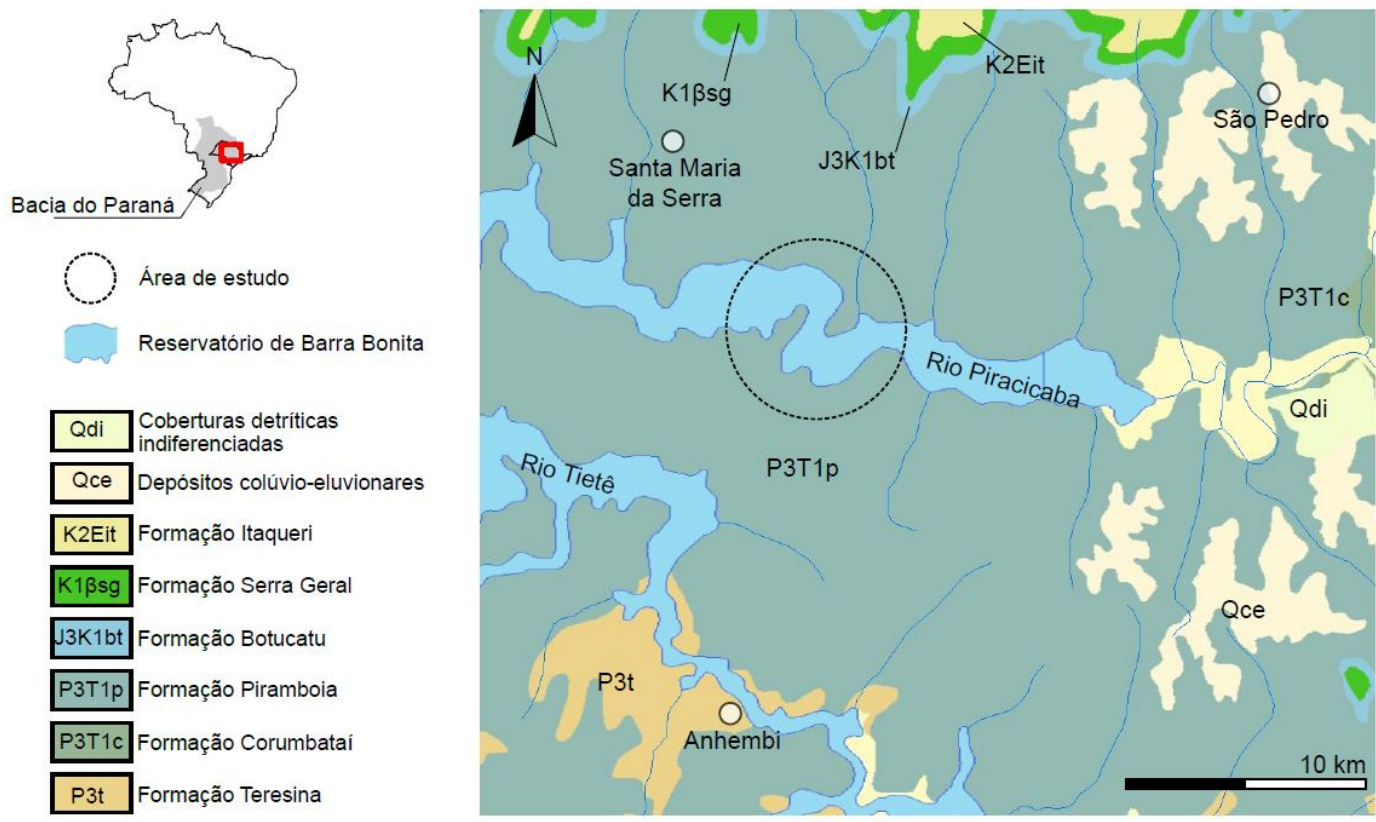

Figura 1.2.1 - Mapa geológico da região de estudo. O círculo indica a área onde foram realizadas as sondagens, cujos testemunhos foram os objetos de investigação desta pesquisa de Mestrado. Fonte: CPRM, 2006.

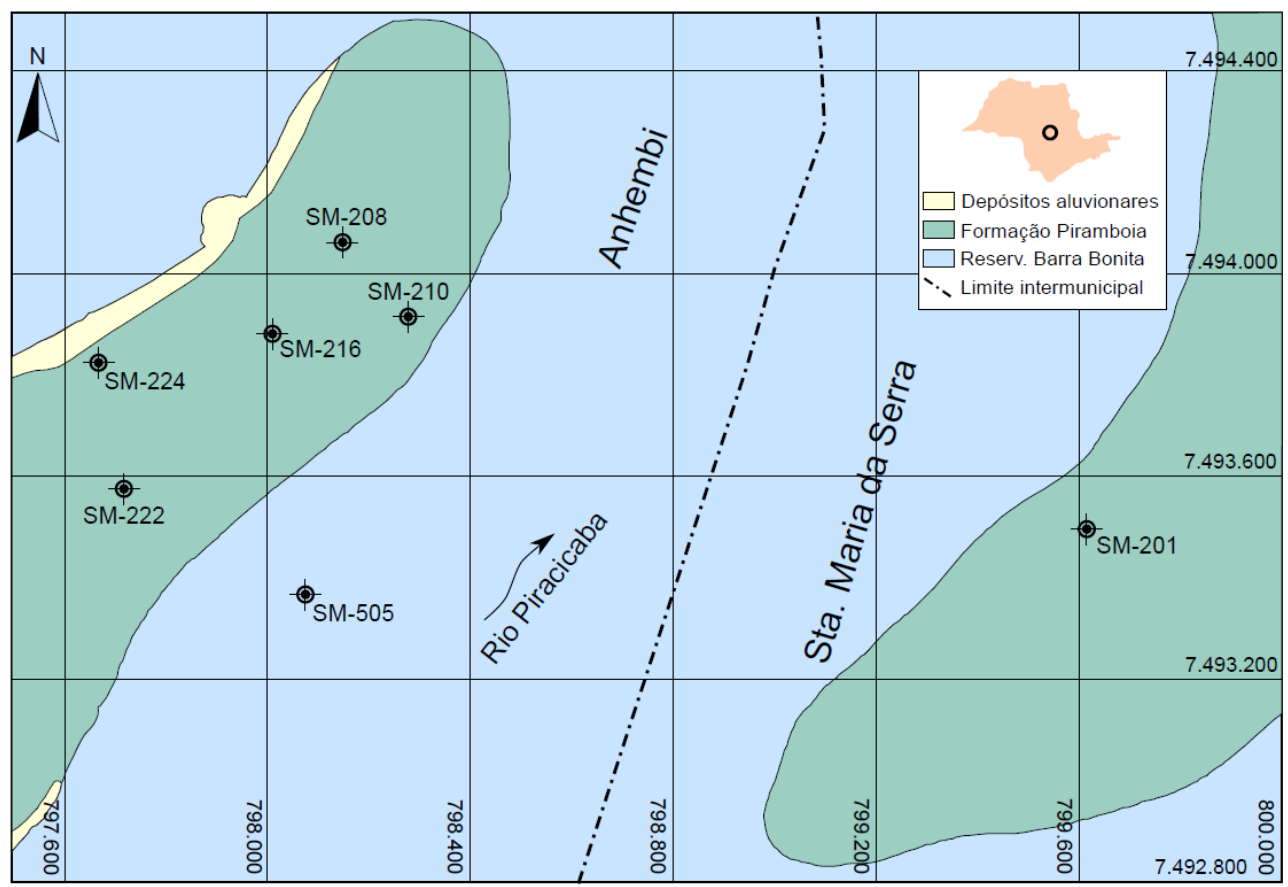

Figura 1.2.2 - Localização das sondagens cujos testemunhos foram amostrados. Projeção UTM, Datum Sirgas 2000, MC 51ํ. Fuso 22, Zona K. 


\section{MATERIAIS E MÉTODOS}

\subsection{Revisão bibliográfica}

A revisão bibliográfica teve dois focos. O primeiro deles foi a caracterização da geologia e geomorfologia da região em estudo, com destaque para a Formação Piramboia. O segundo foco foi a compilação de informações de estudos prévios sobre as correlações entre propriedades petrográficas, físicas e mecânicas de arenitos.

\subsection{Amostragem}

Os testemunhos de sondagem mista a partir dos quais se obtiveram as amostras deste estudo apresentam diâmetro de 7,6 cm e profundidades entre $20 \mathrm{e}$ $40 \mathrm{~m}$. As sondagens foram executadas no período entre junho e setembro de 2013, nos municípios de Anhembi e Santa Maria da Serra, pelo Departamento Hidroviário da Secretaria de Logística e Transportes do Estado de São Paulo (DH). Na sondagem mista, aplicam-se procedimentos de sondagem à percussão com ensaio SPT, para os trechos em solo, e de sondagens rotativas, para os trechos em rocha, conforme Manual de Sondagens (ABGE, 2013).

Também foram fornecidos pelo $\mathrm{DH}$ dados de levantamento topográfico das áreas onde se executaram as sondagens, representados em curvas de nível, e de localização espacial e cotas altimétricas de boca de furo (Figura 1.2.2).

Devido ao longo tempo, mais de três anos, decorrido entre a execução das sondagens e os ensaios de laboratório, este estudo não reproduz as condições in situ dos arenitos.

Para a obtenção de subamostras a partir dos testemunhos de sondagem, foram aplicados diferentes procedimentos de acordo com as duas partes em que se divide este trabalho, isto é: 1) análises petrográficas, granulométricas e aferição dos graus de coerência ao longo da coluna sedimentar dos testemunhos da sondagem SM-222; e 2) análises petrográficas e granulométricas de amostras obtidas em diversos furos de sondagem, que serviram à realização de ensaios de resistência à compressão uniaxial e obtenção de módulos de deformabilidade. Os subitens 2.2.1 e 2.2.2 expõem os critérios de subamostragem em cada um destes dois contextos. 


\subsubsection{Fácies sedimentares reconhecidas em testemunhos e aferição dos graus de coerência}

Os diferentes tipos de arenitos da sondagem SM-222 (cuja localização é indicada na Figura 1.2.2) foram inicialmente reconhecidos com base em critérios relacionados à definição de fácies sedimentares e graus de coerência.

As características faciológicas consideradas foram: 1) granulação da fração areia, avaliada tátil-visualmente, com atenção à presença de bimodalidade granulométrica e segregação granular; e 2) estrutura sedimentar. Posteriormente, foram realizados ensaios granulométricos (Item 2.5), permitindo aferir com maior precisão o tamanho médio dos grãos na fração areia.

Concreções e feições diagenéticas associadas presentes nos arenitos não integraram os critérios de distinção de fácies, mas foram descritas quanto a morfologia, dimensões e distribuição espacial, em vista de suas possíveis implicações tanto em termos de propriedades geomecânicas quanto de interpretação de processos eodiagenéticos. Esta descrição baseou-se não somente na sondagem SM-222, mas em 32 sondagens executadas no local do estudo.

A coerência dos arenitos foi definida tátil-visualmente, com base em suas propriedades de tenacidade, dureza e friabilidade. Avaliou-se a tenacidade pela resistência oferecida ao impacto do martelo. Já dureza e friabilidade foram avaliadas pela resistência e desagregação, respectivamente, ao risco de lâmina de aço, de acordo com Guidicini et al. (1972).

Conforme destacado por Serra Junior \& Ojima (1998), apesar de serem de aplicação subjetiva, estes critérios de coerência permitem avaliar de maneira prática e confiável a intensidade relativa da ação intempérica sobre a rocha.

No contexto deste estudo, admite-se a possibilidade de que diferentes graus de coerência verificados decorram da heterogeneidade de processos e produtos diagenéticos em diferentes horizontes, incluindo telodiagênese, os quais podem atuar ora no aumento ora na diminuição do grau de coerência.

Por exemplo, a cimentação de determinado horizonte, um processo tipicamente eo ou mesodiagenético (Choquette \& Pray, 1970), pode tornar o arenito mais coerente. Já no estágio telodiagenético, a dissolução ou remobilização mecânica de cimentos precipitados anteriormente leva à diminuição do grau de coerência. 
Os critérios de classificação tátil-visual de Guidicini et al. (1972) permitem definir quatro graus de coerência, designados C1 a C4 na ordem decrescente (Quadro 2.2.1). Objetivando detalhar a diferenciação entre as unidades geológicogeotécnicas identificadas, aqui definidas como a combinação entre características faciológicas e mecânicas, e reconhecer arenitos com coerência intermediária, foram também utilizados neste estudo termos compostos, como C2/C3, por exemplo, o qual designa arenitos com características intermediárias entre C2 e C3, mas com predomínio das características de $\mathrm{C} 2$.

Quadro 2.2.1 - Graus de coerência

\begin{tabular}{ccc}
\hline Sigla & Denominação & Comportamento da rocha \\
\hline C1 & Coerente & $\begin{array}{c}\text { Quebra com dificuldade ao golpe do martelo, produzindo } \\
\text { fragmentos de bordas cortantes. Superfície dificilmente } \\
\text { riscável por lâmina de aço. Somente escavável a fogo. }\end{array}$ \\
\hline C2 & Medianamente coerente & $\begin{array}{r}\text { Quebra com dificuldade ao golpe do martelo. Superfície } \\
\text { riscável com lâmina de aço. Escavável a fogo. }\end{array}$ \\
\hline C3 & Pouco coerente & $\begin{array}{r}\text { Quebra com facilidade ao golpe do martelo, produzindo } \\
\text { fragmentos que podem ser partidos manualmente. } \\
\text { Superfície facilmente riscável com lâmina de aço. } \\
\text { Escarificável. }\end{array}$ \\
\hline C4 & Incoerente & $\begin{array}{c}\text { Quebra com a pressão dos dedos, desagregando-se. Pode } \\
\text { ser cortada com lâmina de aço. Friável e escavável com } \\
\text { lâmina. }\end{array}$ \\
\hline
\end{tabular}

Fonte: Guidicini et al. (1972).

Em trechos com alternância recorrente de dois diferentes graus de coerência, sendo um principal e outro subordinado e em intervalos poucos espessos (isto é, com menos de $25 \mathrm{~cm}$ ), foi utilizado um código formado por dois graus de coerência separados por um hífen, sendo a primeira coerência, à esquerda do hífen, a principal, e a segunda, a subordinada. Por exemplo, um trecho com grau de coerência predominante $\mathrm{C} 3 / \mathrm{C} 4$, mas contendo intercalações delgadas de graus de coerência $\mathrm{C} 3 / \mathrm{C} 2$, recebe a codificação $\mathrm{C} 3 / \mathrm{C} 4-\mathrm{C} 3 / \mathrm{C} 2$.

A Tabela 2.2.1 apresenta as 20 amostras coletadas a partir dos testemunhos da sondagem SM-222, submetidas a análises petrográficas e granulométricas. A escolha destas amostras visou representar cada recorrência de unidade geológicogeotécnica definida por fácies e/ou grau de coerência. 
Tabela 2.2.1 - Amostras coletadas nos testemunhos da sondagem SM-222

\begin{tabular}{ccccccc}
\hline Amostra & Prof. $(\mathbf{m})$ & Cota $(\mathbf{m})$ & & Amostra & Prof. $(\mathbf{m})$ & Cota $(\mathbf{m})$ \\
\cline { 1 - 2 } \cline { 5 - 6 } \cline { 5 - 6 } & 10,6 & 454,7 & & 11 & 22,9 & 442,5 \\
2 & 11,1 & 454,3 & & 12 & 24,9 & 440,5 \\
3 & 13,9 & 451,5 & & 13 & 26,9 & 438,4 \\
4 & 14,1 & 451,2 & & 14 & 27,6 & 437,8 \\
5 & 15,3 & 450,1 & & 15 & 28,7 & 436,6 \\
6 & 15,8 & 449,6 & & 16 & 29,1 & 436,2 \\
7 & 16,3 & 449,1 & & 17 & 29,9 & 435,5 \\
8 & 17,2 & 448,2 & & 18 & 30,8 & 434,6 \\
9 & 19,1 & 446,3 & & 19 & 32,0 & 433,4 \\
10 & 20,5 & 444,8 & & 20 & 32,5 & 432,9 \\
\hline
\end{tabular}

\subsubsection{Coleta de amostras para realização de ensaios mecânicos}

Com base nos critérios definidos no item 2.2.1, foram coletadas amostras de diferentes fácies e graus de coerência em testemunhos de outros seis diferentes furos de sondagem (SM-201, SM-208, SM-210, SM-216, SM-224 e SM-505: Figura 1.2.2, Tabela 2.2.2), com a finalidade de obter corpos de prova em número suficiente e nas dimensões adequadas à execução dos ensaios para obtenção de $\sigma_{u}$ e $E$.

Dentre as 90 amostras coletadas nestas sondagens, 39 destinaram-se aos ensaios para obtenção de $\sigma_{u}$, enquanto 27 amostras menores, geralmente com dimensões da ordem de $5 \mathrm{~cm}$, foram utilizadas para a confecção de seções petrográficas. As 24 amostras restantes foram destinadas a ensaios para obtenção da densidade e porosidade aparentes ( $\rho_{\mathrm{a}}$ e $\eta_{\mathrm{a}}$, respectivamente).

Após a realização dos ensaios para obtenção de $\sigma_{u}$ e $E$, trechos não afetados dos corpos de prova rompidos foram utilizados em ensaios granulométricos.

Tabela 2.2.2 - Trechos de testemunhos amostrados para ensaios mecânicos

\begin{tabular}{ccccc}
\hline Sondagem & \multicolumn{2}{c}{ Profundidade $(\mathbf{m})$} & \multicolumn{2}{c}{ Cota $(\mathbf{m})$} \\
& De & Até & De & Até \\
\hline SM-201 & 26,0 & 27,4 & 436,6 & 435,2 \\
SM-208 & 17,9 & 19,8 & 448,8 & 446,9 \\
SM-210 & 17,5 & 19,8 & 446,2 & 444,0 \\
SM-210 & 26,1 & 27,5 & 437,7 & 436,2 \\
SM-216 & 12,1 & 13,1 & 454,9 & 453,9 \\
SM-224 & 21,5 & 23,0 & 439,1 & 437,7 \\
SM-505 & 12,8 & 14,9 & 431,3 & 429,2 \\
\hline
\end{tabular}




\subsection{Análise petrográfica}

Os estudos petrográficos consistiram na caracterização textural e mineralógica dos arenitos em seções delgadas. A análise incluiu a descrição de componentes deposicionais (arcabouço, matriz e empacotamento), seguida dos componentes diagenéticos (cimento, porosidade e compactação).

Após a caracterização petrográfica de cada amostra, as rochas descritas foram agrupadas em petrofácies, definidas de acordo com características texturais e diagenéticas semelhantes. Foi feita uma associação tentativa entre estas petrofácies e as fácies da Formação Piramboia reconhecidas em afloramentos.

Os procedimentos da análise petrográfica são detalhados nos itens a seguir.

\subsubsection{Preparação e confecção de seções delgadas}

Para cada amostra representativa das diferentes unidades geológicogeotécnicas de arenito reconhecidas durante a descrição macroscópica, preparou-se uma seção delgada vertical com espessura de $30 \mu \mathrm{m}$, sem lamínula, destinada à descrição ao microscópio óptico de luz polarizada e aquisição de fotomicrografias digitais e a estudos de Microscopia Eletrônica de Varredura (MEV), com microanálise química pontual quantitativa ao Espectrômetro de Energia Dispersiva (EED, ou EDS na sigla em inglês). No total, foram confeccionadas 27 seções delgadas, sendo 20 referentes a recorrências de unidades geológico-geotécnicas na sondagem SM-222 e sete referentes à parte destas mesmas unidades nas demais sondagens. No processo de preparação para a confecção das seções delgadas, as amostras foram previamente secas em estufa a cerca de $35^{\circ} \mathrm{C}$ até massa constante (atingida quando a diferença entre duas pesagens sucessivas, em um intervalo de pelo menos $24 \mathrm{~h}$ é menor que $0,1 \%$ ) e impregnadas a vácuo com uma mistura composta por resina (Epoxiglass XGY1109), solvente (álcool etílico), endurecedor (Epoxiglass HY951) e corante (Azul de Orassol). A função do solvente foi diminuir a viscosidade da resina e propiciar, assim, o preenchimento dos poros menores. A finalidade do uso de corante foi permitir a diferenciação entre poros originais (coloridos) e poros induzidos durante a confecção das lâminas (incolores).

O procedimento de impregnação foi desenvolvido com 0 auxílio do Laboratório de Laminação do Setor de Minerais e Rochas do Instituto de Pesquisas Tecnológicas (IPT) de São Paulo. Nesse procedimento, a impregnação é feita 
mediante o gotejamento da mistura, para dentro do recipiente plástico onde se encontra a amostra, acondicionado em câmara de vácuo. O vácuo faz com que a solução penetre, em questão de minutos, nos poros da amostra.

\subsubsection{Quantificação dos componentes deposicionais e diagenéticos por meio de análise modal}

Os componentes que constituem a rocha sedimentar, a saber, arcabouço, matriz, cimento e poro, foram quantificados através de análise modal, que consistiu na contagem de pelo menos 300 pontos espaçados regularmente em malha de 0,3×0,3 mm, conforme método de Glagolev-Chayes (Galehouse, 1971). O limite inferior de 300 grãos para a contagem foi estipulado com base na demonstração matemática de Galehouse (1971), segundo a qual 300 pontos é o número que fornece a melhor relação entre precisão e tempo de análise, adequada à finalidade deste estudo.

\subsubsection{Arcabouço}

O arcabouço foi descrito levando em consideração sua mineralogia, textura e petrotrama.

A mineralogia do arcabouço foi quantificada, por meio de análise modal, em relação ao conteúdo percentual de quartzo mono e policristalino, feldspato e fragmento lítico, este incluindo silexito (composição dominada por opala e/ou calcedônia), granitoide e intraclasto. Mica e mineral pesado foram contabilizados à parte.

A descrição textural considerou granulometria modal, desvio padrão, com grau de seleção correspondente, e graus de arredondamento e de esfericidade.

A determinação da distribuição granulométrica foi feita com auxílio do software LAS (Leica Application Suite), da Leica Microsystems. Para tanto, obtiveram-se, por meio de câmera digital acoplada a microscópio de luz polarizada, imagens fotomicrográficas com aumento de 100 ou 50x, igualmente espaçadas ao longo da seção petrográfica, e medidos todos os grãos presentes em cada imagem, até completar ao menos 100 grãos. O grau de seleção foi calculado pelo desvio padrão da medida do eixo maior, transformado para a escala $\varphi$ (phi) de Krumbein 
(1938), seguindo-se a classificação nominal de seleção granulométrica de Folk (1965).

Os graus de arredondamento e de esfericidade foram estimados para pelo menos 100 grãos, com base respectivamente na cartilha de Powers (1953) e na razão entre os comprimentos dos eixos menor e maior de cada grão. Para medir os eixos dos grãos foi utilizado a ferramenta correspondente do software LAS.

A descrição da petrotrama consistiu na identificação de segregação e imbricação dos grãos e na quantificação da densidade e proximidade de empacotamento do arcabouço.

A densidade de empacotamento (packing density $-P_{d}$ ), conforme definido por Kahn (1956), é a razão entre a soma do comprimento dos grãos encontrados ao longo de uma linha e o comprimento total desta linha (Figura 2.3.1), multiplicada pelo fator $m$ de correção da magnificação (Equação 2.3.1).

$$
P_{d}=\frac{m \sum_{i=1}^{n} g_{i}}{t} x 100
$$

Para a análise de $P_{d}$, foram obtidas, por meio de câmera digital acoplada ao microscópio de luz polarizada, ao menos dez imagens digitais fotomicrográficas com aumento de 50x, igualmente espaçadas ao longo da seção petrográfica. Em cada imagem, foram traçadas três linhas paralelas entre si e medidos os comprimentos dos grãos ao longo destas linhas, utilizando para isso o software LAS. Calcularamse os valores da densidade de empacotamento para cada linha e a média aritmética destes valores foi considerada como a densidade de empacotamento da lâmina.

A proximidade de empacotamento (packing proximity $-P_{p}$ ) é dada pela razão entre o número de contatos entre grãos e o número total de grãos (Figura 2.3.1), conforme Equação 2.3.2 (Kahn 1956).

$$
P_{p}=\frac{q}{n} x 100
$$

Para a análise de $P_{p}$, foram computados ao menos 300 grãos. Os tipos de contatos intergranulares - tangencial, reto, côncavo-convexo e suturado - também foram diferenciados e quantificados nesta etapa das análises petrográficas. 


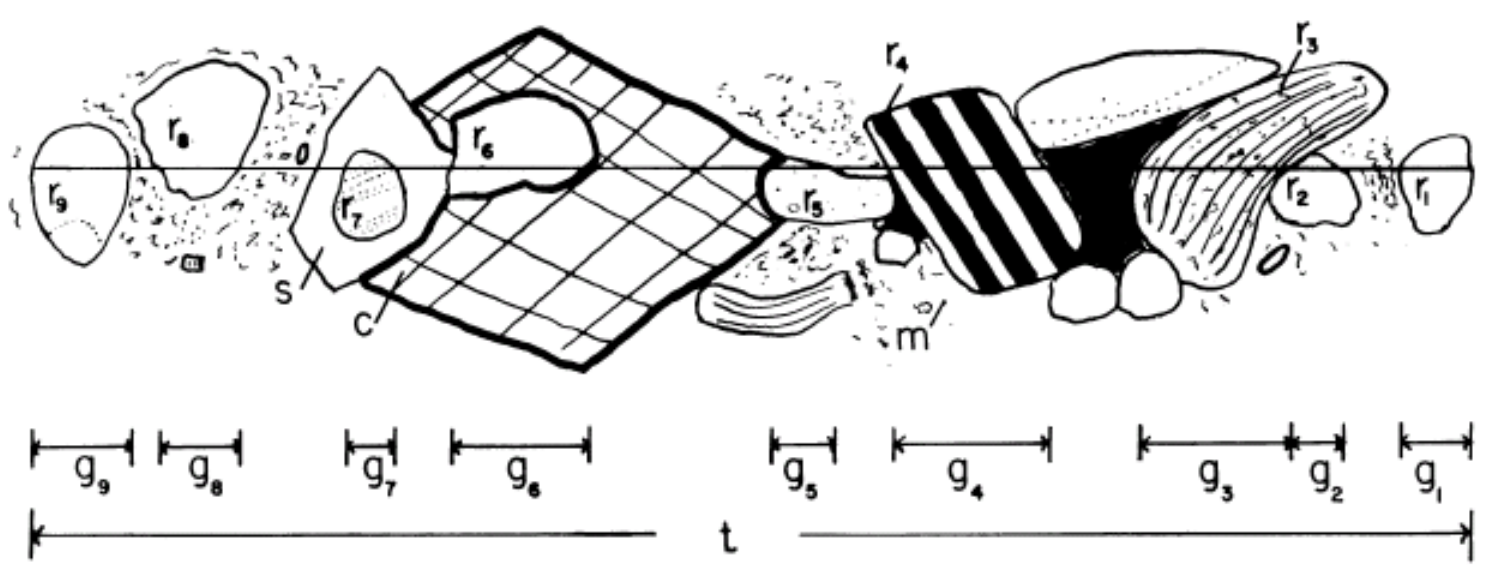

Figura 2.3.1 - Representação esquemática de arenito observado ao microscópio petrográfico. $O$ número total de grãos ao longo da linha é nove. Dentre estes nove grãos, o grão 1 (g1) está em contato com a matriz, o grão 2 em contato com um fragmento lítico, o grão 3 em contato com vazio, o grão 4 em contato com matriz, o grão 5 em contato com cimento carbonático, os grãos 6 e 7 em contato com cimento de sílica e os grãos 8 e 9 estão em contato com a matriz, no que resulta apenas um contato entre grãos dentre nove grãos. Assim, a proximidade de empacotamento é $P_{p} \frac{1}{9} \times 100=$ 11,11\%. Fonte: Kahn (1956). c: cimento carbonático, s: cimento de sílica, m: matriz, a: vazio, $r_{i}:$ grão, $g_{i}$ : comprimento do intercepto entre a linha e o grão.

\subsubsection{Matriz e cimento}

Matriz e cimento foram descritos em relação a mineralogia e textura. Foi definida a origem da matriz, se deposicional (protomatriz, ortomatriz) ou diagenética (epimatriz ou pseudomatriz), seguindo-se assim as definições e critérios de Dickinson (1970), e o cimento foi caracterizado conforme seu hábito, tamanho e/ou cristalinidade e relações espaciais com o arcabouço e o espaço poroso. A ordem temporal de geração das diferentes mineralogias e/ou tramas e texturas de cimento foi avaliada por meio das relações de contato e disposição relativa entre eles ou com o arcabouço. A quantificação destes componentes foi realizada por análise modal (Item 2.3.2).

\subsubsection{Porosidade}

A porosidade total de cada lâmina foi avaliada por dois métodos diferentes: análise de imagens automatizada e análise modal.

A porosidade total via análise de imagens obteve-se por meio de rotina do software LAS. Esta rotina seguiu o método sugerido por Gesicki et al. (2009) e consistiu nos seguintes procedimentos: (1) aquisição de 20 a 30 imagens digitais fotomicrográficas com aumento de 100 ou 50x igualmente espaçadas ao longo da seção petrográfica, obtidas por meio de câmera digital acoplada a microscópio de 
luz polarizada; (2) processamento das imagens, com detecção dos pixels correspondente aos poros (azul), utilizando segmentação do histograma de matiz (hue); (3) edição manual da imagem binária gerada na etapa anterior, para correção de eventuais imprecisões; (4) medição da área do binário editado, que corresponde à área dos poros da imagem processada, e da proporção relativa entre a área dos poros e a área total da imagem, em porcentagem; (5) cálculo da média aritmética da porosidade medida em cada imagem, que é considerada a porosidade da lâmina.

$\mathrm{Na}$ avaliação da porosidade total por meio de análise modal (contagem de 300 pontos, conforme item 2.3.2), diferenciou-se e quantificou-se também a porosidade intragranular. Os tipos de porosidade intragranular foram descritos conforme Schmidt \& McDonald (1979). Para efeito de classificação e contabilidade, a porosidade intragranular também incluiu poros móldicos com indícios de preenchimento por cimento carbonático, com posterior dissolução desse cimento.

A porosidade obtida por meio de análise modal é referida abreviadamente neste trabalho como "porosidade modal", para distingui-la da porosidade por análise de imagens e da porosidade aparente, esta medida por método de saturação com fluidos (descrito adiante: item 2.6).

\subsubsection{Individualização e nomenclatura de petrofácies}

Enquanto as litofácies de Walker (1980) referem-se a agrupamentos de rochas sedimentares baseados em características macroscópicas, sobretudo deposicionais a eodiagenéticas, o conceito de petrofácies, analogamente, refere-se a agrupamentos de rochas sedimentares, porém com base em características principalmente microscópicas, sejam deposicionais, como mineralogia, textura e petrotrama, sejam diagenéticas, como cimento, porosidade secundária e compactação. As petrofácies são, portanto, essencialmente descritivas, e representam o depósito sedimentar de acordo com seus atributos físicos e químicos microscópicos, que supostamente resultam de processos deposicionais e diagenéticos.

A nomenclatura adotada para a individualização das petrofácies neste

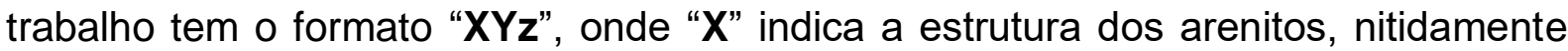
estratificados versus estratificados de maneira incipiente ou maciços, "Y" a granulometria da fração areia, "z" a porcentagem de partículas na fração silte e 
argila, e "w" a mineralogia do cimento predominante. O Quadro 2.3.1 indica o significado das diferentes siglas que figuram em cada campo.

Quadro 2.3.1 - Significado das siglas utilizadas na nomenclatura das petrofácies

\begin{tabular}{|c|c|}
\hline $\begin{array}{c}\mathrm{X} \\
\text { Estrutura } \\
\end{array}$ & $\begin{array}{l}\mathrm{E} \text { - estratificado } \\
\mathrm{M} \text { - maciço ou com estratificação incipiente }\end{array}$ \\
\hline $\begin{array}{l}\text { Yranulometria da fração areia } \\
\text { e teor de pelíticos }\end{array}$ & $\begin{array}{l}m-\text { areia média a fina, em média com teor de pelíticos de } \\
\text { até } 15 \% \\
f-\text { areia fina, com teor de pelíticos de } 15 \text { a } 20 \% \\
p \text { - areia fina, com teor de pelíticos maior do que } 20 \%\end{array}$ \\
\hline $\begin{array}{c}\mathrm{z} \\
\text { Cimento predominante }\end{array}$ & $\begin{array}{l}s-\text { até } 15 \% \text { de esmectita } \\
\text { sx }- \text { mais do que } 15 \% \text { de esmectita } \\
\text { a }-20 \text { a } 40 \% \text { de material argilo-ferruginoso }\end{array}$ \\
\hline
\end{tabular}

\subsection{Análise via MEV-EDS}

Com a finalidade de caracterizar a micromorfologia e a composição química dos cimentos dos arenitos, amostras representativas das diferentes mineralogias de cimento foram selecionadas e submetidas à análise pelo sistema composto pelo MEV e o EDS. O equipamento utilizado foi um LEO 440I, do Laboratório de Microscopia Eletrônica do IGc-USP.

Para verificar os elementos químicos que constituem os cimentos, seções delgadas foram recobertas com películas de carbono e submetidas à incidência do feixe de elétrons. A detecção dos elétrons emitidos pela superfície da amostra foi feita com o detector de elétrons retroespalhados (backscattered electrons detector BSD), que gera imagens em tons de cinza correspondentes a variações do peso atômico médio dos constituintes elementares. O EDS detecta os raios $\mathrm{X}$ emitidos pela amostra, possibilitando realizar análises químicas elementares pontuais; estas análises têm caráter apenas semiquantitativo quando as amostras possuem superfície irregular, caso de amostras brutas em fratura fresca por exemplo; mas fornecem resultado quantitativo se as amostras forem planas, como seções delgadas; neste caso, a quantificação é tão mais precisa quanto mais perfeitamente plana for a superfície da amostra.

A micromorfologia dos cimentos foi avaliada por meio da detecção de elétrons emitidos pela superfície de amostras brutas subcentimétricas de arenitos, em fratura viva, recobertas com película de ouro, após emissão de feixe eletrônico, por meio de detector de elétrons secundários (secondary electrons - SE), que produz imagens representativas da topografia da amostra. 


\subsection{Análises granulométricas}

Amostras desagregadas, com massas secas iniciais de cerca de $60 \mathrm{~g}$, foram submetidas à remoção da fração pelítica através de elutriação e, posteriormente, por meio de peneiramento em malha de $0,063 \mathrm{~mm}$ ao vibrador mecânico. A fração granulométrica entre as peneiras de $0,063 \mathrm{~mm}(4 \varphi)$ e $1 \mathrm{~mm}(0 \varphi)$ foi reservada. A massa seca final do resíduo da elutriação foi pesada e o teor de pelíticos calculado pela proporção percentual, em relação à massa seca total inicial da amostra, da diferença entre esta massa seca total inicial e a massa seca final do elutriado.

A fração areia abaixo de $1 \mathrm{~mm}$, retida no procedimento anterior, foi submetida ao analisador de partículas Malvern Mastersizer 2000, que calcula matematicamente o tamanho das partículas a partir da difração por elas provocada num feixe de raios laser, segundo a teoria de Mie-Fraunhoffer. O modelo físico-matemático adotado considera partículas dispersas em movimento aleatório, das quais se infere, portanto, um eixo geométrico médio.

Os resultados de distribuição granulométrica da areia obtidos no difratômetro a laser agrupados em intervalos de 0,125 $\varphi$ foram submetidos ao cálculo de estatísticas descritivas de tendência central (tamanho médio e desvio padrão) pela técnica analítica dos momentos de Pearson.

Foram submetidas a estes procedimentos 59 amostras, dentre as quais 20 referentes à sondagem SM-222 e 39 às demais sondagens. A partir dos resultados destas 39, calcularam-se medianas dos dados granulométricos de cada unidade geológico-geotécnica, para possibilitar a correlação destas informações com os dados das respectivas seções petrográficas.

\subsection{Determinação da densidade e porosidade aparentes}

Corpos de prova com aproximadamente 100 a $350 \mathrm{~g}$ foram secos em estufa ventilada, a cerca de $35^{\circ} \mathrm{C}$ até massa constante.

Os corpos de prova foram então pesados com resolução de $0,01 \mathrm{~g}$, fornecendo a massa seca $\left(\mathrm{M}_{\mathrm{sec}}\right)$.

Após a pesagem, cada corpo de prova foi colocado em um recipiente individual e, com auxílio de pisseta, foi despejada nos recipientes água ou querosene (nome comercial para mistura líquida de hidrocarbonetos alifáticos, 
naftênicos e aromáticos), até completar cerca de $1 / 3$ da altura das amostras. Após $24 \mathrm{~h}$, adicionou-se água ou querosene até $2 / 3$ da altura das amostras e, após mais $24 \mathrm{~h}$, completou-se o recipiente com água ou querosene até que os corpos de prova ficassem completamente submersos, assim permanecendo por mais $40 \mathrm{~h}$, no mínimo.

Após este procedimento, os corpos de prova foram pesados individualmente na condição de submersão no querosene ou na água, por meio de dispositivo para pesagem hidrostática, obtendo-se assim a massa submersa $\left(M_{\text {sub }}\right)$.

Os corpos de prova foram então retirados da imersão, e suas superfícies enxugadas com pano levemente embebido em querosene ou água, dependendo do líquido de submersão. Após este procedimento, foram pesados ao ar, para obtenção da massa saturada ( $\left.M_{\text {sat }}\right)$.

Com base nas massas medidas pelos procedimentos acima, obtiveram-se os valores da densidade aparente $\left(\rho_{\mathrm{a}}\right)$ e da porosidade aparente $\left(\eta_{\mathrm{a}}\right)$, conforme as equações 2.6 .1 e 2.6.2, onde $\rho_{l}$ é a densidade do líquido de imersão (a densidade aparente obtida para o querosene durante o ensaio foi de $789 \mathrm{~kg} / \mathrm{cm}^{3}$; para a densidade da água, utilizou-se o valor de $1000 \mathrm{~kg} / \mathrm{cm}^{3}$ ).

$$
\begin{aligned}
& \rho_{\mathrm{a}}=\frac{M_{\text {sec }}}{M_{\text {sat }}-M_{\text {sub }}} \times \rho_{l} \\
& \eta_{\mathrm{a}}=\frac{M_{\text {sat }}-M_{\text {sec }}}{M_{\text {sat }}-M_{\text {sub }}} \times 100
\end{aligned}
$$

Equação 2.6.1

Equação 2.6.2

O método para a execução destes ensaios é uma modificação dos procedimentos sugeridos pela norma ABNT NBR 15845-2 (ABNT, 2015). As dimensões e o número dos corpos de prova, o líquido utilizado para saturação e pesagem submersa e a ordem dos procedimentos foram adaptados à situação enfrentada neste trabalho. As dimensões tiveram que ser reduzidas em alguns casos, por não se dispor de amostras maiores, e a água foi muitas vezes substituída pelo querosene, por mostrar-se agressiva à grande parte dos arenitos analisados, isto é, levá-los à desagregação em questão de horas ou mesmo minutos após a imersão. Em vista da substituição da água pelo querosene em parte dos casos, a pesagem das amostras secas foi realizada anteriormente à saturação, de modo a evitar colocar dentro da estufa amostras saturadas em querosene, que é inflamável. 
Foi submetido aos ensaios de determinação de densidade e porosidade aparentes um total de 53 amostras, 24 das quais referentes a 17 pontos distintos distribuídos ao longo da seção colunar da sondagem SM-222. As demais 29 amostras referem-se àquelas obtidas nas sondagens SM-201, SM-208, SM-210, SM-216, SM-224 e SM-505. Para fins de correlação com demais propriedades, calcularam-se as medianas da densidade e porosidade aparentes representativas das diferentes unidades geológico-geotécnicas reconhecidas nestas sondagens. Os dados relativos a estes ensaios são apresentados em detalhe no Apêndice B.

\subsection{Ensaios mecânicos}

Nesta seção, são apresentadas informações relacionadas à obtenção de parâmetros mecânicos dos arenitos, especificamente $\sigma_{u}$ e $E_{s}$, incluindo procedimentos adotados na confecção dos corpos de prova e métodos e aparato utilizados nos ensaios de compressão e medição da deformação axial.

\subsubsection{Moldagem dos corpos de prova}

A moldagem dos corpos de prova consistiu em desgastar o topo e a base de cada amostra, com uso de lixa para ferro, de gramatura entre 100 e 150 mesh (\#).

Para garantir que o topo e a base de cada corpo de prova estariam perfeitamente paralelos entre si, utilizaram-se gabaritos de tubo PVC com $75 \mathrm{~mm}$ de diâmetro. Cada gabarito teve o topo e a base desgastados em um torno, até que ambos ficassem perfeitamente perpendiculares ao eixo do tubo e paralelos entre si. Após este procedimento, os tubos foram serrados paralelamente ao eixo, de maneira que pudessem ser abertos e encaixados ao redor dos testemunhos (Figura 2.7.1 A).

Antes de iniciar o processo de moldagem, as amostras foram mantidas em estufa, à temperatura de cerca de $35^{\circ} \mathrm{C}$ até massa constante.

Após a secagem, cada amostra foi envolvida pelo gabarito e submetida a processo de abrasão. Para isso, foi levemente pressionada contra as lixas, por meio de movimentos circulares em forma de "8" (Figura 2.7.1 B).

Após a moldagem, os corpos de prova foram pesados e tiveram suas dimensões medidas com paquímetro em pelo menos quatro pontos espaçados regularmente. 

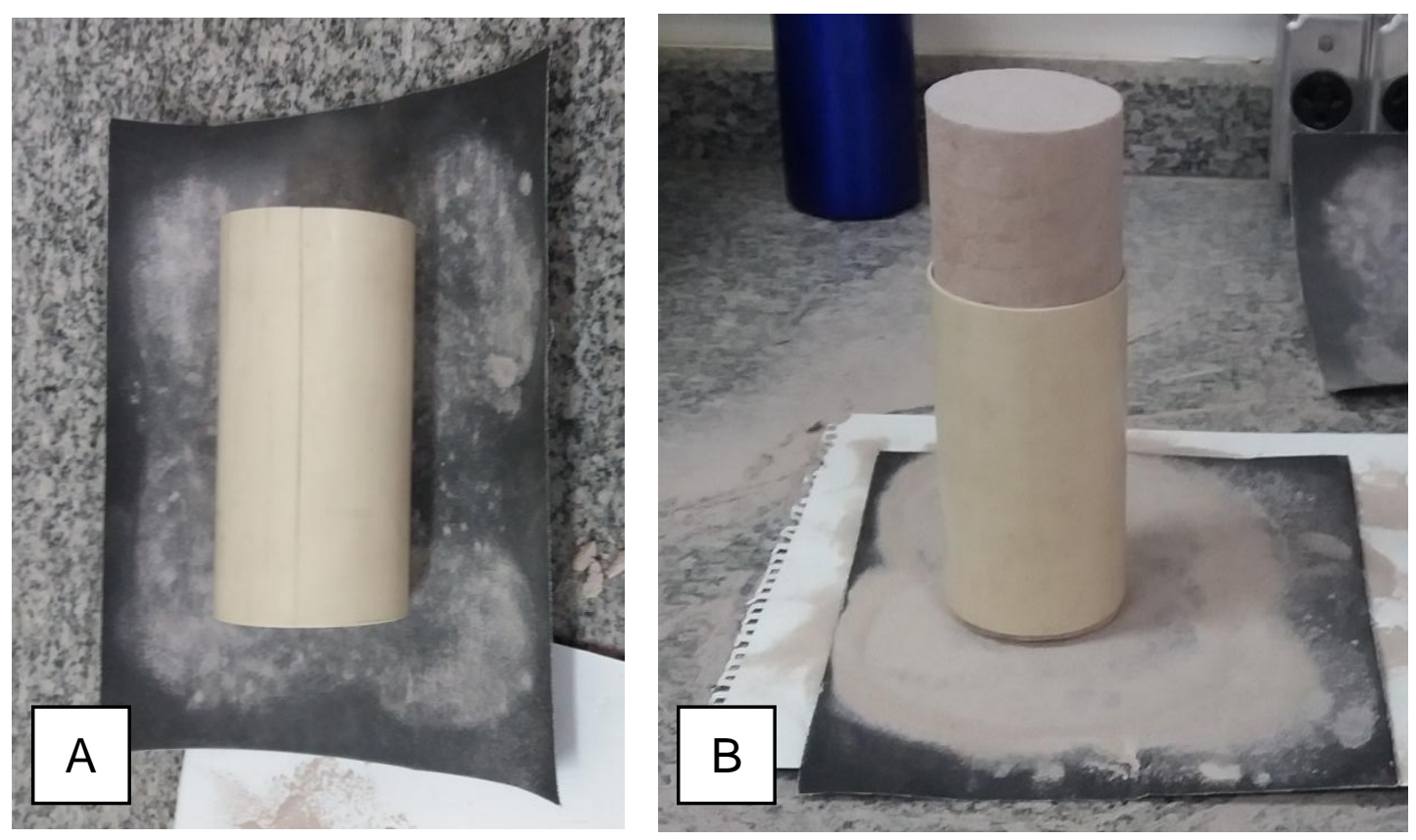

Figura 2.7.1 - Preparação de corpo de prova. A. Lixa para ferro e gabarito de tubo PVC utilizados na moldagem dos corpos de prova. B. Corpo de prova em processo de moldagem.

A moldagem dos corpos de prova impôs uma série de desafios e nem todos puderam ser resolvidos da maneira ideal.

Idealmente, procurou-se moldar corpos de prova com relação comprimento:diâmetro entre 2 e 3, conforme sugestão da ISRM (1999) e ASTM (2017). Porém, isto não foi possível em todos os casos. Alguns tipos de arenitos estratificados fragmentaram-se sistematicamente em peças com relação comprimento/diâmetro menor do que a normatizada.

Para contornar este problema, procuraram-se maneiras de diminuir 0 diâmetro das amostras. Primeiramente, foi feita uma tentativa de tornear uma das amostras. No entanto, já durante o processo de fixação no torno, a amostra quebrou-se ao longo da estratificação, não restando dúvidas de que os arenitos em estudo não resistiriam ao processo de torneamento.

Outra tentativa, mais engenhosa, consistiu na extração de uma amostra de menor diâmetro por meio de um sobrefuro no testemunho. Para tanto, a porção central do testemunho foi envolvida com filme de PVC, deixando apenas duas estreitas faixas expostas no topo e na base. $O$ testemunho foi então colocado, com seu eixo na posição vertical, dentro de um recipiente com cerca de um quarto de seu volume ocupado por argamassa fresca de cimento e areia. Completou-se então o 
recipiente com argamassa. Após a secagem, foram feitas as tentativas de extração. Para isso, utilizaram-se extratores Hilt, gentilmente cedidos pelo IPT. Porém, as amostras fragmentaram-se em tamanhos menores do que o esperado.

Por fim, para contornar este problema, optou-se por utilizar a Equação 2.7.1, proposta por Turk \& Dearman (1986), que padroniza os resultados para razão comprimento:diâmetro 2:1 e diâmetro de $50 \mathrm{~mm}$. Nessa equação, $\sigma_{50}$ é a resistência à compressão uniaxial de um corpo de prova com $50 \mathrm{~mm}$ de diâmetro e relação comprimento:diâmetro 2:1, $\sigma_{\mathrm{m}}$ é a resistência à compressão uniaxial do corpo de prova não padronizado e $\mathrm{D}$ e $\mathrm{L}$ são, respectivamente, o diâmetro e o comprimento do corpo de prova.

$$
\sigma_{50}=\sigma_{m} x \frac{D^{0,18}}{1,754+0,535\left(\frac{D}{L}\right)}
$$

Irregularidades presentes nas superfícies dos corpos de prova foram observadas e medidas. Para eliminar estas irregularidades, fez-se nova tentativa de utilizar um torno para moldar as amostras, desta vez com melhores resultados. O procedimento adotado consistiu em fixar no torno o corpo de prova, com as extremidades previamente esmeradas e auxílio de proteção feita com tubo de PVC. A amostra foi então esmerada manualmente com lixa para ferro de gramatura entre 100 e 150 \#. No entanto, por danificar com frequência os corpos de prova, este procedimento foi adotado apenas em casos de irregularidade extrema.

\subsubsection{Determinação da resistência à compressão uniaxial e módulo de deformabilidade}

Apesar dos procedimentos adotados para minimizar a deformação inelástica dos arenitos, a deformação medida nos ensaios de compressão uniaxial pode não ser puramente elástica. Por esta razão, o que as medidas permitem é o cálculo do "módulo de deformabilidade", termo que pode incluir as duas componentes, elástica e inelástica, da deformação, e não do "módulo de elasticidade", ou "módulo de Young", o qual se refere a rigor apenas à deformação elástica. De acordo com Dobereiner (1984), a expressão "módulo de deformabilidade" é a mais adequada na maioria das rochas brandas. 
Para a realização dos ensaios de resistência à compressão, utilizou-se uma máquina eletromecânica da marca EMIC, modelo DL10000, com capacidade de 100 kN (Figura 2.7.2 A) e, para as medidas de deformação axial, dois extensômetros dessa mesma marca, com resolução de 0,0001 mm (Figura 2.7.2 B). O software utilizado para a leitura dos dados foi o Tesc 13.1. Foram submetidos aos ensaios de resistência à compressão 39 corpos de prova, dentre os quais 27 com medidas de deformação axial por meio dos extensômetros para a determinação do módulo de deformabilidade.

Primeiramente, realizaram-se ensaios-piloto de resistência à compressão uniaxial em até dois corpos de prova representativos de cada uma das unidades geológico-geotécnicas, sem aferir as deformações. Nestes ensaios-piloto, aplicou-se taxa de carregamento de $6 \mathrm{kN} / \mathrm{min}$, até que os corpos de prova se rompessem, 0 que ocorreu em um intervalo variável entre 2 a 15 minutos. As tensões de ruptura assim obtidas foram utilizadas como referência nos ensaios de obtenção dos módulos de deformabilidade, descritos a seguir.

Para a determinação dos módulos de deformabilidade, fizeram-se ensaios de carregamento com medida de deformação axial. O plano de carga destes ensaios consistiu na realização de duas fases de carregamento e descarregamento entre tensões estipuladas a $30 \%$ e 10\% das tensões de ruptura de referência obtidas nos ensaios-piloto (doravante referidas como $\sigma_{B}$ e $\sigma_{A}$, respectivamente), e numa terceira e última fase, que consistiu no carregamento até a ruptura (Quadro 2.7.1).

Antes do início dos ensaios, os extensômetros foram fixados no terço médio dos corpos de prova, em posições diametralmente opostas, com auxílio de anéis de borracha. Na primeira fase, os corpos de prova foram carregados em $60 \mathrm{~s}$ até $\sigma_{\mathrm{B}}$, sob a qual foram mantidos por $30 \mathrm{~s}$. Os corpos de prova foram então descarregados em cerca de $40 \mathrm{~s}$ até $\sigma_{\mathrm{A}}$, sob a qual foram mantidos por mais $30 \mathrm{~s}$. Na segunda fase, repetiu-se o mesmo processo e, na terceira fase de carregamento, após atingir $\sigma_{B}$, os extensômetros foram removidos e o carregamento prosseguiu até a ruptura dos corpos de prova (Figura 2.7.3 A).

$\mathrm{O}$ módulo de deformabilidade secante $\left(\mathrm{E}_{\mathrm{s}}\right)$ corresponde à tangente da reta definida pelos pontos equivalentes à $\sigma_{B}$ e $\sigma_{A}$ e suas respectivas deformações axiais específicas $\left(\varepsilon_{\mathrm{aA}}\right.$ e $\left.\varepsilon_{\mathrm{aB}}\right)$, secante à curva correspondente ao último ciclo de carregamento (Figuras 2.7.3 B e C). Os gráficos de tempo versus tensão $(\sigma)$ e 
deformação axial específica $\left(\varepsilon_{\mathrm{a}}\right)$ versus tensão $(\sigma)$ dos ensaios realizados são apresentados no Apêndice $C$.
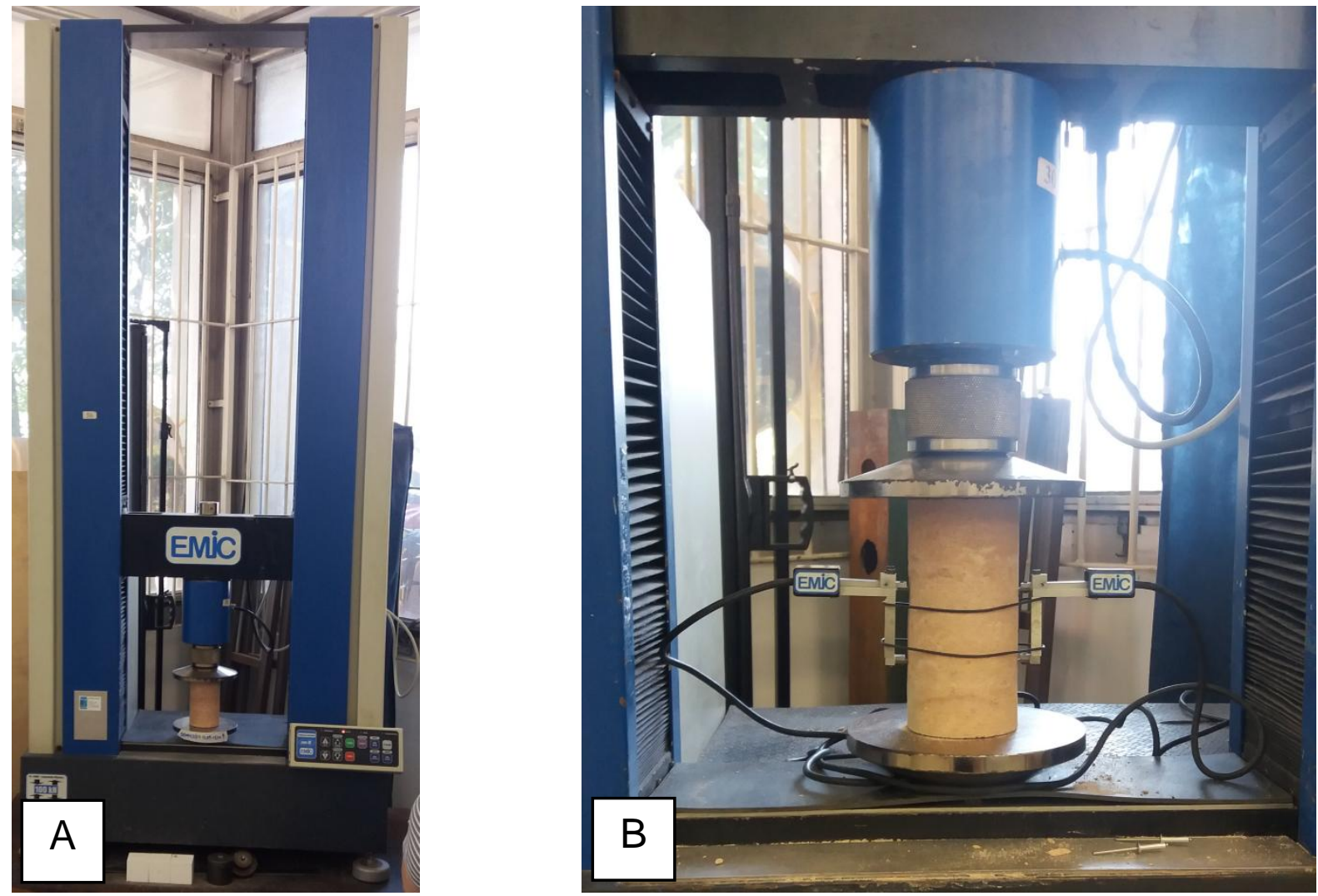

Figura 2.7.2 - Equipamentos utilizados nos ensaios de resistência à compressão uniaxial. A. Máquina eletromecânica com corpo de prova. B. Detalhe da montagem, com extensômetros posicionados no corpo de prova.

Quadro 2.7.1 - Descrição telegráfica do plano de carga utilizado na execução dos ensaios para determinação de $\sigma_{u}$ e $E_{s}$.

\begin{tabular}{|c|c|c|c|}
\hline \multirow{2}{*}{ Fase } & Descrição & $\begin{array}{c}\text { Tempo } \\
(\mathbf{s})\end{array}$ & $\begin{array}{c}\text { Tempo acumulado } \\
(\mathbf{s})\end{array}$ \\
\hline \multirow{4}{*}{1} & Carregamento até tensão $\sigma_{\mathrm{B}}$ & 60 & 60 \\
\cline { 2 - 4 } & Manutenção da tensão $\sigma_{\mathrm{B}}$ & 30 & 90 \\
\cline { 2 - 4 } & Descarregamento até tensão $\sigma_{\mathrm{A}}$ & 40 & 130 \\
\hline \multirow{3}{*}{2} & Manutenção da tensão $\sigma_{\mathrm{A}}$ & 30 & 160 \\
\cline { 2 - 4 } & Carregamento até tensão $\sigma_{\mathrm{B}}$ & 60 & 220 \\
\cline { 2 - 4 } & Manutenção da tensão $\sigma_{\mathrm{B}}$ & 30 & 250 \\
\cline { 2 - 4 } & Descarregamento até tensão $\sigma_{\mathrm{A}}$ & 40 & 290 \\
\hline \multirow{3}{*}{3} & Manutenção da tensão $\sigma_{\mathrm{A}}$ & 30 & 320 \\
\cline { 2 - 4 } & Carregamento até tensão $\sigma_{\mathrm{B}}$ & 60 & 380 \\
\cline { 2 - 4 } & Remoção dos extensômetros e carregamento até a & - & - \\
\hline
\end{tabular}



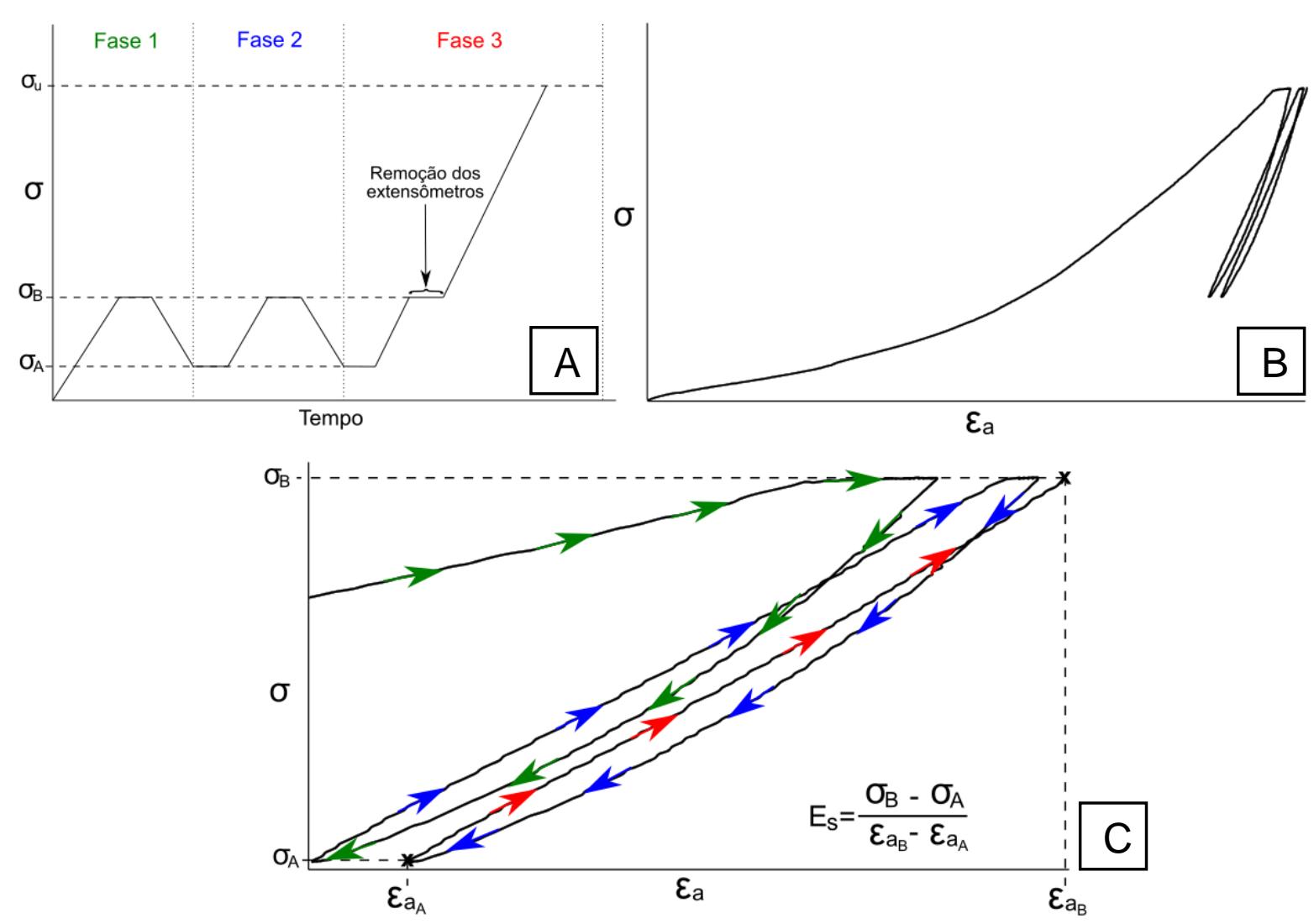

Figura 2.7.3 - Gráficos de determinação dos módulos de deformabilidade. A. Tensão $(\sigma) \times$ tempo, com representação das fases de carregamento. B. Tensão $(\sigma)$ versus deformação axial específica $\left(\varepsilon_{a}\right)$ completa. C. Ampliação do trecho correspondente às fases de carregamento no gráfico da tensão $(\sigma)$ versus deformação axial específica $\left(\varepsilon_{\mathrm{a}}\right)$ completa. $\mathrm{O}$ módulo de deformabilidade secante $\left(\mathrm{E}_{\mathrm{s}}\right)$ equivale à tangente da reta definida pelos pontos $\left(\varepsilon_{\mathrm{aB}} ; \sigma_{\mathrm{B}}\right)$ e $\left(\varepsilon_{\mathrm{aA}} ; \sigma_{\mathrm{A}}\right)$, secante à curva correspondente ao último ciclo de carregamento (setas vermelhas).

\subsection{Tratamento gráfico-estatístico de resultados}

Para verificar a existência de correlações entre as diversas propriedades analisadas, foram construídas matrizes contendo os coeficientes de correlação linear (r) e o respectivo nível de significância $p$ (erro I) e confeccionados diagramas de dispersão, correlacionando propriedades duas a duas.

As correlações entre dados petrográficos e entre estes dados e aqueles obtidos via elutriação (teor de pelíticos) e analisador de partículas Malvern Mastersizer 2000 foram realizadas com um número de amostras $N=27$, referente a cada seção petrográfica analisada. Nestas correlações, os teores de pelíticos e os dados obtidos pelo analisador de partículas referem-se a 20 amostras da sondagem SM-222, e a 39 amostras das sondagens SM-201, SM-208, SM-210, SM-216, SM224 e SM-505. Os dados granulométricos assim obtidos, referentes à sondagem SM-222 foram correlacionados diretamente com os dados petrográficos correlatos 
às respectivas profundidades. No caso das amostras das demais sondagens, foram calculadas medianas representativas das sete unidades geológico-geotécnicas identificadas nestas sondagens (tabelas 4 e 5 do Apêndice A).

Nas correlações de $\rho_{a}$ e $\eta_{a}$ com propriedades petrográficas e dados granulométricos obtidos via analisador de partículas e elutriação o número de amostras utilizado foi $\mathrm{N}=24$.

Em correlações entre dados obtidos via petrografia óptica e dados obtidos nos ensaios mecânicos, o número de amostras utilizado foi $\mathrm{N}=7$, compatível ao número de seções petrográficas avaliadas para as unidades geológico-geotécnicas reconhecidas nos testemunhos das sondagens SM-201, SM-208, SM-210, SM-216, SM-224 e SM-505. Para tanto, foram calculadas sete medianas representativas de $\sigma_{50}$ a partir dos resultados de 39 ensaios de resistência à compressão uniaxial, e outras sete medianas representativas de $E_{s}$ a partir dos resultados de 27 ensaios de compressão com medidadas de deformação axial por meio de extensômetros.

As correlações de $\sigma_{50}$ com teor de pelíticos e dados granulométricos obtidos via analisador de partículas contou com $\mathrm{N}=39$, uma vez que as amostras submetidas a estes ensaios granulométricos foram obtidas a partir dos 39 corpos de prova rompidos após os ensaios de compressão. Assim, correlações de $E_{s}$ com estes dados foram realizadas com $\mathrm{N}=27$, referente ao número de ensaios de compressão com medidas de deformação axial.

Nos resultados (Item 3.6) são discutidas as correlações entre os diferentes parâmetros cujos valores $p$ são menores do que 5\%. A matriz de valores de cada propriedade, relacionadas duas a duas, e seus respectivos valores de $r$ e $p$, encontram-se no Apêndice $E$.

A distribuição de dados por agrupamentos foi representada por meio de diagramas de caixa (boxplots - Figura 2.8.1), que indicam a posição da mediana (ou segundo quartil da curva acumulativa - Q2), do primeiro e terceiro quartis (Q1 e Q3, respectivamente), além dos limites inferior e superior (LI e LS, respectivamente), proporcionais ao intervalo interquartis (IIQ), definidos pelas equações 2.8.1 e 2.8.2. Dados menores ou maiores do que estes limites foram considerados discrepantes (outliers). 
$\circ \longleftarrow$ discrepante

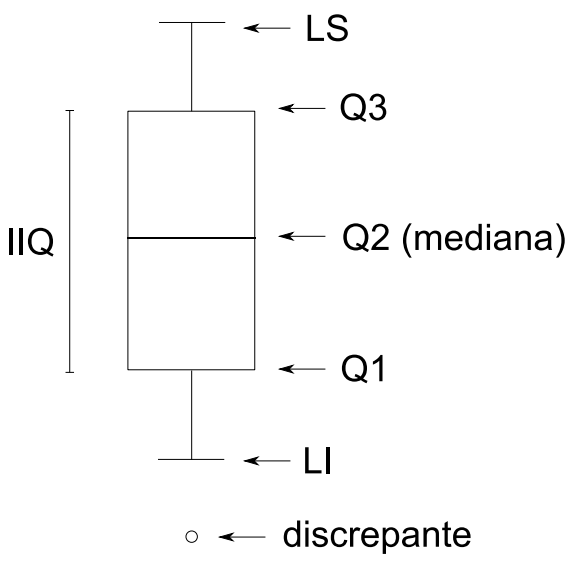

Figura 2.8.1 - Diagrama de caixa utilizado para representar a distribuição de dados por agrupamentos. LI: limite inferior. LS: limite superior. Q1: primeiro quartil. Q2: segundo quartil (mediana). Q3: terceiro quartil. IIQ: intervalo interquartis.

$$
\begin{array}{ll}
L I=Q 1+1,5 x I I Q & \text { Equação 2.8.1 } \\
L S=Q 3+1,5 x I I Q & \text { Equação 2.8.2 }
\end{array}
$$

Para verificar se há diferença significativa nas médias das propriedades petrográficas, físicas e mecânicas entre os agrupamentos por grau de coerência, aplicaram-se análises de variância (ANOVA) para cada variável. Nestes testes, foram considerados significativos os resultados com valor $p<5 \%$.

Anteriormente à aplicação da ANOVA, fizeram-se testes para verificar se os pressupostos básicos da ANOVA eram satisfeitos. As premissas de normalidade da distribuição das populações e de homocedasticidade foram averiguadas com base nos testes de Shapiro-Wilk e Levene, respectivamente, avaliados ao nível de 5\% de significância, de maneira que valores $p$ superiores a $5 \%$ implicam que os resíduos distribuem-se normalmente e que os erros têm variância comum, validando o modelo da ANOVA.

Não sendo satisfeita uma destas premissas básicas, foi conduzido o teste de Kruskal-Wallis $(\mathrm{KW})$, sendo considerados significativos resultados com valores $p<5 \%$.

As variáveis cujos testes ANOVA obtiveram valor $p<5 \%$ foram submetidas ao teste de comparações múltiplas de Tukey, possibilitando verificar quais pares de grupos apresentam diferenças significativas nas médias. Visando cumprir esta 
finalidade para os testes $\mathrm{KW}$ com valor $p<5 \%$, foram feitos testes de comparações múltiplas de Dunn, com valores $p$ ajustados pelo método de Benjamini e Hochberg.

Os números amostrais foram de $\mathrm{N}=27$ para os testes dos graus de coerência com propriedades petrográficas e dados granulométricos obtidos por analisador de partículas e elutriação, $N=24$ para os testes dos graus de coerência com porosidade e densidade aparentes, $\mathrm{N}=39$ para os testes entre graus de coerência e $\sigma_{50}$ e $N=27$ para os testes entre graus de coerência e $E_{s}$.

Os resultados dos testes de normalidade e heterocedasticidade, assim como os da ANOVA e do teste de Kruskal-Wallis, são apresentados no Apêndice F. 


\section{RESULTADOS}

Nesta seção, apresentam-se, primeiramente, os resultados da revisão bibliográfica, e, nos itens subsequentes, os das análises laboratoriais, sucedidos pelos das correlações entre as propriedades petrográficas, físicas e mecânicas avaliadas.

\subsection{Revisão bibliográfica}

A revisão bibliográfica encontra-se dividida em duas subseções, respectivamente referentes à Formação Piramboia e às correlações, verificadas por outros autores, entre propriedades físico-mecânicas de arenitos e seus aspectos mineralógicas ou texturais.

\subsubsection{Formação Piramboia}

Inicialmente, o termo Piramboia era utilizado de modo informal para referir-se às rochas da base do Grupo São Bento, que se consideravam aflorantes apenas no nordeste da Bacia do Paraná, sobretudo no Estado de São Paulo. Assim, até o início dos anos 1970, toda a sucessão sedimentar dominantemente arenosa subjacente aos derrames basálticos era atribuída à Formação Botucatu. $E$, dentro desta formação, eram reconhecidos depósitos sedimentares de origem eólica (Arenito Botucatu strictu sensu), colúvio-flúvio-aluvial (Arenito Piramboia) e lacustre (Arenito ou Fácies Santana) (Washburne, 1930; Almeida \& Barbosa, 1953; Almeida, 1954; Bigarella \& Salamuni, 1961; Salamuni \& Bigarella, 1967).

A subdivisão estratigráfica das unidades sedimentares infra-derrames do Grupo São Bento nas formações Piramboia e Botucatu foi proposta formalmente por Soares (1973, 1975), com base em critérios faciológicos e de mapeabilidade das rochas aflorantes no centro-leste do Estado de São Paulo. De acordo com o autor, as duas unidades teriam origens distintas, de maneira que a Formação Piramboia, mais antiga, seria constituída por depósitos fluviais meandrantes, ao passo que a Formação Botucatu, sobrejacente, representaria depósitos predominantemente eólicos de ambiente desértico. Nestes trabalhos, o autor reconhece a existência de um conglomerado basal na Formação Botucatu. 
O consenso sobre a origem predominantemente subaquosa da Formação Piramboia passou a ser questionado por Lavina (1991), Caetano-Chang (1992) e Caetano-Chang \& Wu (1992a,b), que apontaram nesta unidade evidências de processos eólicos associados à sedimentação flúvio-lacustre. Mais além, de acordo com a interpretação de Caetano-Chang \& Wu (1992a,b), a Formação Piramboia registraria cenário deposicional predominantemente eólico, no qual canais fluviais seriam feições efêmeras e pequenas em comparação aos grandes campos de dunas.

De acordo com as interpretações mais recentes, a Formação Piramboia representa um sistema deposicional eólico úmido (sensu Kocurek \& Havholm, 1993), cuja base é constituída por fácies sedimentares eólicas desenvolvidas em um contexto costeiro proximal, sucedidas por fácies flúvio-eólicas no topo (Giannini et al. 2004; Gesicki 2007; Giannini et al. 2008). Nesta nova concepção, o conglomerado basal de Soares $(1973,1975)$ corresponde possivelmente a uma das fácies aluviais do topo do registro do sistema Piramboia. A umidade, sobretudo na base da unidade, estaria relacionada ao lençol freático raso, dada a proximidade do local de acumulação a um corpo de água (grande lago ou mar fechado, tipo golfo ou laguna) (Sawakuchi, 2000; Giannini, 2001; Donatti et al., 2001; Giannini et al., 2004; Giannini et al. 2008).

Devido principalmente ao escasso registro fossilífero, a idade da Formação Piramboia não é bem definida. Soares $(1973,1975)$ interpreta que a sedimentação se tenha dado entre o Triássico Médio e o limite Jurássico-Cretáceo, entendendo que o contato entre a base da Formação Piramboia e o topo do Grupo Passa Dois seja discordante. Riccomini et al. (1984), Lavina (1991) e Matos (1995), em contraposição, consideram este contato concordante e posicionam a Formação Piramboia no Permo-Triássico, admitindo hiato deposicional com a Formação Botucatu, sobrejacente.

O contato basal da Formação Piramboia com as formações Teresina e Corumbataí representa alteração nos processos de sedimentação, com desvanecimento de mecanismos deposicionais de água rasa e predomínio de processos subaéreos.

Fúlfaro (1972) interpreta esta transição como gradual e contínua, com aridez crescente, observada desde o final da deposição do Grupo Passa Dois até a deposição francamente eólica da Formação Botucatu. Reforçariam esta hipótese 
impressões de caules de licófitas típicas do Permiano (Lycopodiopsis derbyi, Souza et al., 1971) nos "arenitos Botucatu" sensu lato, em Cajuru (SP), atualmente interpretados como Formação Piramboia (Giannini et al. 2004).

Soares $(1973,1975)$, por sua vez, admite hiato deposicional indicado por paleossolo na passagem da Formação Teresina para a Formação Piramboia. Baseou sua interpretação em notável afloramento do contato entre as duas unidades, localizado no km 167 da Rodovia SP.280.

Vieira \& Mainqué (1973) destacaram que, apesar da mudança abrupta das litologias sedimentares dominantes, da formação Teresina para a Formação Piramboia, as fácies indicariam características transicionais, como interdigitações. Similarmente, Riccomini et al. (1984) reconheceram intercalações arenosas cada vez mais volumosas e aumento de granulometria para o topo no contato entre a Formação Rio do Rasto (Teresina) e a Formação Piramboia, no Paraná.

Lavina (1991) caracterizou o contato entre o Grupo Passa Dois e a Formação Piramboia como concordante e gradual no Estado do Rio Grande do Sul, mas não descartou que possam existir diastemas locais. Mais tarde, Lavina \& Faccini (1993) definiram contato interdigitado entre a Formação Rio do Rasto e as formações Piramboia e Sanga do Cabral.

Rohn (1994), com base no registro bioestratigráfico, notou discordância no topo da Formação Rio do Rasto, mas apontou "sugestivos contatos transicionais" ao longo da rodovia PR-090. Matos (1995) descreveu contato abrupto, mas não erosivo, e indicou um marco estratigráfico para a passagem Teresina-Piramboia no norte do Paraná e sul de São Paulo, denominado Camada Porangaba, constituída por brechas intraclásticas parcialmente silicificadas, com recorrência de fácies possivelmente eólicas, o que levou o autor a questionar a existência de discordância erosiva ou mesmo de hiato deposicional entre as unidades. A Camada Porangaba inclui a fácies interpretada como paleossolo por Soares $(1973,1975)$ no km 167 da Rodovia SP.280.

Caetano-Chang (1997) admite contato basal erosivo para a Formação Piramboia no centro-leste de São Paulo. Milani (1997) aponta contato interdigitado nas regiões Sul e Sudeste do país a partir de dados geofísicos. Com base em afloramentos dos estados de São Paulo e Paraná, Giannini et al. (2004) interpretam estruturas da sobrecarga exercida pelas areias da Formação Piramboia sobre as lamas do Grupo Passa Dois como evidência de contato transicional entre as 
unidades. No afloramento localizado no km 167 da Rodovia SP.280, Decloedt (2012) verificou interdigitações das areias características da Formação Piramboia com os bancos de laminações heterolíticas típicos da Formação Teresina, também sugerindo contato transicional.

\subsubsection{Correlação entre parâmetros petrográficos, físicos e mecânicos de arenitos}

Bell (1978) encontrou correlações significativas entre diversas propriedades petrográficas, físicas e mecânicas dos arenitos da Formação Fell (Quadro 3.1.1), e verificou que a densidade de empacotamento se correlaciona significativamente à resistência à compressão uniaxial e ao módulo de deformabilidade, conclusão compartilhada por Zorlu et al. (2008) para os arenitos da Formação Karakava, onde a densidade de empacotamento é a propriedade petrográfica de maior influência na resistência (Quadro 3.1.1). Bell (1978) sugere que, em arenitos compostos principalmente por quartzo, a composição mineralógica do arcabouço não influencia as propriedades físicas e mecânicas, já que pequenas variações mineralógicas do arcabouço não seriam suficientes para influenciar tais propriedades.

Fahy \& Guccione (1979) e Shakoor \& Bonelli (1991), por outro lado, encontraram correlações inversas significativas entre proporção de quartzo e resistência de diferentes formações dos EUA, ao passo que Zorlu et al. (2008) concluíram que o conteúdo de quartzo se correlaciona significativamente à resistência à compressão uniaxial de modo direto. Bell \& Culshaw (1998) e Bell \& Lindsay (1999), apesar de não terem encontrado correlações estatísticamente significativas entre parâmetros petrográficos e de resistência ou deformabilidade, concluíram que os conteúdos de quartzo e de argila influenciam direta e inversamente tanto resistência à compressão uniaxial quanto módulo de deformabilidade.

Contudo, Fahy \& Guccione (1979) concluem que as propriedades que mais afetam a resistência dos arenitos são texturais e de trama, tais como esfericidade, tamanho médio e mediano dos grãos e tipos de contatos intergranulares, além da presença de descontinuidades, como estratificação, e sua orientação em relação à tensão aplicada. 
Dobereiner (1984) e Dobereiner \& De Freitas (1986), em estudo contemplando arenitos de diversas partes do globo, testaram a influência de vários parâmetros texturais e de trama à resistência à compressão uniaxial e ao módulo de deformabilidade, e concluíram que a natureza dos contatos intergranulares é o parâmetro petrográfico de maior influência na resistência e deformabilidade dos arenitos. Posteriormente, outros autores obtiveram conclusões semelhantes (Shakoor \& Bonelli, 1991; Ulusay et al., 1994; Tamrakar et al., 2007; Zorlu et al., 2008).

De acordo com Ulusay et al. (1994), a resistência à compressão uniaxial dos Arenitos Kozlu (Quadro 3.1.1) também é influenciada significativamente pelo arredondamento dos grãos, ao passo que o módulo de deformabilidade se correlaciona ao tamanho médio dos grãos, à proximidade de empacotamento e às proporções de contatos grão-matriz e intergranulares.

Jeng et al. (2004) concluíram que os parâmetros de maior influência na resistência à compressão uniaxial de arenitos terciários de Taiwan são a porosidade e a GAR (grain area ratio) conforme Ersoy \& Waller (1995), que representa a porcentagem de grãos em um arenito.

Segundo Tamrakar et al. (2007), outros parâmetros petrográficos que influenciam a resistência à compressão uniaxial de maneira significativa são porosidade modal, cimentação, proporções de contatos grão-cimento e de contatos intergranulares, densidade e proximidade de empacotamento; enquanto isso, o módulo de deformabilidade seria afetado pela porosidade modal e pela proporção de contatos grão-vazio.

Bell (1978), Shakoor \& Bonelli (1991), Ulusay et al. (1994) e Bell \& Lindsay (1999) encontraram correlações significativas da densidade com resistência à compressão uniaxial e módulo de deformabilidade. Os mesmos autores, com exceção de Ulusay et al. (1994), também encontraram correlações significativas da porosidade com resistência e deformabilidade. 
Quadro 3.1.1 - Unidades litoestratigráficas de arenitos estudadas em trabalhos de correlação entre propriedades petrográficas e geomecânicas.

\begin{tabular}{|c|c|c|c|}
\hline Autor & $\begin{array}{c}\text { Unidade } \\
\text { litoestratigráfica }\end{array}$ & Idade & Local \\
\hline Bell (1978) & Fell & $\begin{array}{c}\text { Carbonífero (Mississipiano, } \\
\text { Viseano) }\end{array}$ & $\begin{array}{l}\text { Northumberland - } \\
\text { Inglaterra }\end{array}$ \\
\hline $\begin{array}{l}\text { Fahy \& } \\
\text { Guccione } \\
\text { (1979) }\end{array}$ & Blackhawk & Cretáceo Superior (Campaneano) & $\begin{array}{c}\text { Huntington, Utah - } \\
\text { EUA }\end{array}$ \\
\hline \multirow{4}{*}{$\begin{array}{c}\text { Dobereiner } \\
(1984) \text { e } \\
\text { Dobereiner \& } \\
\text { De Freitas } \\
(1986)\end{array}$} & Kidderminster & Eotriássico & $\begin{array}{c}\text { Bromsgrove - } \\
\text { Inglaterra }\end{array}$ \\
\hline & Bauru & Cretáceo & $\begin{array}{l}\text { Pereira Barreto, São } \\
\text { Paulo - Brasil }\end{array}$ \\
\hline & Lahti & Neogeno (Plioceno) & Cizre - Turquia \\
\hline & Waterstones & Permo-Triássico & $\begin{array}{l}\text { Tarporley, Cheshire - } \\
\text { Inglaterra }\end{array}$ \\
\hline \multirow{4}{*}{$\begin{array}{c}\text { Shakoor \& } \\
\text { Bonelli (1991) }\end{array}$} & Berea & Carbonífero (Mississipiano) & Ohio - EUA \\
\hline & Sharon & Carbonífero (Pensilvaniano) & Ohio - EUA \\
\hline & Juniata & Ordoviciano & Pensilvânia - EUA \\
\hline & Morgantown-Grafton & Carbonífero (Pensilvaniano) & West Virginia - EUA \\
\hline $\begin{array}{l}\text { Ulusay et } \\
\text { al.(1994) }\end{array}$ & Kozlu & Carbonífero (Westfaliano A) & Zonguldak - Turquia \\
\hline $\begin{array}{l}\text { Bell \& Culshaw } \\
\quad(1998)\end{array}$ & Sneinton & Triássico Médio (Anisiano) & $\begin{array}{l}\text { Nottinghamshire - } \\
\text { Inglaterra }\end{array}$ \\
\hline $\begin{array}{l}\text { Bell \& Lindsay } \\
\quad(1999)\end{array}$ & Newspaper & Ordoviciano-Siluriano & Durban - África do Sul \\
\hline $\begin{array}{l}\text { Jeng et al. } \\
(2004)\end{array}$ & $\begin{array}{c}\text { WGS, MS, TL, ST, NK, } \\
\text { TK, SFG, CL }\end{array}$ & $\begin{array}{c}\text { Paleogeno (Oligoceno) e Neogeno } \\
\text { (Mioceno, Plioceno) }\end{array}$ & Taiwan \\
\hline $\begin{array}{l}\text { Tamrakar et al. } \\
(2007)\end{array}$ & Siwalik & Neogeno (Mioceno) & Nepal \\
\hline $\begin{array}{l}\text { Zorlu et al. } \\
(2008)\end{array}$ & Karakaya & Triássico & Ankara - Turquia \\
\hline
\end{tabular}

\subsection{Fácies reconhecidas}

A partir da análise dos testemunhos da sondagem SM-222 (Figura 3.2.1), foram definidas quatro fácies, descritas a seguir:

- Arenito com intercalações pelíticas - Ap: arenito muito fino a fino, siltoargiloso, com estratificação sub-horizontal (ângulo de mergulho de até $10^{\circ}$ ) e intercalações pelíticas de coloração vermelha. O formato ondulado das intercalações pelíticas (Figura 3.2.2 A) sugere tratar-se de laminação heterolítica (flaser/wavy), nesse caso formada em condições subaquosas; encontram-se também lentes de lama com contatos nítidos, côncavas para cima ou inclinadas ao acamamento, sugestivas de flocos de lama encurvados (Figura 3.2.2 B), estrutura típica de remobilização e soterramento, por ação eólica, de polígonos de gretação de lama. 
- Arenito com estratificação nítida - Ae: arenito muito fino a médio, de coloração cinza, amarela, roxa ou rósea, com estratificação sub-horizontal a inclinada (cerca de 20 $0^{\circ}$ (Figura 3.2.3 A).

- Arenito com estratificação incipiente ou parcialmente obliterada - $A e_{j}$ : arenito muito fino a médio, de coloração, amarela, roxa ou rósea, muitas vezes com aspecto mosqueado, apresentando estratificação tênue sub-horizontal a inclinada (cerca de $10^{\circ}$ ) (Figura 3.2.3 B).

- Arenito maciço - Am: arenito com bimodalidade granulométrica não segregada, muito fino a médio, com grãos esparsos de areia grossa a seixos de até $5 \mathrm{~mm}$ e com clastos de lama, estes geralmente de coloração rósea, podendo também ser cinza, amarela ou roxa (Figura 3.2.4).

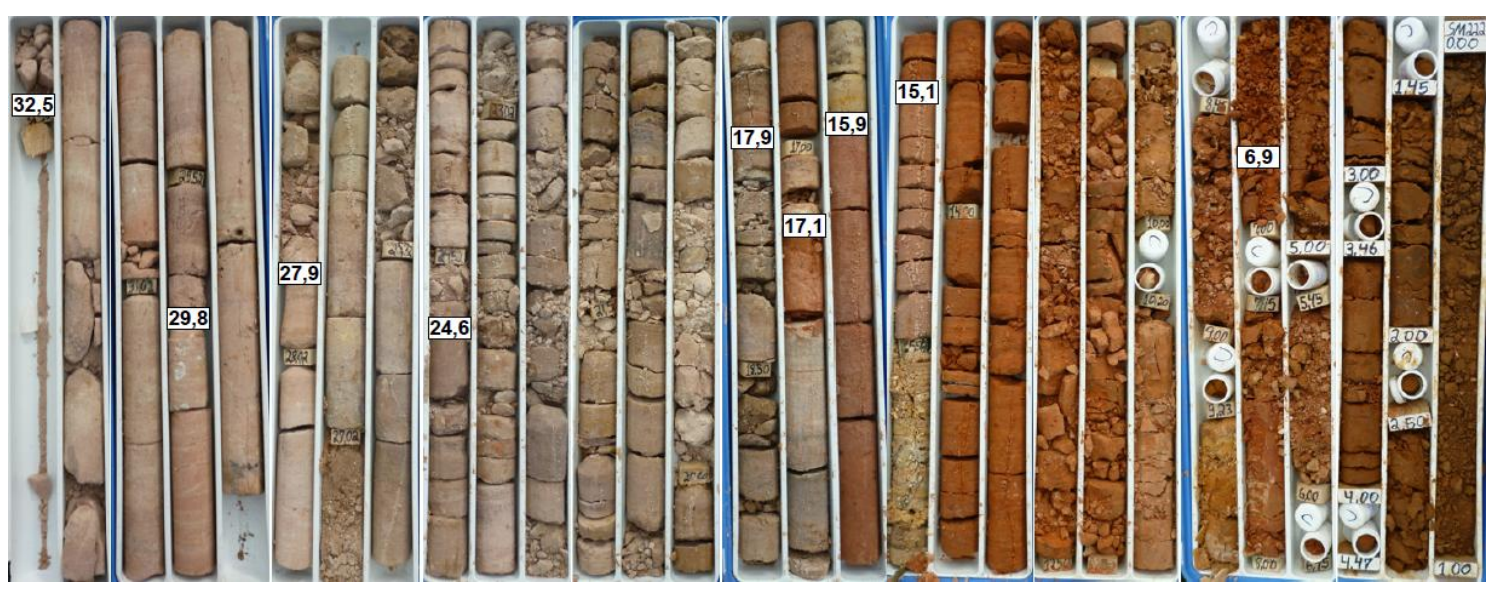

Figura 3.2.1 - Testemunhos da sondagem SM-222. 

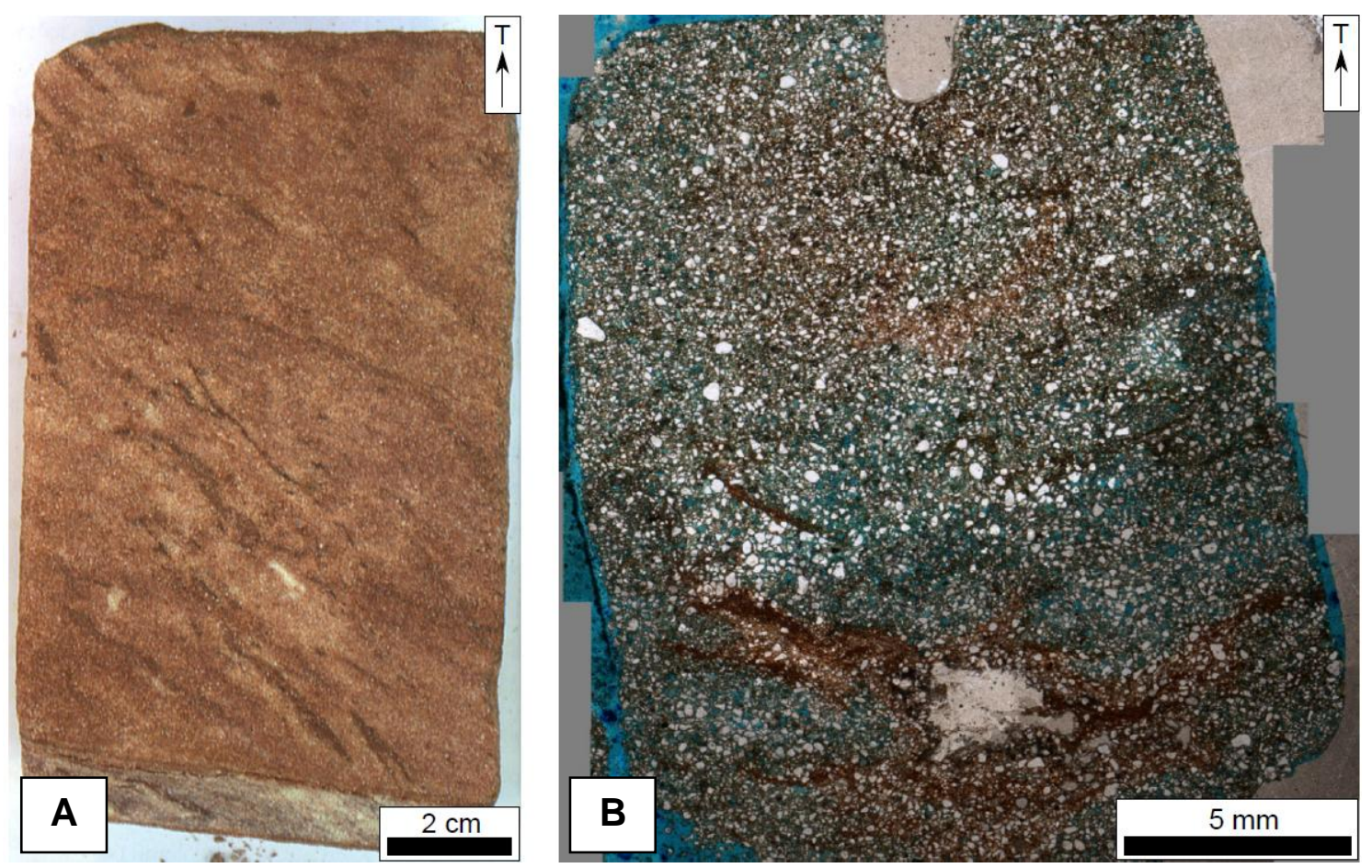

Figura 3.2.2 - Fácies Ap. A. Séries tabulares sub-horizontais de laminações cruzadas, com cerca de $2 \mathrm{~cm}$ de espessura, sugestivas de cavalgamento sub-crítico de marcas onduladas. Amostra coletada em aproximadamente $17,2 \mathrm{~m}$ de profundidade. B. Intraclastos de lama encurvados em meio à areia com bimodalidade granulométrica. Amostra coletada em aproximadamente $11,1 \mathrm{~m}$ de profundidade.
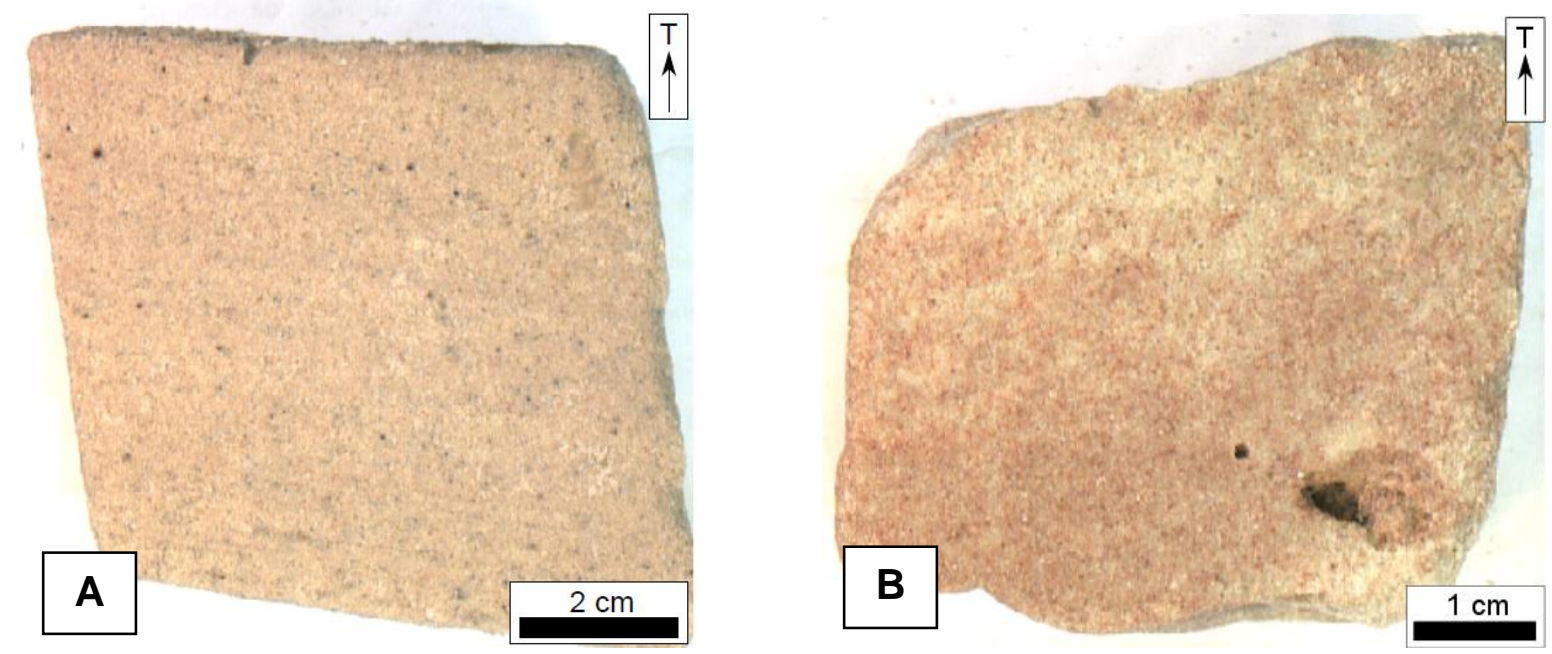

Figura 3.2.3 - Fácies $A e$ e $\mathrm{Ae}_{\mathrm{i}}$. A. Arenito estratificado (fácies Ae), amarelo. Amostra coletada em aproximadamente $22,9 \mathrm{~m}$ de profundidade. B. Arenito com estratificação incipiente (fácies $A e_{i}$ ), amarelo e róseo. Amostra coletada em aproximadamente $28,7 \mathrm{~m}$ de profundidade. 

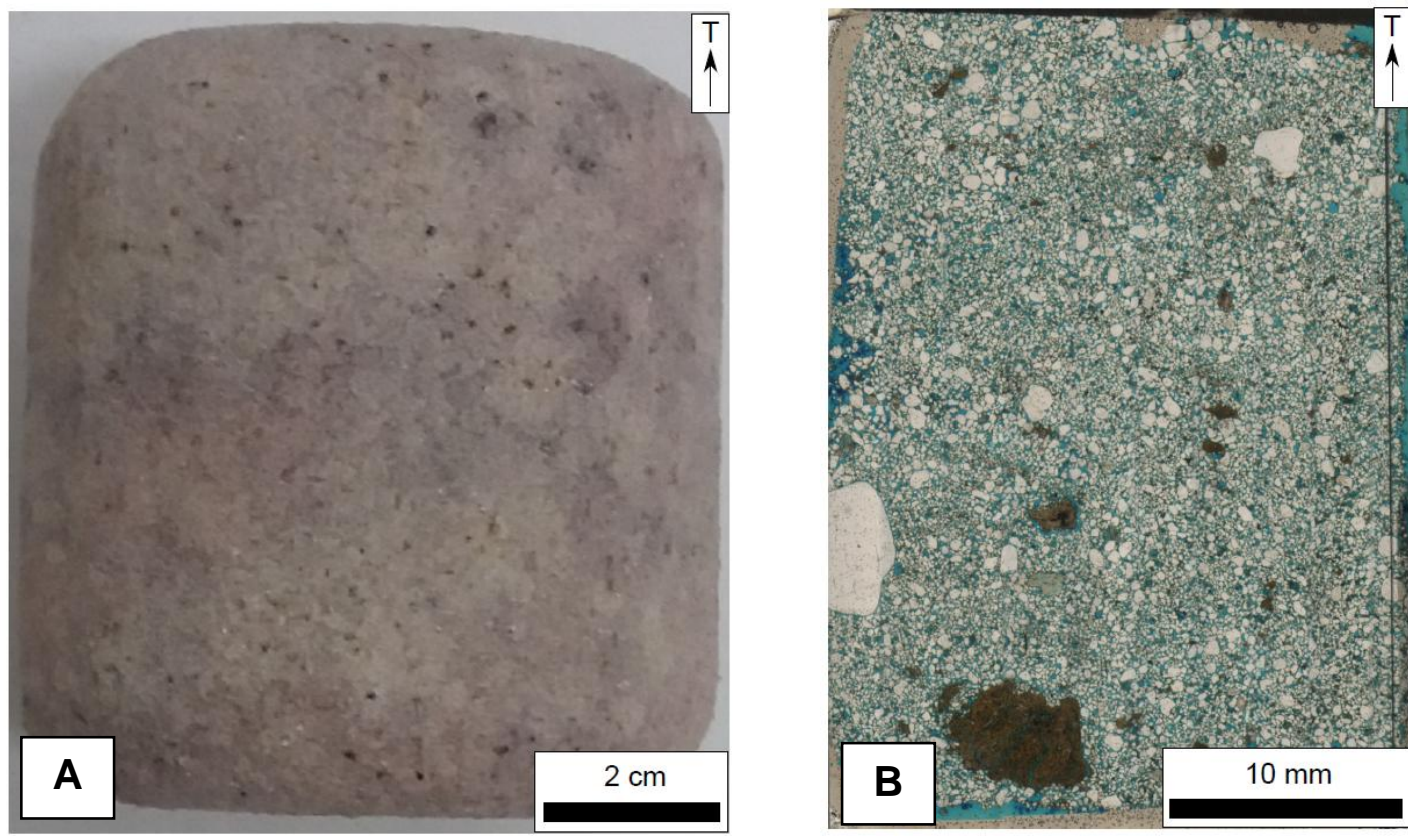

Figura 3.2.4 - Fácies Am. Testemunho (A) e seção petrográfica correspondente (B). Notar, sobretudo em $\mathrm{B}$, forte bimodalidade granulométrica (areia grossa a seixo de $5 \mathrm{~mm}$ e areia média a muito fina) não organizada espacialmente (não segregada), feição típica de depósitos interdunas. Notar ainda intraclastos de lama. Amostra coletada em aproximadamente 26,8 $\mathrm{m}$ de profundidade.

Três feições macroscópicas encontradas nos arenitos, e atribuídas à diagênese merecem destaque por poderem influenciar nas características geomecânicas. São elas: nódulos carbonáticos, concentrações de cimento de óxihidróxido metálico e cavidades subesféricas.

Os nódulos carbonáticos são aproximadamente esféricos, geralmente subcentimétricos a centimétricos (até $2 \mathrm{~cm}$ ) e ocorrem concentrados em intervalos de 20 a $70 \mathrm{~cm}$ de espessura, preferencialmente nos arenitos das fácies $\mathrm{Ae}_{\mathrm{i}}$ e Am (Figura 3.2.5).

O óxi-hidróxido metálico, de cor preta, apresenta duas formas de ocorrência principais. A primeira delas é em associação aos nódulos carbonáticos, dos quais ocupam 5 a $80 \%$ aproximadamente em seção transversal e onde aparecem como manchas milimétricas subequidimensionais a equidimensionais, formadas por inúmeros pontos submilimétricos disseminados, ou como vênulas preenchendo fraturas submilimétricas (Figura 3.2.5). Estas vênulas exibem geometria ligeiramente suturada, algo similar a de estilótitos. A segunda forma de ocorrência do oxihidróxido metálico de cor preta é em manchas irregulares subcentimétricas a centimétricas, nas quais representam cerca de 5 a $30 \%$ em seção transversal (Figura 3.2.6), geralmente concentradas em intervalos de 5 a $10 \mathrm{~cm}$ e de no máximo 
$40 \mathrm{~cm}$ de espessura. Assim como os nódulos, estas manchas ocorrem preferencialmente em arenitos das fácies $\mathrm{Ae}_{i}$ e $\mathrm{Am}$.

As cavidades são aproximadamente esféricas, com diâmetro subcentimétrico a centimétrico (até $2 \mathrm{~cm}$ ) e também concentradas em certas porções do arenito, a exemplo dos nódulos e do óxi-hidróxido metálico. Assim, encontram-se comumente em horizontes de 5 a $20 \mathrm{~cm}$, chegando porém a ocorrer em intervalos contínuos mais espessos, de até 1,3 m. Algumas cavidades exibem manchas de óxi-hidróxido metálico de cor preta em seu interior, em formas equidimensionais a subequidimensionais, e com trama poiquilotópica, na qual envolvem dezenas de grãos, chegando a ocupar cerca de $30 \%$ da área da cavidade (Figura 3.2.7). Estas cavidades não parecem ocorrer preferencialmente em nenhuma fácies específica, mas não foram observadas nos arenitos da fácies Ap.
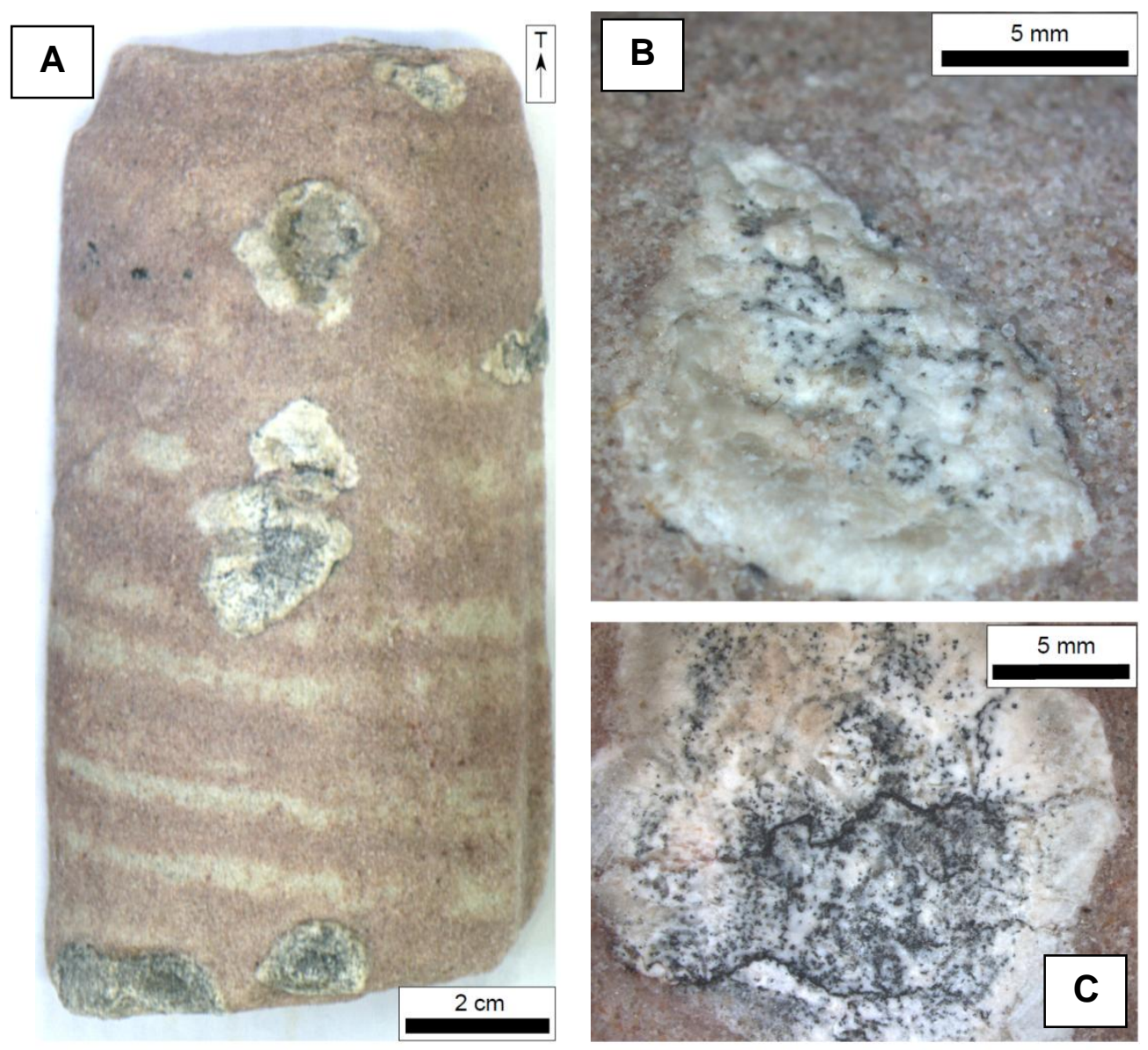

Figura 3.2.5 - Nódulos carbonáticos em arenito da fácies Ae. Os nódulos apresentam manchas de óxi-hidróxido metálico de cor preta $(A)$, formadas por inúmeros pontos submilimétricos disseminados (B e C) e por vênulas submilimétricas de aspecto similar a estilólitos (C). Amostra coletada em aproximadamente $29,9 \mathrm{~m}$ de profundidade. 

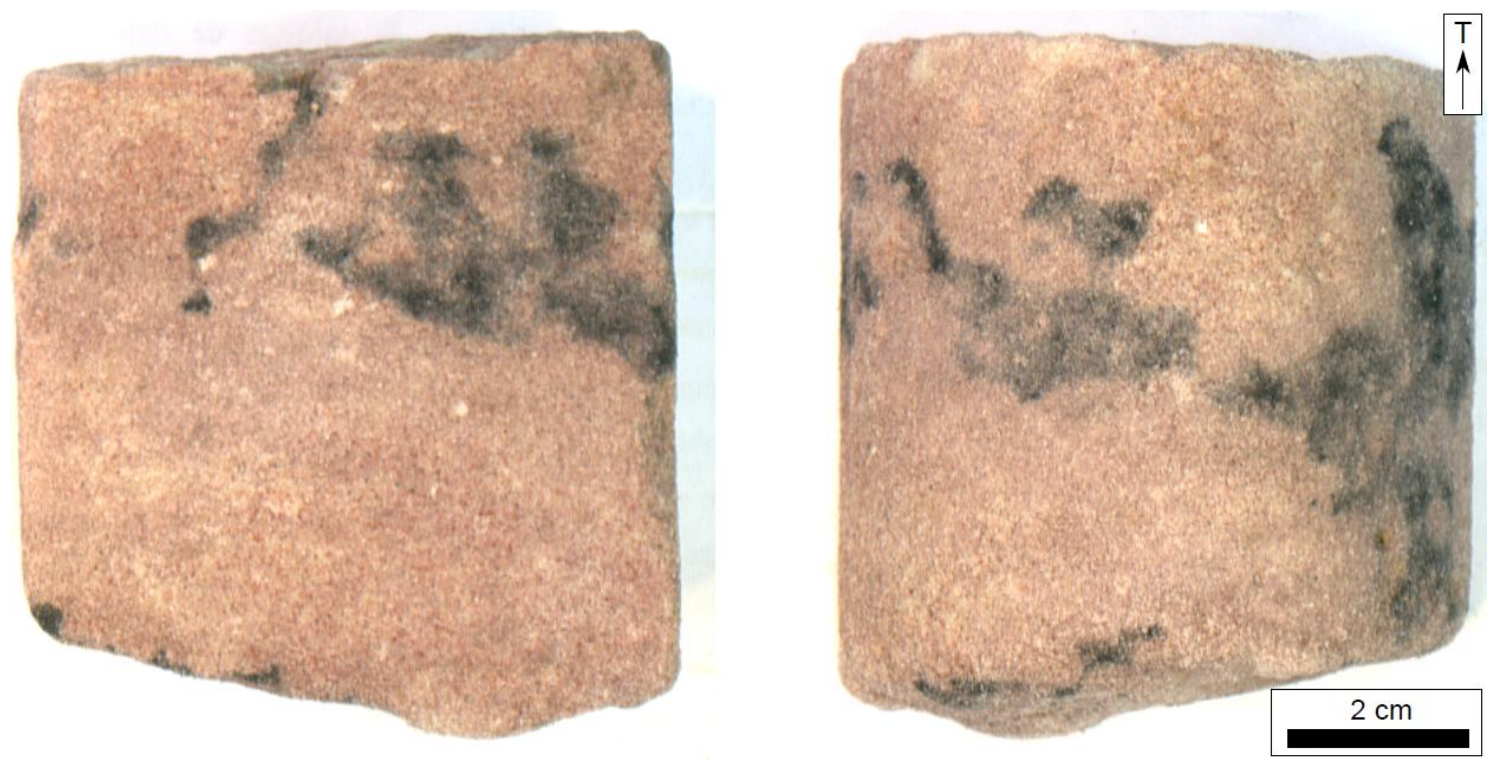

Figura 3.2.6 - Manchas irregulares de cimento de óxi-hidróxido metálico de cor preta em arenito da fácies $\mathrm{Ae}_{\mathrm{i}}$. Amostra coletada em aproximadamente $29,1 \mathrm{~m}$ de profundidade.
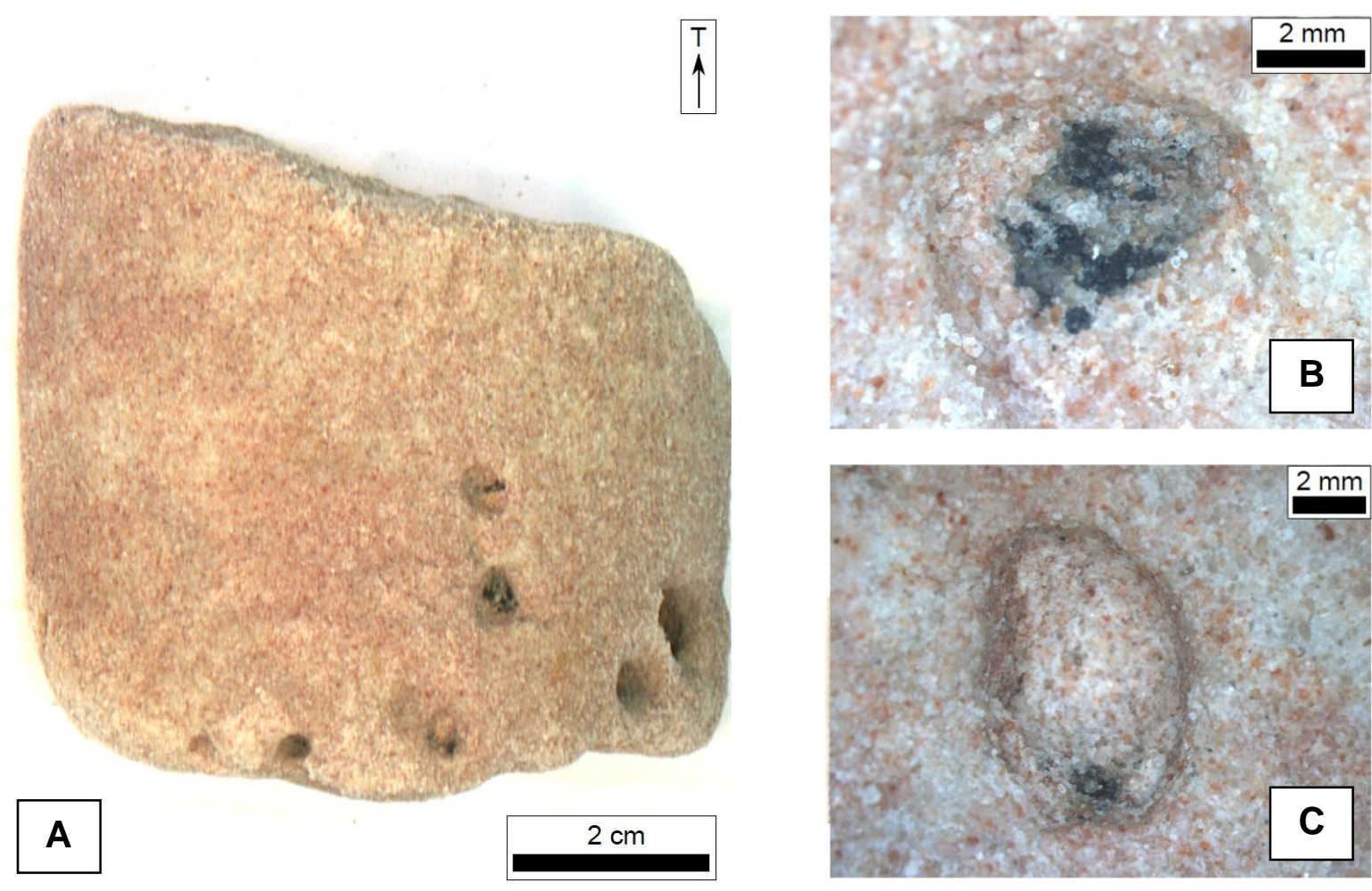

Figura 3.2.7 - Cavidades subcirculares de diâmetro milimétrico, possíveis moldes de dissolução de nódulos carbonáticos, em amostra da fácies $A e_{i}$. As cavidades podem formar concentrações $(A)$ e os grãos de areia que formam suas paredes apresentam-se, às vezes, cimentados por óxi-hidróxido metálico de cor preta (B e C). Amostra coletada em aproximadamente $28,7 \mathrm{~m}$ de profundidade.

Com base nos critérios definidos para a individualização de fácies sedimentares e nas três feições descritas atribuídas a processos diagenéticos (concreções carbonáticas, concentrações de óxi-hidróxido metálico e cavidades), 
foram definidas nove recorrências de fácies (Quadro 3.2.1), as quais tiveram suas coerências avaliadas (Figura 3.2.8).

As amostras das sondagens SM-201, SM-208, SM-210, SM-216, SM-224 e SM-505, destinadas aos ensaios de compressão uniaxial, foram atribuídas às fácies e respectivos graus de coerência apresentados no Quadro 3.2.2.

Quadro 3.2.1 - Recorrências de fácies reconhecidas nos testemunhos da sondagem SM-222.

\begin{tabular}{|c|c|c|c|}
\hline \multicolumn{2}{|c|}{$\begin{array}{l}\text { Profundidade } \\
(\mathrm{m})\end{array}$} & \multirow[t]{2}{*}{ Descrição } & \multirow{2}{*}{$\begin{array}{c}\text { Fácies } \\
\text { reconhecida } \\
\text { em testemunho }\end{array}$} \\
\hline De & Até & & \\
\hline 6,9 & 15,1 & $\begin{array}{l}\text { Arenito fino a muito fino, com lâminas pelíticas em } \\
\text { formato ondulado e lentes de lama com contatos } \\
\text { nítidos, côncavas para cima ou inclinadas ao } \\
\text { acamamento. }\end{array}$ & Ap \\
\hline 15,1 & 15,9 & $\begin{array}{l}\text { Arenito muito fino a fino, com estratificação inclinada } \\
\text { menos de } 10^{\circ} \text {. }\end{array}$ & $\mathrm{Ae}$ \\
\hline 15,9 & 17,1 & $\begin{array}{l}\text { Arenito bimodal, muito fino, com grãos de areia grossa } \\
\text { esparsos, maciço. }\end{array}$ & Am \\
\hline 17,1 & 17,9 & $\begin{array}{l}\text { Arenito muito fino com lâminas pelíticas e presença de } \\
\text { séries tabulares sub-horizontais de laminações } \\
\text { cruzadas com cerca de } 2 \mathrm{~cm} \text { de espessura. }\end{array}$ & Ap \\
\hline 17,9 & 21,7 & $\begin{array}{l}\text { Arenito fino a médio, com estratificação sub-horizontal } \\
\text { e cavidades milimétricas concentradas em horizonte } \\
\text { de até } 2 \mathrm{~cm} \text {. }\end{array}$ & $\mathrm{Ae}$ \\
\hline 21,7 & 25,7 & Arenito fino, com estratificação inclinada cerca de $20^{\circ}$. & $\mathrm{Ae}$ \\
\hline 25,7 & 27,9 & $\begin{array}{l}\text { Arenito com bimodalidade granulométrica não } \\
\text { segregada, fino a médio, com grãos de areia grossa a } \\
\text { seixos de até } 5 \mathrm{~mm} \text {, maciço. }\end{array}$ & Am \\
\hline 27,9 & 29,8 & $\begin{array}{l}\text { Arenito fino, com estratificação incipiente, localmente } \\
\text { mosqueados, com cavidades de até } 2 \mathrm{~cm} \\
\text { concentradas em horizonte de até } 15 \mathrm{~cm} \text {. }\end{array}$ & $\mathrm{Ae}_{\mathrm{i}}$ \\
\hline 29,8 & 32,5 & $\begin{array}{l}\text { Arenito fino a médio, com estratificação incipiente a } \\
\text { localmente nítida, de baixo ângulo de mergulho, } \\
\text { marcada pela presença de segregação granular, e } \\
\text { com nódulos carbonáticos de até } 2 \mathrm{~cm} \text {, concentrados } \\
\text { em horizonte de cerca de } 20 \mathrm{~cm} \text {. }\end{array}$ & $\mathrm{Ae}_{\mathrm{i}}$ \\
\hline
\end{tabular}



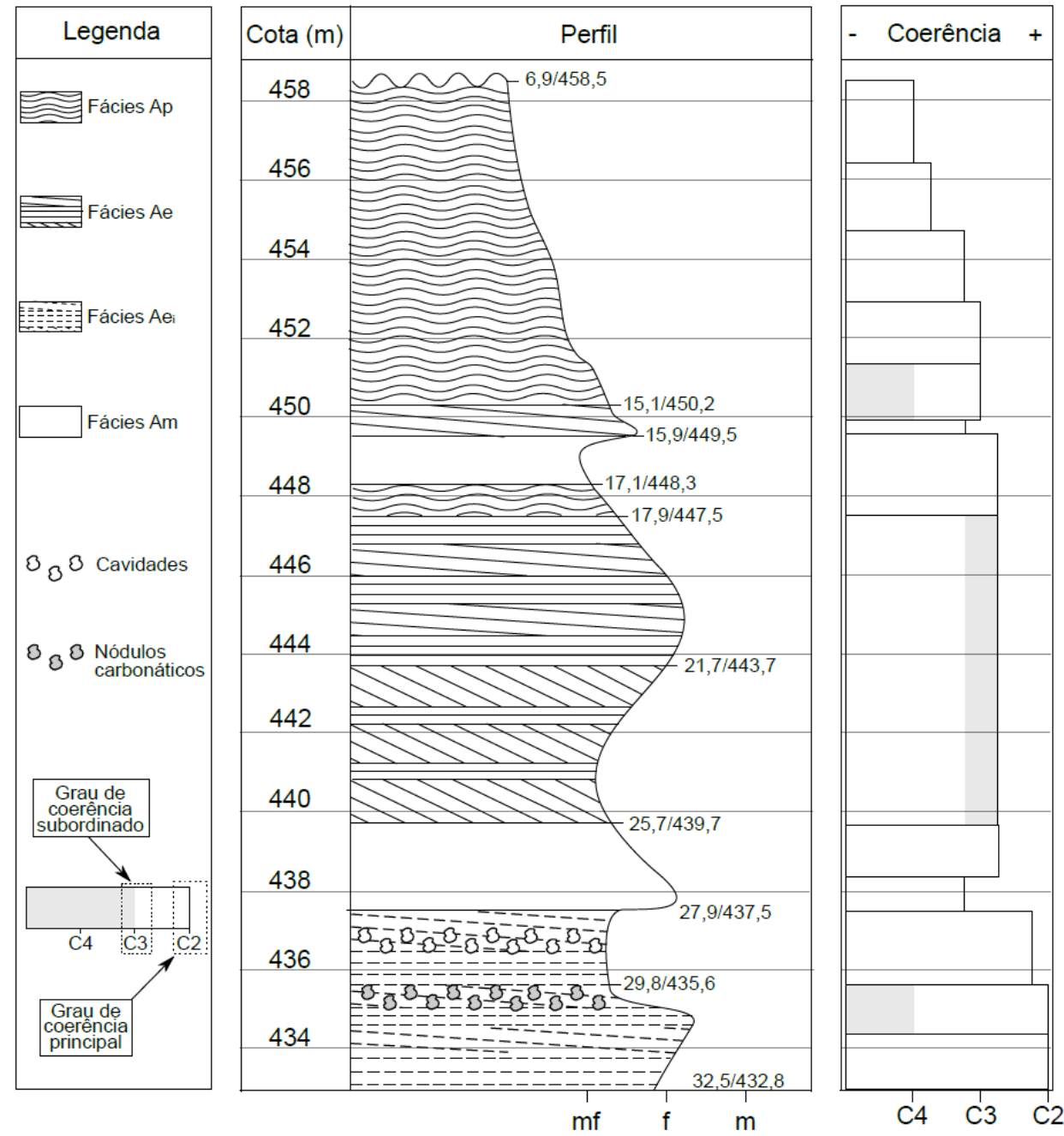

Figura 3.2.8 - Seção colunar estratigráfica da sondagem SM-222, com granulometria e graus de coerência.

Quadro 3.2.2 - Fácies e graus de coerência atribuídos às amostras destinadas aos ensaios de compressão uniaxial.

\begin{tabular}{cccc}
\hline Sondagem & Cota & Fácies & Coerência \\
\hline SM-201 & 436,6 a 435,2 $\mathrm{m}$ & $\mathrm{Ae}_{\mathrm{i}}$ & $\mathrm{C} / \mathrm{C} 2$ \\
$\mathrm{SM}-208$ & $448,8 \mathrm{a} 446,9 \mathrm{~m}$ & $\mathrm{Ae}$ & $\mathrm{C} 3 / \mathrm{C} 2$ \\
$\mathrm{SM}-210$ & $446,2 \mathrm{a} 444,0 \mathrm{~m}$ & $\mathrm{Ae}$ & $\mathrm{C} 3$ \\
$\mathrm{SM}-210$ & $437,7 \mathrm{a} 436,2 \mathrm{~m}$ & $\mathrm{Ae}$ & $\mathrm{C} 3$ \\
SM-216 & $454,9 \mathrm{a} 453,9 \mathrm{~m}$ & $\mathrm{Ap}$ & $\mathrm{C} 3$ \\
SM-224 & $439,1 \mathrm{a} 437,7 \mathrm{~m}$ & $\mathrm{Ae}_{\mathrm{i}}$ & $\mathrm{C} 2 / \mathrm{C} 3$ \\
SM-505 & $431,3 \mathrm{a} 429,2 \mathrm{~m}$ & $\mathrm{Ae}_{\mathrm{i}}$ & $\mathrm{C} 2 / \mathrm{C} 3$ \\
\hline
\end{tabular}




\subsection{Petrografia}

Nesta seção, são apresentados os resultados obtidos por meio de análise petrográfica para todo o conjunto de amostras. Dados quantitativos mais específicos de cada amostra analisada, como proporções de componentes modais, granulometria, porosidade, empacotamento, arredondamento, esfericidade etc., estão disponibilizados no Apêndice A.

\subsubsection{Componentes - arcabouço, matriz, cimento e poros}

Considerando todas as amostras analisadas, as quantidades relativas do arcabouço e do cimento variam entre 46 e $74 \%$ e entre 3 e $40 \%$, respectivamente (Tabela 3.3.1). A porosidade avaliada por meio de análise de imagens digitais varia entre 7 e $27 \%$, ao passo que a porosidade contabilizada na análise modal apresenta intervalo de variação pouco maior, entre 5 e 28\% (Tabela 3.3.1).

A matriz, interpretada como de origem diagenética (epi ou pseudomatriz), é escassa em todos os arenitos analisados, sempre apresentando proporções menores ou iguais a $2 \%$ (Tabela 3.3.1).

A proporção de cimento atinge seus maiores valores (em torno de $40 \%$ ) no topo ( $4 \mathrm{~m}$ superiores) da coluna sedimentar analisada, em detrimento do arcabouço $\mathrm{e}$ da porosidade (Figura 3.3.1). Já os valores mais elevados (acima de $20 \%$ ) de porosidade determinada por meio de software (LAS) encontram-se na metade inferior da coluna, onde se encontram também os arenitos mais grossos e os maiores graus de coerência (Figura 3.3.1).

Tabela 3.3.1 - Parâmetros estatísticos descritivos referentes aos componentes modais de todas as amostras analisadas. Matriz refere-se a epi e pseudomatriz sensu Dickinson (1970). A coluna "porosidade" a direita refere-se àquela avaliada por meio de software analisador de imagens digitais.

\begin{tabular}{cccccc}
\hline & $\begin{array}{c}\text { Arcabouço } \\
(\%)\end{array}$ & $\begin{array}{c}\text { Matriz } \\
(\%)\end{array}$ & $\begin{array}{c}\text { Cimento } \\
(\%)\end{array}$ & $\begin{array}{c}\text { Porosidade modal } \\
(\%)\end{array}$ & $\begin{array}{c}\text { Porosidade } \\
(\%)\end{array}$ \\
\hline Mínimo & 46 & 0 & 3 & 5 & 7 \\
Máximo & 74 & 2 & 40 & 28 & 27 \\
Média & 65 & 0 & 19 & 16 & 17 \\
Mediana & 65 & 0 & 19 & 16 & 17 \\
Desvio & 7 & 0 & 11 & 7 & 5 \\
padrão & 7 & & & & \\
\hline
\end{tabular}



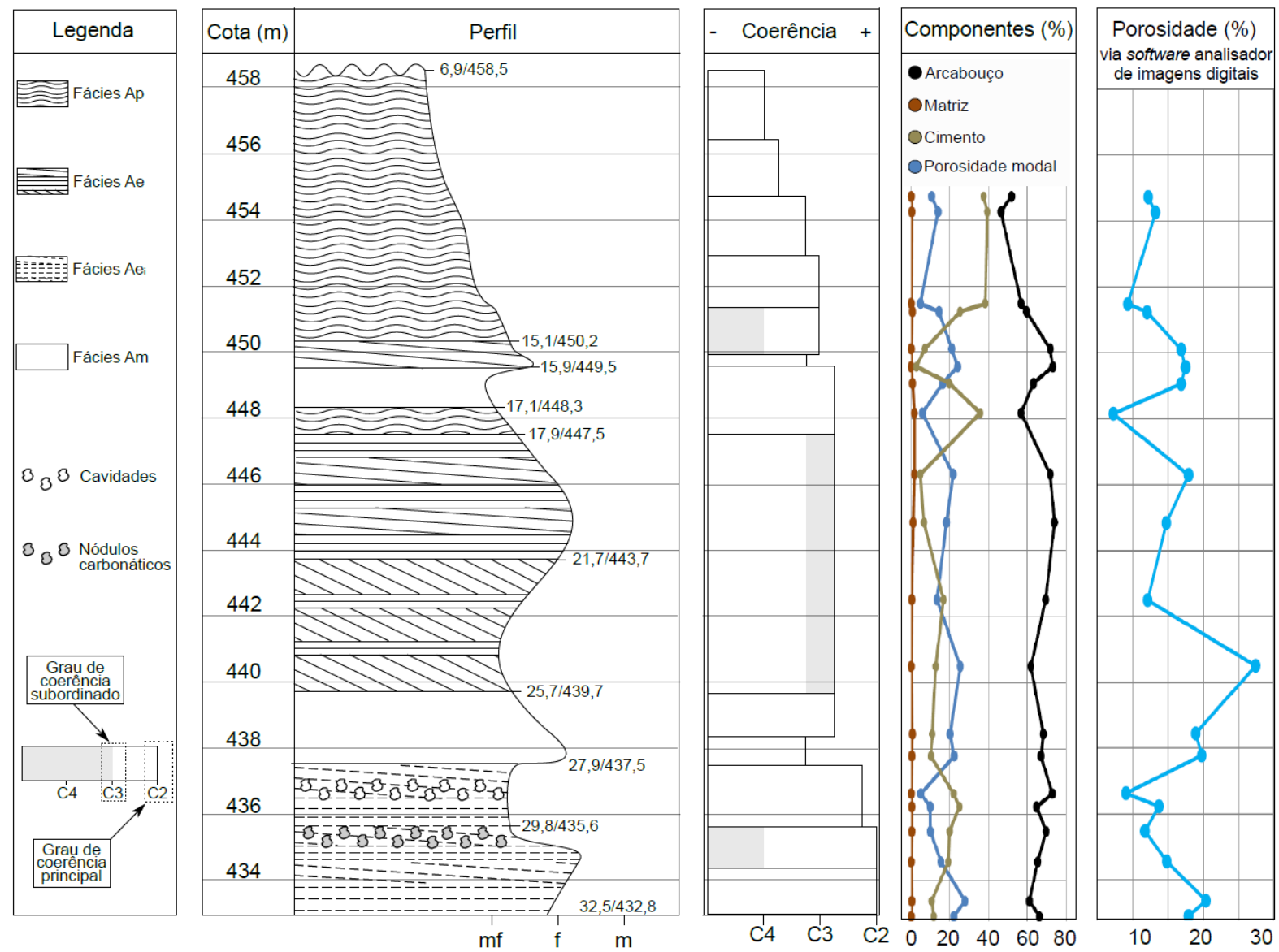

Figura 3.3.1 - Seção estratigráfica colunar da sondagem SM-222 apresentando graus de coerência, proporção relativa entre os componentes petrográficos e porosidades (modal e avaliada por meio de software analisador de imagens digitais).

\subsubsection{Arcabouço - mineralogia, textura e petrotrama}

Os arenitos analisados são constituídos essencialmente por grãos de quartzo, cuja proporção relativa varia entre 85 e 93\%. Os grãos de feldspato compõem 7 a $14 \%$ do arcabouço e os fragmentos líticos, dominados por silexito e intraclastos pelíticos, com raras ocorrências de granitoides, 0 a $4 \%$. De acordo com as classificações de Dott (1964), os arenitos correspondem a arenitos feldspáticos e quartzo arenitos, e segundo a classificação de Folk (1968), a subarcóseos (Figura 3.3.2). Na seção petrográfica da cota $438,4 \mathrm{~m}$ da sondagem SM-222, identificaramse intraclastos argilosos, correspondentes a cerca de $2 \%$ da área da seção, muitas vezes amolgados entre os demais grãos do arcabouço, neste caso constituindo pseudomatriz (Figura 3.3.3). 

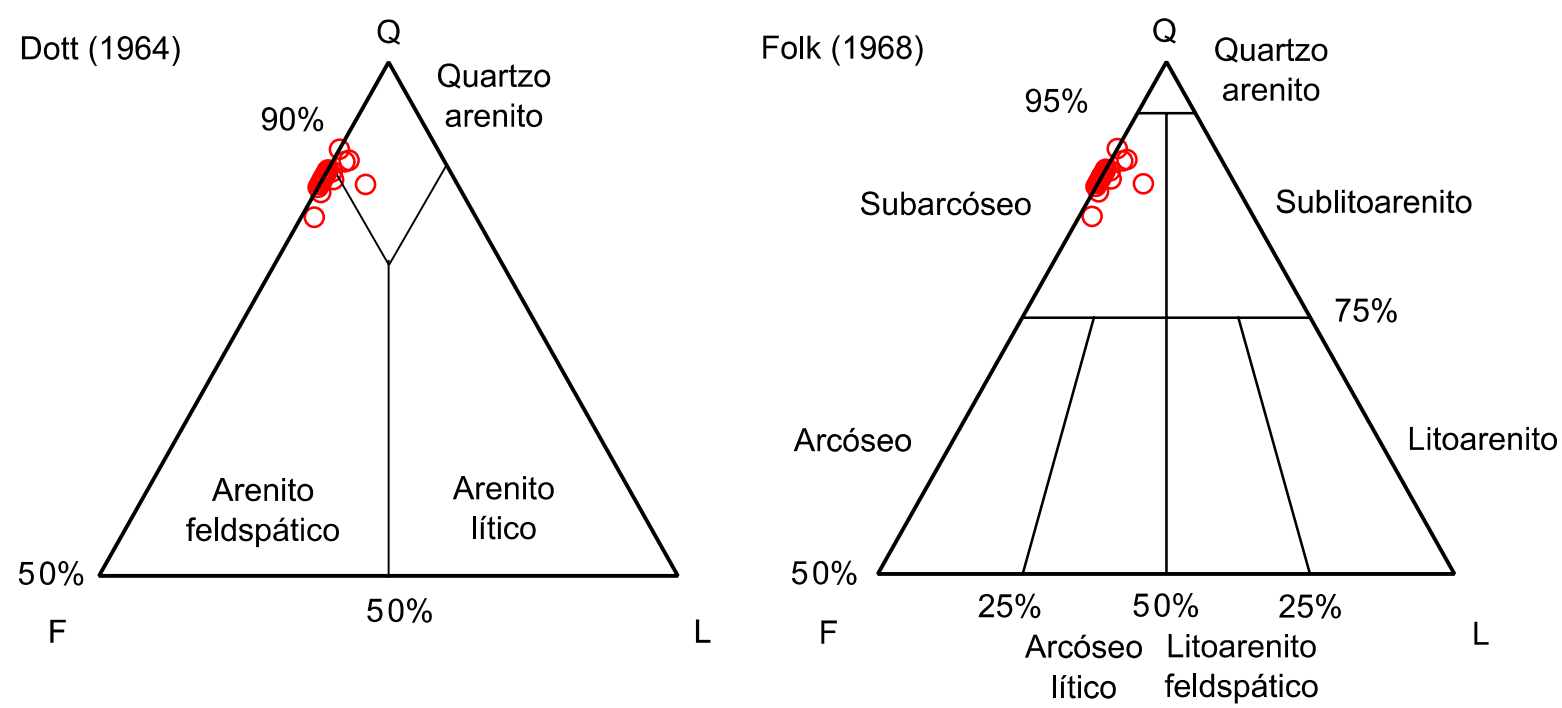

Figura 3.3.2 - Classificações de Dott (1964) e Folk (1968) para todos os arenitos analisados.
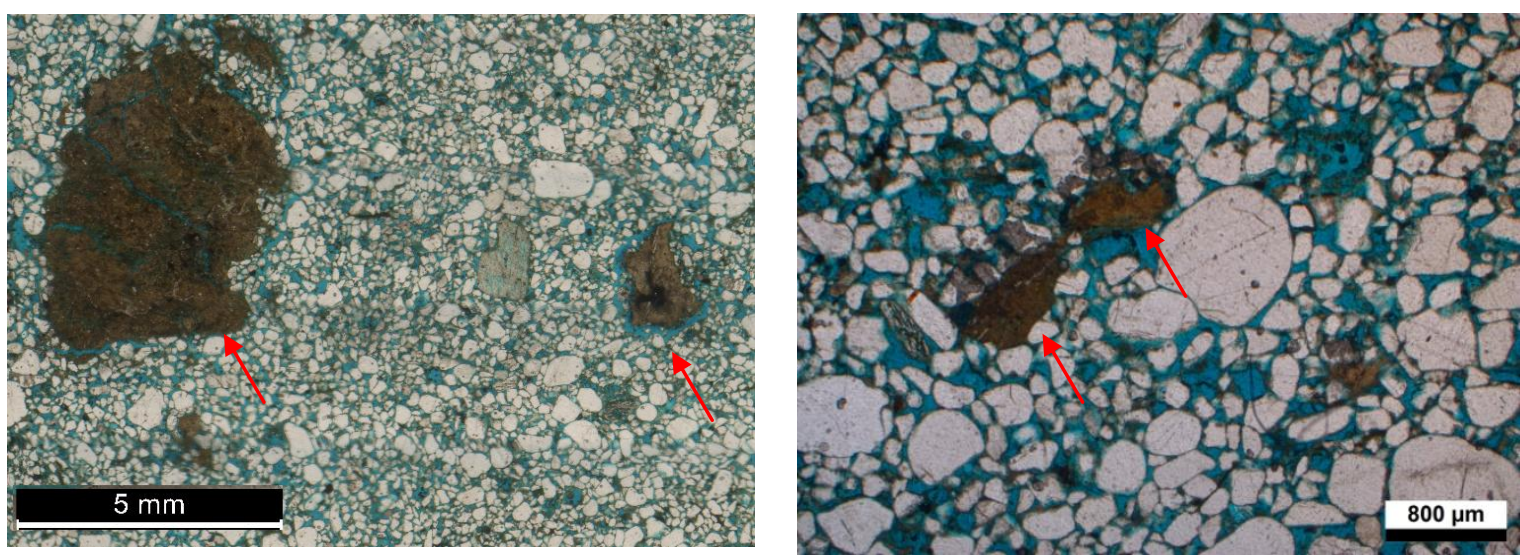

Figura 3.3.3 - Intraclastos argilosos (setas). Amostra da cota 438,4 m da sondagem mista SM-222. Polarizadores paralelos.

Os arenitos são muito finos a médios e, na maior parte dos casos, apresentam seleção moderada. Dentre as 27 amostras de arenitos analisadas, 22 apresentam segregação granular por tamanho dos grãos, das quais sete de maneira incipiente. (tabelas 3.3.2 e 3.3.3).

Quando presente, a segregação granular pode ocorrer entre as classes areia muito fina, areia fina e areia média, ou dentro de uma mesma classe granulométrica, sendo a seleção por moda moderada a boa (tabelas 3.3 .2 e 3.3.3). O teor de pelíticos varia entre 4 e $43 \%$ (tabelas 3.3 .4 e 3.3.5).

A granulometria avaliada por meio do difratômetro de laser apresentou, sistematicamente, maiores valores de tamanho médio dos grãos de areia em comparação aos valores obtidos por meio de petrografia. As diferenças nos valores de desvio padrão da distribuição granulométrica medidos pelos dois métodos são 
menos evidentes, com tendência para valores menores e variação mais abrupta ao longo da coluna sedimentar na difratometria de laser de que na petrografia (Figura 3.3.4).

Os grãos de quartzo são subangulares a arredondados, com predomínio franco de subarredondados (quase $70 \%$ dos grãos em média). A razão entre os eixos menor e maior dos grãos varia entre 0,64 (subalongados) e 0,71 (subequidimensionais), com média de 0,67 (intermediários).

Entre os índices de empacotamento, $P_{d}$ varia entre 57 e $76 \%$, e $P_{p}$ entre 9 e $34 \%$, o que permite classificá-lo como aberto.

Tabela 3.3.2 - Dados granulométricos das amostras analisadas da sondagem SM-222 via petrografia ótica. As colunas "Moda 1" e "Moda 2" referem-se às modas granulométricas segregadas, respectivamente em grãos de tamanho menor e maior. A coluna "Geral" apresenta os dados obtidos por meio de passos equidistantes ao microscópio petrográfico, considerando a amostra como um todo.

\begin{tabular}{|c|c|c|c|c|c|c|c|c|c|c|c|c|c|c|c|}
\hline \multirow{3}{*}{$\begin{array}{l}\text { Cota } \\
\text { (m) }\end{array}$} & \multicolumn{4}{|c|}{ Geral } & \multirow{3}{*}{$\begin{array}{l}\text { Segr. } \\
\text { gran. }\end{array}$} & \multicolumn{5}{|c|}{ Moda 1} & \multicolumn{5}{|c|}{ Moda 2} \\
\hline & \multicolumn{2}{|c|}{$\Phi$} & \multirow{2}{*}{ Moda } & \multirow{2}{*}{ DP $(\varphi)$} & & \multicolumn{2}{|l|}{$\Phi$} & \multirow{2}{*}{ Moda } & \multirow{2}{*}{ DP $(\varphi)$} & \multirow{2}{*}{ Sel } & \multicolumn{2}{|c|}{$\Phi$} & \multirow{2}{*}{ Moda } & \multirow{2}{*}{ DP $(\varphi)$} & \multirow{2}{*}{ Sel } \\
\hline & $\mu \mathrm{m}$ & $\varphi$ & & & & $\mu \mathrm{m}$ & $\varphi$ & & & & $\mu \mathrm{m}$ & $\varphi$ & & & \\
\hline 454,7 & 95,3 & 3,4 & $\mathrm{mf}$ & 0,78 & $S$ & 87,9 & 3,5 & $\mathrm{mf}$ & 0,47 & boa & 122,0 & 3,0 & $\mathrm{mf}$ & 0,55 & mod \\
\hline 454,3 & 95,2 & 3,4 & $\mathrm{mf}$ & 0,77 & $S$ & 93,6 & 3,4 & $\mathrm{mf}$ & 0,52 & $\bmod$ & 108,2 & 3,2 & $\mathrm{mf}$ & 0,50 & mod \\
\hline 451,5 & 100,7 & 3,3 & $\mathrm{mf}$ & 0,75 & $S$ & 99,9 & 3,3 & $\mathrm{mf}$ & 0,50 & $\bmod$ & 146,0 & 2,8 & $f$ & 0,67 & $\bmod$ \\
\hline 451,2 & 130,4 & 2,9 & $f$ & 0,73 & $S$ & 100,8 & 3,3 & $\mathrm{mf}$ & 0,59 & $\bmod$ & 153,5 & 2,7 & $f$ & 0,76 & mod \\
\hline 450,1 & 154,8 & 2,7 & $f$ & 0,65 & $S$ & 129,9 & 2,9 & $f$ & 0,54 & $\bmod$ & 175,8 & 2,5 & $f$ & 0,70 & $\bmod$ \\
\hline 449,6 & 191,2 & 2,4 & f & 0,59 & $S$ & 175,3 & 2,5 & $f$ & 0,50 & $\bmod$ & 229,2 & 2,1 & $f$ & 0,58 & $\bmod$ \\
\hline 449,1 & 117,7 & 3,1 & $\mathrm{mf}$ & 0,62 & $\mathrm{~N}$ & - & - & - & - & - & - & - & - & - & - \\
\hline 448,2 & 132,7 & 2,9 & $f$ & 0,77 & $S$ & 86,1 & 3,5 & $\mathrm{mf}$ & 0,57 & $\bmod$ & 174,8 & 2,5 & $f$ & 0,56 & mod \\
\hline 446,3 & 225,3 & 2,2 & $f$ & 0,59 & $S$ & 197,0 & 2,3 & $f$ & 0,46 & boa & 251,0 & 2,0 & $\mathrm{~m}$ & 0,68 & mod \\
\hline 444,8 & 290,9 & 1,8 & $\mathrm{~m}$ & 0,75 & $S$ & 353,3 & 1,5 & $\mathrm{~m}$ & 0,50 & $\bmod$ & 488,1 & 1,0 & $\mathrm{~m}$ & 0,59 & $\bmod$ \\
\hline 442,5 & 175,4 & 2,5 & $f$ & 0,54 & $S$ & 122,5 & 3,0 & $\mathrm{mf}$ & 0,46 & boa & 153,2 & 2,7 & $f$ & 0,60 & $\bmod$ \\
\hline 440,5 & 135,1 & 2,9 & $f$ & 0,71 & $S$ (inc) & & - & - & - & - & - & - & - & - & - \\
\hline 438,4 & 228,5 & 2,1 & $f$ & 0,70 & $\mathrm{~N}$ & - & - & - & - & - & - & - & - & - & - \\
\hline 437,8 & 272,0 & 1,9 & $\mathrm{~m}$ & 0,82 & $\mathrm{~N}$ & - & - & - & - & - & - & - & - & - & - \\
\hline 436,6 & 148,3 & 2,8 & $f$ & 0,58 & $\mathrm{~N}$ & - & - & - & - & - & - & - & - & - & - \\
\hline 436,2 & 147,4 & 2,8 & $f$ & 0,63 & $\mathrm{~N}$ & - & - & - & - & - & - & - & - & - & - \\
\hline 435,5 & 151,6 & 2,7 & $f$ & 0,68 & $S$ & 128,0 & 3,0 & $\mathrm{mf}$ & 0,50 & $\bmod$ & 216,2 & 2,2 & $f$ & 0,66 & $\bmod$ \\
\hline 434,6 & 313,8 & 1,7 & $\mathrm{~m}$ & 0,72 & $S$ (inc) & - & - & - & - & - & - & - & - & - & - \\
\hline 433,4 & 242,3 & 2,0 & $f$ & 0,76 & $S$ (inc) & - & - & - & - & - & - & - & - & - & - \\
\hline 432,9 & 223,3 & 2,2 & $f$ & 0,67 & $S$ (inc) & - & - & - & - & - & - & - & - & - & - \\
\hline
\end{tabular}


Tabela 3.3.3 - Dados granulométricos das amostras analisadas das sondagens SM-201, SM-208, SM-210, SM-216, SM-224 e SM-505 via petrografia ótica. As colunas "Moda 1" e "Moda 2" referem-se às modas granulométricas segregadas, respectivamente em grãos de tamanho menor e maior. A coluna "Geral" apresenta os dados obtidos por meio de passos equidistantes ao microscópio petrográfico, considerando a amostra como um todo.

\begin{tabular}{|c|c|c|c|c|c|c|c|c|c|c|c|c|c|c|c|c|c|c|}
\hline \multirow{3}{*}{ Sond. } & \multirow{3}{*}{ Cota (m) } & \multirow{3}{*}{ Fácies } & \multicolumn{5}{|c|}{ Geral } & \multirow{3}{*}{$\begin{array}{l}\text { Segr. } \\
\text { gran. }\end{array}$} & \multicolumn{5}{|c|}{ Moda 1} & \multicolumn{5}{|c|}{ Moda 2} \\
\hline & & & \multicolumn{2}{|c|}{$\Phi$} & \multirow{2}{*}{ Moda } & \multirow{2}{*}{ DP $(\varphi)$} & \multirow{2}{*}{ Sel } & & \multicolumn{2}{|c|}{$\Phi$} & \multirow{2}{*}{ Moda } & \multirow{2}{*}{ DP $(\varphi)$} & \multirow{2}{*}{ Sel } & \multicolumn{2}{|c|}{$\Phi$} & \multirow{2}{*}{ Moda } & \multirow{2}{*}{$\mathrm{DP}(\varphi)$} & \multirow{2}{*}{ Sel } \\
\hline & & & $\mu \mathrm{m}$ & $\varphi$ & & & & & $\mu \mathrm{m}$ & $\varphi$ & & & & $\mu \mathrm{m}$ & $\varphi$ & & & \\
\hline SM-201 & 435,4 & $A e_{i}$ & 272,6 & 1,9 & $m$ & 0,68 & $\bmod$ & S (inc) & - & - & - & - & - & - & - & - & - & - \\
\hline SM-208 & 448,8 & $\mathrm{Ae}$ & 157,5 & 2,7 & $f$ & 0,70 & mod & $S$ & 126,5 & 3,0 & $\mathrm{mf}$ & 0,52 & mod & 223,2 & 2,2 & $f$ & 0,64 & mod \\
\hline SM-210 & 444,8 & $\mathrm{Ae}$ & 164,7 & 2,6 & $f$ & 0,67 & mod & $\mathrm{S}$ & 126,0 & 3,0 & $\mathrm{mf}$ & 0,49 & boa & 216,9 & 2,2 & $f$ & 0,54 & mod \\
\hline SM-210 & 436,7 & $\mathrm{Ae}$ & 279,7 & 1,8 & $\mathrm{~m}$ & 0,47 & boa & $S$ & 345,0 & 1,5 & $\mathrm{~m}$ & 0,41 & boa & 652,0 & 0,6 & $g$ & 0,47 & boa \\
\hline SM-216 & 454,5 & $A p$ & 118,8 & 3,1 & $\mathrm{mf}$ & 0,70 & mod & $S$ & 89,7 & 3,5 & $\mathrm{mf}$ & 0,43 & boa & 181,1 & 2,5 & $f$ & 0,65 & mod \\
\hline SM-224 & 437,7 & $\mathrm{Ae}_{\mathrm{i}}$ & 159,2 & 2,7 & $f$ & 0,63 & mod & $S$ (inc) & - & - & - & - & - & - & - & - & - & - \\
\hline SM-505 & 429,3 & $\mathrm{Ae}_{\mathrm{i}}$ & 122,7 & 3,0 & $\mathrm{mf}$ & 0,79 & mod & $S$ (inc) & - & - & - & - & - & - & - & - & - & - \\
\hline
\end{tabular}



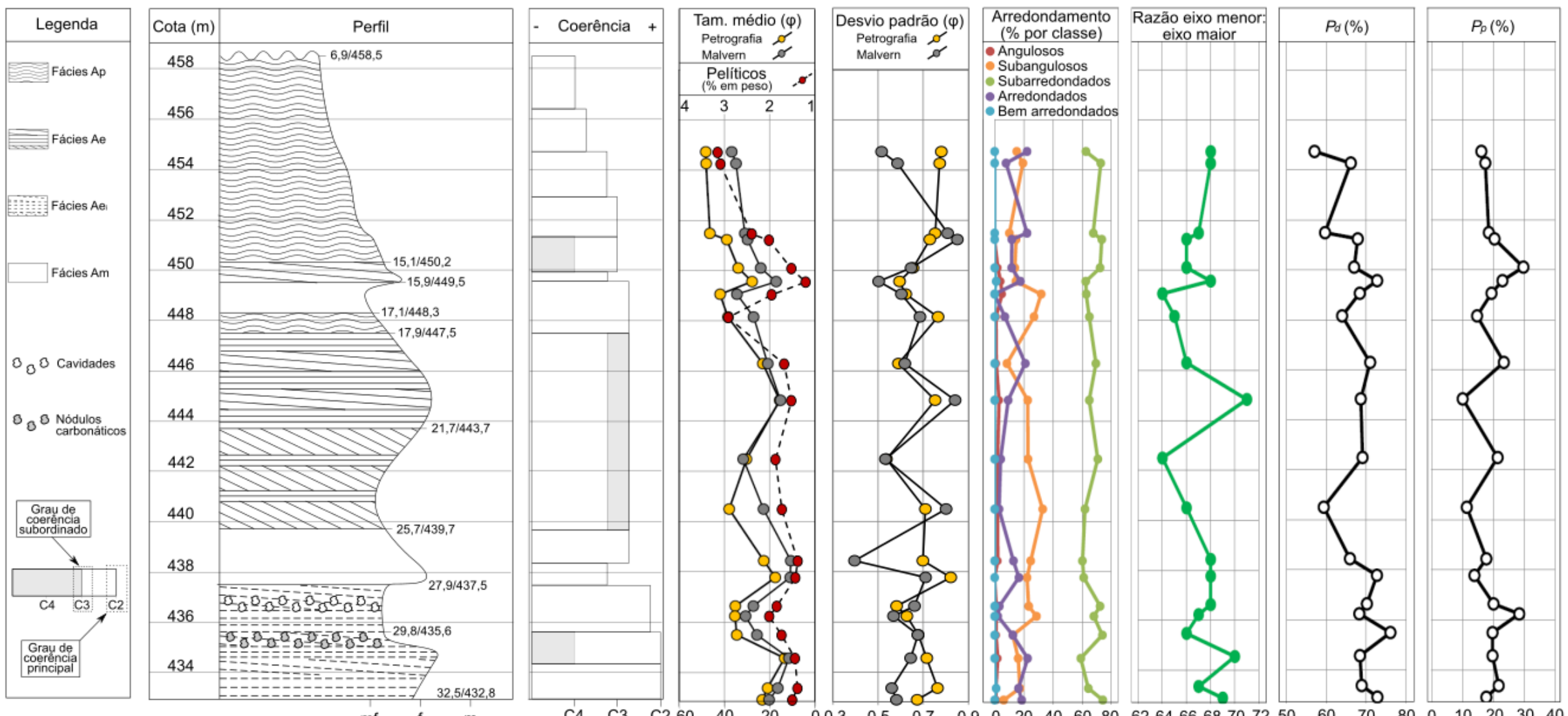

Figura 3.3.4 - Seção estratigráfica colunar da sondagem SM-222, com dados de grau de coerência e de textura e trama: estatísticas da distribuição granulométrica (média e desvio padrão) da fração areia obtidas por meio de petrografia e difração de laser, teor de pelíticos via elutriação, arredondamento, razão entre os eixos menor e maior dos grãos de quartzo, densidade de empacotamento $\left(P_{d}\right)$ e proximidade de empacotamento $\left(P_{p}\right)$. 
Tabela 3.3.4 - Estatísticas da distribuição granulométrica da fração areia obtidas pelo equipamento de difração de laser e teor de pelíticos em massa obtido por elutriação para as amostras da sondagem SM-222.

\begin{tabular}{cccc}
\hline Cota $(\mathbf{m})$ & Tamanho médio $(\boldsymbol{\varphi})$ & DP $(\boldsymbol{\varphi})$ & Pelíticos $(\%$ peso) \\
\hline 454,7 & 2,8 & 0,52 & 43 \\
454,3 & 2,7 & 0,59 & 42 \\
451,5 & 2,5 & 0,81 & 28 \\
451,2 & 2,5 & 0,85 & 20 \\
450,1 & 2,2 & 0,65 & 10 \\
449,6 & 1,9 & 0,50 & 4 \\
449,1 & 2,7 & 0,60 & 19 \\
448,2 & 2,4 & 0,69 & 39 \\
446,3 & 2,0 & 0,62 & 14 \\
444,8 & 1,8 & 0,84 & 10 \\
442,5 & 2,6 & 0,53 & 17 \\
440,5 & 2,1 & 0,80 & 15 \\
438,4 & 1,5 & 0,40 & 7 \\
437,8 & 1,5 & 0,71 & 9 \\
436,6 & 2,4 & 0,66 & 17 \\
436,2 & 2,5 & 0,57 & 20 \\
435,5 & 2,3 & 0,68 & 15 \\
434,6 & 1,6 & 0,64 & 9 \\
433,4 & 1,8 & 0,56 & 8 \\
432,9 & 2,0 & 0,58 & 10 \\
\hline
\end{tabular}

Tabela 3.3.5 - Valores medianos das estatísticas da distribuição granulométrica da fração areia obtidas pelo equipamento de difração de laser e teor de pelíticos em massa obtido por elutriação para as amostras destinadas aos ensaios de compressão uniaxial.

\begin{tabular}{|c|c|c|c|c|c|c|c|}
\hline \multirow{2}{*}{ Sondagem } & \multirow{2}{*}{$\begin{array}{c}\mathrm{n}^{\circ} \text { de } \\
\text { amostras }\end{array}$} & \multicolumn{2}{|c|}{ Cota $(m)$} & \multirow{2}{*}{ Fácies } & \multirow{2}{*}{$\begin{array}{l}\text { Tamanho } \\
\text { médio }(\varphi)\end{array}$} & \multirow{2}{*}{$\mathrm{DP}(\varphi)$} & \multirow{2}{*}{$\begin{array}{l}\text { Pelíticos } \\
\text { (\% peso) }\end{array}$} \\
\hline & & $\mathrm{De}$ & Até & & & & \\
\hline SM-201 & 6 & 436,6 & 435,2 & $A e_{i}$ & 2,0 & 0,72 & 8 \\
\hline SM-208 & 5 & 448,8 & 446,9 & $\mathrm{Ae}$ & 2,4 & 0,66 & 20 \\
\hline SM-210 & 6 & 446,2 & 444,0 & $\mathrm{Ae}$ & 2,1 & 0,62 & 15 \\
\hline SM-210 & 5 & 437,7 & 436,2 & $\mathrm{Ae}$ & 1,7 & 0,89 & 7 \\
\hline SM-216 & 4 & 454,9 & 453,9 & Ap & 2,8 & 0,60 & 42 \\
\hline SM-224 & 5 & 439,1 & 437,7 & $\mathrm{Ae}_{\mathrm{i}}$ & 2,0 & 0,71 & 12 \\
\hline SM-505 & 8 & 431,3 & 429,2 & $A e_{i}$ & 2,4 & 0,71 & 18 \\
\hline
\end{tabular}

\subsubsection{Produtos diagenéticos}

\subsubsection{Cimentos}

Foram identificados cinco tipos distintos de cimento, quanto à composição químico-mineralógica: esmectíticos, argilo-ferruginosos, óxi-hidróxidos metálicos, carbonáticos e de quartzo. Dentre as mineralogias identificadas, foram quantificadas todas exceto o quartzo, pois este tipo de cimento é escasso em relação aos demais e sua identificação é muito limitada ao microscópio óptico. 
cimento carbonático é encontrado, de maneira simultânea (numa mesma amostra) como preenchimento tanto intersticial como móldico e forma concentrações (nódulos). Apresenta textura espática a microespática. Ocorre abaixo da cota 435,6 $\mathrm{m}$, onde constitui aproximadamente 1 a $12 \%$ em volume e coexiste com o cimento esmectítico, em relação ao qual, com base na avaliação das relações de contato, parece ser tanto anterior quanto posterior, pois foi encontrado envolvido por cutícula esmectítica (Figura 3.3.5), mas também preenchendo moldes de grãos do arcabouço dissolvidos, previamente envolvidos por cutícula destes argilominerais (Figura 3.3.6). Análises de MEV por meio dos detectores de elétrons secundários e EDS confirmaram a presença deste tipo de cimento, tanto pela morfologia romboédrica dos cristais quanto pela composição química (Figuras 3.3.7 e 3.3.8).
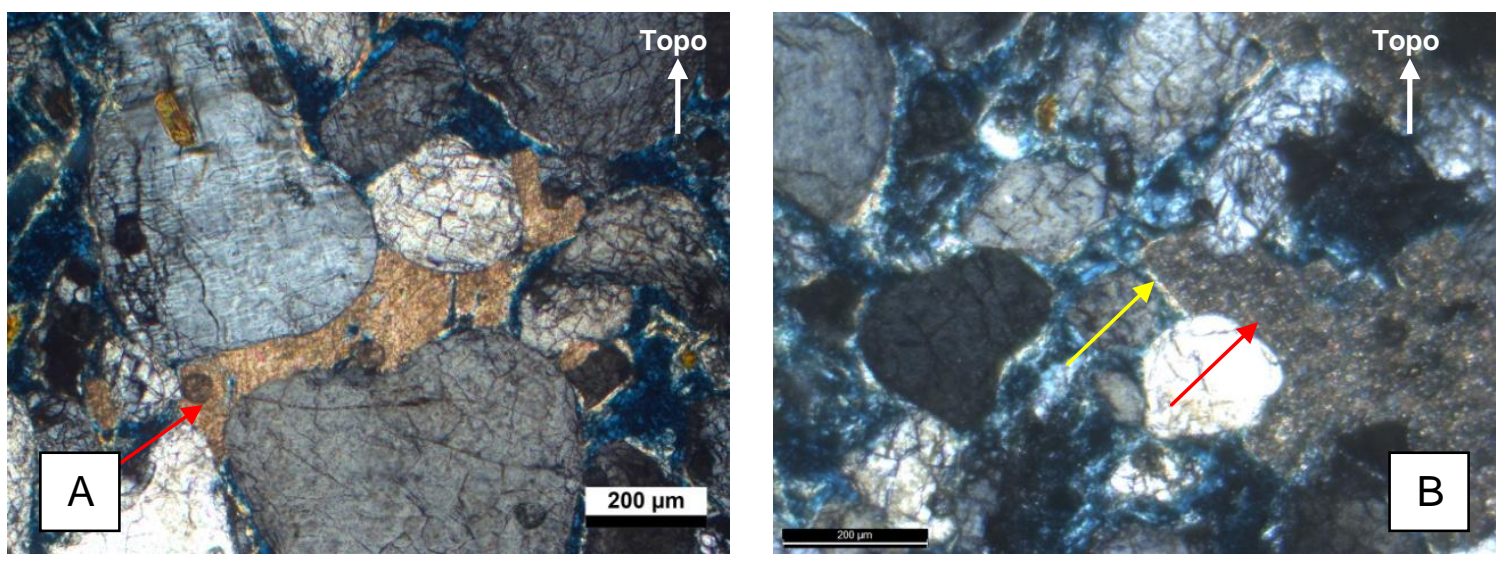

Figura 3.3.5 - Cimento carbonático espático intersticial (setas vermelhas). Na imagem B, notar a cutícula de cimento esmectítico (seta amarela) recobrindo o cimento carbonático. Amostras das cotas $432,9 \mathrm{~m}(\mathrm{~A})$ e 434,6 m (B) da sondagem SM-222, respectivamente a 32,5 e 30,8 m de profundidade. Polarizadores cruzados.
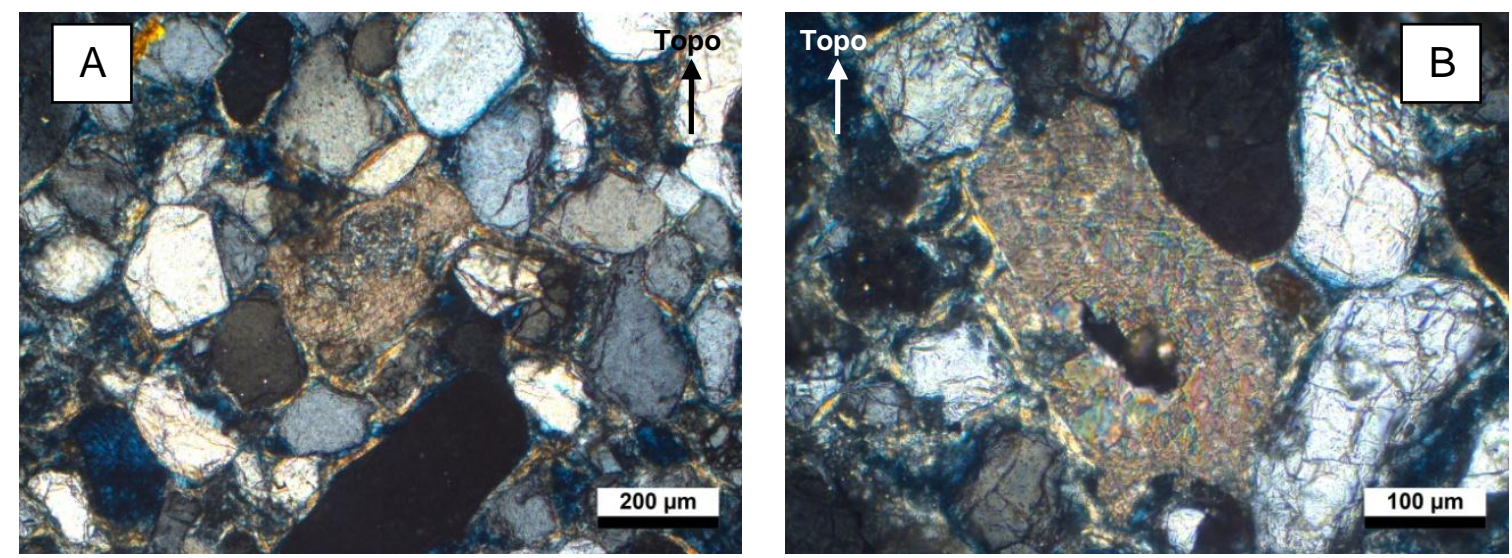

Figura 3.3.6 - Moldes de grãos do arcabouço, com preenchimento de carbonato espático, envoltos por cutícula de esmectita. Amostra da cota 435,5 m da sondagem SM-222, 29,9 m de profundidade. Polarizadores cruzados. 


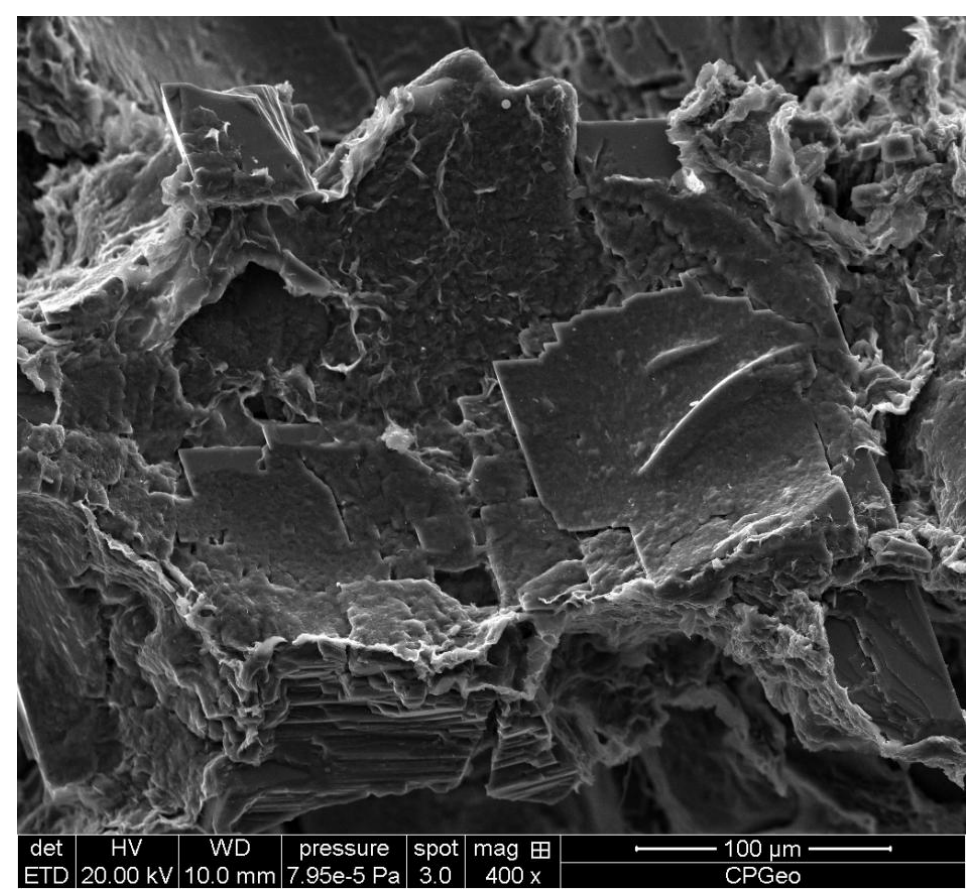

Figura 3.3.7 - Fotomicrografia do cimento carbonático espático, romboédrico, obtida ao MEV por meio de detector de elétrons secundários. Amostra da cota 434,6 m da sondagem SM-222, 30,8 m de profundidade.
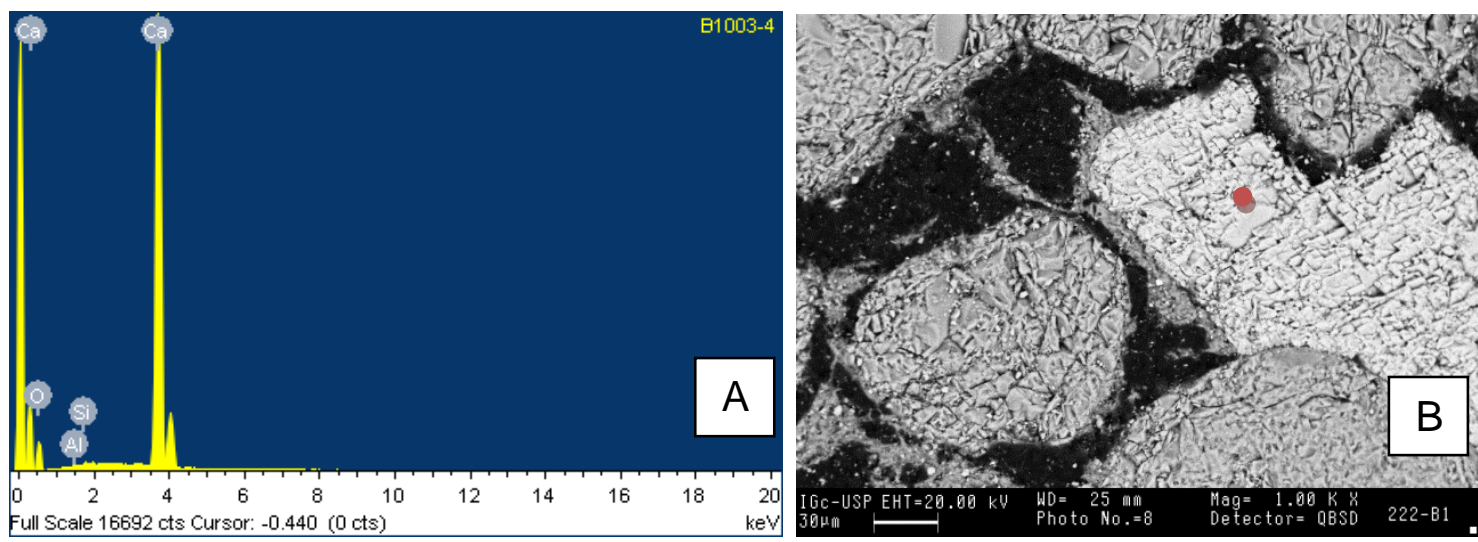

Figura 3.3.8 - A. Espectrograma obtido pelo sistema MEV-EDS referente ao cimento carbonático observado na amostra da cota 434,6 $\mathrm{m}$ da sondagem SM-222, correspondente a 30,8 m de profundidade. B. Local na seção petrográfica no qual se incidiu o feixe de elétrons (ponto vermelho). Notar que se trata do mesmo local da Figura 3.3.5.B, no qual se observa cutícula de esmectita recobrindo cimento carbonático.

O cimento de esmectita geralmente forma cutículas ao redor dos grãos, mas ocorre também, às vezes, como preenchimento, inteiro ou parcial, de poro intergranular. Está presente ao longo de praticamente toda a coluna sedimentar analisada, mas é mais comum abaixo de cerca de $17 \mathrm{~m}$ de profundidade, onde chega a constituir mais de $20 \%$ em volume. Ao microscópio óptico, apresenta pleocroísmo entre tons de marrom e amarelo e, com polarizadores cruzados, cor de interferência 
amarela a laranja de $1^{a}$ ordem (Figuras 3.3 .9 e 3.3.10). Este cimento foi identificado ao sistema MEV-EDS graças à micromorfologia característica (Figura 3.3.11) associada à presença notável de $\mathrm{Mg}$, com $\mathrm{Ca}$ em menor quantidade, detectada via EDS (Figura 3.3.12). A presença significativa de K permite sugerir associação com illita, que ocorreria na forma de filamentos finos (menores que $5 \mu \mathrm{m}$ ) associados às terminações dos flocos encurvados de esmectita (Figura 3.3.11).
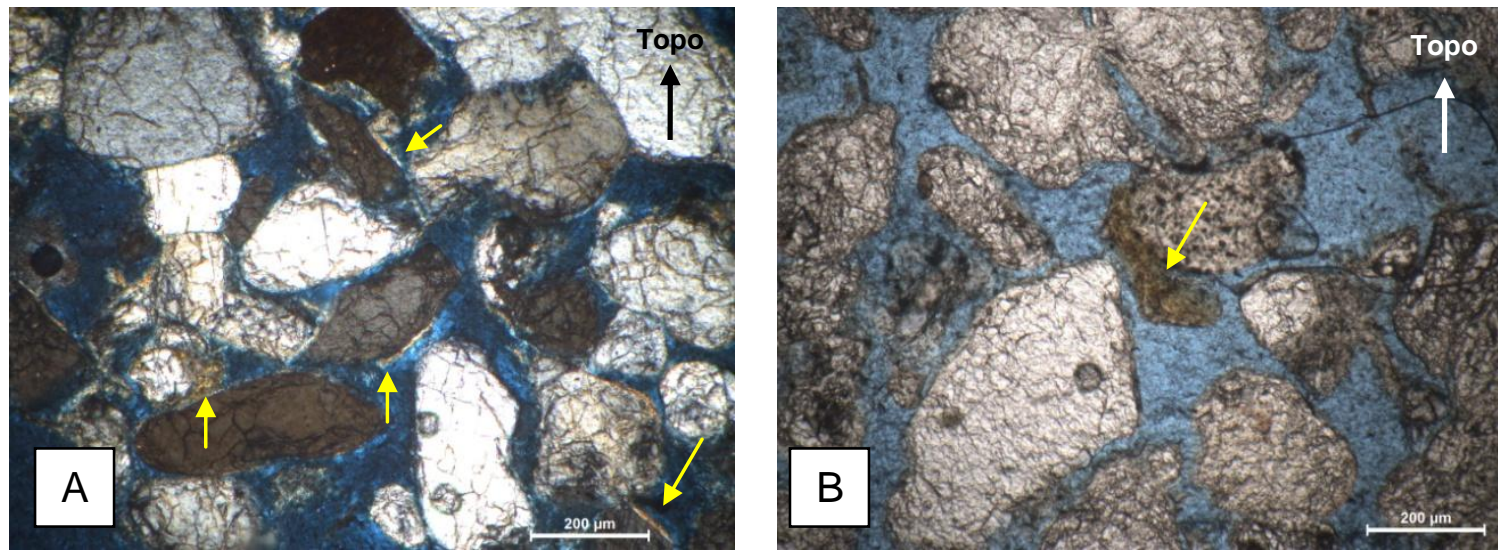

Figura 3.3.9 - A. Cutícula de esmectita ao redor de grãos do arcabouço. Polarizadores cruzados. B. Cimento esmectítico intergranular, preenchendo poro parcialmente, com cor amarela (com pleocroísmo). Polarizadores paralelos. Amostra da cota 432,9 m da sondagem SM-222, 32,5 m de profundidade.
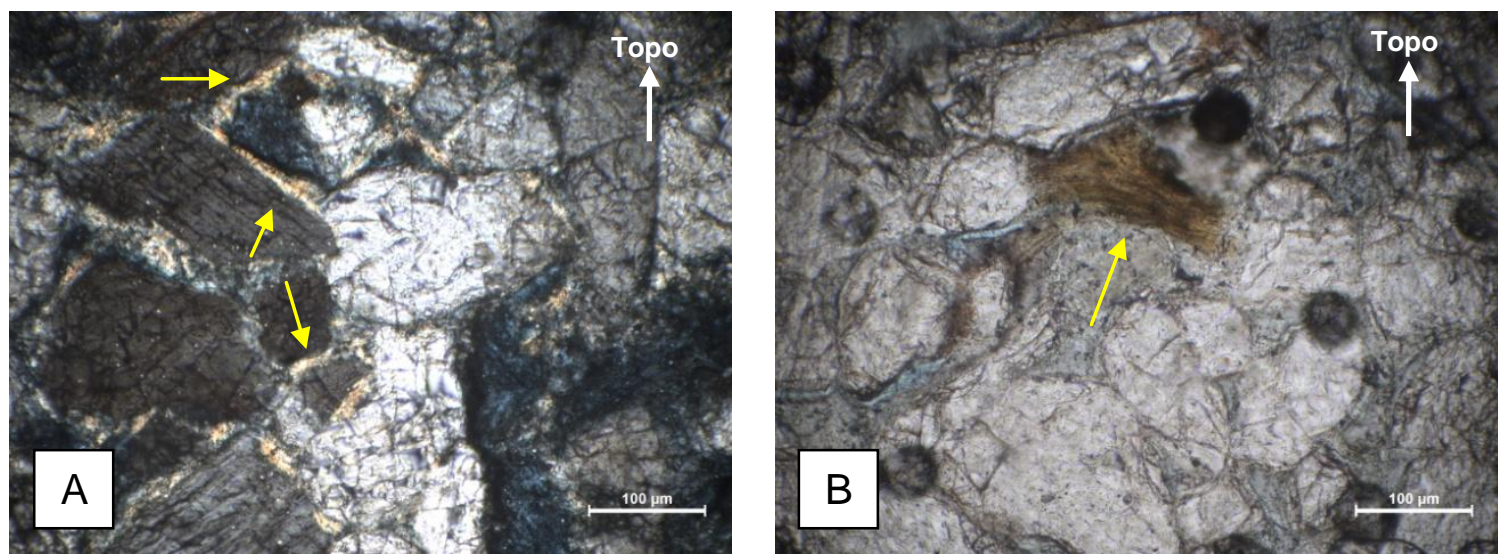

Figura 3.3.10 - Cimentos de esmectita. A. Na forma de cutículas, inclusive no contorno de poro móldico. Polarizadores cruzados. B. Como preenchimento de poro. Notar cor (com pleocroísmo) marrom amarelado. Polarizadores paralelos. Amostra da cota 436,6 m da sondagem SM-222, 28,7 m de profundidade. 

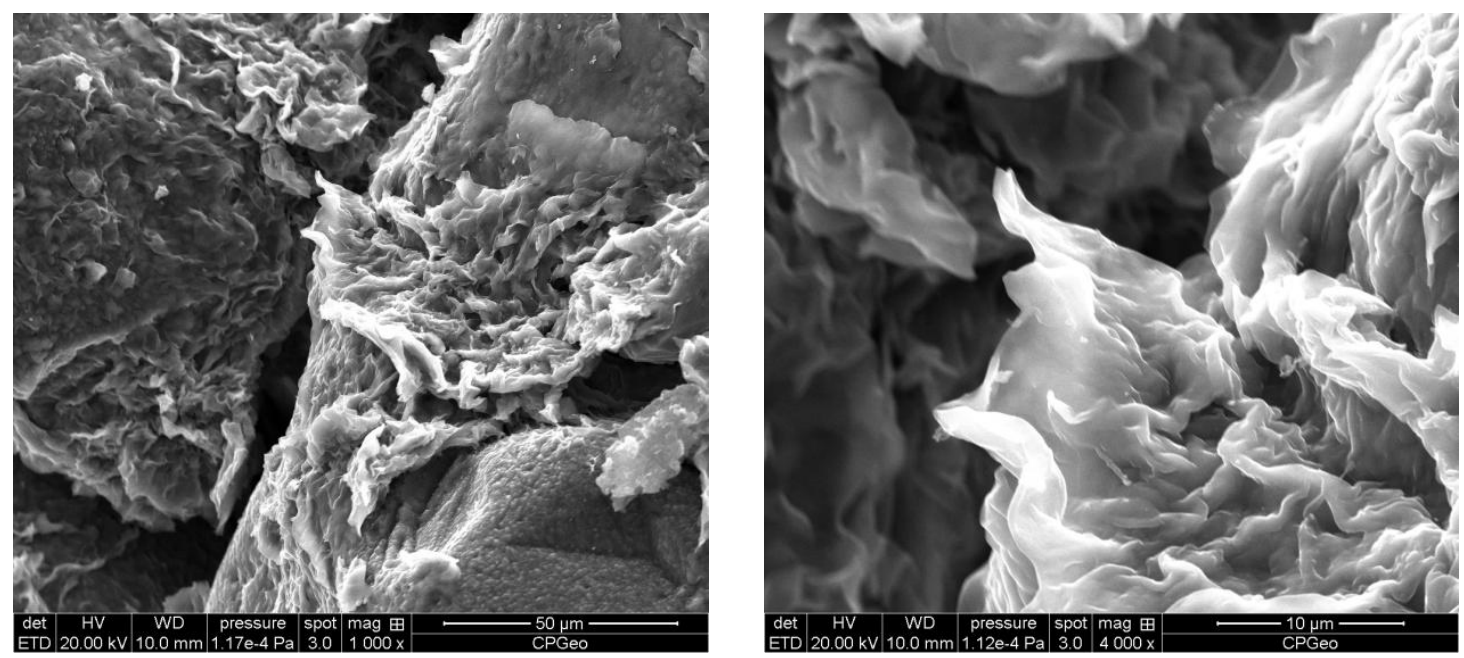

Figura 3.3.11 - Imagens do cimento esmectítico obtidas ao MEV por meio de detector de elétrons secundários. Filamentos menores podem corresponder a illita, a julgar pela presença de $\mathrm{K}$ detectada via EDS. Amostra da cota 434,6 m, 30,8 m de profundidade, sondagem SM-222.

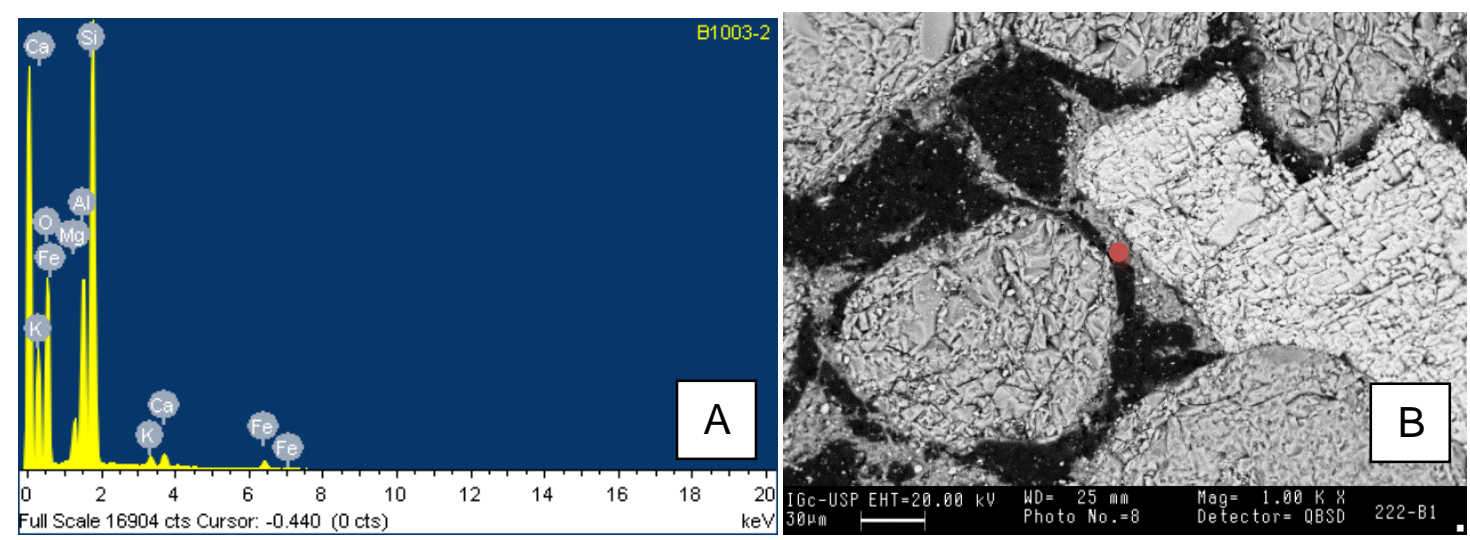

Figura 3.3.12 - A. Espectrograma obtido pelo sistema MEV-EDS referente ao cimento esmectítico observado na amostra da cota 434,6 m da sondagem SM-222, correspondente a 30,8 m de profundidade. O pico de $\mathrm{K}$ indica presença associada provável de illita. B. Local na seção petrográfica no qual incidiu o feixe de elétrons (ponto vermelho).

Os óxi-hidróxidos metálicos ocorrem como cutículas anisópacas que ocasionalmente coalescem, quando preenchem poros parcial ou completamente ou mesmo chegam a formar microconcreções (figuras 3.3 .13 e 3.3.14). Este tipo de cimento é escasso na coluna sedimentar analisada, geralmente perfazendo menos de $2 \%$ em volume, e é mais comum nas porções mais rasas, até cerca de $16 \mathrm{~m}$, onde se associa aos cimentos argilo-ferruginosos. Apresenta coloração avermelhada, quando examinado sob luz convergente, ou pode ser completamente opaco (Figura 3.3.15). Análises ao sistema MEV-EDS indicaram a presença marcante de Fe (Figura 3.3.14), e, em uma das amostras, de $\mathrm{Mn}$ e $\mathrm{Ba}$ (Figura 3.3.16). Composições mineralógicas possíveis são hematita $\left(\mathrm{Fe}_{2} \mathrm{O}_{3}\right)$, goethita $(\mathrm{FeO}(\mathrm{OH}))$, psilomelano $\left(\left(\mathrm{Ba}, \mathrm{H}_{2} \mathrm{O}\right)_{2} \mathrm{Mn}_{5} \mathrm{O}_{10}\right)$ e pirolusita $\left(\mathrm{MnO}_{2}\right)$. 

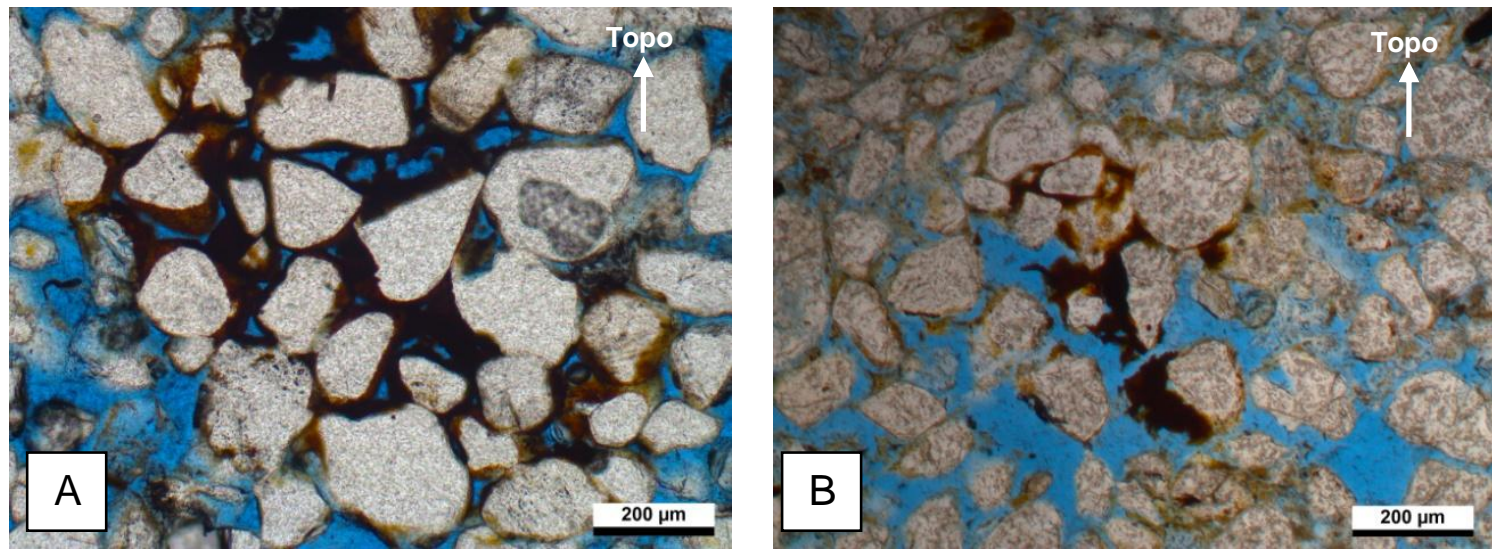

Figura 3.3.13 - Cimento de óxi-hidróxido metálico avermelhado. A. Na forma de microconcreção em amostra da cota 449,6 m da sondagem SM-222, 15,8 m de profundidade. Polarizadores paralelos. B. Com hábito intersticial, preenchendo poros parcialmente, a cuticular anisópaco, em amostra da cota $454,3 \mathrm{~m}, 11,1 \mathrm{~m}$ de profundidade. Polarizadores paralelos.
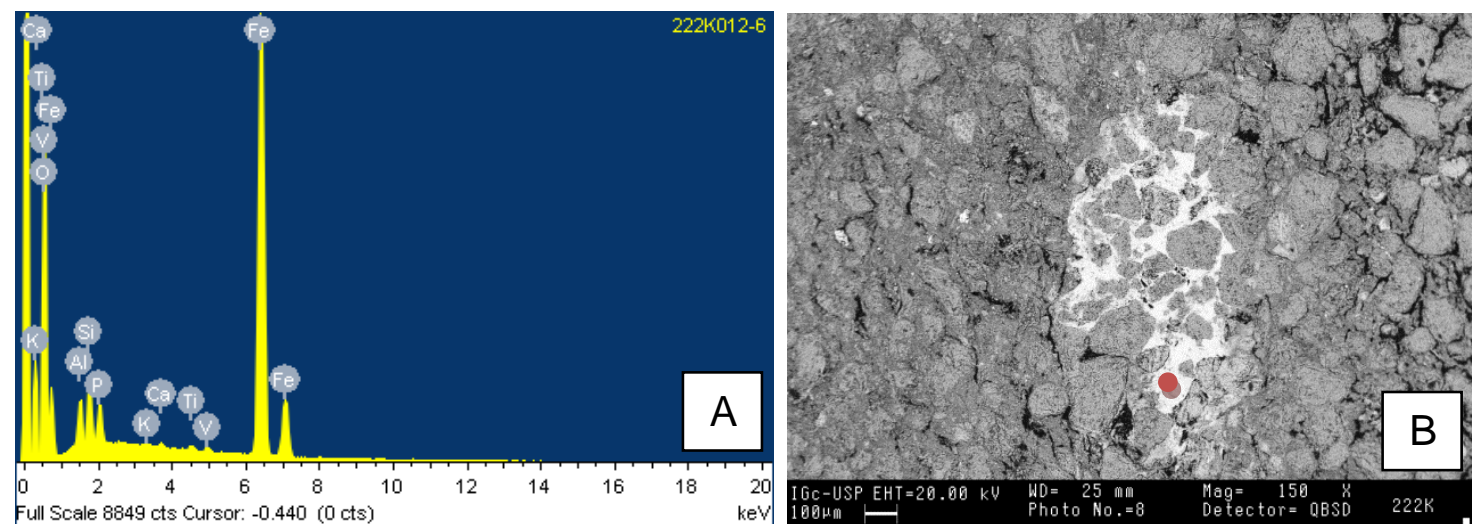

Figura 3.3.14 - A. Espectrograma obtido pelo sistema MEV-EDS referente ao cimento constituído por óxi-hidróxido metálico. Amostra da cota 454,7 $\mathrm{m}$ da sondagem SM-222, a 10,6 m de profundidade. B. Local na seção petrográfica no qual incidiu o feixe de elétrons (ponto vermelho). Notar trama em microconcreção.
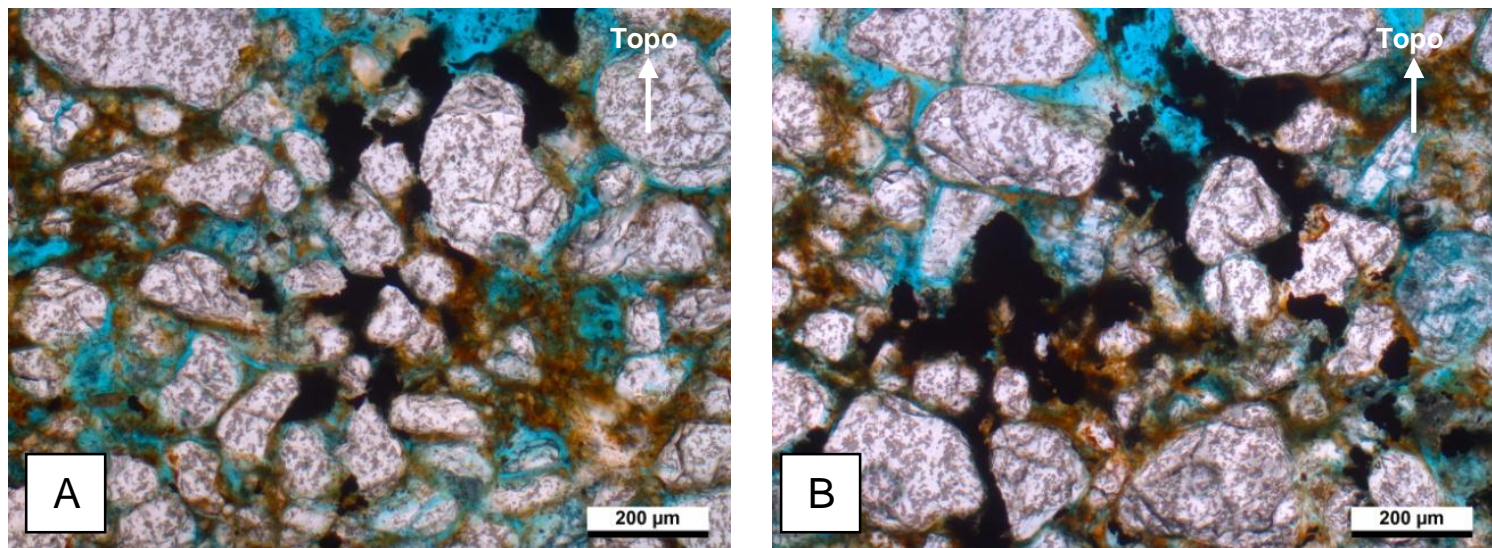

Figura 3.3.15 - A e B: Cimento de óxi-hidróxido metálico opaco em amostra da cota $451,5 \mathrm{~m}$ da sondagem SM-222, 13,8 $\mathrm{m}$ de profundidade. Notar envolvimento por cimento argilo-ferruginoso (tons amarelados). Polarizadores paralelos. 

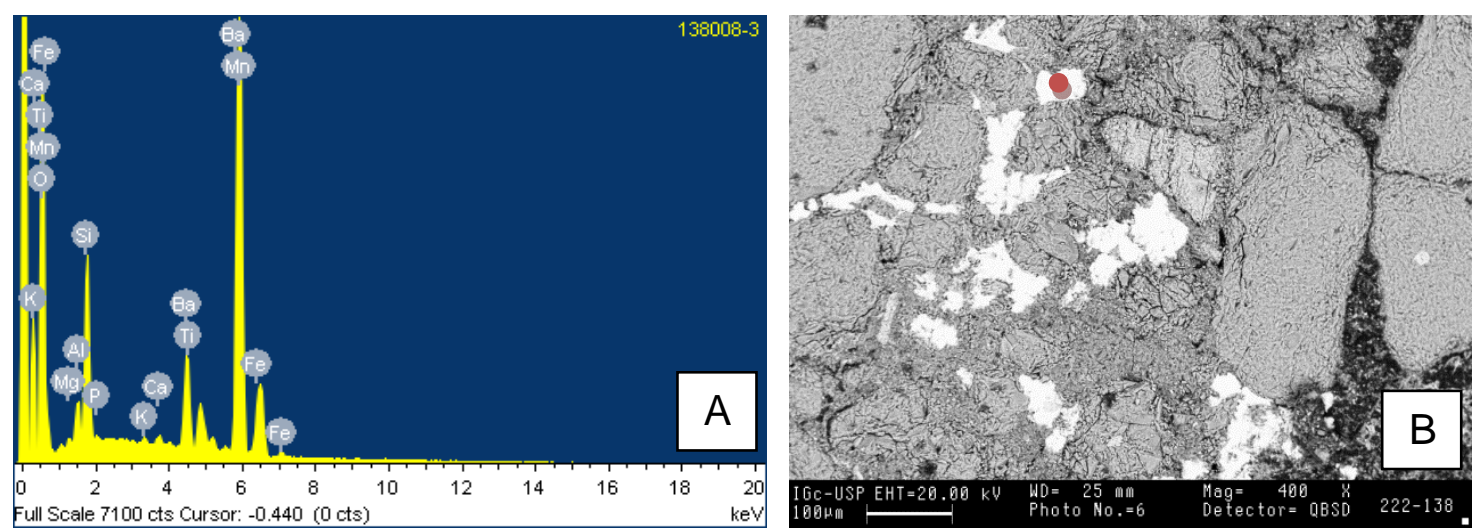

Figura 3.3.16 - A. Espectrograma obtido pelo sistema MEV-EDS referente ao cimento constituído por óxi-hidróxido metálico. Amostra da cota 451,5 m, 13,8 m de profundidade, sondagem SM-222. B. Local na seção petrográfica no qual incidiu o feixe de elétrons (ponto vermelho).

O cimento argilo-ferruginoso ocorre até cerca de $14 \mathrm{~m}$ de profundidade, onde perfaz mais de $30 \%$ em volume das amostras analisadas, principalmente com hábito intersticial, marcando a segregação granular de arenitos estratificados (Figura 3.3.17). Esta distribuição vertical favorece a interpretação de que se trate de argilas infiltradas. Apresenta coloração entre marrom, marrom avermelhado e amarelo (talvez devido a variações no teor de elementos metálicos) e birrefringência entre 0,001 e 0,004 (Figuras 3.3.17 e 3.3.18). O imageamento ao MEV permitiu observar características micromorfológicas comuns a esmectita e illita (Figura 3.3.19), hipótese reforçada ao EDS pela presença de $\mathrm{Mg}$, e, subordinadamente $\mathrm{Ca}$ e $\mathrm{K}$ (Figuras 3.3.20 e 3.3.21).

As relações de contato entre o cimento de óxi-hidróxido metálico e o argiloferruginoso indicam que o cimento de óxi-hidróxido se tenha formado antes, pois muitas vezes se apresenta envolvido pelo material argilo-ferruginoso (Figura 3.3.22). 

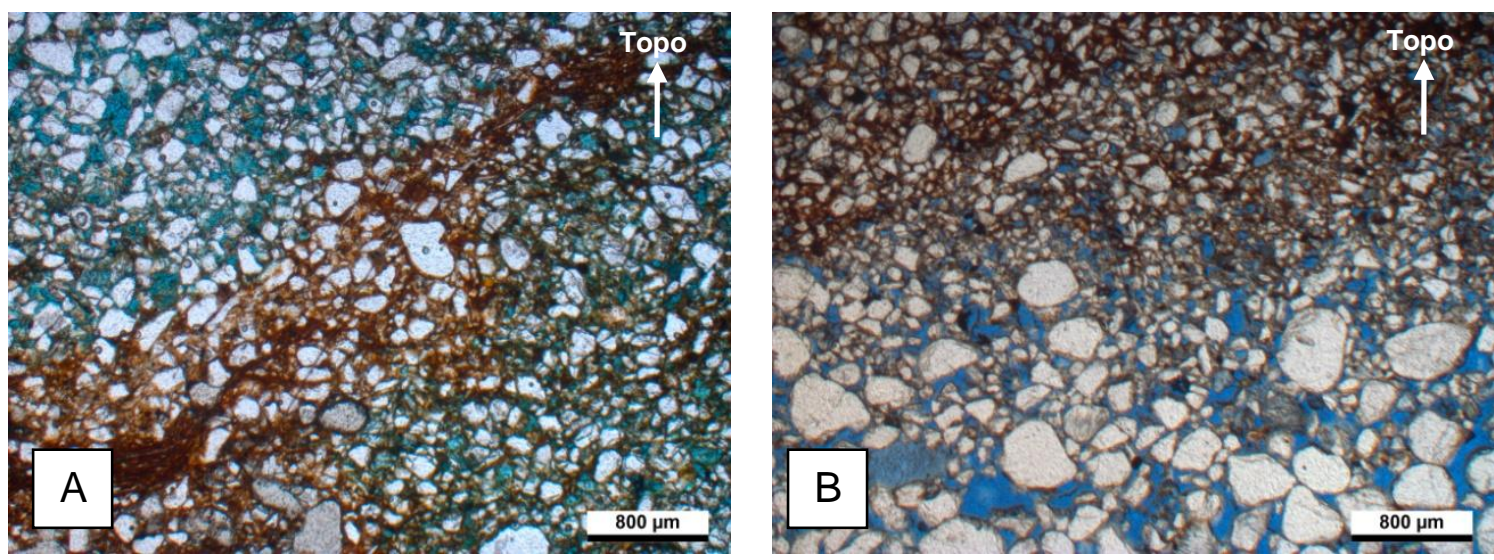

Figura 3.3.17 - Cimento argilo-ferruginoso intersticial com cor marrom avermelhado, marcando lâmina de granulometria mais fina. Polarizadores paralelos. A. Amostra da cota 454,3 m, 11,1 m de profundidade. B. Amostra da cota 451,2 m, 14,1 m. Sondagem SM-222.
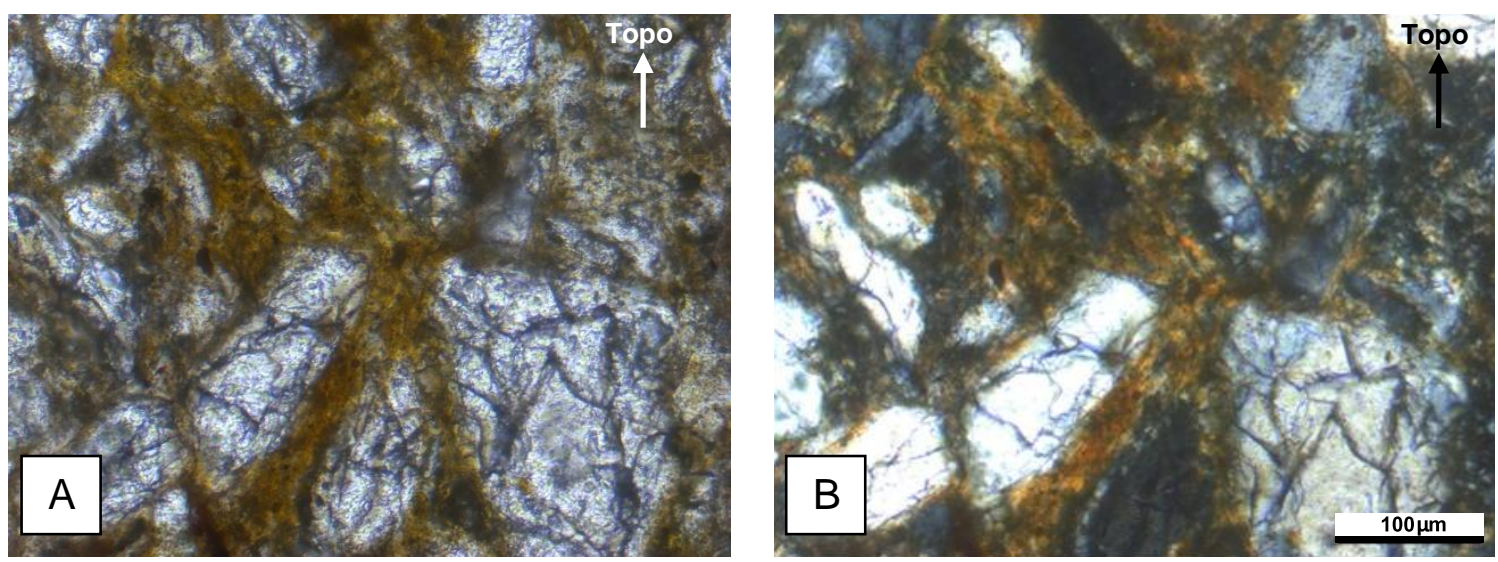

Figura 3.3.18 - Cimento argilo-ferruginoso intersticial. Notar cor pardo amarelado. Amostra coletada próximo à cota 454,7 $\mathrm{m}$ da sondagem SM-222, 10,6 $\mathrm{m}$ de profundidade. Polarizadores paralelos $(\mathrm{A}) \mathrm{e}$ cruzados (B).
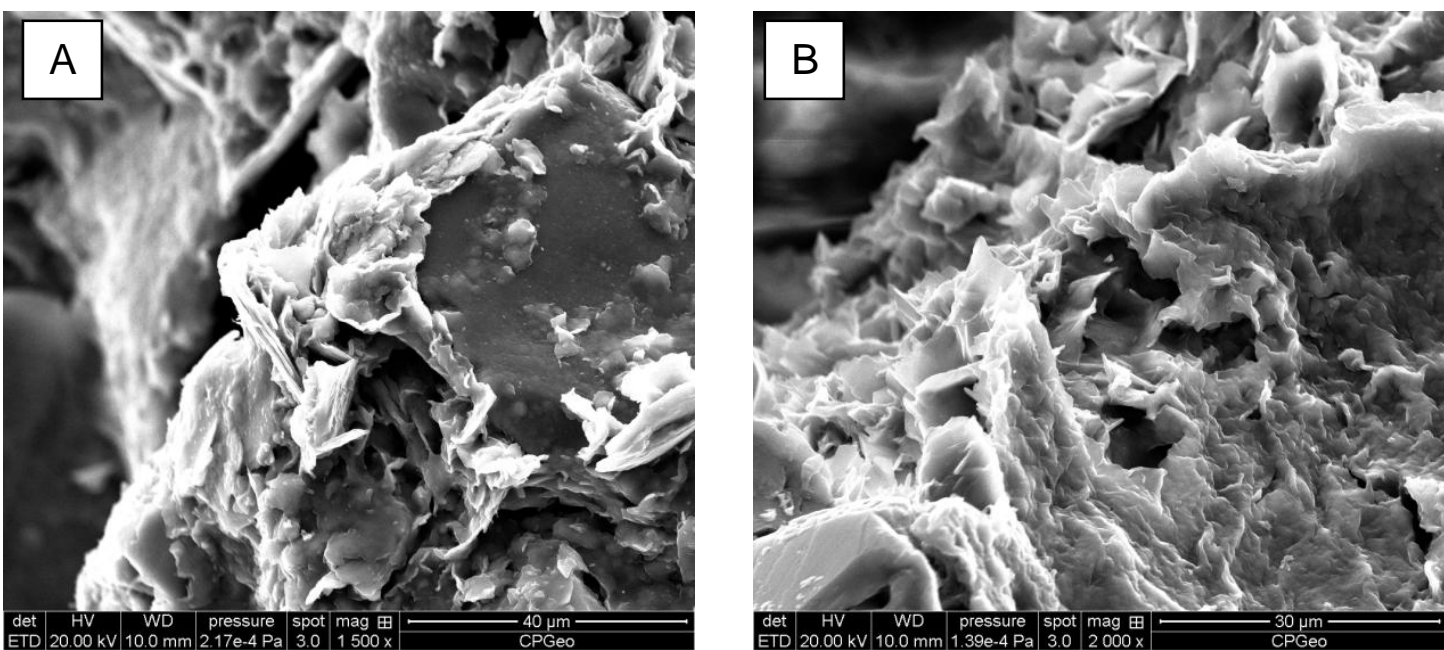

Figura 3.3.19 - Imagens do cimento argilo-ferruginoso obtidas ao MEV por meio de detector de elétrons secundários. A. Amostra da cota 454,7 m, da sondagem SM-222, a 10,6 m de profundidade. B. Amostra da cota 448,2 m da sondagem SM-222, a 17,2 m de profundidade. Notar características micromorfologicas atribuíveis a esmectita e illita. 

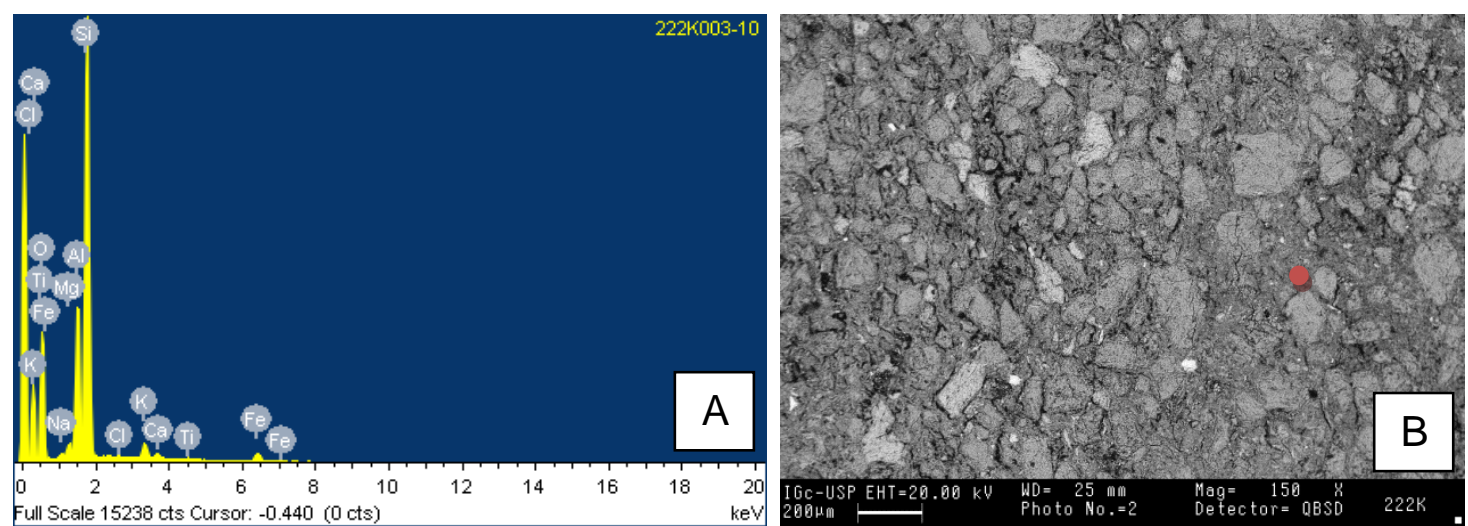

Figura 3.3.20 - A. Espectrograma obtido pelo sistema MEV-EDS referente ao cimento argiloferruginoso observado na amostra da cota 454,7 $\mathrm{m}$ da sondagem SM-222, a 10,6 $\mathrm{m}$ de profundidade. B. Local na seção petrográfica no qual incidiu o feixe de elétrons (ponto vermelho).
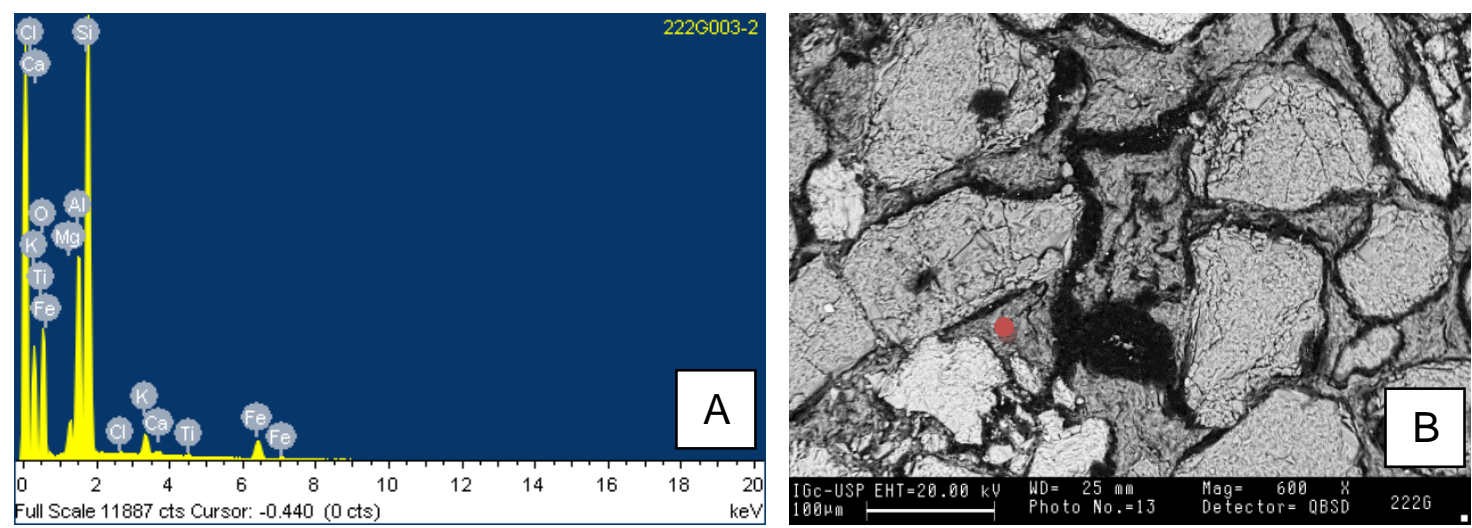

Figura 3.3.21 - A. Espectrograma obtido pelo sistema MEV-EDS referente ao cimento argiloferruginoso observado na amostra da cota 448,2 m da sondagem SM-222, a 17,2 $\mathrm{m}$ de profundidade. B. Local na seção petrográfica no qual incidiu o feixe de elétrons (ponto vermelho).
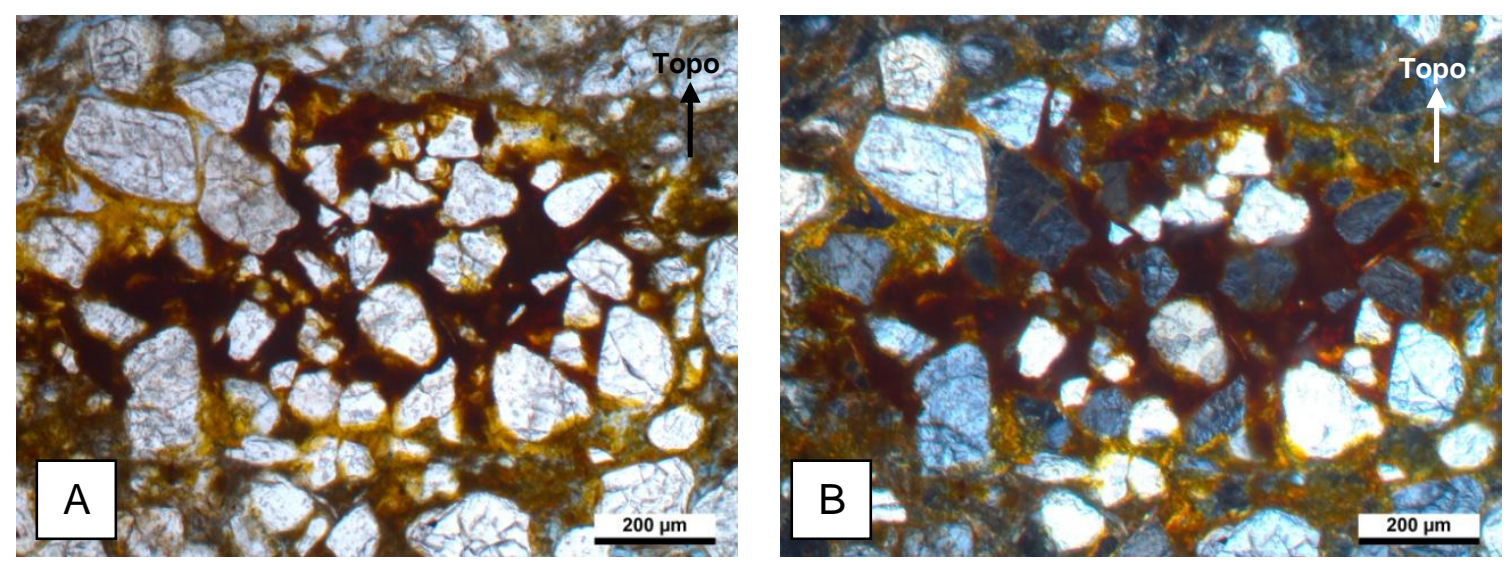

Figura 3.3.22 - Microconcreção de óxi-hidróxido metálico (pardo avermelhado escuro) envolvida por cimento argilo-ferruginoso (amarelo) em amostra da cota 454,7 $\mathrm{m}$ da sondagem SM-222, 10,6 m de profundidade. Polarizadores paralelos (A) e cruzados (B). 


\subsubsection{Matriz diagenética}

A matriz diagenética, presente em 15 das 27 amostras de arenitos analisadas, geralmente em quantidades inferiores a $1 \%$, abrange casos de epi e de pseudomatriz.

A epimatriz é constituída por grãos de feldspato do arcabouço alterados e recristalizados para argilomineral de baixa birrefringência (cor de interferência cinza a branco de $1^{\text {a }}$ ordem), provável caulinita (Figura 3.3.23).

A pseudomatriz é constituída por intraclastos pelíticos, provavelmente constituídos por esmectita ou caulinita (Figura 3.3.24), deformados pelos grãos rígidos via compactação mecânica. Distingue-se do cimento destes mesmos minerais pela ocorrência heterogênea, concentrada em certos pontos do arenito.
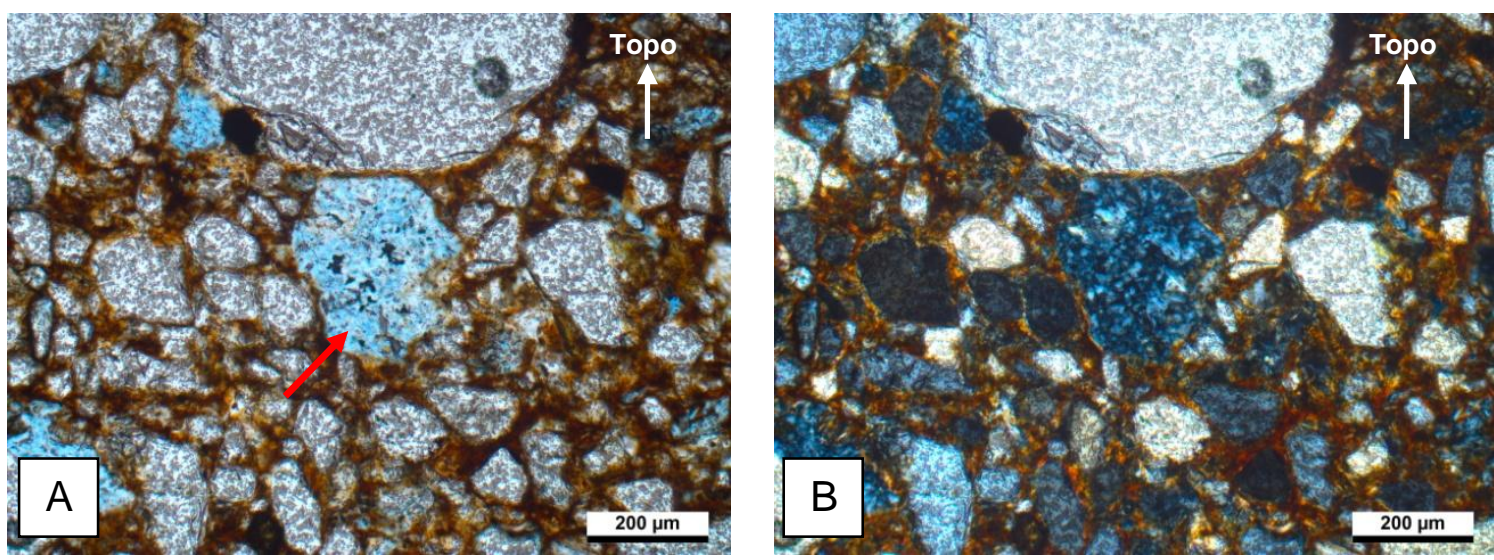

Figura 3.3.23 - Epimatriz, formada pela alteração e recristalização de grão de feldspato do arcabouço para provável caulinita, em amostra da cota 448,2 m da sondagem SM-222, cerca de 17,2 m de profundidade. A. Polarizadores paralelos. B. Polarizadores cruzados. 

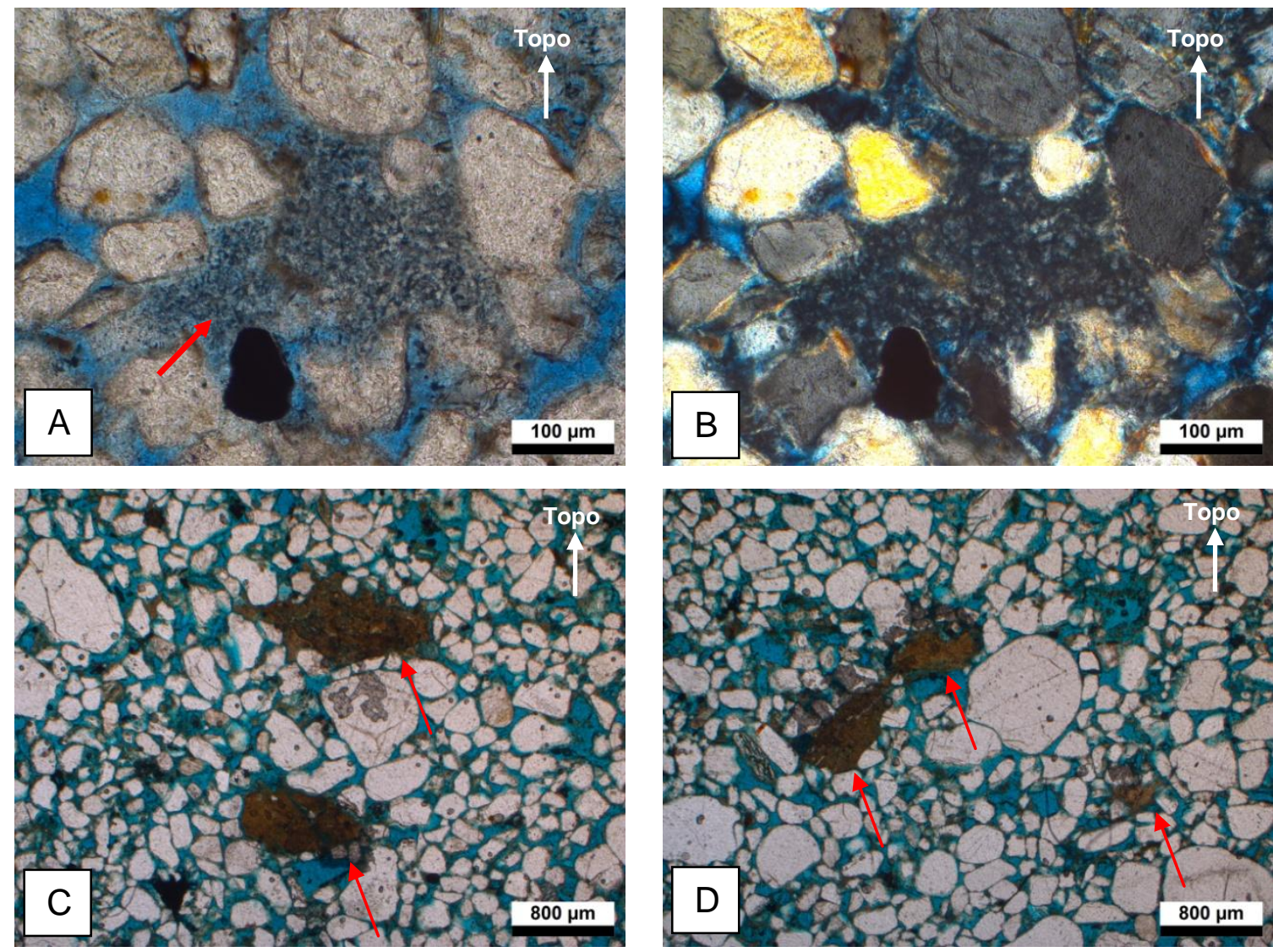

Figura 3.3.24 - Pseudomatriz (setas), constituída por intraclastos argilosos amolgados entre demais grãos do arcabouço. A. Provavelmente caulinítica. Amostra da cota 446,3 m da sondagem SM-222, 19,1 m de profundidade. Polarizadores paralelos. B. Idem, polarizadores cruzados. C e D: Provavelmente esmectítica. Amostra da cota 438,4 m da mesma sondagem, 26,9 m de profundidade. Polarizadores paralelos.

\subsubsection{Porosidade intragranular}

A porosidade intragranular constitui em média cerca de $4 \%$ da porosidade total nas amostras analisadas, variando entre 0 e $50 \%$. Os principais tipos de poros intragranulares verificados são moldes e grãos sulcados ("honeycombed grains"), os quais resultam respectivamente da dissolução total ou parcial de grãos de feldspato (Figuras 3.3.25 e 3.3.26). Em arenitos com cimentação carbonática móldica, ocorrem poros diagenéticos formados pela dissolução parcial deste tipo de cimento (Figura 3.3.25 B).

Com base no que foi observado, conclui-se que a formação da porosidade intragranular nos grãos de feldspato é posterior à formação dos cimentos esmectítico, de óxi-hidróxidos metálicos e argilo-ferruginoso, uma vez que estes cimentos marcam o contorno destes grãos. A porosidade formada pela dissolução dos cimentos carbonáticos móldicos, portanto, é posterior à porosidade formada pela dissolução de grãos de feldspato. 

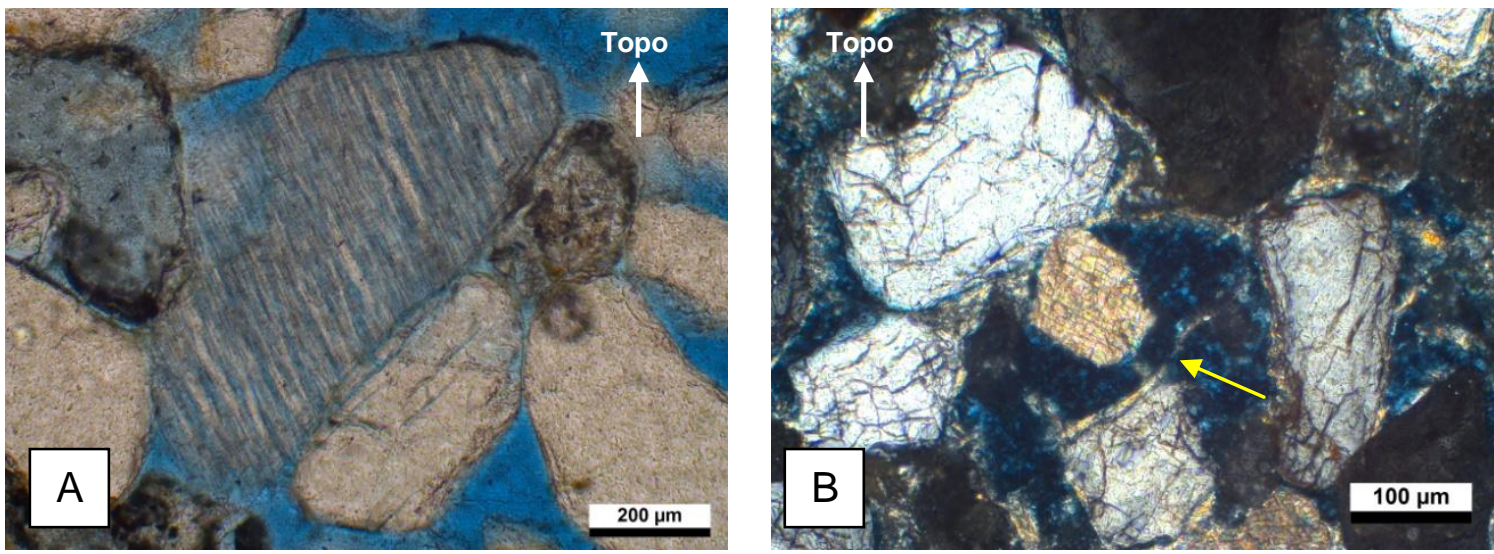

Figura 3.3.25 - Porosidade intragranular $(A)$ e de dissolução parcial de cimento móldico (B). A. Sulcos de dissolução parcial de grãos de feldspato. Amostra da cota 449,6 m da sondagem SM-222, 15,8 m de profundidade. Polarizadores paralelos. B. Dissolução parcial de carbonato espático móldico (com clivagens), posterior à cutícula de esmectita (seta amarela). Amostra da cota 435,5 m, 29,9 m de profundidade, mesma sondagem. Polarizadores cruzados.
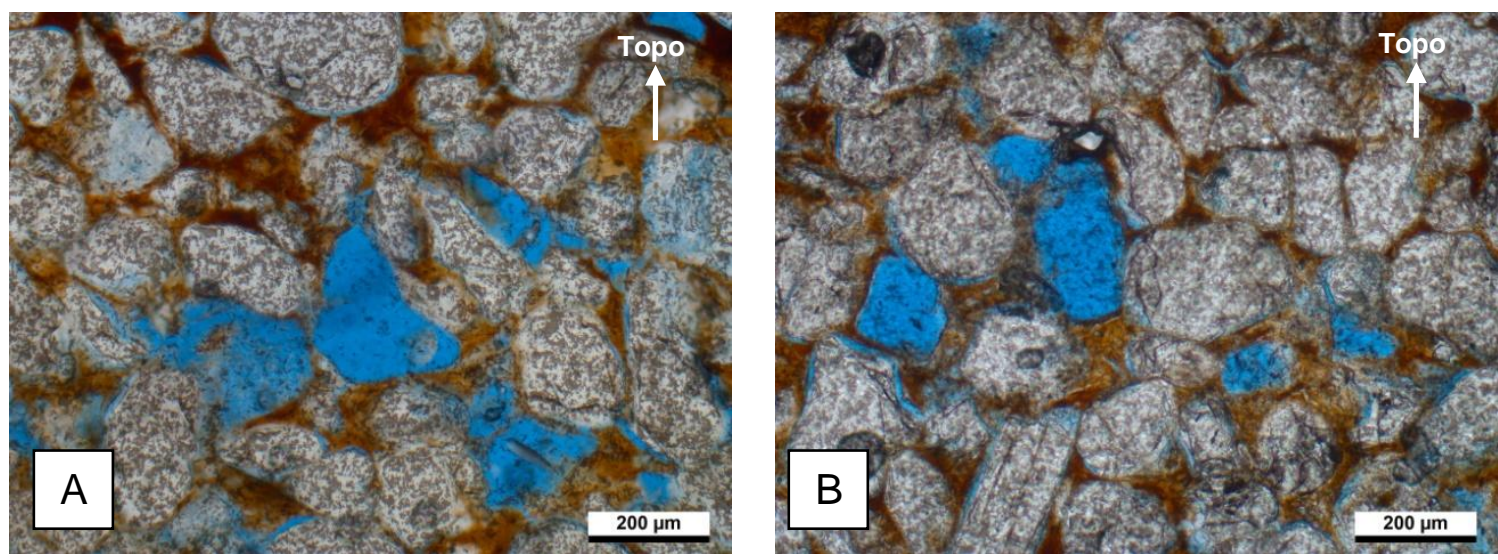

Figura 3.3.26 - Porosidade intragranular móldica, provavelmente devido à dissolução total de grãos de feldspato. Polarizadores paralelos. Amostra da cota 448,2 m da sondagem SM-222, 17,2 m de profundidade (A e B). Nesta amostra, com porosidade modal de aproximadamente $3 \%$, a porosidade intragranular chega a constituir metade da porosidade total.

\subsubsection{Compactação}

O amassamento leve a mediano de grãos de filossilicatos, sem presença associada de feldspatos deformados, é indicativo de que houve compactação mecânica, fraca a moderada (Figura 3.3.27). A compactação química, por sua vez, avaliada por meio do tipo de contato entre os grãos, foi considerada incipiente a moderada, em vista de os contatos intergranulares variarem entre tangenciais e retos. Dentre os contatos intergranulares, a proporção de contatos tangenciais varia entre 30 e $82 \%$, com mediana em $53 \%$, ao passo que a proporção de contatos retos varia entre 15 e $60 \%$, com mediana em $43 \%$. 
A Figura 3.3.28 apresenta a porcentagem relativa dos tipos de contatos intergranulares ao longo da coluna sedimentar da SM-222.
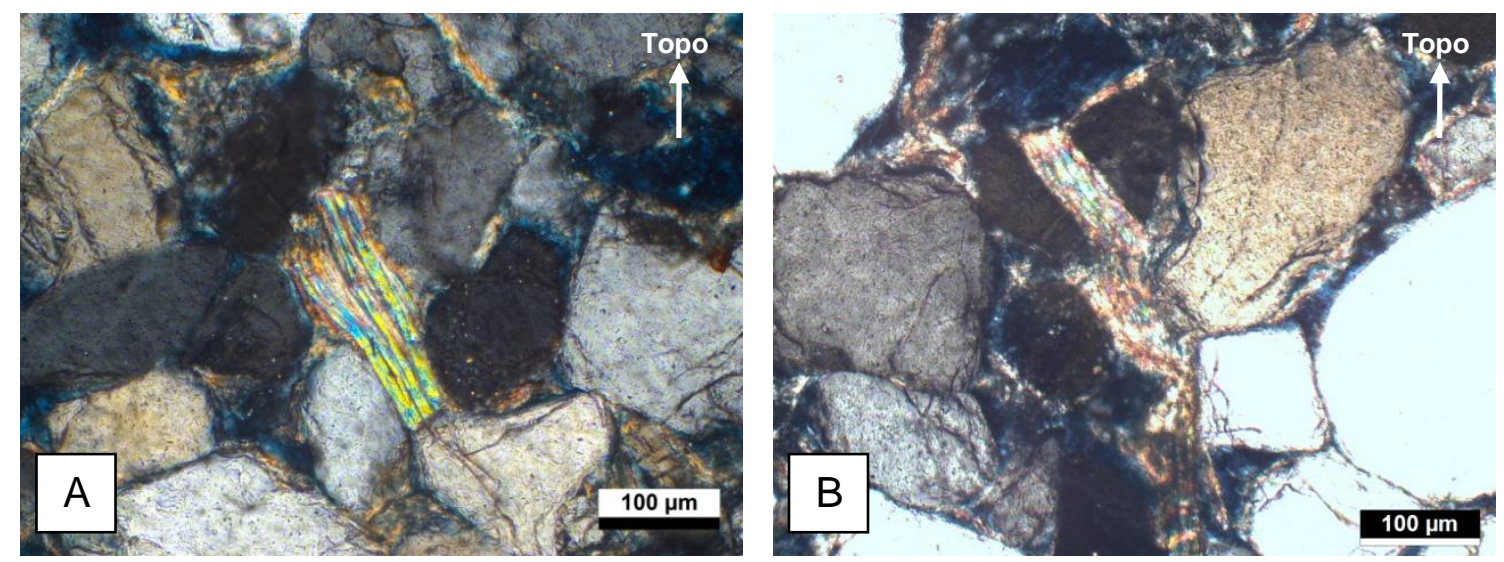

Figura 3.3.27 - Grãos de filossilicatos leve (A) a moderadamente (B) deformados, indícios de compactação mecânica fraca a moderada. Amostra da cota $435,5 \mathrm{~m}$ da sondagem SM-222, correspondente a 29,9 m de profundidade. Polarizadores cruzados. 


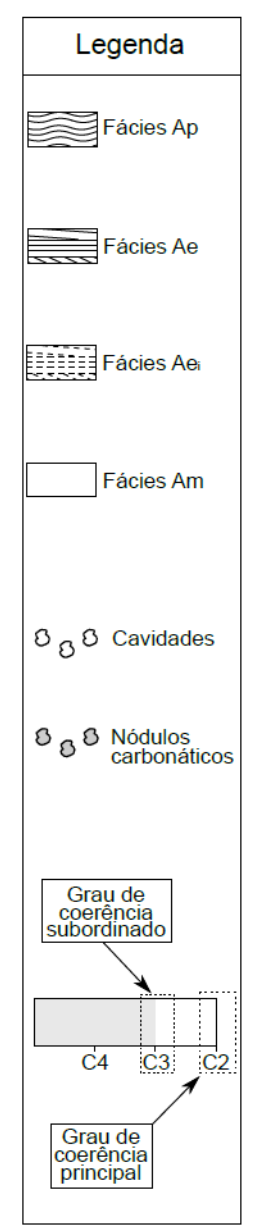
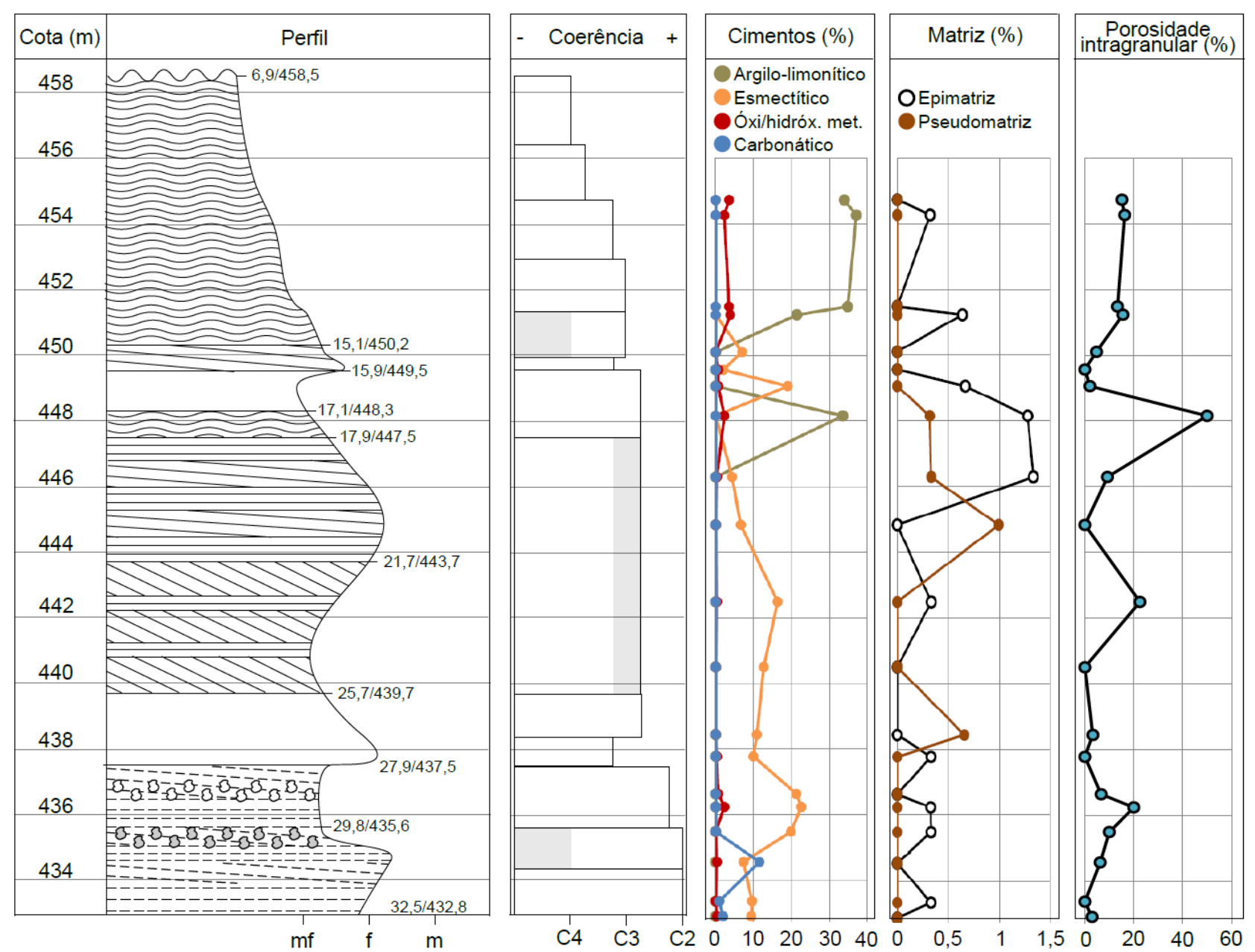

\begin{tabular}{|l|}
\hline Contatos inter- \\
granulares (\%) \\
\hline Tangenciais \\
Retos \\
Conc.-convex. \\
\hline
\end{tabular}

Cont. grãos e

Grão-matriz

- Grão-cimento

Conc.-convex

Grão-vazio
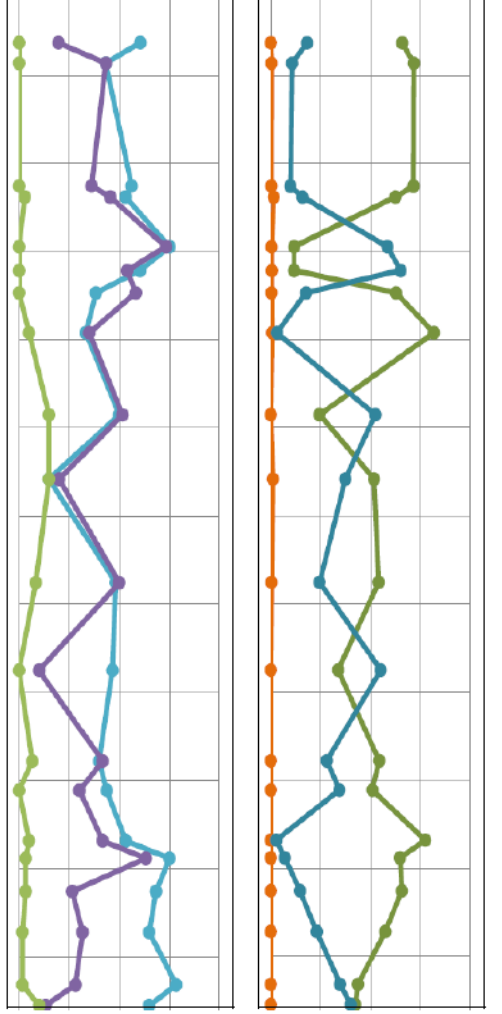

Figura 3.3.28 - Produtos diagenéticos - cimentos, epi e pseudomatriz, porosidade intragranular - e proporção de contatos intergranulares e contatos entre grãos e demais componentes petrográficos, das amostras analisadas na sondagem SM-222. 


\subsubsection{Petrofácies}

Com base nos critérios estabelecidos no Item 2.3.6, foram definidas cinco petrofácies, apresentadas a seguir.

\section{Petrofácies Efsx - arenito fino estratificado rico em cimento de esmectita}

A petrofácies Efsx compreende arenitos feldspáticos (Dott, 1964) e subarcóseos (Folk, 1968) finos com segregação granular nítida, teor de pelíticos maior ou igual a $15 \%$ e proporções relativas de esmectita entre 15 e $20 \%$. Enquadram-se nesta petrofácies quatro dentre as 27 seções petrográficas analisadas (Tabela 3.3.6).

A segregação granular observa-se entre a classe areia fina $(2,2$ a 2,7 $\varphi)$ e o seu limite com areia muito fina $(3,0 \varphi)$, com seleção moderada a boa por moda. Considerando ambas as modas, o tamanho médio dos grãos varia entre 2,5 e 2,7 $\varphi$, conforme dados obtidos via petrografia óptica, e entre 2,1 e 2,6 $\varphi$, de acordo com dados do granulômetro a laser. O teor de pelíticos varia entre 15 e $21 \%$.

O cimento principal é a esmectita, a qual ocorre como preenchimento de poro e em cutícula Ocorrem ainda pequenas quantidades, inferiores a $2 \%$, de óxihidróxido metálico, na forma de preenchimento de poros e cuticulas anisópacas. A porosidade avaliada por meio de software analisador de imagens varia entre $12 \mathrm{e}$ $26 \%$.

Tabela 3.3.6 - Dados de granulometria, mineralogia de cimento e porosidade das amostras da petrofácies Efsx. M1 e M2: modas granulométricas segregadas, respectivamente em grãos de tamanho menor e maior. TM $(\varphi)$ e DP $(\varphi)$ - ptrgrf: tamanho médio e desvio padrão dos grãos do arcabouço na fração areia avaliados via petrografia ótica. TM $(\varphi)$ e DP $(\varphi)$ - Mlv: idem, avaliados via granulômetro a laser (Malvern). Plt.: teor de pelíticos, em peso. Esm.: proporção de cimento de esmectita, no total. Oxh.: proporção de cimento constituído por óxi-hidróxido metálico, no total. Poros.: porosidade avaliada por meio de software analisador de imagens digitais.

\begin{tabular}{cccccccccccc}
\hline Sond. & $\begin{array}{c}\text { Cota } \\
(\mathbf{m})\end{array}$ & $\mathbf{M 1}$ & $\mathbf{M} 2$ & $\begin{array}{c}\text { TM }(\boldsymbol{\varphi})- \\
\text { ptrgrf }\end{array}$ & DP $(\boldsymbol{\varphi})$ - ptrgrf $\begin{array}{c}\text { TM }(\boldsymbol{\varphi})- \\
\mathbf{M l v}\end{array}$ & DP $(\boldsymbol{\varphi})$ - Mlv & $\begin{array}{c}\text { PIt. } \\
(\%)\end{array}$ & Esm. (\%) & Ox. (\%) & Poros. $(\%)$ \\
\hline SM-222 & 443 & 3,0 & 2,7 & 2,5 & 0,54 & 2,6 & 0,53 & 17,4 & 16,3 & 0,3 & 12,0 \\
SM-222 & 435,5 & 3,0 & 2,2 & 2,7 & 0,68 & 2,3 & 0,68 & 14,7 & 19,9 & 0,0 & 11,7 \\
SM-208 & 448,8 & 3,0 & 2,2 & 2,7 & 0,70 & 2,4 & 0,66 & 20,8 & 15,0 & 1,3 & 22,1 \\
SM-210 & 444,8 & 3,0 & 2,2 & 2,6 & 0,67 & 2,1 & 0,63 & 14,5 & 18,0 & 1,7 & 26,1 \\
\hline
\end{tabular}




\section{Petrofácies Ems - arenito médio a fino estratificado pobre em cimento de esmectita}

A petrofácies Ems é constituída por quartzo arenitos e arenitos feldspáticos (Dott, 1964), ou subarcóseos (Folk, 1968), médios a finos, com teor de pelíticos em média da ordem de 10\%, e que apresentam segregação granular nítida e proporções relativas de esmectita menores do que 15\%. Cinco das 27 amostras analisadas correspondem a esta petrofácies (Tabela 3.3.7).

A segregação granular pode ocorrer entre diferentes modas dentro da classe areia fina $(2,1$ a 2,9 $\varphi)$, entre diferentes modas dentro da classe areia média (1,0 a 2,0 $\varphi$ ) e entre as classes areia fina $(2,3 \varphi)$ e areia média $(2,0 \varphi)$. Uma das amostras admitida nesta petrofácies apresenta segregação granular entre as classes areia média $(1,5 \varphi)$ e areia grossa $(0,6 \varphi)$. O grau de seleção por moda segregada varia entre moderado e bom. Considerando ambas as modas de todas as amostras desta petrofácies, o tamanho médio dos grãos varia entre 1,8 e 2,7 $\varphi$, de acordo com os dados obtidos via petrografia óptica, e de 1,6 a 2,2 $\varphi$, conforme dados obtidos por granulômetro a laser.

A esmectita é o tipo de cimento predominante, e ocorre principalmente na forma de cutículas, com proporções relativas que variam entre 2 e $7 \%$ no total. Subordinadamente, podem ocorrer quantidades de cimento constituído por óxihidróxido metálico que não ultrapassam $2 \%$, na forma de cutículas anisópacas ou preenchimento de poros (Figura 3.3.31). A porosidade avaliada por software analisador de imagens varia entre 15 e $18 \%$.

Tabela 3.3.7 - Dados de granulometria, mineralogia de cimento e porosidade das amostras da petrofácies Ems. M1 e M2: modas granulométricas segregadas, respectivamente em grãos de tamanho menor e maior. TM $(\varphi)$ e DP $(\varphi)$ - ptrgrf: tamanho médio e desvio padrão dos grãos do arcabouço na fração areia avaliados via petrografia ótica. TM $(\varphi)$ e DP $(\varphi)$ - Mlv: idem, avaliados via granulômetro a laser (Malvern). Plt.: teor de pelíticos, em peso. Esm.: proporção de cimento esmectita, no total. Oxh.: proporção de cimento constituído por óxi-hidróxido metálico, no total. Poros.: porosidade avaliada por meio de software analisador de imagens digitais.

\begin{tabular}{cccccccccccc}
\hline Sond & $\begin{array}{c}\text { Cota } \\
(\mathbf{m})\end{array}$ & M1 & M2 & $\begin{array}{c}\text { TM } \\
(\boldsymbol{\varphi})-\end{array}$ & DP $(\boldsymbol{\varphi})$ - ptrgrf & TM $(\boldsymbol{\varphi})$ - Mlv & DP $(\boldsymbol{\varphi})$ - Mlv & Plt. $(\%)$ & Esm. $(\%)$ & Oxh. $(\%)$ & Poros. $(\%)$ \\
\hline SM-222 & 450,1 & 2,9 & 2,5 & 2,7 & 0,65 & 2,2 & 0,65 & 10,3 & 7,0 & 0,0 & 16,9 \\
SM-222 & 449,6 & 2,5 & 2,1 & 2,4 & 0,59 & 1,9 & 0,50 & 3,9 & 2,0 & 0,7 & 17,5 \\
SM-222 & 446,3 & 2,3 & 2 & 2,2 & 0,59 & 2,0 & 0,62 & 13,5 & 4,3 & 0,3 & 17,9 \\
SM-222 & 444,8 & 1,5 & 1 & 1,8 & 0,75 & 1,8 & 0,84 & 10,3 & 6,6 & 0,0 & 14,7 \\
SM-210 & 436,7 & 1,5 & 0,6 & 1,8 & 0,47 & 1,6 & 0,81 & 8,8 & 4,3 & 1,7 & 16,3 \\
\hline
\end{tabular}




\section{Petrofácies Epa - arenito fino estratificado rico em cimento argilo-ferruginoso}

A petrofácies Epa compreende arenitos feldspáticos e quartzo-arenitos (Dott, 1964) ou subarcóseos (Folk, 1968) muito finos a finos, com teor de pelíticos maior do que $20 \%$, chegando a mais de $40 \%$ em algumas amostras. Esta petrofácies é representada por seis das 27 amostras analisadas (Tabela 3.3.8).

Arenitos da petrofácies Epa apresentam nítida segregação granular por tamanho médio de grãos, marcada por cimentação diferencial argilo-ferruginosa, que geralmente constitui mais de $30 \%$ no total, à qual se associa cimentação por óxidohidróxido metálico em quantidades relativas de 2 a 4\%. Em função da densa cimentação argilo-ferruginosa, arenitos da petrofácies Epa apresentam porosidades baixas, da ordem de $10 \%$.

A segregação granular ocorre entre as classes areia muito fina $(3,3$ e 3,5 $\varphi)$ e areia fina $(2,5$ a $3,0 \varphi)$, com seleção moderada a boa por moda. Considerando ambas as modas, os arenitos apresentam tamanho médio dos grãos entre 2,9 e 3,4 $\varphi$, com base nos dados petrográficos, ou entre 2,4 e 2,8 $\varphi$, de acordo com a análise feita pelo granulômetro a laser.

Tabela 3.3.8 - Dados de granulometria, mineralogia de cimento e porosidade das amostras da petrofácies Epa. M1 e M2: modas granulométricas segregadas, respectivamente em grãos de tamanho menor e maior. TM $(\varphi)$ e DP $(\varphi)$ - ptrgrf: tamanho médio e desvio padrão dos grãos do arcabouço na fração areia avaliados via petrografia ótica. TM $(\varphi)$ e DP $(\varphi)$ - Mlv: idem, avaliados via granulômetro a laser (Malvern). Plt.: teor de pelíticos, em peso. Agl.: proporção de cimento argiloferruginoso, no total. Oxh.: proporção de cimento constituído por óxi-hidróxido metálico, no total. Poros.: porosidade avaliada por meio de software analisador de imagens digitais.

\begin{tabular}{cccccccccccc}
\hline Sond. & $\begin{array}{c}\text { Cota } \\
(\mathbf{m})\end{array}$ & $\mathbf{M 1}$ & $\mathbf{M} 2$ & $\begin{array}{c}\text { TM }(\boldsymbol{\varphi}) \\
\mathbf{-}\end{array}$ & DP $(\boldsymbol{\varphi})$ - ptrgrf & TM $(\boldsymbol{\varphi})$ - Mlv & DP $(\boldsymbol{\varphi})$ - Mlv & $\begin{array}{c}\text { Plt. } \\
(\%)\end{array}$ & Agl. $(\%)$ & Ox. $(\%)$ & Poros. $(\%)$ \\
\hline SM-222 & 454,3 & 3,4 & 3,2 & 3,4 & 0,77 & 2,7 & 0,59 & 42,0 & 37,1 & 2,3 & 13,2 \\
SM-222 & 451,5 & 3,3 & 2,8 & 3,3 & 0,75 & 2,5 & 0,81 & 28,0 & 34,8 & 3,5 & 9,3 \\
SM-222 & 451,2 & 3,3 & 2,7 & 2,9 & 0,73 & 2,5 & 0,85 & 20,3 & 21,4 & 3,8 & 12,0 \\
SM-222 & 448,2 & 3,5 & 2,5 & 2,9 & 0,77 & 2,4 & 0,69 & 38,5 & 33,5 & 2,2 & 7,2 \\
SM-216 & 454,5 & 3,5 & 2,5 & 3,1 & 0,70 & 2,8 & 0,63 & 40,8 & 36,7 & 3,2 & 13,0 \\
\hline
\end{tabular}

\section{Petrofácies Mfsx - arenito fino maciço rico em cimento de esmectita}

A petrofácies Mfsx compreende arenitos feldspáticos (Dott, 1964) e subarcóseos (Folk, 1968) finos a muito finos, com teores de pelíticos em geral maiores do que $15 \%$, com segregação granular por tamanho de grãos ausente ou 
pouco evidente e proporções de cimento esmectítico maiores do que 15\%. Cinco dentre as 27 amostras analisadas integram esta petrofácies (Tabela 3.3.9).

O tamanho médio dos grãos na petrofácies varia entre 2,8 e 3,1 $\varphi$ ou entre 2,4 e 2,7 $\varphi$, de acordo com os dados obtidos via petrografia ótica ou granulômetro a laser, respectivamente, com grau de seleção moderado a bom. O teor de pelíticos fica entre 17 e $20 \%$.

A esmectita ocorre em proporções relativamente altas, entre 19 e 23\% no total, na forma de preenchimento de poros ou cutículas, com quantidades subordinadas, até pouco mais de $2 \%$, de oxi-hidróxido metálico, este como preenchimento de poros e ou em cutículas anisópacas. A porosidade avaliada por software analisador de imagens varia entre 9 e $24 \%$.

Tabela 3.3.9 - Dados de granulometria, mineralogia de cimento e porosidade das amostras da petrofácies Mfsx. TM $(\varphi)$ e DP $(\varphi)$ - ptrgrf: tamanho médio e desvio padrão dos grãos do arcabouço na fração areia avaliados via petrografia ótica. TM $(\varphi)$ e DP $(\varphi)$ - Mlv: idem, avaliados via granulômetro a laser (Malvern). Plt.: teor de pelíticos em peso. Esm.: proporção de cimento esmectita no total. Oxh.: proporção de cimento constituído por óxi-hidróxido metálico, no total. Poros.: porosidade avaliada por meio de software analisador de imagens digitais.

\begin{tabular}{cccccccccc}
\hline Sond. & $\begin{array}{c}\text { Cota } \\
(\mathbf{m})\end{array}$ & $\begin{array}{c}\text { TM }(\boldsymbol{\varphi}) \text { - } \\
\text { ptrgrf }\end{array}$ & DP $(\boldsymbol{\varphi})$ - ptrgrf & TM $(\boldsymbol{\varphi})$ - Mlv & DP $(\boldsymbol{\varphi})$ - Mlv & PIt. (\%) & Esm. (\%) & Oxh. (\%) & Poros. (\%) \\
\hline SM-222 & 449,1 & 3,1 & 0,62 & 2,7 & 0,60 & 19,1 & 19,0 & 0,7 & 16,9 \\
SM-222 & 436,6 & 2,8 & 0,58 & 2,4 & 0,66 & 16,9 & 21,3 & 0,7 & 9,0 \\
SM-222 & 436,2 & 2,8 & 0,63 & 2,5 & 0,57 & 20,2 & 22,6 & 2,3 & 13,7 \\
SM-224 & 437,7 & 2,7 & 0,63 & 2,1 & 0,75 & 13,2 & 19,0 & 0,0 & 21,4 \\
SM-505 & 429,3 & 3,0 & 0,79 & 2,4 & 0,71 & 17,9 & 21,7 & 1,0 & 24,4 \\
\hline
\end{tabular}

\section{Petrofácies Mms - arenito médio a fino maciço pobre em cimento de esmectita}

A petrofácies Mms é constituída principamente por arenitos feldspáticos (Dott, 1964) e subarcóseos (Folk, 1968), subordinadamente quartzo-arenitos (Dott, 1964), médios a finos, com teores de pelíticos geralmente abaixo de $10 \%$, apresentando segregação granular por tamanho médio de grãos ausente ou pouco evidente e proporções de cimento esmectítico de até 15\%. Sete das 27 amostras analisadas fazem parte desta petrofácies (Tabela 3.3.10).

O tamanho médio dos grãos varia entre 1,7 e 2,9 $\varphi$ de acordo com os dados de petrografia, ou de 1,5 a 2,1 $\varphi$, com base nas análises por granulômetro a laser, sendo o grau de seleção moderado.

A esmectita ocorre na forma cuticular ou preenchendo poros, em proporções que variam entre 7 e 13\%. Cimento de oxi-hidróxido metálico pode ocorrer de 
maneira subordinada, geralmente em proporções de no máximo 0,5\%, na forma de microconcreções preenchendo poros ou como cutículas anisópacas. Esta petrofácies pode apresentar cimentação carbonática, chegando a representar mais de $10 \%$ no total. A porosidade avaliada por meio de software analisador de imagens varia de 15 a $27 \%$.

Tabela 3.3.10 - Dados de granulometria, mineralogia de cimento e porosidade das amostras da petrofácies Mms. TM $(\varphi)$ e DP $(\varphi)$ - ptrgrf: tamanho médio e desvio padrão dos grãos do arcabouço na fração areia avaliados via petrografia ótica. TM $(\varphi)$ e DP $(\varphi)$ - Mlv: idem, avaliados via granulômetro a laser (Malvern). Plt.: teor de pelíticos em peso. Esm.: proporção de cimento esmectita, no total. Oxh.: proporção de cimento constituído por óxi-hidróxido metálico, no total. Crb.: porporção de cimento carbonático, no total. Poros.: porosidade avaliada por meio de software analisador de imagens digitais.

\begin{tabular}{ccccccccccc}
\hline Sond. & $\begin{array}{c}\text { Cota } \\
(\mathbf{m})\end{array}$ & $\begin{array}{c}\text { TM }(\boldsymbol{\varphi}) \\
\text { - ptrgrf }\end{array}$ & DP $(\varphi)$ - ptrgrf & TM $(\varphi)$ - Mlv & DP $(\varphi)$ - Mlv & PIt. $(\%)$ & Esm. $(\%)$ & Oxh. (\%) & Crb (\%) & Poros. $(\%)$ \\
\hline SM-222 & 440,5 & 2,9 & 0,71 & 2,1 & 0,80 & 14,5 & 12,7 & 0,0 & 0,0 & 27,4 \\
SM-222 & 438,4 & 2,1 & 0,70 & 1,5 & 0,40 & 7,5 & 10,9 & 0,0 & 0,0 & 18,9 \\
SM-222 & 437,8 & 1,9 & 0,82 & 1,5 & 0,71 & 8,5 & 9,9 & 0,3 & 0,0 & 19,7 \\
SM-222 & 434,6 & 1,7 & 0,72 & 1,6 & 0,64 & 8,7 & 7,3 & 0,3 & 11,5 & 14,8 \\
SM-222 & 433,4 & 2,0 & 0,76 & 1,8 & 0,56 & 7,6 & 9,6 & 0,0 & 1,0 & 20,4 \\
SM-222 & 432,9 & 2,2 & 0,67 & 2,0 & 0,58 & 9,9 & 9,4 & 0,3 & 1,9 & 17,9 \\
SM-201 & 435,4 & 1,9 & 0,68 & 2,0 & 0,72 & 8,4 & 8,3 & 1,7 & 0,0 & 19,7 \\
\hline
\end{tabular}




\subsection{Densidade e porosidade aparentes}

A densidade aparente dos arenitos analisados varia entre 1,7 e $2,1 \mathrm{~g} / \mathrm{cm}^{3}$, com mediana de $2,0 \mathrm{~g} / \mathrm{cm}^{3}$. A porosidade aparente varia entre 12 e $30 \%$, com mediana de $22 \%$. Os gráficos do tipo boxplot da Figura 3.4.1 representam, separadamente, os valores de densidade e porosidade aparentes obtidos a partir de todas as amostras analisadas.

A Figura 3.4.2 apresenta os dados de densidade e porosidade referentes a 17 pontos distintos distribuídos ao longo da seção colunar da sondagem SM-222.

A Figura 3.4.3 representa a dispersão dos valores de densidade e de porosidade aparentes de cada uma das 29 amostras obtidas nas sondagens SM201, SM-208, SM-210, SM-216, SM-224 e SM-505. As medianas das distribuições de densidade e porosidade aparentes das amostras representativas das diferentes fácies e petrofácies reconhecidas nestas sondagens encontram-se na Tabela 3.4.1.

Dados mais detalhados referentes a cada amostra submetida aos ensaios de obtenção da densidade e porosidade aparentes podem ser consultados no Apêndice B.
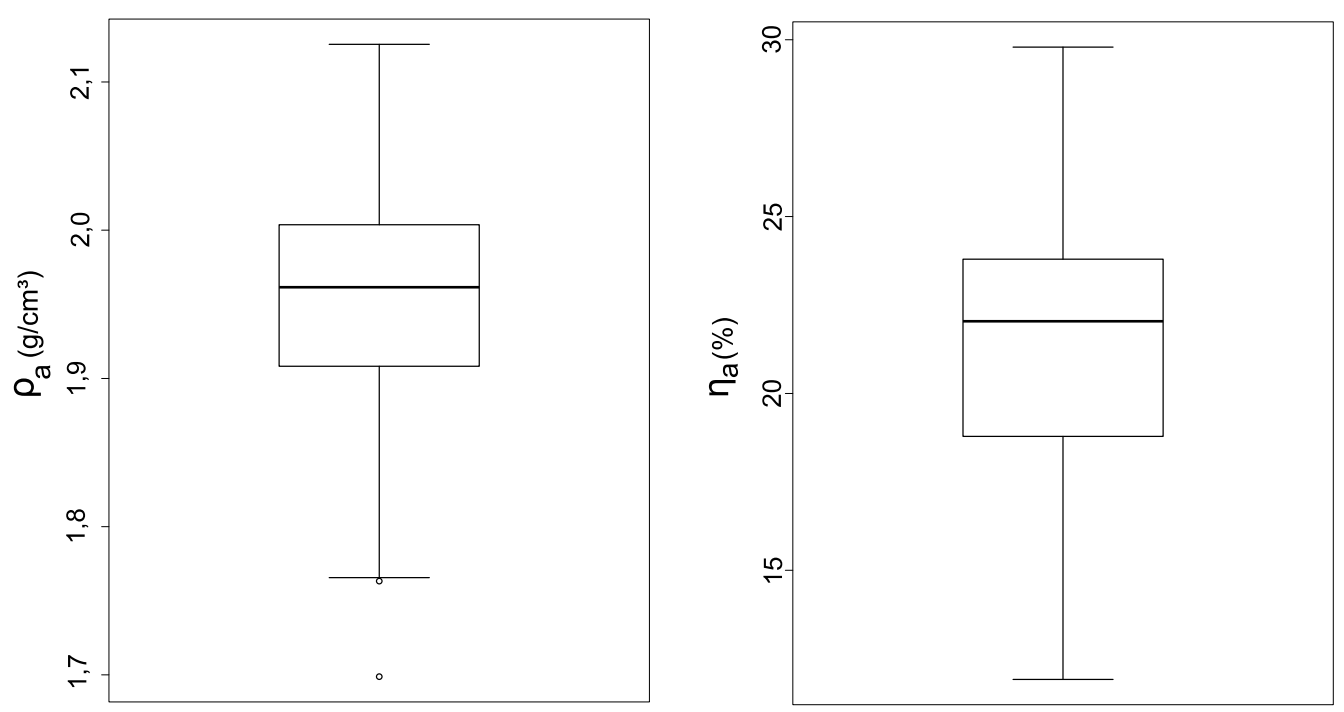

Figura 3.4.1 - Gráficos do tipo boxplot representando a distribuição dos resultados de densidade $\left(\rho_{\mathrm{a}}\right)$ e porosidade $\left(\mathrm{n}_{\mathrm{a}}\right)$ aparentes das amostras analisadas. Número de amostras $\mathrm{N}=24$. 

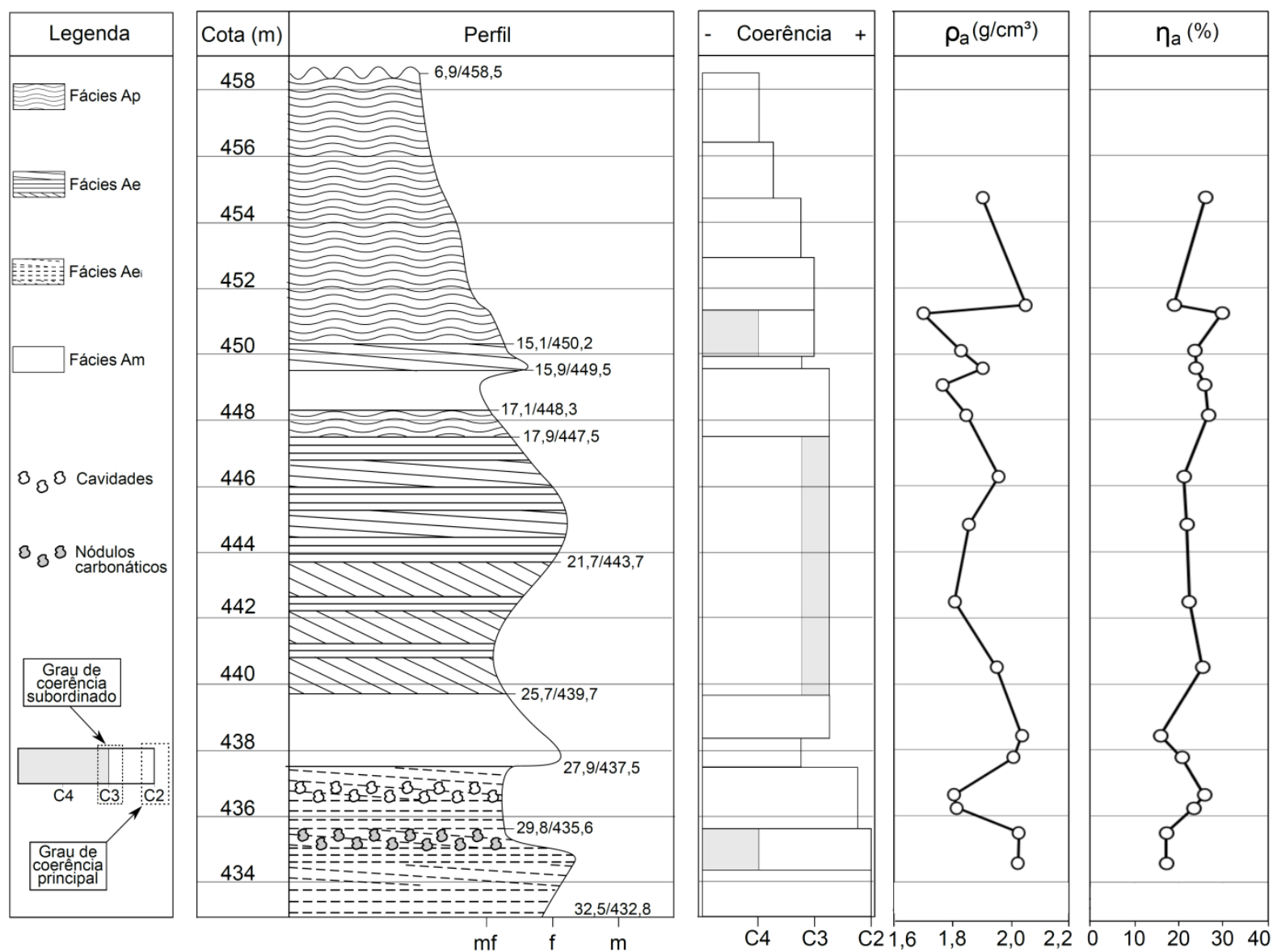

Figura 3.4.2 - Seção estratigráfica colunar da sondagem SM-222 apresentando graus de coerência e valores de densidade e porosidade aparentes $\left(\rho_{\mathrm{a}}\right.$ e $\eta_{\mathrm{a}}$, respectivamente).

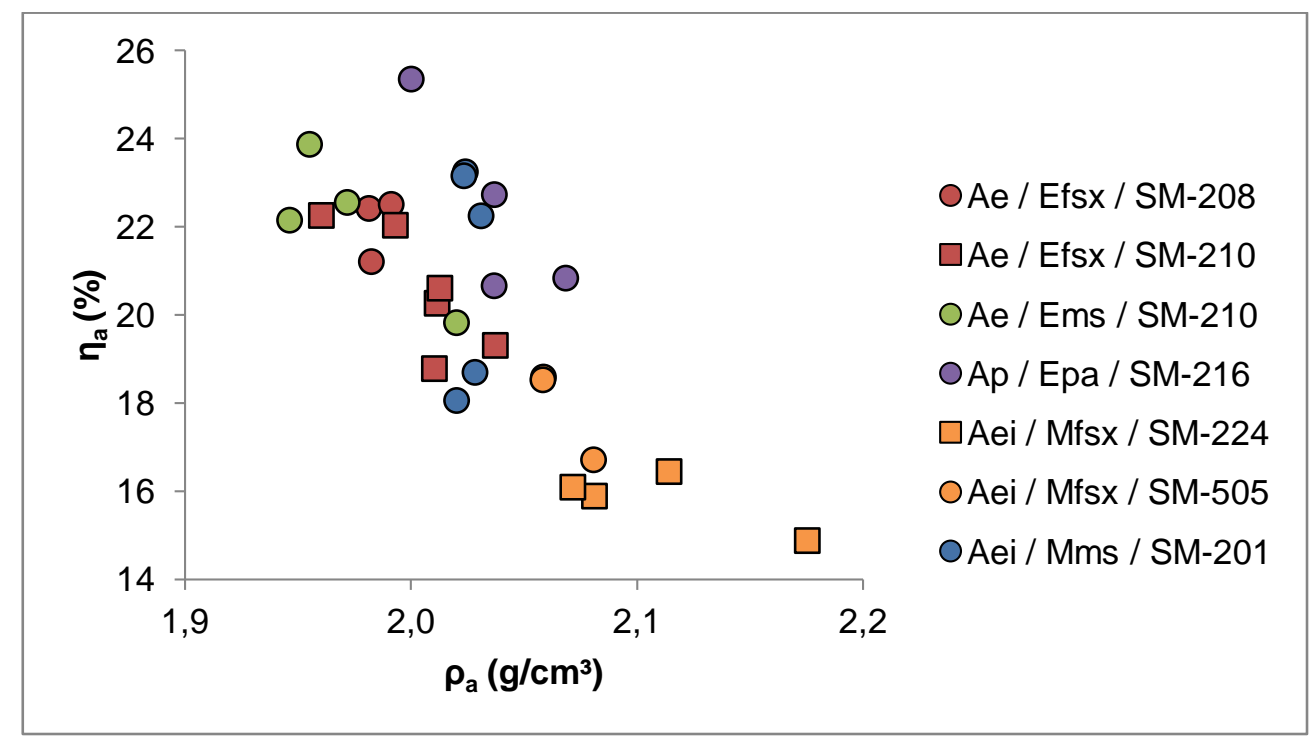

Figura 3.4.3 - Diagrama de dispersão com os valores de densidade $\left(\rho_{\mathrm{a}}\right)$ e porosidade $\left(\mathrm{n}_{\mathrm{a}}\right)$ aparentes das amostras das sondagens SM-201, SM-208, SM-210, SM-216, SM-224 e SM-505. 
Tabela 3.4.1 - Medianas das distribuições de densidade e porosidade aparentes $\left(\rho_{a}\right.$ e $\eta_{a}$, respectivamente) das amostras das sondagens SM-201, SM-208, SM-210, SM-216, SM-224 e SM505.

\begin{tabular}{ccccc}
\hline Sondagem & Fácies & Petrofácies & $\boldsymbol{\rho}_{\mathbf{a}}\left(\mathbf{g} / \mathbf{c m}^{\mathbf{3}}\right)$ & $\boldsymbol{\eta}_{\mathbf{a}}(\%)$ \\
\hline SM-208 & $\mathrm{Ae}$ & Efsx & 1,9 & 22 \\
SM-210 & $\mathrm{Ae}$ & Efsx & 2,0 & 20 \\
SM-210 & $\mathrm{Ae}$ & Ems & 1,9 & 22 \\
SM-216 & $\mathrm{Ap}$ & Epa & 2,0 & 22 \\
SM-224 & $\mathrm{Ae}$ & Mfsx & 2,0 & 16 \\
SM-505 & $\mathrm{Ae}_{\mathrm{i}}$ & Mfsx & 2,0 & 19 \\
SM-201 & $\mathrm{Ae}_{\mathrm{i}}$ & Mms & 2,0 & 22 \\
\hline
\end{tabular}

\subsection{Propriedades mecânicas}

Os resultados dos ensaios de resistência à compressão uniaxial $\left(\sigma_{u}\right)$, com ou sem medida de deformação axial, e os módulos de deformabilidade secante $\left(E_{s}\right)$ são apresentados, para cada sondagem e petrofácies, nas tabelas 3.5.1 a 3.5.7.

Optou-se por utilizar a mediana como medida de tendência central para calcular valores de resistência à compressão uniaxial e de módulo de elasticidade representativos de cada unidade, uma vez que esta medida é menos afetada por valores discrepantes, como ocorre com a média.

Arenitos de diferentes sondagens apresentaram, na maior parte dos casos, resistência e módulos de deformabilidade semelhantes entre si, ocupando posições próximas no diagrama de dispersão $\sigma_{50} \times E_{s}$ (Tabela 3.5.8 e Figura 3.5.1).

Conforme a Figura 3.5.2, adaptada de Hawkins (1998), os arenitos analisados neste estudo podem ser classificados como brandos a moderadamente brandos (BGS - Anon., 1970; BS, 1981) ou muito brandos a brandos (Coates, 1964; IAEG, 1979; ISRM, 1981), de resistência muito baixa a baixa (Deere \& Miller, 1966; Broch \& Franklin, 1972; Bieniawski, 1973). As dimensões, peso e registro fotográfico dos corpos de prova e outros dados referentes aos ensaios geomecânicos são apresentados no Apêndice C. 
Tabela 3.5.1 - Dados referentes aos corpos de prova da sondagem SM-208, petrofácies Efsx, submetidos aos ensaios geomecânicos. L: comprimento, D: diâmetro, F: carga de ruptura, $\sigma_{\mathrm{u}}$ : resistência à compressão uniaxial, $\sigma_{50}$ : resistência à compressão uniaxial corrigida conforme Turk e Dearman (1986), $E_{s}$ : módulo de elasticidade secante.

\begin{tabular}{ccccccccc}
\hline \multicolumn{2}{c}{ Prof. $(\mathbf{m})$} & \multirow{2}{*}{$(\mathbf{m m})$} & $\mathbf{D}(\mathbf{m m})$ & $\mathbf{L}: \mathbf{D}$ & $\mathbf{F}(\mathbf{N})$ & $\boldsymbol{\sigma}_{\mathrm{u}}(\mathbf{M P a})$ & $\boldsymbol{\sigma}_{50}(\mathbf{M P a})$ & $\mathbf{E}_{\mathbf{s}}(\mathrm{GPa})$ \\
\hline $\mathbf{D e}$ & Até & & & & & \\
18,0 & 18,2 & 171,4 & 68,8 & 2,5 & 15.026 & 4,0 & 4,4 & - \\
18,2 & 18,4 & 114,6 & 67,2 & 1,7 & 15.453 & 4,4 & 4,5 & 1,0 \\
18,7 & 18,8 & 173,8 & 61,8 & 2,8 & 8.267 & 2,8 & 3,0 & 0,7 \\
19,2 & 19,3 & 161,7 & 61,6 & 2,6 & 10.089 & 3,4 & 3,6 & 0,9 \\
19,7 & 19,8 & 91,5 & 69,0 & 1,3 & 16.773 & 4,5 & 4,5 & - \\
\hline
\end{tabular}

Tabela 3.5.2 - Dados referentes aos corpos de prova da sondagem SM-210, petrofácies Efsx, submetidos aos ensaios geomecânicos. L: comprimento, $D$ : diâmetro, $F$ : carga de ruptura, $\sigma_{\mathrm{u}}$ : resistência à compressão uniaxial, $\sigma_{50}$ : resistência à compressão uniaxial corrigida conforme Turk e Dearman (1986), $E_{s}$ : módulo de elasticidade secante.

\begin{tabular}{ccccccccc}
\hline \multicolumn{2}{c}{ Prof. $(\mathbf{m})$} & $\mathbf{L}(\mathbf{m m})$ & $\mathbf{D}(\mathbf{m m})$ & $\mathbf{L}: \mathbf{D}$ & $\mathbf{F}(\mathbf{N})$ & $\boldsymbol{\sigma}_{\mathrm{u}}(\mathbf{M P a})$ & $\boldsymbol{\sigma}_{\mathbf{5 0}}(\mathbf{M P a})$ & $\mathbf{E}_{\mathbf{s}}(\mathbf{G P a})$ \\
\hline $\mathbf{D e}$ & Até & & & & & \\
\hline 17,8 & 18,0 & 155,1 & 59,3 & 2,6 & 12.086 & 4,4 & 4,7 & 0,9 \\
18,2 & 18,4 & 86,7 & 49,5 & 1,8 & 9.046 & 4,7 & 4,6 & - \\
18,4 & 18,5 & 113,1 & 59,1 & 1,9 & 15.692 & 5,7 & 5,9 & 0,9 \\
19,0 & 19,1 & 82,3 & 73,9 & 1,1 & 22.967 & 5,4 & 5,2 & - \\
19,1 & 19,2 & 111,3 & 62,0 & 1,8 & 12.576 & 4,2 & 4,3 & 2,3 \\
19,5 & 19,8 & 121,7 & 53,5 & 2,3 & 9.976 & 4,4 & 4,6 & 2,1 \\
\hline
\end{tabular}

Tabela 3.5.3 - Dados referentes aos corpos de prova da sondagem SM-210, petrofácies Ems, submetidos aos ensaios geomecânicos. L: comprimento, D: diâmetro, F: carga de ruptura, $\sigma_{\mathrm{u}}$ : resistência à compressão uniaxial, $\sigma_{50}$ : resistência à compressão uniaxial corrigida conforme Turk e Dearman (1986), $E_{s}$ : módulo de elasticidade secante.

\begin{tabular}{ccccccccc}
\hline \multicolumn{2}{c}{ Prof. $(\mathbf{m})$} & \multirow{2}{*}{$(\mathbf{m m})$} & $\mathbf{D}(\mathbf{m m})$ & $\mathbf{L}: \mathbf{D}$ & $\mathbf{F}(\mathbf{N})$ & $\boldsymbol{\sigma}_{\mathbf{u}}(\mathbf{M P a})$ & $\boldsymbol{\sigma}_{50}(\mathbf{M P a})$ & $\mathbf{E}_{\mathbf{s}}(\mathbf{G P a})$ \\
\hline $\mathbf{D e}$ & Até & & & & & \\
\hline 26,1 & 26,3 & 151,6 & 55,0 & 2,8 & 6.634 & 2,8 & 2,9 & 3,1 \\
26,7 & 26,8 & 67,9 & 59,6 & 1,1 & 6.046 & 2,2 & 2,0 & - \\
26,8 & 27,0 & 156,2 & 70,2 & 2,2 & 12.049 & 3,1 & 3,4 & 2,4 \\
27,2 & 27,4 & 135,6 & 72,9 & 1,9 & 9.272 & 2,2 & 2,4 & - \\
27,4 & 27,5 & 142,8 & 72,1 & 2,0 & 9.322 & 2,3 & 2,4 & 1,8 \\
\hline
\end{tabular}

Tabela 3.5.4 - Dados referentes aos corpos de prova da sondagem SM-216, petrofácies Epa, submetidos aos ensaios geomecânicos. L: comprimento, D: diâmetro, F: carga de ruptura, $\sigma_{\mathrm{u}}$ : resistência à compressão uniaxial, $\sigma_{50}$ : resistência à compressão uniaxial corrigida conforme Turk e Dearman (1986), $E_{s}$ : módulo de elasticidade secante.

\begin{tabular}{|c|c|c|c|c|c|c|c|c|}
\hline \multicolumn{2}{|c|}{ Prof. (m) } & \multirow{2}{*}{ L (mm) } & \multirow{2}{*}{$\mathrm{D}(\mathrm{mm})$} & \multirow{2}{*}{ L:D } & \multirow{2}{*}{$F(N)$} & \multirow{2}{*}{$\sigma_{\mathrm{u}}(\mathrm{MPa})$} & \multirow{2}{*}{$\sigma_{50}(\mathrm{MPa})$} & \multirow{2}{*}{$E_{s}(G P a)$} \\
\hline $\mathrm{De}$ & Até & & & & & & & \\
\hline 12,1 & 12,2 & 131,5 & 61,5 & 2,1 & 15.830 & 5,3 & 5,6 & 0,7 \\
\hline 12,2 & 12,4 & 138,0 & 65,8 & 2,1 & 17.652 & 5,2 & 5,5 & 0,6 \\
\hline 12,7 & 12,9 & 155,2 & 59,5 & 2,6 & 14.360 & 5,2 & 5,5 & - \\
\hline 12,9 & 13,1 & 144,1 & 62,6 & 2,3 & 16.031 & 5,2 & 5,5 & 0,8 \\
\hline
\end{tabular}


Tabela 3.5.5 - Dados referentes aos corpos de prova da sondagem SM-224, petrofácies Mfsx, submetidos aos ensaios geomecânicos. L: comprimento, D: diâmetro, $F$ : carga de ruptura, $\sigma_{\mathrm{u}}$ : resistência à compressão uniaxial, $\sigma_{50}$ : resistência à compressão uniaxial corrigida conforme Turk $\mathrm{e}$ Dearman (1986), $E_{s}$ : módulo de elasticidade secante.

\begin{tabular}{ccccccccc}
\hline \multicolumn{2}{c}{ Prof. $(\mathbf{m})$} & \multirow{2}{*}{$(\mathbf{m m})$} & $\mathbf{D}(\mathbf{m m})$ & $\mathbf{L}: \mathbf{D}$ & $\mathbf{F}(\mathbf{N})$ & $\boldsymbol{\sigma}_{\mathbf{u}}(\mathbf{M P a})$ & $\boldsymbol{\sigma}_{\mathbf{5 0}}(\mathbf{M P a})$ & $\mathbf{E}_{\mathbf{s}}(\mathbf{G P a})$ \\
\hline $\mathbf{D e}$ & Até & & & & & & \\
21,5 & 21,7 & 139,0 & 69,1 & 2,0 & 13.632 & 3,6 & 3,9 & 3,7 \\
21,7 & 21,8 & 146,7 & 73,4 & 2,0 & 28.093 & 6,6 & 7,1 & 4,5 \\
21,8 & 22,0 & 145,1 & 72,6 & 2,0 & 27.087 & 6,5 & 7,0 & - \\
22,0 & 22,2 & 198,8 & 72,8 & 2,7 & 25.580 & 6,2 & 6,8 & 3,1 \\
22,6 & 23,0 & 186,1 & 73,3 & 2,5 & 25.329 & 6,0 & 6,6 & 2,9 \\
\hline
\end{tabular}

Tabela 3.5.6 - Dados referentes aos corpos de prova da sondagem SM-505, petrofácies Mfsx, submetidos aos ensaios geomecânicos. L: comprimento, D: diâmetro, $\mathrm{F}$ : carga de ruptura, $\sigma_{\mathrm{u}}$ : resistência à compressão uniaxial, $\sigma_{50}$ : resistência à compressão uniaxial corrigida conforme Turk e Dearman (1986), $E_{s}$ : módulo de elasticidade secante.

\begin{tabular}{ccccccccc}
\hline \multicolumn{2}{c}{ Prof. $(\mathbf{m})$} & \multirow{2}{*}{$(\mathbf{m m})$} & $\mathbf{D}(\mathbf{m m})$ & $\mathbf{L}: \mathbf{D}$ & $\mathbf{F}(\mathbf{N})$ & $\boldsymbol{\sigma}_{\mathbf{u}}(\mathbf{M P a})$ & $\boldsymbol{\sigma}_{\mathbf{5 0}}(\mathbf{M P a})$ & $\mathbf{E}_{\mathbf{s}}(\mathbf{G P a})$ \\
\hline $\mathbf{D e}$ & Até & & & & & \\
12,3 & 12,5 & 148,0 & 73,6 & 2,0 & 14.486 & 3,4 & 3,7 & 2,4 \\
12,5 & 12,6 & 154,9 & 74,4 & 2,1 & 14.938 & 3,4 & 3,7 & 2,5 \\
12,6 & 12,8 & 180,8 & 73,5 & 2,5 & 23.884 & 5,6 & 6,2 & - \\
12,9 & 13,0 & 153,8 & 73,8 & 2,1 & 21.522 & 5,0 & 5,4 & 1,9 \\
13,0 & 13,2 & 118,7 & 74,0 & 1,6 & 20.378 & 4,7 & 4,9 & - \\
13,3 & 13,5 & 128,7 & 74,0 & 1,7 & 12.426 & 2,9 & 3,0 & 3,1 \\
13,5 & 13,6 & 128,0 & 73,9 & 1,7 & 18.921 & 4,4 & 4,6 & 2,3 \\
14,7 & 14,9 & 151,6 & 74,0 & 2,0 & 19.411 & 4,5 & 4,9 & 1,4 \\
\hline
\end{tabular}

Tabela 3.5.7 - Dados referentes aos corpos de prova da sondagem SM-201, petrofácies Mms, submetidos aos ensaios geomecânicos. L: comprimento, D: diâmetro, $F$ : carga de ruptura, $\sigma_{\mathrm{u}}$ : resistência à compressão uniaxial, $\sigma_{50}$ : resistência à compressão uniaxial corrigida conforme Turk e Dearman (1986), $\mathrm{E}_{\mathrm{s}}$ : módulo de elasticidade secante.

\begin{tabular}{ccccccccc}
\hline \multicolumn{2}{c}{ Prof. $(\mathbf{m})$} & $\mathbf{L}(\mathbf{m m})$ & $\mathbf{D}(\mathbf{m m})$ & $\mathbf{L}: \mathbf{D}$ & $\mathbf{F}(\mathbf{N})$ & $\boldsymbol{\sigma}_{\mathbf{u}}(\mathbf{M P a})$ & $\boldsymbol{\sigma}_{\mathbf{5 0}}(\mathbf{M P a})$ & $\mathbf{E}_{\mathbf{s}}(\mathbf{G P a})$ \\
\hline $\mathbf{D e}$ & Até & & & & & \\
\hline 26,0 & 26,2 & 162,8 & 72,6 & 2,2 & 21.647 & 5,2 & 5,7 & 4,8 \\
26,2 & 26,4 & 189,5 & 72,4 & 2,6 & 19.650 & 4,8 & 5,3 & 5,1 \\
26,4 & 26,7 & 193,8 & 71,9 & 2,7 & 19.248 & 4,7 & 5,2 & 5,2 \\
26,8 & 27,0 & 185,2 & 72,2 & 2,6 & 20.982 & 5,1 & 5,6 & 5,4 \\
27,0 & 27,2 & 156,1 & 71,8 & 2,2 & 21.409 & 5,3 & 5,7 & - \\
27,3 & 27,4 & 135,6 & 71,8 & 1,9 & 19.386 & 4,8 & 5,1 & - \\
\hline
\end{tabular}

Tabela 3.5.8 - Valores medianos de $\sigma_{50}$ e $E_{s}$, representativos de cada sondagem

\begin{tabular}{cccccc}
\hline Sondagem & Fácies & Petrofácies & Coerência & $\boldsymbol{\sigma}_{50}(\mathbf{M P a})$ & $\mathbf{E}_{\mathbf{s}}(\mathbf{G P a})$ \\
\hline $\mathrm{SM}-208$ & $\mathrm{Ae}$ & $\mathrm{Efsx}$ & $\mathrm{C} 3 / \mathrm{C} 2$ & 4,4 & 0,9 \\
$\mathrm{SM}-210$ & $\mathrm{Ae}$ & $\mathrm{Efsx}$ & $\mathrm{C} 3$ & 4,6 & 1,5 \\
$\mathrm{SM}-210$ & $\mathrm{Ae}$ & $\mathrm{Ems}$ & $\mathrm{C} 3$ & 2,4 & 2,4 \\
$\mathrm{SM}-216$ & $\mathrm{Ap}$ & $\mathrm{Epa}$ & $\mathrm{C} 3$ & 5,5 & 0,7 \\
$\mathrm{SM}-224$ & $\mathrm{Ae}_{\mathrm{i}}$ & $\mathrm{Mfsx}$ & $\mathrm{C} 2 / \mathrm{C} 3$ & 6,8 & 3,4 \\
$\mathrm{SM}-505$ & $\mathrm{Ae}_{\mathrm{i}}$ & $\mathrm{Mfsx}$ & $\mathrm{C} 2 / \mathrm{C} 3$ & 4,9 & 2,4 \\
$\mathrm{SM}-201$ & $\mathrm{Ae}_{\mathrm{i}}$ & $\mathrm{Mms}$ & $\mathrm{C} 3 / \mathrm{C} 2$ & 5,5 & 5,1 \\
\hline
\end{tabular}




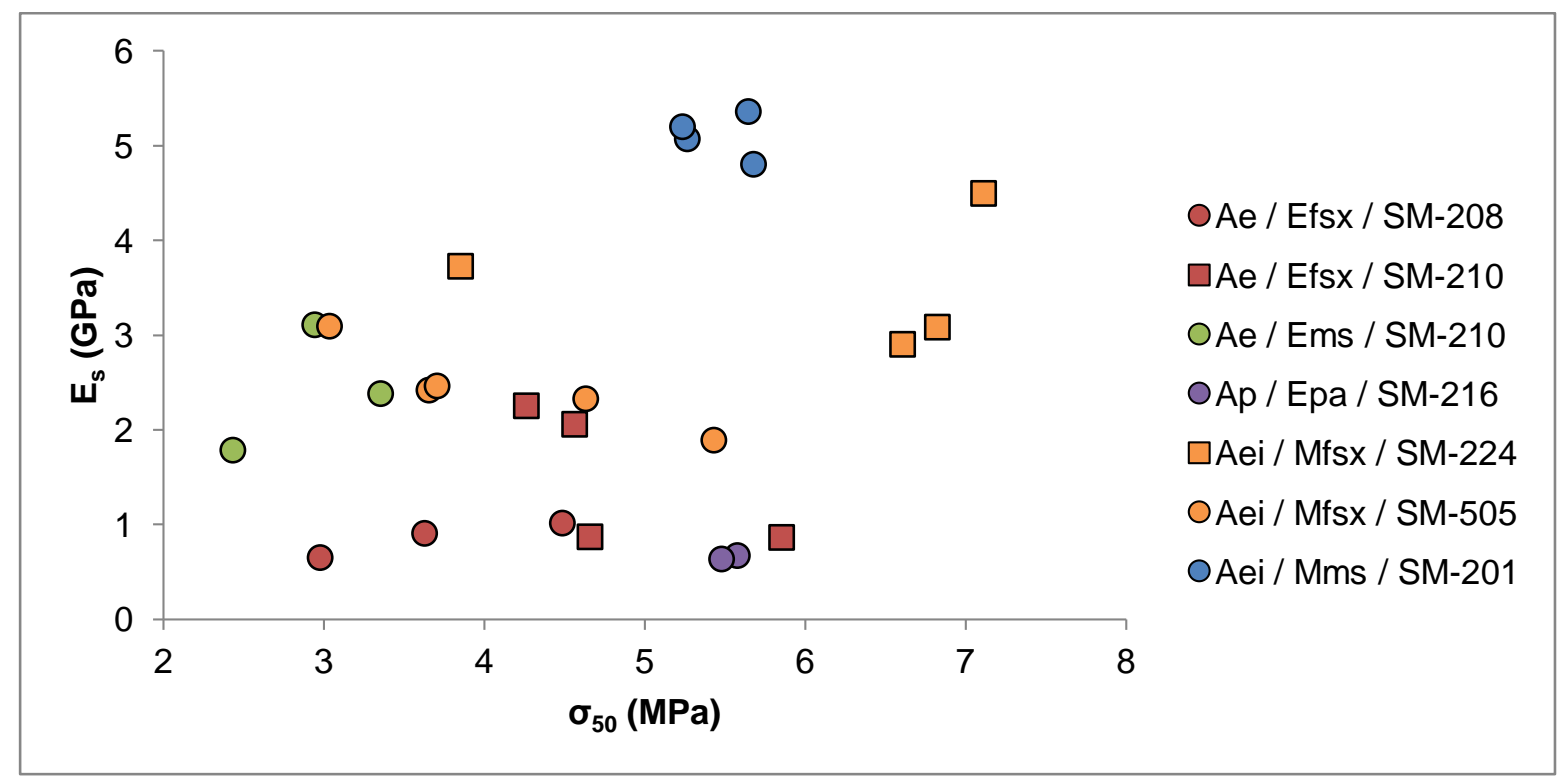

Figura 3.5.1 - Diagrama de dispersão com valores de $\sigma_{50}$ versus $E_{s}$ para todos os corpos de prova submetidos a estes tipos de ensaio.

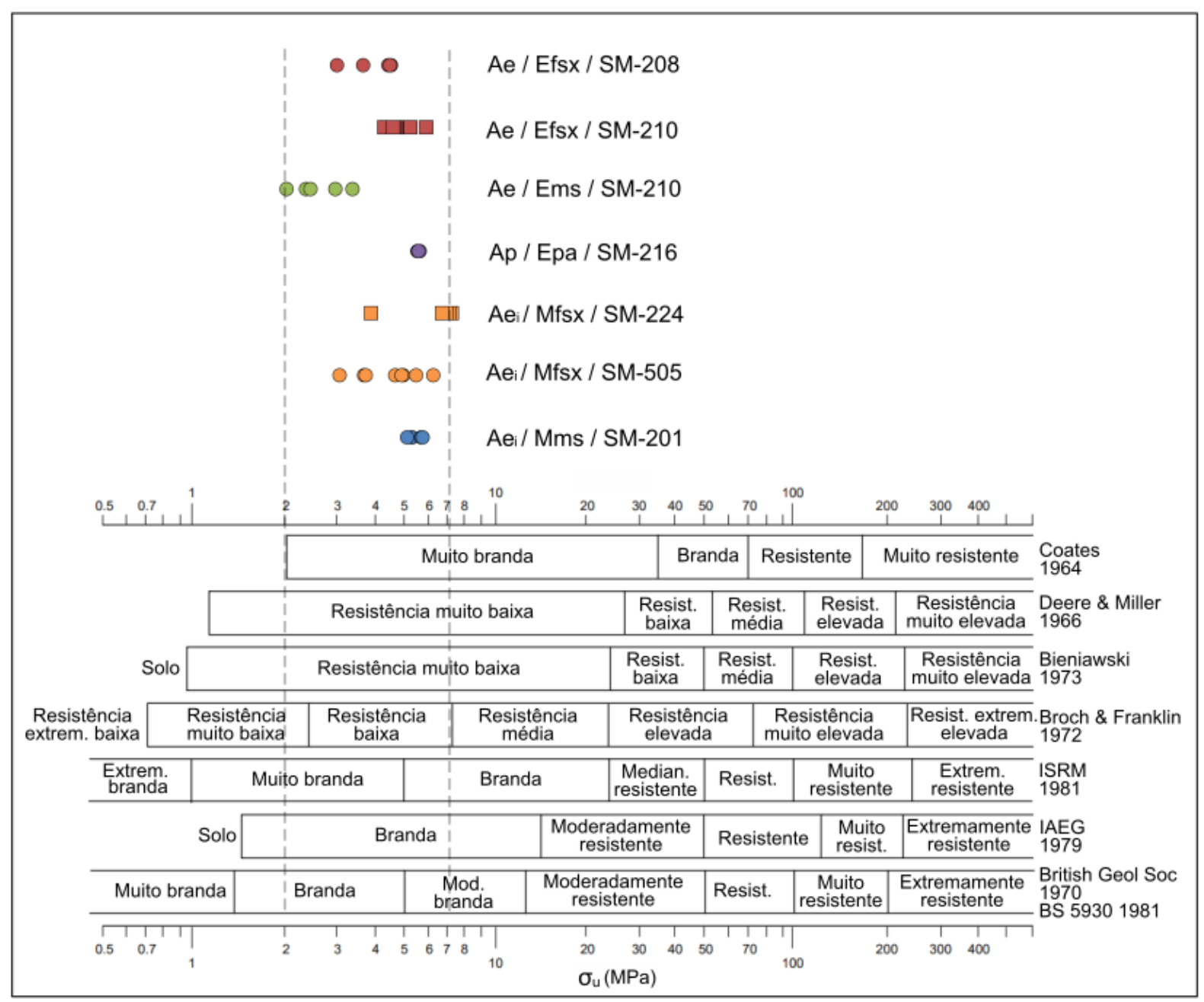

Figura 3.5.2 - Valores de $\sigma_{50}$ dos arenitos analisados comparados aos diferentes termos utilizados na designação da resistência das rochas. Figura adaptada de Hawkins (1998). British Geol Soc referida como BGS nesta dissertação. 


\subsection{Correlações}

Neste item, apresentam-se os resultados das correlações lineares testadas entre as diversas propriedades petrográficas, físicas e mecânicas, cujos dados foram mostrados nos itens prévios deste capítulo.

\subsubsection{Correlações entre propriedades petrográficas}

O teor de pelíticos é inversamente proporcional ao tamanho médio dos grãos do arcabouço arenoso, tanto o medido via petrografia quanto o obtido no analisador de partículas por difração de laser (Figura 3.6.1).

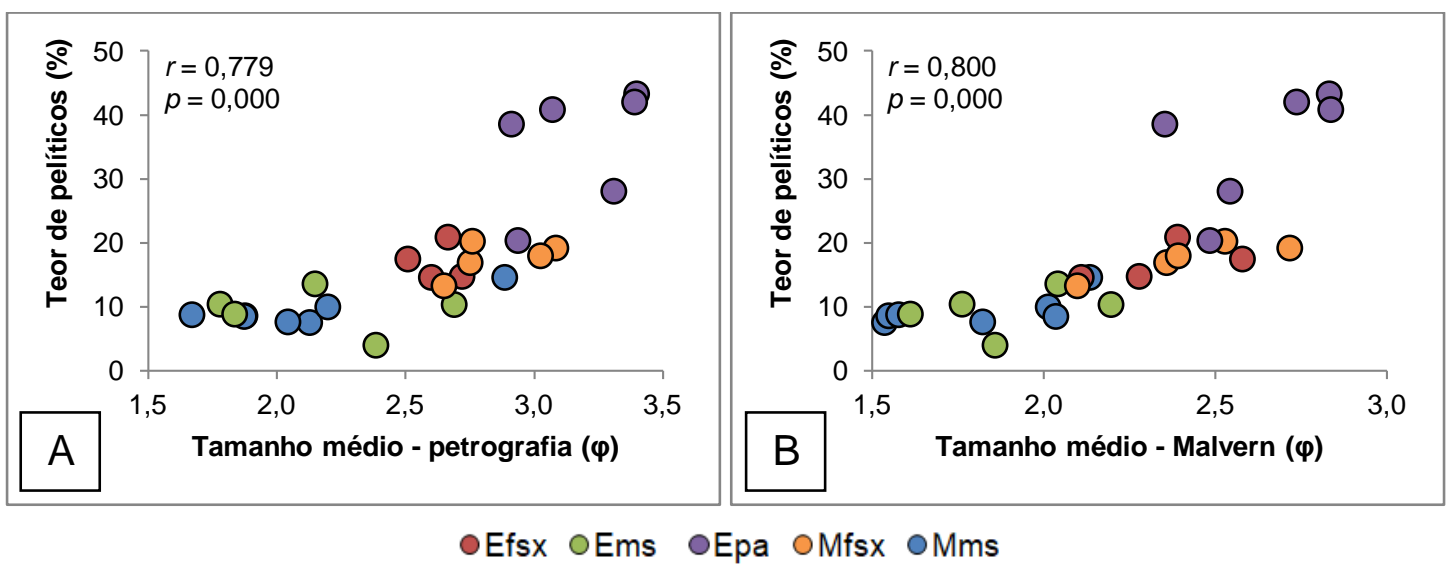

Figura 3.6.1 - Diagramas de dispersão entre teor de pelíticos obtido por elutriação e tamanho médio dos grãos obtido via petrografia óptica (A) e granulômetro de difração de laser (B) na fração areia, por petrofácies.

A porosidade intragranular parece correlacionar-se inversamente ao tamanho médio dos grãos de areia, sendo mais comum em amostras de granulometria mais fina (Figura 3.6.2 A e B). Esta correlação, porém, é discutível, uma vez que o coeficiente de correlação entre porosidade intragranular e dados de tamanho médio dos grãos obtidos via petrografia deixa de ser significativo, quando não se considera o dado referente à amostra da cota 448,2 $\mathrm{m}$ da sondagem SM-222 (Figuras 3.6.2 C e D), cuja proporção de poros secundários destoa em relação aos demais valores (Figura 3.6.3). 

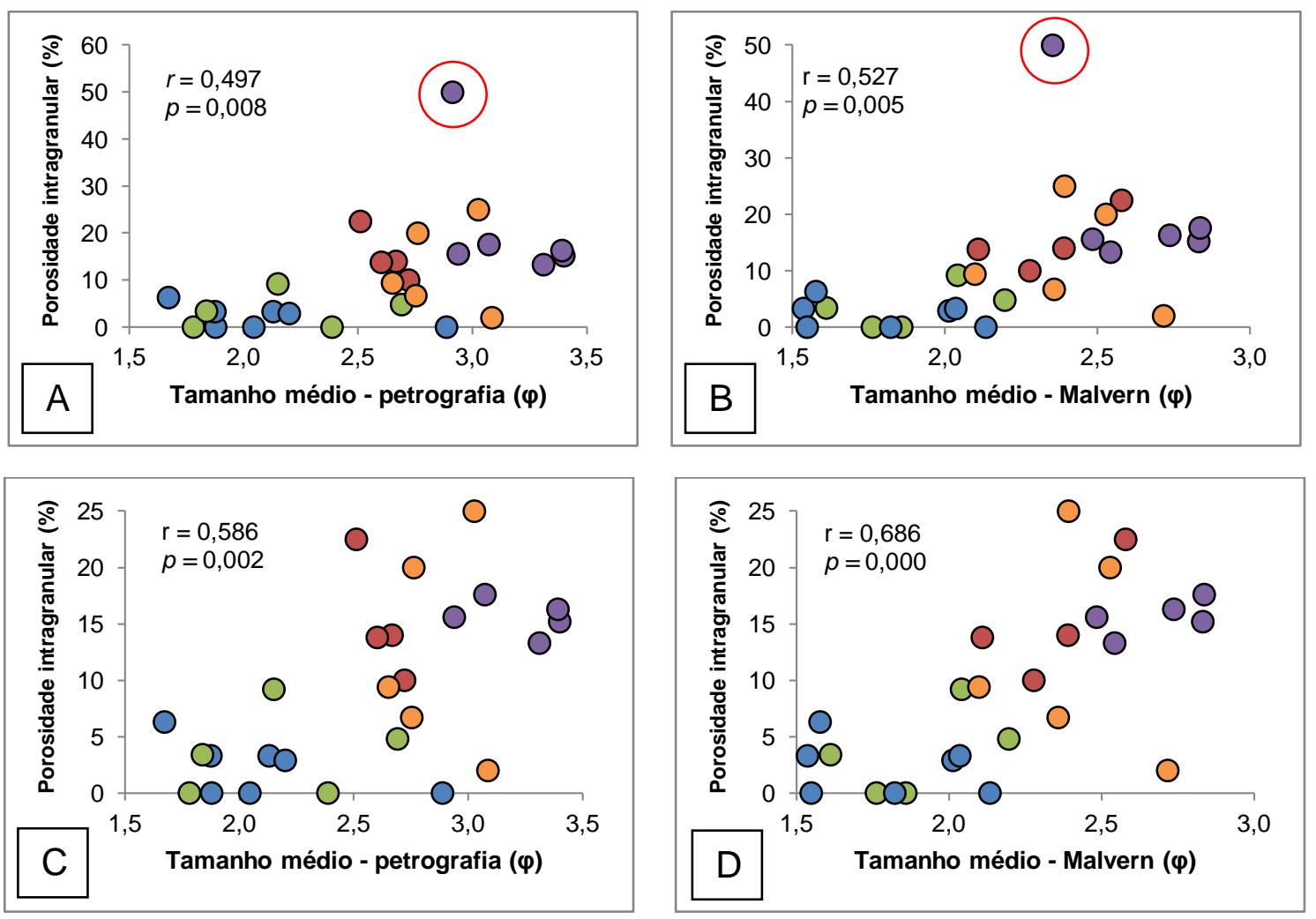

oEfsx OEms OEpa OMfsx OMms

Figura 3.6.2 - Diagramas de dispersão entre proporção de porosidade intragranular (na fração) e tamanho médio dos grãos obtido via petrografia óptica ( $A$ e $C$ ) e granulômetro de difração de laser (B e D) na fração areia, por petrofácies. Os diagramas inferiores ( $C$ e D) suprimem o dado referente à amostra da cota 448,2 $\mathrm{m}$ da sondagem SM-222 (indicado pelo círculo vermelho nos gráficos superiores), pois se trata de dado discrepante (outlier) em relação aos demais.

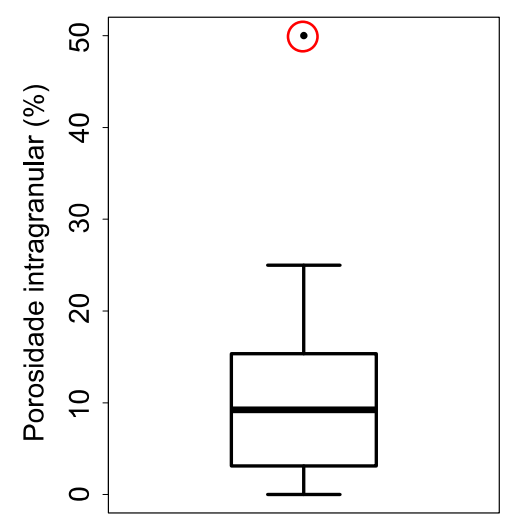

Figura 3.6.3 - Boxplot dos dados de porosidade intragranular, na fração. Notar como o valor referente à amostra da cota 448,2 m da sondagem SM-222 (círculo vermelho) é discrepante em relação aos demais (outlier).

A densidade de empacotamento mostra correlação linear positiva com o tamanho médio dos grãos, para ambos os métodos utilizados para a análise granulométrica da fração areia (Figura 3.6.4). 


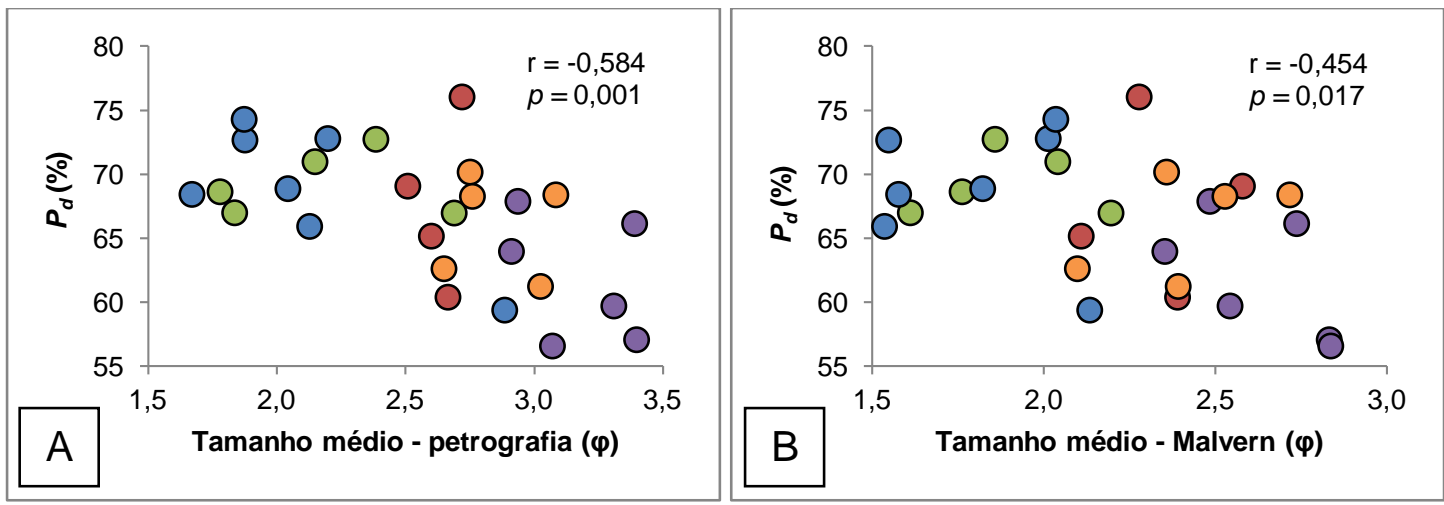

OEfsx OEms OEpa OMfsx OMms

Figura 3.6.4 - Diagramas de dispersão entre densidade de empacotamento $\left(P_{d}\right)$ e tamanho médio dos grãos obtido via petrografia óptica $(A)$ e granulômetro de difração de laser (B) na fração areia, por petrofácies.

A correlação linear do tamanho médio dos grãos com a proporção de arcabouço é positiva (Figura 3.6.5) e com a de cimento é negativa (Figura 3.6.6). Considerando as diferentes mineralogias de cimento, apenas o óxido-hidróxido metálico e a esmectita se correlacionam (inversamente) ao tamanho médio dos grãos (Figuras 3.6.7 e 3.6.8), sendo que, no caso da esmectita, esta correlação é significativa somente quando se suprimem os dados referentes a amostras que não contêm este tipo de cimento (Figura 3.6.8 C e D).

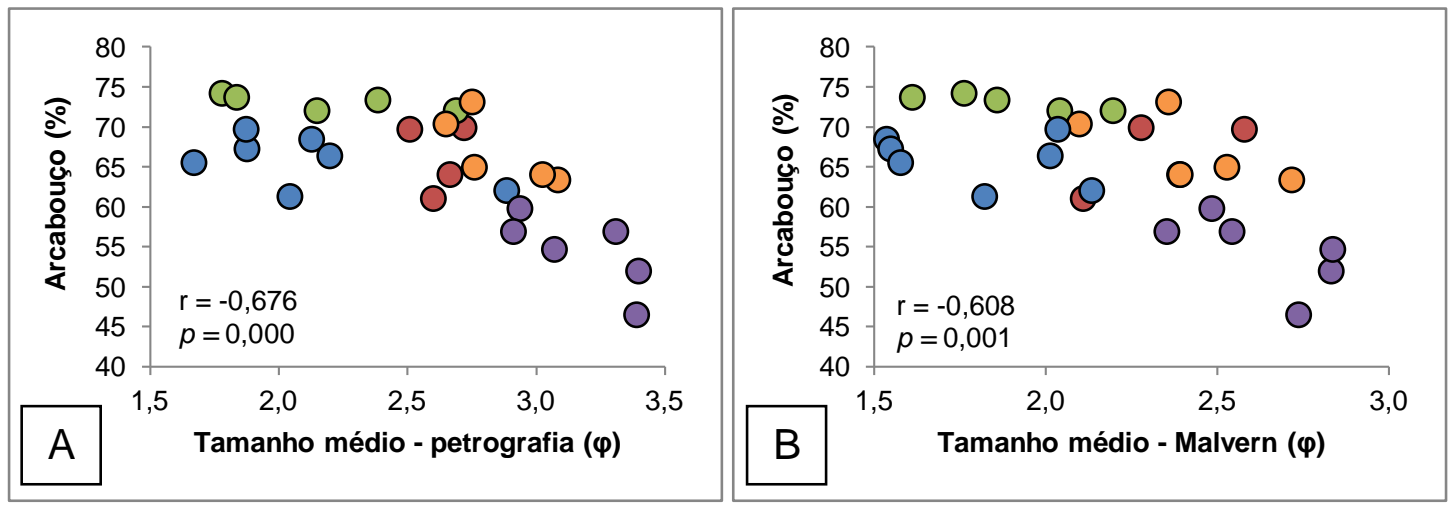

OEfsx OEms OEpa OMfsx OMms

Figura 3.6.5 - Diagramas de dispersão entre proporção de grãos do arcabouço e tamanho médio dos grãos obtido via petrografia óptica $(A)$ e granulômetro de difração de laser (B) na fração areia, por petrofácies. 


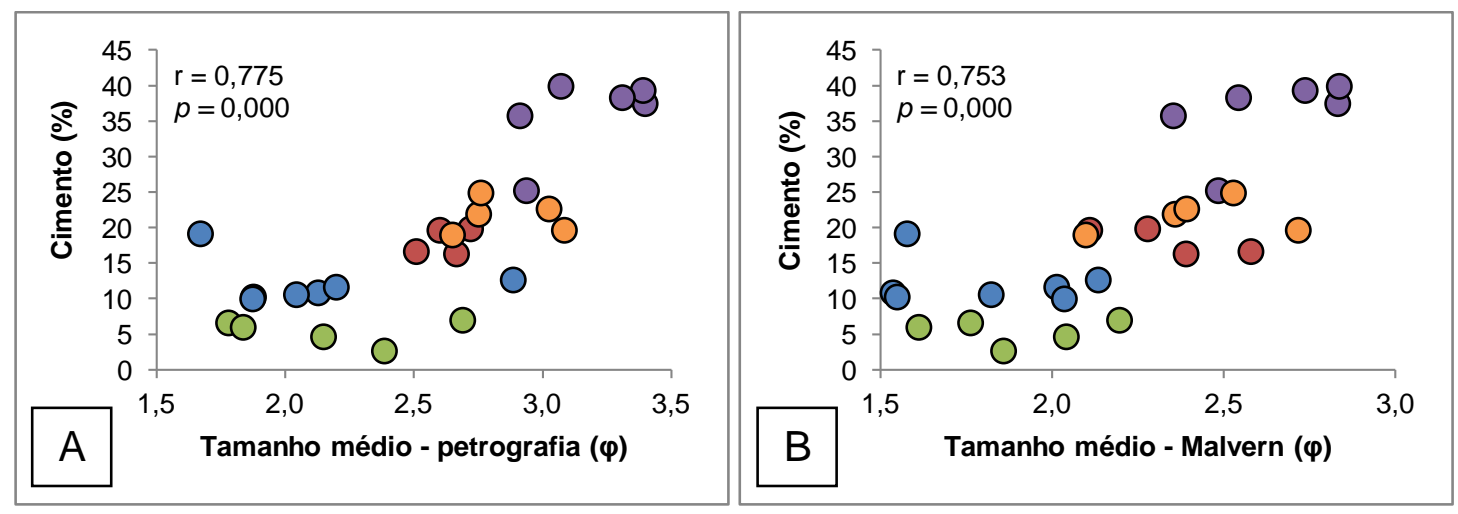

oEfsx OEms OEpa OMfsx OMms

Figura 3.6.6 - Diagramas de dispersão entre proporção de cimento e tamanho médio dos grãos obtido via petrografia óptica $(A)$ e granulômetro de difração de laser (B) na fração areia, por petrofácies.

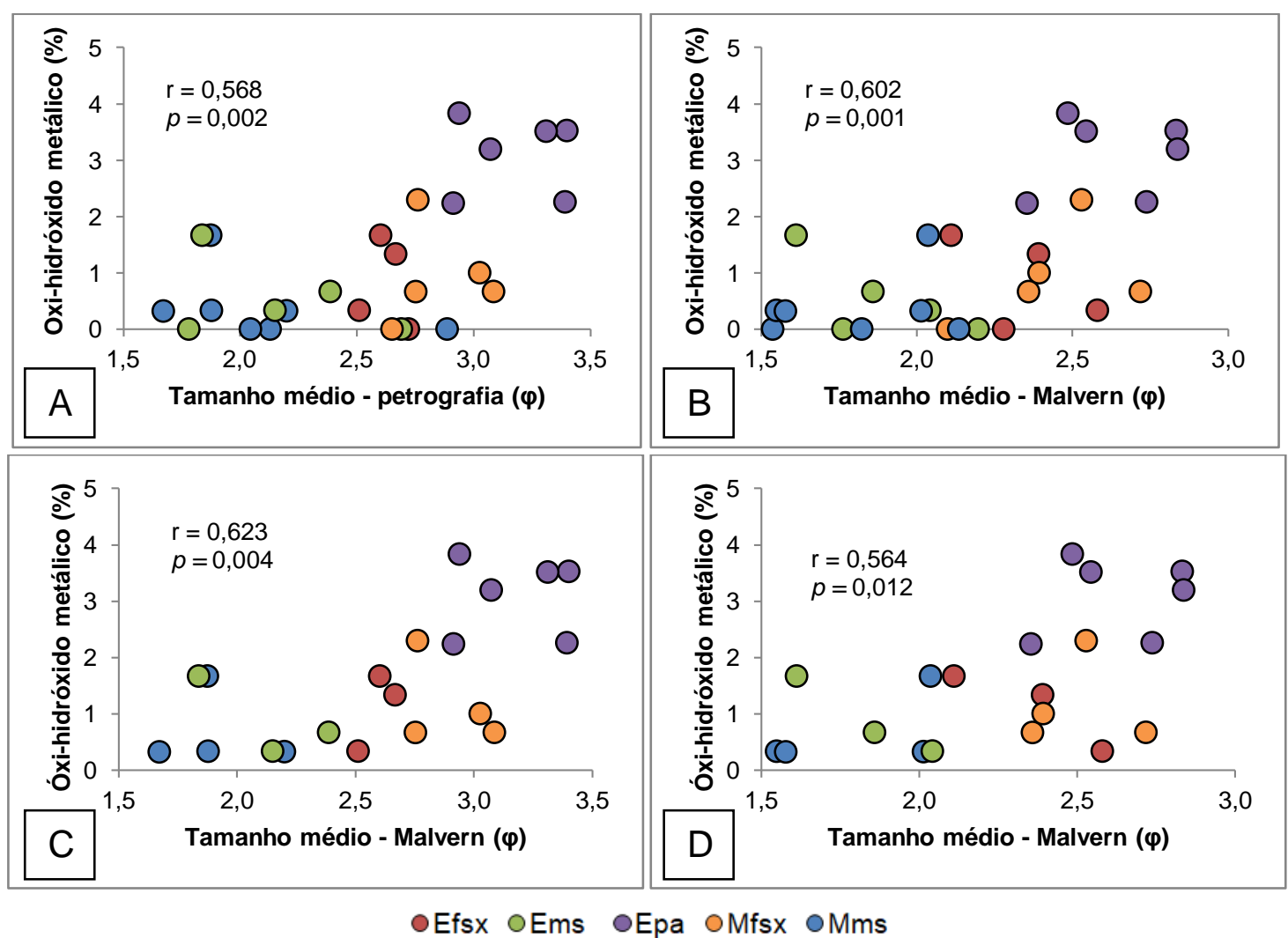

Figura 3.6.7 - Diagramas de dispersão entre proporção de cimento constituído por óxi-hidróxido metálico e tamanho médio dos grãos obtido via petrografia óptica $(A, C)$ e granulômetro de difração de laser $(B, D)$ na fração areia, por petrofácies. Nos diagramas inferiores $(C, D)$, suprimem-se os dados referentes às amostras cuja proporção deste tipo de cimento é igual à zero. 


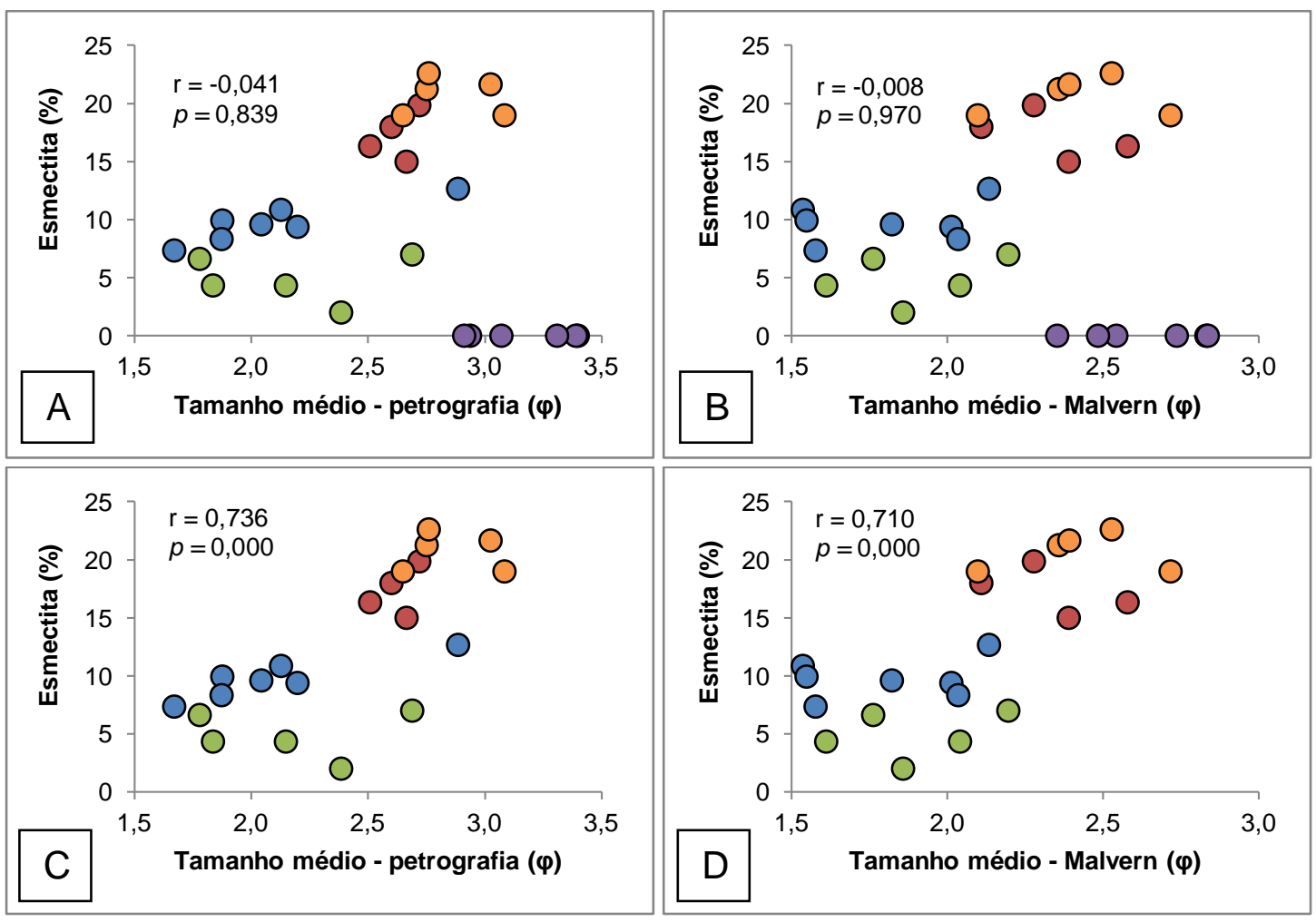

oEfsx OEms OEpa OMfsx OMms

Figura 3.6.8 - Diagramas de dispersão entre proporção de cimento constituído por esmectita e tamanho médio dos grãos obtido via petrografia óptica ( $A$ e C) e granulômetro de difração de laser (B e D) na fração areia, por petrofácies. Nos diagramas inferiores (C e D), suprimem-se os dados referentes às amostras cuja proporção deste tipo de cimento é igual à zero.

Observa-se correlação linear inversa entre o tamanho médio dos grãos e a quantidade relativa de contatos entre cimento e grãos do arcabouço, o que vale para ambos os métodos de análise granulométrica adotados neste estudo (Figura 3.6.9). A proporção de contatos entre grãos e vazios, por sua vez, correlaciona-se positivamente com o tamanho médio dos grãos (Figura 3.6.10).

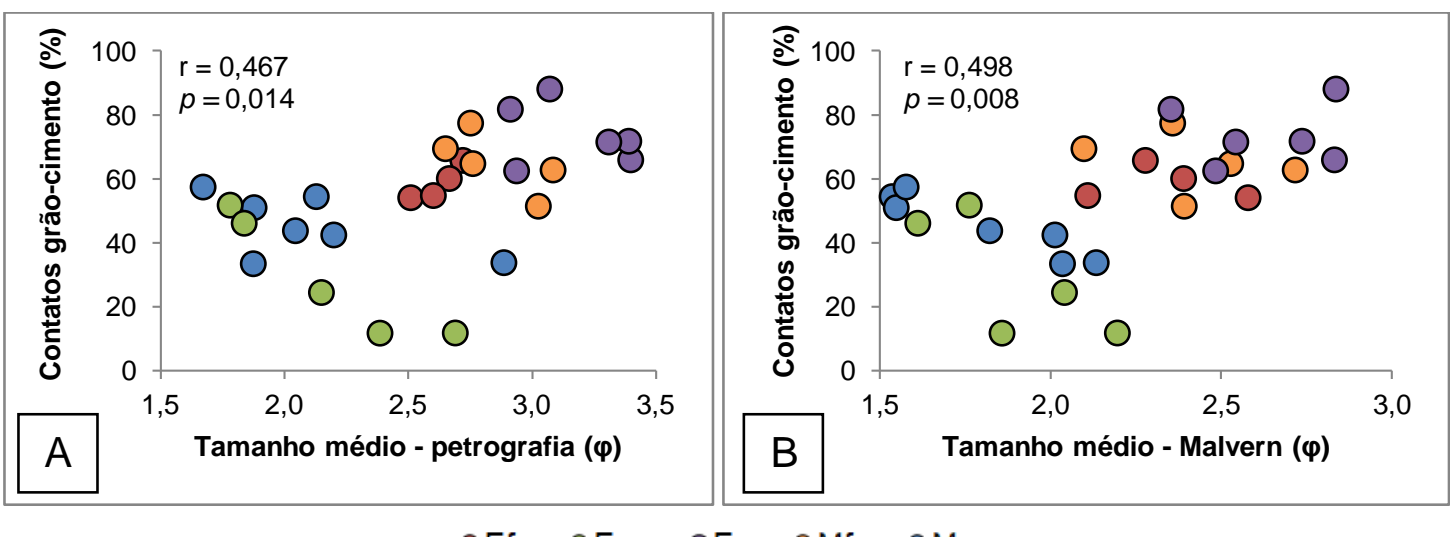

Figura 3.6.9 - Diagramas de dispersão entre proporção de contatos entre grãos do arcabouço e cimento e tamanho médio dos grãos obtido via petrografia óptica $(A)$ e granulômetro de difração de laser (B) na fração areia, por petrofácies. 

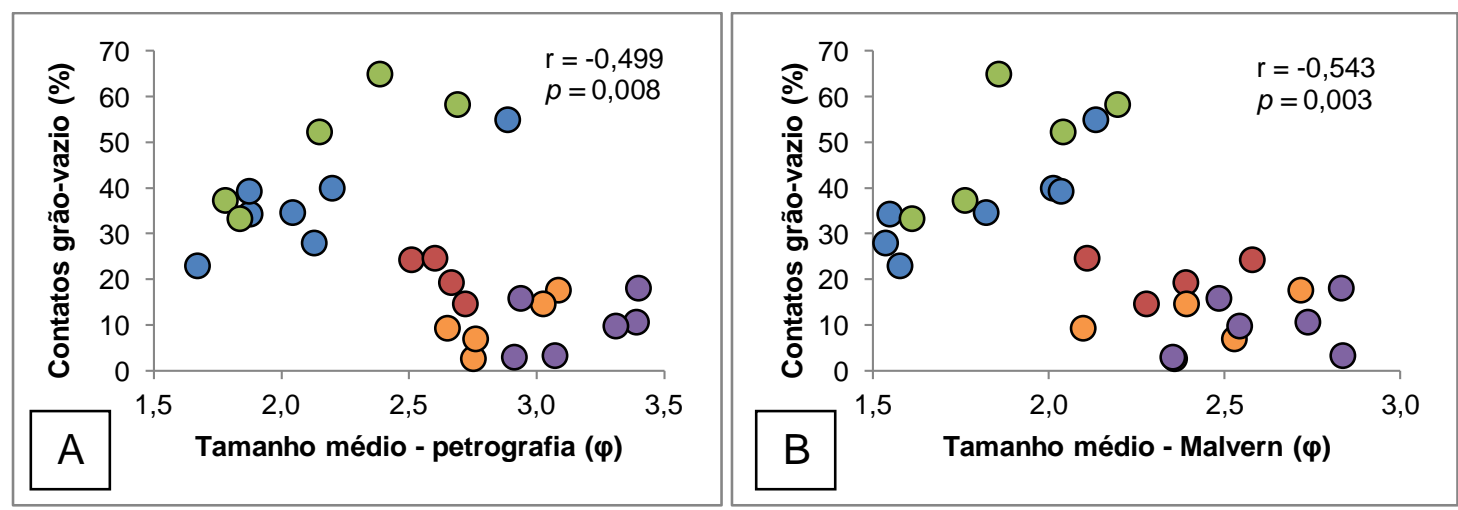

oEfsx OEms OEpa OMfsx OMms

Figura 3.6.10 - Diagramas de dispersão entre proporção de contatos dos grãos do arcabouço com vazios e tamanho médio dos grãos obtido via petrografia óptica $(A)$ e granulômetro de difração de laser (B) na fração areia, por petrofácies.

O tamanho médio dos grãos também se correlaciona à média da razão entre os eixos menor e maior dos grãos. Os arenitos com maiores tamanhos médios tendem a apresentar grãos mais equidimensionais (Figura 3.6.11).

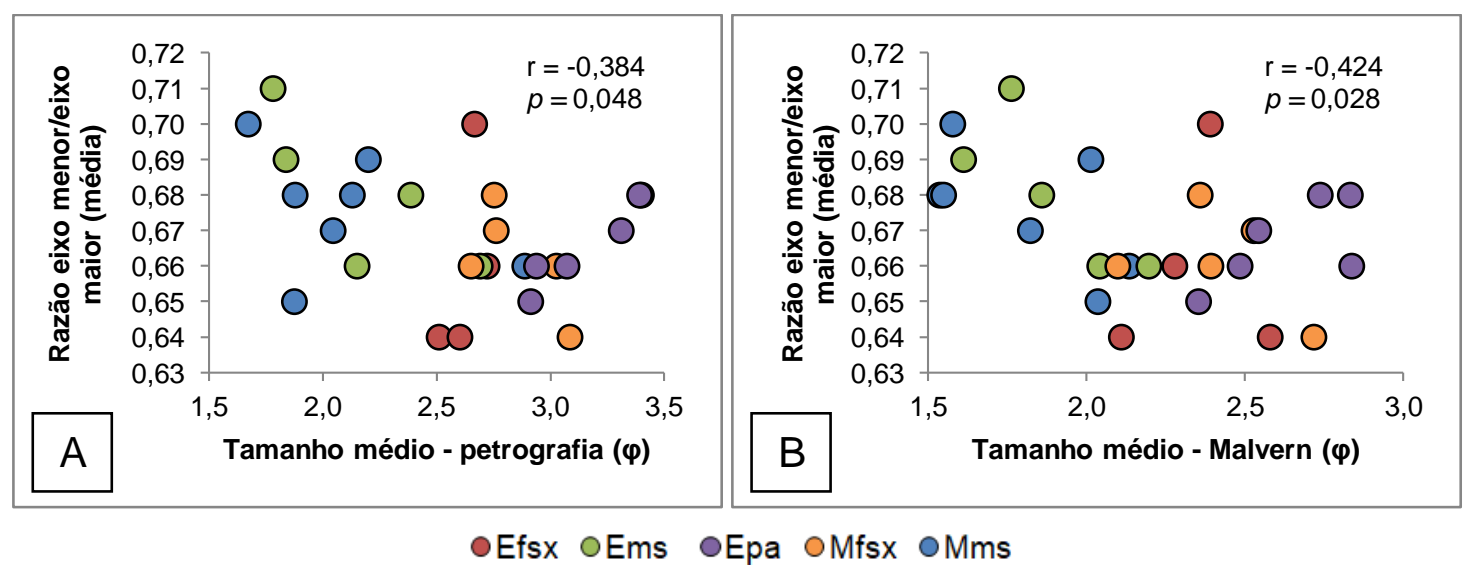

Figura 3.6.11 - Diagramas de dispersão entre a forma dos grãos, avaliada pela razão média entre os eixos menor e maior, e o tamanho médio dos grãos obtido via petrografia óptica $(A)$ e granulômetro de difração de laser (B) na fração areia, por petrofácies. É possível que grãos maiores tendam a ter formas mais equidimensionais.

Foram observadas poucas correlações entre o grau de seleção granulométrica e demais propriedades petrográficas, e estas correlações restringemse apenas aos dados obtidos via petrografia óptica. O desvio padrão da distribuição granulométrica assim determinada correlaciona-se negativamente com a proporção de arcabouço e positivamente com a de cimento total (Figura 3.6.12). 


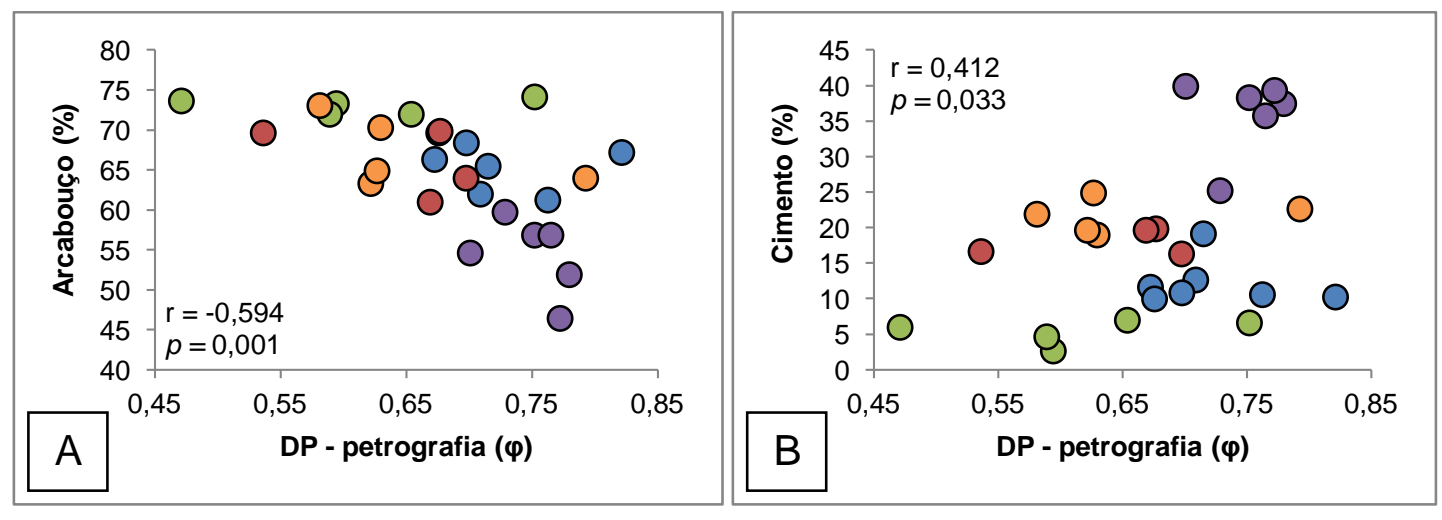

- Efsx OEms OEpa OMfsx OMms

Figura 3.6.12 - Diagramas de dispersão entre desvio padrão do tamanho dos grãos de areia (calculado a partir dos dados petrográficos) e proporções de arcabouço (A) e cimento total (B), por petrofácies.

O teor de pelíticos correlaciona-se negativamente com a porosidade total e a densidade de empacotamento (Figuras 3.6.13 e 3.6.14). Porém, sua correlação com a porosidade intragranular é positiva (Figura 3.6.13 B).

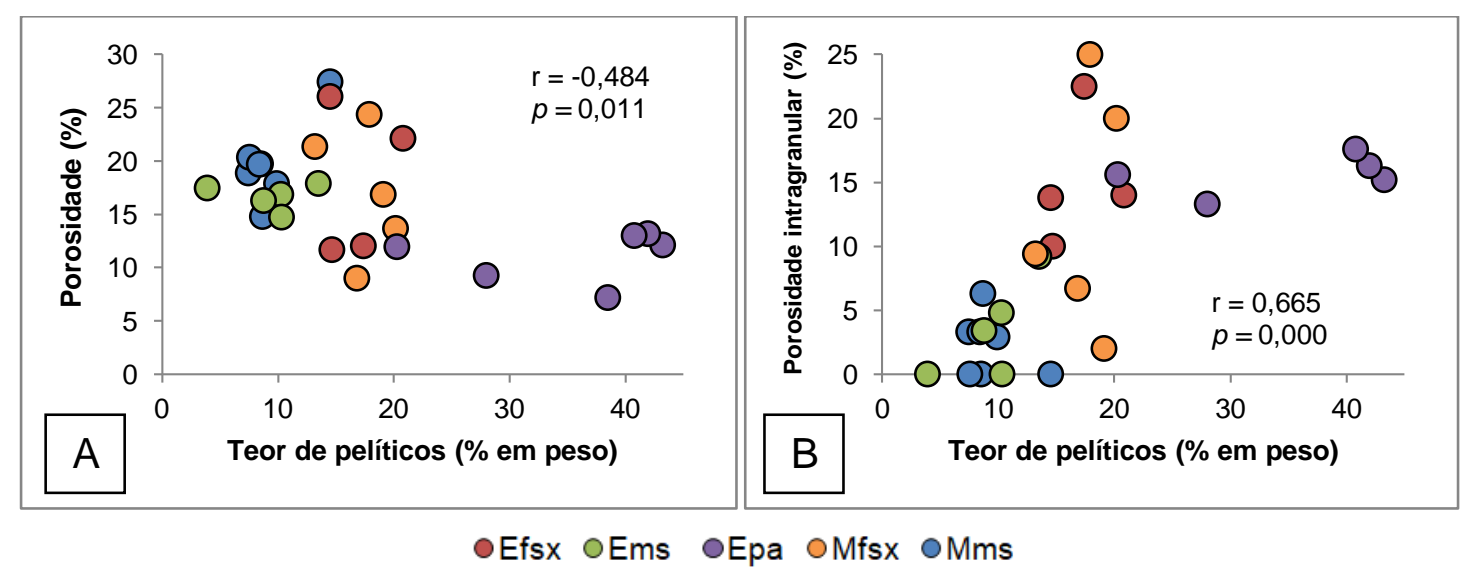

Figura 3.6.13 - Diagramas de dispersão do teor de pelíticos com a porosidade total obtida via analisador de imagens digitais $(A)$ e com a porosidade intragranular (na fração) quantificada por meio de análise modal $(B)$, por petrofácies.

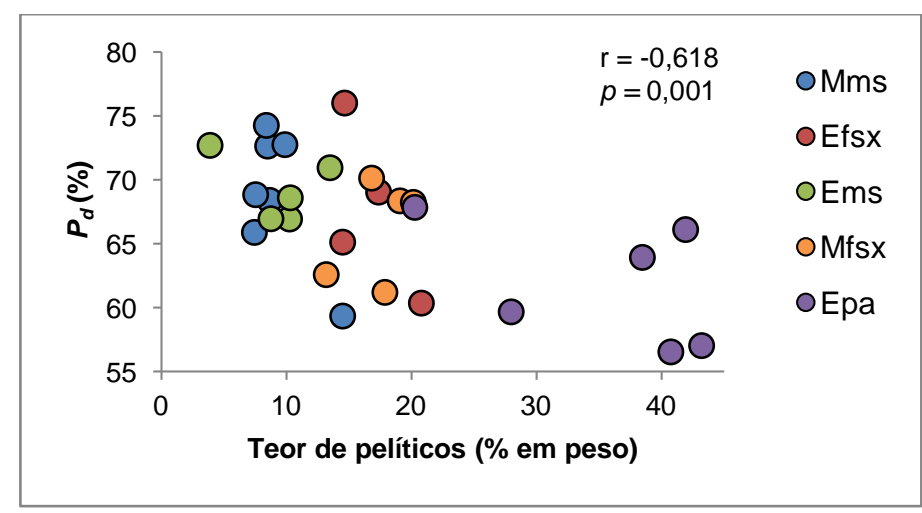

Figura 3.6.14 - Diagramas de dispersão do teor de pelíticos com a densidade de empacotamento $\left(P_{d}\right)$ (A) e com a proporção de arcabouço (B), por petrofácies. 
Observam-se também correlações do teor de pelíticos com as proporções de contatos grão-cimento e grão-vazio, positiva no primeiro caso e negativa no segundo (Figura 3.6.15).

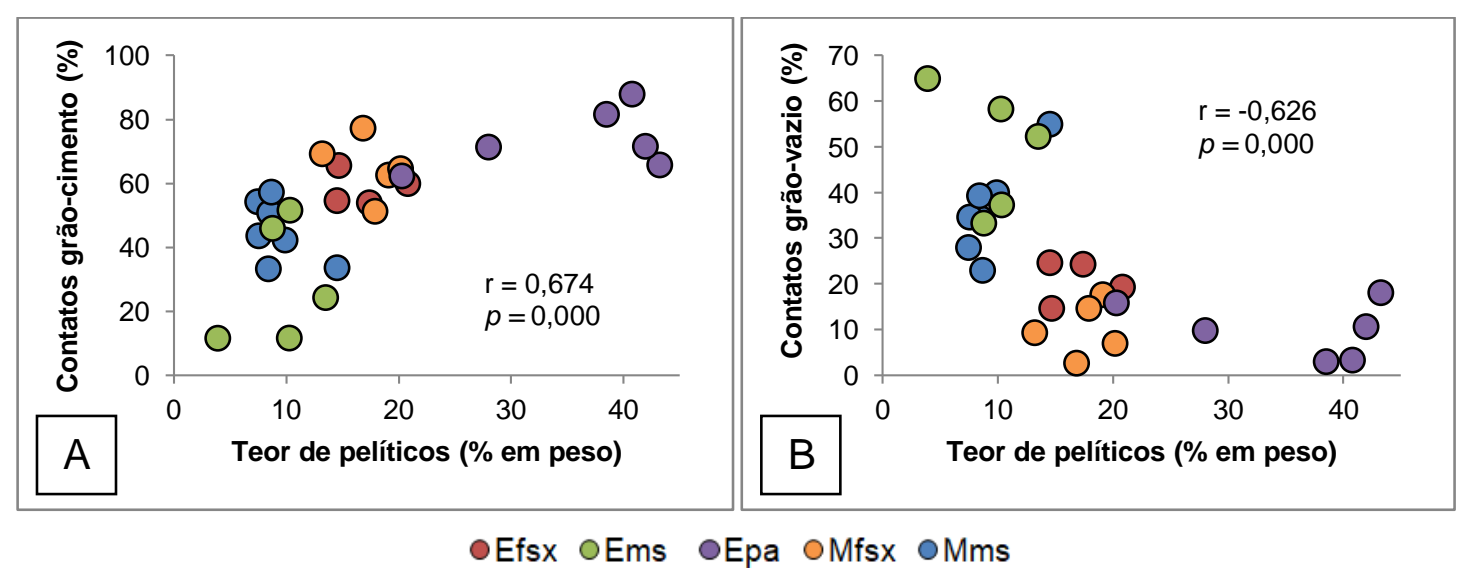

Figura 3.6.15 - Diagramas de dispersão do teor de pelíticos com as proporções de contatos grãocimento (A) e grão-vazio(B), por petrofácies.

Há correlação inversa do teor de pelíticos com a proporção de arcabouço e direta com a proporção de cimento (Figura 3.6.16), bem como com as concentrações de cimentos de óxi-hidróxido metálico e de esmectita (Figura 3.6.17).

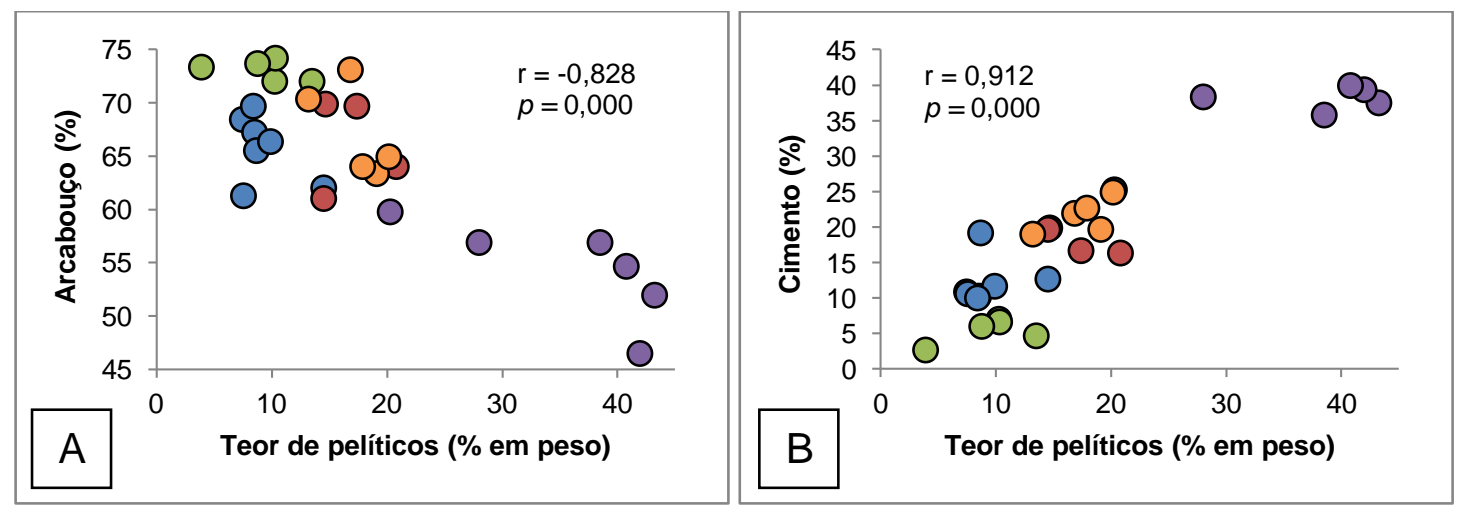

OEfsx OEms OEpa OMfsx OMms

Figura 3.6.16 - Diagramas de dispersão entre teor de pelíticos e proporções de arcabouço $(A)$ e cimento total $(B)$, por petrofácies. 

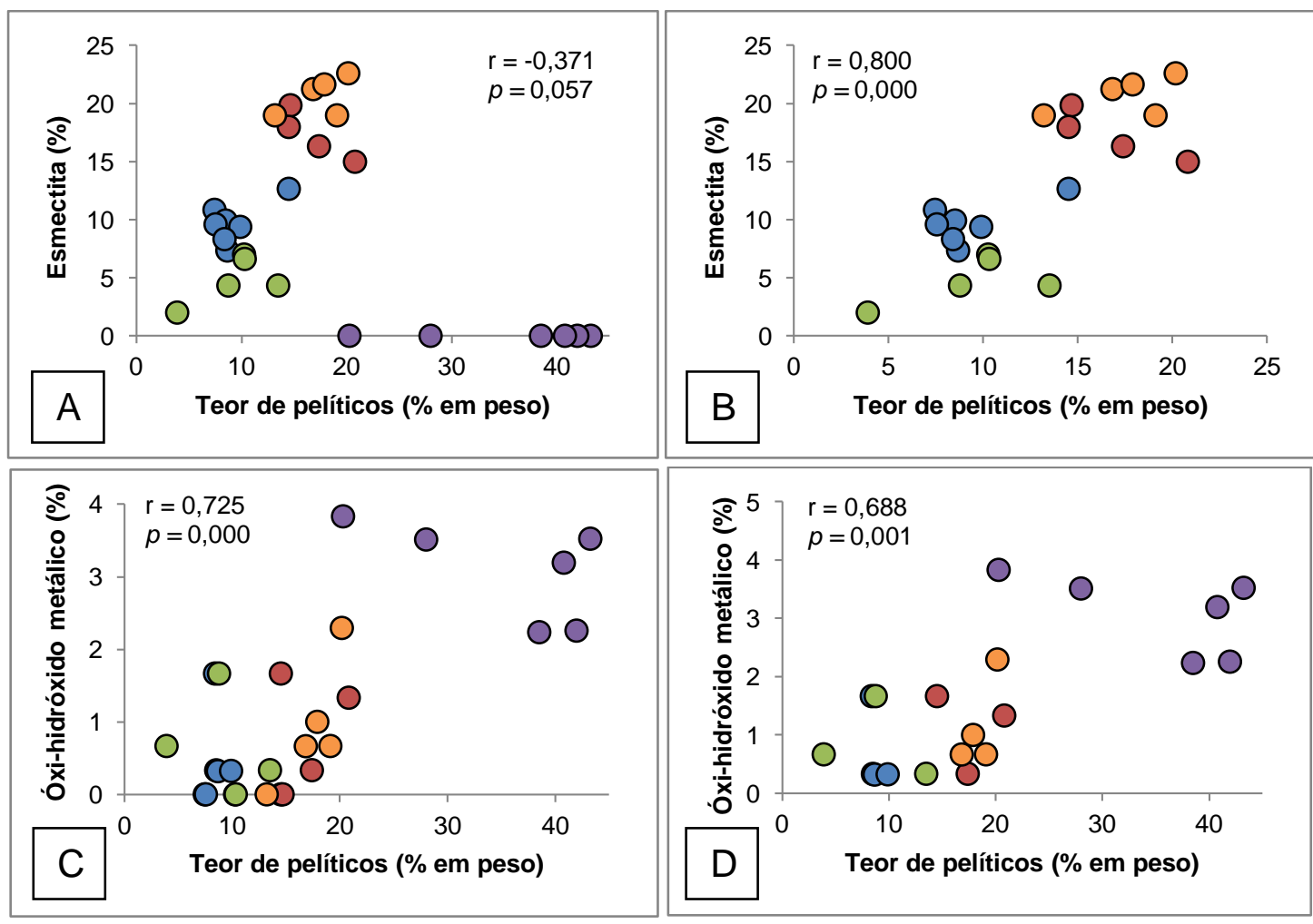

OEfsx OEms OEpa OMfsx OMms

Figura 3.6.17 - Diagramas de dispersão do teor de pelíticos com as proporções de cimento esmectítico ( $A, B)$ e cimento de óxi-hidróxido metálico (C, D), por petrofácies. Nos diagramas da direita, $\mathrm{B}$ e $\mathrm{D}$, suprimem-se os dados referentes às amostras cuja proporção destes tipos de cimento é igual à zero.

Observam-se correlações lineares negativas da porosidade com a proporção de contatos grão-cimento e com a concentração total de cimento (Figura 3.6.18). Verifica-se correlação negativa também entre a porosidade total e a proporção de cimento constituído por óxi-hidróxido metálico. Porém, se forem desconsiderados os valores referentes às amostras cuja proporção deste tipo de cimento é igual a zero, a correlação deixa de ser considerada significativa estatisticamente (Figura 3.6.19). Demais mineralogias de cimento não apresentaram correlação com a porosidade. 


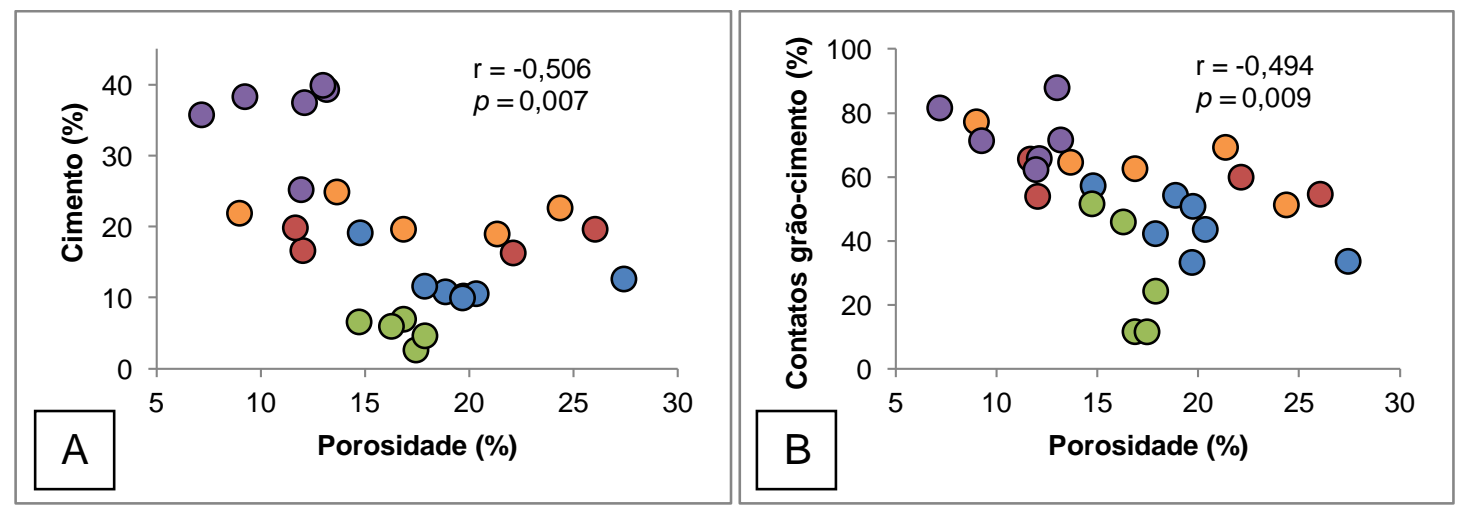

o Efsx OEms OEpa OMfsx OMms

Figura 3.6.18 - Diagramas de dispersão da porosidade total com as proporções de cimento $(A)$ e de contatos entre grãos do arcabouço e cimento (B), por petrofácies.

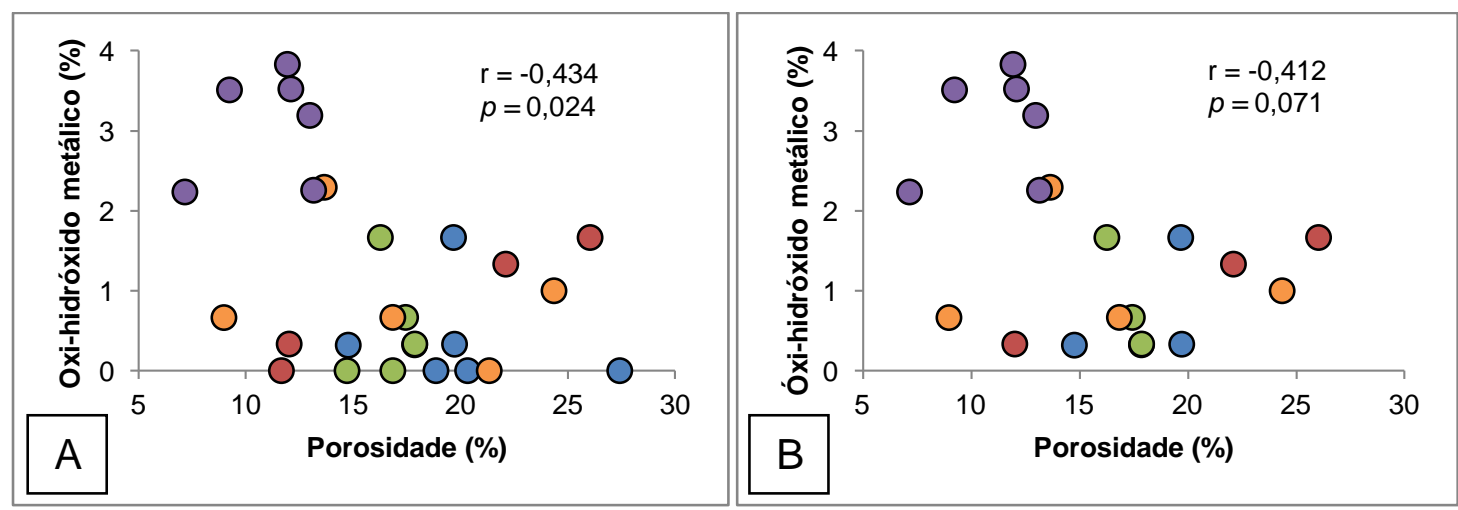

OEfsx OEms OEpa OMfsx OMms

Figura 3.6.19 - Diagramas de dispersão entre porosidade total e proporção de cimento constituído por óxi-hidróxido metálico, por petrofácies. No diagrama $B$, suprimem-se os dados referentes às amostras cuja proporção deste tipo de cimento é igual à zero.

Verifica-se correlação linear inversa entre proporção de grãos subarredondados e porosidade total (Figura 3.6.20). Também se observa correlação inversa entre a proporção de grãos arredondados e a de cimento esmectítico (Figura 3.6.21).

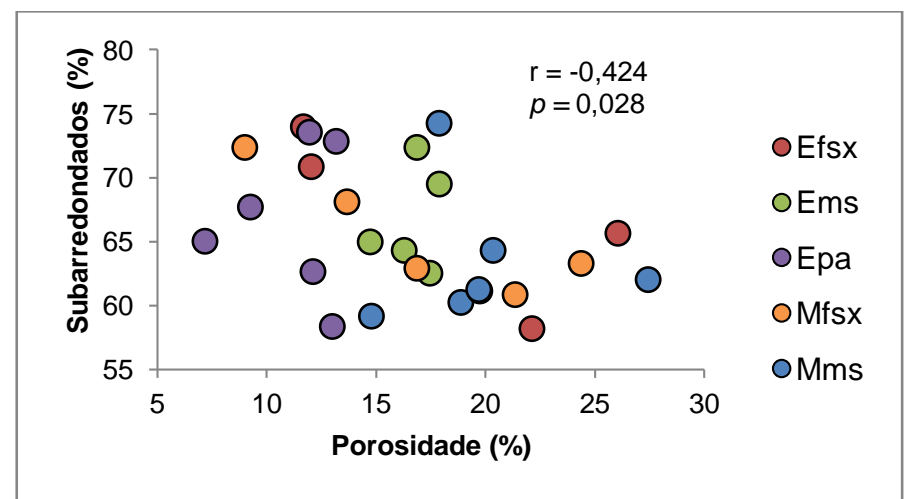

Figura 3.6.20 - Diagrama de dispersão entre porosidade total e proporção de grãos subarredondados, por petrofácies. 


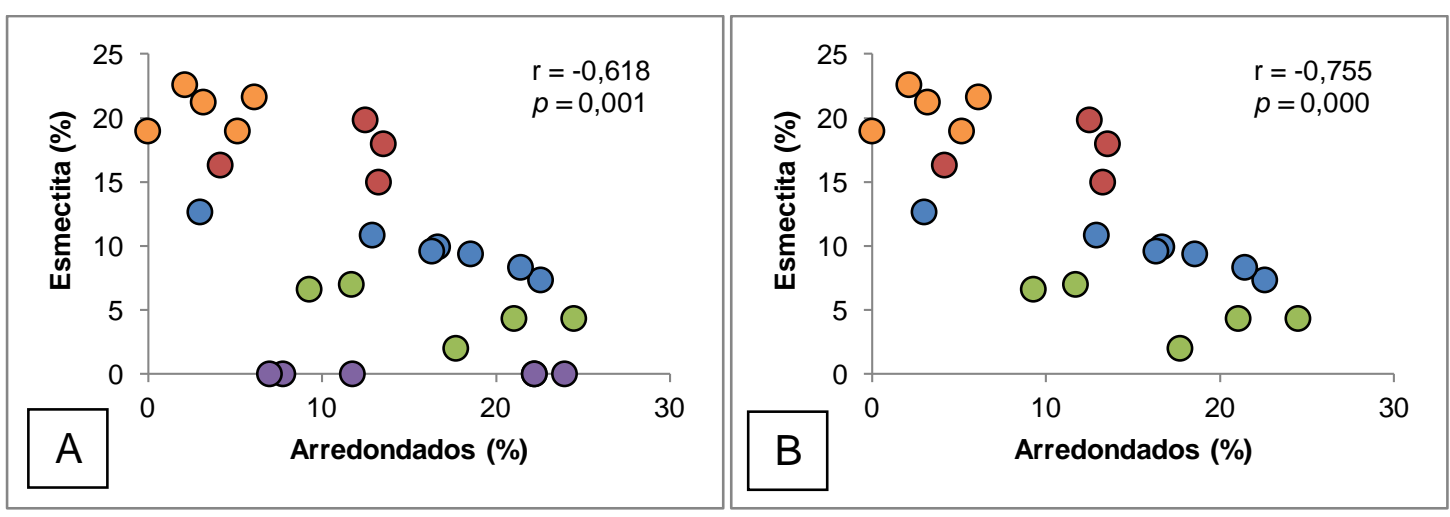

OEfsx OEms OEpa OMfsx OMms

Figura 3.6.21 - Diagramas de dispersão entre as proporções de grãos arredondados e de cimento esmectítico, por petrofácies. No diagrama $B$, suprimem-se os dados referentes às amostras que não apresentam este tipo de cimento.

A porosidade intragranular correlaciona-se à proporção total de cimento e à de contatos entre grãos do arcabouço e cimento (Figuras 3.6.22 e 3.6.23). Considerando as diversas mineralogias de cimento individualmente, a porosidade intragranular apresenta correlação linear, ainda que fraca, com a proporção de cimento constituído por óxi-hidróxido metálico (Figura 3.6.24), mas não com a de esmectita (Figura 3.6.25).

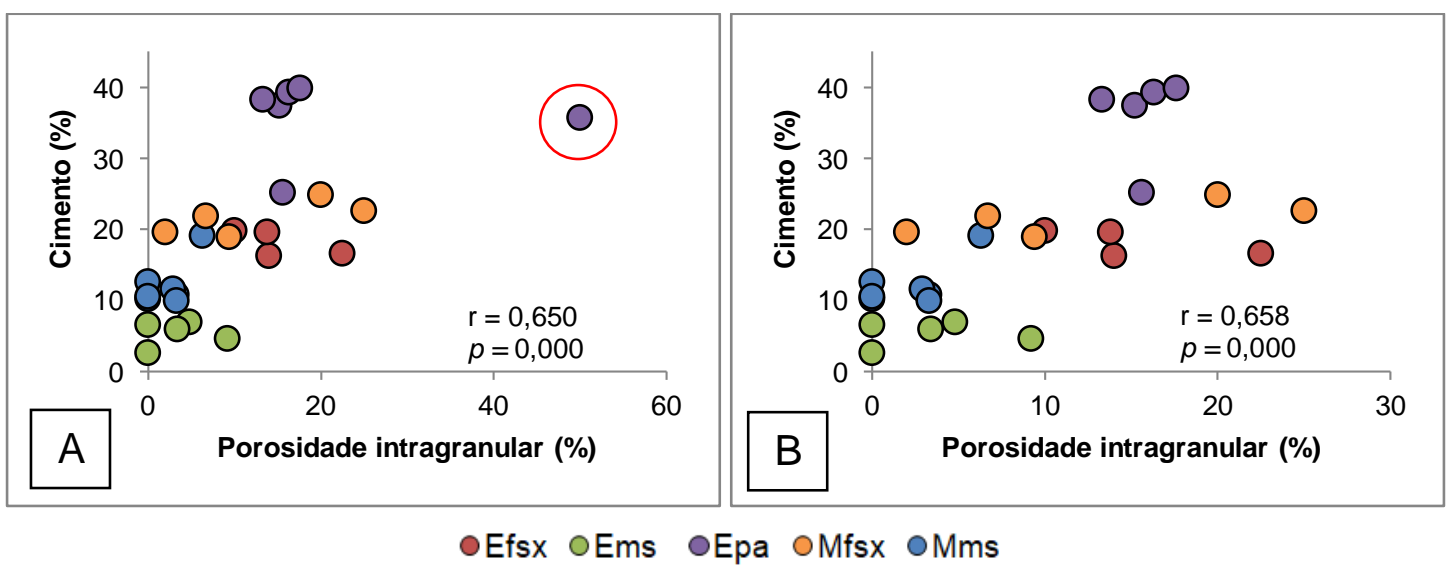

Figura 3.6.22 - Diagramas de dispersão entre porosidade intragranular e proporção de cimento total, por petrofácies. No diagrama B, suprime-se o dado referente à amostra da cota 448,2 $\mathrm{m}$ da sondagem SM-222 (círculo vermelho). 


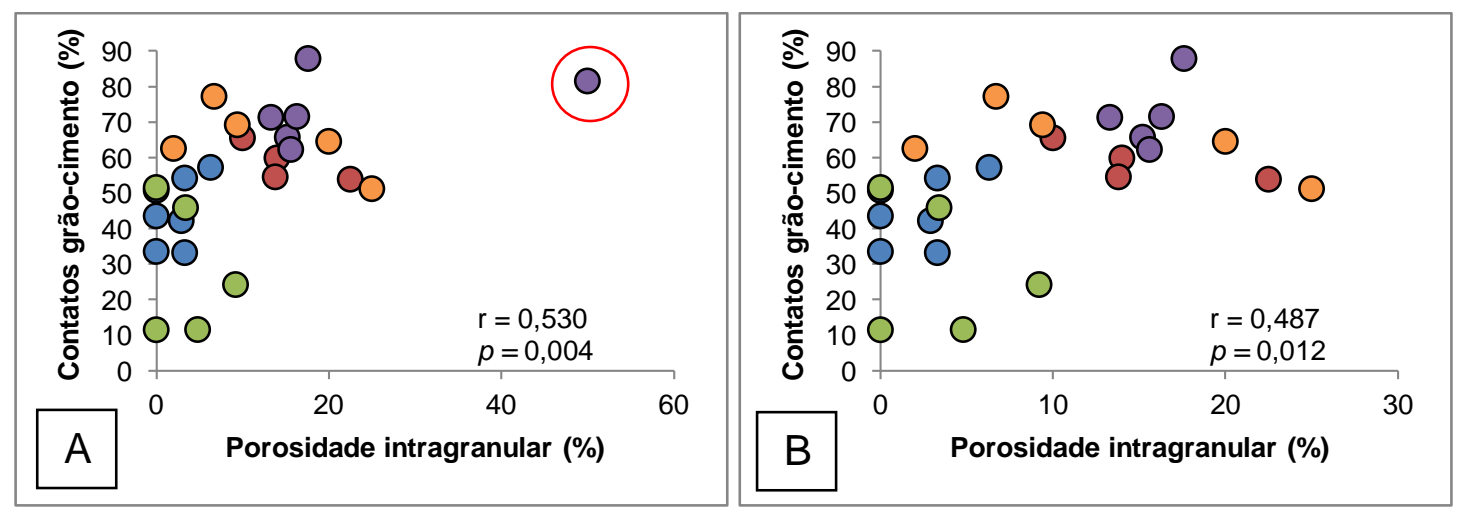

\section{OEfsx OEms OEpa OMfsx OMms}

Figura 3.6.23 - Diagramas de dispersão entre porosidade intragranular e proporção de contatos entre grãos do arcabouço e cimento, por petrofácies. No diagrama $B$, suprime-se o dado referente à amostra da cota 448,2 m da sondagem SM-222 (círculo vermelho).

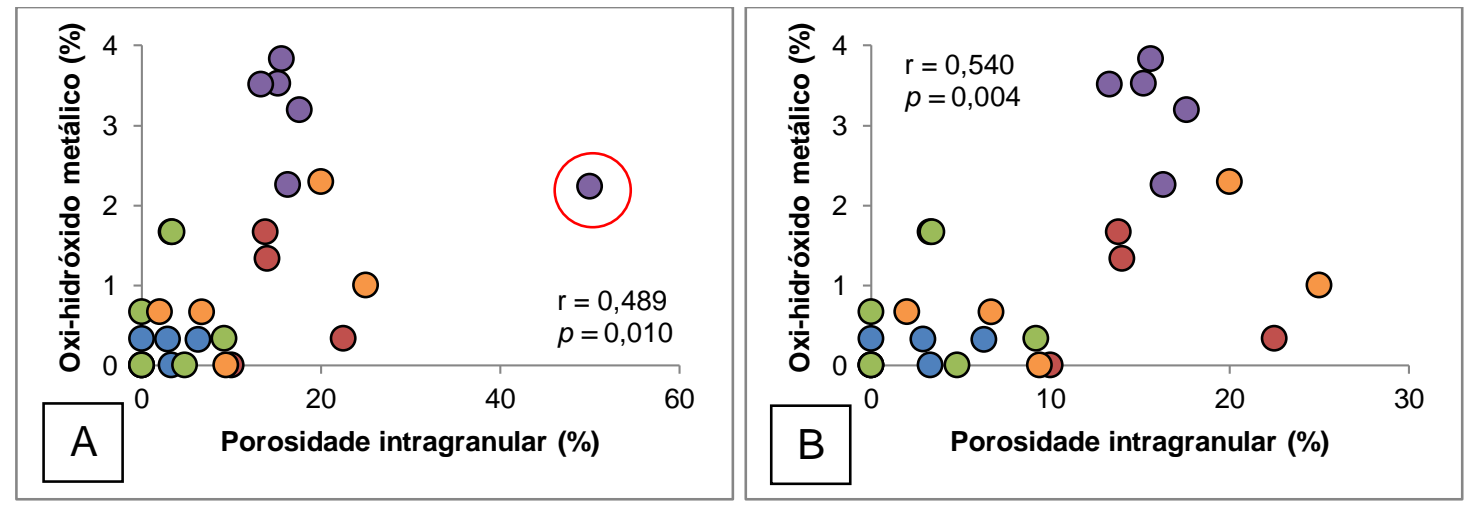

oEfsx OEms OEpa OMfsx OMms

Figura 3.6.24 - Diagramas de dispersão entre porosidade intragranular (na fração porosidade modal) e proporção de cimento constituído por óxi-hidróxido metálico, por petrofácies. No diagrama $B$, suprime-se o dado referente à amostra da cota 448,2 m da sondagem SM-222 (círculo vermelho).

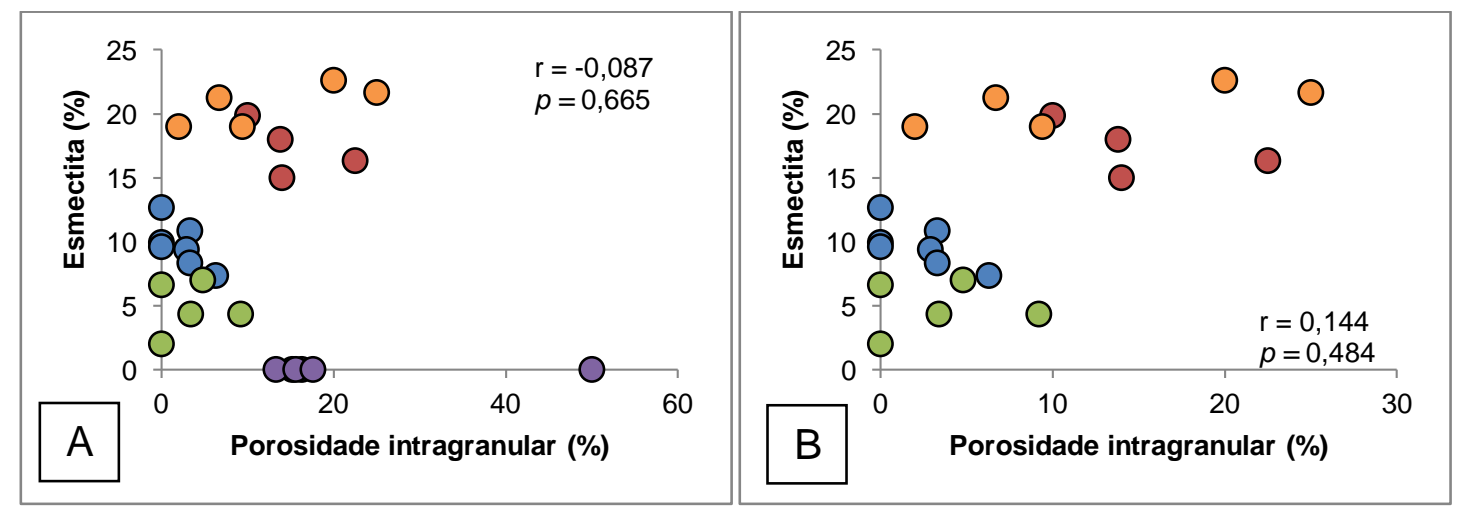

OEfsx OEms OEpa OMfsx OMms

Figura 3.6.25 - Diagramas de dispersão entre porosidade intragranular (na fração porosidade modal) e proporção de cimento constituído por esmectita, por petrofácies. No diagrama B, suprimem-se os dados referentes às amostras que não contêm esmectita. 
Verifica-se também correlação linear negativa da porosidade intragranular com as proporções de grãos de arcabouço (Figura 3.6.26) e de contatos grão-vazio (Figura 3.6.27).

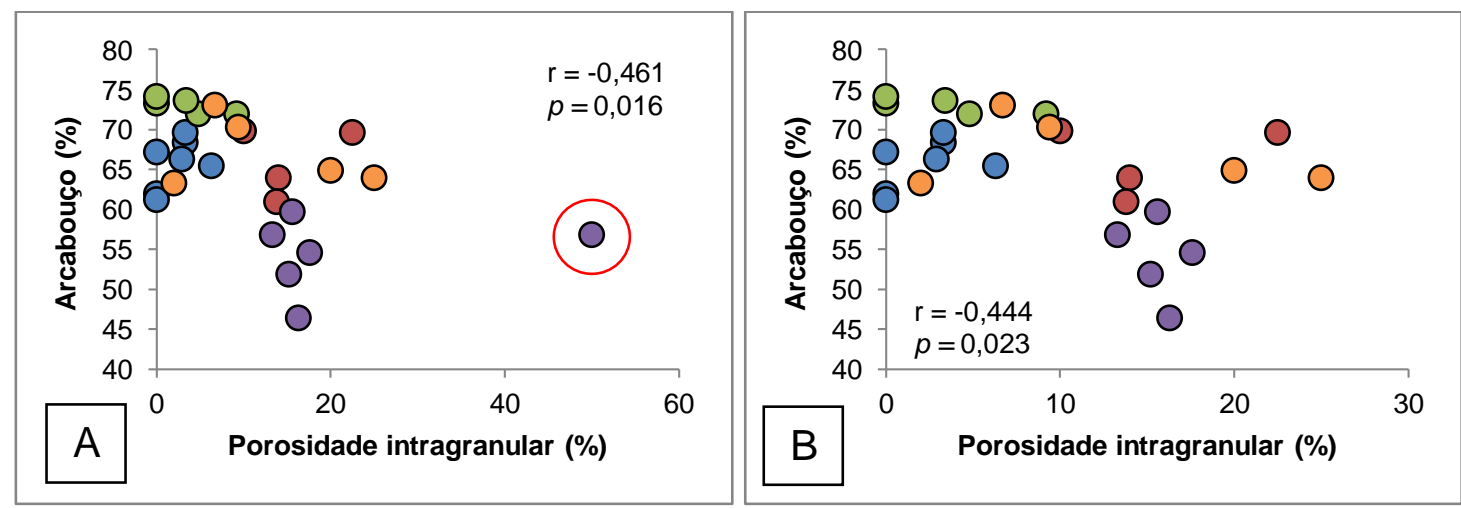

o Efsx OEms OEpa OMfsx OMms

Figura 3.6.26 - Diagramas de dispersão entre porosidade intragranular (na fração porosidade modal) e proporção de arcabouço, por petrofácies. No diagrama $\mathrm{B}$, suprime-se o dado referente à amostra da cota 448,2 $\mathrm{m}$ da sondagem SM-222 (círculo vermelho). Mesmo apresentando menor coeficiente de correlação, após a supressão deste valor a significância da correlação se mantém.

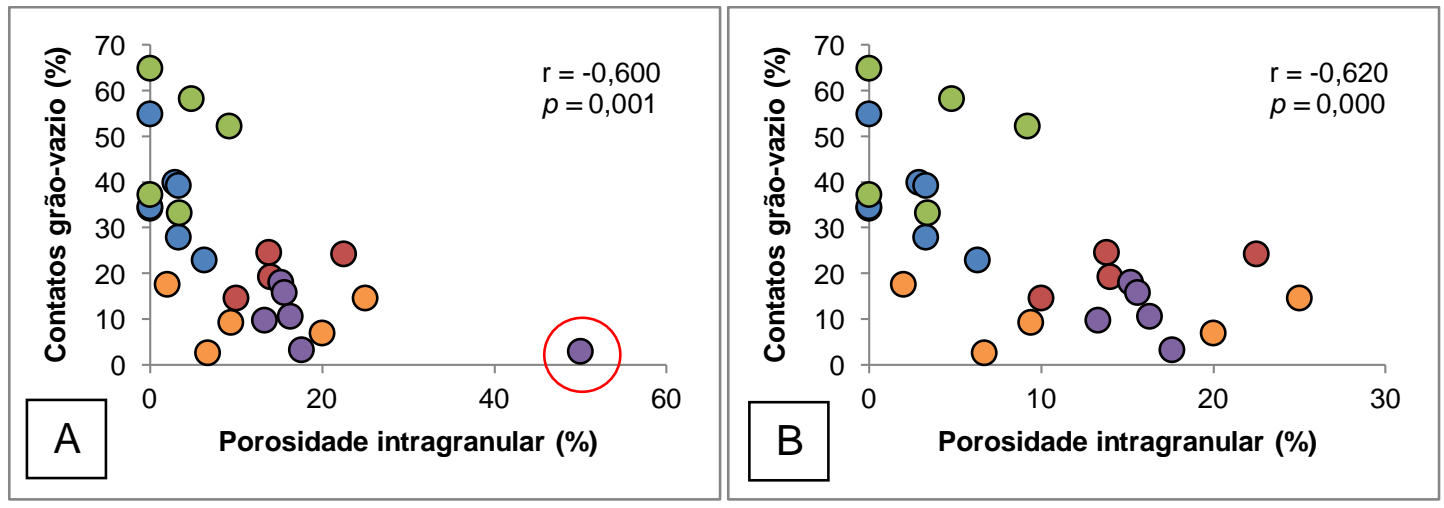

OEfsx OEms OEpa OMfsx OMms

Figura 3.6.27 - Diagramas de dispersão entre porosidade intragranular (na fração porosidade modal) e proporção de contatos entre grãos do arcabouço e vazios, por petrofácies. No diagrama B, suprimese o dado referente à amostra da cota 448,2 m da sondagem SM-222 (círculo vermelho).

A densidade de empacotamento $\left(P_{d}\right)$ correlaciona-se positivamente à proporção de grãos do arcabouço, e negativamente a índices relacionados à cimentação, como as proporções de cimento total e de contatos entre grãos do arcabouço e cimento. Considerando a mineralogia dos cimentos individualmente, apenas a fração constituída por óxi-hidróxido metálico correlaciona-se à densidade de empacotamento (Figuras 3.6.28 e 3.6.29). 

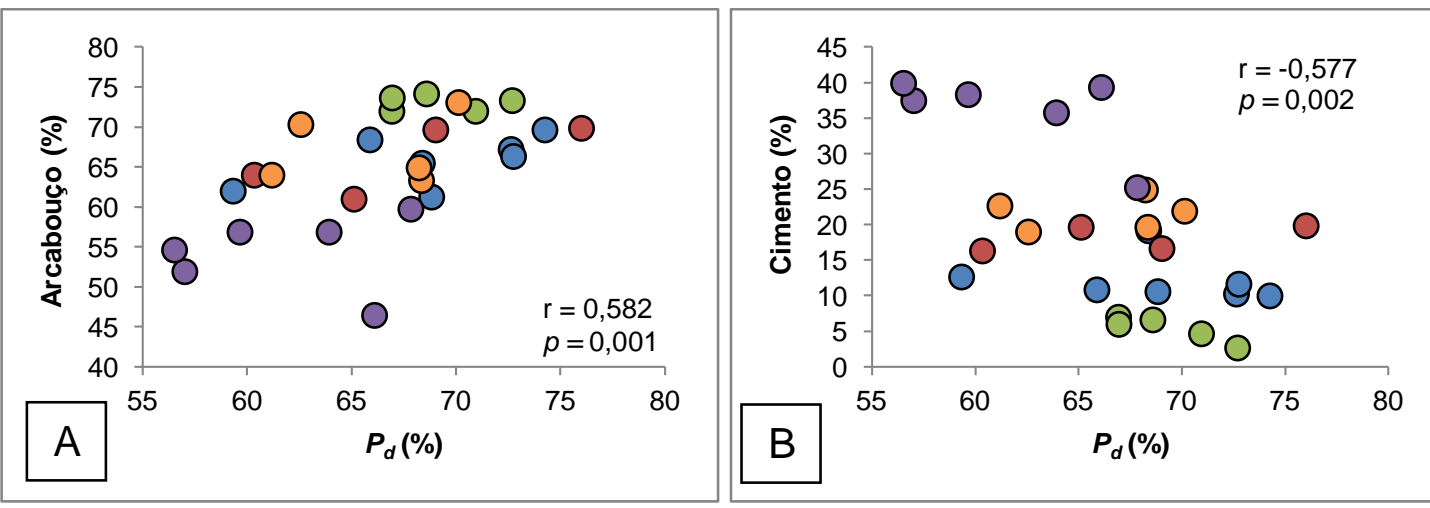

OEfsx OEms OEpa OMfsx OMms

Figura 3.6.28 - Diagramas de dispersão da densidade de empacotamento $\left(P_{d}\right)$ com as proporções de arcabouço (A) e cimento (B), por petrofácies.

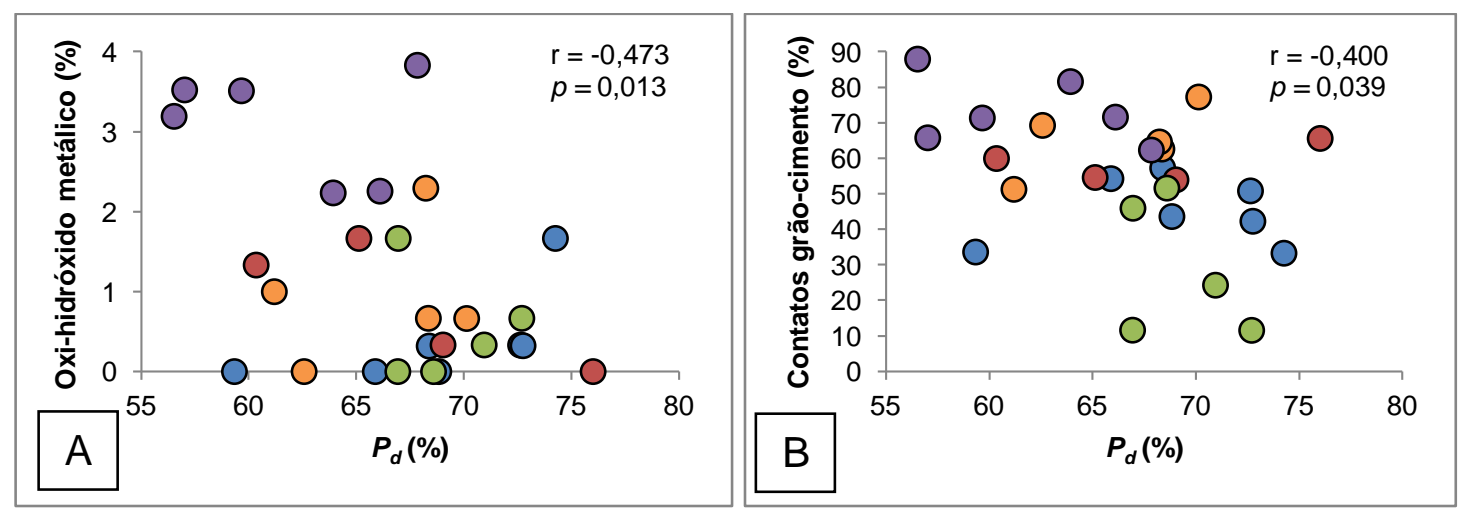

OEfsx OEms OEpa OMfsx OMms

Figura 3.6.29 - Diagramas de dispersão da densidade de empacotamento $\left(P_{d}\right)$ com a proporção de cimento constituído por óxi-hidróxido metálico $(\mathrm{A})$ e com a proporção de contatos entre grãos do arcabouço e cimento $(B)$, por petrofácies.

A correlação verificada entre a proximidade de empacotamento $\left(P_{p}\right)$ e a quantidade relativa de cimento puramente esmectítico (Figura 3.6.30 A) deixa de ser significativa ao suprimirem-se dos cálculos os dados referentes a amostras que não apresentaram este tipo de cimento (Figura 3.6.30 B). 


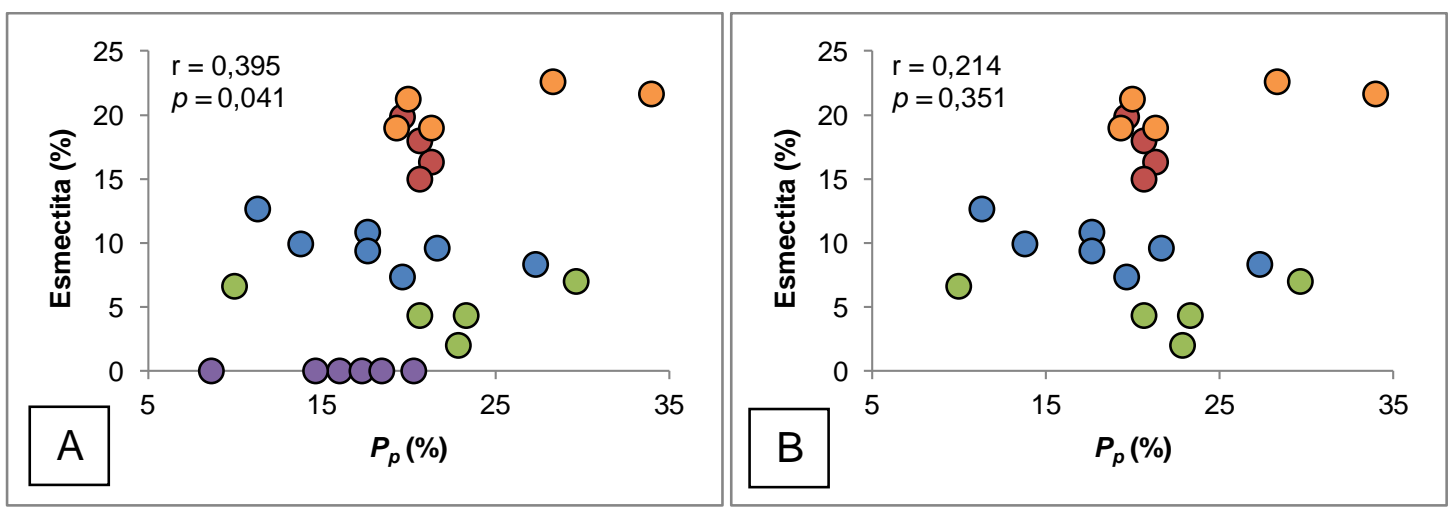

- Efsx OEms OEpa OMfsx OMms

Figura 3.6.30 - Diagramas de dispersão entre proximidade de empacotamento $\left(P_{p}\right)$ e proporção de cimento esmectítico, por petrofácies. No diagrama B, suprimem-se os valores iguais a zero, ou seja, referentes a amostras que não apresentam cimento constituído por esmectita. Neste caso, a correlação deixa de ser significativa estatisticamente.

Observa-se correlação linear negativa entre a proporção de contatos intergranulares retos e a média das razões entre as medidas dos eixos menor e maior dos grãos do arcabouço (Figura 3.6.31).

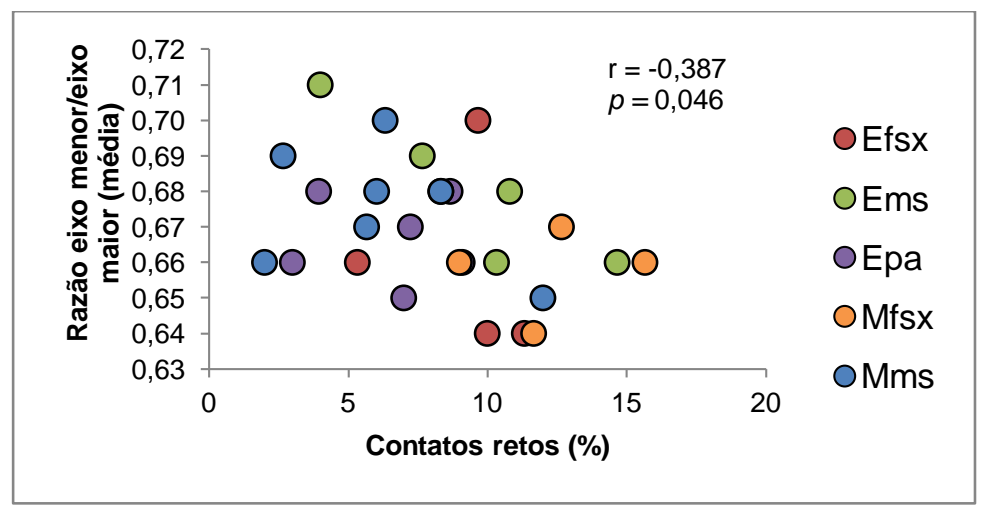

Figura 3.6.31 - Diagrama de dispersão entre proporção de contatos retos e a média das razões entre os eixos menor e maior dos grãos do arcabouço, por petrofácies.

Verifica-se também correlação linear direta da proporção de contatos côncavo-convexos com a proporção de arcabouço, e correlação inversa com a proporção de cimento. Contudo, como a proporção de contatos côncavo-convexos é ausente em algumas amostras, testou-se a validade destas correlações suprimindo os dados referentes às amostras sem este tipo de contato. Neste caso, apenas a correlação com a proporção de cimento permanece significativa estatisticamente (Figuras 3.6 .32 e 3.6.33). 


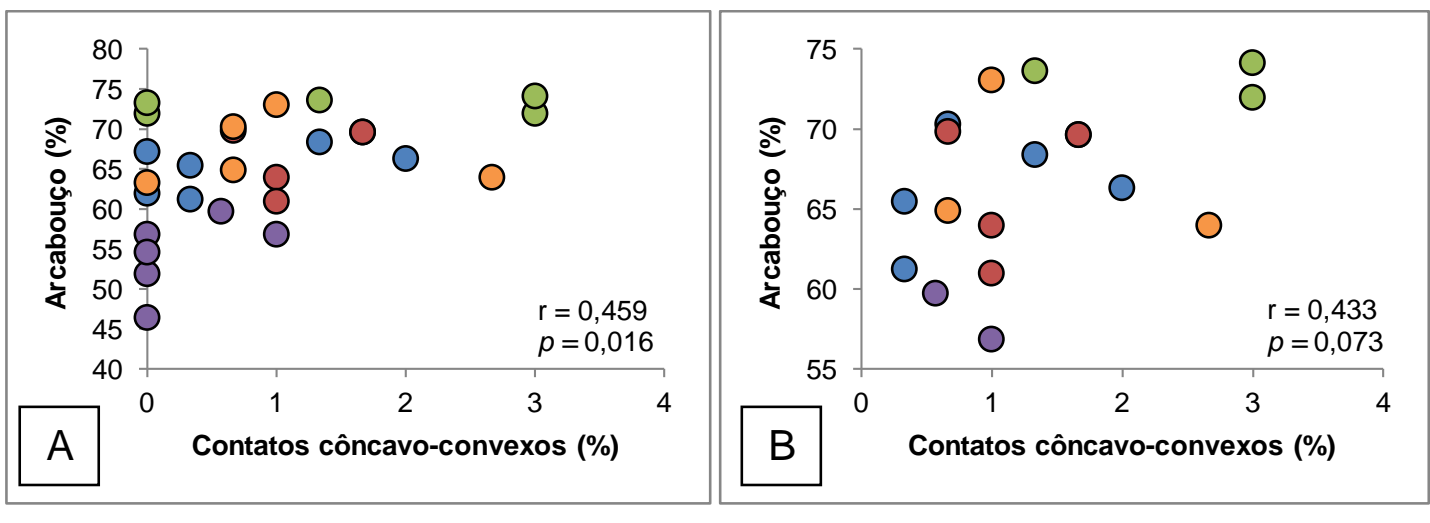

OEfsx OEms OEpa OMfsx OMms

Figura 3.6.32 - Diagrama de dispersão entre proporção de contatos côncavo-convexos e proporção de arcabouço, por petrofácies. No diagrama $B$, suprimem-se os dados referentes às amostras cuja proporção deste tipo de contato intergranular é nula.

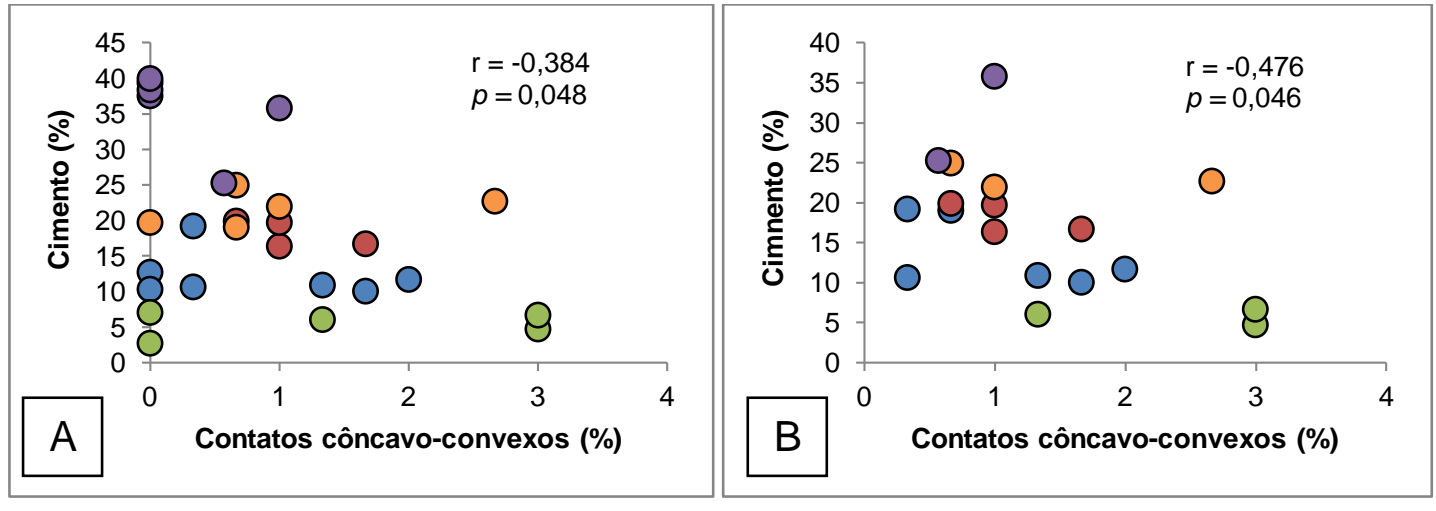

OEfsx OEms OEpa OMfsx OMms

Figura 3.6.33 - Diagrama de dispersão entre proporção de contatos côncavo-convexos e a proporção total de cimento, por petrofácies. No diagrama $B$, suprimem-se os dados referentes às amostras cuja proporção deste tipo de contato intergranular é nula.

O teor de feldspato apresentou correlação linear positiva com a proporção de cimento esmectítico (porcentagens em relação ao total). Contudo, esta correlação deixa de ser significativa ao desconsiderarem-se os dados das amostras que não contêm este tipo de cimento. A concentração de cimento constituído por óxihidróxido metálico, ao contrário, correlaciona-se negativamente ao teor de feldspato (Figuras 3.6.34 e 3.6.35). 

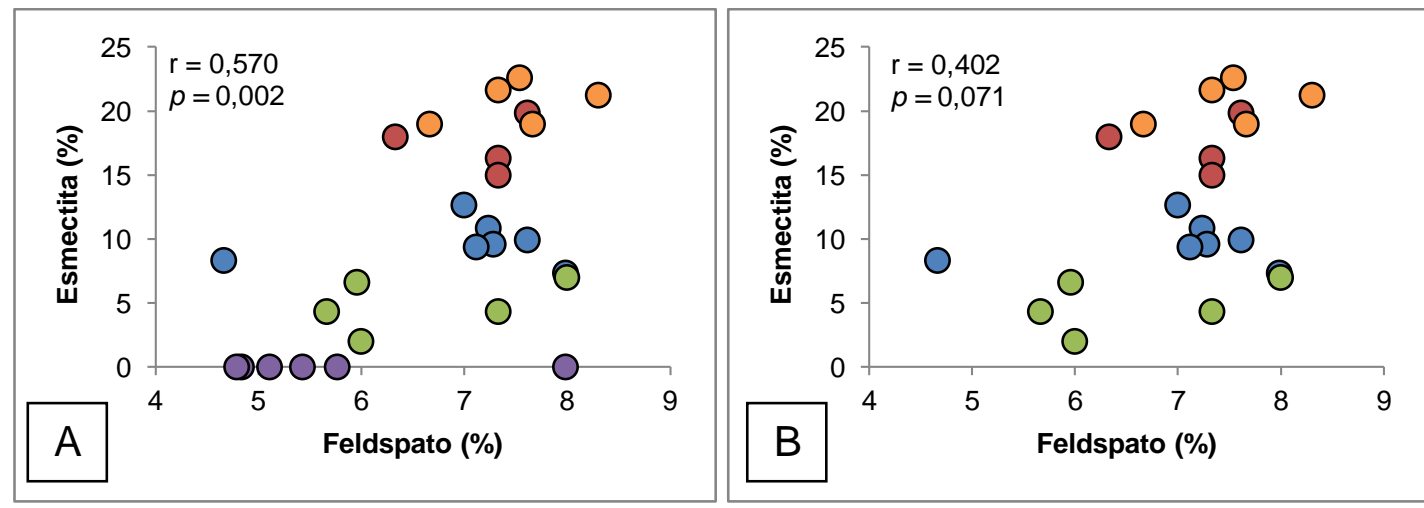

- Efsx OEms OEpa OMfsx OMms

Figura 3.6.34 - Diagrama de dispersão entre proporção de grãos de feldspato e proporção de cimento esmectítico (porcentagens no total), por petrofácies. No diagrama B, suprimem-se os dados referentes às amostras que não apresentam este tipo de cimento.

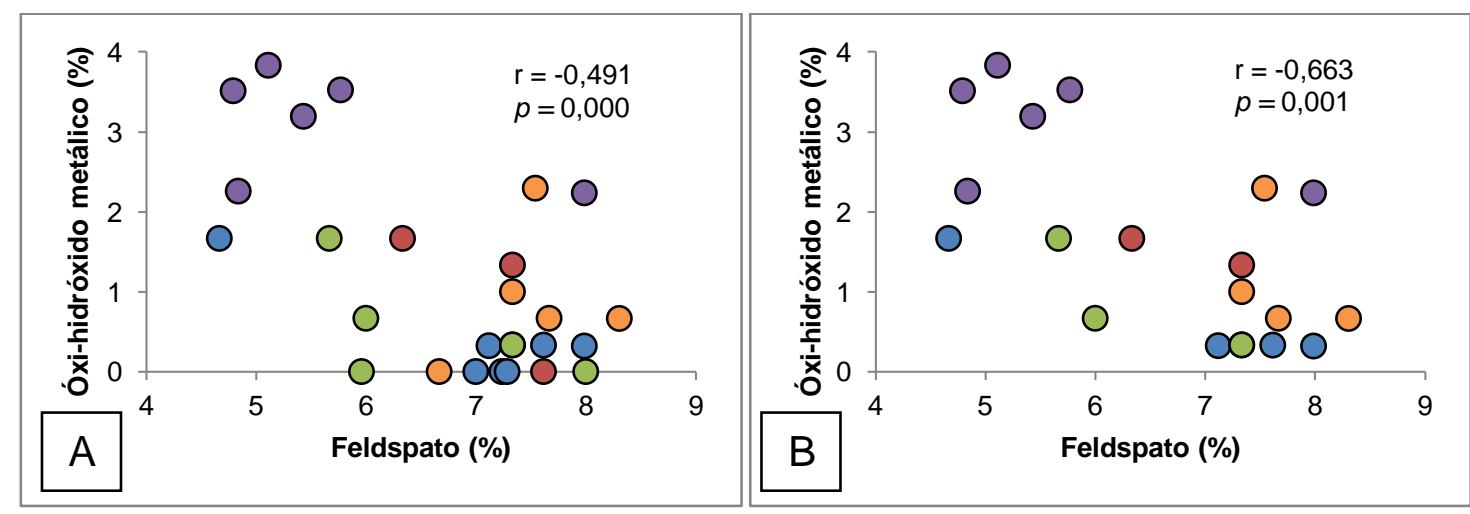

oEfsx OEms OEpa OMfsx OMms

Figura 3.6.35 - Diagrama de dispersão entre proporção de grãos de feldspato e proporção de cimento constituído por óxi-hidróxido metálico (porcentagens no total), por petrofácies. No diagrama $B$, suprimem-se os dados referentes às amostras que não apresentam este tipo de cimento.

\subsubsection{Correlações entre propriedades petrográficas e profundidade}

A correlação das propriedades petrográficas com a profundidade foi testada, tendo em vista que, se duas propriedades se correlacionam mutuamente com uma terceira, esta mútua correlação pode gerar, como subproduto, correlação entre as duas primeiras, sem existir necessariamente interdependência entre elas.

Dentre as propriedades granulométricas, as correlações lineares com a profundidade encontradas apontam tendências para o topo de afinamento do tamanho médio do arcabouço (Figura 3.6.36) e de aumento no teor de pelíticos (Figura 3.6.37A), este acompanhado de incremento na proporção de cimento (Figura 3.6.37B). 


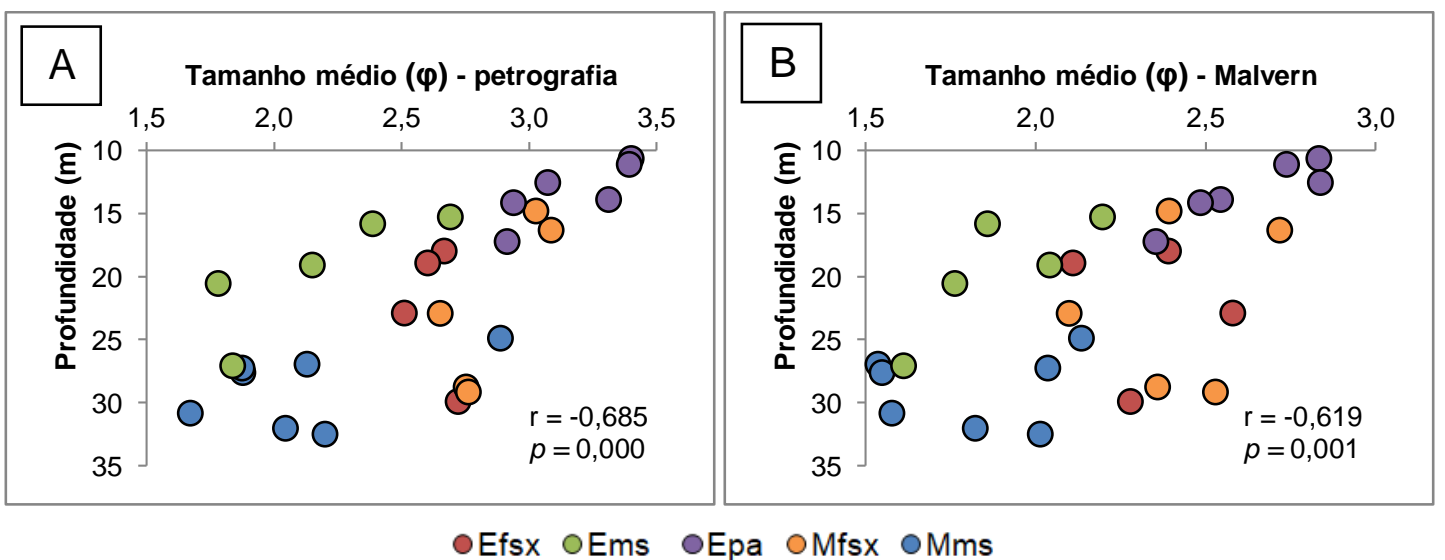

Figura 3.6.36 - Diagramas de dispersão entre profundidade e tamanho médio dos grãos na fração areia obtido via petrografia óptica $(A)$ e granulômetro a laser $(B)$, por petrofácies.

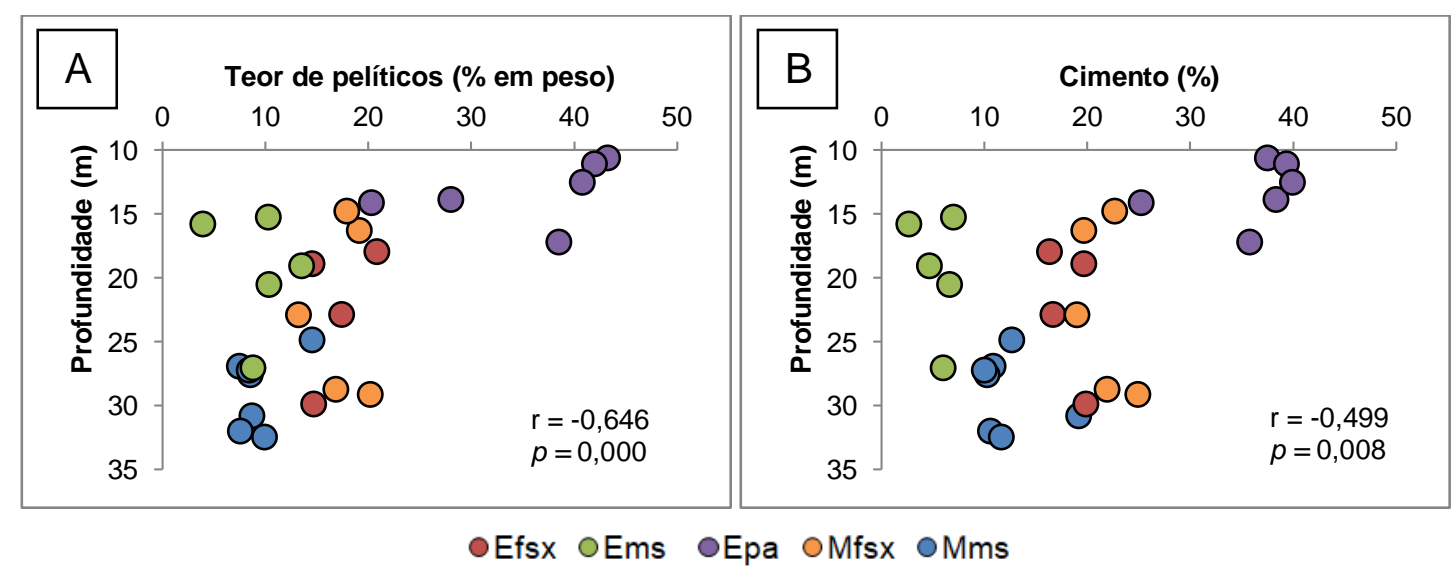

Figura 3.6.37 - Diagramas de dispersão da profundidade com o teor de pelíticos (A) e com a proporção de cimento (B), por petrofácies.

Ao correlacionar à profundidade as diferentes mineralogias de cimento individualmente, nota-se que a correlação observada com o teor de cimento total (Figura 3.6.37B) perde força, mas se mantém significativa (figuras 3.6 .38 a 3.6.40). Contudo, muitas amostras apresentam ausência total de determinados tipos de cimento. Suprimindo os valores iguais a zero para cada mineralogia, apenas o cimento constituído por óxi-hidróxido metálico continua a apresentar correlação significativa (negativa) com a profundidade (gráfico B das figuras 3.6.38 a 3.6.40). 


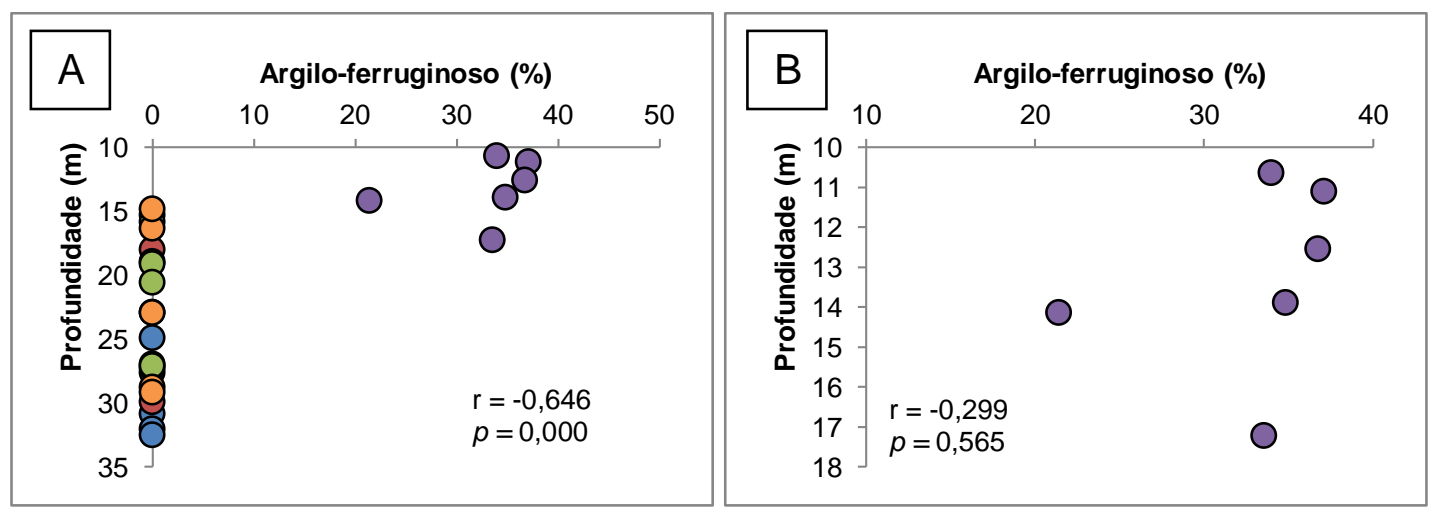

OEfsx OEms OEpa OMfsx OMms

Figura 3.6.38 - Diagramas de dispersão entre profundidade e proporção de cimento argiloferruginoso, por petrofácies. No diagrama $B$, suprimem-se os dados referentes às amostras cuja proporção deste tipo de cimento é igual à zero.

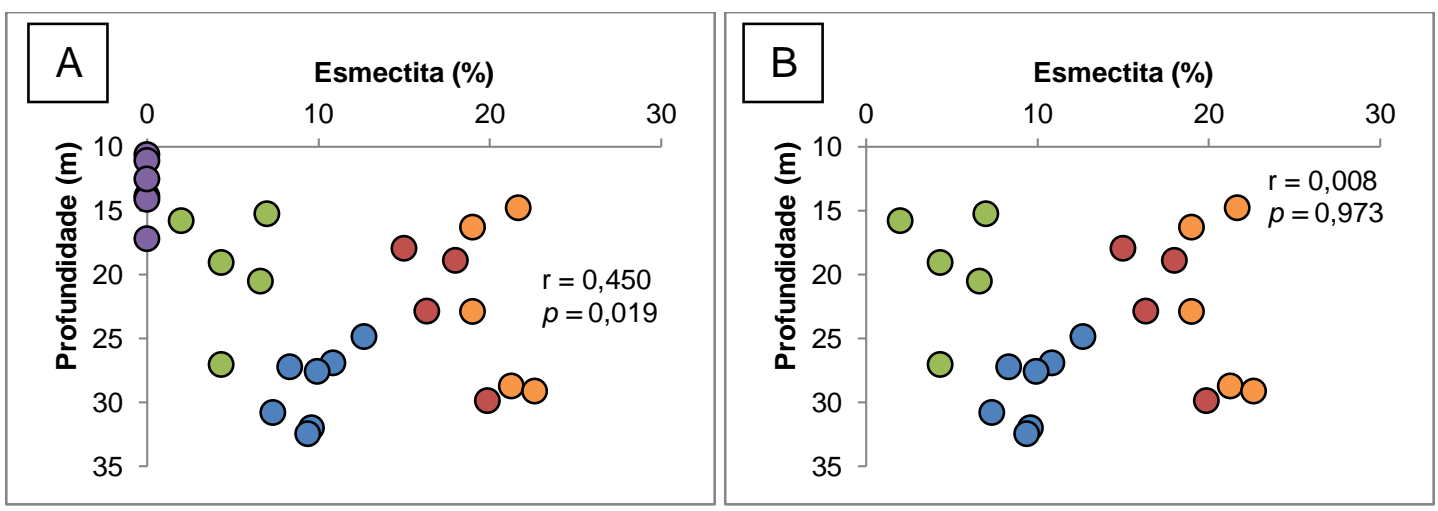

OEfsx OEms OEpa OMfsx OMms

Figura 3.6.39 - Diagramas de dispersão entre profundidade e proporção de cimento esmectítico, por petrofácies. No diagrama $B$, suprimem-se os dados referentes às amostras cuja proporção deste tipo de cimento é igual à zero.

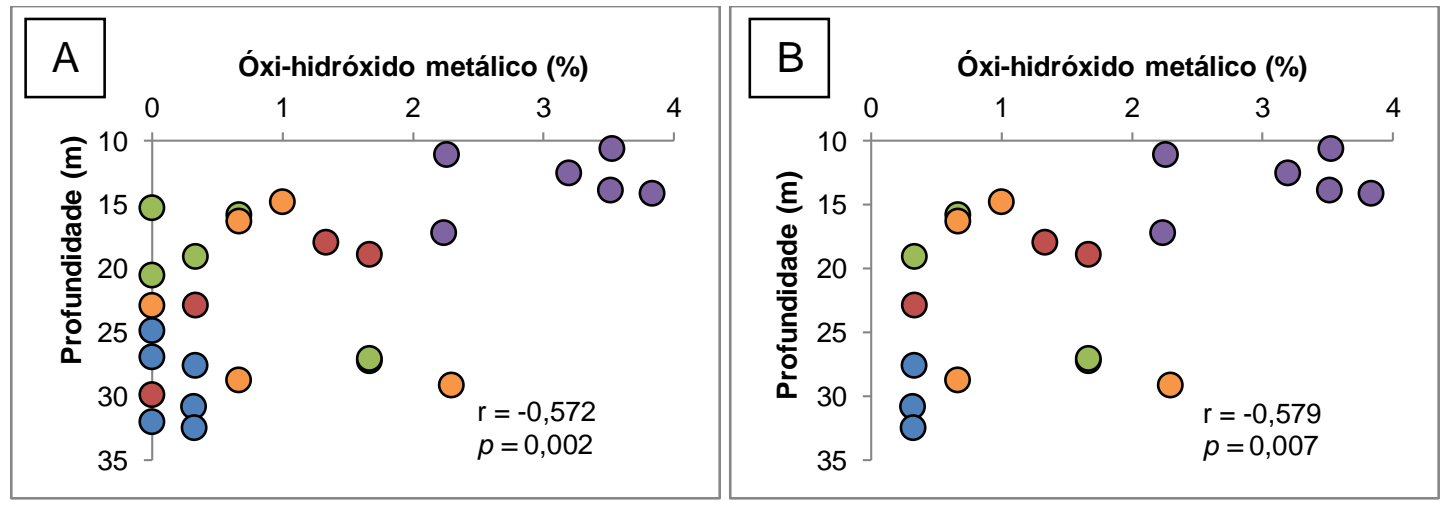

OEfsx OEms OEpa OMfsx OMms

Figura 3.6.40 - Diagramas de dispersão entre profundidade e proporção de cimento constituído por óxi-hidróxido metálico, por petrofácies. No diagrama $B$, suprimem-se os dados referentes às amostras cuja proporção deste tipo de cimento é igual à zero. 
A densidade de empacotamento apresenta correlação linear positiva com a profundidade (Figura 3.6.41 A), bem como a quantidade relativa de arcabouço (Figura 3.6.41 B).

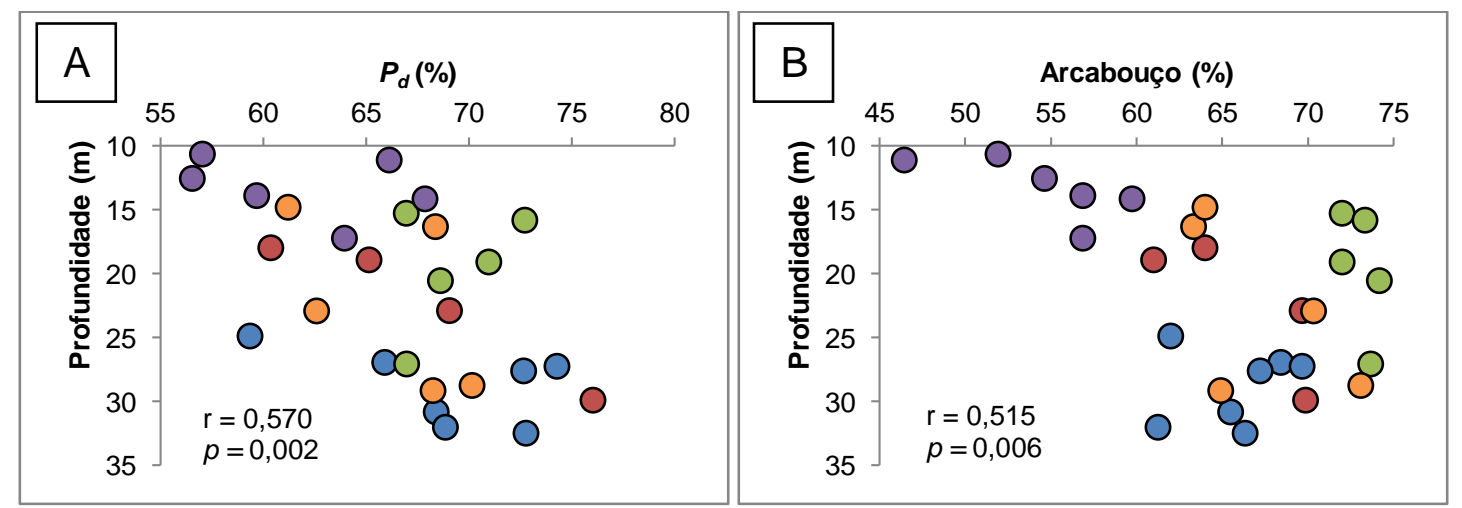

OEfsx OEms OEpa OMfsx OMms

Figura 3.6.41 - Diagramas de dispersão da profundidade com a densidade de empacotamento $P_{d}(\mathrm{~A})$ e com a proporção de arcabouço (B), por petrofácies.

A quantidade de feldspato no total da amostra exibe correlação linear positiva com a profundidade (Figura 3.6.42 A), porém esta correlação deixa de ser significativa se for considerada a proporção do feldspato na fração, isto é, a calculada em relação à somatória das proporções de quartzo, feldspato e fragmentos líticos (Figura 3.6.42 B).

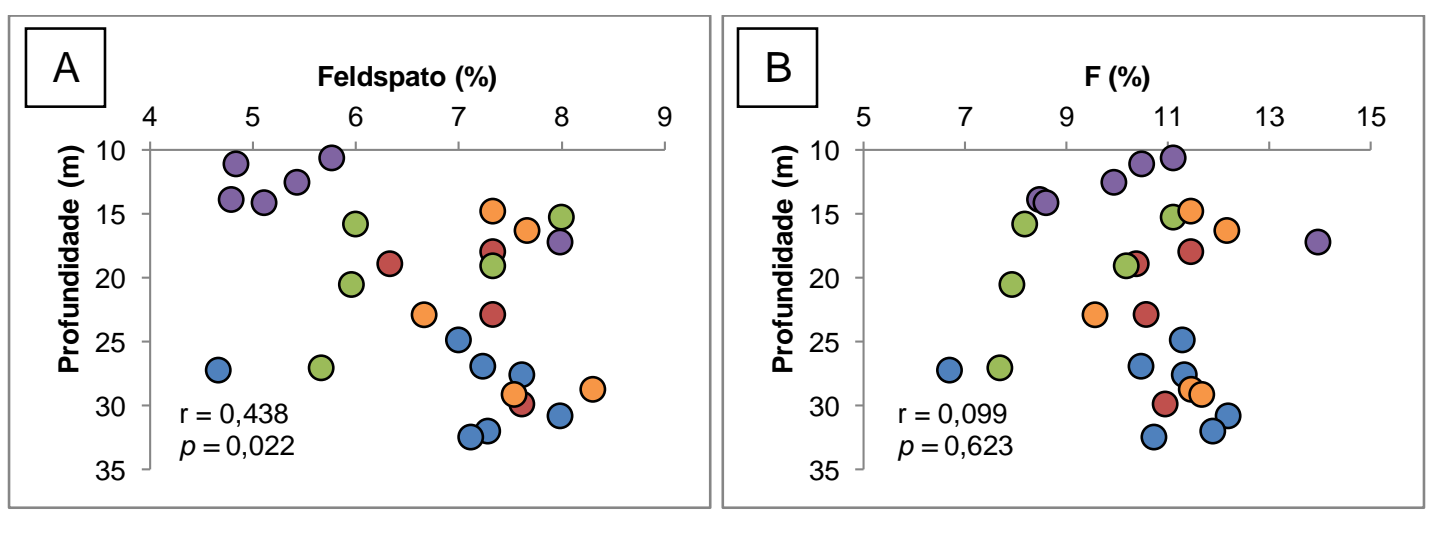

OEfsx OEms OEpa OMfsx OMms

Figura 3.6.42 - Diagramas de dispersão da profundidade com a proporção total de feldspato $(A)$ e calculada em relação à somatória das proporções de quartzo, feldspato e fragmentos líticos (B), por petrofácies.

Encontra-se ainda correlação linear negativa da porosidade intragranular com profundidade, porém não significativa estatisticamente (Figura 3.6.43). 


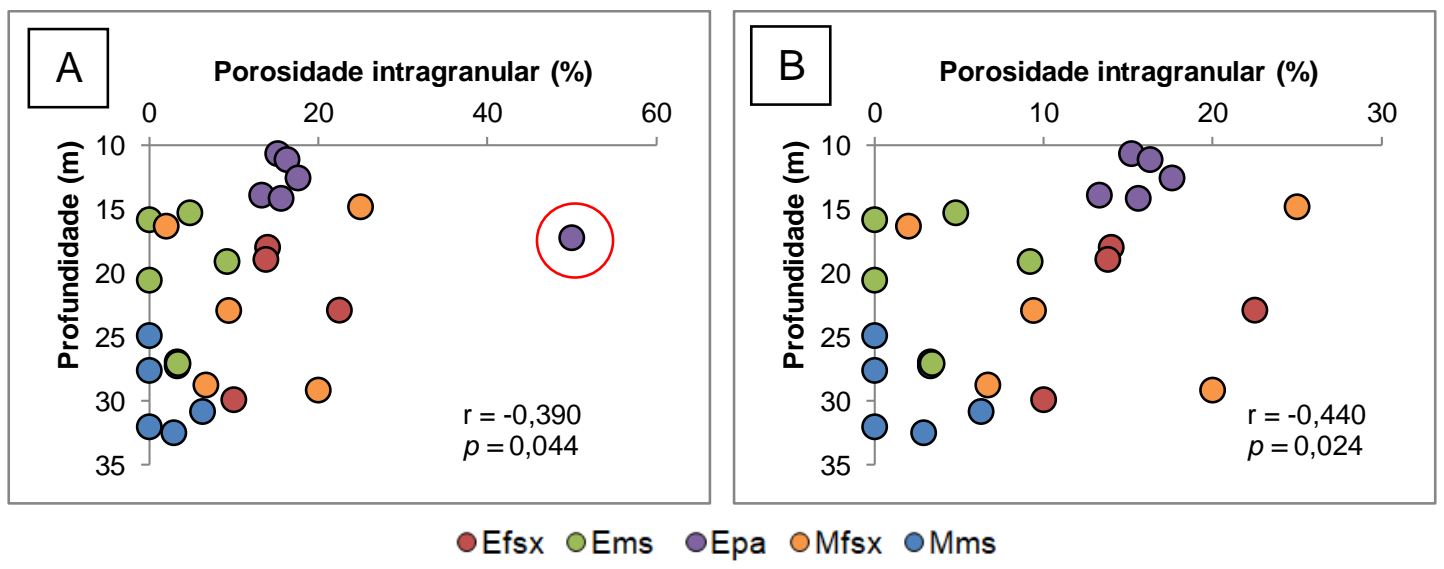

Figura 3.6.43 - Diagramas de dispersão entre proporção de porosidade intragranular e profundidade. No diagrama $B$, suprime-se o dado referente à amostra da cota 448,2 $\mathrm{m}$ da sondagem SM-222 (indicado pelo círculo vermelho nos gráficos superiores), por se tratar de dado discrepante (outlier) em relação aos demais.

\subsubsection{Correlações entre propriedades petrográficas e coerência}

Os intervalos interquartis dos tamanhos médios de grãos do arcabouço das quatro classes de coerência entre $\mathrm{C} 2$ e C3, analisados via petrografia ótica, seguem padrão de engrossamento com o aumento do grau de coerência. Mesmo padrão se observa nas medianas dos tamanhos médios de grãos das classes C3/C2 a C2. Contudo, estes padrões não se repetem com os tamanhos de grão obtidos via analisador de partículas a laser (Figura 3.6.44). Além disso, a ANOVA indica que as diferenças entre o tamanho médio dos grãos por grau de coerência não são significativas.

O desvio padrão das distribuições granulométricas não apresenta relação com o grau de coerência (Figura 3.6.45). 

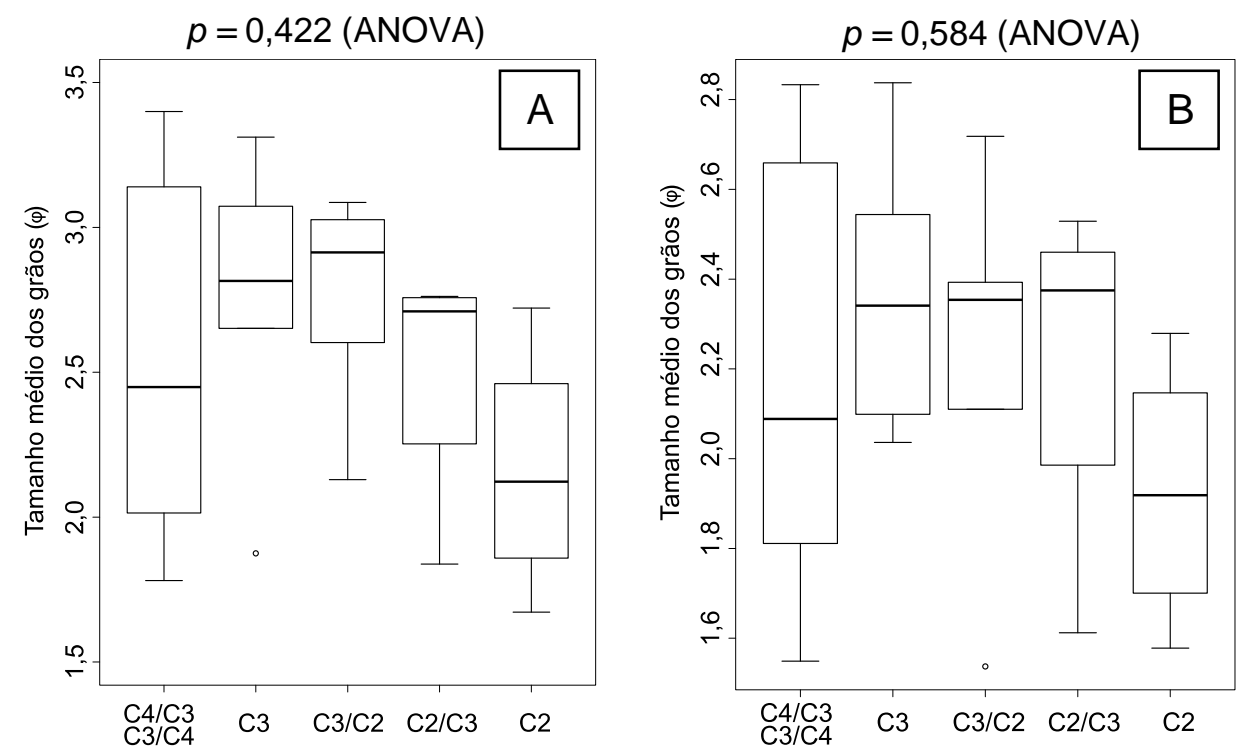

Figura 3.6.44 - Boxplots representando o tamanho médio dos grãos de cada grau de coerência, analisado via petrografia ótica $(\mathrm{A})$ e analisador de partículas Malvern (B). Número de amostras: C4/C3 e C3/C4 = 8; $\mathrm{C} 3=6 ; \mathrm{C} 3 / \mathrm{C} 2=5 ; \mathrm{C} 2 / \mathrm{C} 3=4 ; \mathrm{C} 2=4$.
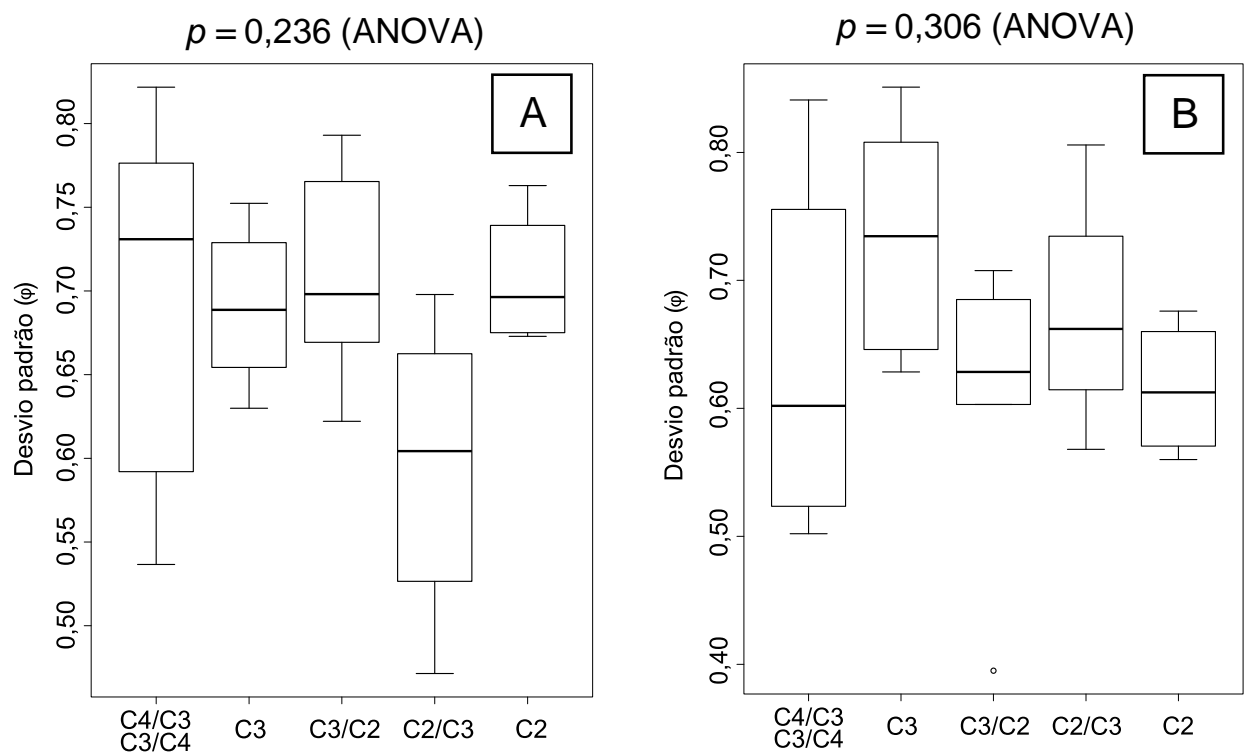

Figura 3.6.45 - Boxplots representando o desvio padrão da distribuição granulométrica para cada grau de coerência, analisado via petrografia ótica $(A)$ e analisador de partículas Malvern (B). Número de amostras: $\mathrm{C} 4 / \mathrm{C} 3$ e $\mathrm{C} 3 / \mathrm{C} 4=8 ; \mathrm{C} 3=6 ; \mathrm{C} 3 / \mathrm{C} 2=5 ; \mathrm{C} 2 / \mathrm{C} 3=4 ; \mathrm{C} 2=4$.

A mediana do teor de pelíticos segue padrão crescente entre as classes de coerência C4/C3 e C2/C3. Já a classe de coerência mais elevada, C2, apresenta mediana menor que as demais (Figura 3.6.46). Contudo, o teste de KW indica que as variações entre os grupos não são significativas. 


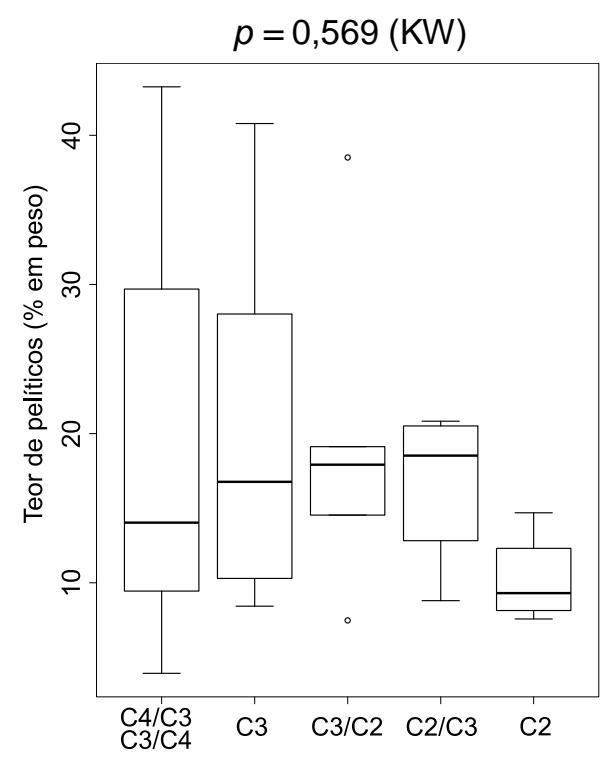

Figura 3.6.46 - Boxplots representando o teor de pelíticos para cada grau de coerência. Número de amostras: $\mathrm{C} 4 / \mathrm{C} 3$ e $\mathrm{C} 3 / \mathrm{C} 4=8 ; \mathrm{C} 3=6 ; \mathrm{C} 3 / \mathrm{C} 2=5 ; \mathrm{C} 2 / \mathrm{C} 3=4 ; \mathrm{C} 2=4$.

Em relação à porosidade, não se observa qualquer padrão que permita relacionar a variação deste parâmetro ao grau de coerência, sendo as medianas entre os diferentes agrupamentos muito próximas entre si, com forte sobreposição de intervalos interquartis entre eles (Figura 3.6.47 A). Da mesma forma, a porosidade intragranular não guarda relação evidente com o grau de coerência (Figura 3.6.47 B). Também não se verificou padrão claro entre graus de coerência e densidade e porosidade aparentes (Figura 3.6.48).
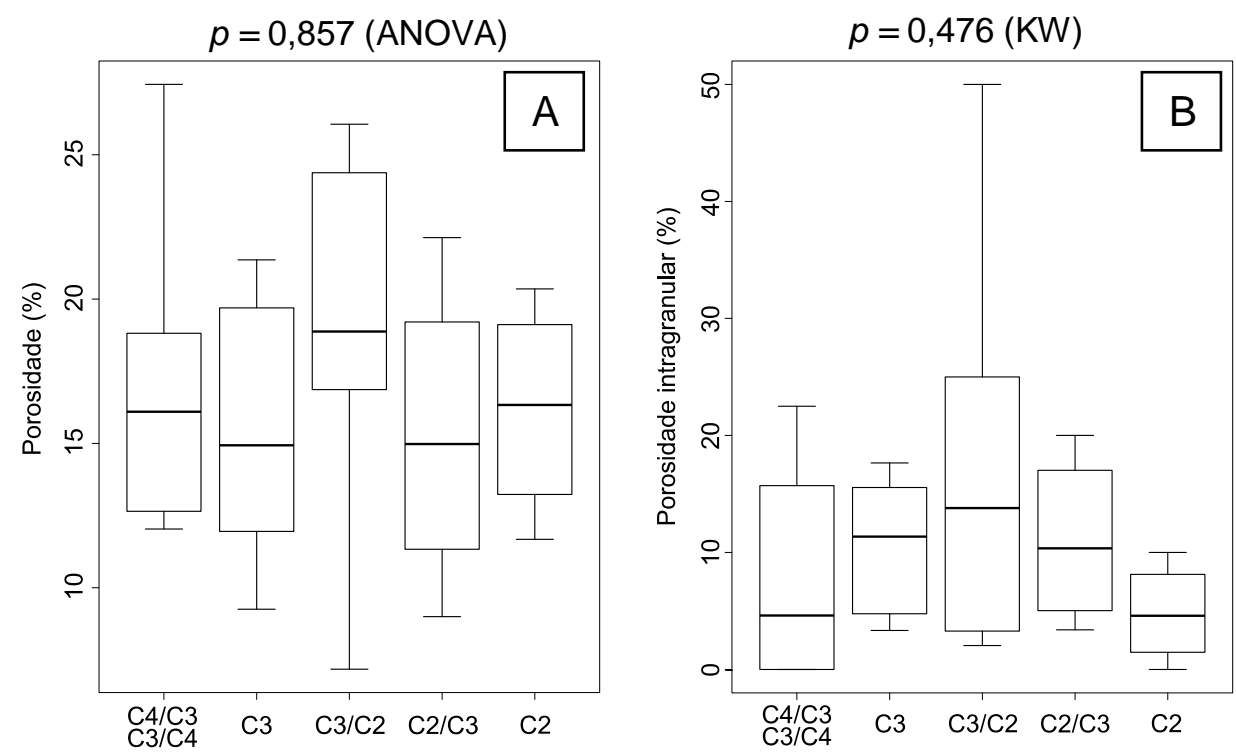

Figura 3.6.47 - Boxplots representando a porosidade total (A), avaliada via software analisador de imagens, e a porosidade intragranular ( $\mathrm{B}$ - proporção na fração), avaliada por meio de análise modal, para os diferentes graus de coerência. Número de amostras: $\mathrm{C} 4 / \mathrm{C} 3$ e C3/C4 = 8; $\mathrm{C} 3=6 ; \mathrm{C} 3 / \mathrm{C} 2=5$; $\mathrm{C} 2 / \mathrm{C} 3=4 ; \mathrm{C} 2=4$. 

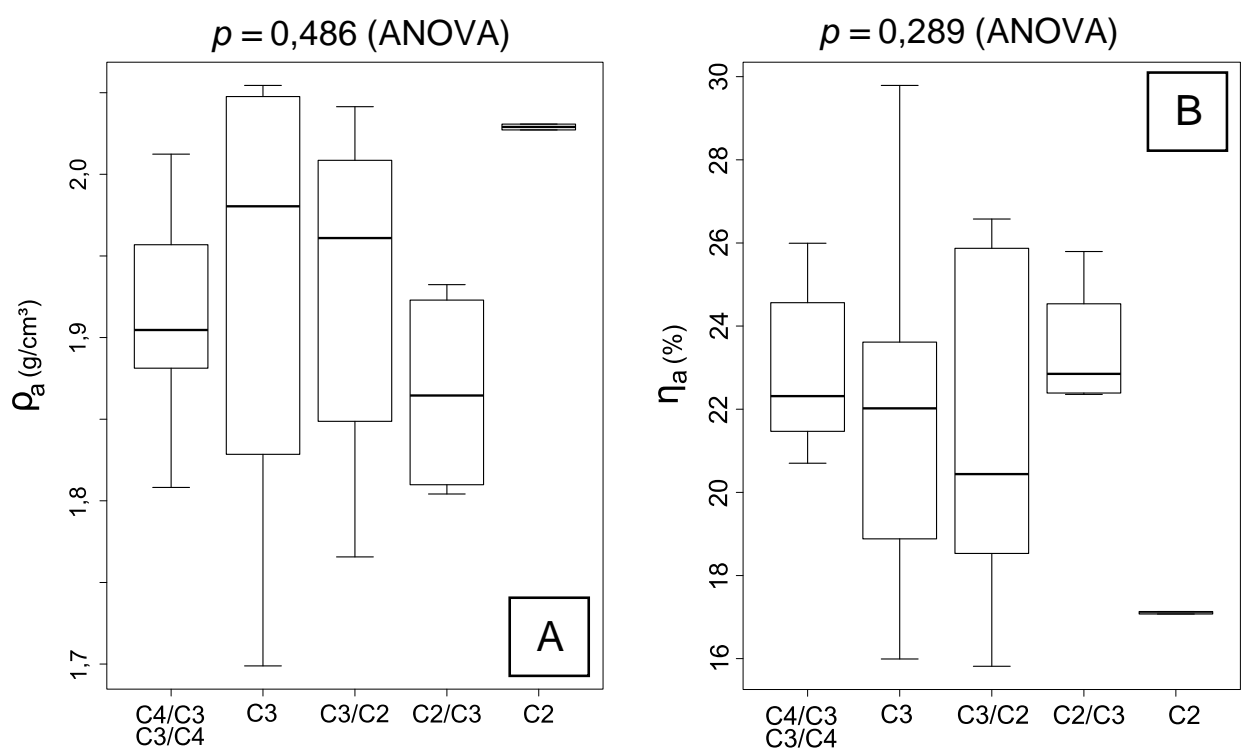

Figura 3.6.48 - Boxplots representando a densidade (A) e porosidade (B) aparentes agrupadas segundo o grau de coerência. Número de amostras: $\mathrm{C} 4 / \mathrm{C} 3$ e C3/C4 = 7; $\mathrm{C} 3=6 ; \mathrm{C} 3 / \mathrm{C} 2=5 ; \mathrm{C} 2 / \mathrm{C} 3=$ $4 ; \mathrm{C} 2=2$.

Apesar dos gráficos box-plot de índices de empacotamento em relação a graus de coerência mostrarem alguma relação entre eles (Figura 3.6.49), os resultados da ANOVA indicam que as variações observadas não são significativas. A mediana das densidades de empacotamento $\left(P_{d}\right)$ apresenta padrão crescente do grau C3 ao C2 (Figura 3.6.49 A). No caso da proximidade de empacotamento $\left(P_{p}\right)$, o grau de coerência mais baixo, $\mathrm{C} 4 / \mathrm{C} 3-\mathrm{C} 3 / \mathrm{C} 4$, possui valor mediano menor em relação aos demais (Figura 3.6.49 B).
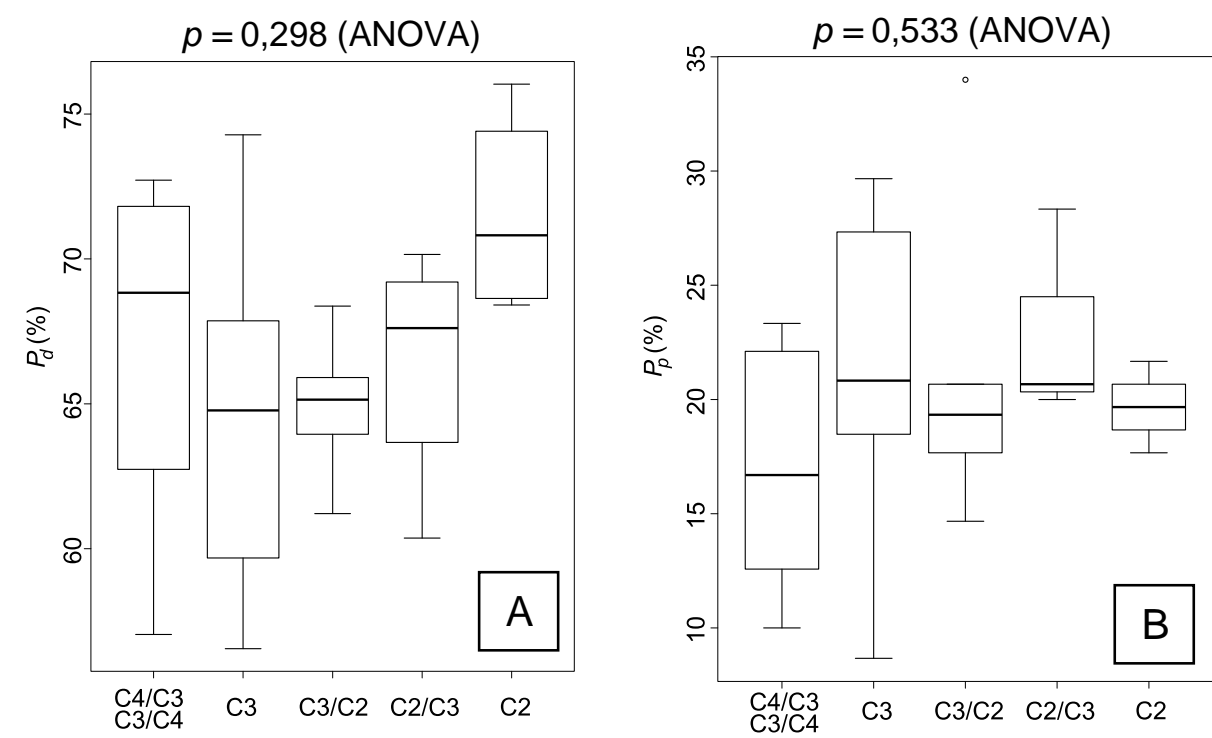

Figura 3.6.49 - Boxplots representando a densidade de empacotamento $\left(P_{d}\right)$ e a proximidade de empacotamento $\left(P_{p}\right)$ em arenitos com diferentes graus de coerência. Número de amostras: C4/C3 e $\mathrm{C} 3 / \mathrm{C} 4=8 ; \mathrm{C} 3=6 ; \mathrm{C} 3 / \mathrm{C} 2=5 ; \mathrm{C} 2 / \mathrm{C} 3=4 ; \mathrm{C} 2=4$. 
Os tipos de contatos intergranulares não apresentam padrão contínuo de variação entre as cinco classes de coerência consideradas (Figura 3.6.50). A proporção de contatos tangenciais apresenta padrão crescente, tanto em termos de intervalo interquartis quanto de valor mediano, se forem considerados separadamente os intervalos entre as classes C4/C3-C3/C4 a C3 e C3/C2 a C2 (Figura 3.6.50 A). Já a proporção de contatos retos mostra padrão crescente de valor mediano entre as classes $\mathrm{C} 4 / \mathrm{C} 3-\mathrm{C} 3 / \mathrm{C} 4$ e $\mathrm{C} 3 / \mathrm{C} 2$ e decrescente entre as classes C3/C2 e C2 (Figura 3.6.50 B). No caso dos contatos côncavo-convexos, pode-se afirmar que as medianas das proporções deste tipo de contato são maiores nos graus de coerência C3/C2 a C2 do que nos graus C4/C3, C3/C4 e C3 (Figura 3.6.50 C). Esta última relação é de certo modo esperada, uma vez admitido que arenitos com mais contatos côncavo-convexos reflitam maior grau de compactação química, o que deve aumentar o grau de coerência. Porém, nenhum dos resultados da ANOVA ou KW permite afirmar que as proporções dos diferentes tipos de contatos intergranulares exerça alguma influência no grau de coerência.
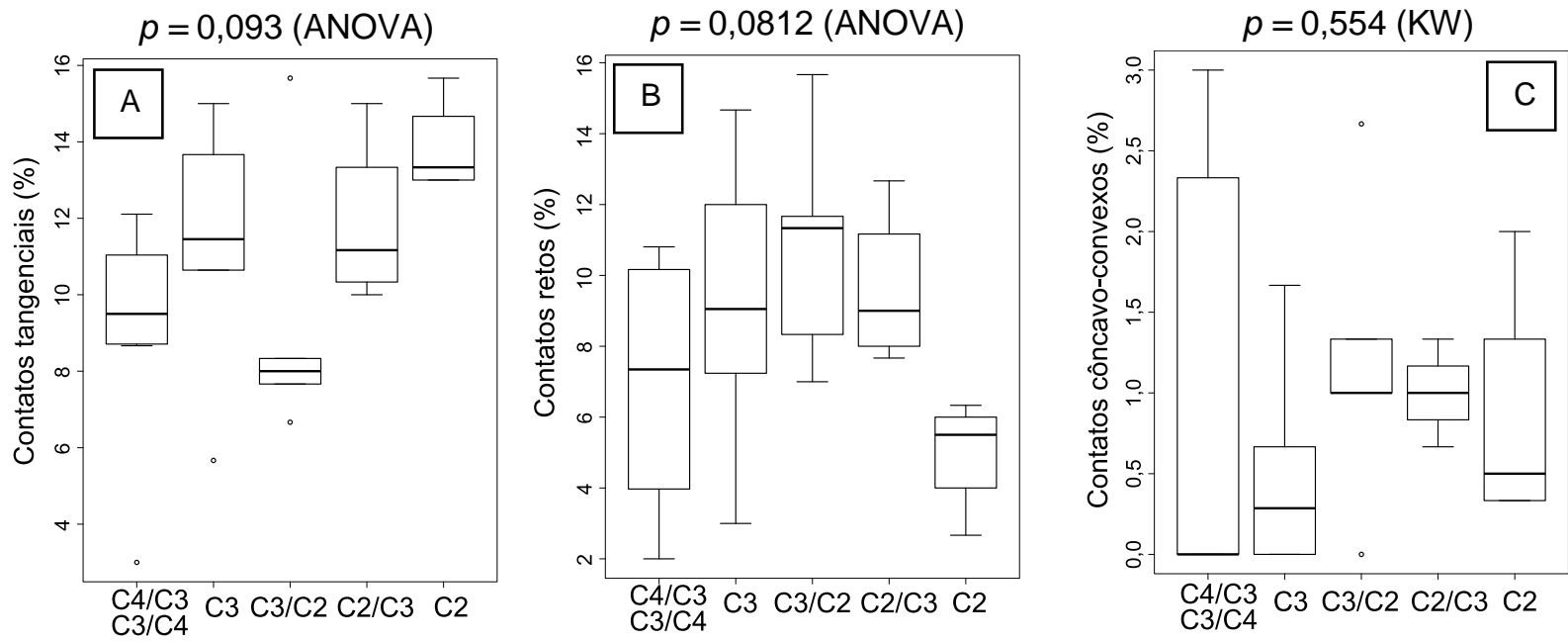

Figura 3.6.50 - Boxplots representando as quantidades relativas dos diferentes tipos de contatos intergranulares em arenitos agrupados por grau de coerência. Número de amostras: $\mathrm{C} 4 / \mathrm{C} 3$ e C3/C4 = $8 ; \mathrm{C} 3=6 ; \mathrm{C} 3 / \mathrm{C} 2=5 ; \mathrm{C} 2 / \mathrm{C} 3=4 ; \mathrm{C} 2=4$.

A proporção de contatos entre grãos do arcabouço e cimento total não mostra nenhum padrão que se relacione ao grau de coerência (Figura 3.6.51 A). Já a de contatos entre grãos do arcabouço e vazios apresenta intervalo interquartis e mediana em valores mais elevados nos arenitos da classe de coerência mais baixa, C4/C3-C3/C4 (Figura 3.6.51 B). Porém, estes resultados não são suportados pela 
ANOVA, de modo que, estatisticamente, não há indicação de que as porcentagens de contatos grão-vazio exerçam influência na coerência.
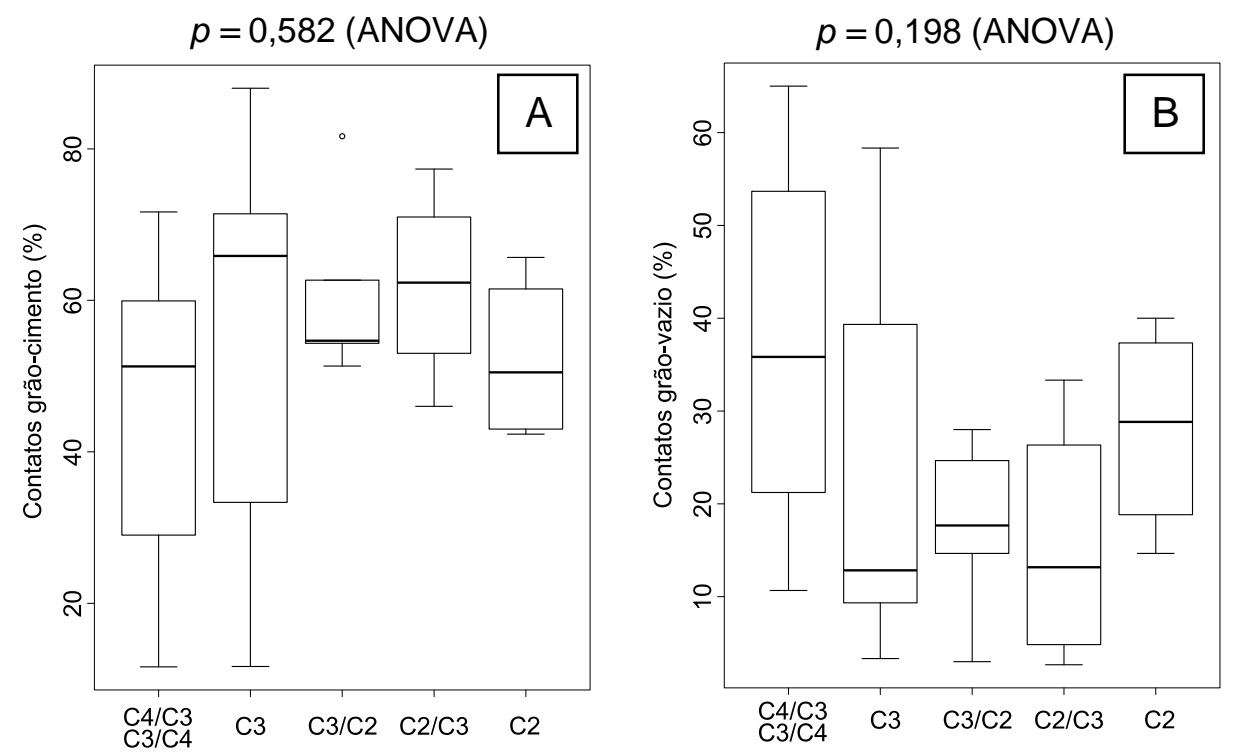

Figura 3.6.51 - Boxplots representando as proporções dos contatos entre grãos do arcabouço e cimentos (A) e entre grãos do arcabouço e vazios (B) por grau de coerência. Número de amostras: $\mathrm{C} 4 / \mathrm{C} 3$ e $\mathrm{C} 3 / \mathrm{C} 4=8 ; \mathrm{C} 3=6 ; \mathrm{C} 3 / \mathrm{C} 2=5 ; \mathrm{C} 2 / \mathrm{C} 3=4 ; \mathrm{C} 2=4$.

Em relação à forma dos grãos, a ANOVA e o KW não indicam haver influência deste parâmetro sobre a coerência, mas nota-se que a mediana das proporções de grãos subangulares apresenta padrão decrescente com o aumento do grau de coerência, de C3/C2 a C2 (Figura 3.6.52 A). A mediana das quantidades relativas de grãos subarredondados e arredondados, por sua vez, apresenta padrão crescente dentro deste mesmo intervalo de grau de coerência (Figuras 3.6.52 B e 3.6.52 C). A variação da média das razões entre os eixos menor e maior dos grãos do arcabouço não é significativa para diferenciar de maneira sensível os diferentes graus de coerência. Porém, nota-se padrão decrescente desta razão com o aumento do grau de coerência entre C4/C3 C3/C4 e C3/C2 (Figura 3.6.53). O resultado da ANOVA indica diferença significativa entre pelo menos dois graus de coerência, mas o teste de comparações múltiplas de Tukey (Tabela 3.6.1) não apresenta nenhum valor $p$ menor do que 0,05 . A análise de variância com valor $p$ menor se dá entre os graus $\mathrm{C} 2 / \mathrm{C} 3$ e C3/C2. 

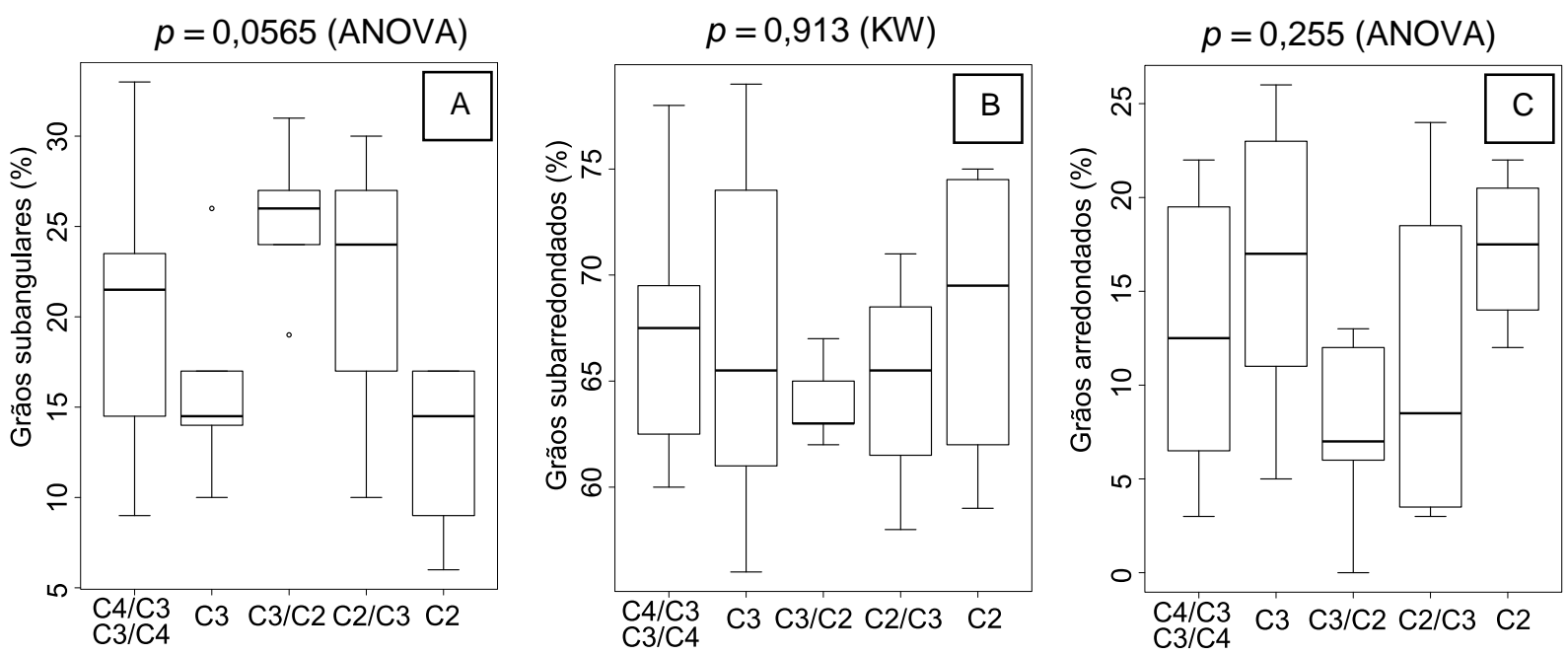

Figura 3.6.52 - Boxplots representando as proporções de grãos subangulares (A), subarredondados (B) e arredondados (C) em arenitos agrupados de acordo com o grau de coerência. Número de amostras: $\mathrm{C} 4 / \mathrm{C} 3$ e $\mathrm{C} 3 / \mathrm{C} 4=8 ; \mathrm{C} 3=6 ; \mathrm{C} 3 / \mathrm{C} 2=5 ; \mathrm{C} 2 / \mathrm{C} 3=4 ; \mathrm{C} 2=4$.

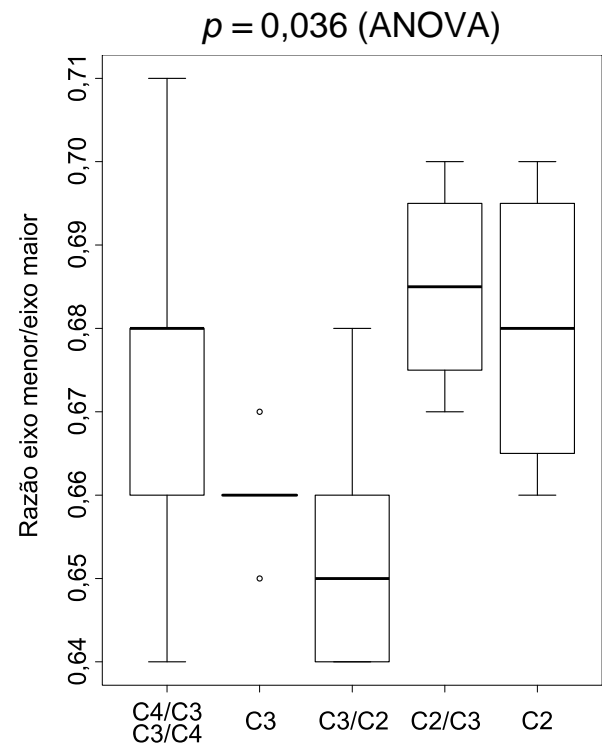

Figura 3.6.53 - Boxplots representando os valores médios das razões entre os eixos menor e maior dos arenitos com diferentes graus de coerência. Número de amostras: C4/C3 e C3/C4 = 8; C3 = 6; $\mathrm{C} 3 / \mathrm{C} 2=5 ; \mathrm{C} 2 / \mathrm{C} 3=4 ; \mathrm{C} 2=4$.

Tabela 3.6.1 - Teste de comparações múltiplas de Tukey para a razão entre os eixos menor e maior dos grãos, por grau de coerência.

\begin{tabular}{cccccc}
\hline Comparação & Diferença & \multicolumn{1}{c}{ I.C. 95\% } & $\boldsymbol{p}$ \\
\hline C3 vs C4/C3 e C3/C4 & $-0,01$ & $-0,04$ & $:$ & 0,01 & 0,533 \\
C3/C2 vs C4/C3 e C3/C4 & $-0,02$ & $-0,05$ & $:$ & 0,01 & 0,242 \\
C2/C3 vs C4/C3 e C3/C4 & 0,01 & $-0,02$ & $:$ & 0,04 & 0,789 \\
C2 vs C4/C3 e C3/C4 & 0,01 & $-0,02$ & $:$ & 0,04 & 0,969 \\
C3/C2 vs C3 & $-0,01$ & $-0,04$ & $:$ & 0,02 & 0,972 \\
C2/C3 vs C3 & 0,03 & $-0,01$ & $:$ & 0,06 & 0,157 \\
C2 vs C3 & 0,02 & $-0,01$ & $:$ & 0,05 & 0,343 \\
C2/C3 vs C3/C2 & 0,03 & 0,00 & $:$ & 0,06 & 0,064 \\
C2 vs C3/C2 & 0,03 & $-0,01$ & $:$ & 0,06 & 0,157 \\
C2 vs C2/C3 & $-0,01$ & $-0,04$ & $:$ & 0,03 & 0,992 \\
\hline
\end{tabular}


A proporção do arcabouço em relação aos demais componentes não apresenta relação direta com o grau de coerência, e os resultados da ANOVA indicam que as variações destes parâmetros entre os graus de coerência não são significativas. A mediana desta proporção diminui com o aumento do grau de coerência, dos graus $\mathrm{C} 4 / \mathrm{C} 3$ e C3/C4 ao grau C3/C2 e do grau C2/C3 ao grau C2 (Figura 3.6.54 A). Já a proporção de cimento total mostra padrão decrescente dentre os graus C3 e C2, com medianas cada vez menores à medida que aumenta a coerência (Figura 3.6.54 B).
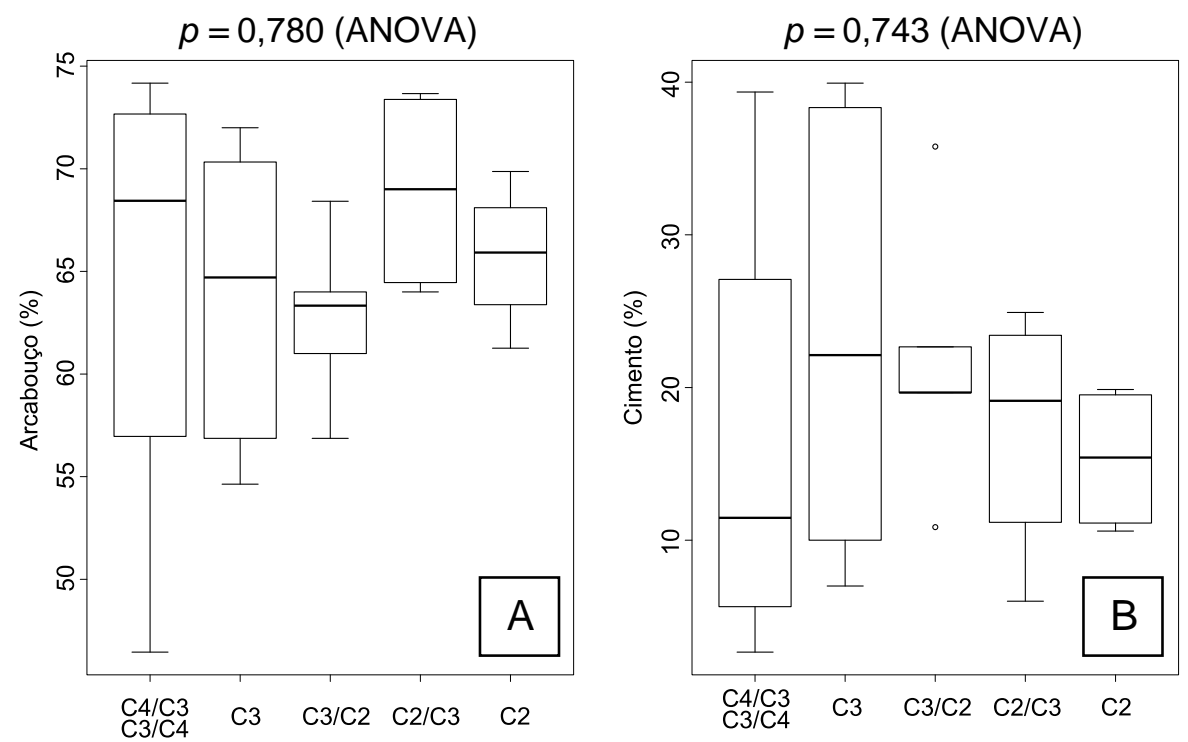

Figura 3.6.54 - Boxplots representando as proporções de grãos do arcabouço (A) e de cimento (B) nos arenitos com diferentes graus de coerência. Número de amostras: C4/C3 e C3/C4 = 8; C3 =6; $\mathrm{C} 3 / \mathrm{C} 2=5 ; \mathrm{C} 2 / \mathrm{C} 3=4 ; \mathrm{C} 2=4$.

A proporção de grãos de feldspato geralmente é maior em arenitos com graus de coerência C3/C2 a C2 (Figura 3.6.55), o que é suportado também pela ANOVA e pelos testes de comparações múltiplas de Tukey (Tabela 3.6.2). 

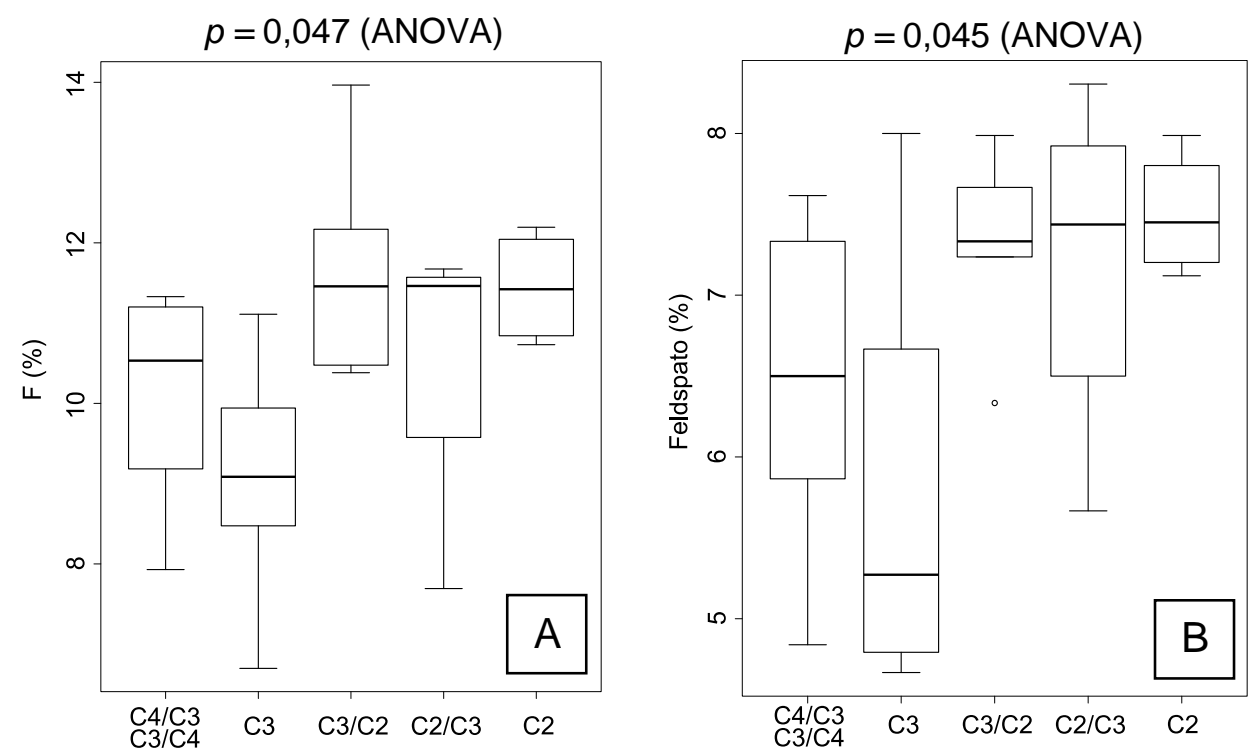

Figura 3.6.55 - Boxplots representando as proporções de feldspato, na fração (em relação à somatória entre grãos de quartzo, feldspato e fragmentos líticos) (A) e no total (B), nos arenitos com diferentes graus de coerência. Número de amostras: $\mathrm{C} 4 / \mathrm{C} 3$ e C3/C4 = 8; $\mathrm{C} 3=6$; $\mathrm{C} 3 / \mathrm{C} 2=5 ; \mathrm{C} 2 / \mathrm{C} 3=$ $4 ; \mathrm{C} 2=4$.

Tabela 3.6.2 - Teste de comparações múltiplas de Tukey para as proporções de feldspato no total e na fração QFL, por grau de coerência.

\begin{tabular}{|c|c|c|c|c|c|c|}
\hline & Comparação & Diferença & \multicolumn{3}{|c|}{ I.C. $95 \%$} & $p$ \\
\hline \multirow{10}{*}{ Feldspato (\%) } & C3 vs C4/C3 e C3/C4 & $-0,70$ & $-2,27$ & : & 0,86 & 0,673 \\
\hline & $\mathrm{C} 3 / \mathrm{C} 2$ vs $\mathrm{C} 4 / \mathrm{C} 3$ e $\mathrm{C} 3 / \mathrm{C} 4$ & 0,83 & $-0,82$ & : & 2,48 & 0,577 \\
\hline & $\mathrm{C} 2 / \mathrm{C} 3$ vs $\mathrm{C} 4 / \mathrm{C} 3$ e $\mathrm{C} 3 / \mathrm{C} 4$ & 0,73 & $-1,04$ & : & 2,50 & 0,738 \\
\hline & C2 vs C4/C3 e C3/C4 & 1,02 & $-0,75$ & : & 2,79 & 0,449 \\
\hline & C3/C2 vs C3 & 1,53 & $-0,22$ & : & 3,28 & 0,105 \\
\hline & $\mathrm{C} 2 / \mathrm{C} 3$ vs $\mathrm{C} 3$ & 1,43 & $-0,43$ & : & 3,30 & 0,190 \\
\hline & C2 vs C3 & 1,72 & $-0,14$ & : & 3,59 & 0,080 \\
\hline & $\mathrm{C} 2 / \mathrm{C} 3$ vs $\mathrm{C} 3 / \mathrm{C} 2$ & $-0,10$ & $-2,04$ & : & 1,84 & 1,000 \\
\hline & C2 vs C3/C2 & 0,19 & $-1,75$ & : & 2,13 & 0,998 \\
\hline & $\mathrm{C} 2$ vs $\mathrm{C} 2 / \mathrm{C} 3$ & 0,29 & $-1,76$ & : & 2,34 & 0,993 \\
\hline \multirow{10}{*}{$\mathbf{F}(\%)$} & C3 vs C4/C3 e C3/C4 & $-1,07$ & $-3,37$ & : & 1,23 & 0,646 \\
\hline & $\mathrm{C} 3 / \mathrm{C} 2$ vs $\mathrm{C} 4 / \mathrm{C} 3$ e $\mathrm{C} 3 / \mathrm{C} 4$ & 1,55 & $-0,87$ & : & 3,98 & 0,347 \\
\hline & $\mathrm{C} 2 / \mathrm{C} 3$ vs $\mathrm{C} 4 / \mathrm{C} 3$ e $\mathrm{C} 3 / \mathrm{C} 4$ & 0,44 & $-2,17$ & : & 3,05 & 0,987 \\
\hline & C2 vs C4/C3 e C3/C4 & 1,31 & $-1,30$ & : & 3,91 & 0,582 \\
\hline & C3/C2 vs C3 & 2,62 & 0,04 & : & 5,20 & 0,045 \\
\hline & C2/C3 vs C3 & 1,51 & $-1,24$ & : & 4,26 & 0,497 \\
\hline & C2 vs C3 & 2,38 & $-0,37$ & : & 5,13 & 0,112 \\
\hline & $\mathrm{C} 2 / \mathrm{C} 3$ vs C3/C2 & $-1,12$ & $-3,97$ & : & 1,74 & 0,773 \\
\hline & C2 vs C3/C2 & $-0,25$ & $-3,11$ & : & 2,61 & 0,999 \\
\hline & $\mathrm{C} 2$ vs $\mathrm{C} 2 / \mathrm{C} 3$ & 0,87 & $-2,14$ & : & 3,88 & 0,910 \\
\hline
\end{tabular}

Do mesmo modo, não há correlação persistente e suportada pela ANOVA entre as proporções de esmectita ou de óxi-hidróxido metálico e os diferentes graus de coerência. A proporção de esmectita é geralmente maior nas três classes de graus de coerência mais altos: $\mathrm{C} 3 / \mathrm{C} 2, \mathrm{C} 2 / \mathrm{C} 3$ e C2 (Figura 3.6.56 A). Já com relação 
à proporção de cimento constituído por óxi-hidróxido metálico, intervalo interquatis mais amplo e mediana mais elevada encontram-se nos arenitos com grau de coerência C3, e intervalo interquartis mais restrito e mediana mais baixa, nos arenitos com coerência C2 (Figura 3.6.56 B).
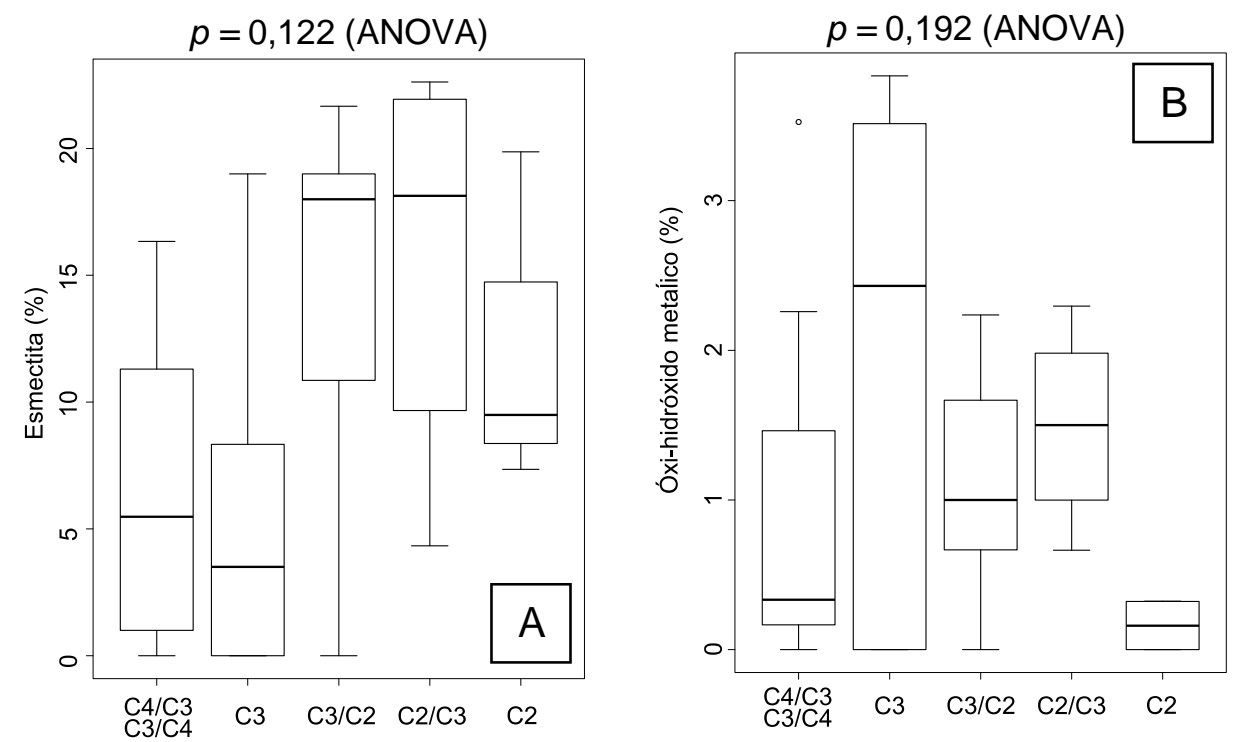

Figura 3.6.56 - Boxplots representando as proporções de cimentos constituídos por esmectita (A) e óxi-hidróxido metálico (B) nos diferentes graus de coerência. Número de amostras: $\mathrm{C} 4 / \mathrm{C} 3$ e C3/C4 = $8 ; \mathrm{C} 3=6 ; \mathrm{C} 3 / \mathrm{C} 2=5 ; \mathrm{C} 2 / \mathrm{C} 3=4 ; \mathrm{C} 2=4$.

Os arenitos de graus de coerência C3, C3/C4 e C4/C3 são, preferencialmente, estratificados, ao passo que arenitos com grau de coerência C2 são, em geral, maciços ou apresentam estratificação incipiente, indicando que pode existir correlação inversa entre a presença de estratificação e o grau de coerência (Figura 3.6.57). 


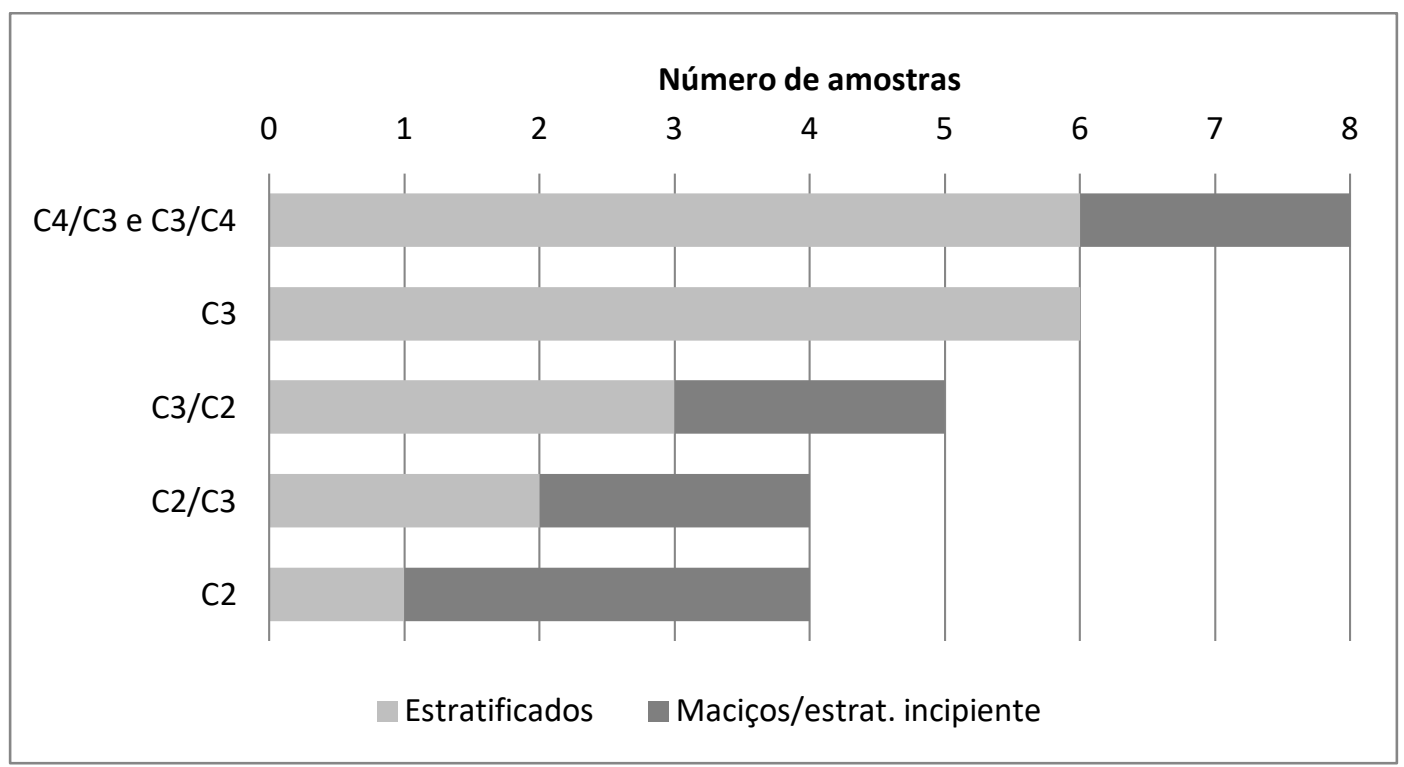

Figura 3.6.57 - Número de amostras estratificadas ou com estrutura maciça/estratificação incipiente, agrupadas por grau de coerência.

A ANOVA aponta diferenças significativas na distribuição das petrofácies em profundidade (Figura 3.6.58). Analisando o grau de coerência da perspectiva petrofaciológica, é possível afirmar que as petrofácies Mfsx e Mms, ambas maciças ou com estratificação incipiente, apresentam a maior proporção de amostras com graus de coerência mais elevados, C3/C2, C2/C2 e C2, enquanto as petrofácies Ems e Epa apresentam o maior número de amostras menos coerentes, C3, C3/C4 e C4/C3. Esta característica também se associa à profundidade de ocorrência destas petrofácies: Mfsx e Mms apresentam intervalos interquartis em profundidades maiores que $15 \mathrm{~m}$ e mediana acima de $21 \mathrm{~m}$, ao passo que as petrofácies Ems e Epa mostram mediana e intervalos interquartis menores do que $21 \mathrm{~m}$ (Figura 3.6.59). $\mathrm{O}$ teste de Tukey aponta que as diferenças de profundidade significativas se dão nas seguintes comparações entre petrofácies: Mms vs Epa, Mms vs Ems, Mfsx vs Epa e Epa vs Efsx (Tabela 3.6.3). 


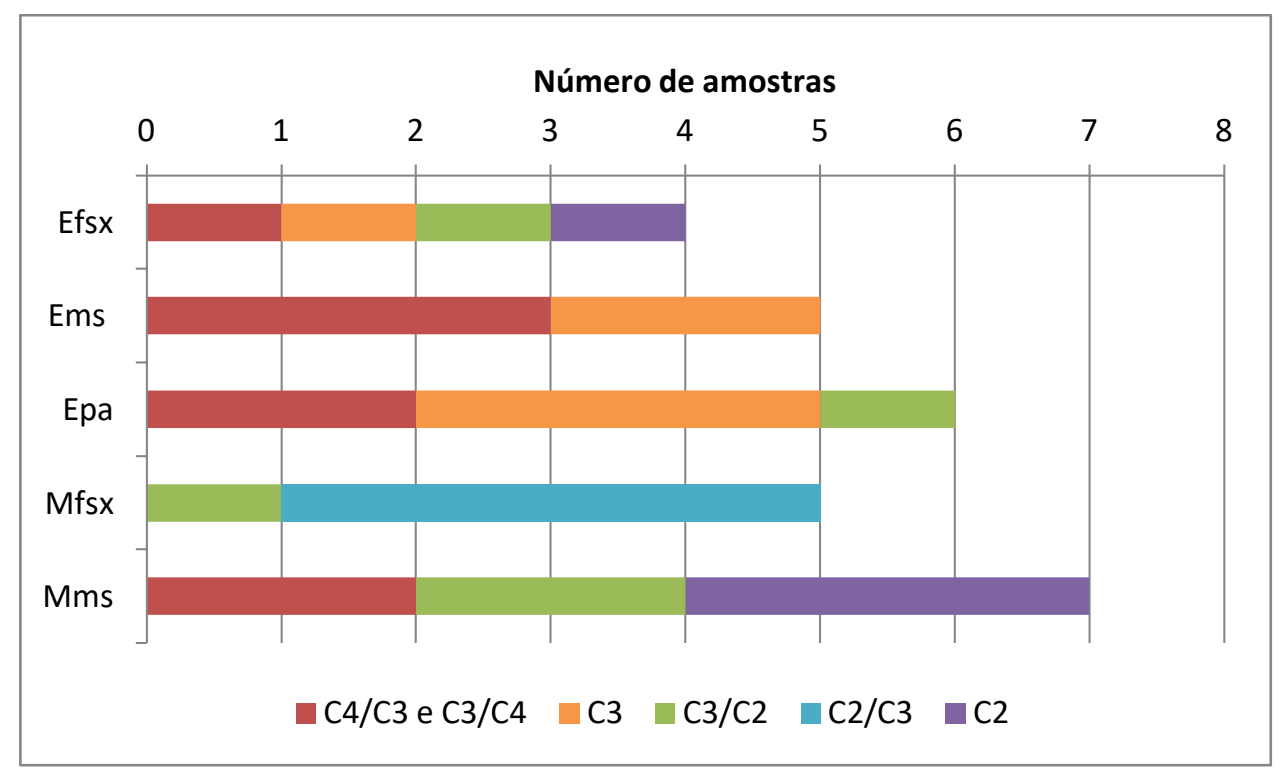

Figura 3.6.58 - Número de amostras com diferentes graus de coerência, agrupadas por petrofácies.

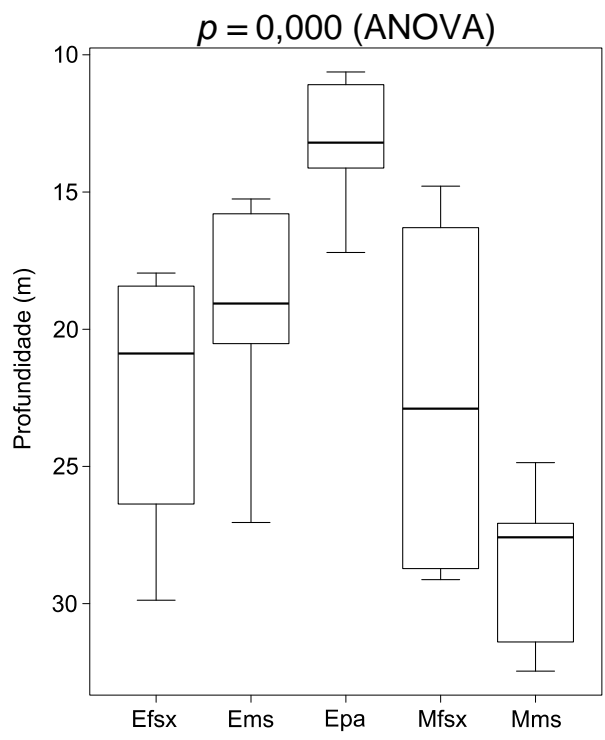

Figura 3.6.59 - Boxplots representando as profundidades de ocorrência das diferentes petrofácies. Número de amostras: Efsx = 4; Ems $=5 ; \mathrm{Epa}=6 ; \mathrm{Mfsx}=5 ; \mathrm{Mms}=7$.

Tabela 3.6.3 - Teste de comparações múltiplas de Tukey para a profundidade das diferentes petrofácies.

\begin{tabular}{cccccc}
\hline Comparação & Diferença & \multicolumn{3}{c}{ I.C. $\mathbf{9 5 \%}$} & $\boldsymbol{p}$ \\
\hline Ems-Efsx & $-2,86$ & $-11,75$ & $:$ & 6,02 & 0,871 \\
Epa-Efsx & $-9,16$ & $-17,71$ & $:$ & $-0,61$ & $\mathbf{0 , 0 3 2}$ \\
Mfsx-Efsx & $-0,03$ & $-8,92$ & $:$ & 8,85 & 1,000 \\
Mms-Efsx & 6,44 & $-1,86$ & $:$ & 14,73 & 0,182 \\
Epa-Ems & $-6,30$ & $-14,31$ & $:$ & 1,72 & 0,173 \\
Mfsx-Ems & 2,83 & $-5,55$ & $:$ & 11,20 & 0,851 \\
Mms-Ems & 9,30 & 1,54 & $:$ & 17,05 & $\mathbf{0 , 0 1 4}$ \\
Mfsx-Epa & 9,12 & 1,11 & $:$ & 17,14 & $\mathbf{0 , 0 2 1}$ \\
Mms-Epa & 15,59 & 8,23 & $:$ & 22,96 & $\mathbf{0 , 0 0 0}$ \\
Mms-Mfsx & 6,47 & $-1,28$ & $:$ & 14,22 & 0,133 \\
\hline
\end{tabular}


Como esperado e observado na descrição dos arenitos ao longo da sondagem SM-222, o grau de coerência é geralmente maior em maiores profundidades, observação suportada pela ANOVA. Porém, são encontrados graus de coerência baixos em diversos trechos da coluna sedimentar, e, desse modo, a mediana das profundidades da classe de graus de coerência mais baixos, C4/C3C3/C4, não segue o padrão observado nos demais graus de coerência (Figura 3.6.60). O teste de Tukey mostra que as maiores diferenças de profundidade encontram-se entre o grau C2 e os graus C3/C2, C3 e C4/C3-C3/C4 (Tabela 3.6.4).

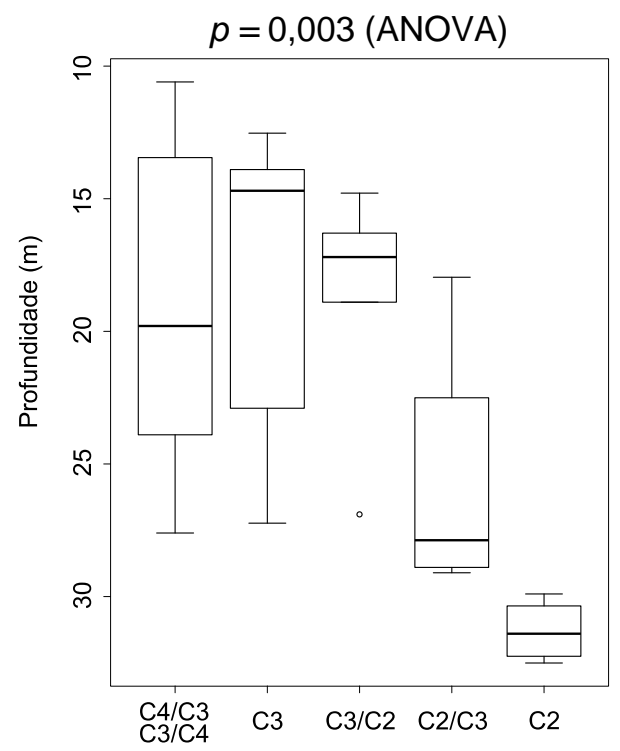

Figura 3.6.60 - Boxplots representando a relação entre os diferentes graus de coerência e a profundidade. Notar que os graus de coerência crescentes, C3, C3/C2, C2/C3 e C2, apresentam valores medianos de profundidade progressivamente maiores. A classe de graus de coerência mais baixos, C4/C3-C3/C4, no entanto, não se encaixa no padrão observado. Isto ocorre, porque estas coerências baixas, apesar de serem as dominantes em profundidades mais rasas, muitas vezes se apresentam intercaladas a coerências maiores em porções mais profundas do testemunho. Número de amostras: $\mathrm{C} 4 / \mathrm{C} 3$ e $\mathrm{C} 3 / \mathrm{C} 4=8 ; \mathrm{C} 3=6 ; \mathrm{C} 3 / \mathrm{C} 2=5 ; \mathrm{C} 2 / \mathrm{C} 3=4 ; \mathrm{C} 2=4$.

Tabela 3.6.4 - Teste de comparações múltiplas de Tukey para a profundidade, por grau de coerência.

\begin{tabular}{cccccc}
\hline Comparação & Diferença & \multicolumn{3}{c}{ I.C. 95\% } & $\boldsymbol{p}$ \\
\hline C3 vs C4/C3 e C3/C4 & $-1,40$ & $-9,93$ & $:$ & 7,13 & 0,988 \\
C3/C2 vs C4/C3 e C3/C4 & $-0,23$ & $-9,24$ & $:$ & 8,78 & 1,000 \\
C2/C3 vs C4/C3 e C3/C4 & 6,66 & $-3,01$ & $:$ & 16,34 & 0,280 \\
C2 vs C4/C3 e C3/C4 & 12,23 & 2,56 & $:$ & 21,91 & $\mathbf{0 , 0 0 9}$ \\
C3/C2 vs C3 & 1,17 & $-8,40$ & $:$ & 10,74 & 0,996 \\
C2/C3 vs C3 & 8,06 & $-2,14$ & $:$ & 18,26 & 0,168 \\
C2 vs C3 & 13,63 & 3,43 & $:$ & 23,83 & $\mathbf{0 , 0 0 5}$ \\
C2/C3 vs C3/C2 & 6,89 & $-3,71$ & $:$ & 17,49 & 0,332 \\
C2 vs C3/C2 & 12,46 & 1,86 & $:$ & 23,06 & $\mathbf{0 , 0 1 6}$ \\
C2 vs C2/C3 & 5,57 & $-5,60$ & $:$ & 16,74 & 0,586 \\
\hline
\end{tabular}




\subsubsection{Correlações entre propriedades petrográficas e resistência à compressão uniaxial}

Quando consideradas as medianas de $\sigma_{50}$ por associação petrofácies/sondagem, não se verificam correlações deste parâmetro com tamanho médio dos grãos e desvio padrão obtidos por análise petrográfica (Figura 3.6.61A e B), nem com os obtidos pelo granulômetro de difração de laser, estes também expressos em valores medianos (Figura 3.6.61C e D).
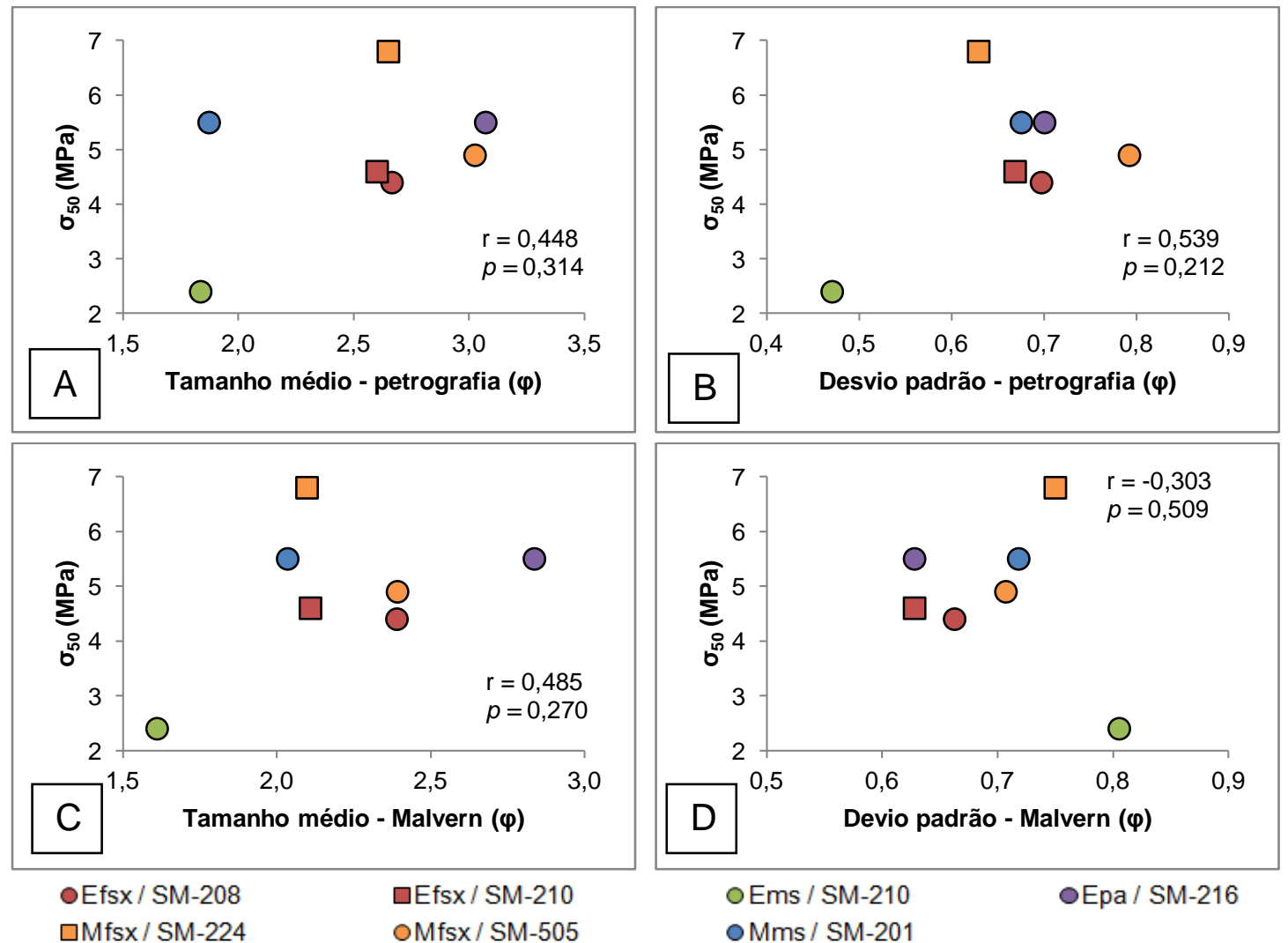

-Efsx / SM-208

口Efsx / SM-210

口Mfsx / SM-224

OMfsx / SM-505

o Mms / SM-201

Figura 3.6.61 - Diagramas de dispersão de valores medianos de $\sigma_{50}$ versus tamanho médio dos grãos e desvio padrão obtidos por análise ao microscópio óptico (A e B) e difratômetro a laser ( $\mathrm{C}$ e D), por petrofácies/sondagem.

Já para todos os corpos de prova considerados individualmente, existe correlação linear significativa entre o tamanho médio dos grãos na fração areia obtido no granulômetro a laser e $\sigma_{50}$, de maneira que arenitos com menor tamanho médio de grão tendem a apresentar maior resistência (Figura 3.6.62). Teor de pelíticos e desvio padrão também se correlacionam, positivamente, à resistência à compressão, porém esta correlação não é estatisticamente significativa (Figuras 3.6 .63 e 3.6.64). 


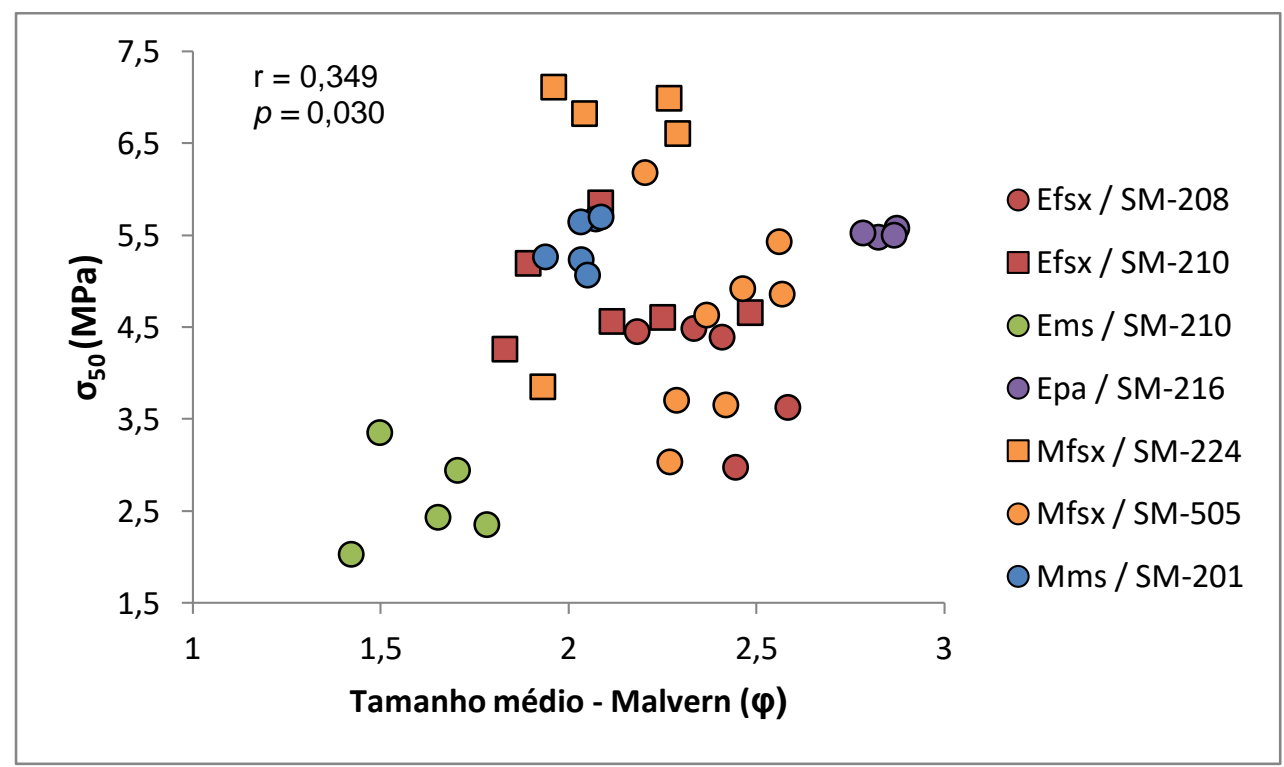

Figura 3.6.62 - Diagrama de dispersão de $\sigma_{50}$ versus tamanho médio dos grãos, para cada corpo de prova (petrofácies/sondagem).

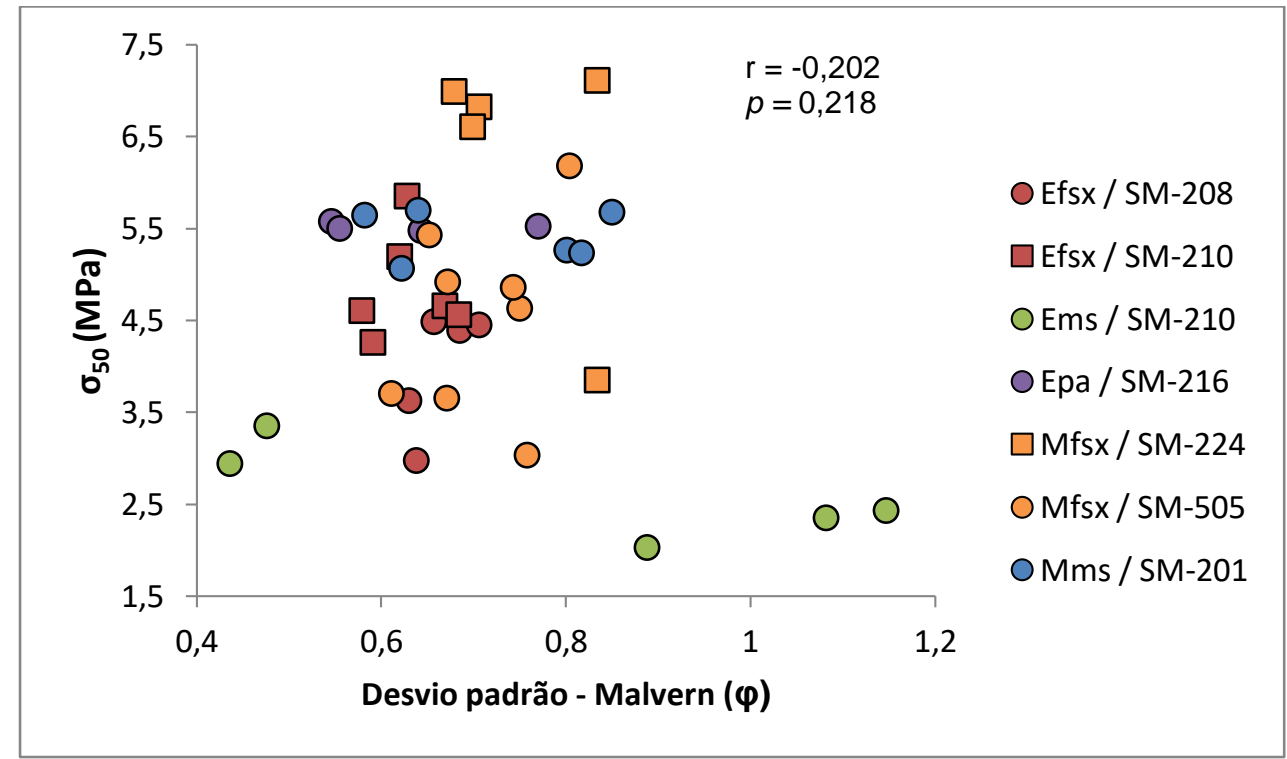

Figura 3.6.63 - Diagrama de dispersão de $\sigma_{50}$ versus desvio padrão, para cada corpo de prova (petrofácies/sondagem). 


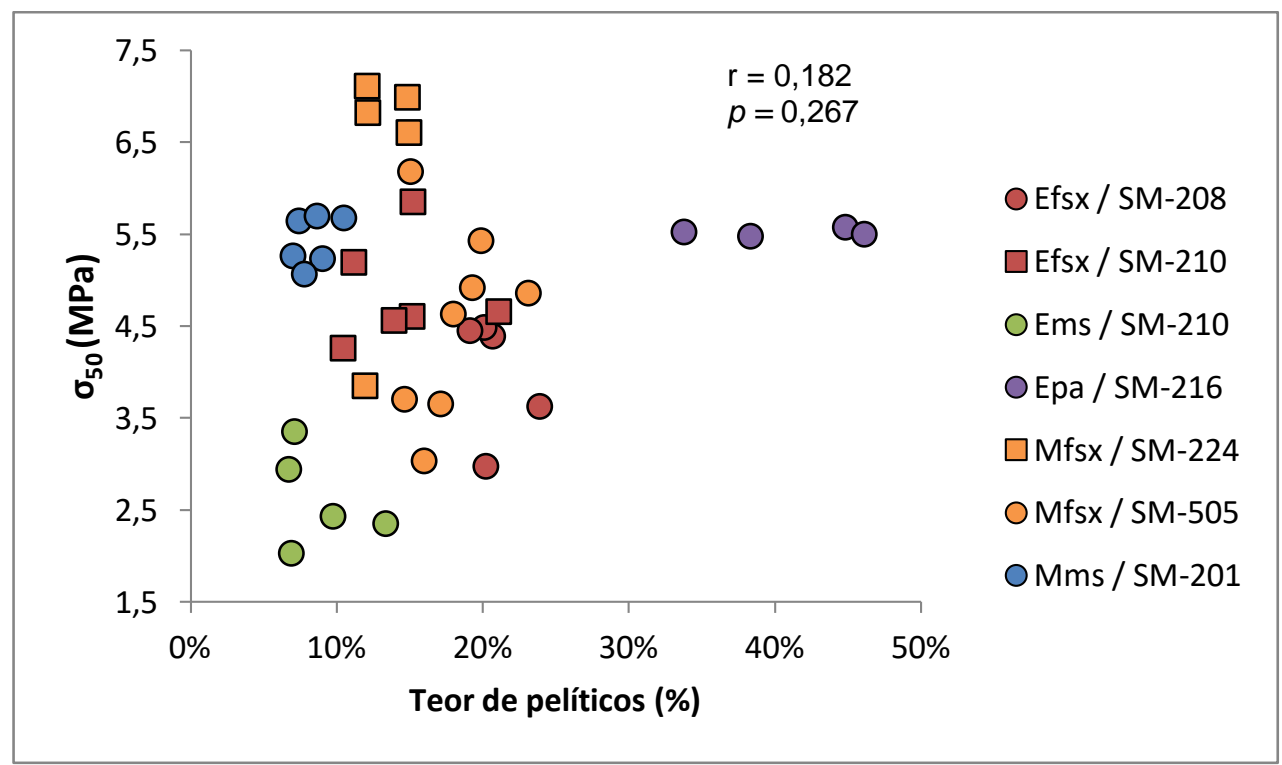

Figura 3.6.64 - Diagrama de dispersão de teor de pelíticos versus $\sigma_{50}$, para cada corpo de prova (petrofácies/sondagem).

A relação entre profundidade e $\sigma_{50}$ não parece existir (Figura 3.6.65). 0 diagrama box-plot representando os resultados de ensaios de compressão uniaxial por classe de graus de coerência (Figura 3.6.66) mostram quartis mais elevados para a classe de maior coerência (C2/C3), porém com grande sobreposição de intervalos interquartis entre as diferentes classes. Considerando a média dos valores adotados para os corpos de prova referentes às diferentes sondagens, observa-se correspondência discreta entre grau de coerência e $\sigma_{50}$ (Tabela 3.6.5).

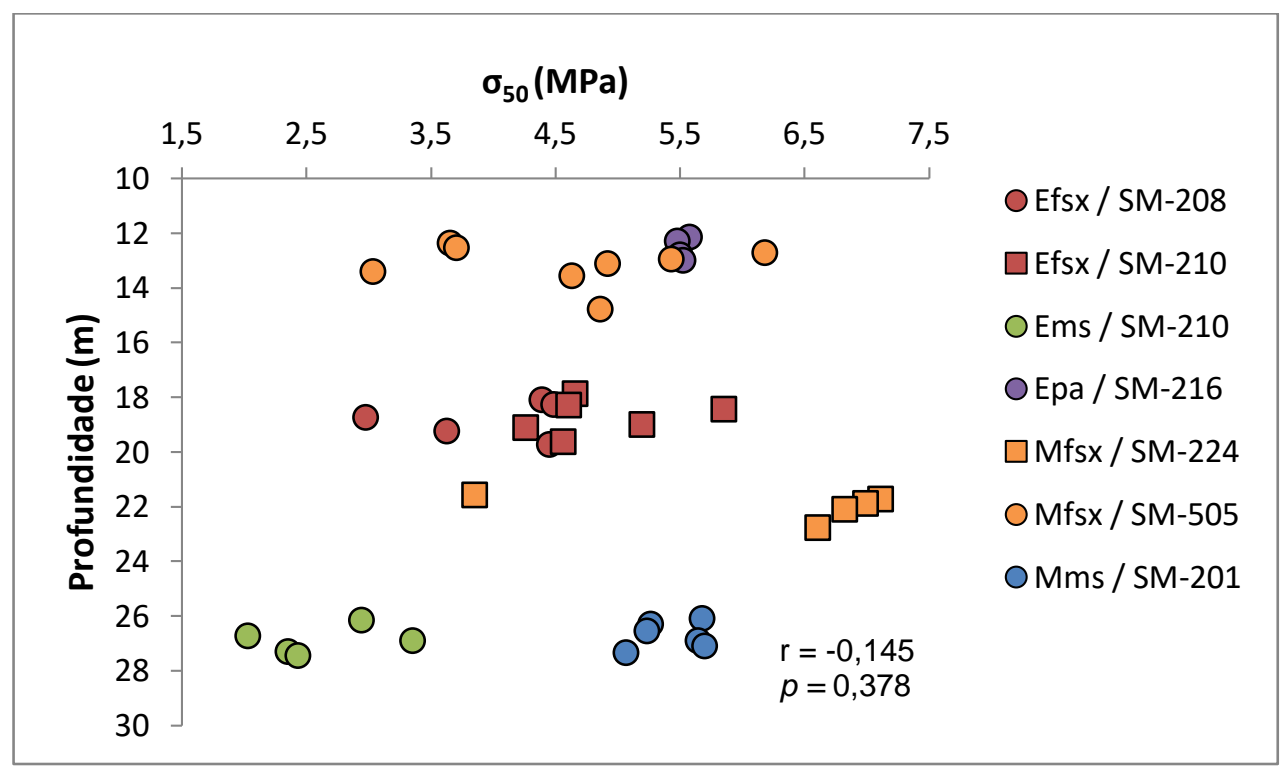

Figura 3.6.65 - Diagrama de dispersão de $\sigma_{50}$ versus profundidade, para cada corpo de prova (petrofácies/sondagem). 


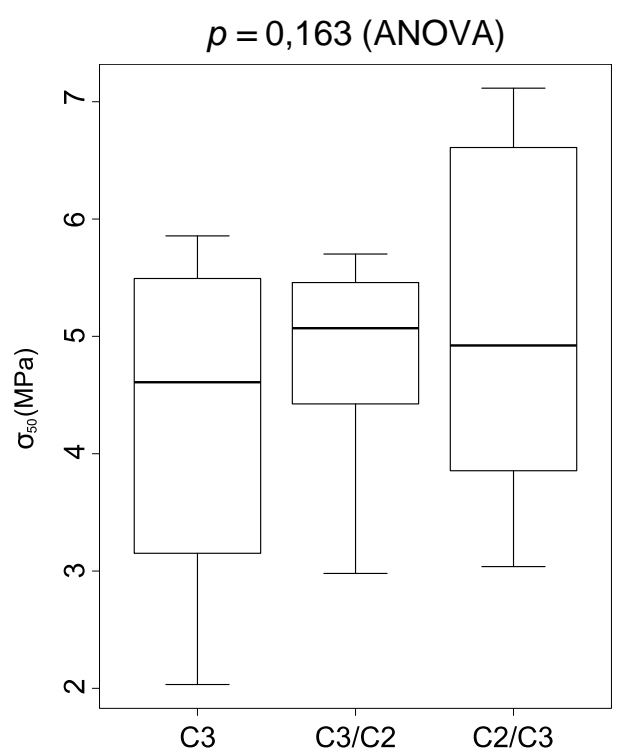

Figura 3.6.66 - Boxplots representando a distribuição dos valores de $\sigma_{50}$ para os graus de coerência atribuídos aos 39 corpos de prova submetidos aos ensaios de resistência à compressão. Número de amostras: $\mathrm{C} 3=15 ; \mathrm{C} 3 / \mathrm{C} 2=11 ; \mathrm{C} 2 / \mathrm{C} 3=13$.

Tabela 3.6.5 Dados estatísticos de $\sigma_{50}$ por grau de coerência, para os 39 corpos de prova submetidos ao ensaio de compressão. $\mathrm{N}$ = número de amostras.

\begin{tabular}{cccccc}
\hline Coerência & $\mathbf{N}$ & Média de $\boldsymbol{\sigma}_{\mathbf{5 0}}(\mathbf{M P a})$ & Mediana de $\boldsymbol{\sigma}_{\mathbf{5 0}} \mathbf{( M P a )}$ & $\boldsymbol{\sigma}_{\mathbf{5 0}}$ mín. (MPa) & $\boldsymbol{\sigma}_{\mathbf{5 0}}$ máx. (MPa) \\
\hline $\mathrm{C} 3$ & 15 & 4,3 & 4,6 & 2,0 & 5,9 \\
$\mathrm{C} 3 / \mathrm{C} 2$ & 11 & 4,8 & 5,1 & 3,0 & 5,7 \\
$\mathrm{C} 2 / \mathrm{C} 3$ & 13 & 5,2 & 4,9 & 3,0 & 7,1 \\
\hline
\end{tabular}

Não se verificam correlações das medianas calculadas de $\sigma_{50}$ por associação de petrofácies/sondagem com a porosidade avaliada por meio do software analisador de imagens, e uma das petrofácies menos porosas (Ems, sondagem SM210) foi a que apresentou menor resistência (Figura 3.3.67 A). A porosidade intragranular também não apresentou correlação com a resistência (Figura 3.6.67 B). A petrofácies com a menor proporção de poros intragranulares (Ems, sondagem SM-210), mais uma vez, apresentou a menor resistência, ao passo que uma das petrofácies mais resistentes (Epa, sondagem SM-216) apresentou a maior proporção de poros intragranulares. Contudo, existe evidente correlação negativa entre a resistência à compressão uniaxial e a porosidade aparente, ainda que não significativa estatisticamente (Figura 3.6.68 A). Mais evidente ainda, e significativa, é a correlação entre densidade aparente e $\sigma_{50}$ (Figura 3.6.68 B). 


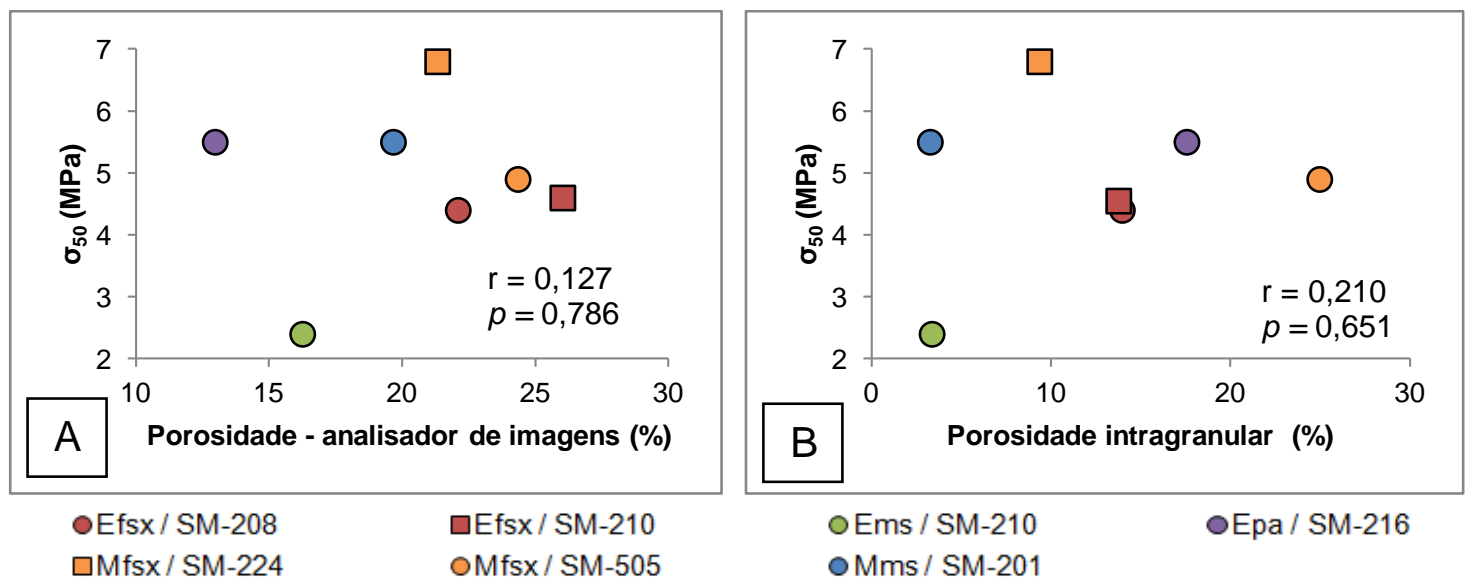

Figura 3.6.67 - Diagramas de dispersão com medianas de $\sigma_{50}$ por petrofácies/sondagem versus porosidade total (A) avaliada por meio de software analisador de imagens e porosidade intragranular (na fração porosidade modal) (B), avaliada via análise modal.

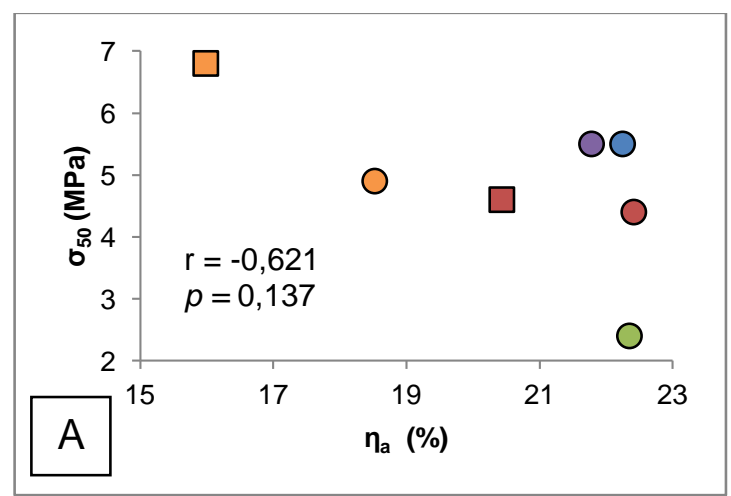

OEfsx / SM-208

口Mfsx / SM-224 $\square$ Efsx / SM-210

OMfsx / SM-505

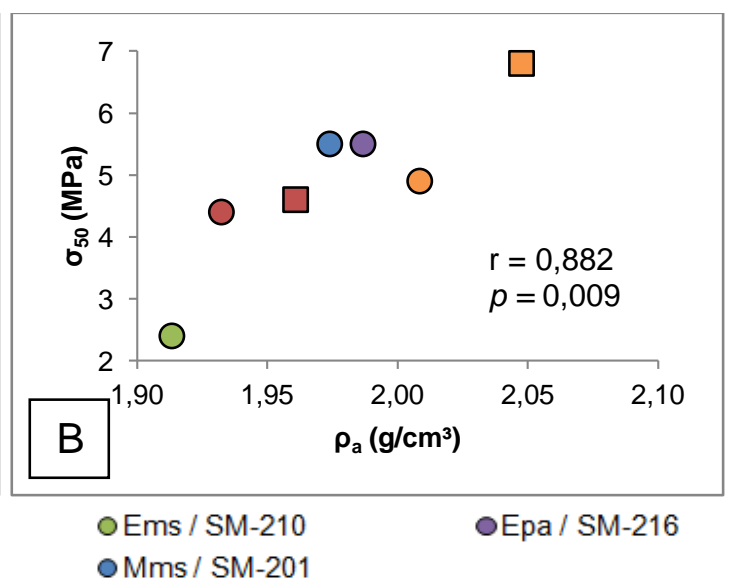

O Mms / SM-201

Figura 3.6.68 - Diagramas de dispersão das medianas de $\sigma_{50}$ versus medianas da densidade aparente $\left(\rho_{a}, A\right)$ e porosidade aparente $\left(\eta_{a}, B\right)$, por petrofácies/sondagem.

A densidade de empacotamento não apresentou correlação linear com $\sigma_{50}$ para cada associação de petrofácies/sondagem, sendo que a amostra representativa dos corpos de prova da petrofácies Ems, sondagem SM-210, cujos valores de $\sigma_{50}$ foram os menores, apresenta uma das maiores densidades de empacotamento, ao passo que a amostra referente aos corpos de prova da petrofácies Epa, sondagem SM-216, com valores relativamente altos de $\sigma_{50}$, mostra a menor densidade de empacotamento. A proximidade de empacotamento não mostra qualquer correlação com a resistência (Figura 3.6.69). 


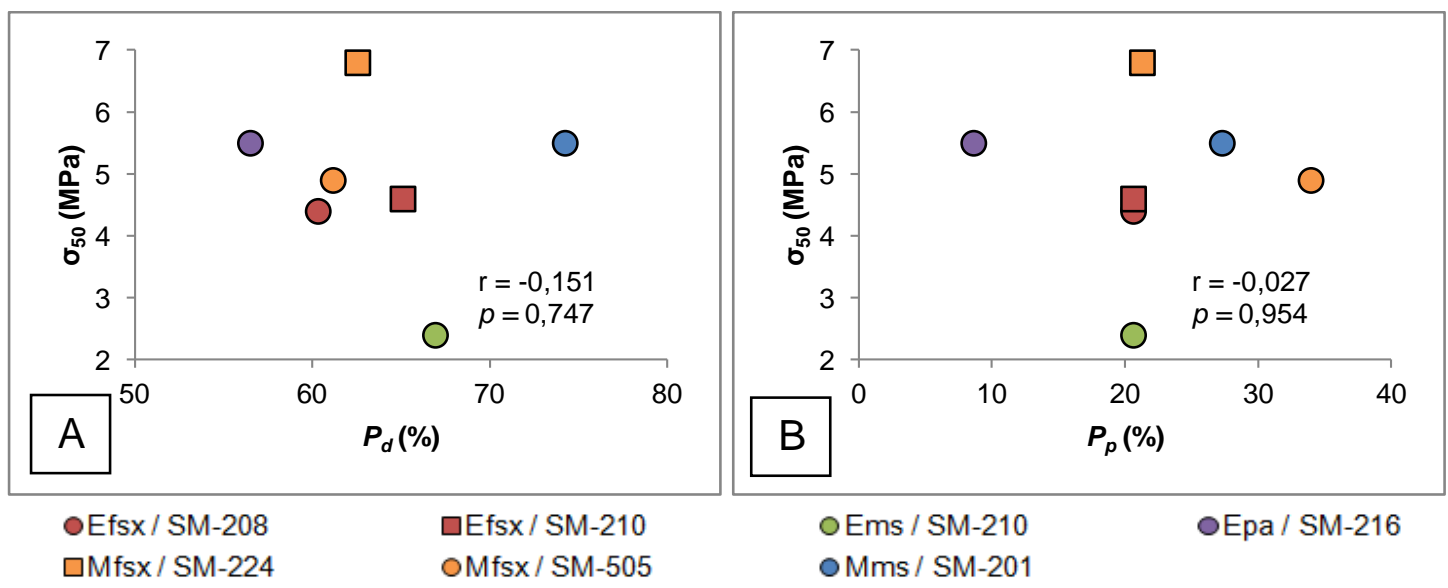

Figura 3.6.69 - Diagramas de dispersão das medianas de $\sigma_{50}$ por petrofácies/sondagem versus densidade de empacotamento $\left(P_{d}, \mathrm{~A}\right)$ e proximidade de empacotamento $\left(P_{p}\right.$, B).

Também não ficou evidente qualquer influência dos tipos de contatos intergranulares sobre $\sigma_{50}$ das amostras analisadas (Figura 3.6.70). Observa-se correlação linear positiva de $\sigma_{50} \mathrm{com}$ a porcentagem de contatos entre grãos do arcabouço e cimento, e negativa com a porcentagem de contatos entre grãos do arcabouço e vazios (Figura 3.6.71), porém ambas são não significativas estatisticamente.

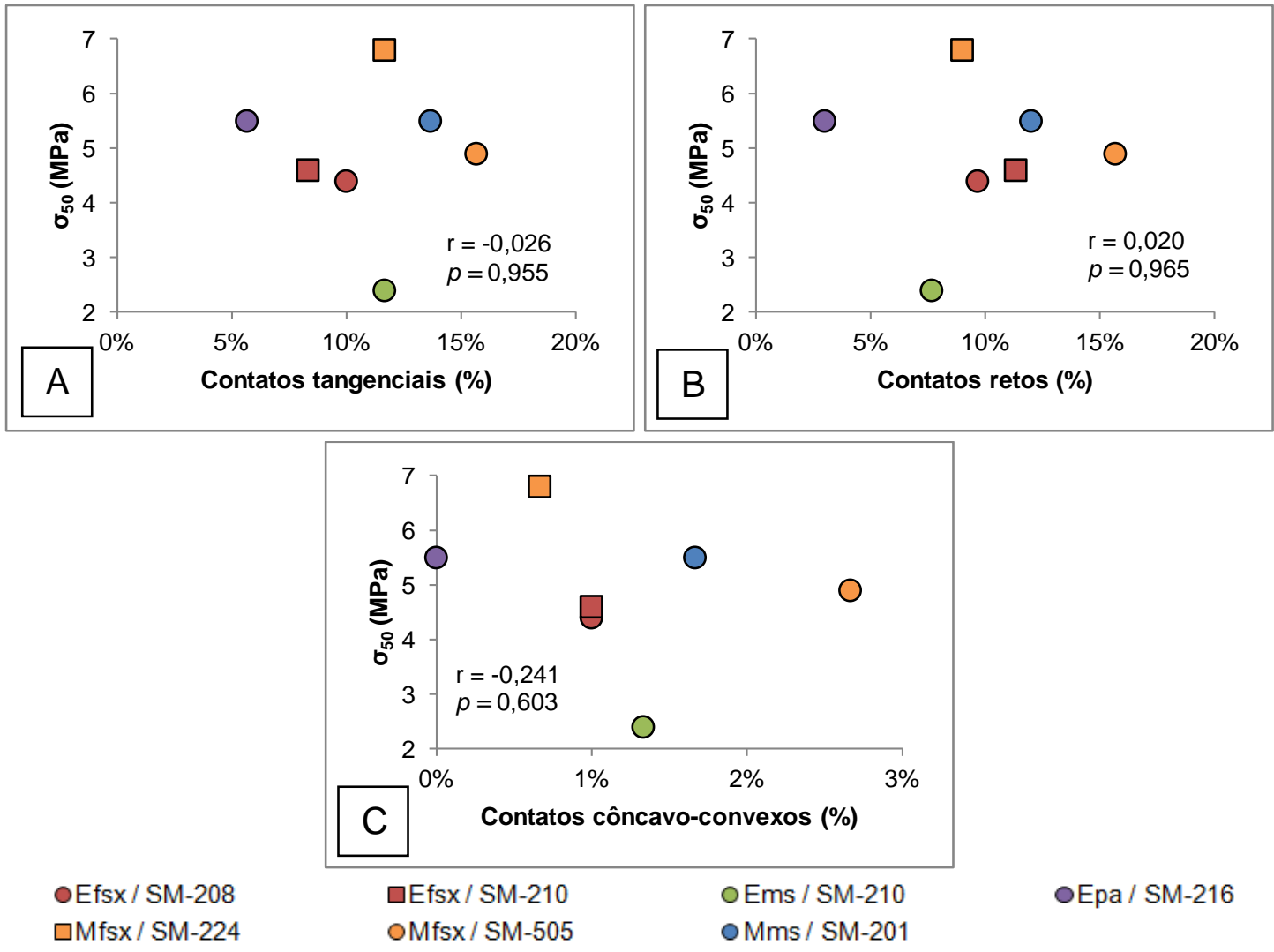

Figura 3.6.70 - Diagramas de dispersão das medianas de $\sigma_{50}$ por petrofácies/sondagem versus porcentagem de contatos tangencias $(A)$, retos $(B)$ e côncavo-convexos $(C)$. 


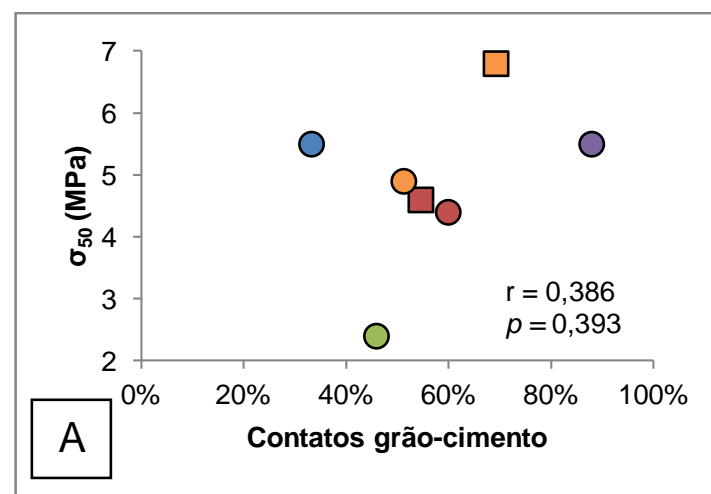

oEfsx / SM-208

口Mfsx / SM-224
口Efsx / SM-210

OMfsx / SM-505

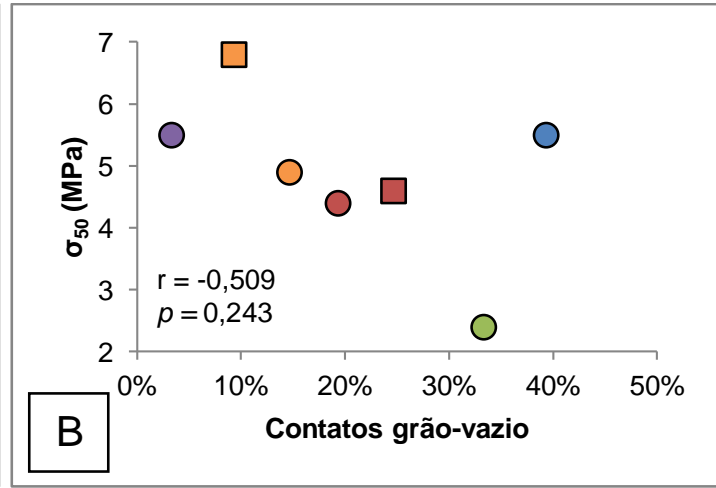

o Ems / SM-210

O Mms / SM-201

OEpa / SM-216

Figura 3.6.71 - Diagramas de dispersão entre as medianas de $\sigma_{50}$ por petrofácies/sondagem e as proporções de contatos entre grãos do arcabouço e cimento $(A)$ e entre grãos do arcabouço e vazios (B).

Nota-se correlação linear positiva de $\sigma_{50}$ com a proporção de grãos angulosos, e negativa com as proporções de grãos subarredondados e arredondados e com a média da razão entre os eixos menor e maior. Contudo, os coeficientes de correlação são pequenos, muito abaixo do que se considera estatisticamente significativo (Figura 3.6.72).

Do mesmo modo, as quantidades relativas de grãos do arcabouço e de cimento correlacionam-se de maneira inversa e direta com $\sigma_{50}$, porém com coeficientes de correlação não significativos (Figura 3.6.73). Considerando as frações do cimento constituídas por esmectita e óxi-hidróxido metálico, observam-se correlações positiva e negativa com $\sigma_{50}$, respectivamente, também não significativas (Figura 3.6.74). 

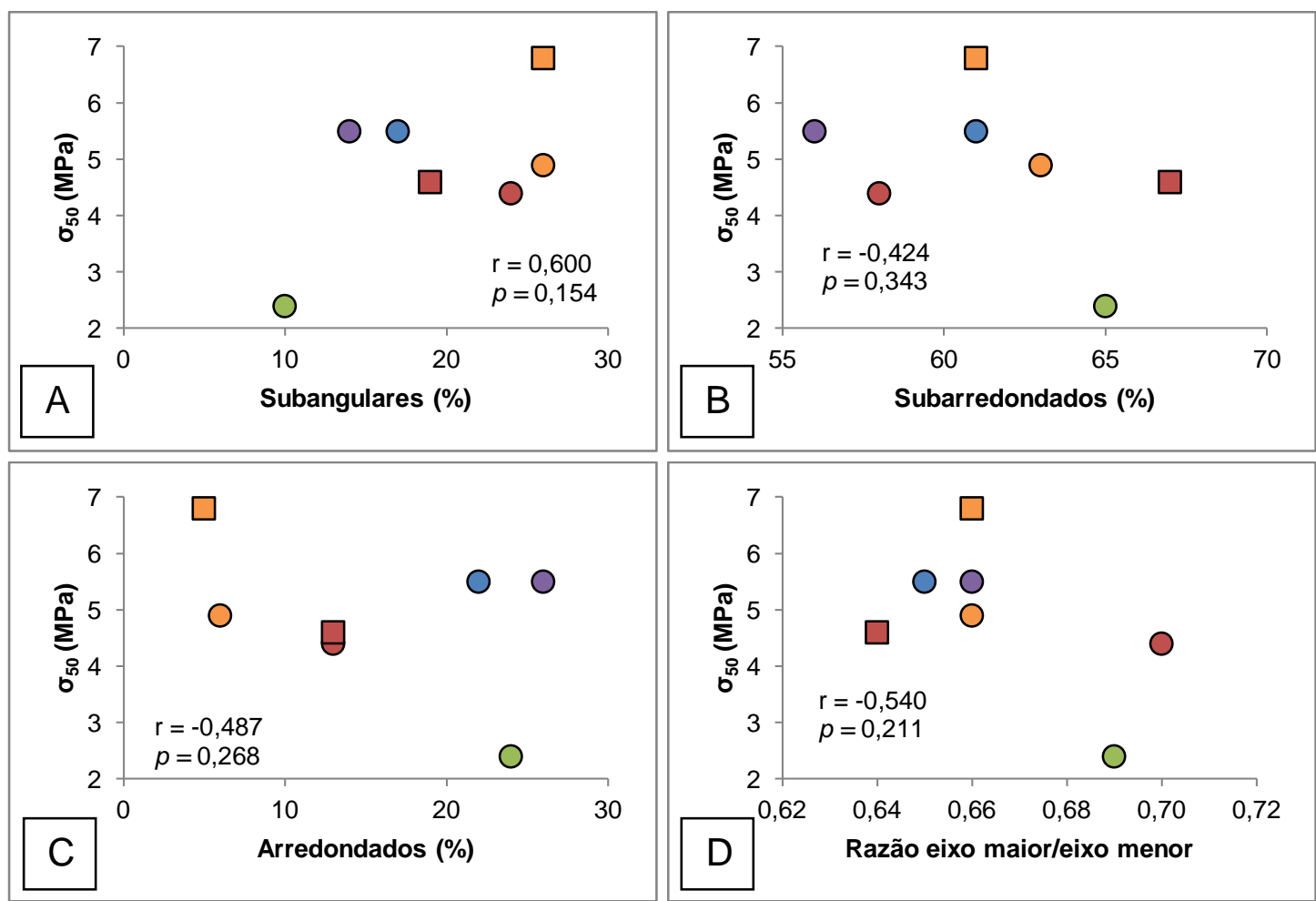

oEfsx / SM-208

口Efsx / SM-210

$\square \mathrm{Mfsx} / \mathrm{SM}-224$

OMfsx / SM-505

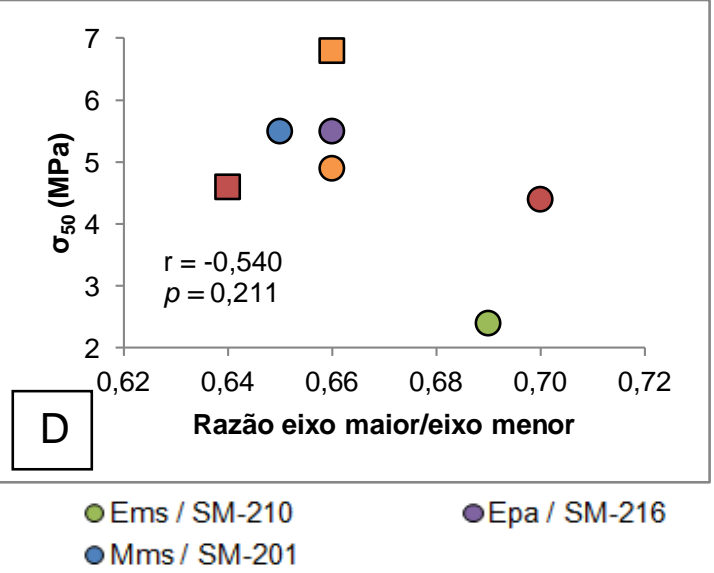

Figura 3.6.72 - Diagramas de dispersão relacionando índices relativos ao formato dos grãos com as medianas de $\sigma_{50}$, por petrofácies/sondagem.

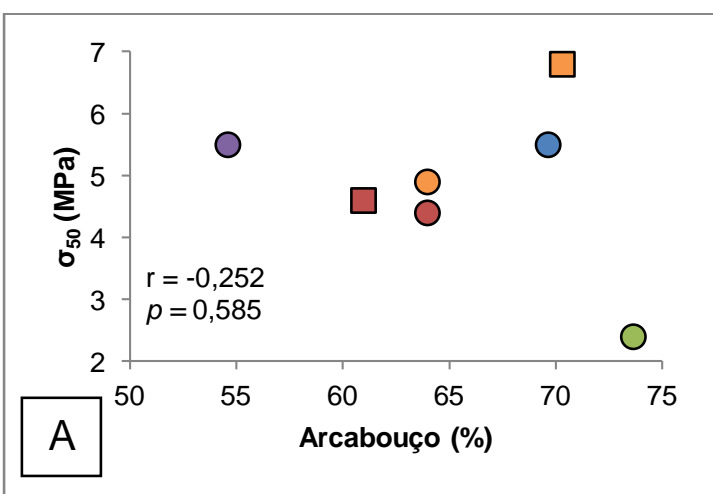

oEfsx / SM-208

$\square \mathrm{Mfsx} / \mathrm{SM}-224$
口Efsx / SM-210

OMfsx / SM-505

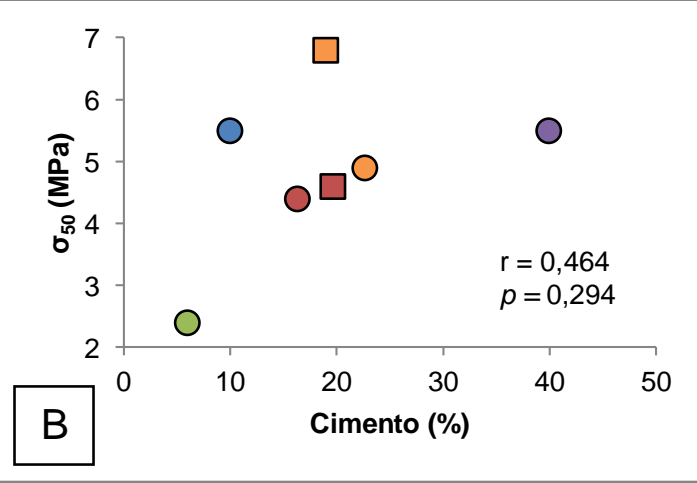

O Ems / SM-210

OEpa / SM-216

O Mms / SM-201

Figura 3.6.73 - Diagrama de dispersão relacionando as medianas de $\sigma_{50}$ por petrofácies/sondagem e as proporções relativas de arcabouço (A) e cimento total (B). 


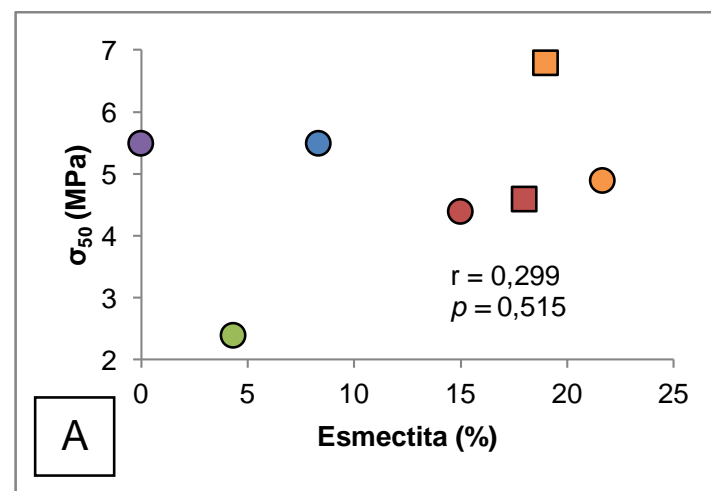

oEfsx / SM-208

$\square \mathrm{Mfsx} / \mathrm{SM}-224$
口Efsx / SM-210

OMfsx / SM-505

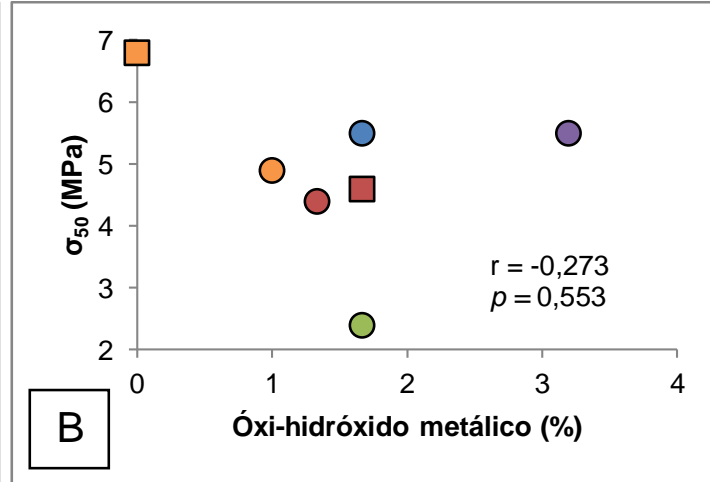

OEms / SM-210

O Mms / SM-201

Figura 3.6.74 - Diagrama de dispersão relacionando proporções de cimento constituída por esmectita (A) e óxi-hidróxido (B) metálico versus medianas de $\sigma_{50}$, por associação petrofácies/sondagem.

\subsubsection{Correlações entre propriedades petrográficas e módulo de deformabilidade}

A profundidade apresenta correlação linear positiva significativa com 0 módulo de deformabilidade $\left(E_{s}\right)$ (Figura 3.6.75).

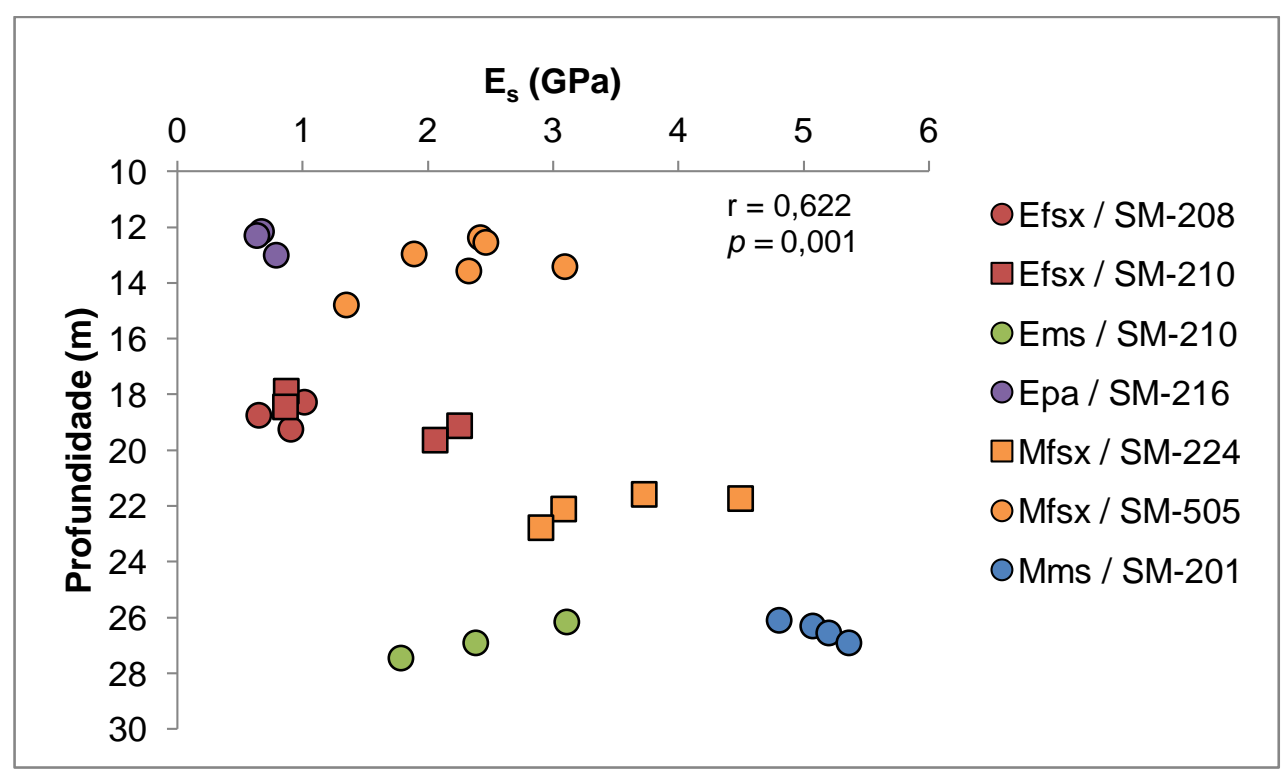

Figura 3.6.75 - Diagrama de dispersão entre profundidade e $E_{s}$, para os 27 corpos de prova submetidos ao ensaio de compressão uniaxial com medidas de deformação axial.

Tamanho médio dos grãos e desvio padrão da distribuição granulométrica correlacionam-se diretamente a $E_{s}$ (figuras 3.6 .76 e 3.6.77), sendo essa correlação significativa apenas no primeiro caso. No segundo caso, a correlação torna-se significativa se for suprimido um valor considerado extremo (Figura 3.6.77 B). O teor de pelíticos correlaciona-se inversamente a $\mathrm{E}_{\mathrm{s}}$ (Figura 3.6.78). 


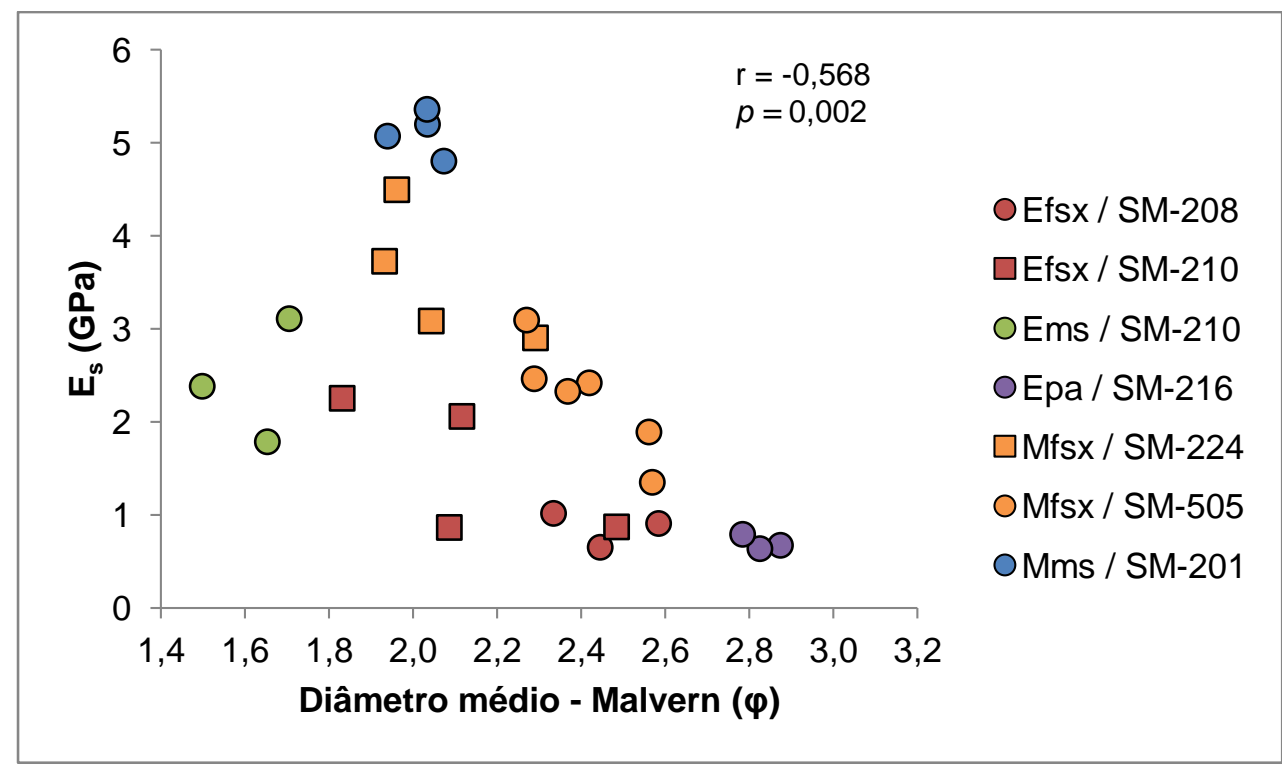

Figura 3.6.76 - Diagrama de dispersão entre tamanho médio dos grãos do arcabouço e $E_{s}$, para os 27 corpos de prova submetidos ao ensaio de compressão uniaxial com medidas de deformação axial, identificados por petrofácies/sondagem.

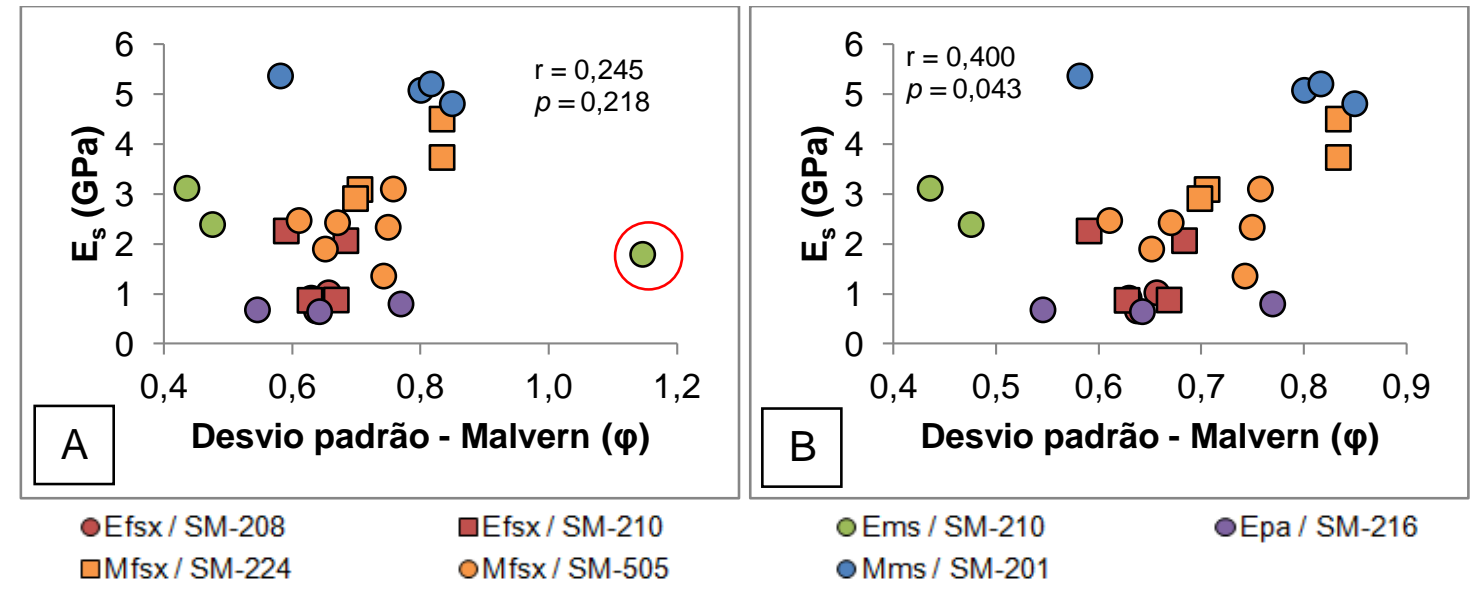

Figura 3.6.77 - Diagramas de dispersão entre desvio padrão da distribuição granulométrica e $E_{s}$, para os 27 corpos de prova submetidos ao ensaio de compressão uniaxial com medidas de deformação axial, identificados por petrofácies/sondagem. No diagrama B, suprime-se o valor extremo (outlier), indicado pelo circulo vermelho no diagrama $(A)$. 


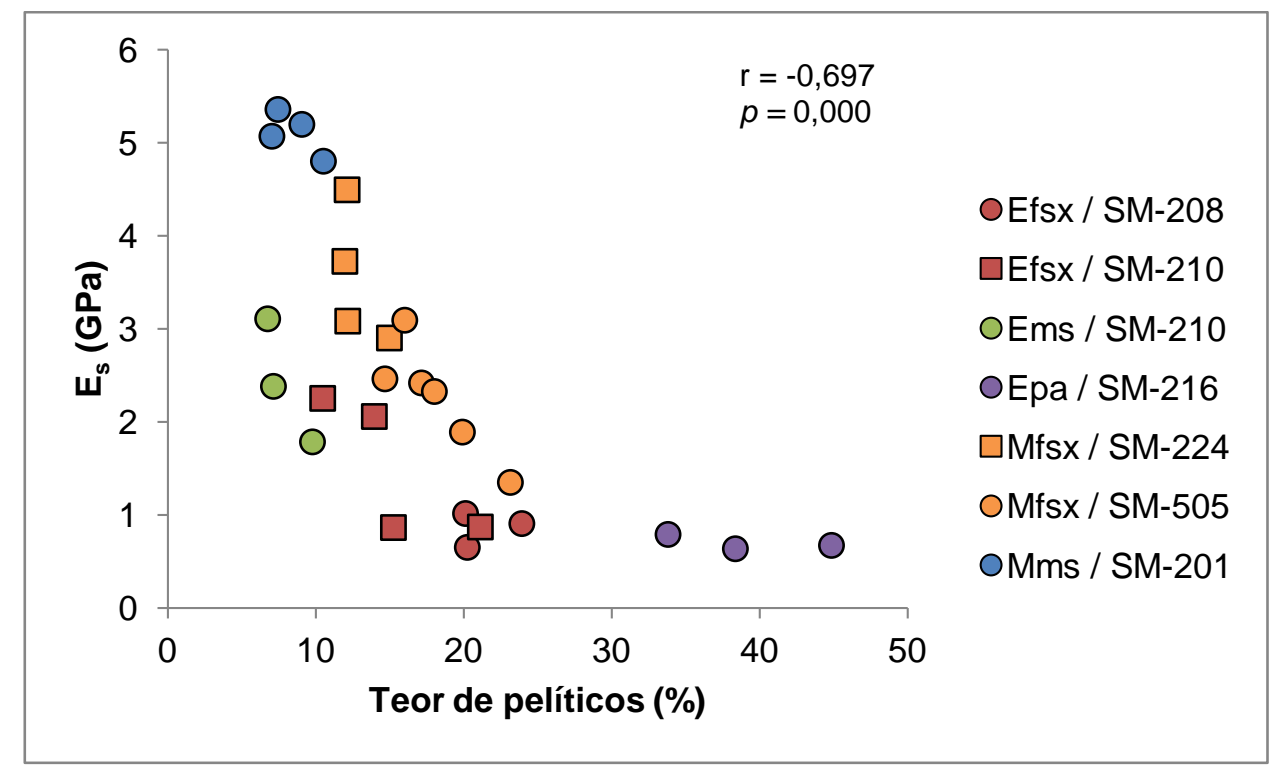

Figura 3.6.78 - Diagrama de dispersão entre teor de pelíticos e $E_{s}$, para os 27 corpos de prova submetidos ao ensaio de compressão uniaxial com medidas de deformação axial, por petrofácies/sondagem.

As porosidades total e intragranular, avaliadas respectivamente por meio do analisador de imagens e análise modal via petrografia, não apresentaram correlação linear com as medianas de $E_{s}$ calculadas por associação de petrofácies/sondagem (Figura 3.6.79). As correlações das medianas de $\mathrm{E}_{\mathrm{s}}$ com as medianas da porosidade e densidade aparentes também não são significativas (Figura 3.6.80).

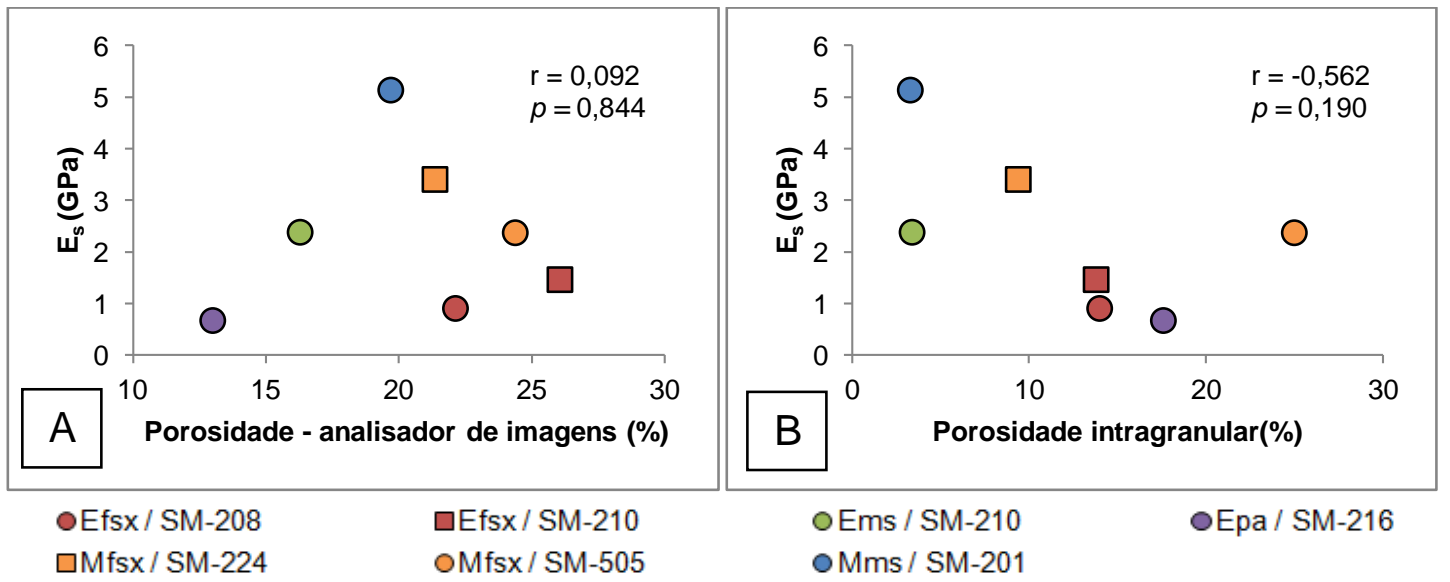

Figura 3.6.79 - Diagramas de dispersão entre as medianas de $E_{s}$ por petrofácies/sondagem e porosidade total avaliada via software analisador de imagens digitais $(A)$ e porosidade intragranular (na fração porosidade modal), avaliada por meio de análise modal (B). 


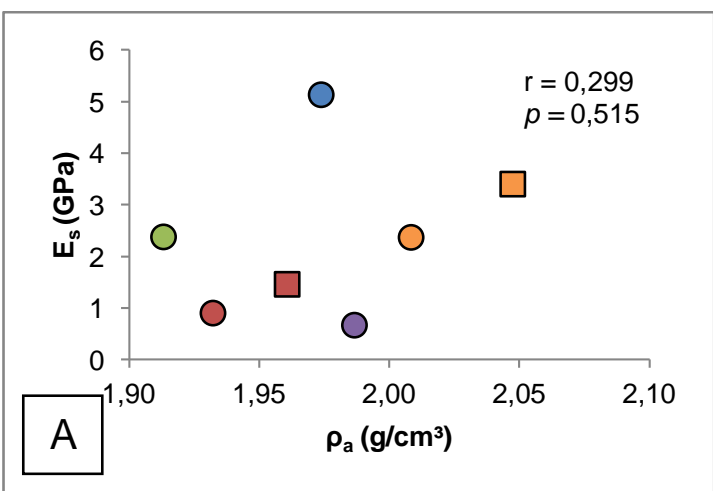

oEfsx / SM-208

$\square \mathrm{Mfsx} / \mathrm{SM}-224$
口Efsx / SM-210

OMfsx / SM-505

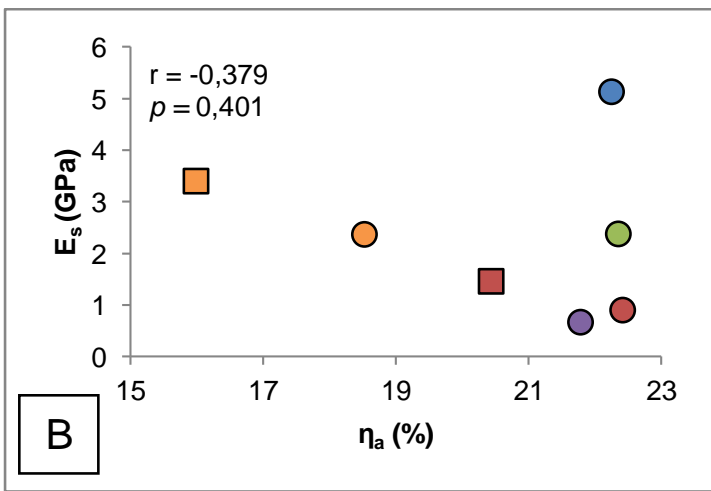

o Ems / SM-210

O Mms / SM-201

OEpa / SM-216

Figura 3.6.80 - Diagramas de dispersão das medianas de $E_{s}$ versus medianas de densidade $(A)$ e porosidade aparentes (B), por petrofácies/sondagem.

Observa-se correlação linear positiva significativa entre densidade de empacotamento $e$ as medianas de $E_{s}$ para cada petrofácies/sondagem. A proximidade de empacotamento também se correlaciona positivamente a estes valores, porém esta correlação não é significativa estatisticamente (Figura 3.6.81).

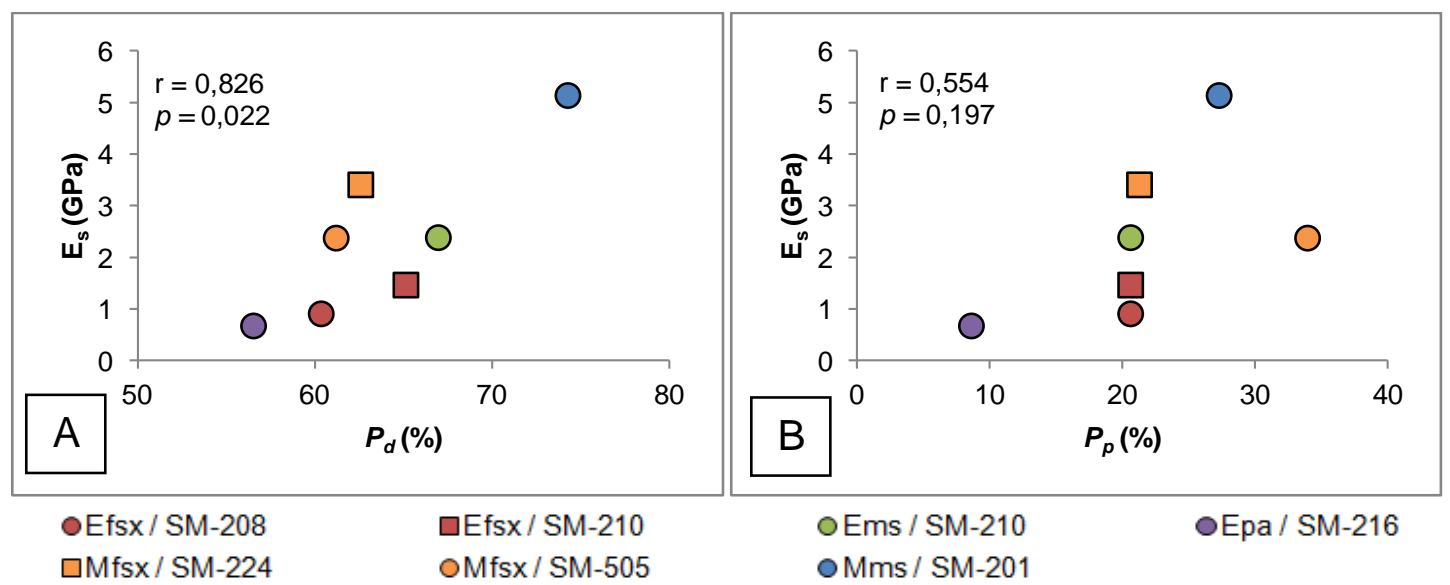

Figura 3.6.81. Diagramas de dispersão das medianas de $E_{s}$ por petrofácies/sondagem com densidade de empacotamento $\left(P_{d}\right.$ A $)$ e proximidade de empacotamento $\left(P_{p}, \mathrm{~B}\right)$.

As proporções relativas de contatos intergranulares de quaisquer tipos relacionam-se positivamente a $E_{s}$, mas as correlações lineares não são significativas. Os contatos tangenciais foram aqueles que apresentaram coeficiente de correlação mais alto (Figura 3.6.82).

A proporção de contatos entre grãos do arcabouço e cimento correlaciona-se inversamente $a E_{s}$, ao passo que a de contatos entre grãos e vazios correlaciona-se diretamente, porém ambas correlações são não significativas (Figura 3.6.83). 

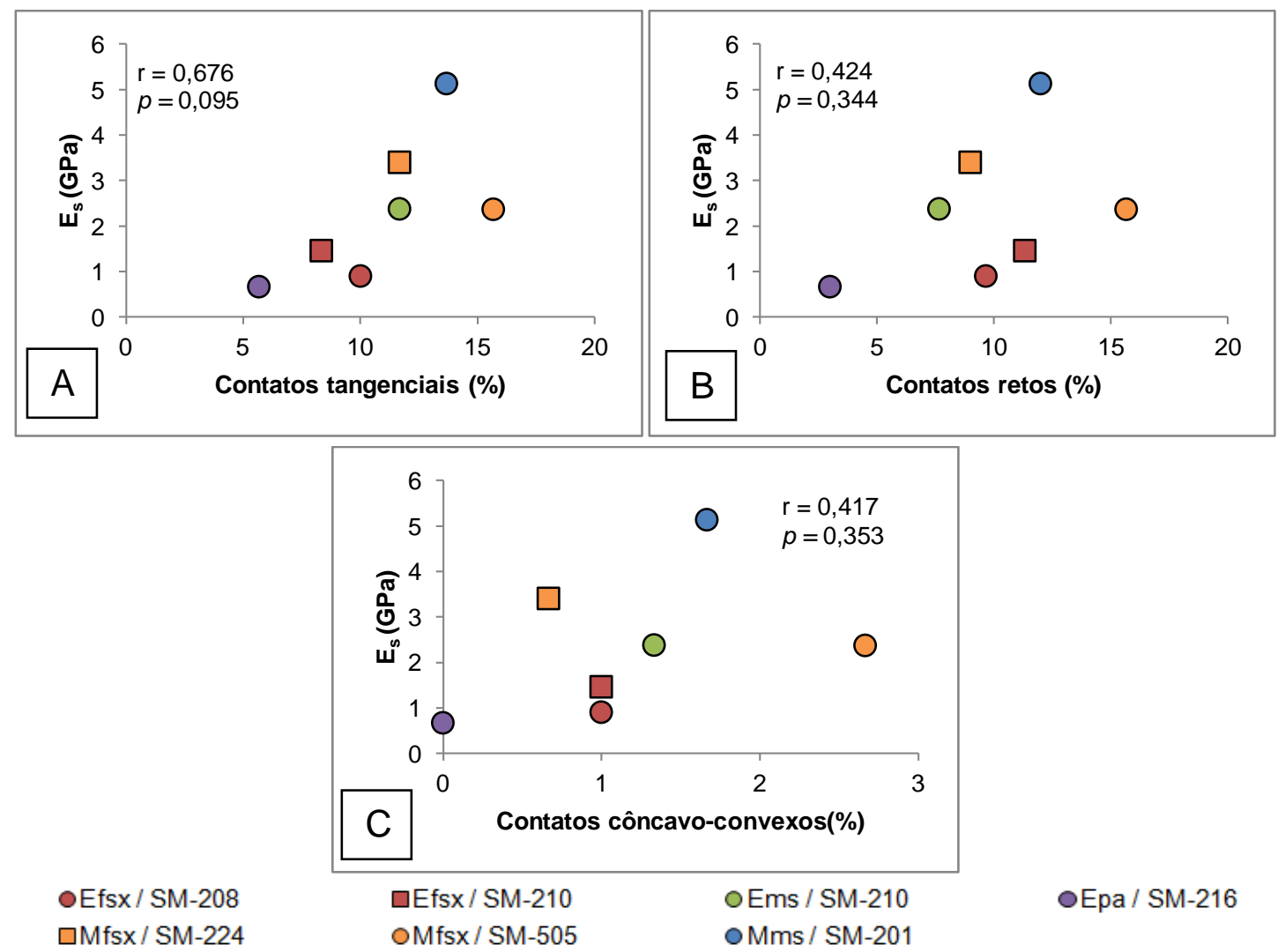

Figura 3.6.82 - Diagramas de dispersão relacionando as proporções de cada tipo de contato intergranular às medianas de $E_{s}$, por petrofácies/sondagem.
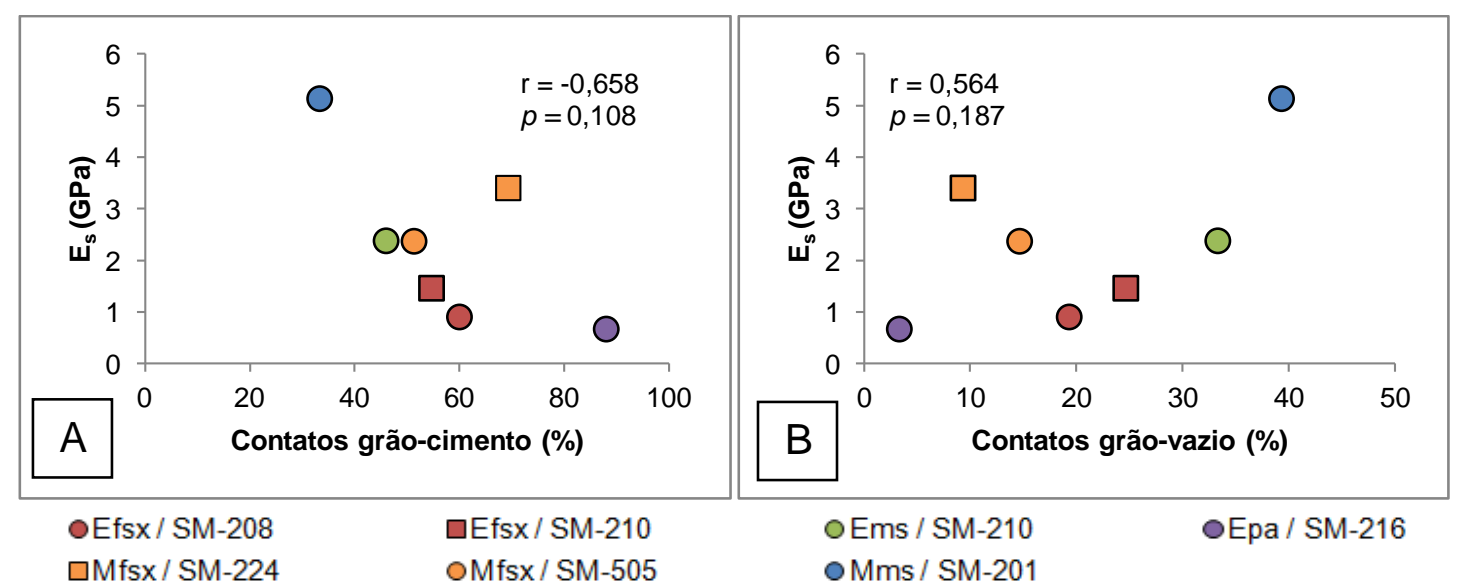

Figura 3.6.83 - Diagramas de dispersão das medianas de $E_{s}$, por petrofácies/sondagem, com as proporções de contatos grão-cimento (A) e grão-vazio (B),

Não se observa relação entre forma dos grãos e $E_{s}$. Todos os coeficientes de correlação referentes aos parâmetros de forma dos grãos são extremamente baixos (Figura 3.6.84 A, B e C). A correlação entre $E_{s}$ e esfericidade, aqui avaliada pela razão média entre os eixos menor e maior dos grãos, forneceu o coeficiente mais alto $(0,38)$, mas ainda assim não significativo (Figura 3.6.84 D). 


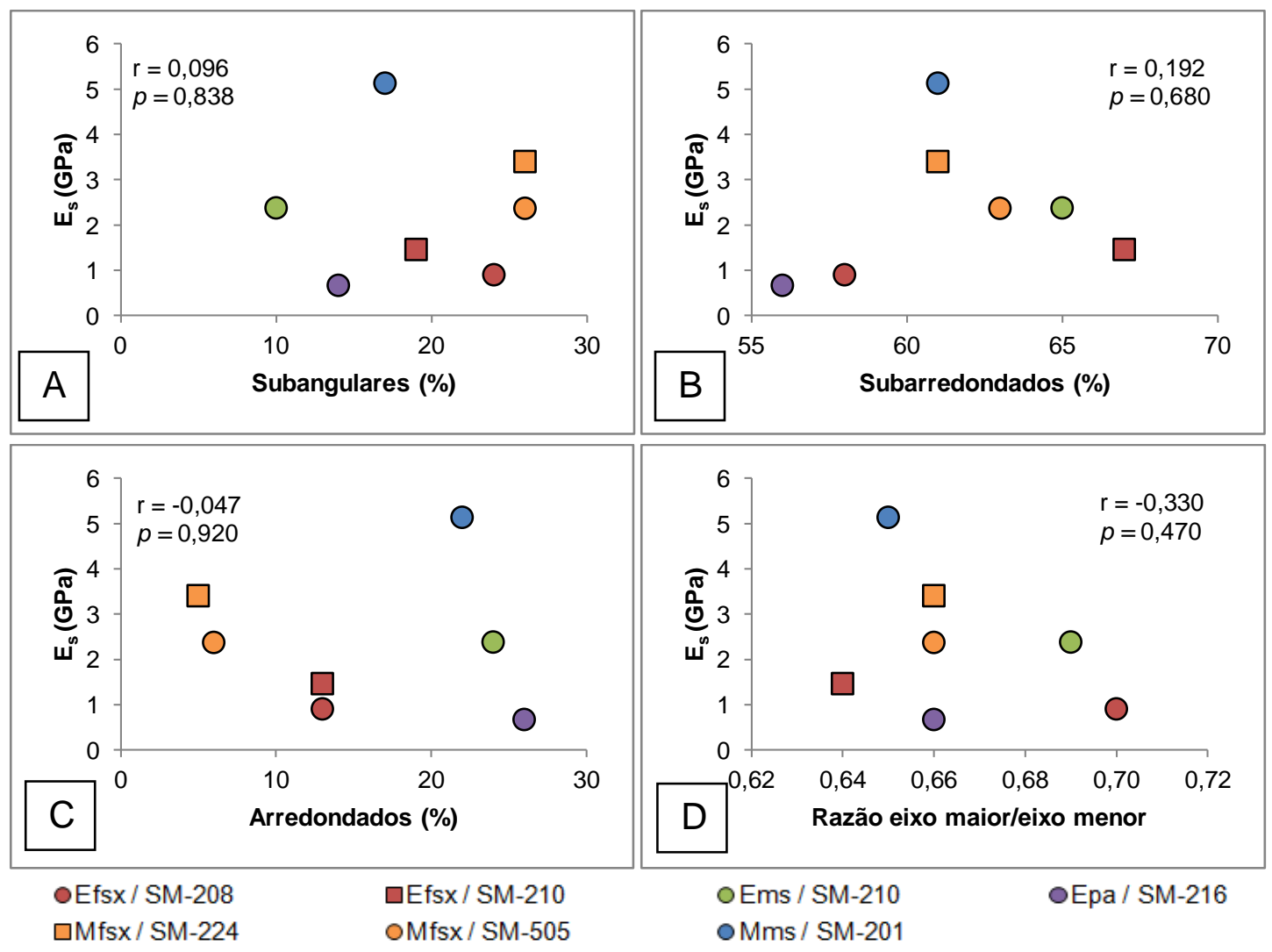

Figura 3.6.84 - Diagramas de dispersão relacionando parâmetros relativos à forma dos grãos do arcabouço e as medianas de $\mathrm{E}_{\mathrm{s}}$, por petrofácies/sondagem.

As proporções de grãos do arcabouço e de cimento total apresentam, respectivamente, correlação linear positiva e negativa com $E_{s}$, porém estas correlações não são significativas (Figura 3.6.85). As concentrações de quartzo e feldspato no arcabouço apresentam correlação direta e inversa com $E_{s}$, respectivamente, significativa apenas para o quartzo (Figura 3.6.86).

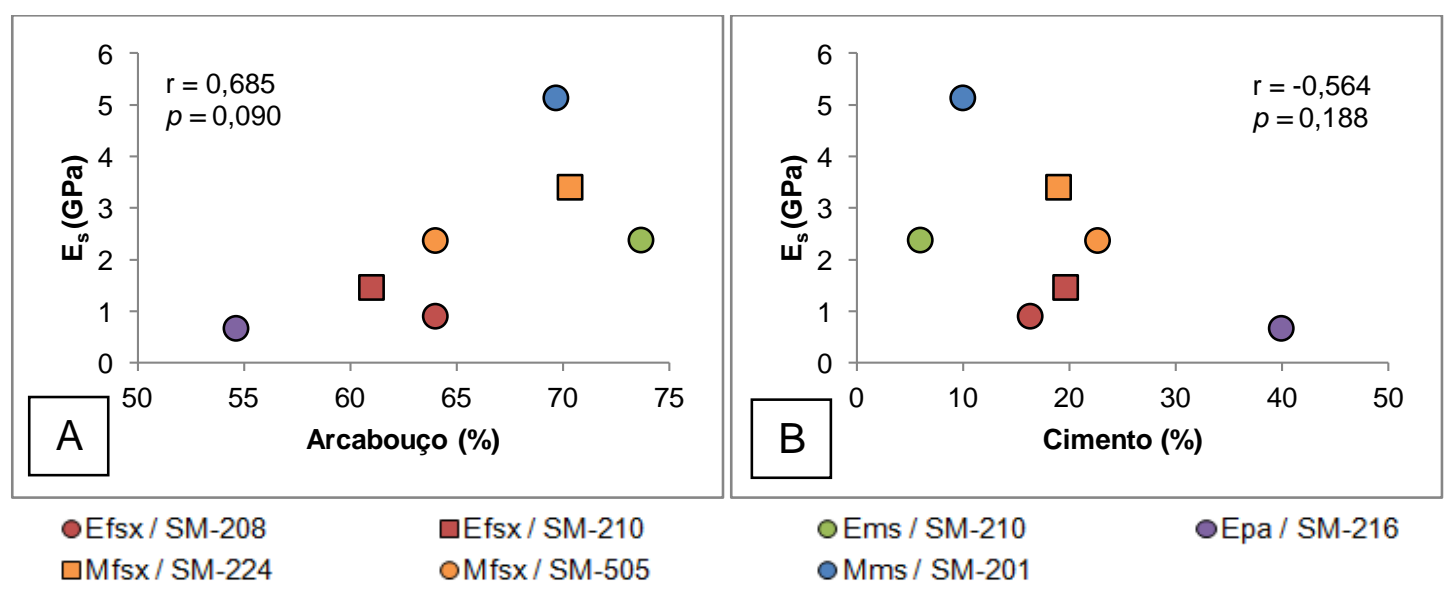

Figura 3.6.85 - Diagramas de dispersão relacionando as medianas de $E_{s}$ por petrofácies/sondagem às proporções de arcabouço $(A)$ e cimento total $(B)$. 


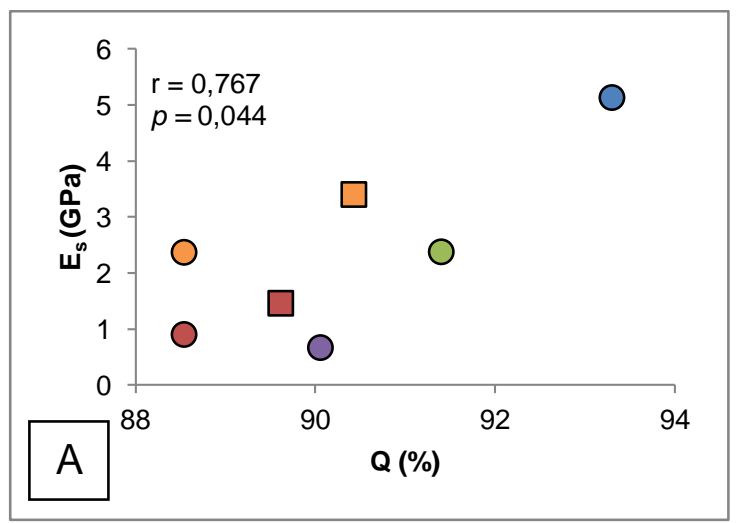

OEfsx / SM-208

口Mfsx / SM-224

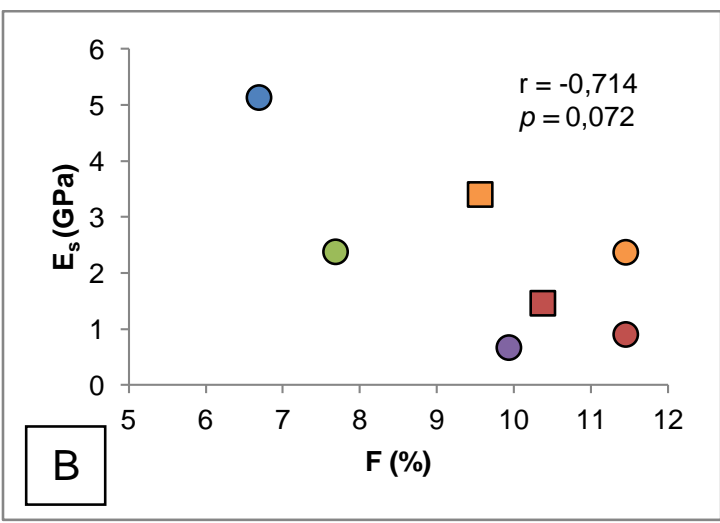

o Ems / SM-210

o Mms / SM-201

Figura 3.6.86 - Diagramas de dispersão entre as medianas de $E_{s}$ por petrofácies/sondagem e concentrações de quartzo $(A)$ e feldspato $(B)$ no arcabouço.

Os diagramas de dispersão entre $E_{s}$ e proporções dos cimentos de esmectita e de óxi-hidróxido metálico não apresentam padrão claro de variação (Figura 3.6.87). A correlação linear encontrada, não significativa estatisticamente, é positiva com esmectita e negativa com óxi-hidróxido metálico.

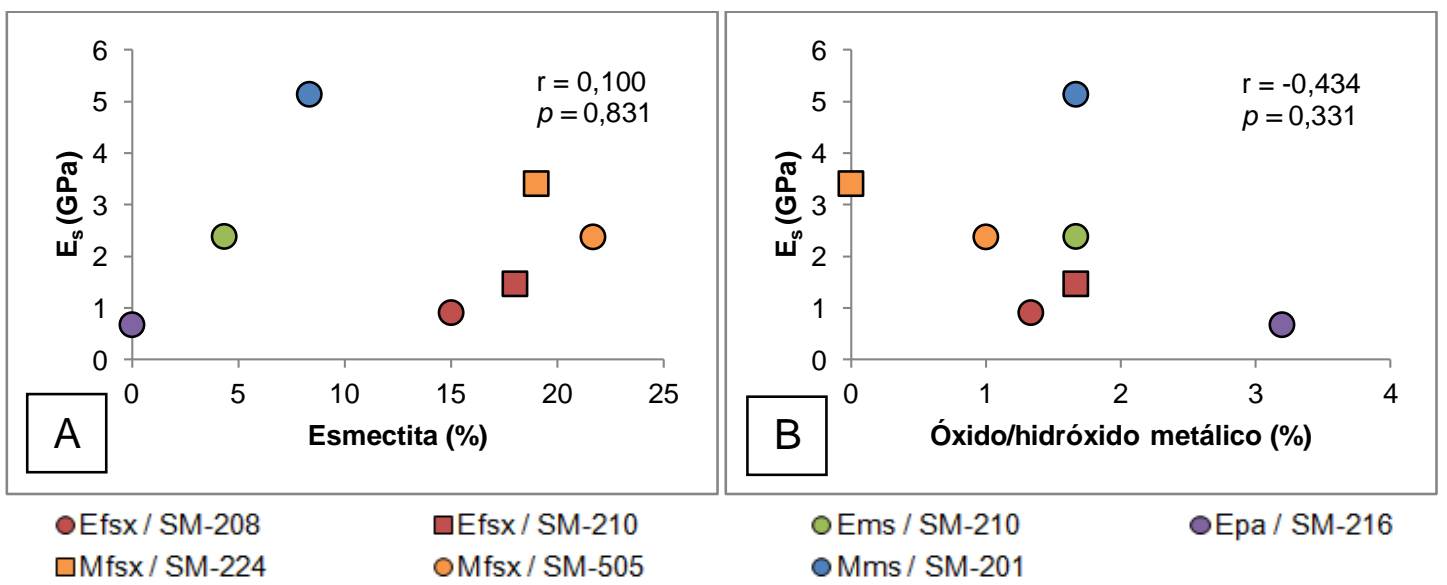

Figura 3.6.87 - Diagramas de dispersão entre medianas de $E_{s}$ por petrofácies/sondagem e proporções de cimento esmectítico $(A)$ e de óxi-hidróxido metálico $(B)$.

As medianas de $E_{s}$ dos graus de coerência C3/C2 e C2/C3 são mais altas que a do grau C3 (Figura 3.6.88), porém não de maneira significativa, conforme revelam os testes de comparações múltiplas de Dunn (Tabela 3.6.6). As amplitudes de variação total e interquartis de $E_{s}$ no grau C3 é ampla, abarcando inteiramente as amplitides dos demais graus de coerência. 


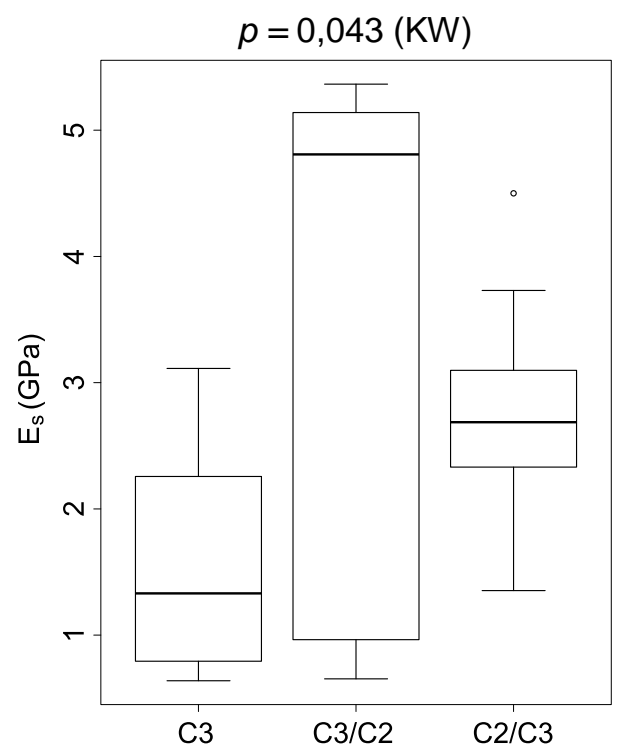

Figura 3.6.88 - Boxplots representando a distribuição dos valores de $E_{s}$ para os graus de coerência atribuídos aos 27 corpos de prova submetidos aos ensaios de resistência à compressão com medidas de deformação axial. Número de amostras: $\mathrm{C} 3=10 ; \mathrm{C} 3 / \mathrm{C} 2=7 ; \mathrm{C} 2 / \mathrm{C} 3=10$.

Tabela 3.6.6. Teste de comparações múltiplas de Dunn para o $E_{s}$, por grau de coerência, com valores $p$ ajustados pelo método de Benjamini-Hochberg.

\begin{tabular}{cccc}
\hline Comparação & $\mathbf{Z}$ & $\boldsymbol{p}$ & $\boldsymbol{p}$ ajustado \\
\hline C3 vs C3/C2 & $-2,05$ & 0,041 & 0,061 \\
C3 vs C2/C3 & $-2,23$ & 0,026 & 0,078 \\
C3/C2 vs C2/C3 & $-0,03$ & 0,980 & 0,980 \\
\hline
\end{tabular}




\section{INTERPRETAÇÃO E DISCUSSÃO DOS RESULTADOS}

\subsection{Associação entre fácies reconhecidas em testemunhos e em afloramentos}

As recorrências de fácies reconhecidas nos testemunhos foram tentativamente associadas às fácies descritas em campo por Gesicki (2007), com base em Giannini et al. (2004) (quadros 4.1.1 e 4.1.2).

Quadro 4.1.1 - Fácies sedimentares características do sistema eólico úmido Piramboia no Estado de São Paulo.

(continua)

\begin{tabular}{|c|c|c|c|}
\hline Fácies & Granulometria & $\begin{array}{l}\text { Estruturas e fácies } \\
\text { associadas }\end{array}$ & $\begin{array}{c}\text { Processos e contexto } \\
\text { deposicional }\end{array}$ \\
\hline $\begin{array}{l}\text { Aca - arenito com } \\
\text { estratificação } \\
\text { cruzada de alto } \\
\text { ângulo }\end{array}$ & $\begin{array}{l}\text { Areia bimodal - } \\
\text { fina e média }\end{array}$ & $\begin{array}{c}\text { Estratificação cruzada } \\
\text { acanaladas de alto ângulo } \\
\left(>10^{\circ}\right)\end{array}$ & $\begin{array}{l}\text { Migração de frentes de } \\
\text { dunas eólicas, } \\
\text { provavelmente } \\
\text { barcanas ou } \\
\text { barcanoides }\end{array}$ \\
\hline $\begin{array}{l}\text { Acb - arenito com } \\
\text { estratificação } \\
\text { cruzada de baixo } \\
\text { ângulo }\end{array}$ & $\begin{array}{l}\text { Areia muito fina, } \\
\text { síltica, até areia } \\
\text { média }\end{array}$ & $\begin{array}{l}\text { Estratificação cruzada de baixo } \\
\text { ângulo }\left(<10^{\circ}\right) \text { e, localmente, } \\
\text { aspecto maciço; laminações } \\
\text { cavalgantes subcríticas e } \\
\text { bioturbação eventuais }\end{array}$ & $\begin{array}{c}\text { Deflação e migração de } \\
\text { ôndulas eólicas em } \\
\text { domínio de interdunas } \\
\text { úmidas }\end{array}$ \\
\hline $\begin{array}{l}\text { Acbd - arenito com } \\
\text { estratificação de } \\
\text { baixo ângulo } \\
\text { deformada }\end{array}$ & $\begin{array}{l}\text { Areia muito fina, } \\
\text { siltica, a areia } \\
\text { média }\end{array}$ & $\begin{array}{l}\text { Estratificação deformada na } \\
\text { forma de convoluções, } \\
\text { confinadas entre camadas de } \\
\text { arenitos com estratificação } \\
\text { horizontal ou cruzada de baixo } \\
\text { ângulo (fácies Acb e Ash) }\end{array}$ & $\begin{array}{c}\text { Fluidificação, talvez } \\
\text { induzida por sismos, em } \\
\text { domínio de interdunas } \\
\text { úmidas }\end{array}$ \\
\hline $\begin{array}{l}\text { Acbl - arenito com } \\
\text { estratificação } \\
\text { horizontal ou } \\
\text { cruzada de baixo } \\
\text { ângulo e } \\
\text { intercalação de } \\
\text { lutitos }\end{array}$ & $\begin{array}{l}\text { Areia muito fina, } \\
\text { síltica, com } \\
\text { intercalações } \\
\text { argilo-siltosas } \\
\text { milimétricas a } \\
\text { subdecimétricas }\end{array}$ & $\begin{array}{l}\text { Estratificação horizontal ou } \\
\text { cruzada de baixo ângulo, } \\
\text { laminação horizontal } \\
\text { heterolítica, localmente } \\
\text { ondulada, laminação cruzada } \\
\text { de cavalgamento, estruturas de } \\
\text { sobrecarga na base de estratos } \\
\text { arenosos, gretas de } \\
\text { dessecação com flocos de lama } \\
\text { encurvados }\end{array}$ & $\begin{array}{l}\text { Inundações efêmeras } \\
\text { em domínio de } \\
\text { interdunas úmidas }\end{array}$ \\
\hline $\begin{array}{l}\text { Ash - arenito com } \\
\text { estratificação sub- } \\
\text { horizontal }\end{array}$ & $\begin{array}{l}\text { Areia muito fina, } \\
\text { síltica }\end{array}$ & $\begin{array}{l}\text { Laminação milimétrica, sub- } \\
\text { horizontal, com frequente } \\
\text { obliteração por bioturbação }\end{array}$ & $\begin{array}{c}\text { Abandono da } \\
\text { sedimentação em } \\
\text { domínio de interdunas } \\
\text { úmidas }\end{array}$ \\
\hline
\end{tabular}


Quadro 4.1.1 - Fácies sedimentares características do sistema eólico úmido Piramboia no Estado de São Paulo.

(conclusão)

\begin{tabular}{|c|c|c|c|}
\hline Fácies & Granulometria & $\begin{array}{c}\text { Estruturas e fácies } \\
\text { associadas }\end{array}$ & $\begin{array}{c}\text { Processos e contexto } \\
\text { deposicional }\end{array}$ \\
\hline $\begin{array}{c}\text { Acp - arenito com } \\
\text { intraclastos } \\
\text { preenchendo } \\
\text { paleocanais }\end{array}$ & $\begin{array}{c}\text { Areia fina a muito } \\
\text { fina, com } \\
\text { grânulos e seixos } \\
\text { intraclásticos } \\
\text { acanalada de baixo ângulo de } \\
\text { mergulho, truncada por } \\
\text { paleocanal decamétrico, com } \\
\text { origem erosiva (canal) inferida } \\
\text { pela associação de marcas de } \\
\text { sola e brecha basal com } \\
\text { intraclastos do arenito abaixo }\end{array}$ & $\begin{array}{c}\text { Fluxos subaquosos } \\
\text { trativos efêmeros } \\
\text { desenvolvidos em } \\
\text { depressões interdunas, } \\
\text { provavelmente } \\
\text { enxurradas ou wadi } \\
\text { (Caetano-Chang \& Wu }\end{array}$ \\
$\begin{array}{c}\text { Am - arenito } \\
\text { maciço }\end{array}$ & $\begin{array}{c}\text { Areia muito fina, } \\
\text { síltica }\end{array}$ & $\begin{array}{c}\text { Ausência de estrutura aparente, } \\
\text { geralmente sobre fácies de } \\
\text { brecha intraformacional (Bm) }\end{array}$ & $\begin{array}{c}\text { Avanço de lençóis de } \\
\text { areia, em estágio inicial } \\
\text { de instalação do } \\
\text { sistema eólico e em } \\
\text { margem de campo de } \\
\text { dunas costeiro }\end{array}$ \\
\hline $\begin{array}{c}\text { Bm - brecha } \\
\text { intraformacional } \\
\text { maciça com clastos } \\
\text { de silexito }\end{array}$ & $\begin{array}{c}\text { Clastos de silexito } \\
\text { ou intraclastos } \\
\text { pelíticos (siltitos) } \\
\text { dispersos em } \\
\text { matriz areno- } \\
\text { pelítica maciça }\end{array}$ & $\begin{array}{c}\text { Ausência de estrutura aparente, } \\
\text { com ocorrência na interface } \\
\text { entre a sucessão de siltitos da } \\
\text { Formação Corumbataí/Teresina } \\
\text { e os arenitos estratificados ou } \\
\text { maciços da Formação } \\
\text { Piramboia }\end{array}$ & $\begin{array}{c}\text { Passagem entre } \\
\text { sistemas deposicionais } \\
\text { marinho raso e eólico } \\
\text { úmido (Camada } \\
\text { Porangaba de Matos \& } \\
\text { Coimbra, 1997) }\end{array}$ \\
\hline
\end{tabular}

Fonte: Gesicki (2007), com base em Giannini et al. (2004).

Quadro 4.1.2 - Associação tentativa entre fácies reconhecidas em campo (Gesicki, 2007, com base em Giannini et al., 2004) e fácies reconhecidas em testemunhos.

(continua)

\begin{tabular}{|c|c|c|c|c|}
\hline \multicolumn{2}{|c|}{$\begin{array}{l}\text { Profundidade } \\
(\mathbf{m})\end{array}$} & \multirow{2}{*}{ Descrição } & \multirow{2}{*}{$\begin{array}{l}\text { Fácies } \\
\text { reconhecida } \\
\text { em } \\
\text { testemunho }\end{array}$} & \multirow{2}{*}{$\begin{array}{l}\text { Possível(s) } \\
\text { fácies de } \\
\text { campo }\end{array}$} \\
\hline De & Até & & & \\
\hline 6,9 & 15,1 & $\begin{array}{l}\text { Arenito fino a muito fino, com lâminas pelíticas em } \\
\text { formato ondulado e lentes de lama com contatos } \\
\text { nítidos, côncavas para cima ou inclinadas ao } \\
\text { acamamento. }\end{array}$ & Ap & Acbl \\
\hline 15,1 & 15,9 & $\begin{array}{l}\text { Arenito muito fino a fino, com estratificação inclinada } \\
\text { menos de } 10^{\circ} \text {. }\end{array}$ & $\mathrm{Ae}$ & Aca ou Acb \\
\hline 15,9 & 17,1 & $\begin{array}{l}\text { Arenito bimodal, muito fino, com grãos de areia } \\
\text { grossa esparsos, maciço. }\end{array}$ & $\mathrm{Am}$ & $\begin{array}{l}\text { Ash, Am, } \\
\quad \text { Acb }\end{array}$ \\
\hline 17,1 & 17,9 & $\begin{array}{l}\text { Arenito muito fino com lâminas pelíticas e presença } \\
\text { de séries tabulares sub-horizontais de laminações } \\
\text { cruzadas com cerca de } 2 \mathrm{~cm} \text { de espessura. }\end{array}$ & Ap & Acbl \\
\hline 17,9 & 21,7 & $\begin{array}{l}\text { Arenito fino a médio, com estratificação sub- } \\
\text { horizontal e cavidades milimétricas concentradas } \\
\text { em horizonte de até } 2 \mathrm{~cm} \text {. }\end{array}$ & $\mathrm{Ae}$ & Aca ou Acb \\
\hline
\end{tabular}


Quadro 4.1.2 - Associação tentativa entre fácies reconhecidas em campo (Gesicki, 2007, com base em Giannini et al., 2004) e fácies reconhecidas em testemunhos.

(conclusão)

\begin{tabular}{|c|c|c|c|c|}
\hline \multicolumn{2}{|c|}{$\begin{array}{l}\text { Profundidade } \\
\qquad(\mathrm{m})\end{array}$} & \multirow{2}{*}{ Descrição } & \multirow{2}{*}{$\begin{array}{l}\text { Fácies } \\
\text { reconhecida } \\
\text { em } \\
\text { testemunho }\end{array}$} & \multirow{2}{*}{$\begin{array}{l}\text { Possível(s) } \\
\text { fácies de } \\
\text { campo }\end{array}$} \\
\hline $\mathrm{De}$ & Até & & & \\
\hline 25,7 & 27,9 & $\begin{array}{l}\text { Arenito com bimodalidade granulométrica não } \\
\text { segregada, fino a médio, com grãos de areia grossa } \\
\text { a seixos de até } 5 \mathrm{~mm} \text {, maciço. }\end{array}$ & Am & $\begin{array}{c}\text { Ash, Am ou } \\
\text { Acb }\end{array}$ \\
\hline 27,9 & 29,8 & $\begin{array}{l}\text { Arenito fino, com estratificação incipiente, } \\
\text { localmente mosqueados, com cavidades de até } 2 \\
\text { cm concentradas em horizonte de até } 15 \mathrm{~cm} \text {. }\end{array}$ & $\mathrm{Ae}_{i}$ & $\begin{array}{c}\text { Aca, Acb ou } \\
\text { Ash }\end{array}$ \\
\hline 29,8 & 32,5 & $\begin{array}{l}\text { Arenito fino a médio, com estratificação incipiente a } \\
\text { localmente nítida, de baixo ângulo de mergulho, } \\
\text { marcada pela presença de segregação granular, e } \\
\text { com nódulos carbonáticos de até } 2 \mathrm{~cm} \text {, } \\
\text { concentrados em horizonte de cerca de } 20 \mathrm{~cm} \text {. }\end{array}$ & $A e_{i}$ & Aca ou Acb \\
\hline
\end{tabular}

As fácies com estratificações cruzadas na Formação Piramboia em São Paulo são dominadas pelo padrão acanalado, associado à migração de formas de leito de crista e perfil sinuoso, como, por exemplo, dentre as eólicas, consideradas dominantes nesta unidade, dunas barcanas e cadeias barcanoides (Giannini et al. 2004). Estratificações cruzadas acanaladas possuem geometria assintótica ou tangencial na base. Desse modo, as séries (sets) destas estratificações exibem ângulos de mergulho baixos $\left(<10^{\circ}\right)$ por extensões muito maiores que ângulos altos. Isto leva, como uma espécie de viés metodológico, a uma super-representação de estratificações de ângulo baixo (fácies Acb, no Quadro 4.1.2), que é tão mais acentuada quanto menores as dimensões do afloramento, já que em escala espacial restrita a informação sobre a continuidade lateral entre cruzadas de ângulo baixo e alto, numa mesma série, é frequentemente perdida. Em testemunhos de sondagem, onde a representatividade espacial é tipicamente muito reduzida, este viés é fortemente presente. Por esta razão, em estratificação cruzadas acanaladas, testemunhos de sondagem subestimam a presença de estratificações cruzadas de ângulo alto, em comparação com afloramentos, o que leva, por extensão, a superinterpretação de fácies interdunas em relação às de dunas.

Assim, o baixo ângulo de mergulho observado nas estratificações das fácies $A e$ e $\mathrm{Ae}_{\mathrm{i}}$, embora aponte para a fácies $\mathrm{Acb}$, não permite descartar a possibilidade de continuidade lateral, na mesma série de estratos, com cruzadas de alto ângulo, o que, em afloramento, seria provavelmente descrito como fácies Aca (quadros 4.1.1 e 
4.1.2). Por outro lado, a segregação granular $e o$ alto ângulo de mergulho observado no arenito da fácies Ae amostrado na sondagem SM-222 entre 21,7 e 25,7 m de profundidade indica, com relativa segurança, tratar-se da fácies Aca, formada por migração de frente de dunas eólicas.

A pouca nitidez da estratificação, tipicamente observada em arenitos da fácies $\mathrm{Ae}_{i}$ entre 27,9 a 32,5 m de profundidade na sondagem SM-222, pode ser atribuída à obliteração das estruturas deposicionais por processos penecontemporâneos à sedimentação como bioturbação, pedogênese e liquidificação. Liquidificação, por depender da saturação em água, associa-se preferencialmente, em sistemas eólicos, a zonas interdunas úmidas ou inundadas. Pedogênese, da mesma maneira, tem melhor condições de desenvolver-se onde a taxa de sedimentação for menor, portanto nas zonas deflacionárias de planícies interdunas (Kocurek, 1981; Kocurek \& Dott, 1981; Kocurek \& Nielson, 1986). Efeito semelhante controla a distribuição e intensidade das bioturbações. Sob esse ponto de vista, a fácies $\mathrm{Ae}_{i}$ possui, em comparação com a fácies $\mathrm{Ae}$, probabilidade maior de, de fato, representar superfícies deposicionais pouco inclinadas de zonas interdunas. Além disso, na fácies $\mathrm{Ae}_{\mathrm{i}}$ em cerca de $30 \mathrm{~m}$ de profundidade, tem-se a ocorrência dos nódulos carbonáticos, que, admitida sua correspondência com calcretes, também seriam mais tipicamente desenvolvidos sobre fácies interdunas, sobretudo aquelas com menor taxa de sedimentação, caracterizadas pela intensificação de processos de bioturbação e pedogênese. Em dois dos intervalos associados à ocorrência das fácies $\mathrm{Ae}_{i}$ e $\mathrm{Ae}$, aproximadamente entre 28 e $30 \mathrm{~m}$ e entre 18 e $22 \mathrm{~m}$, as cavidades subesféricas encontradas (Figura 3.2.7) podem ser vestígios, na forma de poros móldicos, da antiga presença de nódulos carbonáticos, que teriam sido dissolvidos na diagênese mais tardia (Figura 3.2.5).

Bimodalidade granulométrica acentuada, como a dos arenitos maciços da fácies Am (Figura 3.2.4 e Quadro 4.1.2), é uma feição típica de interdunas eólicas (Taira \& Scholle, 1979; Giannini et al., 2008), e representa a alternância entre deflação, concentrando pavimentos superficiais (lags) de areia média a grânulos, e deposição. Os clastos de lama encontrados nesta fácies podem ser interpretados como resultado da erosão e redeposição subaquosa de depósitos de decantação, mais uma vez evidenciando o contexto de interdunas, no caso sujeitas a inundação.

As laminações cruzadas observadas no arenito da fácies Ap a cerca de 17,2 $\mathrm{m}$ de profundidade (Figura 3.2.2 A) são sugestivas de cavalgamento subcrítico de 
marcas onduladas, e podem tanto ser eólicas como subaquosas, mas, em ambos os casos, mais características de zonas interdunas. Já o formato ondulado das lâminas pelíticas do arenito da fácies Ap a cerca de 11,1 m (Figura 3.2.2 B) sugere que se trate de laminação heterolítica (flaser, wavy), tipicamente formada em condições subaquosas e, portanto, associável a interdunas inundadas. As lentes de lama côncavas para cima ou inclinadas ao acamamento encontradas nesta unidade podem ser flocos de lama encurvados, formados por dessecação da lama acumulada nas interdunas intermitentemente inundadas, seguida de seu remanejamento e soterramento por areia eólica. Portanto, é provável que a fácies Ap, reconhecida nos testemunhos, corresponda à fácies Acbl de Gesicki (2007) (Quadro 4.1.1).

O fato de o teor de pelíticos ser inversamente proporcional ao tamanho médio dos grãos (Figura 3.6.1) indica que parte desta fração granulométrica, sobretudo a presente nas amostras mais finas da petrofácies Epa, a qual é associada à fácies Ap, e portanto a Acbl de Gesicki (2007), seja deposicional.

O teor de material pelítico correlaciona-se ainda às concentrações totais e parciais de cimento (figuras 3.6.6 a 3.6.8) e à proporção de contatos grão-cimento (Figura 3.6.9), indicando que esta fração granulométrica também inclui, especialmente em outras fácies que não a Ap, material de origem diagenética, como confirmado ao MEV-EDS pela presença de cristálitos bem formados de esmectita, típicos de autigênese (Figura 3.3.11). A presença notável de cimento argiloferruginoso em grandes quantidades nas porções mais rasas do intervalo estratigráfico estudado pode ser considerada indício de que o material pelítico é, pelo menos em parte, diageneticamente infiltrado a partir de horizontes superiores.

A correlação positiva entre densidade de empacotamento e profundidade (Figura 3.6.41A) pode indicar compactação eodiagenética anterior à cimentação nos depósitos mais profundos. Isto também explicaria em parte a maior porcentagem de arcabouço nestes depósitos. A compactação mais intensa na base da coluna sedimentar pode estar relacionada ao maior efeito da própria carga de soterramento e/ou à cimentação comparativamente mais lenta das fácies de dunas, mais comuns na parte inferior da sucessão, em relação às fácies de interdunas, que aumentam no topo da sucessão. Deve-se lembrar que a cimentação precoce, bastante factível nas fácies interdunas, previne a compactação por fechar os poros e "congelar" a trama original do arcabouço. 
A correlação inversa entre as proporções de grãos arredondados e de cimento esmectítico (Figura 3.6.21) pode ser considerada inusitada e, portanto, difícil de ser explicada. Admitindo-se que a presença de grãos arredondados tenha controle faciológico e que seja favorecida nas fácies de dunas eólicas, é possível que esta correlação se deva ao fato de que as fácies interdunas, mais ricas em grãos não eólicos e, portanto, menos arredondados, sejam preferencialmente cimentadas por argilominerais na eodiagênese, dada a presença mais frequente $\mathrm{e}$ constante de água e solutos. A maior cimentação eodiagenética nas fácies interdunas da parte superior da coluna é compatível com a queda ascendente de densidade de empacotamento (Figura 3.6.41A).

\subsection{Influência da petrotrama, textura e mineralogia sobre parâmetros geomecânicos}

As relações testadas entre o grau de coerência e as diversas propriedades petrográficas são em grande parte inconclusivas, mas algumas hipóteses podem ser formuladas para explicar as possíveis correlações encontradas.

A possível correlação positiva entre a coerência e o tamanho médio dos grãos (Figura 3.6.44), mais clara ao considerar os dados granulométricos obtidos por análise petrográfica, pode ser subproduto da granodecrescência ascendente observada ao longo da sondagem SM-222. Nesse caso, haveria não necessariamente interdependência entre tamanho médio dos grãos e coerência, mas sim correlação de ambas as variáveis com uma terceira variável em comum neste estudo de caso, a profundidade, que mostra clara correlação com a coerência (Figura 3.6.60). Horizontes mais rasos costumam ser menos coerentes, pois estão mais expostos a processos telodiagenéticos que, em geral, atuam na decomposição da rocha.

Neste sentido, a tendência de arenitos mais coerentes apresentarem arcabouços com maiores quantidades de feldspato (Figura 3.6.55) pode estar relacionada ao fato destes arenitos serem mais comuns em maiores profundidades, onde teriam sido menos expostos aos processos telodiagenéticos, supostamente responsáveis pela dissolução dos grãos de feldspato. Seria esperado, portanto, encontrar correlação positiva entre porcentagem de feldspato e profundidade e, pressupondo que todos os poros intragranulares móldicos e alveolares sejam 
formados pela dissolução de feldspato, seria esperado também encontrar correlação inversa entre porosidade intragranular e profundidade, o que de fato ocorre (figuras 3.6.42A e 3.6.43). A correlação inversa entre as proporções de feldspato e de cimento constituído por óxi-hidróxido metálico (Figura 3.6.35) evidencia que grãos de feldspato dissolvidos foram preferencialmente preenchidos pelos óxi-hidróxidos e/ou que as condições oxidantes envolvidas na formação deste cimento são propicias à dissolução de grãos de feldspato.

$\sigma_{50}$ correlaciona-se de maneira inversa ao tamanho médio dos grãos (Figura 3.6.61), resultado semelhante ao encontrado por Fahy \& Guccione (1979), ao passo que $E_{s}$ se correlaciona diretamente (Figura 3.6.76), conforme verificado por Ulusay et al. (1994), ou seja, arenitos mais finos, apesar de mais resistentes, deformam-se com mais facilidade. No caso dos arenitos da Formação Piramboia analisados, existe a possibilidade de que correlação inversa entre tamanho médio dos grãos e $E_{s}$ seja subproduto da correlação inversa entre teor de pelíticos e tamanho médio dos grãos.

A correlação inversa entre tamanho médio dos grãos e $\sigma_{50}$ contraria a correlação direta do tamanho médio dos grãos com o grau de coerência. Era esperado que $\sigma_{50}$ e grau de coerência se correlacionassem do mesmo modo com tamanho médio dos grãos, pois o grau de coerência é em tese uma estimativa qualitativa da resistência à compressão.

O fato de a correlação entre grau de coerência e resistência à compressão uniaxial ser pouco evidente (Figura 3.6.66 e Tabela 3.6.5) pode ser consequência de dois fatores, ligados aos procedimentos analíticos: 1) o tempo decorrido entre as avaliações de graus de coerência, realizadas no ano de 2013, e os ensaios de compressão, executados em 2017; 2) a diferença entre estas duas avaliações quanto à condição de umidade da rocha, já que o grau de coerência foi medido com a amostra em condições naturais, ao passo que os ensaios de compressão foram executados após secagem dos corpos de prova em estufa. Os corpos de prova da petrofácies Epa apresentaram os valores de $\sigma_{50}$ mais discrepantes em relação às estimativas por meio do grau de coerência, provavelmente em consequência do seu maior teor de pelíticos e da cimentação por argilominerais, haja visto que arenitos com maiores teores de argila são mais sensíveis a variações na umidade e apresentam maiores variações na resistência entre os estados seco e saturado (Hawkins \& McConnel, 1992). 
Outra questão que interfere na baixa correlação entre graus de corência e resistência à compressão neste estudo de caso é o fato de as diferenças entre os valores de $\sigma_{u}$ dos arenitos analisados serem irrisórias frente à sensibilidade grosseira das escalas de graus de coerência. O Quadro 4.1.3 faz uma comparação tentativa dos graus de coerência de Guidicini et al. (1972), no qual se baseou a avaliação da coerência dos arenitos neste estudo, com a classificação definida pela ABGE (1983). Por terem as rochas aqui estudadas resistências muito baixas (Figura 3.5.2), a grande maioria delas seria enquadrada na coerência muito branda ( $\sigma_{u}$ entre 1 e $5 \mathrm{MPa}$ ), com menor parte situando-se no limiar entre branda e muito branda ( $\sigma_{u}$ entre 5 e $7 \mathrm{MPa}$ ), entre os graus $\mathrm{C} 3$ e C2.

Quadro 4.1.3 - Quadro comparativo entre os graus de coerência de Guidicini et al. (1972) e da ABGE (1983), baseados em características de tenacidade, dureza e friabilidade, avaliadas pela resistência oferecida ao impacto do martelo e ao risco de lâmina de aço, e estimativa de $\sigma_{u}$ proposta pela ABGE (1983).

\begin{tabular}{|c|c|c|c|c|c|c|}
\hline \multicolumn{3}{|c|}{ Guidicini et al. (1972) } & \multicolumn{4}{|c|}{ ABGE (1983) } \\
\hline Sigla & Denominação & Características & Sigla & Denominação & Características & $\begin{array}{c}\sigma_{\mathrm{u}} \\
(\mathrm{MPa})\end{array}$ \\
\hline C4 & Incoerente & $\begin{array}{l}\text { Quebra com a pressão } \\
\text { dos dedos, } \\
\text { desagregando-se. } \\
\text { Pode ser cortada com } \\
\text { lâmina de aço. Friável e } \\
\text { escavável com lâmina. }\end{array}$ & $\mathrm{R}_{0}$ & $\begin{array}{c}\text { Extremamente } \\
\text { branda }\end{array}$ & Marcada pela unha & $\begin{array}{c}0,25- \\
1,0\end{array}$ \\
\hline C3 & $\begin{array}{l}\text { Pouco } \\
\text { coerente }\end{array}$ & $\begin{array}{l}\text { Quebra com facilidade } \\
\text { ao golpe do martelo, } \\
\text { produzindo fragmentos } \\
\text { que podem ser partidos } \\
\text { manualmente. } \\
\text { Superfície facilmente } \\
\text { riscável com lâmina de } \\
\text { aço. Escarificável. }\end{array}$ & $\mathrm{R}_{1}$ & Muito branda & $\begin{array}{l}\text { Esmigalha-se sob o } \\
\text { impacto da ponta do } \\
\text { martelo; pode ser } \\
\text { raspada por canivete. }\end{array}$ & $1-5$ \\
\hline \multirow[t]{2}{*}{$\mathrm{C} 2$} & \multirow{2}{*}{$\begin{array}{l}\text { Medianamente } \\
\text { coerente }\end{array}$} & \multirow{2}{*}{$\begin{array}{l}\text { Quebra com dificuldade } \\
\text { ao golpe do martelo. } \\
\text { Superfície riscável com } \\
\text { lâmina de aço. } \\
\text { Escavável a fogo. }\end{array}$} & $\mathrm{R}_{2}$ & Rocha branda & $\begin{array}{l}\text { Pode ser raspada por } \\
\text { canivete com } \\
\text { dificuldade; marcada } \\
\text { por firme pancada com } \\
\text { ponta do martelo de } \\
\text { geólogo. }\end{array}$ & $5-25$ \\
\hline & & & $\mathrm{R}_{3}$ & $\begin{array}{l}\text { Medianamente } \\
\text { resistente }\end{array}$ & $\begin{array}{l}\text { Não pode ser raspada } \\
\text { por canivete; amostras } \\
\text { podem ser fraturadas } \\
\text { com um único golpe do } \\
\text { martelo de geólogo. }\end{array}$ & $25-50$ \\
\hline \multirow{3}{*}{ C1 } & \multirow{3}{*}{ Coerente } & \multirow{3}{*}{$\begin{array}{l}\text { Quebra com dificuldade } \\
\text { ao golpe do martelo, } \\
\text { produzindo fragmentos } \\
\text { de bordas cortantes. } \\
\text { Superfície dificilmente } \\
\text { riscável por lâmina de } \\
\text { aço. Somente } \\
\text { escavável a fogo. }\end{array}$} & $\mathrm{R}_{4}$ & Resistente & $\begin{array}{l}\text { Amostras requerem } \\
\text { mais de um golpe de } \\
\text { martelo para } \\
\text { fraturarem-se. }\end{array}$ & $50-100$ \\
\hline & & & $\mathrm{R}_{5}$ & $\begin{array}{l}\text { Muito } \\
\text { resistente }\end{array}$ & $\begin{array}{l}\text { Amostras requerem } \\
\text { muitos golpes de } \\
\text { martelo para } \\
\text { fraturarem-se. }\end{array}$ & $\begin{array}{l}100- \\
250\end{array}$ \\
\hline & & & $\mathrm{R}_{6}$ & $\begin{array}{l}\text { Extremamente } \\
\text { resistente }\end{array}$ & $\begin{array}{l}\text { Amostras podem ser } \\
\text { apenas lascadas com o } \\
\text { martelo de geólogo. }\end{array}$ & $>250$ \\
\hline
\end{tabular}

Fontes: Guidicini et al. (1972); ABGE (1983). 
A correlação inversa observada entre $E_{s}$ e teor de pelíticos (Figura 3.6.78) está possivelmente associada à microporosidade dos argilominerais. Kowallis et al. (1984) e Han et al. (1986) concluíram que arenitos com maiores proporções de argila apresentam menores módulos elásticos, devido à redução das velocidades de propagação de ondas mecânicas com o incremento desta fração granulométrica, o que os primeiros autores atribuíram à significativa microporosidade dos argilominerais. Shuckla et al. (2013) encontraram correlação inversa entre teor de argila em folhelhos e módulo de elasticidade (E) obtido por meio de nanoindentação.

Arenitos de fácies interdunas e petrofácies Epa, os quais têm maior quantidade relativa de argilominerais, tendem a apresentar maiores resistências à compressão e menores módulos de deformabilidade (figuras 3.5.1, 3.6.64 e 3.6.78). A hipótese aqui aventada para explicar este resultado é a de que a microporosidade dos argilominerais permite a estes arenitos armazenar a energia da compressão, sem que se rompam. Por isso, verifica-se, no caso dos corpos de prova mais pelíticos, resistência à compressão relativamente alta e módulo de deformabilidade muito mais baixo. $O$ teor de quartzo teria efeito oposto ao dos argilominerais, haja visto que os seus grãos são muito menos suscetíveis à deformação que os filossilicatos. A correlação positiva encontrada entre $E_{s}$ e porcentagem de grãos de quartzo (Figura 3.6.86) estaria relacionada com esse último efeito.

A maior porcentagem de pelíticos também é uma característica comum aos arenitos com grãos do arcabouço mais finos. Talvez, por este motivo, também se observa correlação inversa entre tamanho médio de grãos do arcabouço e módulo de deformabilidade.

O teor de pelíticos, quando examinado em termos de distribuição estatística por classe de grau de coerência, apresenta tendência para aumento dos valores de intervalo interquartis e mediana com o aumento do grau de coerência, com exceção do grau C2 (Figura 3.6.46). Como foi observada correlação entre teor de pelíticos e proporção de cimento total (Figura 3.6.16), poder-se-ia supor que a parcela deste teor referente à cimentação das amostras seja responsável pelo padrão observado. Porém, nota-se que as classes de arenitos mais coerentes apresentam porcentagens medianas de cimento total cada vez menores, excetuando-se os graus C4/C3 e C3/C4 (Figura 3.6.54), ao passo que as quantidades de cimento esmectítico são, em geral, maiores nos arenitos de coerência C3/C2 a C2, com pequena 
sobreposição dos intervalos interquartis (Figura 3.6.56). Isto sugere que, dentre os cimentos, é especificamente o esmectítico, provavelmente eo a mesodiagenético, que contribui para aumentar a coerência dos arenitos; e explica também porque a petrofácies Ems, relativamente pobre em cimento esmectítico, associa-se a graus de coerência mais baixos (Figura 3.6.58). Do mesmo modo, a petrofácies Epa, sem esmectita e rica em cimento argilo-ferruginoso, possivelmente associado a processos superficiais telodiagenéticos, também se associa a graus de coerência relativamente baixos.

Os arenitos de baixa resistência (abaixo de $20 \mathrm{MPa}$ ), ao serem submetidos a esforços compressivos, desenvolvem fraturas intergranulares, ao passo que arenitos mais resistentes desenvolvem fraturas intragranulares (Dobereiner \& De Freitas, 1986). Assim, a influência de parâmetros relacionados ao entrosamento dos grãos de areia em arenitos pouco resistentes, como empacotamento, tipos de contato e formato dos grãos, pode ser comparável ao que ocorre nas areias incoesivas.

O formato dos grãos influencia o comportamento mecânico das areias incoesivas, pois determina o encaixe e entrosamento entre os grãos e o modo como eles deslizam entre si frente às solicitações por fontes externas. Areias constituídas por partículas esféricas e arredondadas têm ângulos de atrito sensivelmente menores do que areias constituídas por grãos angulosos. Por outro lado, grãos mais angulosos são mais suscetíveis a se quebrarem, pois as forças são transmitidas pelos contatos entre os grãos (Pinto, 2006).

Apesar de ser um resultado estatisticamente não significativo, a proporção de grãos subangulares é uma das propriedades avaliadas que melhor se correlaciona a $\sigma_{u}$. Presume-se que esta correlação possa ser explicada pelo fato de que a maior presença de grãos mais angulosos favoreça em tese o encaixe mútuo entre os grãos, resultando em algum acréscimo na resistência.

Grãos com menores valores medianos da razão entre os eixos menor e maior apresentam tendência para quantidade relativa mais elevada de contatos retos (Figura 3.6.31), em detrimento de contatos tangenciais, devido à sua morfologia menos equidimensional. Considerando que equidimensionalidade, no caso, corresponde à esfericidade sensu stricto, haja vista o domínio de grãos arredondados a subarredondados nos arenitos estudados, quanto menos equidimensionais os grãos, maior a probabilidade de encaixe entre eles através de contatos longos. 
Pressupondo que arenitos com empacotamento mais denso representem areias mais compactas antes da diagênese, a relação entre coerência e empacotamento observada nos arenitos (Figura 3.6.49) pode ser justificada por analogia ao que se verifica em areias compactas, nas quais o entrosamento dos grãos é maior. Nestas areias, as tensões de cisalhamento devem ser suficientes para vencer os obstáculos representados pelos outros grãos em sua trajetória (Pinto, 2006).

Segundo Dobereiner \& De Freitas (1986), o contato intergranular é o parâmetro de trama que se correlacionou de maneira mais significativa com $\sigma_{u}$ e $E$, sendo diretamente proporcional ao empacotamento dos grãos. Contudo, o empacotamento não mostrou correlação com $\sigma_{50}$ neste estudo (Figura 3.6.69), assim como em outros trabalhos anteriores (Shakoor \& Bonelli, 1991; Ulusay et al., 1994; Bell \& Culshaw, 1998; Bell \& Lindsay, 1999). Já $E_{s}$ apresentou correlação significativa e positiva com a densidade de empacotamento (Figura 3.6.81), assim como encontrado também por Bell (1978). Resultado semelhante foi constatado por Ulusay et al. (1994), que encontraram correlação significativa e positiva entre módulo de deformabilidade e proximidade de empacotamento. Neste contexto, distribuições granulométricas do arcabouço com maior desvio padrão também favoreceriam maiores módulos de deformabilidade (Figura 3.6.77), já que grãos menores podem preencher melhor os espaços intergranulares formados por grãos maiores, o que tornaria o arenito menos deformável.

A estratificação mostrou-se característica mais comum nos arenitos menos coerentes (Figura 3.6.57), e as petrofácies com estratificação nítida (Efsx, Epa e Ems) são aquelas que apresentam maior proporção de amostras com graus de coerência mais baixos (Figura 3.6.58). Esta relação, porém, pode ser apenas uma decorrência da queda da coerência com a redução de profundidade, controlada por outros fatores (aumento da telodiagênse, por exemplo), uma vez que os arenitos estudados com estratificação mais nítida situam-se preferencialmente em menores profundidades, como é possível observar no perfil vertical da sondagem SM-222 (Figura 3.2.8).

É nítida a correlação entre densidade aparente e resistência (Figura 3.6.68 A), resultado encontrado por diversos autores (Bell, 1978; Dobereiner, 1984; Shakoor \& Bonelli, 1991; Bell \& Culshaw, 1998; Bell \& Lindsay, 1999). Esperava-se encontrar também correlação inversa entre porosidade e resistência, conforme observado em 
trabalhos anteriores (Bell, 1978; Shakoor \& Bonelli, 1991; Bell \& Culshaw, 1998; Bell \& Lindsay, 1999; Jeng et al., 2004; Tamrakar et al., 2007), uma vez que a porosidade é propriedade de trama e textura com influência direta no valor da densidade. Esta correlação de fato ocorre (Figura 3.6.68 B), porém não de maneira significativa. Neste caso, a ausência de significância estatística provavelmente se deve ao reduzido número de amostras $(\mathrm{N}=7)$. 


\section{CONCLUSÕES}

Com base nos resultados apresentados e discutidos, foi possível chegar às seguintes conclusões:

1. Nos testemunhos estudados foram identificadas as fácies $A p, A m$ e $A e_{i}$, associadas a domínio de interdunas úmidas ou inundadas, e a fácies $A e$, que, nos casos de ângulo de mergulho da estratificação maior que $10^{\circ}$, associam-se provavelmente à migração de frente de dunas eólicas. Arenitos da fácies Ae com estratificação de baixo ângulo podem ser tanto depósitos de interdunas como de dunas, uma vez que a reduzida representatividade espacial dos testemunhos não é suficiente para identificar eventual continuidade lateral para cruzadas acanaladas de alto ângulo.

2. A correlação inversa entre a proporção de contatos retos e a média das razões entre os eixos menor e maior dos grãos do arcabouço aponta para a morfologia dos grãos como um dos fatores controladores da natureza dos contatos intergranulares. Mantida constante a condição de compactação química, grãos menos equidimensionais tendem a formar maior número de contatos retos, ao passo que grãos mais equidimensionais e mais arredondados favorecem maior número de contatos tangenciais.

3. É mais comum encontrar a petrofácies Epa em um estado menos coerente pelo fato de ela ser rica em argila, componente suscetível a grandes alterações no comportamento geomecânico por conta de variações de umidade, aliado à sua posição mais superficial no perfil, onde esteve, portanto, mais sujeita aos processos telodiagenéticos.

4. Os graus de coerência sugeridos por Guidicini et al. (1972) e a classificação da ABGE (1983), aferidos com base em propriedades de tenacidade, dureza e friablidade, puderam fornecer uma estimativa adequada da resistência à compressão uniaxial dos arenitos estudados, tendo em vista a finalidade à qual se propõem.

5. A diferença de teor de umidade entre o momento da avaliação da coerência, realizada em 2013, e o momento dos ensaios à compressão, executados em 2017, deve ser a principal responsável pela falta de correlação direta entre coerência e resistência à compressão uniaxial. Admitida a grande sensibilidade da argila à 
umidade, em termos de comportamento mecânico, esta hipótese é reforçada pelo fato de os corpos de prova que apresentaram maior discrepância entre resistência à compressão uniaxial e grau de coerência serem justamente os mais argilosos.

6. A correlação direta entre coerência do arenito e proporção de grãos de feldspato no arcabouço não necessariamente indica que a proporção de feldspato no arcabouço favoreça a coerência. A hipótese mais provável é que as rochas mais ricas em feldspato são as menos expostas à telodiagênese, a qual seria a responsável pela dissolução dos feldspatos e, ao mesmo tempo, pela diminuição da coerência.

7. A correlação inversa entre as proporções de feldspato e de cimentação por oxihidróxido metálico permite sugerir a possibilidade de que a porosidade deixada pela dissolução de grãos de feldspato foi preferencialmente preenchida, nas profundidades menores, por cimento de óxi-hidróxidos metálicos. Uma interpretação possível, não excludente, é a de que condições oxidantes sejam favoráveis à dissolução dos grãos de feldspato. Essas condições parecem atuar com maior intensidade em direção ao topo do intervalo estratigráfico estudado, uma vez que as proporções de cimento constituído por óxi-hidróxidos metálicos correlacionam-se inversamente à profundidade.

8. A densidade aparente correlaciona-se à resistência de maneira direta, enquanto que tamanho médio dos grãos do arcabouço e teor de pelíticos correlacionam-se inversamente ao módulo de deformabilidade. A correlação entre tamanho médio de grãos e módulo de deformabilidade pode ser subproduto da correlação deste módulo com o teor de pelíticos, visto que tamanho médio de grãos e teor de pelíticos também se correlacionam de maneira inversa. São necessários mais estudos para detalhar e entender melhor o significado destas correlações.

9. No estado seco, arenitos de fácies interdunas e petrofácies Epa, com maior quantidade relativa de argilominerais, tendem a apresentar maiores resistências à compressão e menores módulos de deformabilidade.

10. Arenitos com empacotamento mais fechado tendem a deformar-se menos, pois apresentam menor espaço intergranular para acomodar a deformação.

11. Arenitos com distribuição granulométrica pior selecionada apresentam maiores módulos de deformabilidade, uma vez que os espaços intergranulares que serviriam à acomodação da deformação, por meio de rearranjo da posição dos grãos do arcabouço, podem já estar preenchidos por grãos menores. 


\section{REFERÊNCIAS BIBLIOGRÁFICAS}

Ab'Sáber, A.N., 1969, A depressão periférica paulista: um setor das áreas de circundesnundação pós-cretácica na bacia do Paraná: Geomorfologia, São Paulo, no. 5, p. 1-15.

Almeida, F.F.M., Barbosa, O. 1953, Geologia das quadrículas de Piracicaba e Rio Claro, Estado de São Paulo: Boletim da Divisão de Geologia e Mineralogia, DNPM, no. 143, p. 1-96.

Almeida, F.F.M., 1954, Botucatu, um deserto triássico da América do Sul: Boletim da Divisão de Geologia e Mineralogia, DNPM, Notas Preliminares e Estudos, no. 86, p. 1-21.

Almeida, F.F.M, 1964, Fundamentos geológicos do relevo paulista: Boletim do Instituto Geográfico e Geológico, São Paulo, n.41, p. 167-263.

Almeida, F.F.M., 1981, Síntese sobre a tectônica da Bacia do Paraná, in Atas, Simpósio Regional de Geologia, 3, São Paulo: Sociedade Brasileira de Geologia, v. 1, p.1-20.

ASTM - American Society for Testing and Materials. 2017, D7012 - 14: Standard test methods for compressive strength and elastic moduli of intact rock core specimens under varying states of stress and temperatures. West Conshohocken: $9 \mathrm{p}$.

Anon, 1970, The logging of rock cores for engineering purposes: Quarterly Journal of Engineering Geology, 3:1-14.

Assine, M.L., Piranha, J.M, Carneiro, C. D. R., 2004, Os Paleodesertos Pirambóia e Botucatu, in Mantesso-Neto, V., Bartorelli, A., Carneiro, C.D.R. e Brito-Neves, B.B., eds., Geologia do Continente Sul-Americano: evolução da obra de Fernando Flávio Marques de Almeida. SP, Brasil, Beca Produções Culturais Ltda, p. 77-92.

ABGE - Associação Brasileira de Geologia de Engenharia, 2013, Manual de Sondagens. Boletim no 3, 5a edição. São Paulo, ABGE.

ABNT - Associação Brasileira de Normas Técnicas, 2015, NBR 15845-2 - Rochas para revestimento - Parte 2: Determinação da densidade aparente, da porosidade aparente e da absorção de água. Rio Janeiro.

Bell, F.G., Culshaw, M.G., 1998, Petrographic and engineering properties of sandstones from the Sneiton Formation, Nottinghamshire, England: Quarterly Journal of Engineering Geology, no. 31, p. 5-19.

Bell, F.G., 1978, The physical and mechanical properties of the Fell sandstone, Northumberland, England: Engineering Geology, no. 12, p. 1-29.

Bell, F.G., Lindsay, P., 1999, The petrographic and geomechanical properties of some sandstones from the Newspaper Member of the Natal Group near Durban, South Africa: Engineering Geology, no. 53, p. 57-81.

Bieniawski, Z.T., 1973, Engineering classification of jointed rock amsses: Transactions of the South African Institution of Civil Engineers, 15:335-344.

Bigarella, J.J., Salamuni, R. 1961, Early Mesozoic wind patterns as suggested by dune bedding in the Botucatu Sandstones of Brazil and Uruguay. Geological Society of America, Bull. 72, p. 1089-1106.

BS - British Standard 5930, 1981, Code of practice for site investigations: British Standards Institution, London, $147 \mathrm{p}$.

Broch, E.M., Franklin, J.A., 1972, The point load strength test: International Journal of Rock Mechanics and Mining Sciences, 9:669-697. 
Caetano-Chang, M.R., Wu, F.T.A, 1992a, Composição faciológica das formações Pirambóia e Botucatu no centro-leste paulista e a delimitação do contato entre as unidades, in Resumos, Simpósio de Cronoestratigrafia da Bacia do Paraná, 1: Rio Claro, IGCE-UNESP, 1993, p. 93.

Caetano-Chang, M.R., Wu, F.T., 1992b, Bacia do Paraná: Formações Pirambóia e Botucatu, in Roteiro de Excursão, Congresso Brasileiro de Geologia, 37: São Paulo, Sociedade Brasileira de Geologia, vol. 2.

Caetano-Chang, M.R., Wu, F.T., 1994, Afloramento-modelo da Formação Pirambóia: Geociências, 13(2): 371-385.

Caetano-Chang, M.R., 1992, Estado d'arte dos conhecimentos sedimentológicos/estratigráficos das formações Pirambóia e Botucatu no Estado de São Paulo, in Resumos, Simpósio de Cronoestratigrafia da Bacia do Paraná, 1: Rio Claro, IGCE-UNESP, 1993, p. 84-85.

Caetano-Chang, M. R., 1997, A Formação Pirambóia no centro-leste do Estado de São Paulo [Tese de Livre Docência]: São Paulo, Universidade Estadual Paulista, Instituto de Geociências e Ciências Exatas, 196 p.

Choquette, P.W., L.C., Pray., 1970, Geologic nomenclature and classification of porosity in sedimentary carbonates: AAPG Bulletin, v. 54/2, p. 207-244.

Coates, D.F., 1964, Classification of rock for rock mechanics: International Journal of Rock Mechanics and Mining Sciences, 1:421-429.

CPRM - Serviço Geológico do Brasil, 2006, Mapa geológico do Estado de São Paulo, escala 1:750.000.

Decloedt, F.E. 2012. A Sucessão Serra Alta - Teresina - Piramboia Inferior no Centro-Sul do Estado de São Paulo: um Estudo de Petrografia e Minerais Pesados [Monografia de Trabalho de Formatura]: São Paulo, Universidade de São Paulo, Instituto de Geociências, 65 p.

Deere, D.U., Miller, R.P., 1966, Engineering classification and index properties of intact rock: Air Force Laboratory Tech. Report AFNL-TR-65-116, Albuquerque, NM.

Dickinson, W.R., 1970, Interpreting detrital modes of graywacke and arkose: Journal of Sedimentary Petrology, v. 40, p. 695-707.

Dobereiner, L., 1984, Engineering geology of weak sandstones [PhD thesis]: London, Imperial College, $471 \mathrm{p}$.

Doberenier L., De Freitas M.H., 1986, Geotechnical properties of weak sandstones: Geotechnique, 36, 79-94.

Donatti, L.M., Sawakuchi, A.O., Giannini, P.C.F., Fernandes, L.A., 2001, The Pirambóia-Botucatu Succession in São Paulo and Paraná States: different eolian systems in the Paraná Basin: Anais da Academia Brasileira de Ciências, Rio de Janeiro, 73(3): 465.

Ersoy, A., Waller, M.D, 1995, Textural characterisation of rock: Engineering Geology no. 39, p. 123-136.

Fahy, M .P., Guccione, M. J, 1979, Estimating strength of sandstones using petrographic thin-section data: Bulletin of the Association of Engineering Geologists 16(4), 467-485.

Folk, R.L., 1965, Petrology of sedimentary rocks: Austin, Texas University, 154 p.

Folk, R.L., 1968, Petrology of sedimentary rocks: Hemphill Publ. Co., Austin, Texas, $170 \mathrm{p}$.

Fúlfaro, V.J., 1972, The Paraná Basin upper Permian and lower Mesozoic stratigraphic succession: Anais da Academia Brasileira de Ciências, 44:147-148. 
Galehouse, J.S, 1971, Point Counting, in Carver, R.E., ed., Procedures in sedimentary petrology: New York, NY, USA: Wiley and Sons, p. 385-407.

Gesicki, A.L.D., Sayeg, I.J., Curti, D.K., Boggiani, P.C., Giannini, P.C.F., 2009, Determinação quantitativa de parâmetros texturais de arenitos eólicos através de análise de imagens digitais de seções delgadas: Revista Brasileira de Geociências, 39(2): 267-275.

Gesicki, A.L.D., Giannini, P.C.F., Sayeg, I.J, 2008, Aspectos petrográficos das formações Pirambóia e Botucatu (Sistema Aqüífero Guarani - SAG) no Estado de São Paulo, in Anais, Congresso Brasileiro de Geologia, 44: Curitiba, PR, Sociedade Brasileira de Geologia (SBG), p. 939-939.

Gesicki, A.L.D., 2007, Evolução diagenética das formações Pirambóia e Botucatu (Sistema Aqüífero Guarani) no Estado de São Paulo [Tese de Doutorado]: São Paulo, Universidade de São Paulo, Instituto de Geociências, 175 p.

Giannini, P.C.F., 2001, As formações Pirambóia e Botucatu nos estados de São Paulo e Paraná, São Paulo, Universidade de São Paulo, Instituto de Geociências, Relatório final de pesquisa, $143 \mathrm{p}$.

Giannini, P.C.F., Sawakuchi, A.O., Fernandes, L.A., Donatti, L.M, 2004, Paleoventos e paleocorrentes subaquosas do Sistema Deposicional Pirambóia nos estados de São Paulo e Paraná, Bacia do Paraná: estudo baseado em análise estatística de dados azimutais: Revista Brasileira de Geociências, São Paulo, 34(2): 282-292.

Giannini, P.C.F., Assine, M.L., Sawakuchi, A.O, 2008, Ambientes Eólicos, in Silva, A. J.C.L.P., Aragão, M.A.N.F., Magalhães, A.J.C., org., Ambientes de Sedimentação Silicilástica do Brasil: São Paulo, Beca, p. 72-101.

Guidicini, G., Santos Oliveira, A.M., Pires de Camargo, F.; Kaji, N., 1972, Um método de classificação geotécnica preliminar de meios rochosos, in Anais, Semana Paulista de Geologia Aplicada, 4: APGA, São Paulo, p. 275-284.

Han, D., Nur, A., Morgan, D., 1986, Effects of porosity and clay content on wave velocities in sandstones: Geophysics, Vol. 51, n. 11, pp. 2093-2107.

Hawkins, A.B.; Mcconnell, B.J., 1992, Sensitivity of sandstone srength and deformability to changes in moisture content: Quartertly Journal of Engineering Geology, 25: 115-130.

Hawkins, A.B., 1998, Aspects of rock strength: Bulletin of Engineering Geology and the Environment, 57: 17-30.

IAEG - International Association for Engineering Geology and the Environment, 1979, Report of the comission on engineering geological mapping: Bulletin IAEG, 19: $364-371$.

ISRM - International Society for Rock Mechanics, 1981, Rock Characterization, Testing and Monitoring, in E.T. Brown, ed., ISRM Suggested Methods: Oxford, Pergamon Press, $211 \mathrm{pp}$.

ISRM - International Society for Rock Mechanics, 1999, Draft ISRM suggested method for the complete stress-strain curve for intact rock in uniaxial compression: International Journal of Rock Mechanics and Mining Sciences 36(3): 279-289.

Jeng, F.S., Weng, M.C., Lin, M.L.; Huang, T.H, 2004, Influence of petrographic parameters on geotechnical properties of tertiary sandstones from Taiwan: Engineering Geology, 73, 71-91.

Kahn, J.S., 1956, The analysis and distribution of the properties of packing in sand size sediments: Journal of Geology, Vol. 64, pp. 385-395.

Kanji, M.A, 2014, Critical issues in soft rocks: Journal of Rock Mechanics and Geotechnical Engineering, 6: 186-196. 
Kocurek, G., 1981, Significance of interdune deposits and bounding surfaces in eolian dune sands: Sedimentology, 28(6): 753-780.

Kocurek, G., Dott, R.H. Jr, 1981, Distinction and uses of stratification types in the interpretation of eolian sand: Journal of Sedimentary Petrology, 51(2): 579-595.

Kocurek, G., Havholm, K.G., 1993, Eolian Sequence Stratigraphy - A Conceptual Framework, in Weimer, P.; Posamentier, H.W., eds., Siliciclastic Sequence Stratigraphy: America Association Petroleum Geologists (Memoir, 58), p. 393-409.

Kocurek, G., Nielson, J., 1986, Conditions favourable for the formation of warm climate aeolian sand sheets: Sedimentology, 33(6): 795-816.

Kowallis, B.J., Jones, L.E.A., Wang, H.F., 1984, Velocity-porosity-clay content systematics of poorly consolidated sandstones: Journal of Geophysical Research, Vol. 89, no B12, 10355-10364.

Krumbein, W.C., 1938, Size frequency distribution of sediments: Journal of Sedimentary Petrology, Vol. 18, p. 84-90.

Krumbein, W.C., Sloss, L.L., 1963, Stratigraphy and Sedimentation: San Francisco, W.H. Freeman and Co., 660 p. 1963.

Lavina, E.L., Faccini, U.F., 1993, Formações Piramboia e Sanga do Cabral: um episódio de desertificação na Bacia do Paraná ao final do Permiano?, in Boletim de Resumos Expandidos, Simpósio de Cronoestratigrafia da Bacia do Paraná, 1, p. 94-95.

Lavina, E.L.,1991, Geologia sedimentar e paleogeografia do Neopermiano e Eotriássico (Intervalo Kazaniano-Scythiano) da Bacia do Paraná [Tese de Doutorado]: Porto Alegre, Universidade Federal do Rio Grande do Sul, Instituto de Geociências, 332 p., 2 vol.

Matos, S.L.F., 1995, O contato entre o Grupo Passa Dois e a Formação Piramboia na borda leste da Bacia do Paraná no Estado de São Paulo [Dissertação de Mestrado]: São Paulo, Universidade de São Paulo, Instituto de Geociências, 110 p.

Matos, S.L.F, Coimbra, A.M., 1997, Sucessão de fácies na Camada Porangaba, Grupo Passa Dois, Estado de São Paulo: Revista Brasileira de Geociências, 27(4): 377-386.

Milani, E.J., 1997, Evolução tectono-estratigráfica da Bacia do Paraná e seu relacionamento com a geodinâmica fanerozóica do Gondwana sul-ocidental [Tese de Doutorado]: Porto Alegre, Universidade Federal do Rio Grande do Sul, Instituto de Geociências, 255 p.

Pinto, C.S., 2006, Resistência das areias, in Pinto, C.S., ed., Curso Básico de Mecânica dos Solos: São Paulo, Oficina de Textos, p. 275-294.

Powers, M.C., 1953, A new roundness scale for sedimentary particles: Journal of Sedimentary Petrology, Vol. 23, p. 117-119.

Riccomini, C., Gimenez Filho, A., Almeida, F.F.M, 1984, Considerações sobre a estratigrafia do Permo-Triássico na região da Serra do Cadeado, Paraná, in Anais, Congresso Brasileiro de Geologia, 33: Rio de Janeiro, SBG, v.2, p. 754763.

Rohn, R. 1994, Evolução Ambiental da Bacia do Paraná durante o neopermiano no leste de Santa Catarina e do Paraná [Tese de Doutorado]: São Paulo, Universidade de São Paulo, Instituto de Geociências, 2v, 386p.

Salamuni, R., Bigarella, J.J., 1967, The Botucatu Formation, in Bigarella, J.J., Becker; R.D., Pinto, J.D., eds., Problems in Brazilian Gondwana Geology: Curitiba, UFPR, p. 197-206. 
Sawakuchi, A.O., 2000, Dinâmica e contexto paleogeográfico do Sistema Deposicional Eólico Pirambóia no Estado de São Paulo [Monografia de Trabalho de Formatura]: São Paulo, Universidade de São Paulo, Instituto de Geociências $38 \mathrm{p}$.

Scherer, C.M.S., 2000, Eolian dunes of the Botucatu Formation (Cretaceous) in southernmost Brazil: morphology and origin: Sedimentary Geology, 137 (3/4): 6384.

Schmidt, V., McDonald, D.A., 1979, Texture and recognition of secondary porosity in sandstones: SEPM Special Publication, 26: 209-225.

Shukla P., Kumar, V, Curtis, M., Sondergeld, C.H., Chandra, S.R., 2013, Nanoindentation studies on shales, in Proceedings, US Rock Mechanics/Geomechanics Symposium, 47th: San Francisco, American Rock Mechanics Association (ARMA), Vol. 2, p. 1194-1203.

Serra Junior, E.; Ojima, L.M., 1998, Caracterização e classificação de maciços rochosos, in: Oliveira, A.M.S.; Brito, S.N.A., eds., Geologia de Engenharia: São Paulo, ABGE, p 211-226.

Shakoor, A., Bonelli, R.E., 1991, Relationship between petrographic characteristics, engineering index properties, and mechanical properties of selected sandstones: Bulletin of the International Association of Engineering Geology, 28, 55-71.

Soares, P.C., 1973, O Mesozóico Gondwânico no Estado de São Paulo [Tese de Doutorado]: Rio Claro, Universidade de São Paulo, Faculdade de Filosofia Ciências e Letras, 153 p.

Soares, P.C., 1975, Divisão estratigráfica do Mesozóico do Estado de São Paulo: Revista Brasileira de Geociências, 5: 229-251.

Souza, A., Sinelli, O., Gonçalus, M.M., 1971, Nova ocorrência fossilífera na Formação Botucatu, in Anais, Congresso Brasileiro de Geologia, 25: São Paulo, Sociedade Brasileira de Geologia, v. 2, p.281-295.

Taira, A., Scholle, P.A., 1979, Origin of bimodal sands in some modern environments: Journal of Sedimentary Petrology, 49(3), 777-786.

Tamrakar, N.K., Yokota, S., Shrestha, S.D., 2007, Relationships among mechanical, physical and petrographic properties of Siwalik sandstones, Central Nepal SubHimalayas: Engineering Geology, 90, 105-123.

Turk, N., Dearman, W.R., 1986, A correction equation of the influence of length-todiameter ratio on the uniaxial compressive strength of rocks: Engineering Geology, no. 22, 293-300.

Ulusay, R., Tureli, K., Ider, M.H., 1994, Prediction of engineering properties of a selected litharenite sandstone from its petrographic characteristics using correlation and multivariate statistical techniques: Engineering Geology, no 37, 135-157.

Vieira, A.J., Maingué, E., 1973, Geologia de semi-detalhe do centro e nordeste do Paraná e centro-sul de São Paulo. Ponta Grossa, PR: PETROBRÁS/DESUL. 1973. 49 p. Relatório DESUL - 425.

Walker, R.G., 1980, Facies and Facies Models, General Introduction, in Walker, R.G., ed., Facies Models: Geological Association of Canada, p. 1-7.

Washburne, C.W., 1930, Petroleum geology of State of São Paulo. Boletim da Comissão Geográfica e Geológica do Estado de São Paulo, 22:1-282.

Zorlu, K., Gokceoglu, C., Ocakoglu, F., Nefeslioglu, H.A., Acikalin, S., 2008, Prediction of uniaxial compressive strength of sandstones using petrographybased models: Engineering Geology no. 96, 141-158. 


\section{APÊNDICES}




\section{APÊNDICE A}

\section{Dados petrográficos e granulométricos}

Tabela 1 - Componentes modais e porosidade Tabela 2 - Composição mineralógica do arcabouço

Tabela 3 - Composição mineralógica do cimento Tabela 4- Granulometria

Tabela 5 - Dados obtidos pelo granulômetro a laser Malvern Mastersizer 2000 referentes às amostras das sondagens SM-201, SM-208, SM-210, SM-216, SM-224 e SM-505

Tabela 6 - Morfometria dos grãos

Tabela 7 - Contatos inter e extragranulares 
APÊNDICE A - Tabela 1 - Dados petrográficos referentes aos componentes modais e porosidade obtida por meio de software de análise de imagens (LAS).

\begin{tabular}{|c|c|c|c|c|c|c|c|c|c|c|c|}
\hline Sondagem & $\begin{array}{l}\text { Prof. } \\
\text { (m) }\end{array}$ & $\begin{array}{l}\text { Cota } \\
\text { (m) }\end{array}$ & Fácies & Petrofácies & $\begin{array}{c}\text { Arcabouço } \\
\text { (\%) }\end{array}$ & $\begin{array}{c}\text { Epimatriz } \\
(\%)\end{array}$ & $\begin{array}{c}\text { Pseudomatriz } \\
\text { (\%) }\end{array}$ & $\begin{array}{c}\text { Cimento } \\
(\%)\end{array}$ & $\begin{array}{l}\text { Poros. } \\
\text { modal } \\
(\%)\end{array}$ & $\begin{array}{c}\text { Porosidade } \\
\text { intragranular } \\
(\%)\end{array}$ & $\begin{array}{l}\text { Poros. } \\
\text { LAS (\%) }\end{array}$ \\
\hline SM-222 & 10,6 & 454,7 & $A p$ & Epa & 51,9 & 0,0 & 0,0 & 37,5 & 10,6 & 1,6 & 12,1 \\
\hline SM-222 & 11,1 & 454,3 & $A p$ & Epa & 46,5 & 0,3 & 0,0 & 39,4 & 13,9 & 2,3 & 13,2 \\
\hline SM-222 & 14,1 & 451,2 & Ap & Epa & 59,7 & 0,6 & 0,0 & 25,2 & 14,4 & 2,2 & 12,0 \\
\hline SM-222 & 15,3 & 450,1 & $\mathrm{Ae}$ & Ems & 72,0 & 0,0 & 0,0 & 7,0 & 21,0 & 1,0 & 16,9 \\
\hline SM-222 & 15,8 & 449,6 & $\mathrm{Ae}$ & Ems & 73,3 & 0,0 & 0,0 & 2,7 & 24,0 & 0,0 & 17,5 \\
\hline SM-222 & 16,3 & 449,1 & $\mathrm{Am}$ & Mfsx & 63,3 & 0,7 & 0,0 & 19,7 & 16,3 & 0,3 & 16,9 \\
\hline SM-222 & 20,5 & 444,8 & $\mathrm{Ae}$ & Ems & 74,2 & 0,0 & 1,0 & 6,6 & 18,2 & 0,0 & 14,7 \\
\hline SM-222 & 22,9 & 442,5 & $\mathrm{Ae}$ & Efsx & 69,7 & 0,3 & 0,0 & 16,7 & 13,3 & 3,0 & 12,0 \\
\hline SM-222 & 24,9 & 440,5 & $\mathrm{Ae}_{\mathrm{i}}$ & $\mathrm{Mms}$ & 62,0 & 0,0 & 0,0 & 12,7 & 25,3 & 0,0 & 27,4 \\
\hline SM-222 & 26,9 & 438,4 & $\mathrm{Am}$ & Mms & 68,4 & 0,0 & 0,7 & 10,9 & 20,1 & 0,7 & 18,9 \\
\hline SM-222 & 27,6 & 437,8 & $\mathrm{Am}$ & $\mathrm{Mms}$ & 67,2 & 0,3 & 0,0 & 10,3 & 22,2 & 0,0 & 19,7 \\
\hline SM-222 & 28,7 & 436,6 & $A e_{i}$ & Mfsx & 73,1 & 0,0 & 0,0 & 21,9 & 5,0 & 0,3 & 9,0 \\
\hline SM-201 & 27,23 & 435,4 & $\mathrm{Ae}_{\mathrm{i}}$ & Mms & 69,7 & 0,3 & 0,0 & 10,0 & 20,0 & 0,7 & 19,7 \\
\hline SM-208 & 17,96 & 448,8 & $\mathrm{Ae}$ & Efsx & 64,0 & 0,7 & 0,0 & 16,3 & 19,0 & 2,7 & 22,1 \\
\hline SM-210 & 18,90 & 444,8 & $\mathrm{Ae}$ & Efsx & 61,0 & 0,0 & 0,0 & 19,7 & 19,3 & 2,7 & 26,1 \\
\hline SM-210 & 27,05 & 436,7 & $\mathrm{Ae}$ & Ems & 73,7 & 0,7 & 0,0 & 6,0 & 19,7 & 0,7 & 16,3 \\
\hline SM-216 & 12,53 & 454,5 & $A p$ & Epa & 54,6 & 0,0 & 0,0 & 39,9 & 5,4 & 1,0 & 13,0 \\
\hline SM-224 & 22,90 & 437,7 & $\mathrm{Ae}_{\mathrm{i}}$ & Mfsx & 70,3 & 0,0 & 0,0 & 19,0 & 10,7 & 1,0 & 21,4 \\
\hline SM-505 & 14,79 & 429,3 & $\mathrm{Ae}_{\mathrm{i}}$ & Mfsx & 64,0 & 0,0 & 0,0 & 22,7 & 13,3 & 3,3 & 24,4 \\
\hline
\end{tabular}


APÊNDICE A - Tabela 2 - Dados petrográficos referentes à composição mineralógica do arcabouço.

\begin{tabular}{|c|c|c|c|c|c|c|c|c|c|c|c|c|c|c|c|}
\hline Sondagem & $\begin{array}{l}\text { Prof. } \\
\text { (m) }\end{array}$ & $\begin{array}{c}\text { Cota } \\
(\mathrm{m})\end{array}$ & Fácies & Petrofácies & $\begin{array}{c}\mathbf{Q} \\
(\%)\end{array}$ & $\begin{array}{c}\mathbf{F} \\
(\%)\end{array}$ & $\begin{array}{l}\mathrm{L} \\
(\%)\end{array}$ & QM (\%) & $\begin{array}{l}\text { QP } \\
(\%)\end{array}$ & $\begin{array}{l}\text { Fds } \\
(\%)\end{array}$ & LE (\%) & Intra. (\%) & $\begin{array}{c}\text { Mica } \\
(\%)\end{array}$ & $\begin{array}{c}\text { Pesados } \\
(\%)\end{array}$ & $\begin{array}{c}\text { Opacos } \\
(\%)\end{array}$ \\
\hline SM-222 & 10,6 & 454,7 & Ap & Epa & 88,9 & 11,1 & 0,0 & 46,2 & 0,0 & 5,8 & 0,0 & 0,0 & 0,0 & 0,0 & 0,0 \\
\hline SM-222 & 11,1 & 454,3 & $A p$ & Epa & 89,5 & 10,5 & 0,0 & 41,0 & 0,3 & 4,8 & 0,0 & 0,0 & 0,3 & 0,0 & 0,0 \\
\hline SM-222 & 13,9 & 451,5 & $A p$ & Epa & 91,5 & 8,5 & 0,0 & 50,8 & 1,0 & 4,8 & 0,0 & 0,0 & 0,0 & 0,0 & 0,3 \\
\hline SM-222 & 14,1 & 451,2 & Ap & Epa & 90,3 & 8,6 & 1,1 & 53,0 & 0,6 & 5,1 & 0,3 & 0,3 & 0,0 & 0,0 & 0,3 \\
\hline SM-222 & 15,3 & 450,1 & $\mathrm{Ae}$ & Ems & 88,9 & 11,1 & 0,0 & 62,3 & 1,7 & 8,0 & 0,0 & 0,0 & 0,0 & 0,0 & 0,0 \\
\hline SM-222 & 15,8 & 449,6 & $\mathrm{Ae}$ & Ems & 90,5 & 8,2 & 1,4 & 65,7 & 0,7 & 6,0 & 0,0 & 1,0 & 0,0 & 0,0 & 0,0 \\
\hline SM-222 & 16,3 & 449,1 & $\mathrm{Am}$ & Mfsx & 87,8 & 12,2 & 0,0 & 55,0 & 0,3 & 7,7 & 0,0 & 0,0 & 0,0 & 0,0 & 0,3 \\
\hline SM-222 & 17,2 & 448,2 & $A p$ & Epa & 84,9 & 14,0 & 1,1 & 48,6 & 0,0 & 8,0 & 0,3 & 0,0 & 0,0 & 0,0 & 0,0 \\
\hline SM-222 & 19,1 & 446,3 & $\mathrm{Ae}$ & Ems & 89,4 & 10,2 & 0,5 & 64,3 & 0,0 & 7,3 & 0,0 & 0,0 & 0,0 & 0,3 & 0,0 \\
\hline SM-222 & 20,5 & 444,8 & $\mathrm{Ae}$ & Ems & 88,1 & 7,9 & 4,0 & 63,2 & 3,0 & 6,0 & 0,3 & 1,7 & 0,0 & 0,0 & 0,0 \\
\hline SM-222 & 22,9 & 442,5 & $\mathrm{Ae}$ & Efsx & 89,4 & 10,6 & 0,0 & 61,0 & 1,0 & 7,3 & 0,0 & 0,0 & 0,3 & 0,0 & 0,0 \\
\hline SM-222 & 24,9 & 440,5 & $A e_{i}$ & Mms & 88,7 & 11,3 & 0,0 & 53,7 & 1,3 & 7,0 & 0,0 & 0,0 & 0,0 & 0,0 & 0,0 \\
\hline SM-222 & 26,9 & 438,4 & Am & Mms & 88,6 & 10,5 & 1,0 & 60,9 & 0,3 & 7,2 & 0,0 & 0,0 & 0,0 & 0,0 & 0,0 \\
\hline SM-222 & 27,6 & 437,8 & Am & Mms & 88,7 & 11,3 & 0,0 & 57,9 & 1,7 & 7,6 & 0,0 & 0,0 & 0,0 & 0,0 & 0,0 \\
\hline SM-222 & 28,7 & 436,6 & $A e_{i}$ & Mfsx & 88,5 & 11,5 & 0,0 & 62,8 & 1,3 & 8,3 & 0,0 & 0,0 & 0,0 & 0,0 & 0,7 \\
\hline SM-222 & 29,1 & 436,2 & $A e_{i}$ & Mfsx & 88,3 & 11,7 & 0,0 & 55,1 & 2,0 & 7,5 & 0,0 & 0,0 & 0,0 & 0,3 & 0,0 \\
\hline SM-222 & 29,9 & 435,5 & $\mathrm{Ae}$ & Efsx & 89,0 & 11,0 & 0,0 & 61,3 & 0,7 & 7,6 & 0,0 & 0,0 & 0,3 & 0,0 & 0,0 \\
\hline SM-222 & 30,8 & 434,6 & $A e_{i}$ & Mms & 87,3 & 12,2 & 0,5 & 55,9 & 1,3 & 8,0 & 0,3 & 0,0 & 0,0 & 0,0 & 0,0 \\
\hline SM-222 & 32,0 & 433,4 & $A e_{i}$ & Mms & 88,1 & 11,9 & 0,0 & 53,3 & 0,7 & 7,3 & 0,0 & 0,0 & 0,0 & 0,0 & 0,0 \\
\hline SM-222 & 32,5 & 432,9 & $A e_{i}$ & Mms & 89,3 & 10,7 & 0,0 & 58,3 & 1,0 & 7,1 & 0,0 & 0,0 & 0,0 & 0,0 & 0,0 \\
\hline SM-201 & 27,23 & 435,4 & $A e_{i}$ & Mms & 93,3 & 6,7 & 0,0 & 63,3 & 1,7 & 4,7 & 0,0 & 0,0 & 0,0 & 0,0 & 0,0 \\
\hline SM-208 & 17,96 & 448,8 & $\mathrm{Ae}$ & Efsx & 88,5 & 11,5 & 0,0 & 55,3 & 1,3 & 7,3 & 0,0 & 0,0 & 0,0 & 0,0 & 0,0 \\
\hline SM-210 & 18,90 & 444,8 & $\mathrm{Ae}$ & Efsx & 89,6 & 10,4 & 0,0 & 53,3 & 1,3 & 6,3 & 0,0 & 0,0 & 0,0 & 0,0 & 0,0 \\
\hline SM-210 & 27,05 & 436,7 & $\mathrm{Ae}$ & Ems & 91,4 & 7,7 & 0,9 & 66,3 & 1,0 & 5,7 & 0,0 & 0,7 & 0,0 & 0,0 & 0,0 \\
\hline SM-216 & 12,53 & 454,5 & Ap & Epa & 90,1 & 9,9 & 0,0 & 48,6 & 0,6 & 5,4 & 0,0 & 0,0 & 0,0 & 0,0 & 0,0 \\
\hline SM-224 & 22,90 & 437,7 & $A e_{i}$ & Mfsx & 90,4 & 9,6 & 0,0 & 61,0 & 2,0 & 6,7 & 0,0 & 0,0 & 0,3 & 0,0 & 0,3 \\
\hline SM-505 & 14,79 & 429,3 & $A e_{i}$ & Mfsx & 88,5 & 11,5 & 0,0 & 56,7 & 0,0 & 7,3 & 0,0 & 0,0 & 0,0 & 0,0 & 0,0 \\
\hline
\end{tabular}

QM: quartzo monocristalino; QP: quartzo policristalino; Fds.: feldspato; LE: fragmentos líticos estáveis; Intra.: intraclastos. 
APÊNDICE A - Tabela 3 - Dados petrográficos referentes à composição mineralógica do cimento.

\begin{tabular}{|c|c|c|c|c|c|c|c|c|}
\hline Sondagem & $\begin{array}{c}\text { Prof. } \\
\text { (m) }\end{array}$ & $\begin{array}{c}\text { Cota } \\
(\mathrm{m})\end{array}$ & Fácies & Petrofácies & Argilo-ferruginoso (\%) & Esmectita (\%) & Óx./hidróx. metálico (\%) & Carbonático (\%) \\
\hline SM-222 & 10,6 & 454,7 & Ap & Epa & 34,0 & 0,0 & 3,5 & 0,0 \\
\hline SM-222 & 11,1 & 454,3 & Ap & Epa & 37,1 & 0,0 & 2,3 & 0,0 \\
\hline SM-222 & 13,9 & 451,5 & $A p$ & Epa & 34,8 & 0,0 & 3,5 & 0,0 \\
\hline SM-222 & 15,3 & 450,1 & $\mathrm{Ae}$ & Ems & 0,0 & 7,0 & 0,0 & 0,0 \\
\hline SM-222 & 15,8 & 449,6 & $\mathrm{Ae}$ & Ems & 0,0 & 2,0 & 0,7 & 0,0 \\
\hline SM-222 & 16,3 & 449,1 & $\mathrm{Am}$ & Mfsx & 0,0 & 19,0 & 0,7 & 0,0 \\
\hline SM-222 & 22,9 & 442,5 & $\mathrm{Ae}$ & Efsx & 0,0 & 16,3 & 0,3 & 0,0 \\
\hline SM-222 & 24,9 & 440,5 & $A e_{i}$ & Mms & 0,0 & 12,7 & 0,0 & 0,0 \\
\hline SM-222 & 26,9 & 438,4 & $\mathrm{Am}$ & Mms & 0,0 & 10,9 & 0,0 & 0,0 \\
\hline SM-222 & 27,6 & 437,8 & $\mathrm{Am}$ & $\mathrm{Mms}$ & 0,0 & 9,9 & 0,3 & 0,0 \\
\hline SM-222 & 28,7 & 436,6 & $\mathrm{Ae}_{\mathrm{i}}$ & Mfsx & 0,0 & 21,3 & 0,7 & 0,0 \\
\hline SM-222 & 29,1 & 436,2 & $A e_{i}$ & Mfsx & 0,0 & 22,6 & 2,3 & 0,0 \\
\hline SM-208 & 17,96 & 448,8 & $\mathrm{Ae}$ & Efsx & 0,0 & 15,0 & 1,3 & 0,0 \\
\hline SM-210 & 18,90 & 444,8 & $\mathrm{Ae}$ & Efsx & 0,0 & 18,0 & 1,7 & 0,0 \\
\hline SM-210 & 27,05 & 436,7 & $\mathrm{Ae}$ & Ems & 0,0 & 4,3 & 1,7 & 0,0 \\
\hline SM-216 & 12,53 & 454,5 & Ap & Epa & 36,7 & 0,0 & 3,2 & 0,0 \\
\hline SM-224 & 22,90 & 437,7 & $\mathrm{Ae}_{\mathrm{i}}$ & Mfsx & 0,0 & 19,0 & 0,0 & 0,0 \\
\hline SM-505 & 14,79 & 429,3 & $\mathrm{Ae}_{\mathrm{i}}$ & Mfsx & 0,0 & 21,7 & 1,0 & 0,0 \\
\hline
\end{tabular}


APÊNDICE A - Tabela 4 - Dados granulométricos obtidos por petrografia e analisador de partículas Malvern Mastersizer 2000.

\begin{tabular}{|c|c|c|c|c|c|c|c|c|c|c|c|}
\hline \multirow{2}{*}{ Sondagem } & \multirow{2}{*}{ Prof. (m) } & \multirow{2}{*}{ Cota $(\mathrm{m})$} & \multirow{2}{*}{ Fácies } & \multirow{2}{*}{ Petrofácies } & \multicolumn{4}{|c|}{ Petrografia } & \multicolumn{2}{|c|}{ Malvern } & \multirow{2}{*}{ Teor de pelíticos (\%) } \\
\hline & & & & & $\operatorname{DM}(\varphi)$ & DM $1(\varphi)$ & DM $2(\varphi)$ & $\mathrm{DP}(\varphi)$ & $\mathrm{DM}(\varphi)$ & $\operatorname{DP}(\varphi)$ & \\
\hline SM-222 & 10,6 & 454,7 & Ap & Epa & 3,4 & 3,5 & 3,0 & 0,78 & 2,83 & 0,52 & 43,3 \\
\hline SM-222 & 11,1 & 454,3 & $\mathrm{Ap}$ & Epa & 3,4 & 3,4 & 3,2 & 0,77 & 2,74 & 0,59 & 42,0 \\
\hline SM-222 & 13,9 & 451,5 & Ap & Epa & 3,3 & 3,3 & 2,8 & 0,75 & 2,54 & 0,81 & 28,0 \\
\hline SM-222 & 14,1 & 451,2 & Ap & Epa & 2,9 & 3,3 & 2,7 & 0,73 & 2,49 & 0,85 & 20,3 \\
\hline SM-222 & 15,3 & 450,1 & $\mathrm{Ae}$ & Ems & 2,7 & 2,9 & 2,5 & 0,65 & 2,20 & 0,65 & 10,3 \\
\hline SM-222 & 15,8 & 449,6 & $\mathrm{Ae}$ & Ems & 2,4 & 2,5 & 2,1 & 0,59 & 1,86 & 0,50 & 3,9 \\
\hline SM-222 & 16,3 & 449,1 & $\mathrm{Am}$ & Mfsx & 3,1 & - & - & 0,62 & 2,72 & 0,60 & 19,1 \\
\hline SM-222 & 17,2 & 448,2 & $A p$ & Epa & 2,9 & 3,5 & 2,5 & 0,77 & 2,35 & 0,69 & 38,5 \\
\hline SM-222 & 19,1 & 446,3 & $\mathrm{Ae}$ & Ems & 2,2 & 2,3 & 2,0 & 0,59 & 2,04 & 0,62 & 13,5 \\
\hline SM-222 & 20,5 & 444,8 & $\mathrm{Ae}$ & Ems & 1,8 & 1,5 & 1,0 & 0,75 & 1,76 & 0,84 & 10,3 \\
\hline SM-222 & 22,9 & 442,5 & $\mathrm{Ae}$ & Efsx & 2,5 & 3,0 & 2,7 & 0,54 & 2,58 & 0,53 & 17,4 \\
\hline SM-222 & 24,9 & 440,5 & $\mathrm{Ae}_{i}$ & Mms & 2,9 & - & - & 0,71 & 2,14 & 0,80 & 14,5 \\
\hline SM-222 & 26,9 & 438,4 & $\mathrm{Am}$ & Mms & 2,1 & - & - & 0,70 & 1,54 & 0,40 & 7,5 \\
\hline SM-222 & 27,6 & 437,8 & $\mathrm{Am}$ & Mms & 1,9 & - & - & 0,82 & 1,55 & 0,71 & 8,5 \\
\hline SM-222 & 28,7 & 436,6 & $A e_{i}$ & Mfsx & 2,8 & - & - & 0,58 & 2,36 & 0,66 & 16,9 \\
\hline SM-222 & 29,1 & 436,2 & $\mathrm{Ae}_{i}$ & Mfsx & 2,8 & - & - & 0,63 & 2,53 & 0,57 & 20,2 \\
\hline SM-222 & 29,9 & 435,5 & $\mathrm{Ae}$ & Efsx & 2,7 & 3,0 & 2,2 & 0,68 & 2,28 & 0,68 & 14,7 \\
\hline SM-222 & 30,8 & 434,6 & $\mathrm{Ae}_{\mathrm{i}}$ & Mms & 1,7 & - & - & 0,72 & 1,58 & 0,64 & 8,7 \\
\hline SM-222 & 32,0 & 433,4 & $\mathrm{Ae}_{\mathrm{i}}$ & Mms & 2,0 & - & - & 0,76 & 1,82 & 0,56 & 7,6 \\
\hline SM-222 & 32,5 & 432,9 & $\mathrm{Ae}_{i}$ & Mms & 2,2 & - & - & 0,67 & 2,01 & 0,58 & 9,9 \\
\hline SM-201 & 27,23 & 435,4 & $\mathrm{Ae}_{\mathrm{i}}$ & Mms & 1,9 & - & - & 0,68 & 2,04 & 0,72 & 8,4 \\
\hline SM-208 & 17,96 & 448,8 & $\mathrm{Ae}$ & Efsx & 2,7 & 3,0 & 2,2 & 0,70 & 2,39 & 0,66 & 20,8 \\
\hline SM-210 & 18,90 & 444,8 & $\mathrm{Ae}$ & Efsx & 2,6 & 3,0 & 2,2 & 0,67 & 2,11 & 0,63 & 14,5 \\
\hline SM-210 & 27,05 & 436,7 & $\mathrm{Ae}$ & Ems & 1,8 & 1,5 & 0,6 & 0,47 & 1,61 & 0,81 & 8,8 \\
\hline SM-216 & 12,53 & 454,5 & Ap & Epa & 3,1 & 3,5 & 2,5 & 0,70 & 2,84 & 0,63 & 40,8 \\
\hline SM-224 & 22,90 & 437,7 & $\mathrm{Ae}_{\mathrm{i}}$ & Mfsx & 2,7 & - & - & 0,63 & 2,10 & 0,75 & 13,2 \\
\hline SM-505 & 14,79 & 429,3 & $\mathrm{Ae}_{i}$ & Mfsx & 3,0 & - & - & 0,79 & 2,39 & 0,71 & 17,9 \\
\hline
\end{tabular}

DM: tamanho médio; DP: desvio padrão; DM1 e DM2: tamanho médio das diferentes modas em arenitos com segregação granular e granulometria bimodal. Dados granulométricos obtidos pelo Malvern Mastersizer 2000 para as sondagens SM-201, SM-208, SM-210, SM-216, SM-224 e SM-505 são as medianas dos dados de 39 amostras, apresentados na Tabela 5. 
APÊNDICE A - Tabela 5 - Dados obtidos pelo analisador de partículas Malvern Mastersizer 2000 referentes às amostras das sondagens SM-201, SM-208, SM-210, SM-216, SM-224 e SM-505.

\begin{tabular}{|c|c|c|c|c|c|c|}
\hline Sondagem & Prof. (m) & Cota (m) & Fácies & Petrofácies & $\operatorname{TM}(\varphi)$ & DP $(\varphi)$ \\
\hline SM-201 & 26,09 & 436,54 & $A e_{i}$ & Mms & 2,07 & 0,85 \\
\hline SM-201 & 26,30 & 436,34 & $A e_{i}$ & Mms & 1,94 & 0,80 \\
\hline SM-201 & 26,55 & 436,09 & $A e_{i}$ & Mms & 2,03 & 0,82 \\
\hline SM-201 & 26,90 & 435,73 & $A e_{i}$ & Mms & 2,03 & 0,58 \\
\hline SM-201 & 27,10 & 435,54 & $A e_{i}$ & Mms & 2,09 & 0,64 \\
\hline SM-201 & 27,34 & 435,29 & $A e_{i}$ & Mms & 2,05 & 0,62 \\
\hline SM-208 & 18,10 & 448,62 & $\mathrm{Ae}$ & Efsx & 2,41 & 0,69 \\
\hline SM-208 & 18,27 & 448,45 & $\mathrm{Ae}$ & Efsx & 2,33 & 0,66 \\
\hline SM-208 & 18,74 & 447,98 & $\mathrm{Ae}$ & Efsx & 2,45 & 0,64 \\
\hline SM-208 & 19,24 & 447,48 & $\mathrm{Ae}$ & Efsx & 2,58 & 0,63 \\
\hline SM-208 & 19,73 & 446,99 & $\mathrm{Ae}$ & Efsx & 2,18 & 0,71 \\
\hline SM-210 & 17,88 & 448,84 & $\mathrm{Ae}$ & Efsx & 2,48 & 0,67 \\
\hline SM-210 & 18,29 & 448,43 & $\mathrm{Ae}$ & Efsx & 2,25 & 0,58 \\
\hline SM-210 & 18,44 & 445,28 & $\mathrm{Ae}$ & Efsx & 2,09 & 0,63 \\
\hline SM-210 & 19,00 & 444,72 & $\mathrm{Ae}$ & Efsx & 1,89 & 0,62 \\
\hline SM-210 & 19,12 & 444,60 & $\mathrm{Ae}$ & Efsx & 1,83 & 0,59 \\
\hline SM-210 & 19,63 & 444,09 & $\mathrm{Ae}$ & Efsx & 2,12 & 0,68 \\
\hline SM-210 & 26,15 & 437,57 & $\mathrm{Ae}$ & Ems & 1,71 & 0,44 \\
\hline SM-210 & 26,73 & 436,99 & $\mathrm{Ae}$ & Ems & 1,42 & 0,89 \\
\hline SM-210 & 26,90 & 436,82 & $\mathrm{Ae}$ & Ems & 1,50 & 0,48 \\
\hline SM-210 & 27,30 & 436,42 & $\mathrm{Ae}$ & Ems & 1,78 & 1,08 \\
\hline SM-210 & 27,45 & 436,27 & $\mathrm{Ae}$ & Ems & 1,65 & 1,15 \\
\hline SM-216 & 12,15 & 454,85 & Ap & Epa & 2,87 & 0,55 \\
\hline SM-216 & 12,30 & 454,70 & $A p$ & Epa & 2,83 & 0,64 \\
\hline SM-216 & 12,80 & 454,20 & Ap & Epa & 2,87 & 0,56 \\
\hline SM-216 & 13,00 & 454,00 & Ap & Epa & 2,78 & 0,77 \\
\hline SM-224 & 21,58 & 439,06 & $A e_{i}$ & Mfsx & 1,93 & 0,83 \\
\hline SM-224 & 21,73 & 438,91 & $A e_{i}$ & Mfsx & 1,96 & 0,83 \\
\hline SM-224 & 21,89 & 438,75 & $A e_{i}$ & Mfsx & 2,27 & 0,68 \\
\hline SM-224 & 22,10 & 438,54 & $A e_{i}$ & Mfsx & 2,04 & 0,71 \\
\hline SM-224 & 22,77 & 437,87 & $A e_{i}$ & Mfsx & 2,29 & 0,70 \\
\hline SM-505 & 12,37 & 431,69 & $A e_{i}$ & Mfsx & 2,42 & 0,67 \\
\hline SM-505 & 12,54 & 431,52 & $\mathrm{Ae}_{i}$ & Mfsx & 2,29 & 0,61 \\
\hline SM-505 & 12,72 & 431,34 & $A e_{i}$ & Mfsx & 2,20 & 0,80 \\
\hline SM-505 & 12,96 & 431,11 & $A e_{i}$ & Mfsx & 2,56 & 0,65 \\
\hline SM-505 & 13,12 & 430,94 & $A e_{i}$ & Mfsx & 2,46 & 0,67 \\
\hline SM-505 & 13,41 & 430,65 & $A e_{i}$ & Mfsx & 2,27 & 0,76 \\
\hline SM-505 & 13,57 & 430,50 & $A e_{i}$ & Mfsx & 2,37 & 0,75 \\
\hline SM-505 & 14,79 & 429,28 & $\mathrm{Ae}_{\mathrm{i}}$ & Mfsx & 2,57 & 0,74 \\
\hline
\end{tabular}


APÊNDICE A - Tabela 6 - Dados petrográficos referentes à morfometria dos grãos.

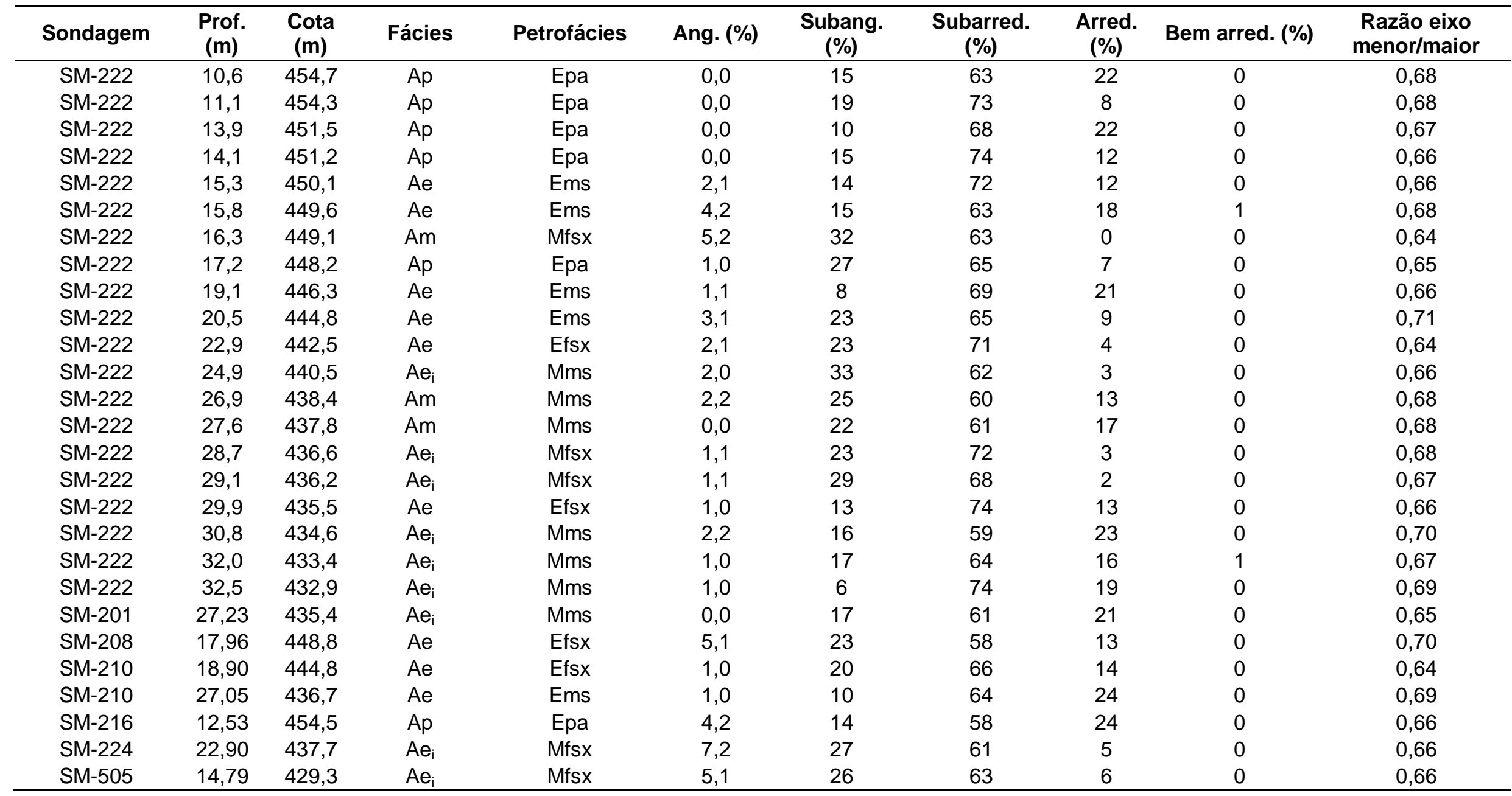


APÊNDICE A - Tabela 7 - Dados petrográficos referentes aos contatos intergranulares e grão-cimento e grão-vazio.

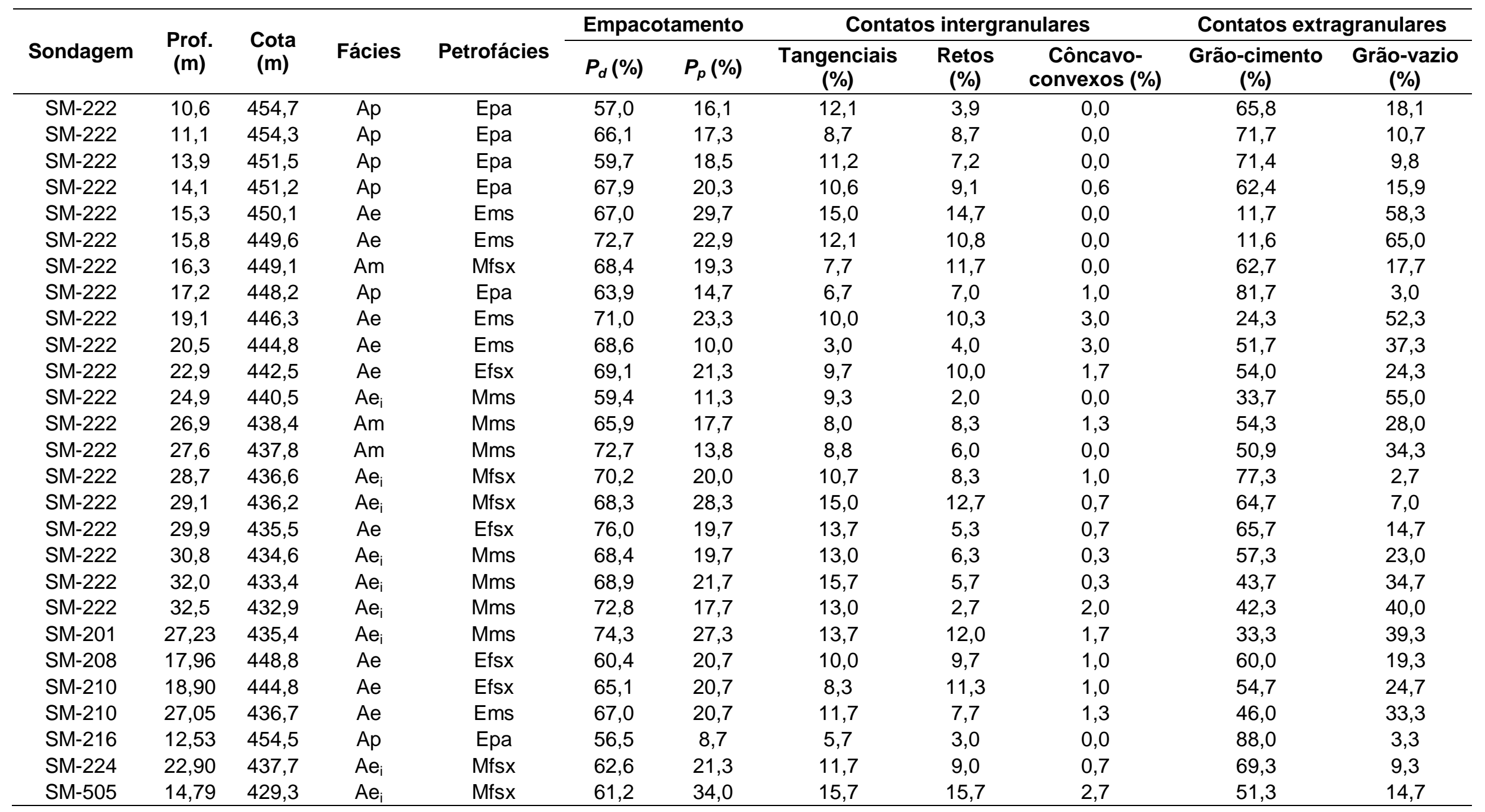




\section{APÊNDICE B}

Dados referentes aos ensaios de determinação da densidade e porosidade aparentes 
APÊNDICE B - Dados referentes aos ensaios de determinação da densidade e porosidade aparentes.

\begin{tabular}{|c|c|c|c|c|c|c|c|c|c|c|}
\hline Sondagem & Prof. (m) & Cota (m) & Fácies & Petrofácies & $M_{\text {sec }}(g)$ & $M_{\text {sat }}(g)$ & $M_{\text {sub }}(g)$ & $\rho_{\mathrm{I}}\left(\mathrm{g} / \mathrm{cm}^{3}\right)$ & $\rho_{a}\left(g / c^{3}\right)$ & $\eta_{a}(\%)$ \\
\hline SM-201 & 26,4 & 436,2 & $\mathrm{Ae}_{\mathrm{i}}$ & Mms & 232,36 & 249,16 & 156,14 & 0,79 & 1,97 & 18,1 \\
\hline SM-201 & 27,2 & 435,4 & $A e_{i}$ & Mms & 230,31 & 247,48 & 155,66 & 0,79 & 1,98 & 18,7 \\
\hline SM-201 & 27,2 & 435,4 & $A e_{i}$ & Mms & 35,44 & 38,58 & 24,47 & 0,79 & 1,98 & 22,3 \\
\hline SM-201 & 27,2 & 435,4 & $A e_{i}$ & Mms & 21,85 & 23,88 & 15,15 & 0,79 & 1,97 & 23,3 \\
\hline SM-201 & 27,2 & 435,4 & $A e_{i}$ & Mms & 24,52 & 26,79 & 16,99 & 0,79 & 1,97 & 23,2 \\
\hline SM-208 & 17,9 & 448,8 & $\mathrm{Ae}$ & Efsx & 325,01 & 353,15 & 220,5 & 0,79 & 1,93 & 21,2 \\
\hline SM-208 & 17,9 & 448,8 & $\mathrm{Ae}$ & Efsx & 147,44 & 160,94 & 100,73 & 0,79 & 1,93 & 22,4 \\
\hline SM-208 & 19,7 & 447,1 & $\mathrm{Ae}$ & Efsx & 219,52 & 239,6 & 150,41 & 0,79 & 1,94 & 22,5 \\
\hline SM-210 & 18,9 & 444,9 & $\mathrm{Ae}$ & Efsx & 317,30 & 341,28 & 213,62 & 0,79 & 1,96 & 18,8 \\
\hline SM-210 & 18,2 & 445,5 & $\mathrm{Ae}$ & Efsx & 213,19 & 229,53 & 144,92 & 0,79 & 1,99 & 19,3 \\
\hline SM-210 & 19,5 & 444,2 & $\mathrm{Ae}$ & Efsx & 216,73 & 236,65 & 147,17 & 0,79 & 1,91 & 22,3 \\
\hline SM-210 & 19,5 & 444,2 & $\mathrm{Ae}$ & Efsx & 348,98 & 377,42 & 237,1 & 0,79 & 1,96 & 20,3 \\
\hline SM-210 & 18,9 & 444,8 & $\mathrm{Ae}$ & Efsx & 196,20 & 212,45 & 133,61 & 0,79 & 1,96 & 20,6 \\
\hline SM-210 & 17,5 & 446,2 & $\mathrm{Ae}$ & Efsx & 342,49 & 373,13 & 234,11 & 0,79 & 1,94 & 22,0 \\
\hline SM-210 & 26,1 & 437,7 & $\mathrm{Ae}$ & Ems & 146,18 & 159,65 & 98,85 & 0,79 & 1,90 & 22,2 \\
\hline SM-210 & 27,0 & 436,7 & $\mathrm{Ae}$ & Ems & 202,53 & 221,28 & 138,16 & 0,79 & 1,92 & 22,6 \\
\hline SM-210 & 26,8 & 436,9 & $\mathrm{Ae}$ & Ems & 120,99 & 132,95 & 82,86 & 0,79 & 1,91 & 23,9 \\
\hline SM-210 & 27,0 & 436,7 & $\mathrm{Ae}$ & Ems & 159,74 & 172,42 & 108,47 & 0,79 & 1,97 & 19,8 \\
\hline SM-216 & 12,9 & 454,1 & $A p$ & Epa & 271,70 & 293,99 & 186,13 & 0,79 & 1,99 & 20,7 \\
\hline SM-216 & 12,5 & 454,5 & $A p$ & Epa & 157,44 & 170,26 & 108,74 & 0,79 & 2,02 & 20,8 \\
\hline SM-216 & 12,4 & 454,6 & $A p$ & Epa & 236,90 & 258,28 & 164,24 & 0,79 & 1,99 & 22,7 \\
\hline SM-216 & 12,7 & 454,3 & $A p$ & Epa & 53,53 & 59,02 & 37,37 & 0,79 & 1,95 & 25,4 \\
\hline SM-224 & 22,8 & 437,8 & $A e_{i}$ & Mfsx & 301,44 & 320,04 & 202,99 & 0,79 & 2,03 & 15,9 \\
\hline SM-224 & 22,6 & 438,1 & $A e_{i}$ & Mfsx & 376,35 & 399,98 & 253,15 & 0,79 & 2,02 & 16,1 \\
\hline SM-224 & 22,0 & 438,7 & $A e_{i}$ & Mfsx & 314,74 & 332,12 & 215,32 & 0,79 & 2,13 & 14,9 \\
\hline SM-224 & 22,8 & 437,8 & $A e_{i}$ & Mfsx & 287,86 & 305,95 & 195,96 & 0,79 & 2,06 & 16,4 \\
\hline SM-505 & 13,6 & 430,4 & $A e_{i}$ & Mfsx & 360,78 & 384,2 & 244,08 & 0,79 & 2,03 & 16,7 \\
\hline SM-505 & 14,7 & 429,4 & $A e_{i}$ & Mfsx & 98,48 & 105,67 & 67,00 & 0,79 & 2,01 & 18,6 \\
\hline SM-505 & 13,6 & 430,4 & $\mathrm{Ae}_{\mathrm{i}}$ & Mfsx & 421,32 & 451,98 & 286,52 & 0,79 & 2,01 & 18,5 \\
\hline
\end{tabular}


APÊNDICE B - Dados referentes aos ensaios de determinação da densidade e porosidade aparentes (continuação).

\begin{tabular}{|c|c|c|c|c|c|c|c|c|c|c|}
\hline $\mathrm{CP}$ & Prof. (m) & Cota $(\mathrm{m})$ & Unidade & Petrofácies & $M_{\text {sec }}(g)$ & $M_{\text {sat }}(g)$ & $M_{\text {sub }}(g)$ & $\rho_{1}\left(g / \mathrm{cm}^{3}\right)$ & $\rho_{\mathrm{a}}\left(\mathrm{g} / \mathrm{cm}^{3}\right)$ & $\eta_{a}(\%)$ \\
\hline SM-222 & 10,6 & 454,8 & $A p$ & Epa & 145,38 & 161,03 & 100,82 & 0,79 & 1,90 & 26,0 \\
\hline SM-222 & 13,8 & 451,6 & Ap & Epa & 314,14 & 336,91 & 216,31 & 0,79 & 2,05 & 18,9 \\
\hline SM-222 & 14,0 & 451,4 & Ap & Epa & 88,34 & 103,83 & 51,83 & 1,00 & 1,70 & 29,8 \\
\hline SM-222 & 15,3 & 450,1 & $\mathrm{Ae}$ & Ems & 110,90 & 125,20 & 64,60 & 1,00 & 1,83 & 23,6 \\
\hline SM-222 & 15,8 & 449,6 & $\mathrm{Ae}$ & Ems & 32,90 & 36,60 & 19,40 & 1,00 & 1,91 & 21,8 \\
\hline SM-222 & 15,8 & 449,6 & $\mathrm{Ae}$ & Ems & 33,40 & 36,60 & 22,90 & 0,79 & 1,92 & 23,8 \\
\hline SM-222 & 15,8 & 449,6 & $\mathrm{Ae}$ & Ems & 23,40 & 26,00 & 16,10 & 0,79 & 1,88 & 25,9 \\
\hline SM-222 & 16,3 & 449,1 & $\mathrm{Am}$ & Mfsx & 503,10 & 576,80 & 291,90 & 1,00 & 1,77 & 25,9 \\
\hline SM-222 & 17,2 & 448,2 & Ap & Epa & 269,10 & 307,80 & 162,20 & 1,00 & 1,85 & 26,6 \\
\hline SM-222 & 19,1 & 446,3 & $\mathrm{Ae}$ & Ems & 19,10 & 20,80 & 13,10 & 0,79 & 1,96 & 21,2 \\
\hline SM-222 & 20,5 & 444,9 & $\mathrm{Ae}$ & Ems & 87,10 & 97,30 & 50,40 & 1,00 & 1,86 & 21,8 \\
\hline SM-222 & 22,9 & 442,5 & $\mathrm{Ae}$ & Efsx & 252,80 & 284,00 & 144,20 & 1,00 & 1,81 & 22,3 \\
\hline SM-222 & 24,9 & 440,5 & $A e_{i}$ & Mms & 17,30 & 19,00 & 12,00 & 0,79 & 1,94 & 25,1 \\
\hline SM-222 & 24,9 & 440,5 & $A e_{i}$ & Mms & 9,70 & 10,80 & 6,80 & 0,79 & 1,93 & 26,1 \\
\hline SM-222 & 24,9 & 440,5 & $A e_{i}$ & Mms & 6,80 & 7,40 & 4,70 & 0,79 & 1,99 & 24,6 \\
\hline SM-222 & 26,9 & 438,4 & Am & Mms & 459,50 & 487,60 & 310,00 & 0,79 & 2,04 & 15,8 \\
\hline SM-222 & 27,6 & 437,8 & Am & Mms & 3,50 & 3,80 & 2,30 & 0,79 & 1,76 & 21,0 \\
\hline SM-222 & 27,6 & 437,8 & Am & Mms & 3,90 & 4,30 & 2,80 & 0,79 & 2,06 & 24,5 \\
\hline SM-222 & 27,6 & 437,8 & Am & Mms & 6,00 & 6,30 & 3,90 & 0,79 & 2,00 & 11,9 \\
\hline SM-222 & 27,6 & 437,8 & $\mathrm{Am}$ & Mms & 2,70 & 3,00 & 1,90 & 0,79 & 1,98 & 25,7 \\
\hline SM-222 & 28,7 & 436,7 & $A e_{i}$ & Mfsx & 206,40 & 235,90 & 121,50 & 1,00 & 1,80 & 25,8 \\
\hline SM-222 & 29,1 & 436,3 & $A e_{i}$ & Mfsx & 246,40 & 278,00 & 142,30 & 1,00 & 1,82 & 23,3 \\
\hline SM-222 & 29,9 & 435,5 & $\mathrm{Ae}$ & Efsx & 185,50 & 197,80 & 125,80 & 0,79 & 2,03 & 17,1 \\
\hline SM-222 & 30,5 & 434,9 & $A e_{i}$ & Mms & 132,00 & 143,20 & 78,10 & 1,00 & 2,03 & 17,1 \\
\hline
\end{tabular}

$M_{\text {sec: }}$ : massa seca; $M_{\text {sat }}$ : massa saturada; $M_{\text {sub: }}$ massa submersa; $\rho_{l:}$ densidade do líquido de submersão e saturação; $\rho_{a}:$ densidade aparente; $\eta_{a}:$ porosidade aparente 


\section{APÊNDICE C}

Corpos de prova submetidos a ensaios de compressão uniaxial 
Neste apêndice são apresentados detalhes de cada corpo de prova submetido a ensaios de compressão uniaxial, com ou sem obtenção do módulo de deformabilidade. Ele contém informações sobre as dimensões, peso, carga de ruptura, $\sigma_{u}$ e $E_{s}$. Apresenta ainda a descrição das irregularidades encontradas em cada corpo de prova e registro fotográfico.

Após a moldagem, cada corpo de prova foi pesado e teve suas dimensões medidas com paquímetro. O diâmetro foi medido a cada $45^{\circ}$ na base e no topo, totalizando quatro medidas no topo (DT1 a DT4) e quatro na base (DB1 a DB4), a partir das quais se obteve a média aritmética $D$. O comprimento de cada corpo de prova foi medido ao longo de oito linhas paralelas contidas na superfície do cilindro, com espaçamento de $45^{\circ}$. A média $L$ dos comprimentos obtidos ( $L 1$ a $L 8$ ) foi considerado como a altura do corpo de prova.

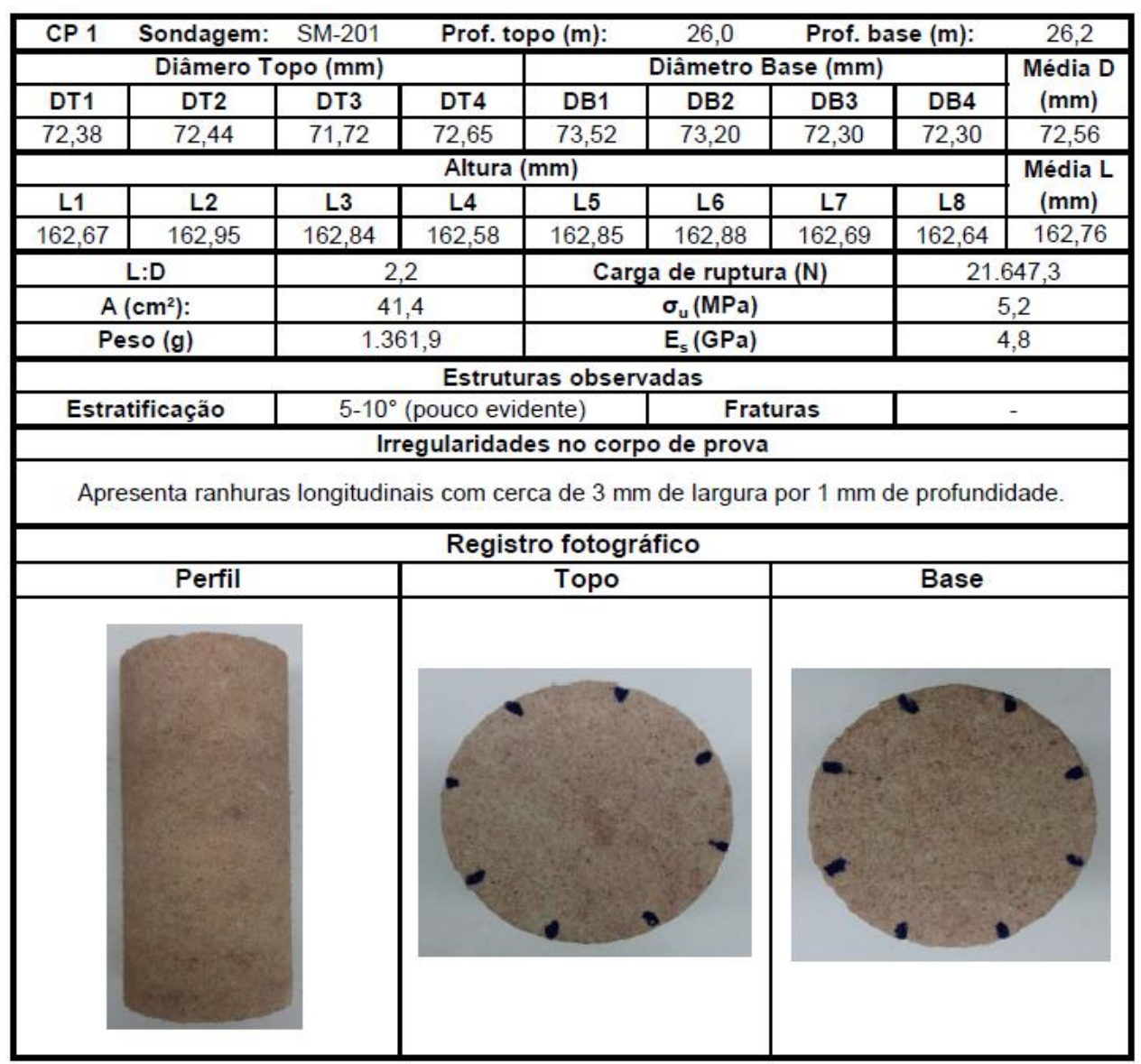




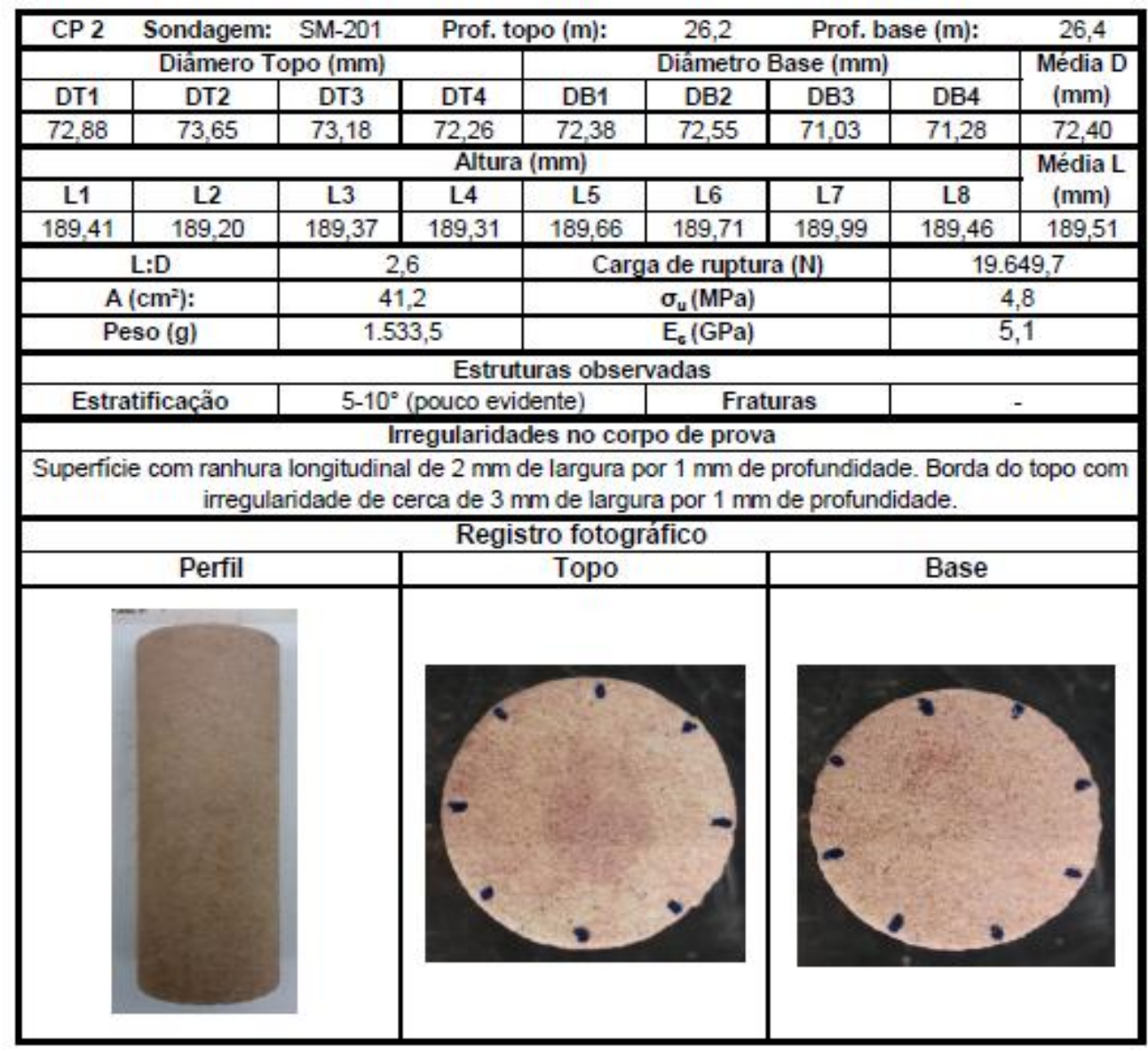

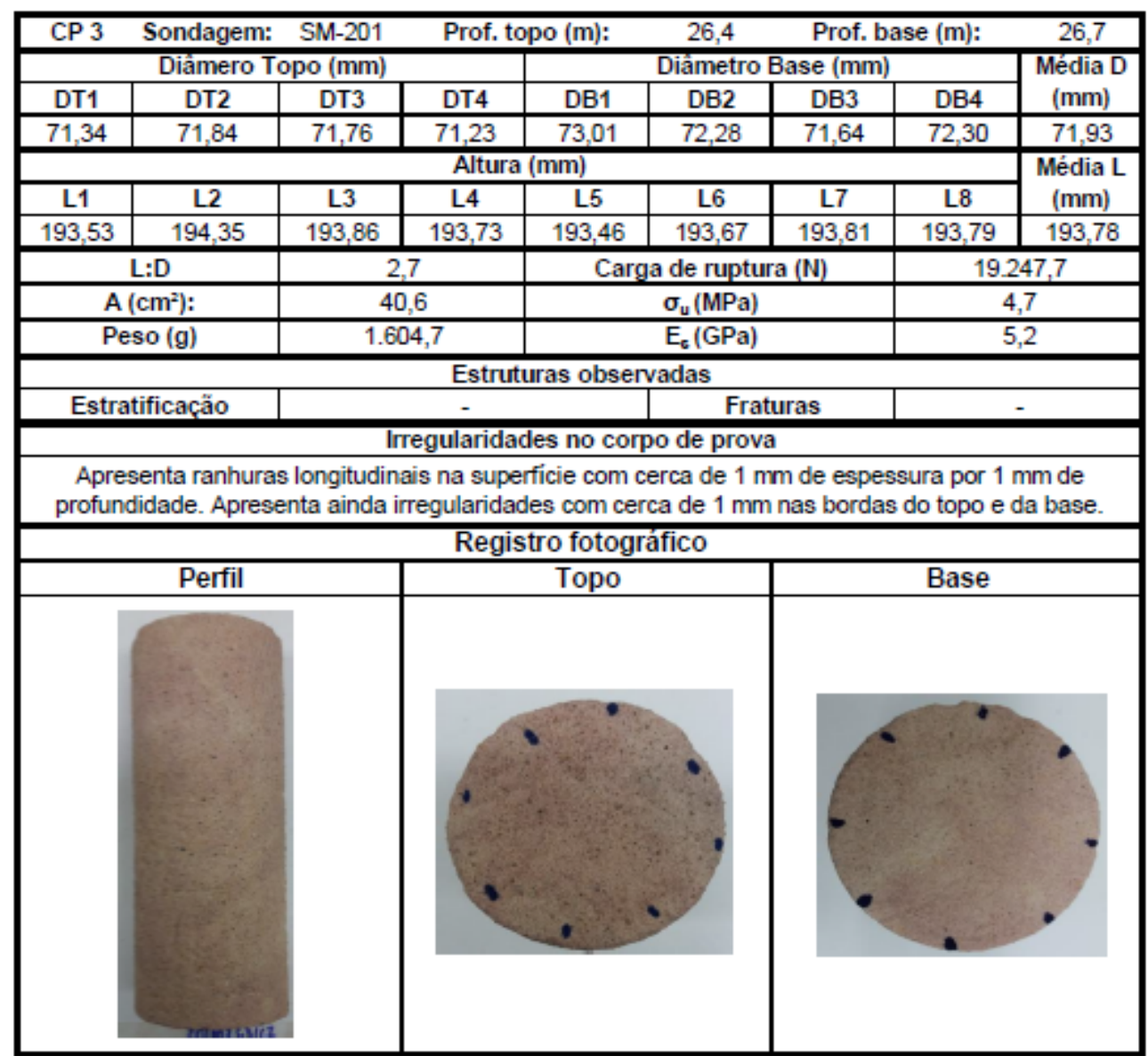




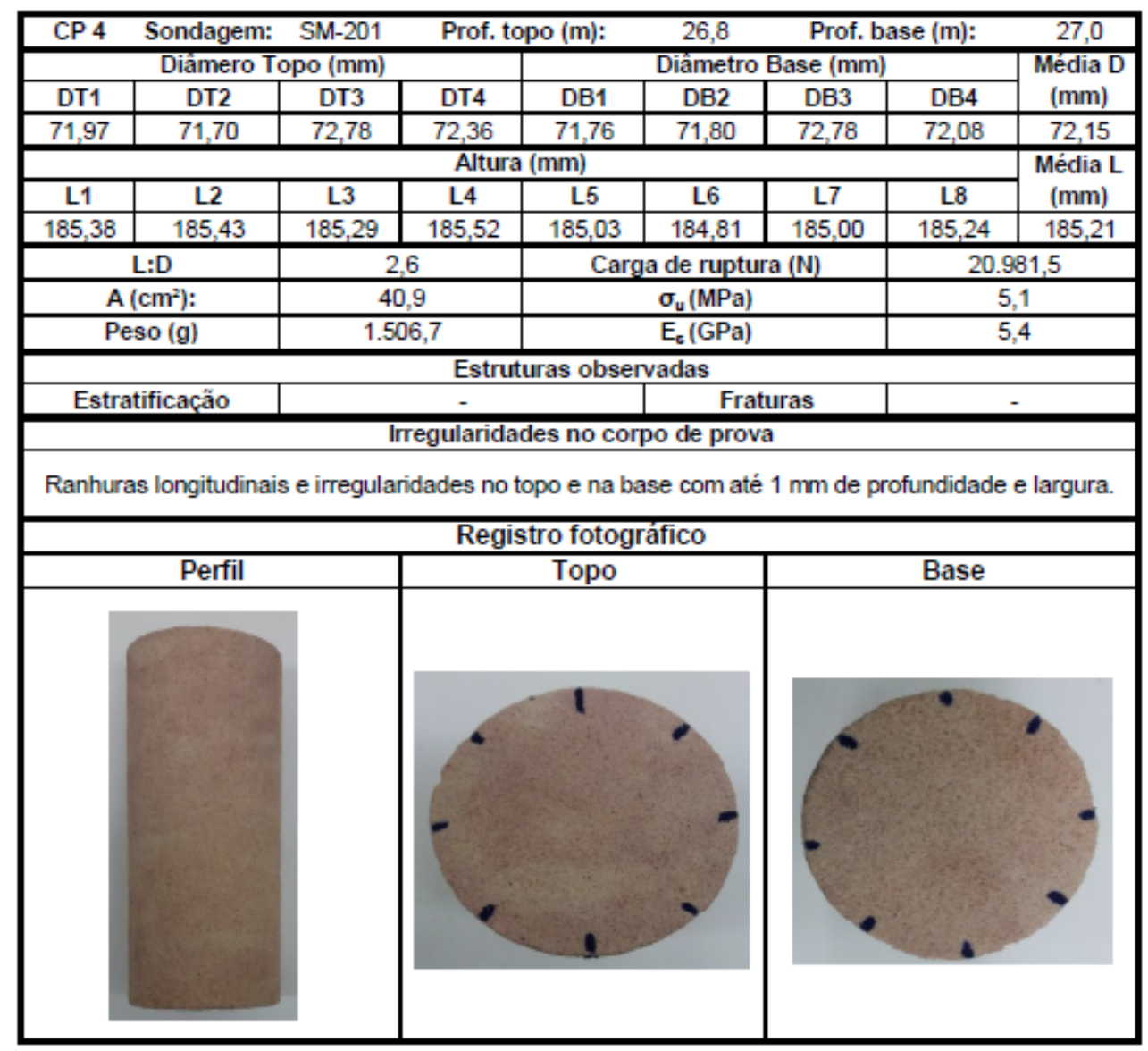

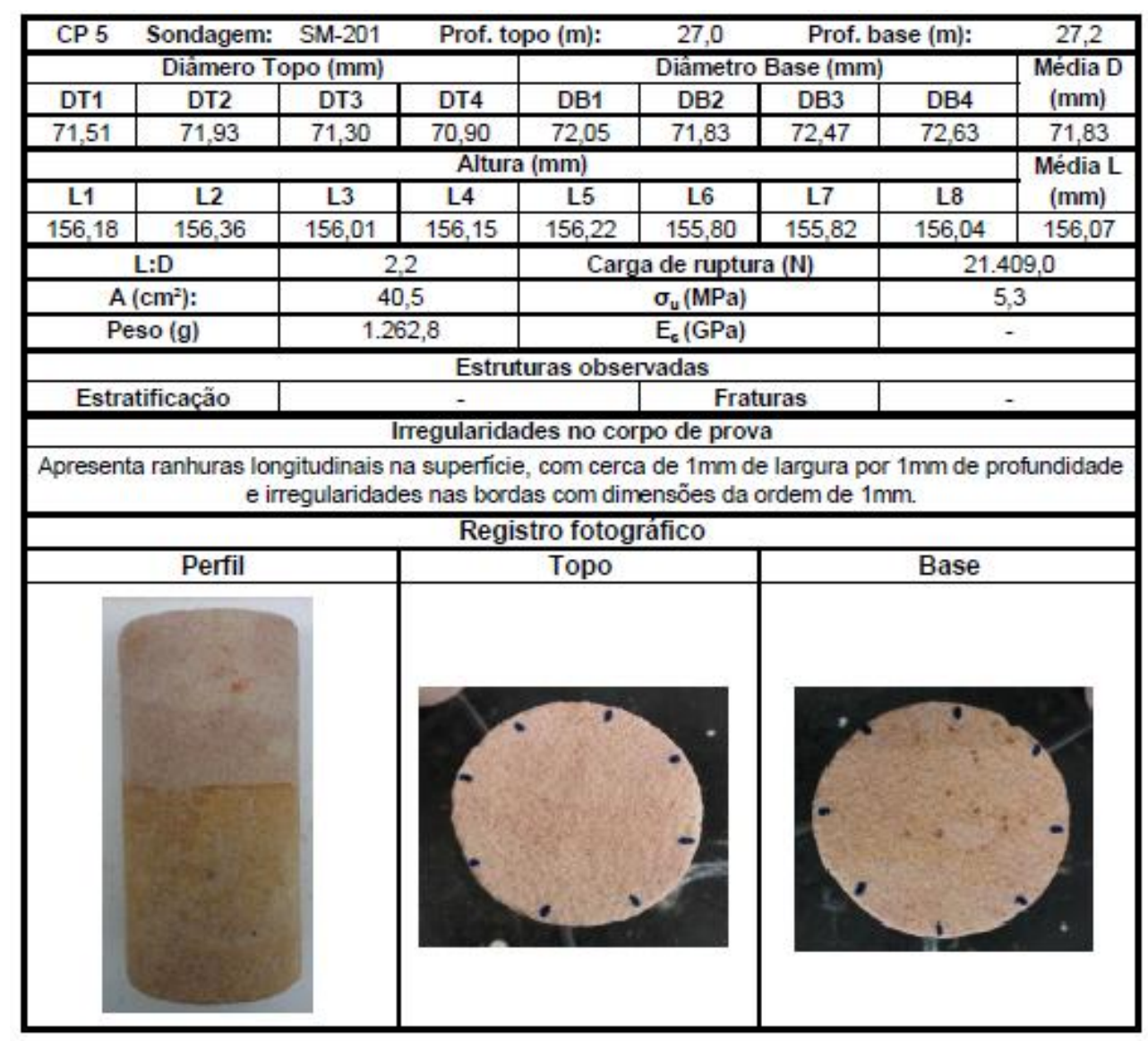




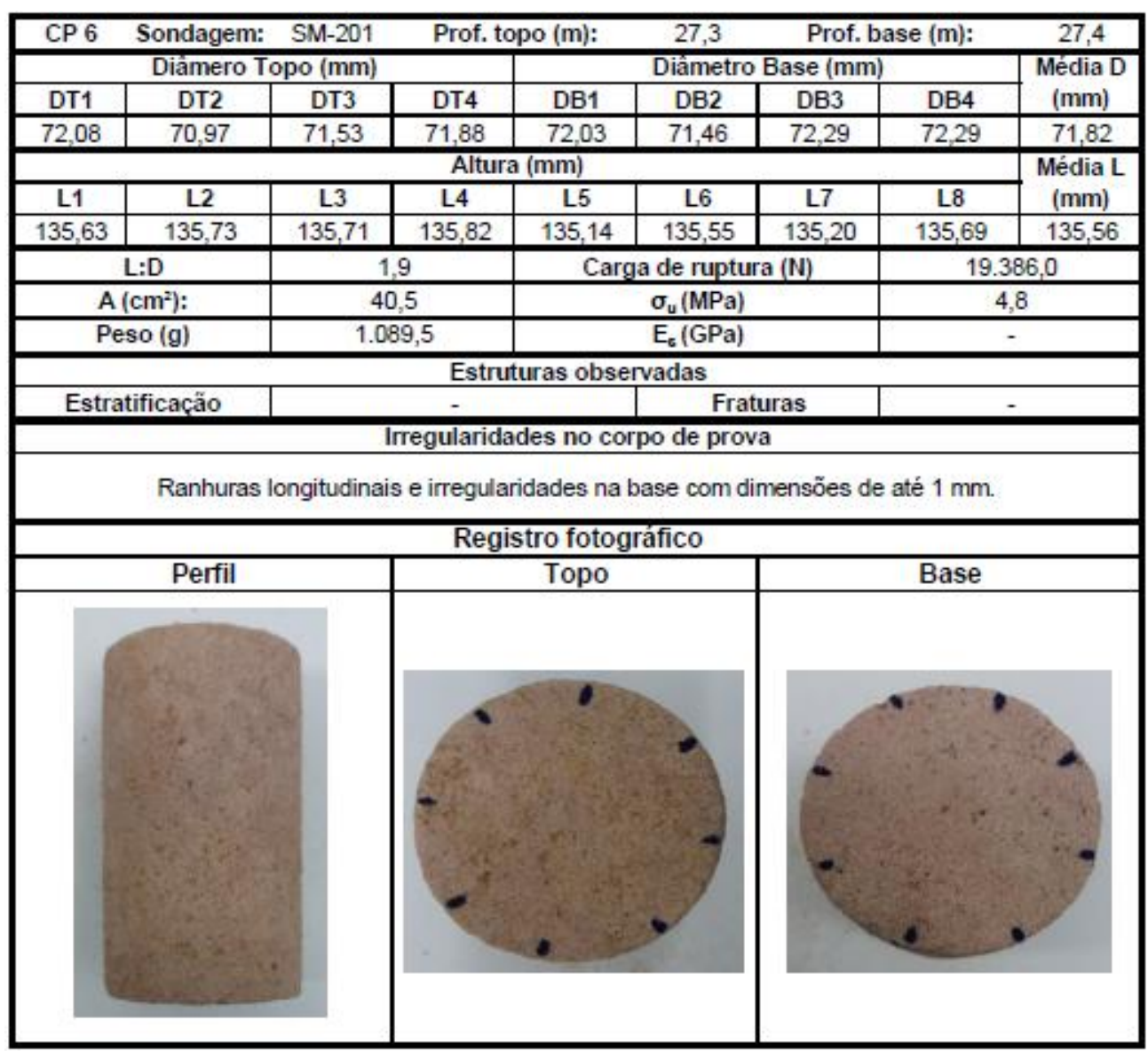

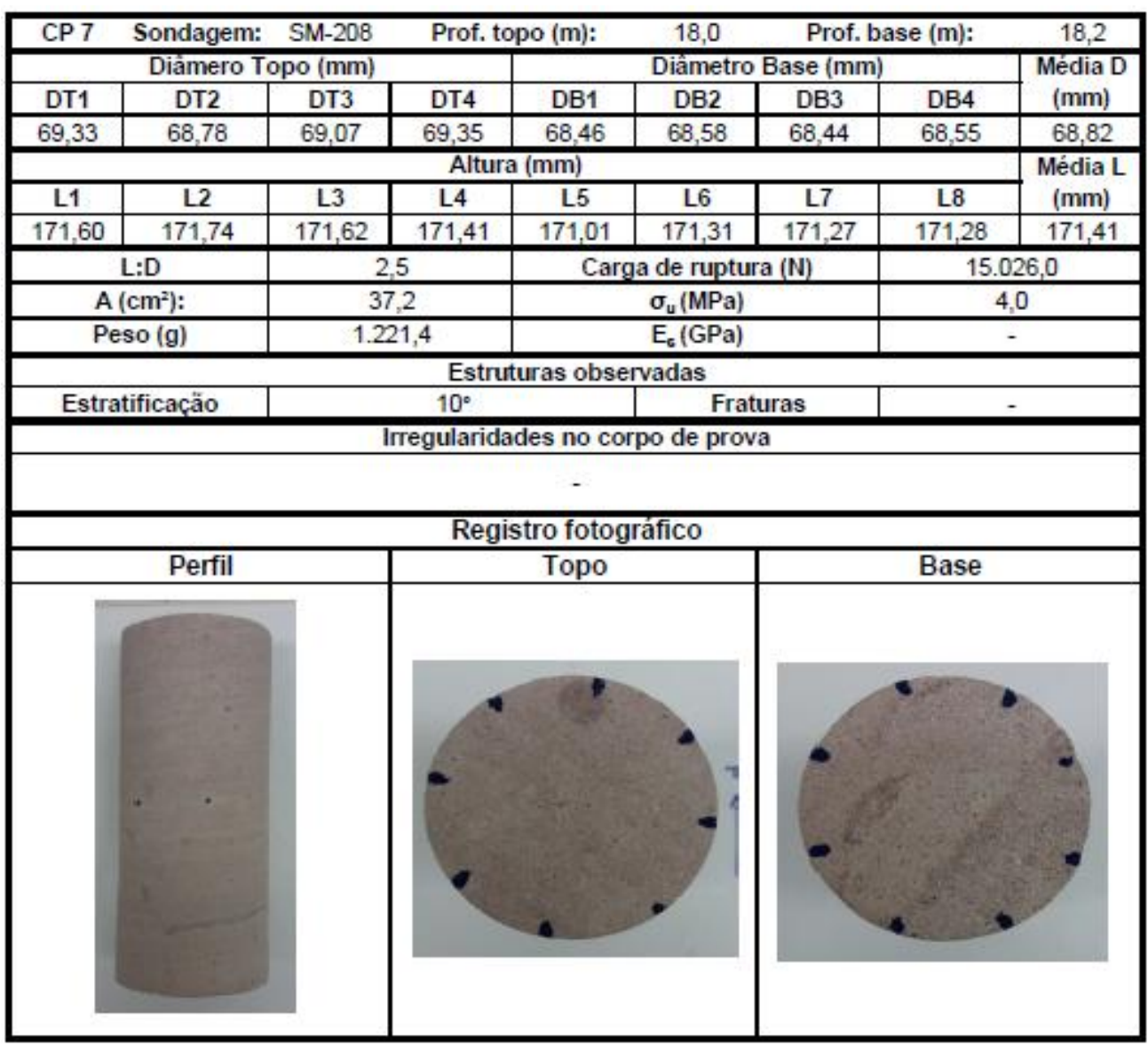




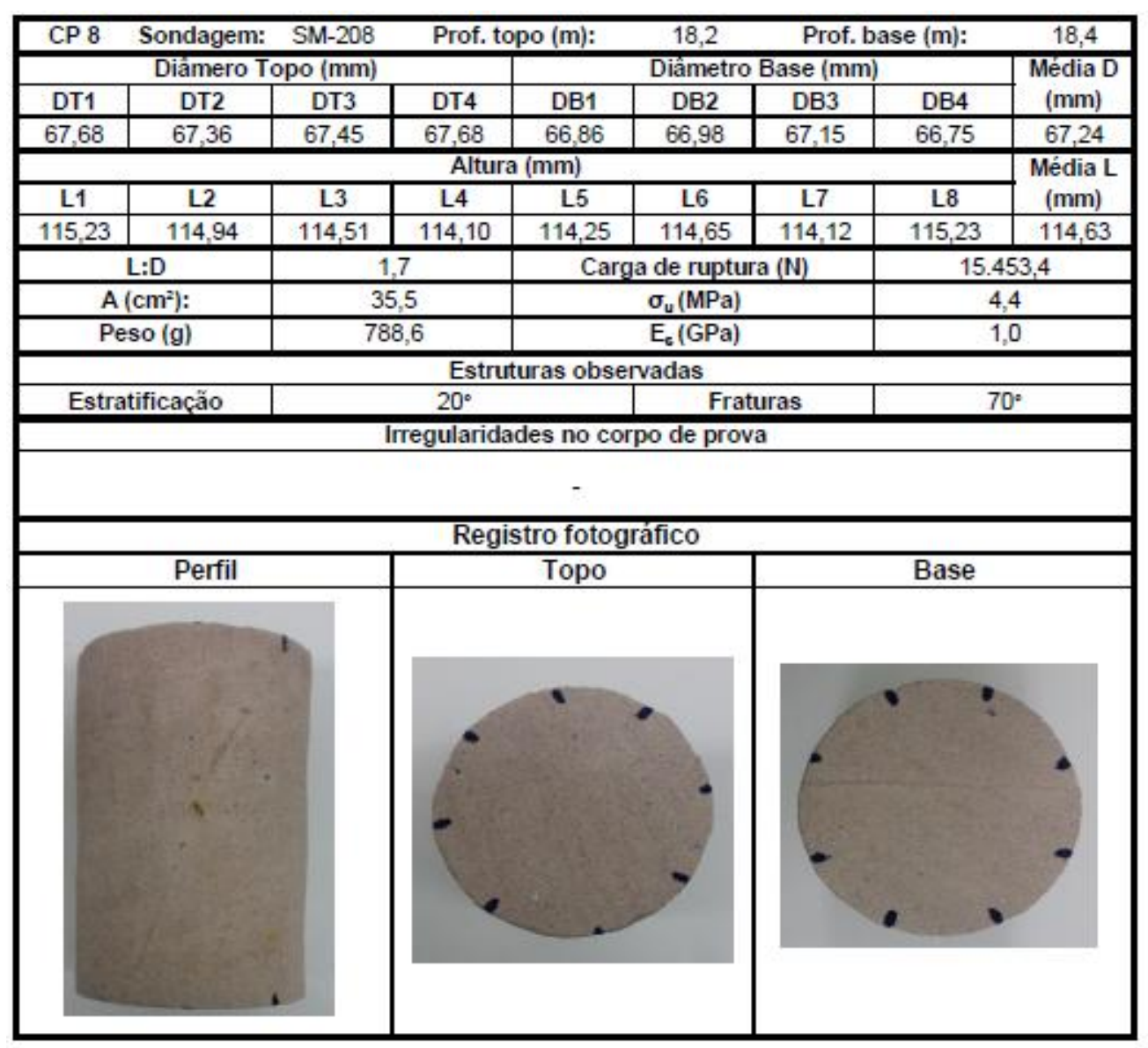

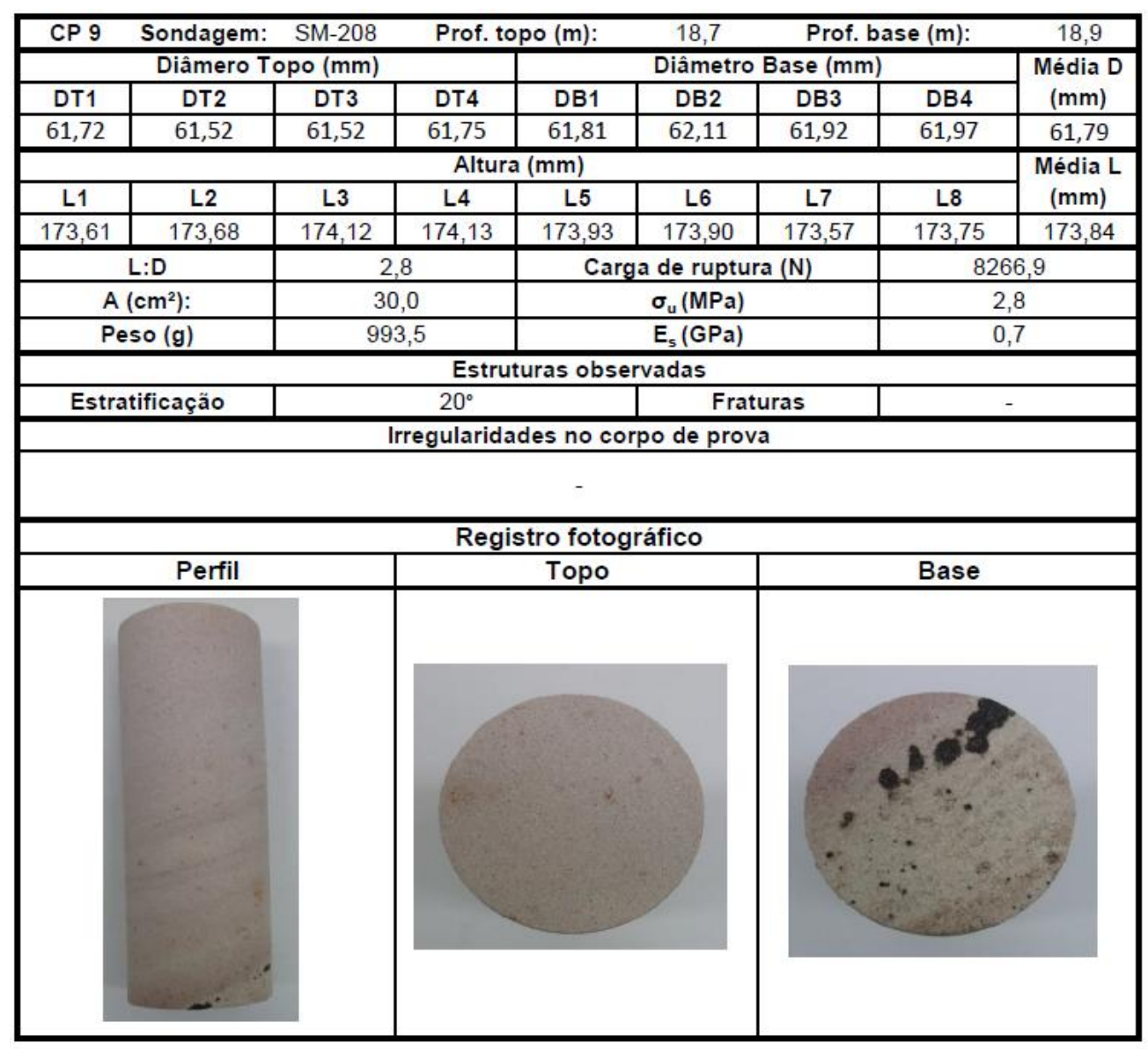




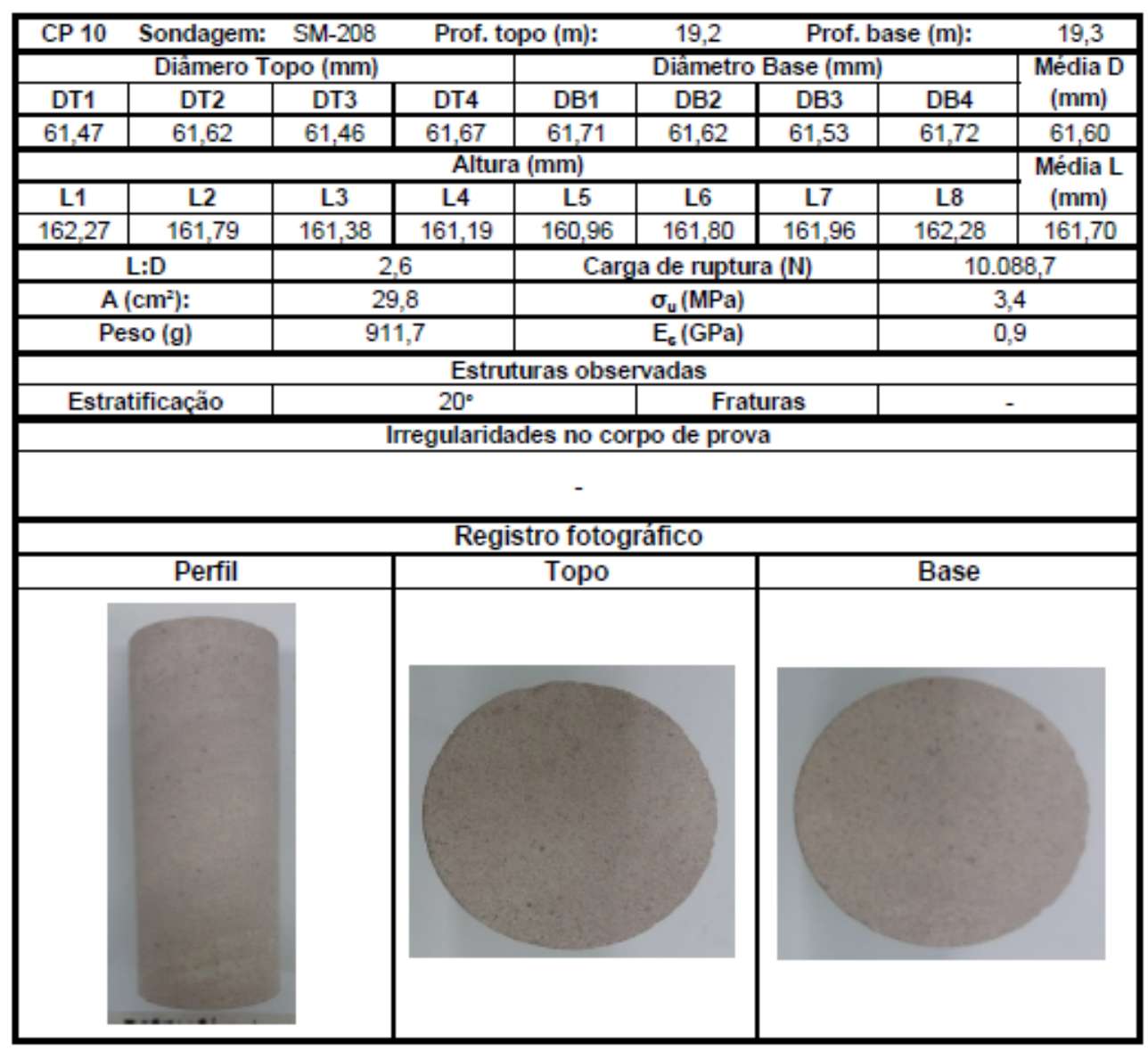

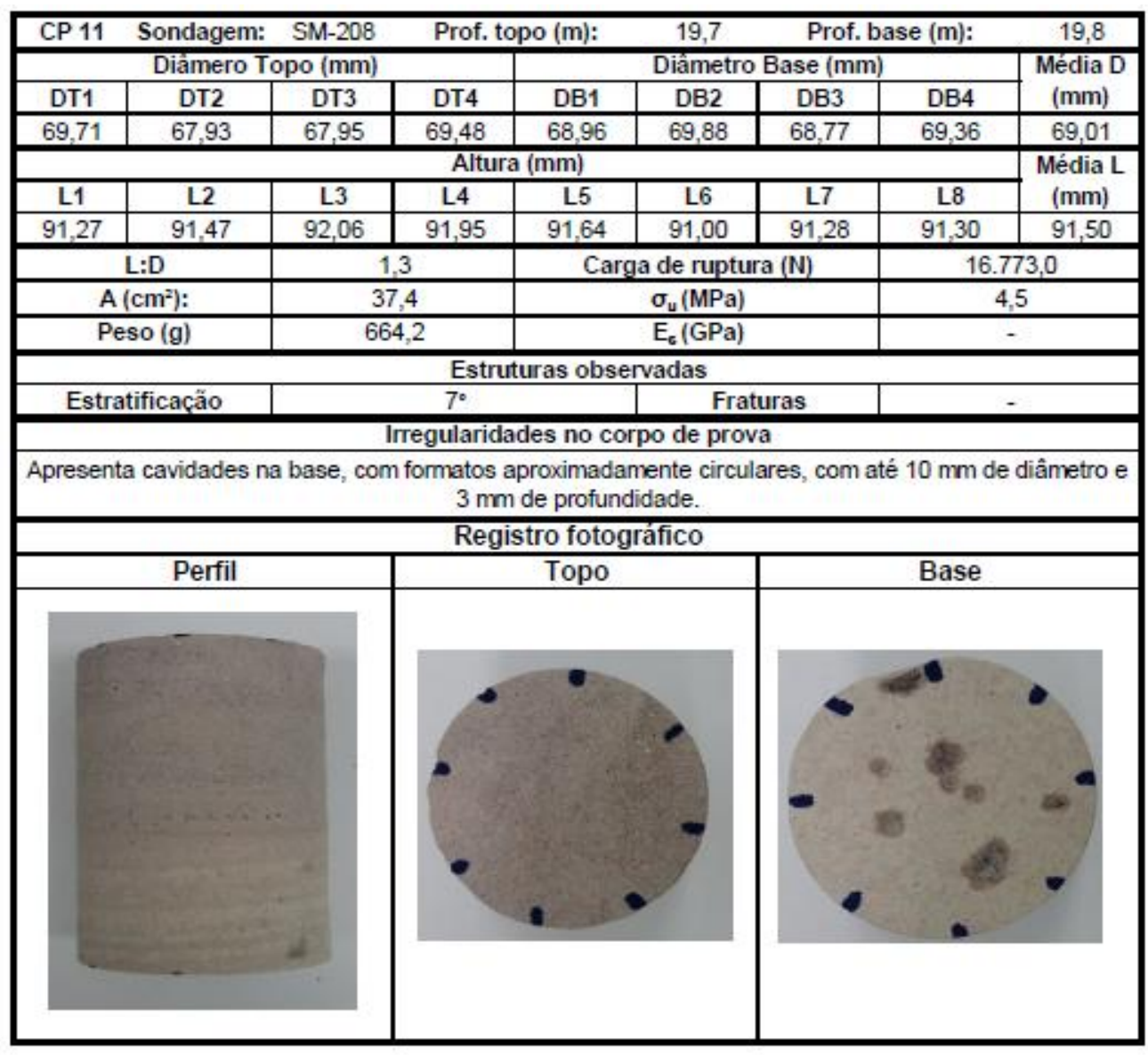




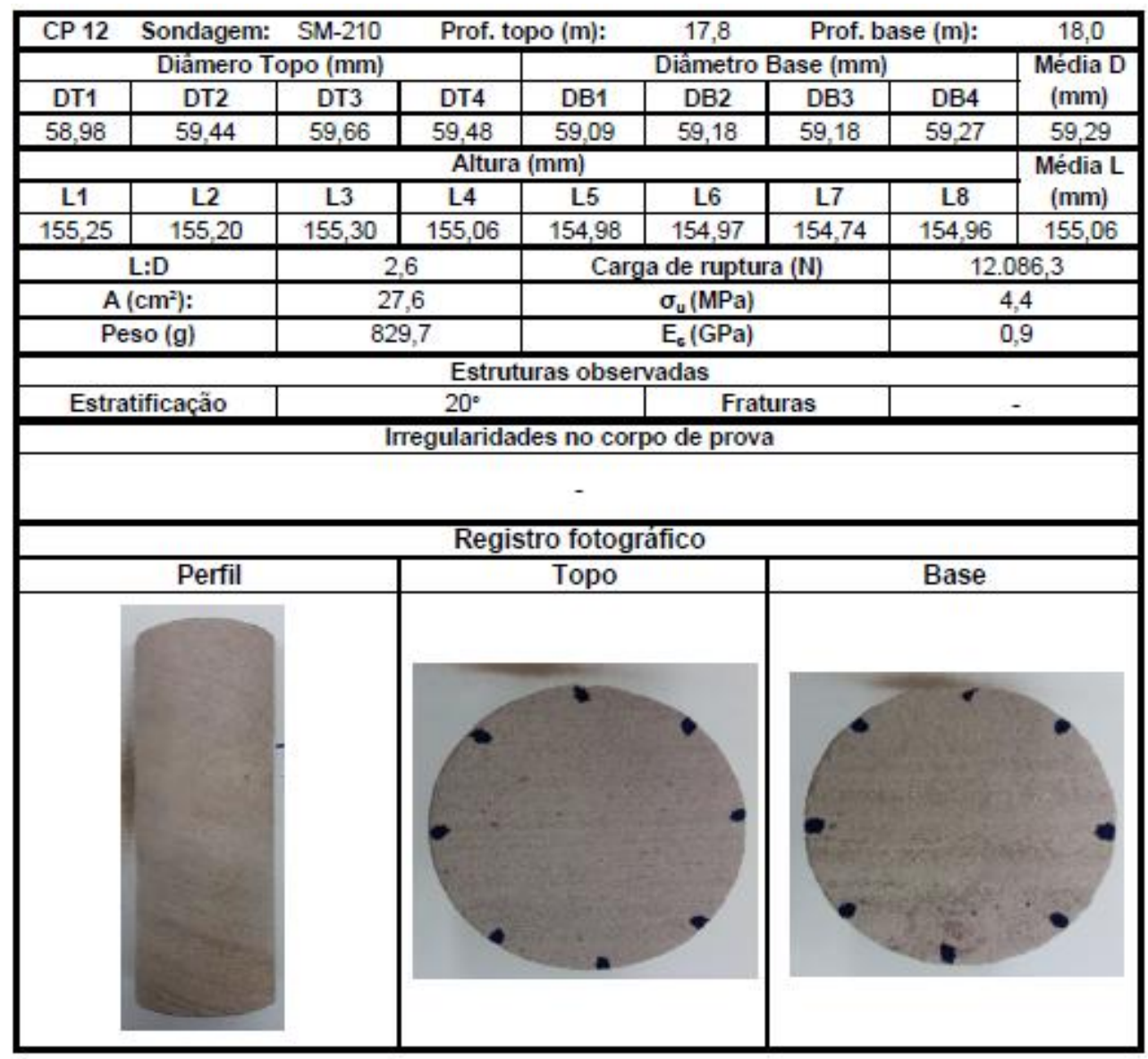

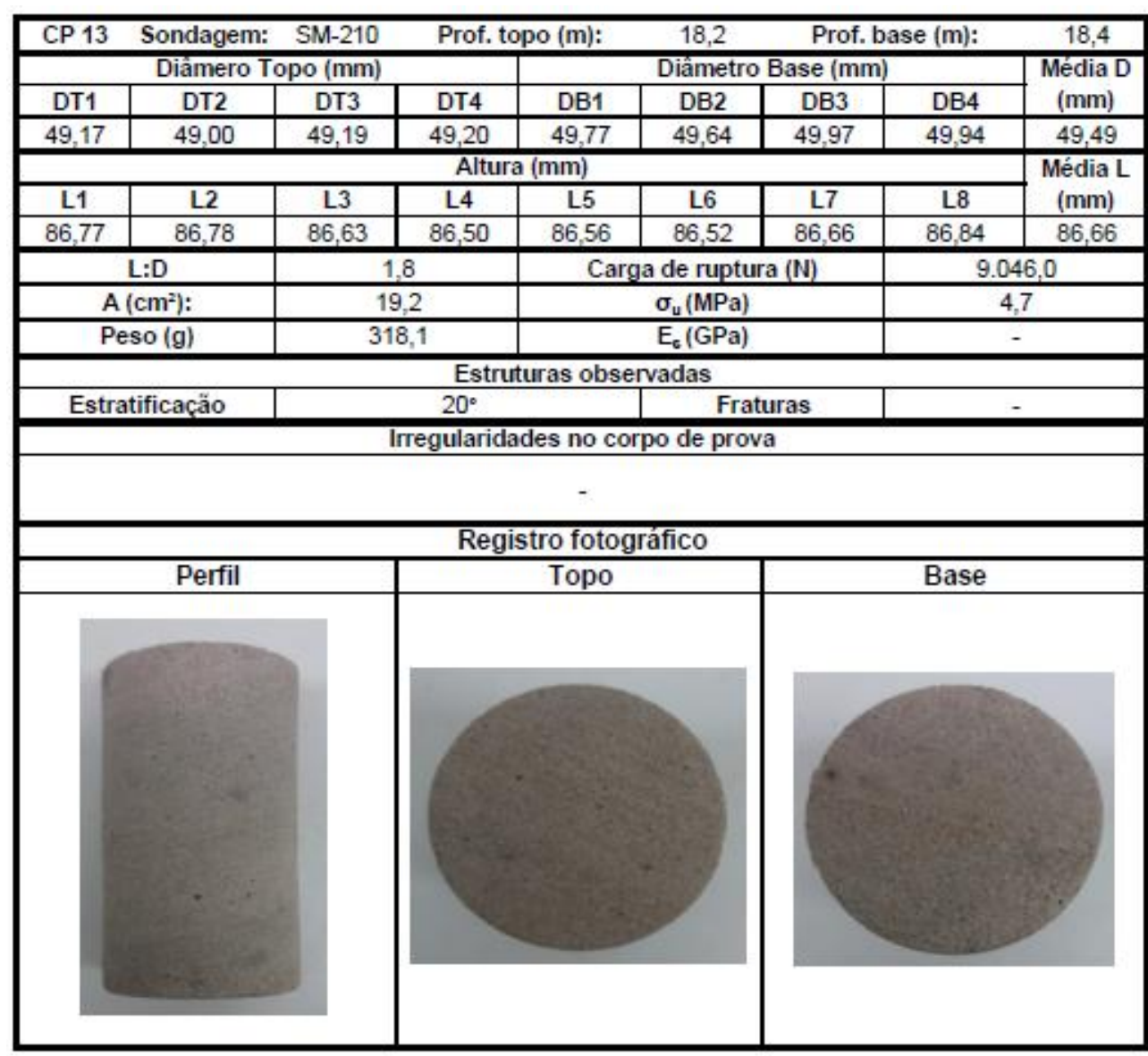




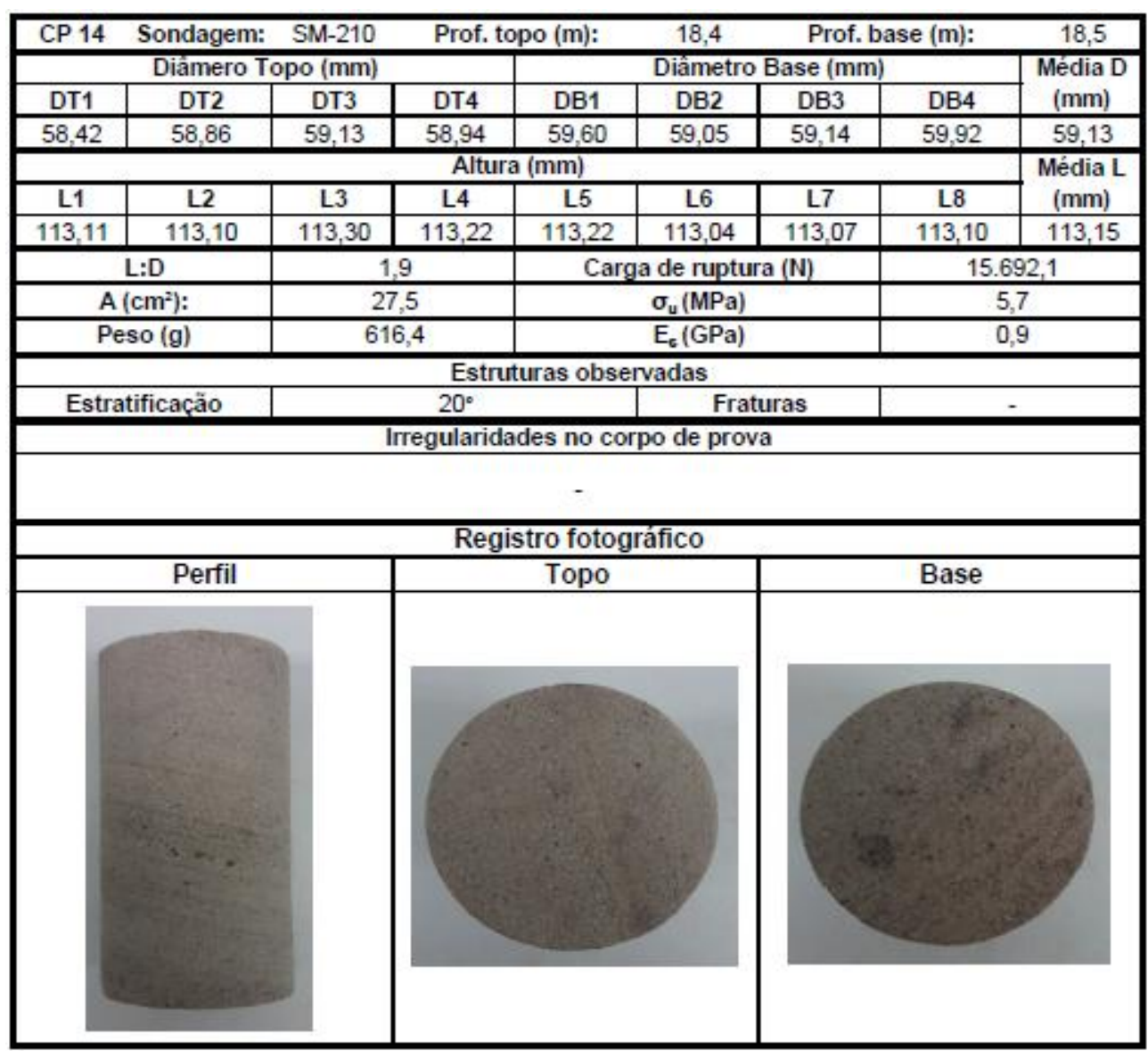

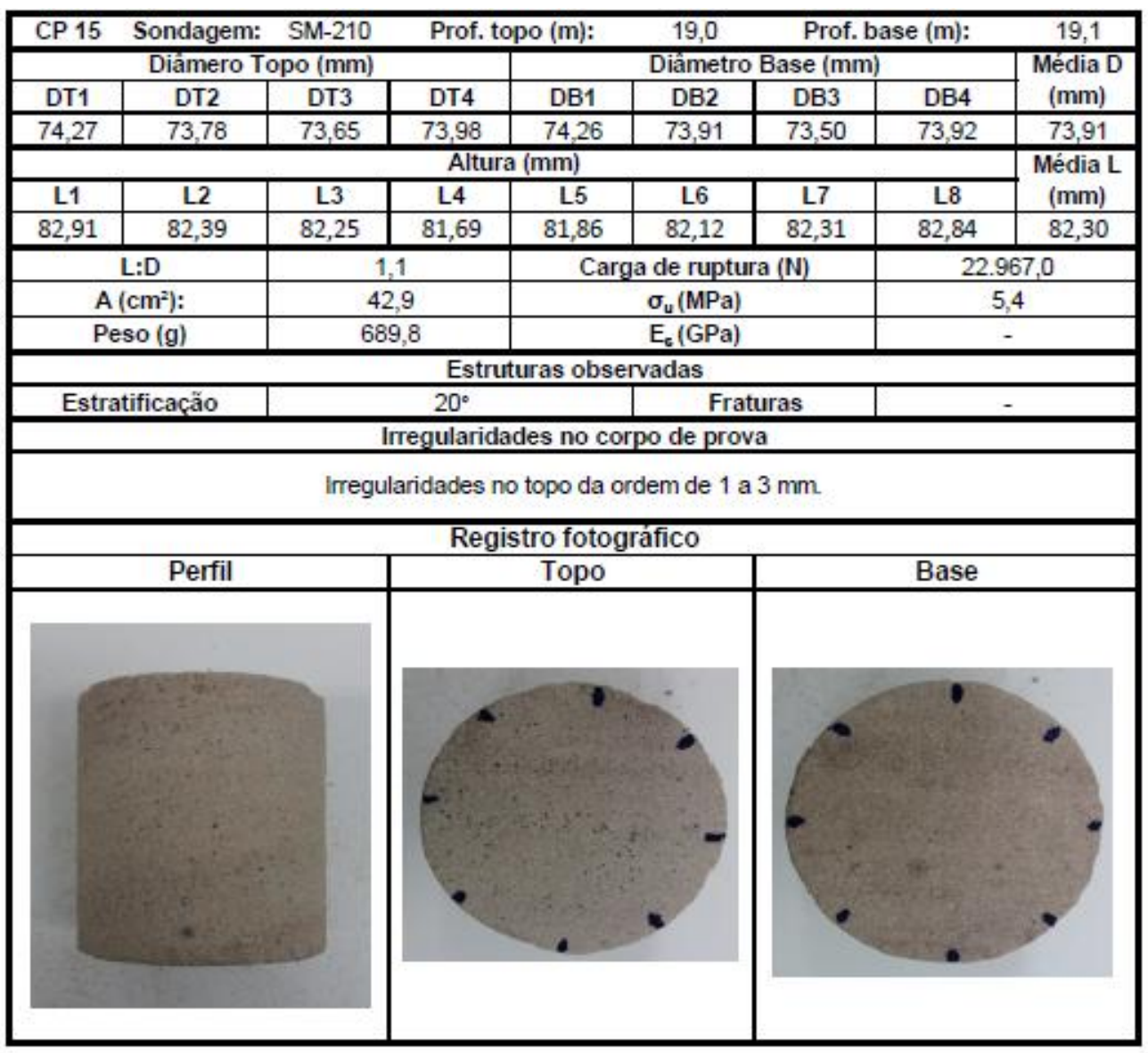




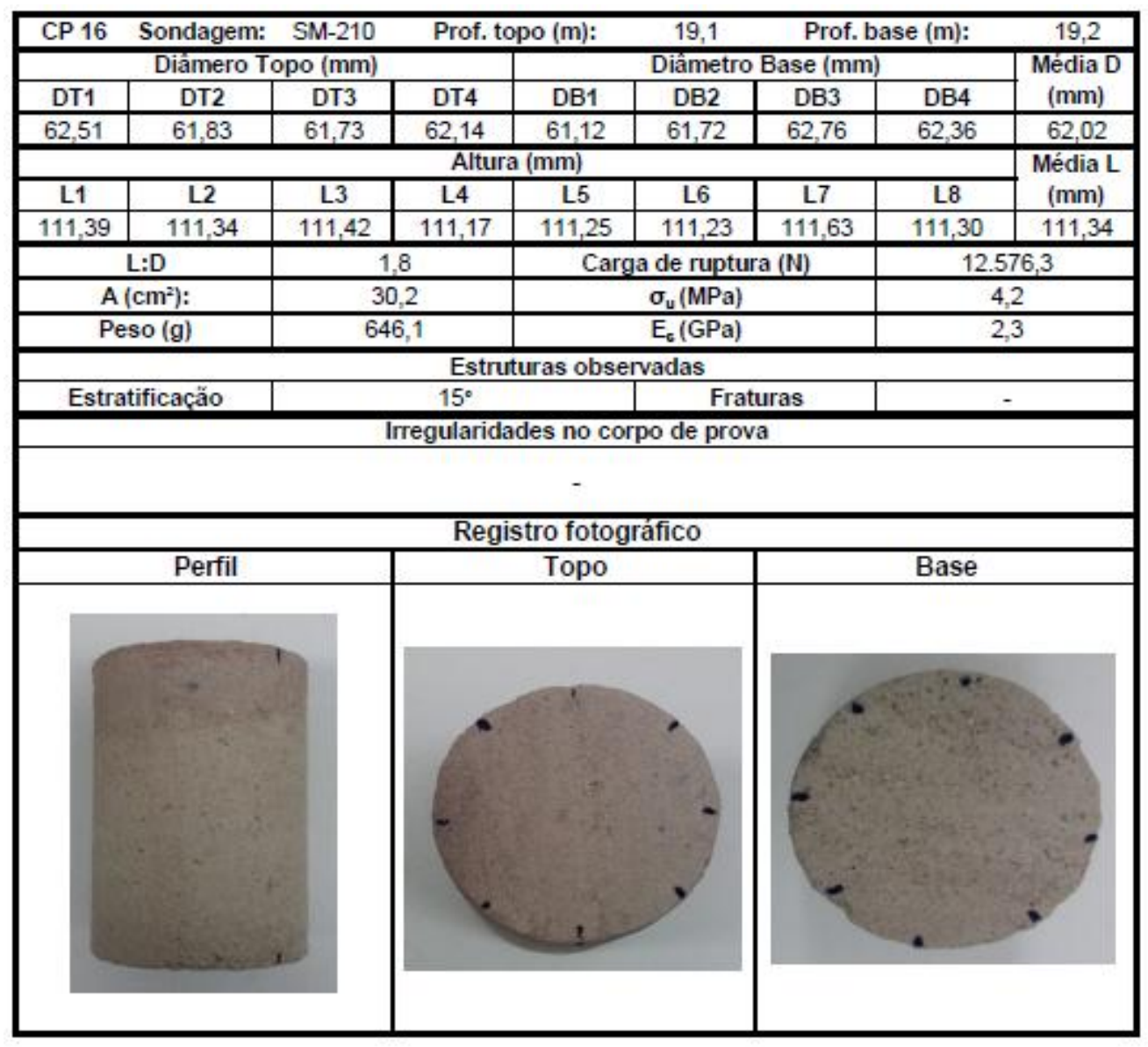

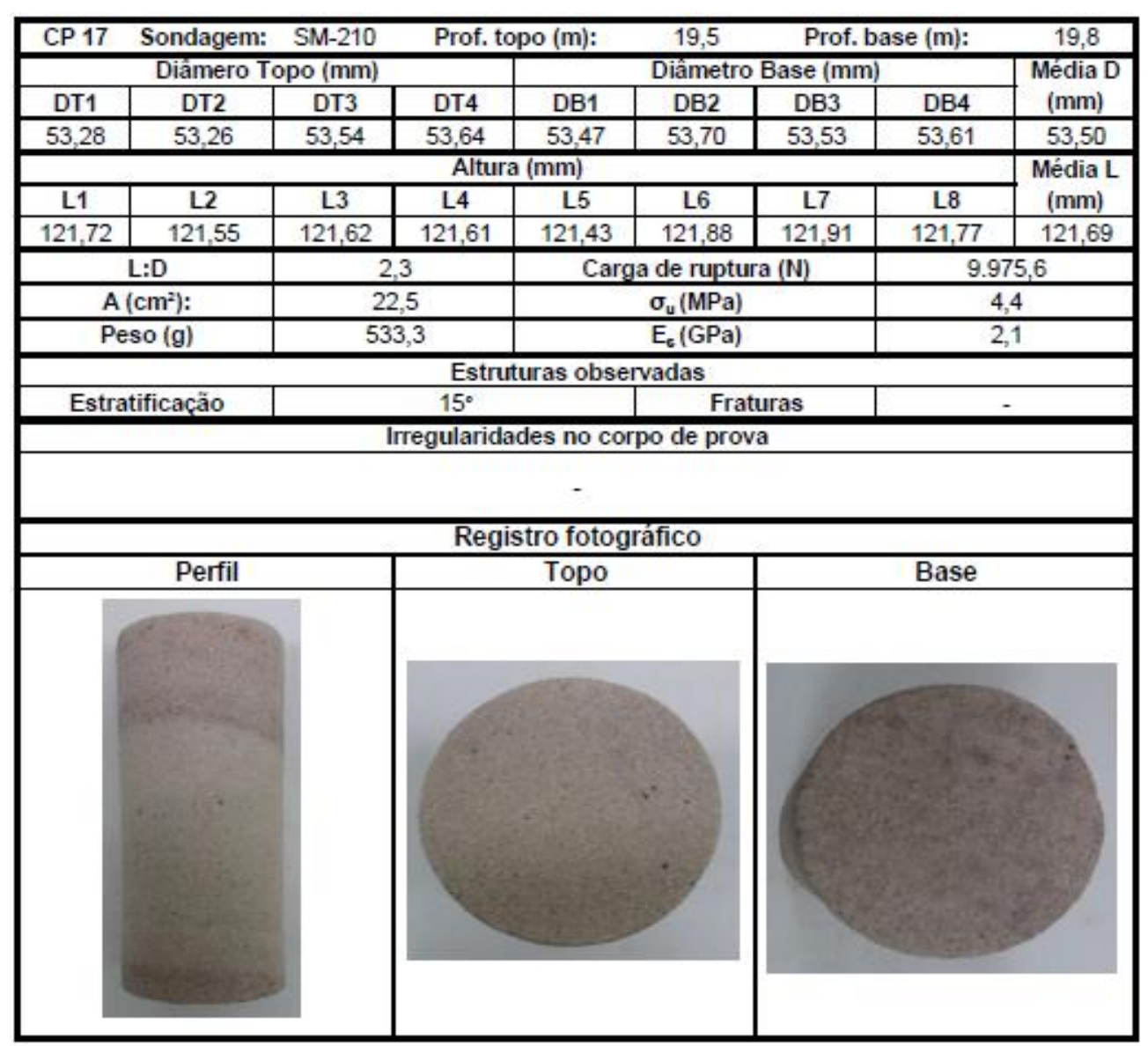




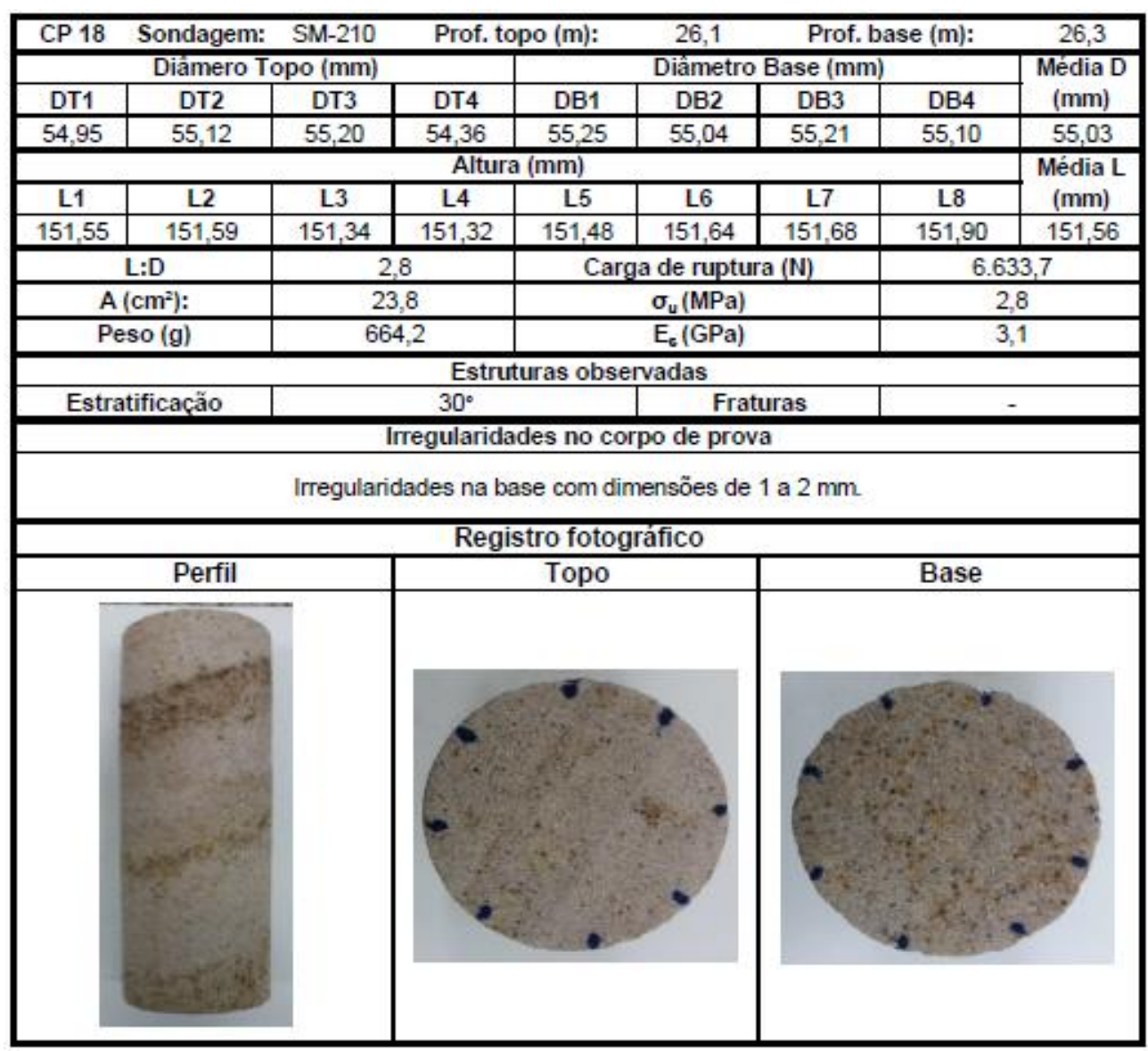

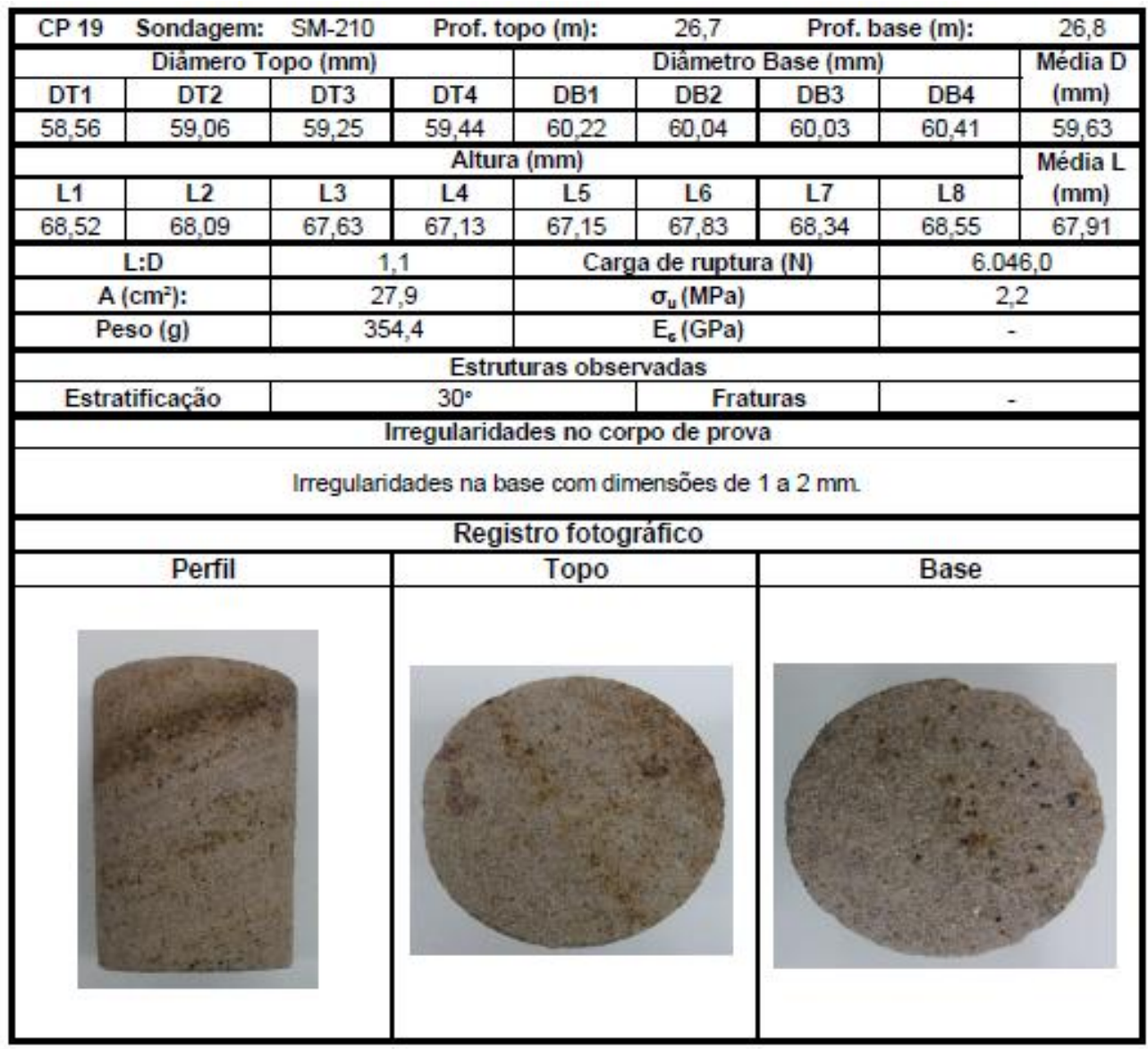




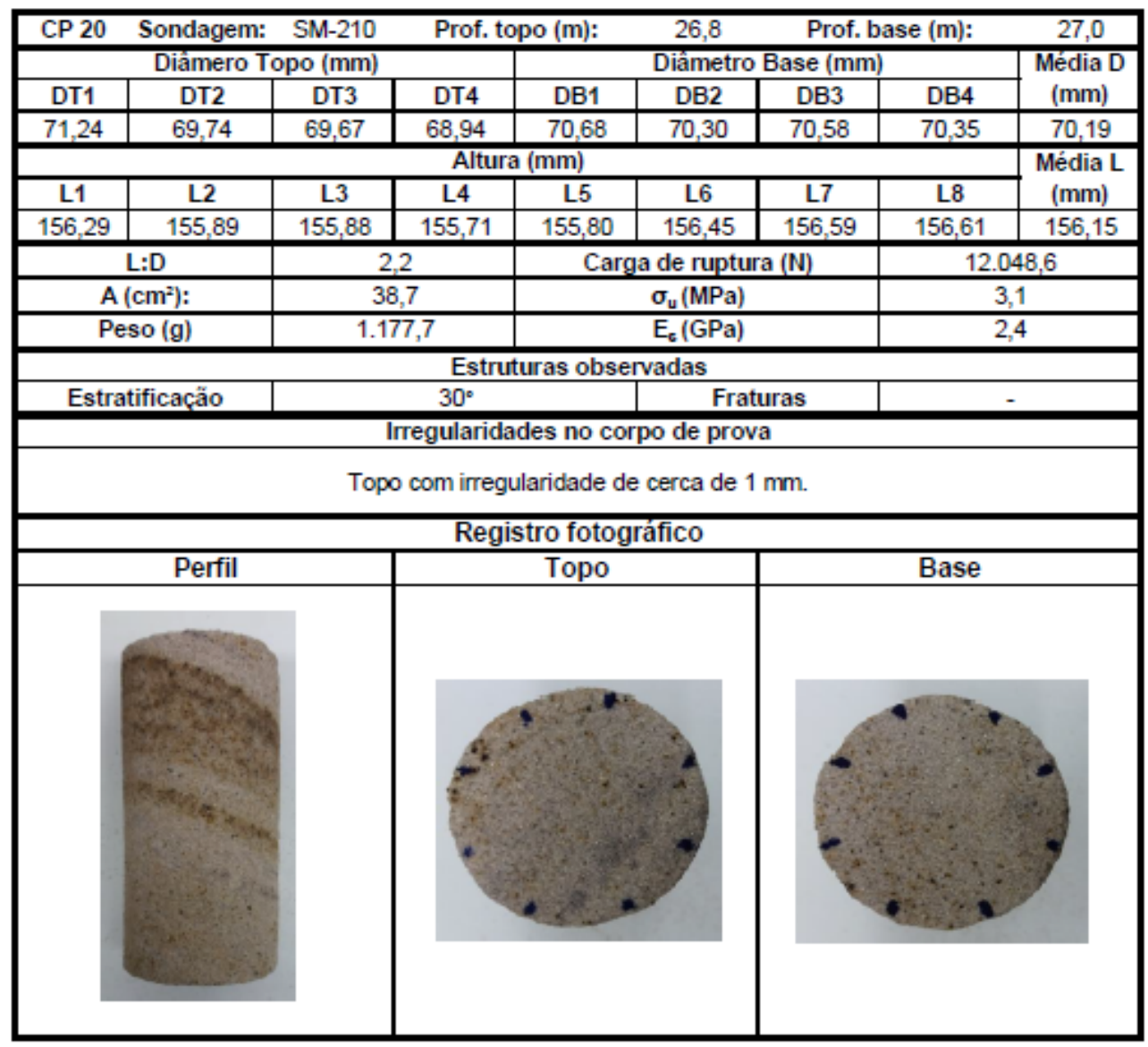

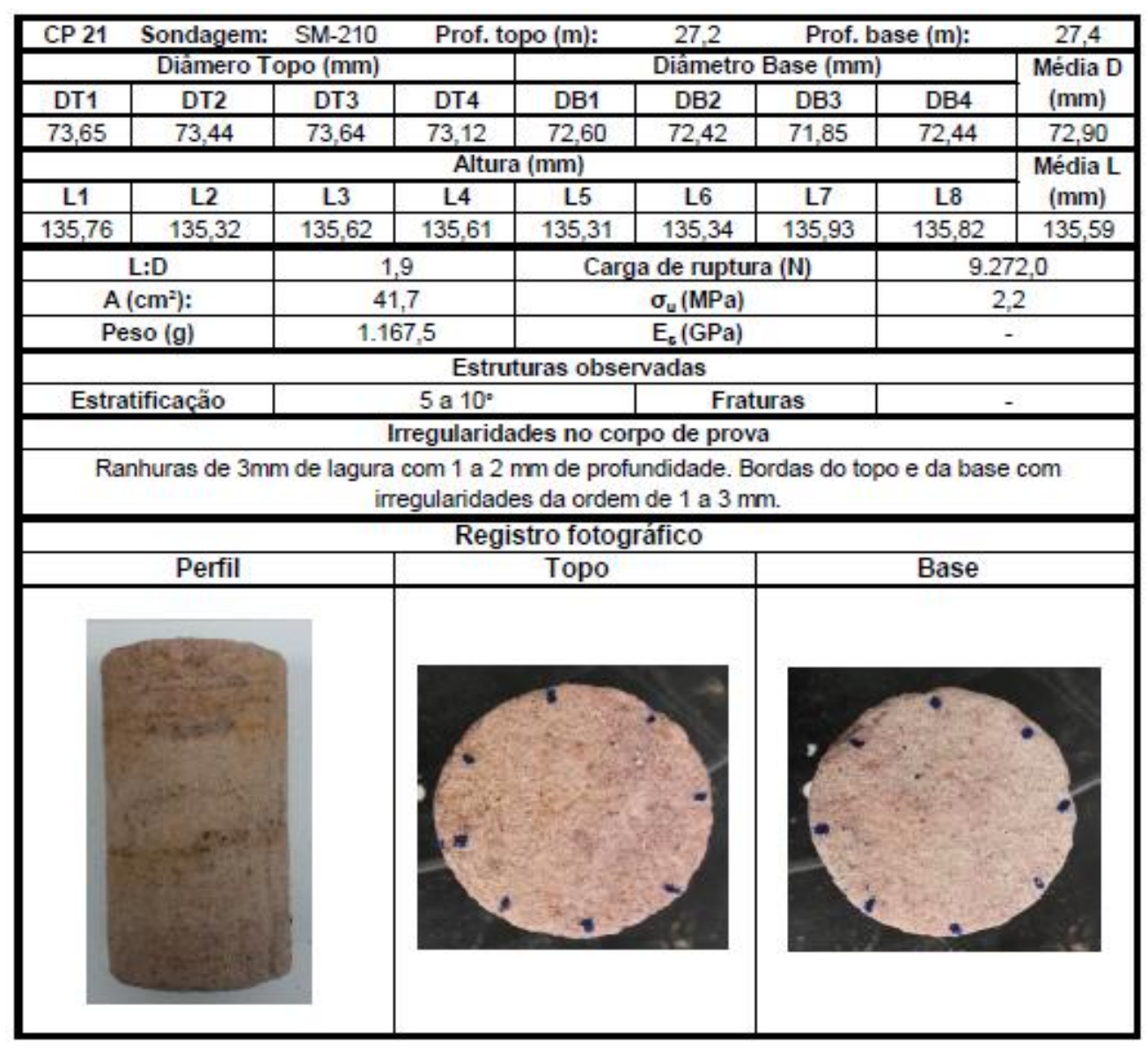




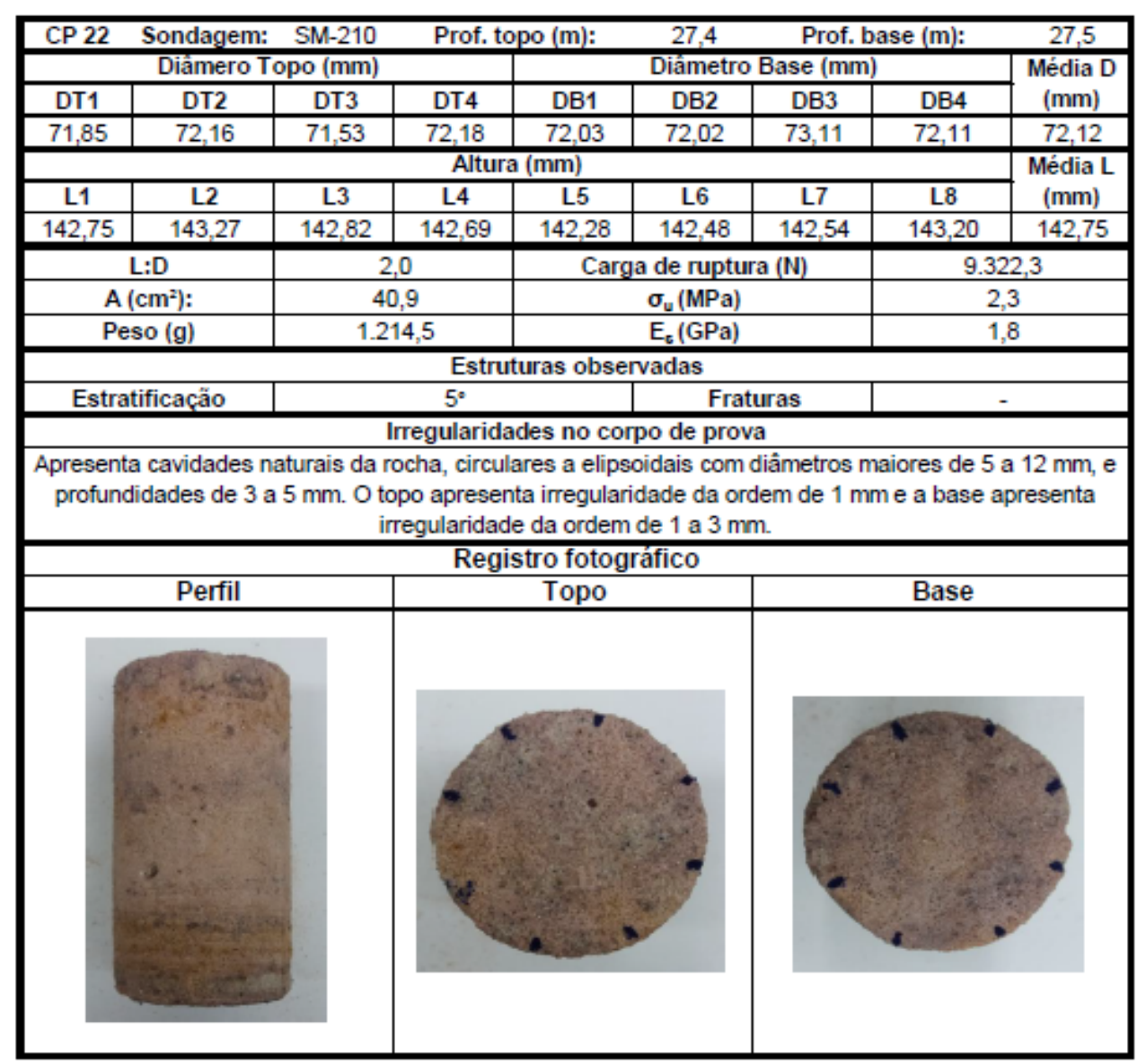

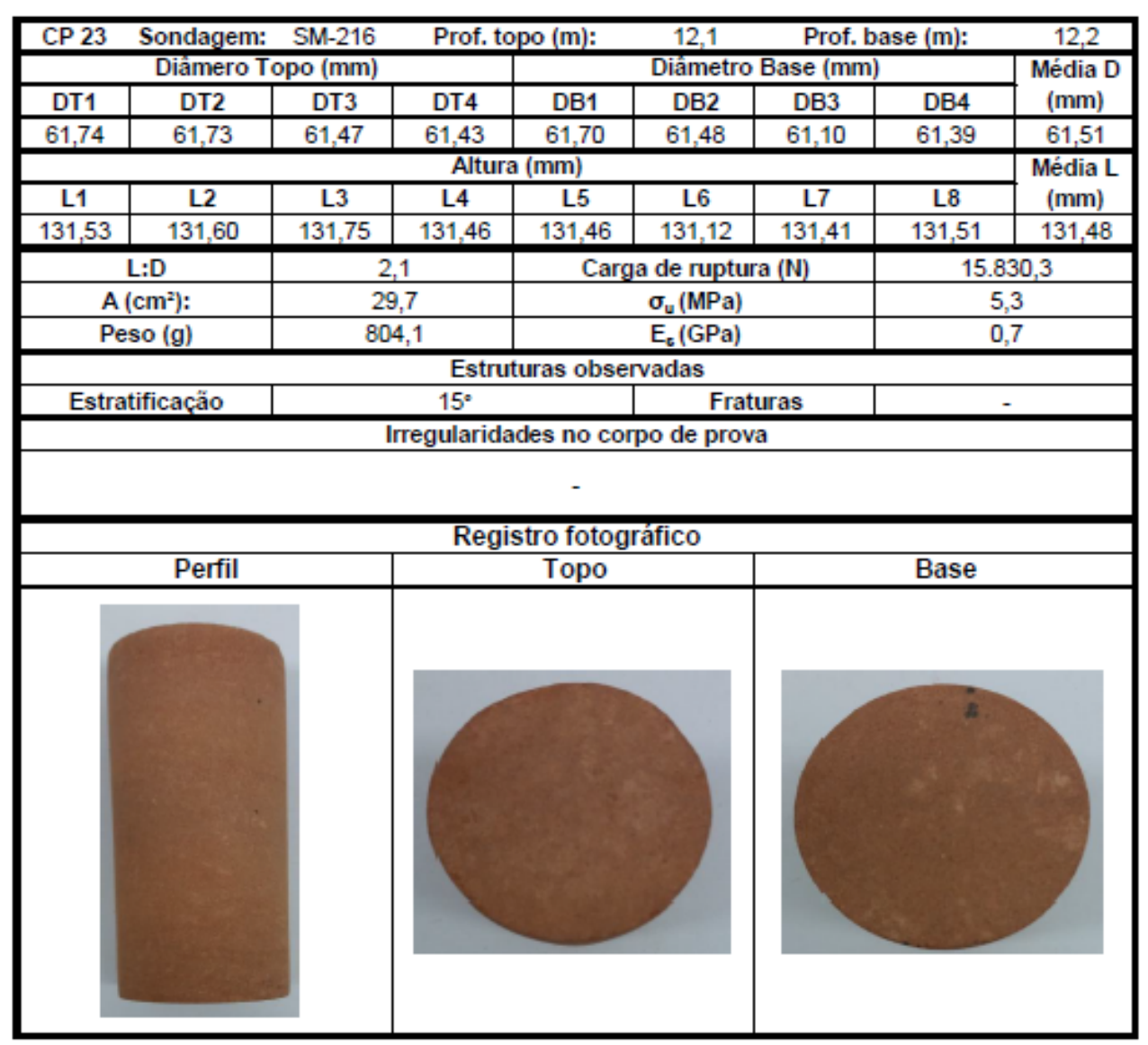




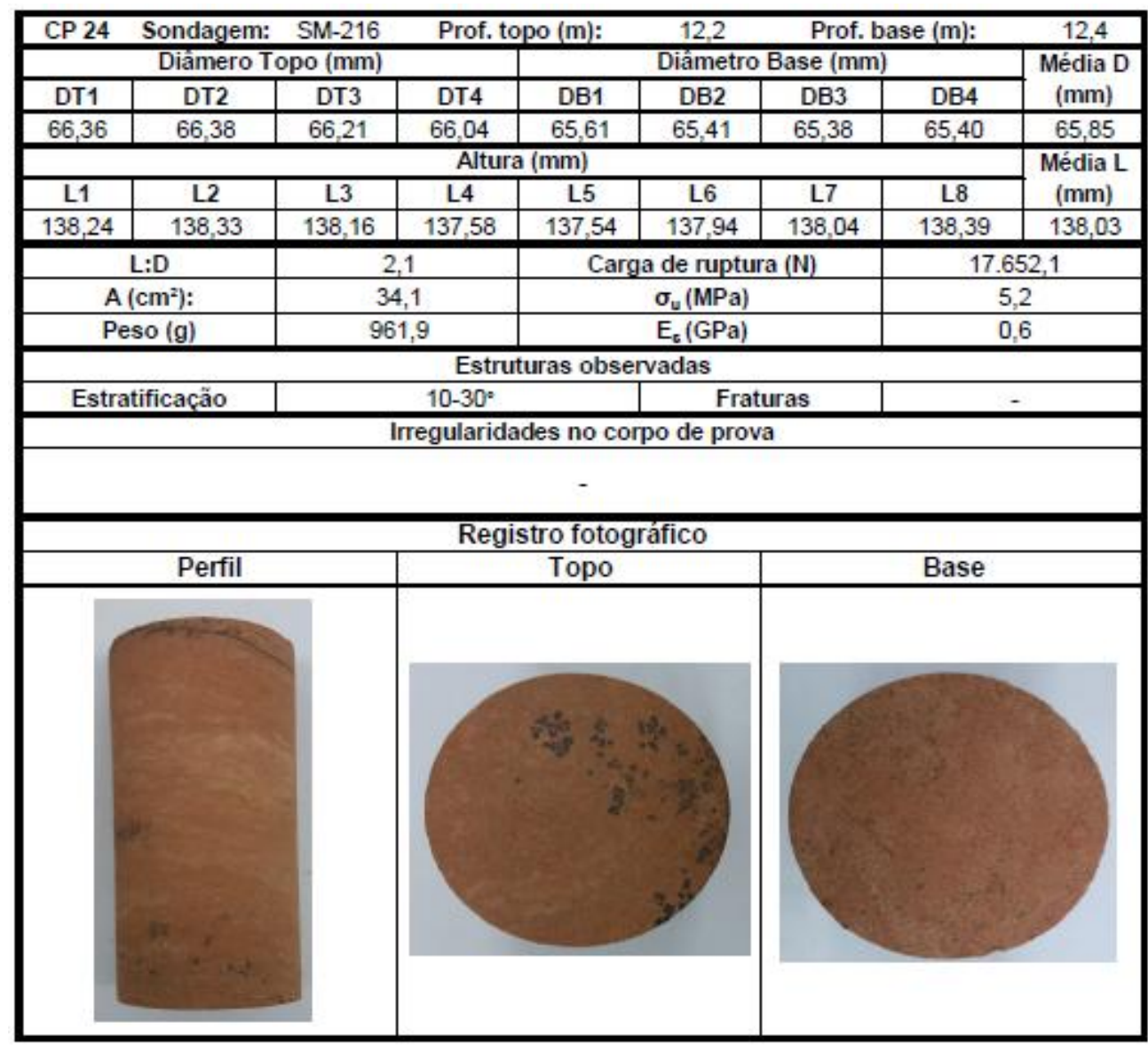

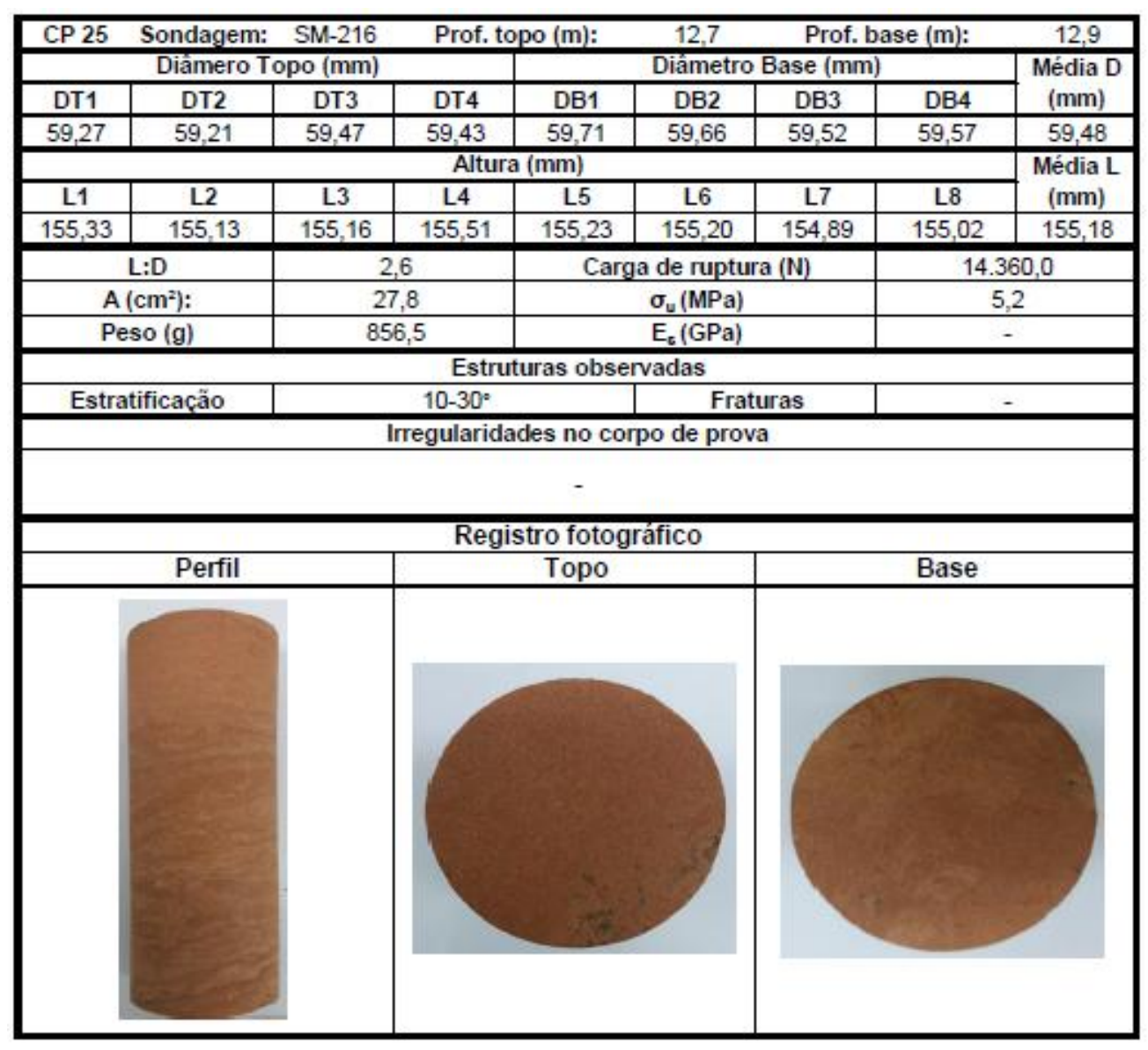




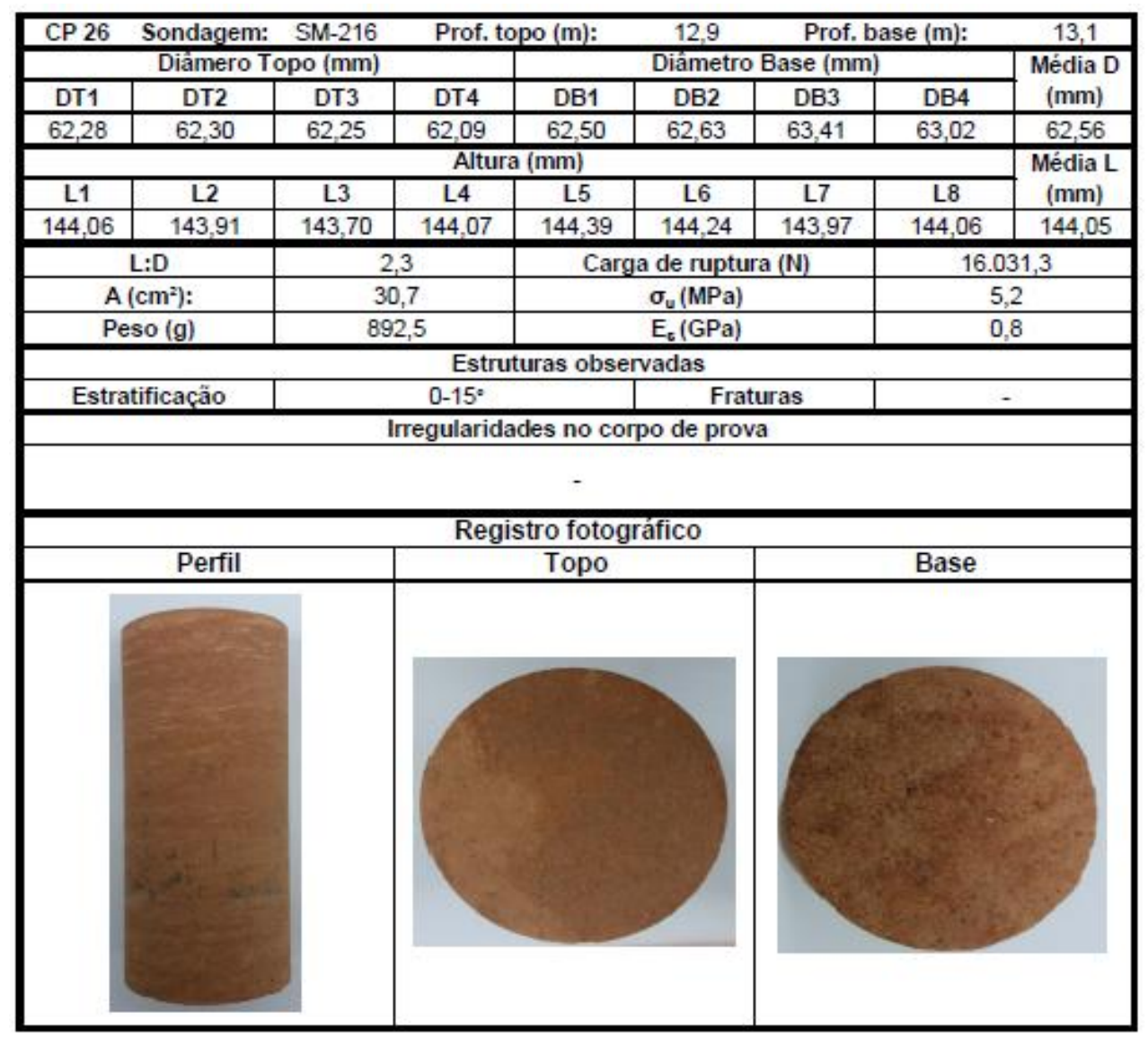

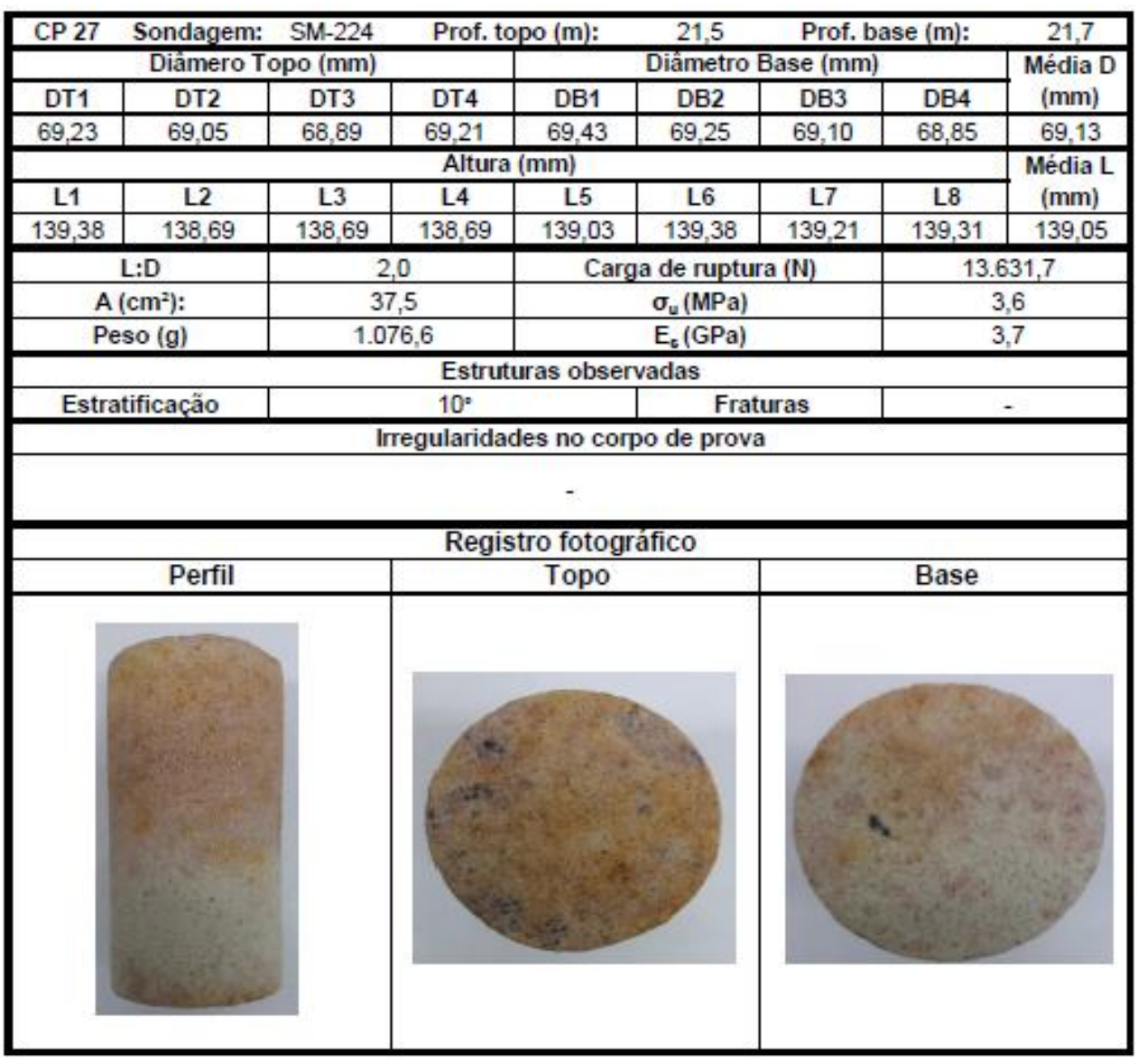






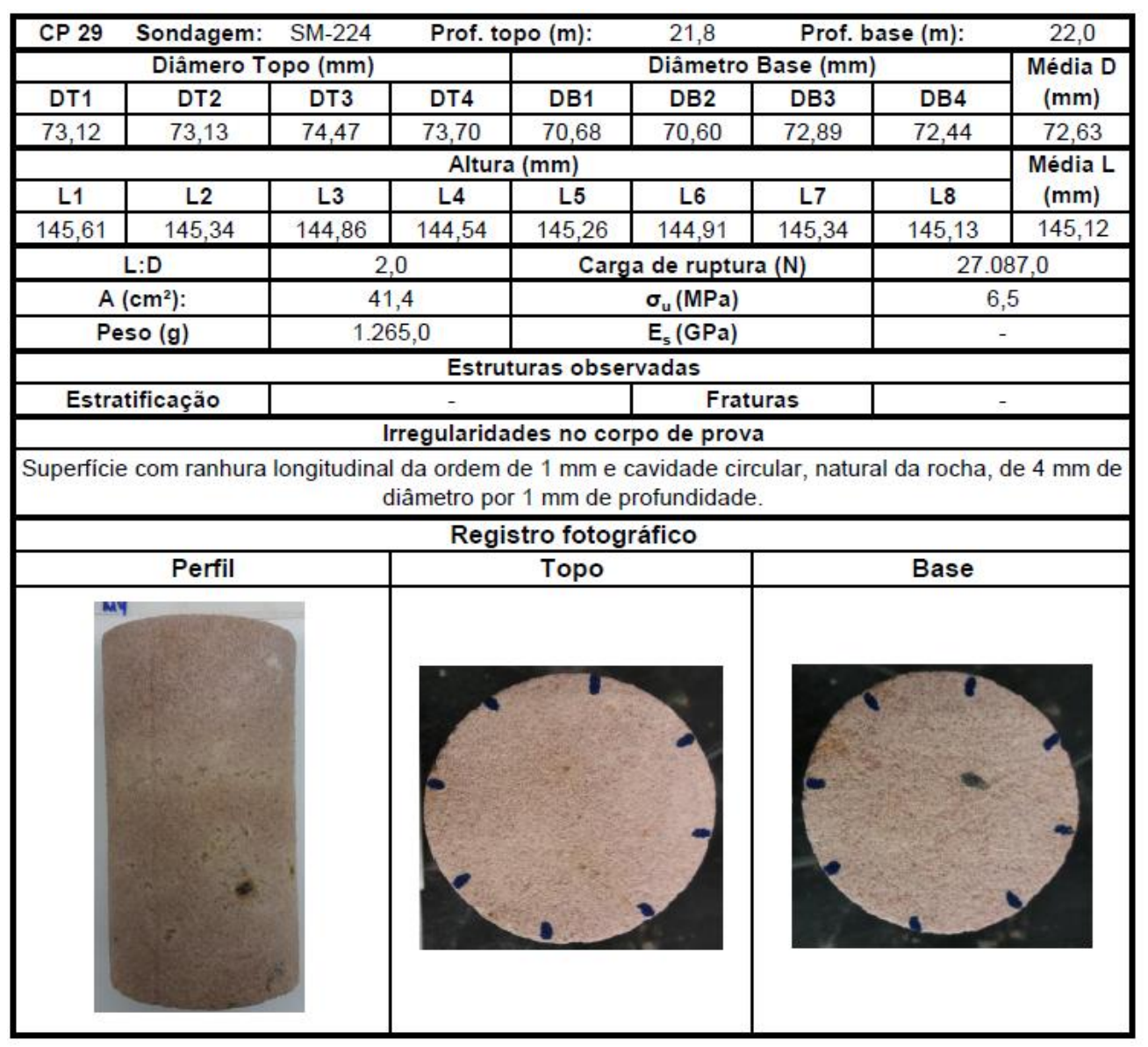




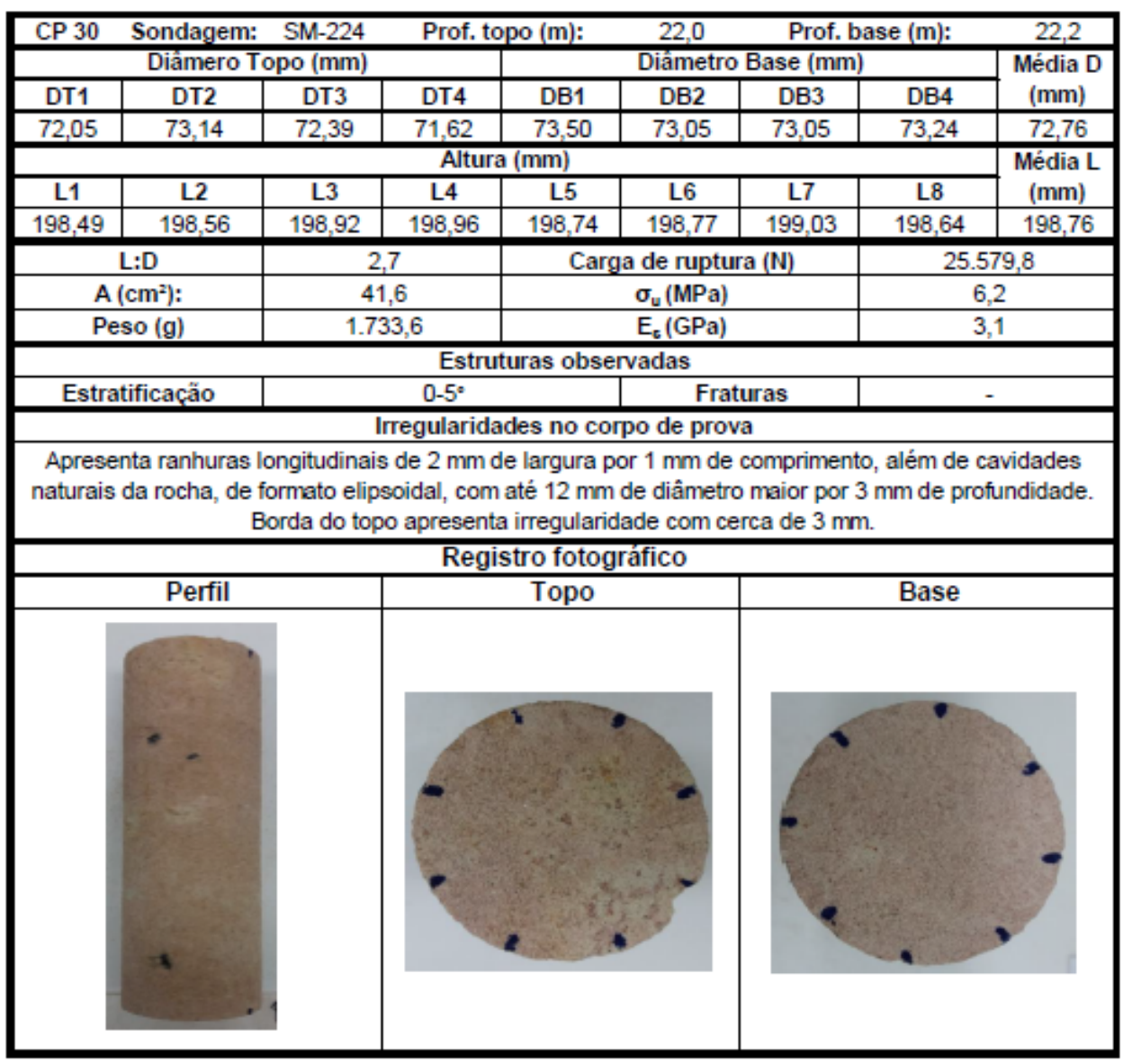

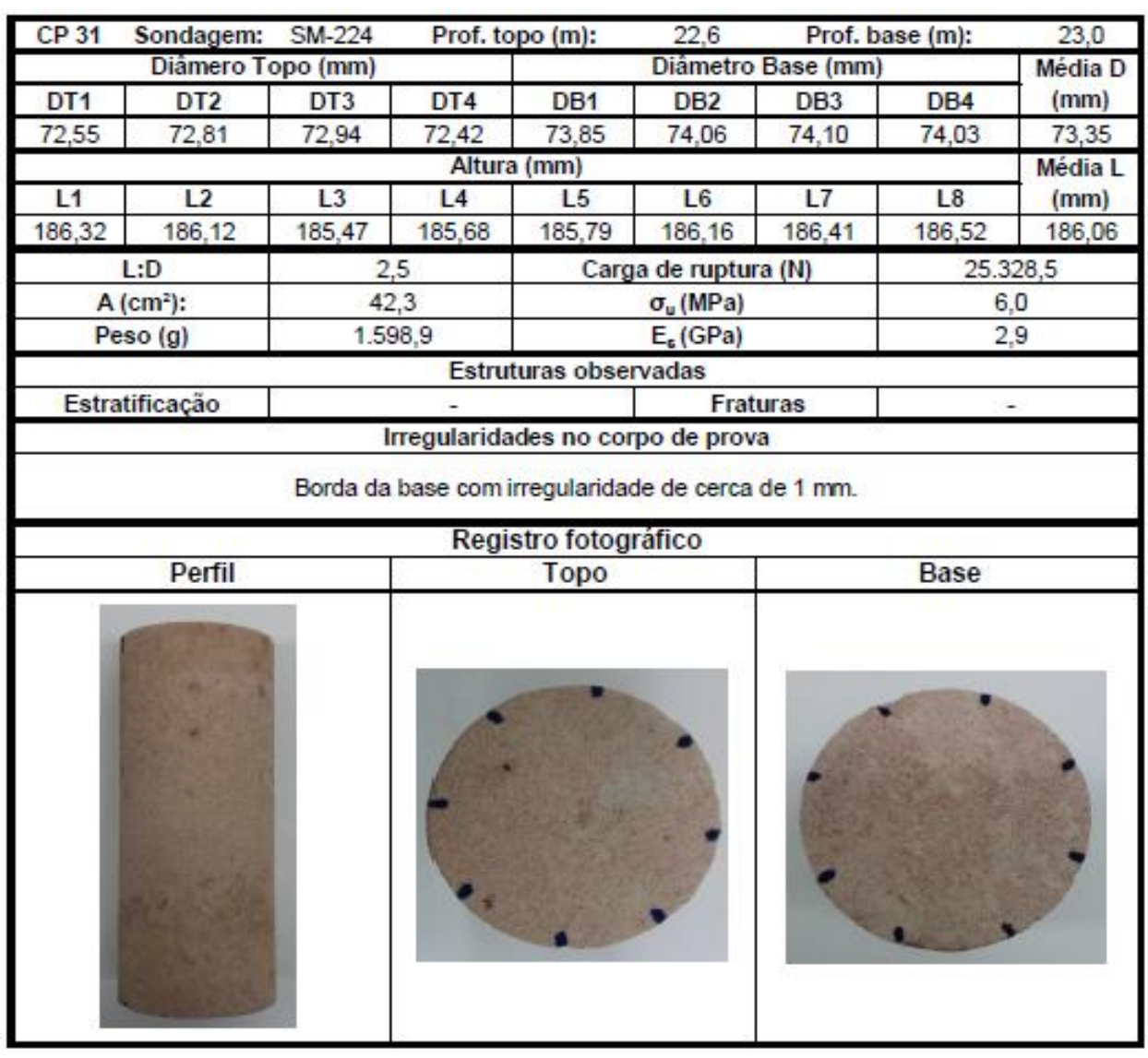




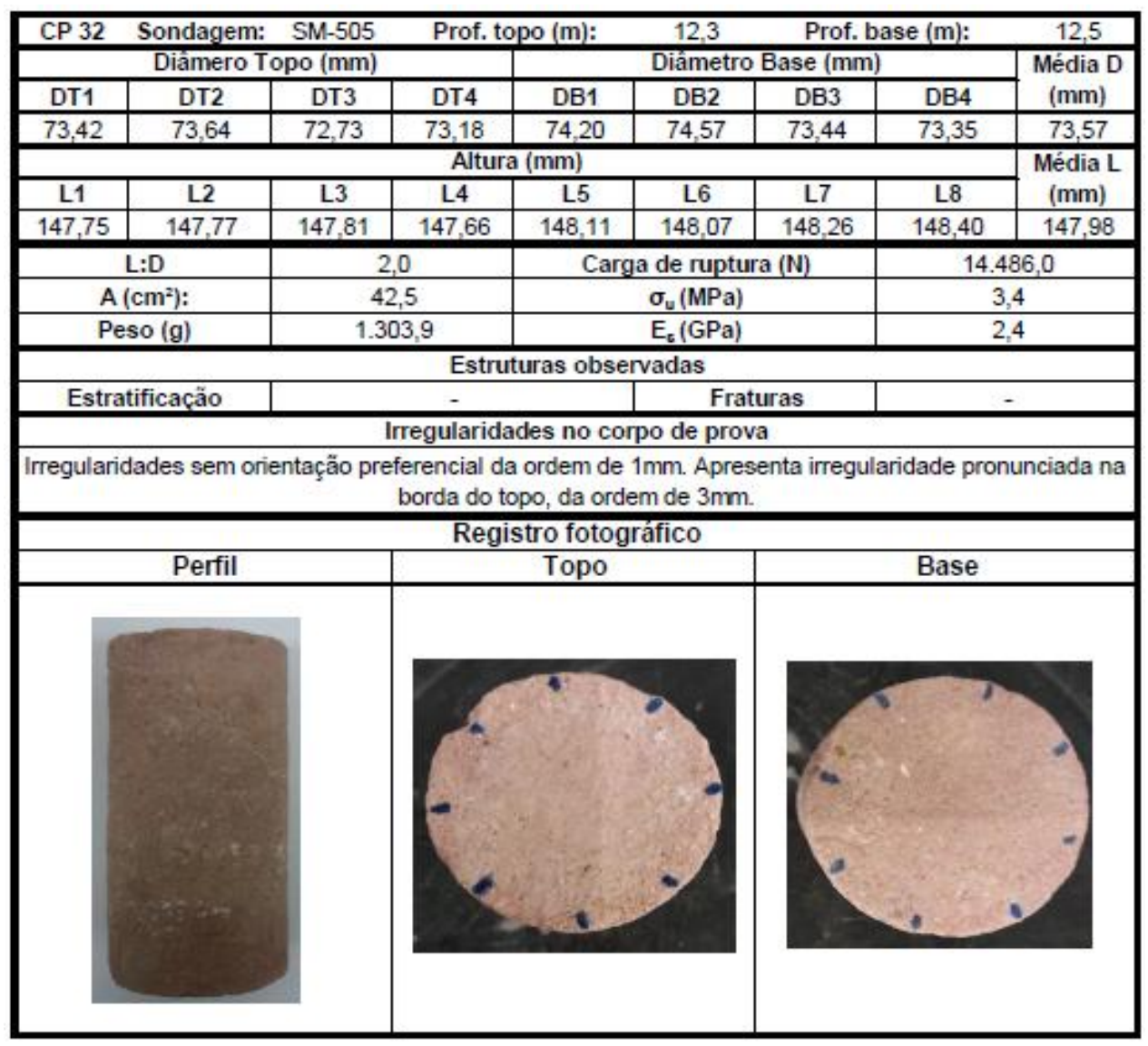

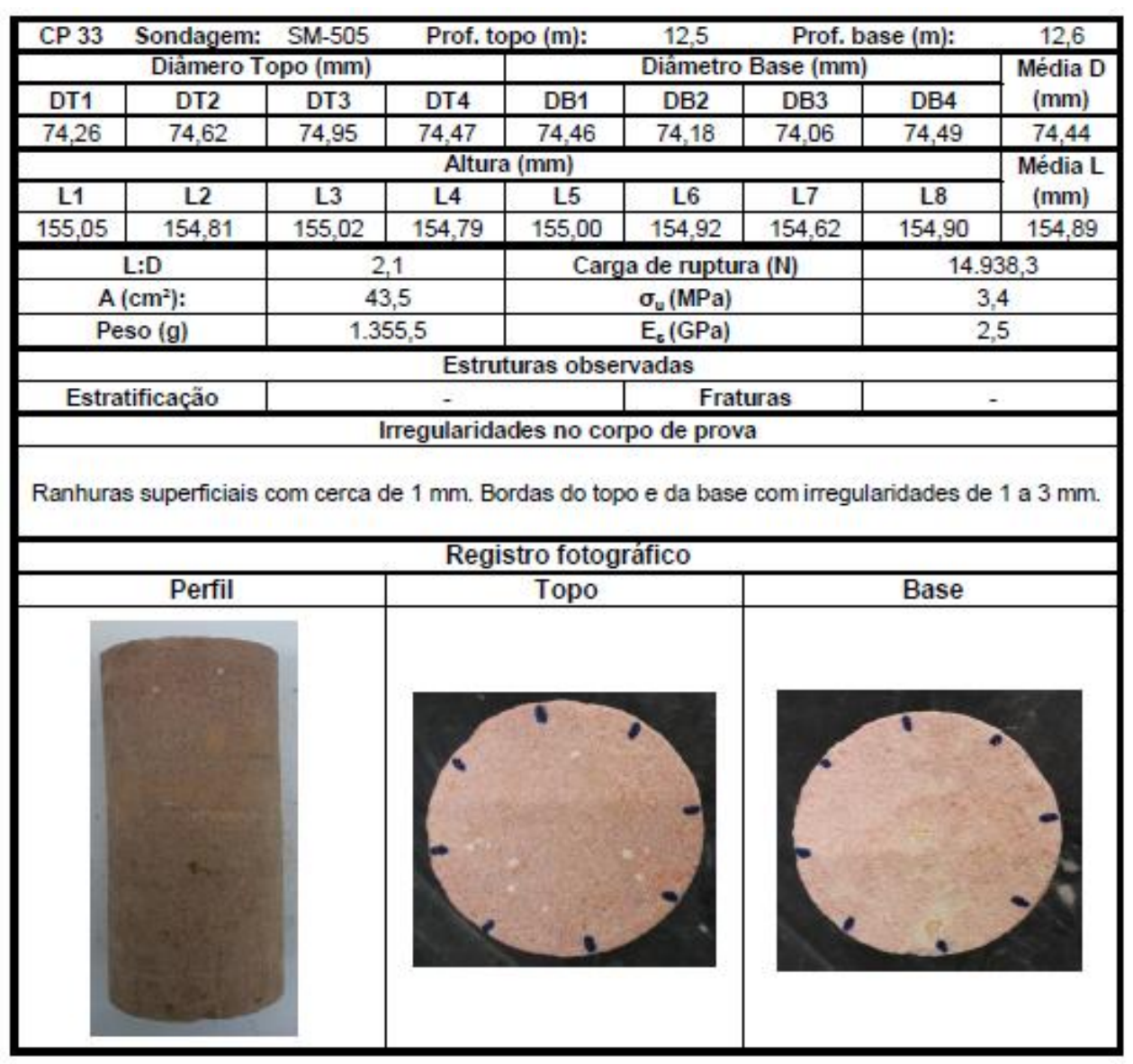




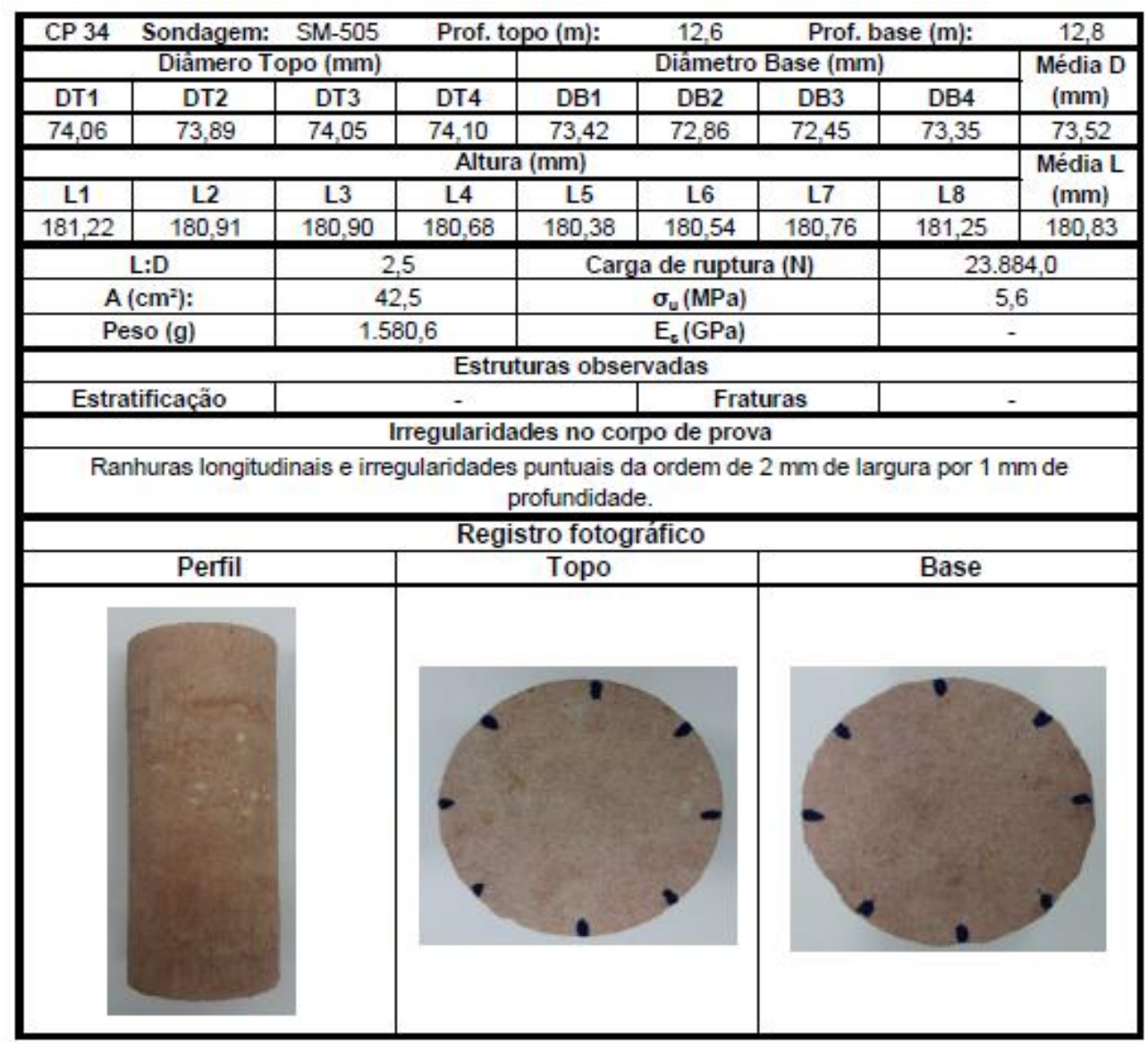

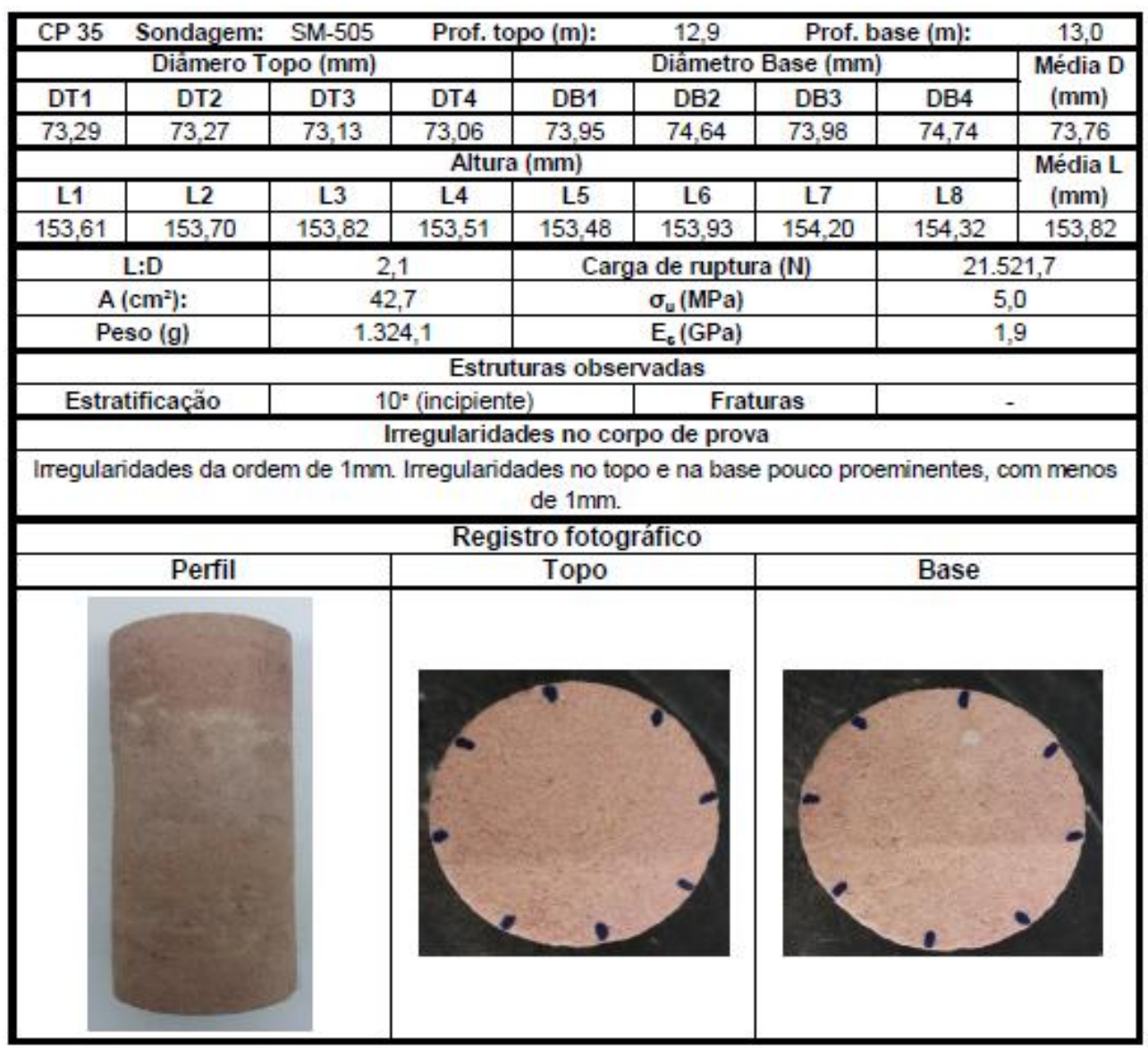




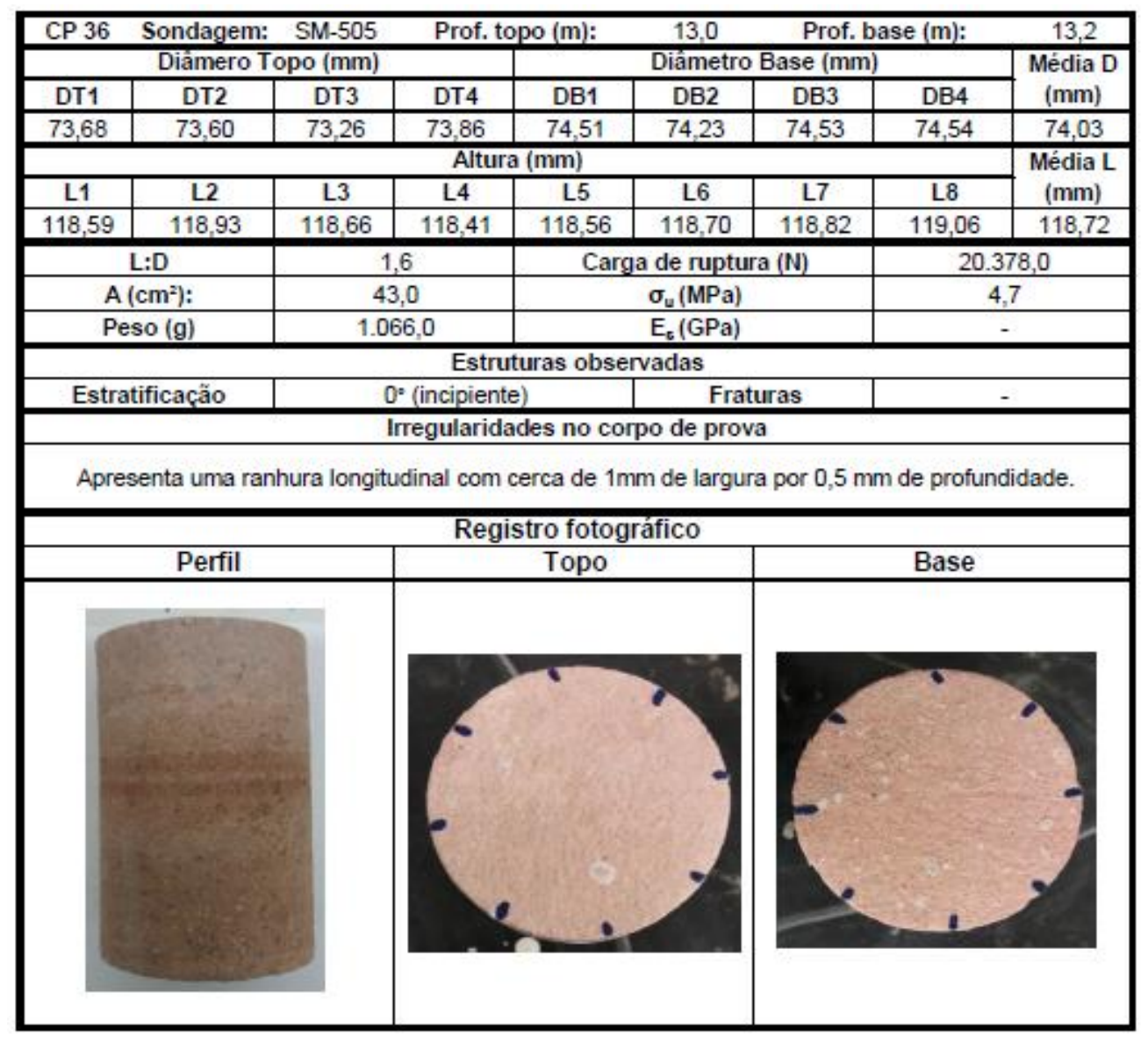

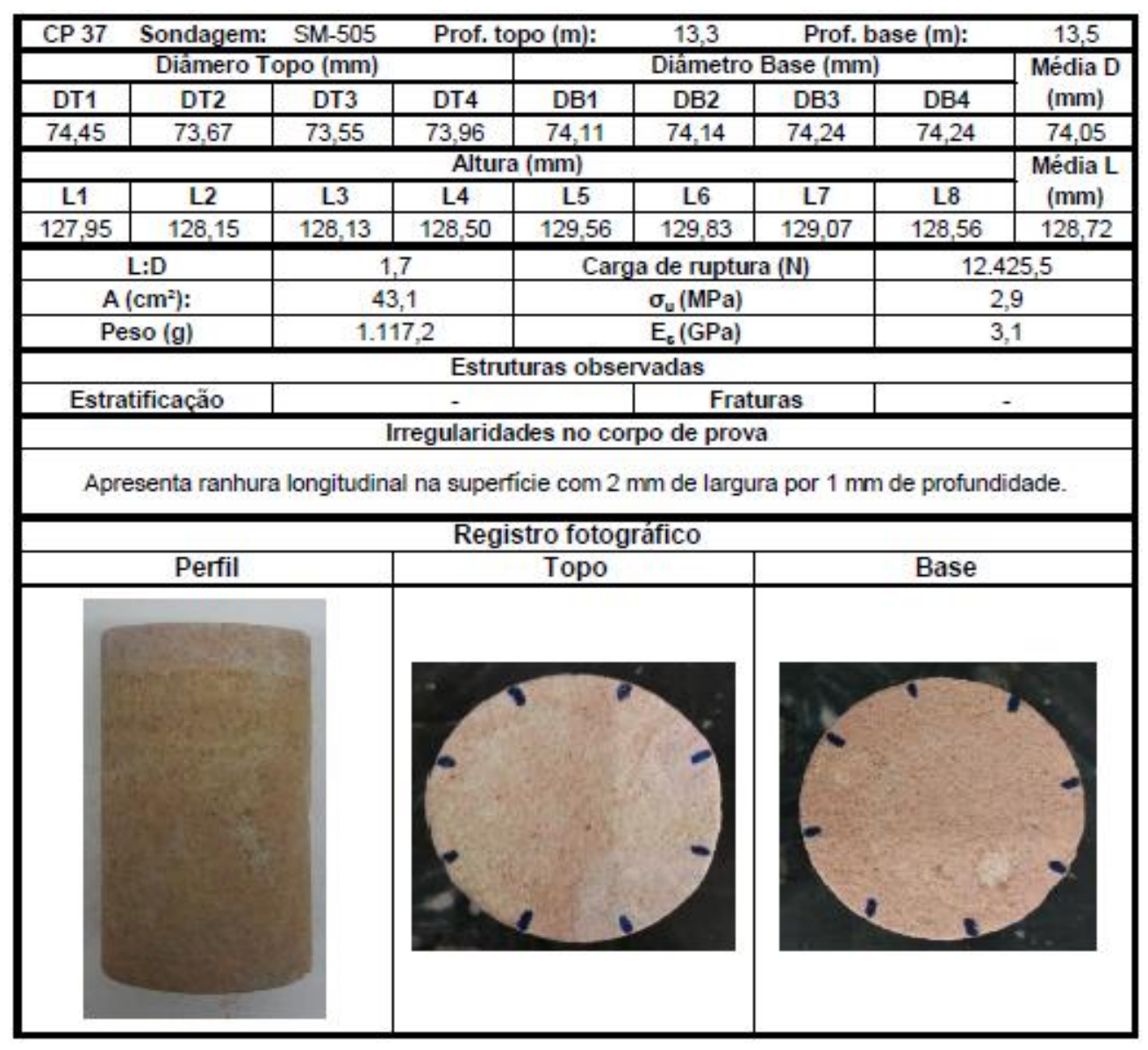




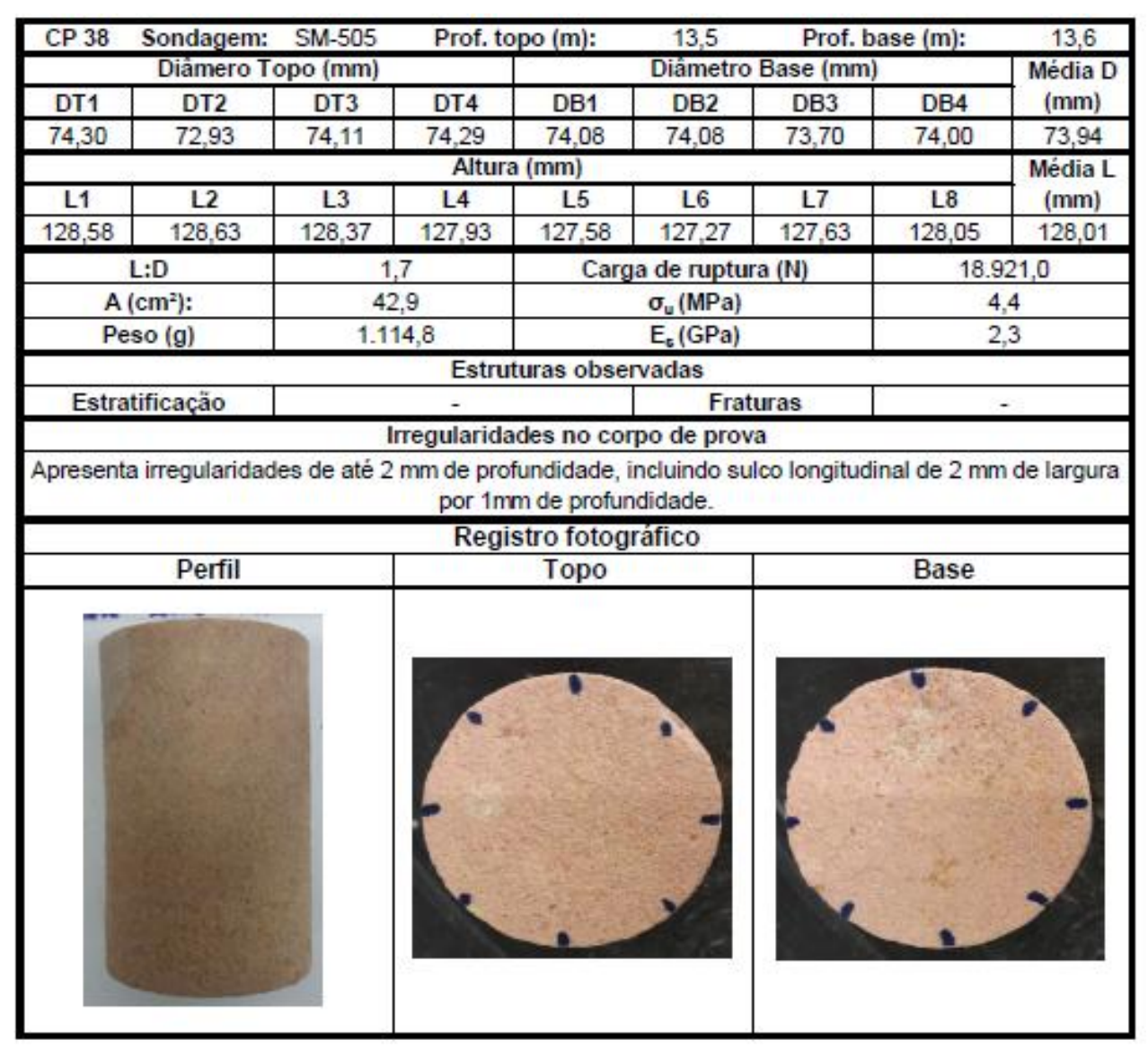

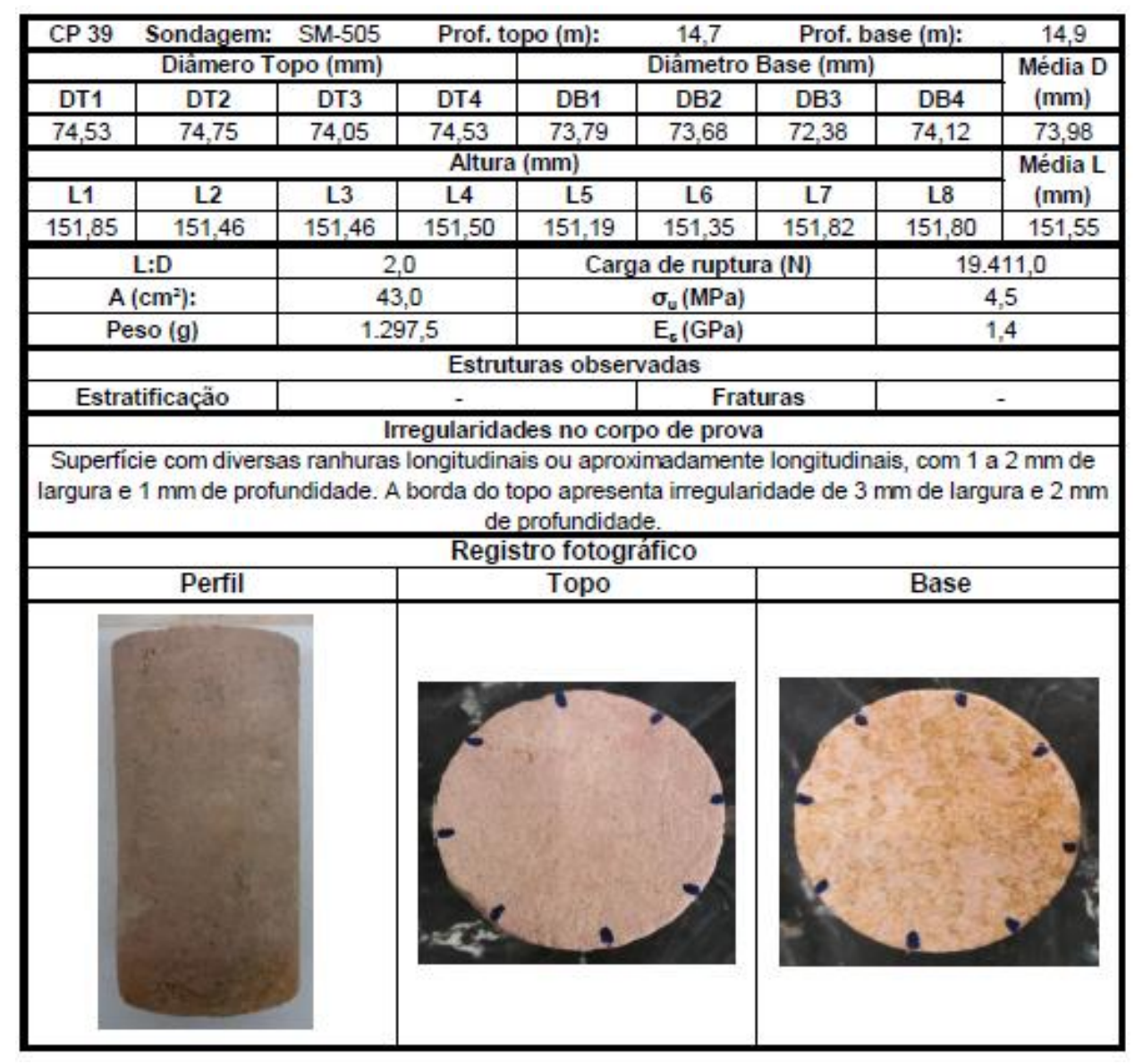




\section{APÊNDICE D}

Gráficos de tensão versus tempo e tensão versus deformação axial específica 
Neste apêndice são apresentados os gráficos de tempo e deformação axial específica $\left(\varepsilon_{\mathrm{a}}\right)$ versus tensão $(\sigma)$. $\varepsilon_{\mathrm{a}}$ foi calculado pela razão entre deformação axial $(\Delta \mathrm{L}$ - equivalente à variação entre os comprimentos inicial e final do material medido), e comprimento inicial do material medido (L), conforme a seguinte equação:

$$
\varepsilon_{a}=\frac{\Delta L}{L}
$$

Nos ensaios em que não houve aferição de $\Delta \mathrm{L}$ com auxílio de extensômetros, $\Delta \mathrm{L}$ foi obtido pelos sensores da própria prensa e $\mathrm{L}$ corresponde à altura do corpo de prova. Nestes ensaios, as curvas tempo versus $\sigma$ e $\varepsilon_{a}$ versus $\sigma$ representam $o$ carregamento contínuo do corpo de prova até o rompimento.

Nos ensaios com aferição de $\Delta \mathrm{L}$ por meio de extensômetros, o valor de $\mathrm{L}$ utilizado para o cálculo da deformação axial específica equivale à distância de 50 $\mathrm{mm}$ entre os transdutores dos extensômetros. No caso destes ensaios, os gráficos $\varepsilon_{\mathrm{a}}$ versus $\sigma$ representam apenas a fase do ensaio em que os extensômetros estavam posicionados no corpo de prova, ao passo que os gráficos de tempo versus $\sigma$ representam as fases de carregamento e descarregamento para a determinação do módulo de deformabilidade, com subsequente remoção dos extensômetros e carregamento até o rompimento do corpo de prova (Item 2.7.2). 

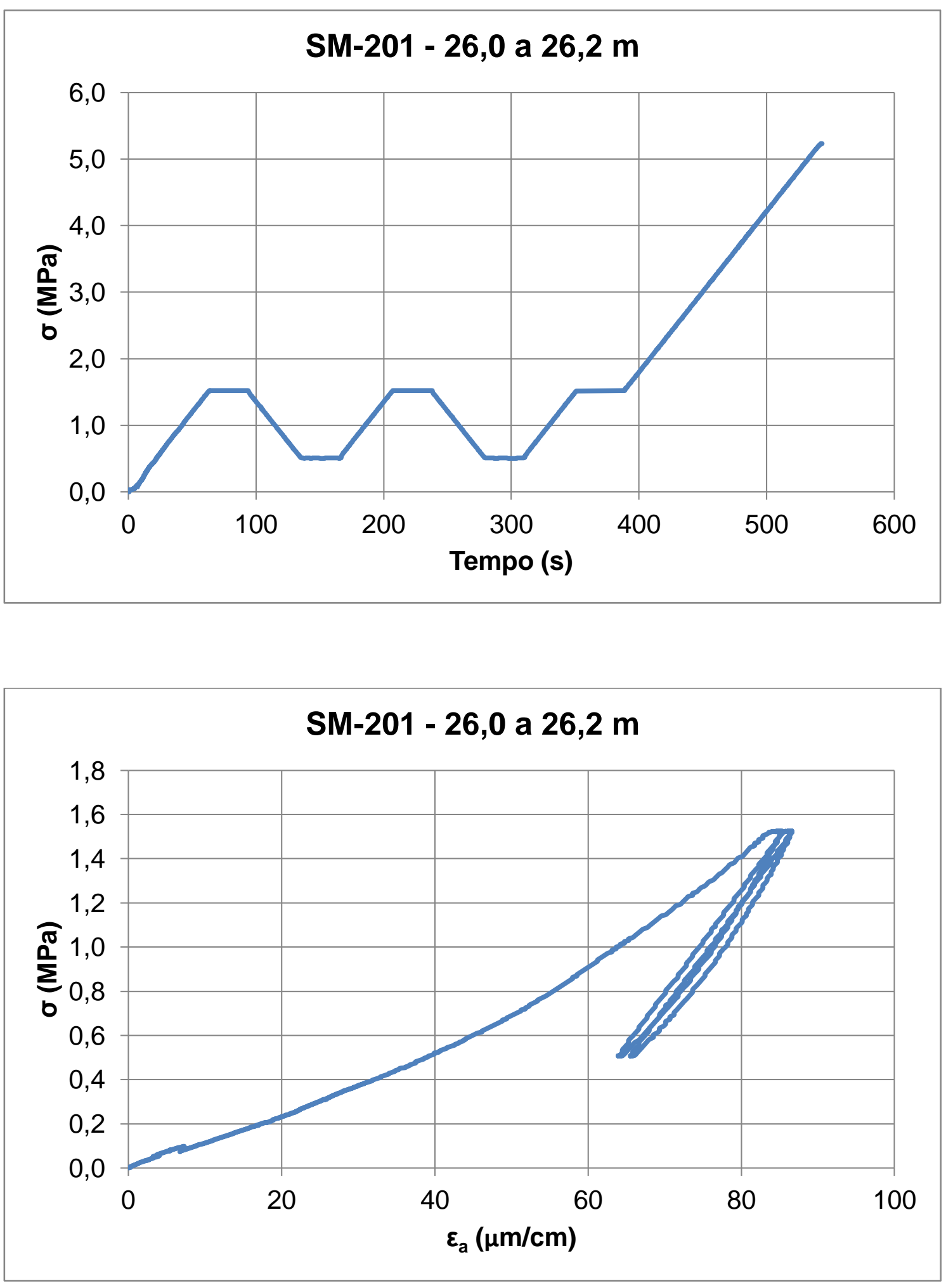

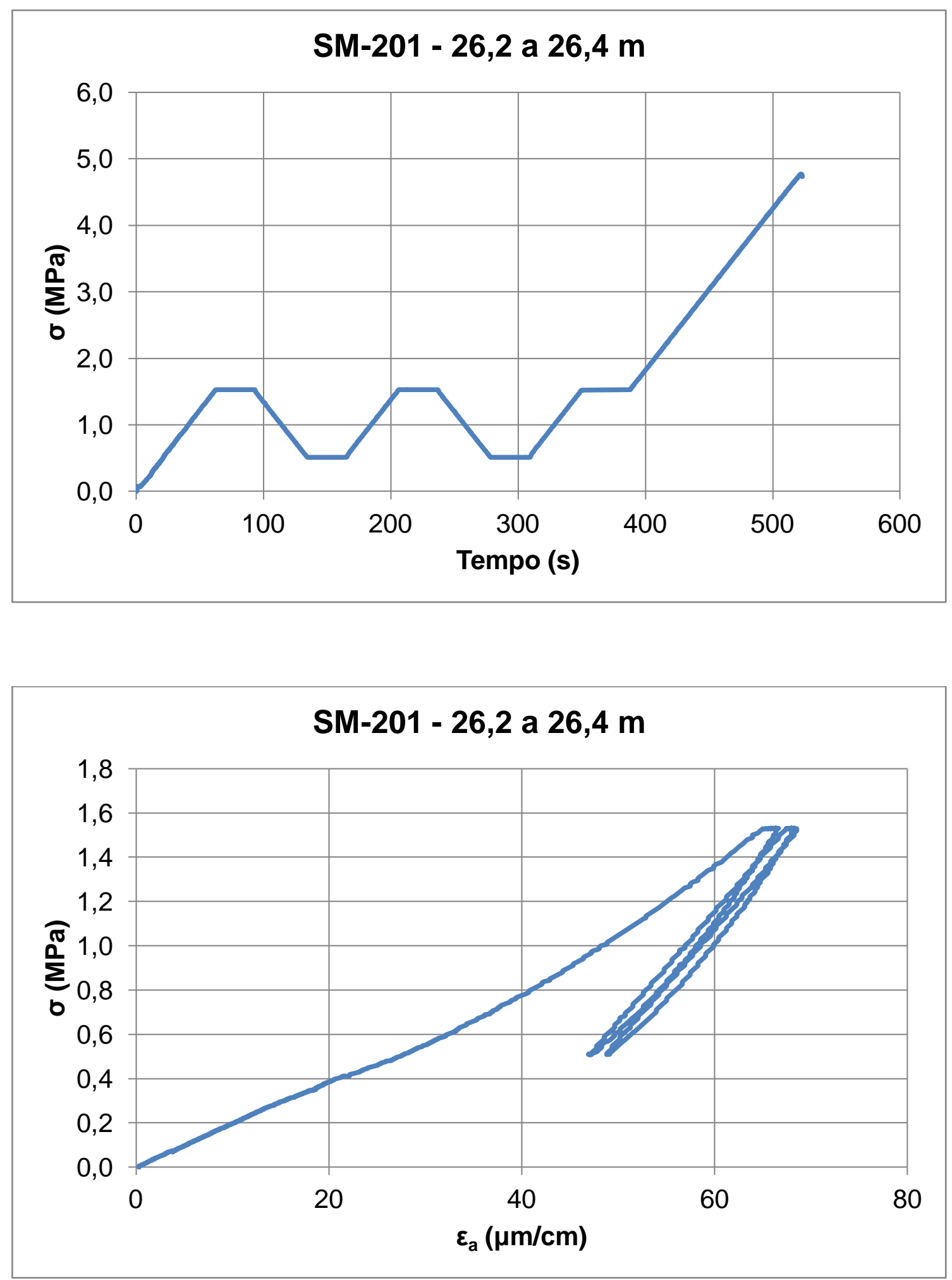

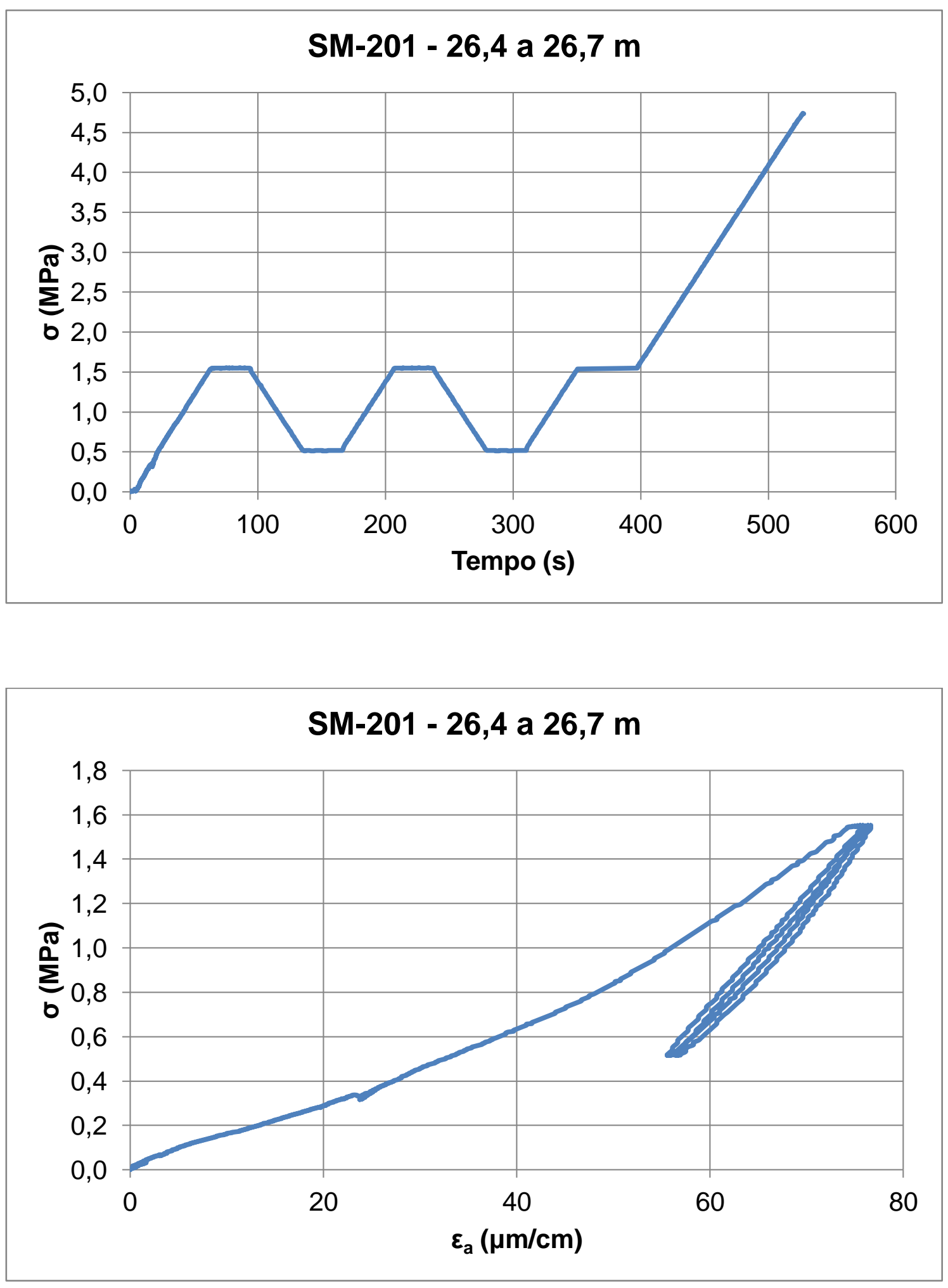

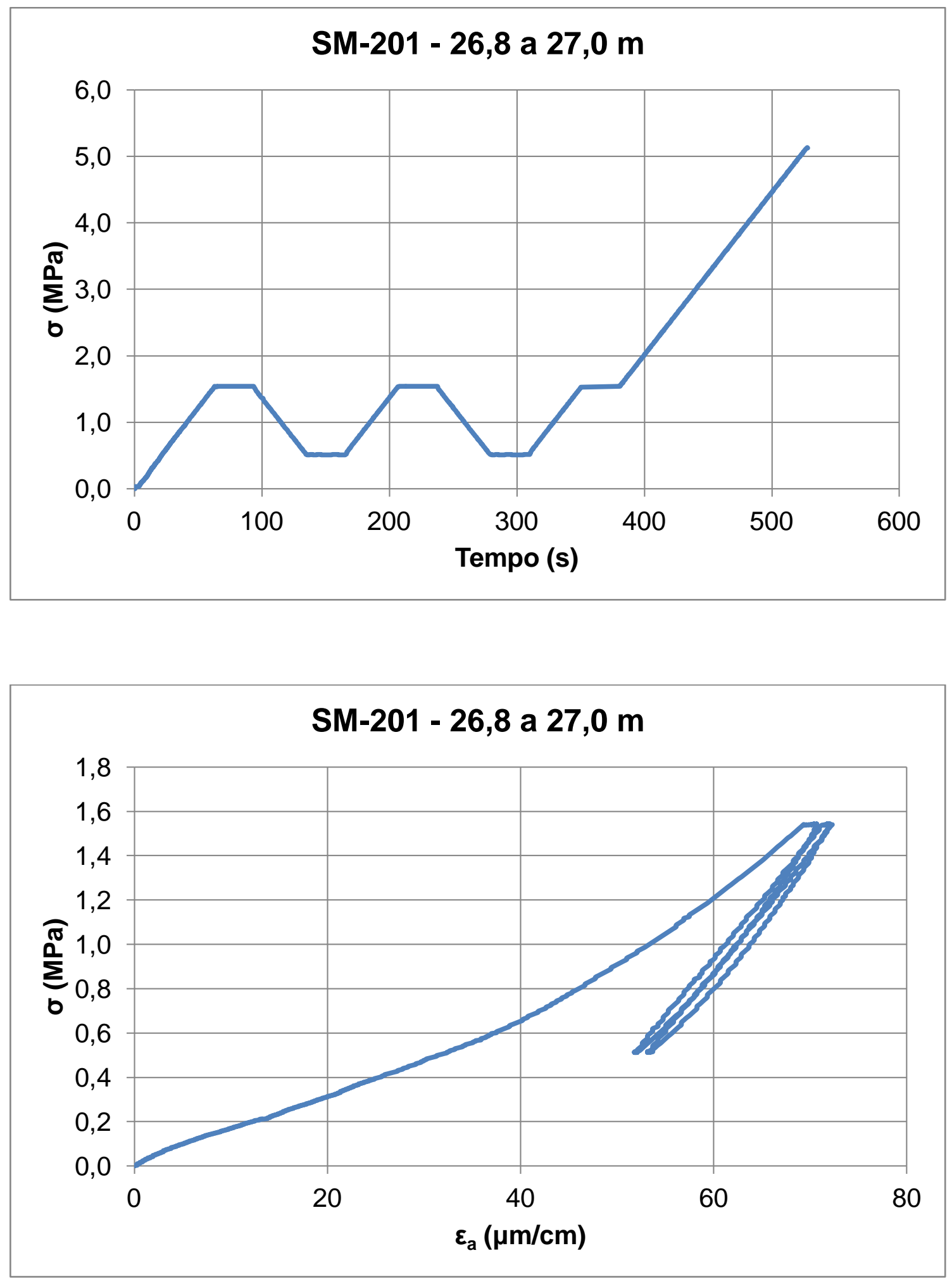

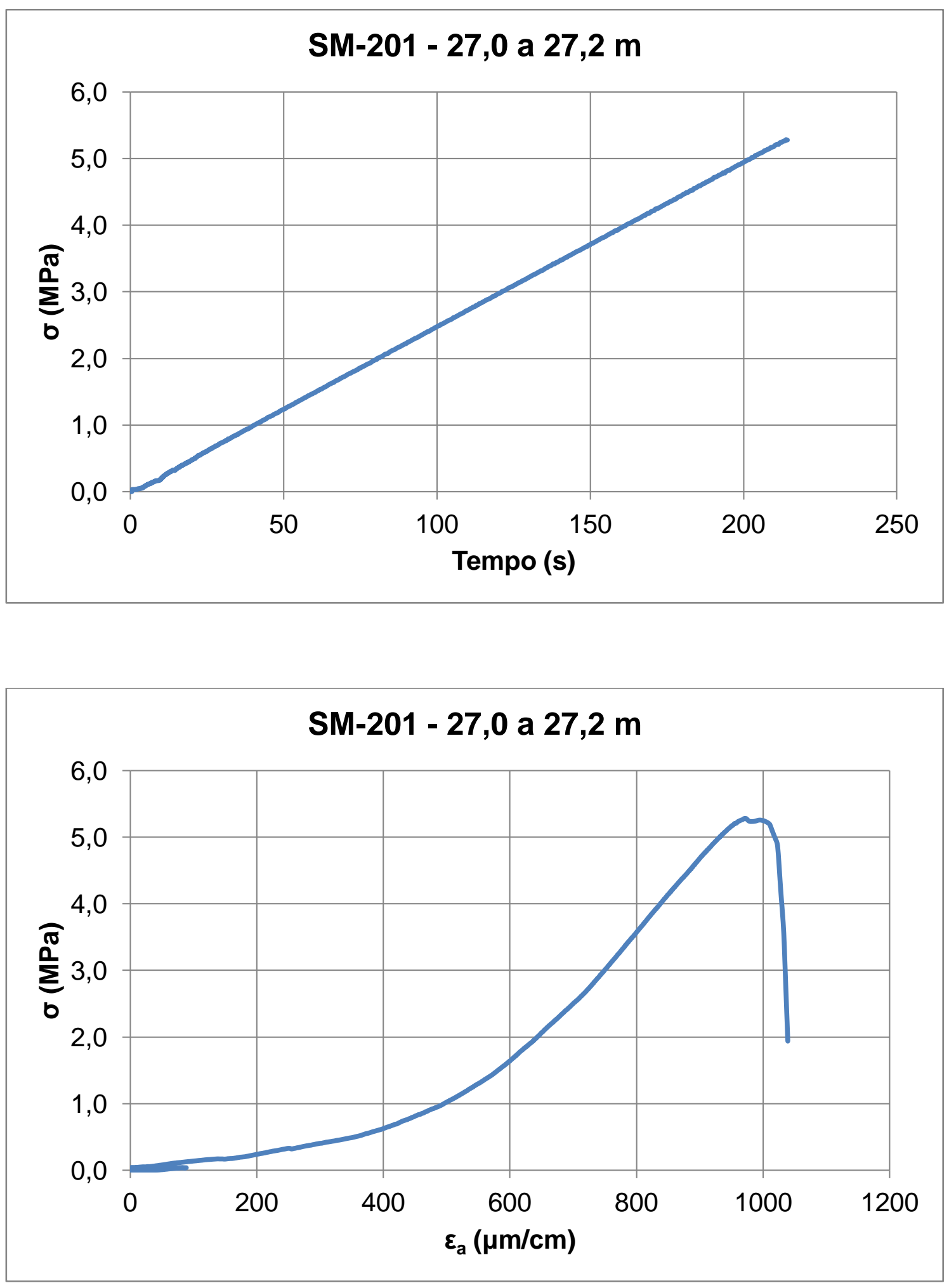

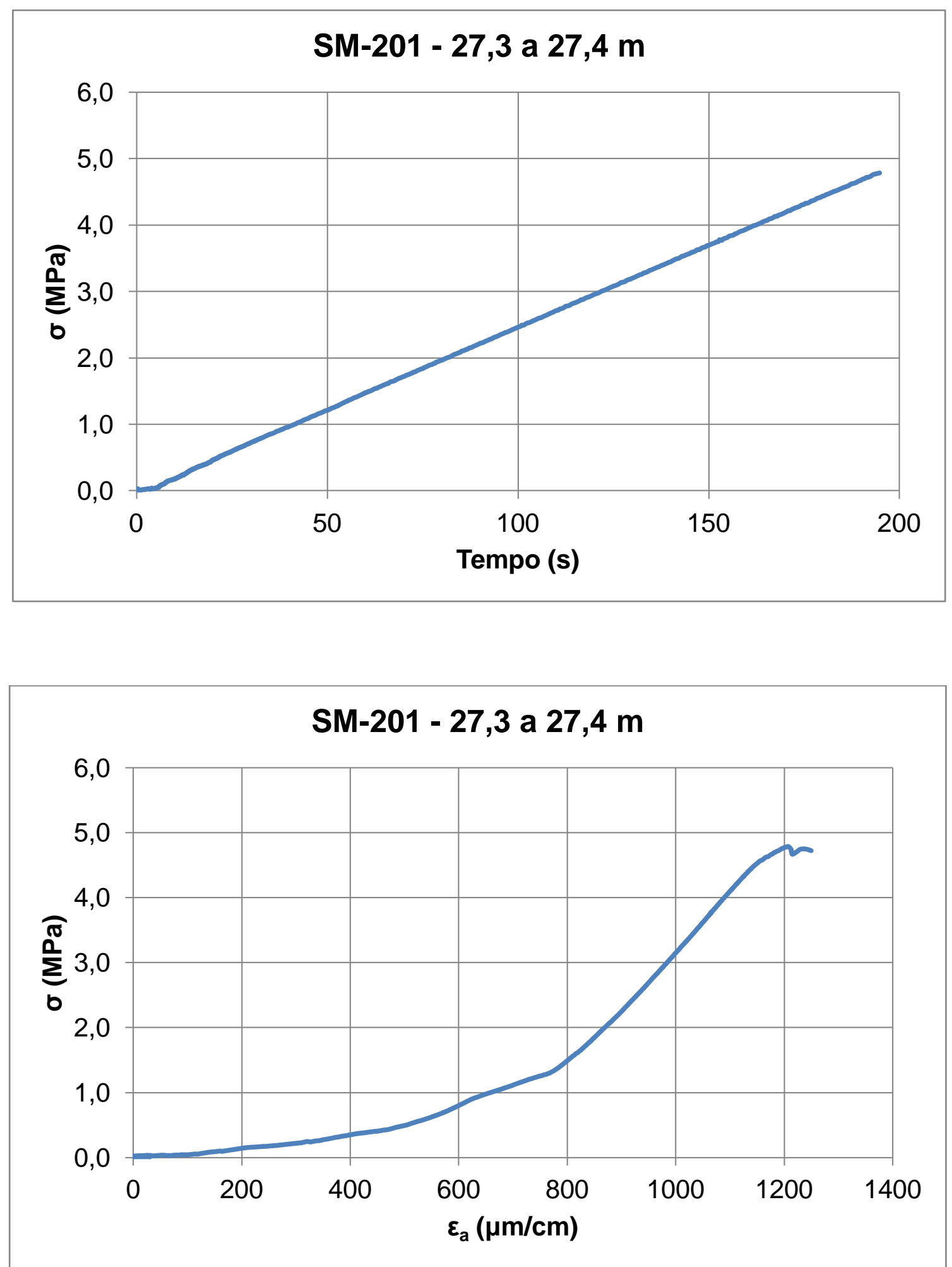

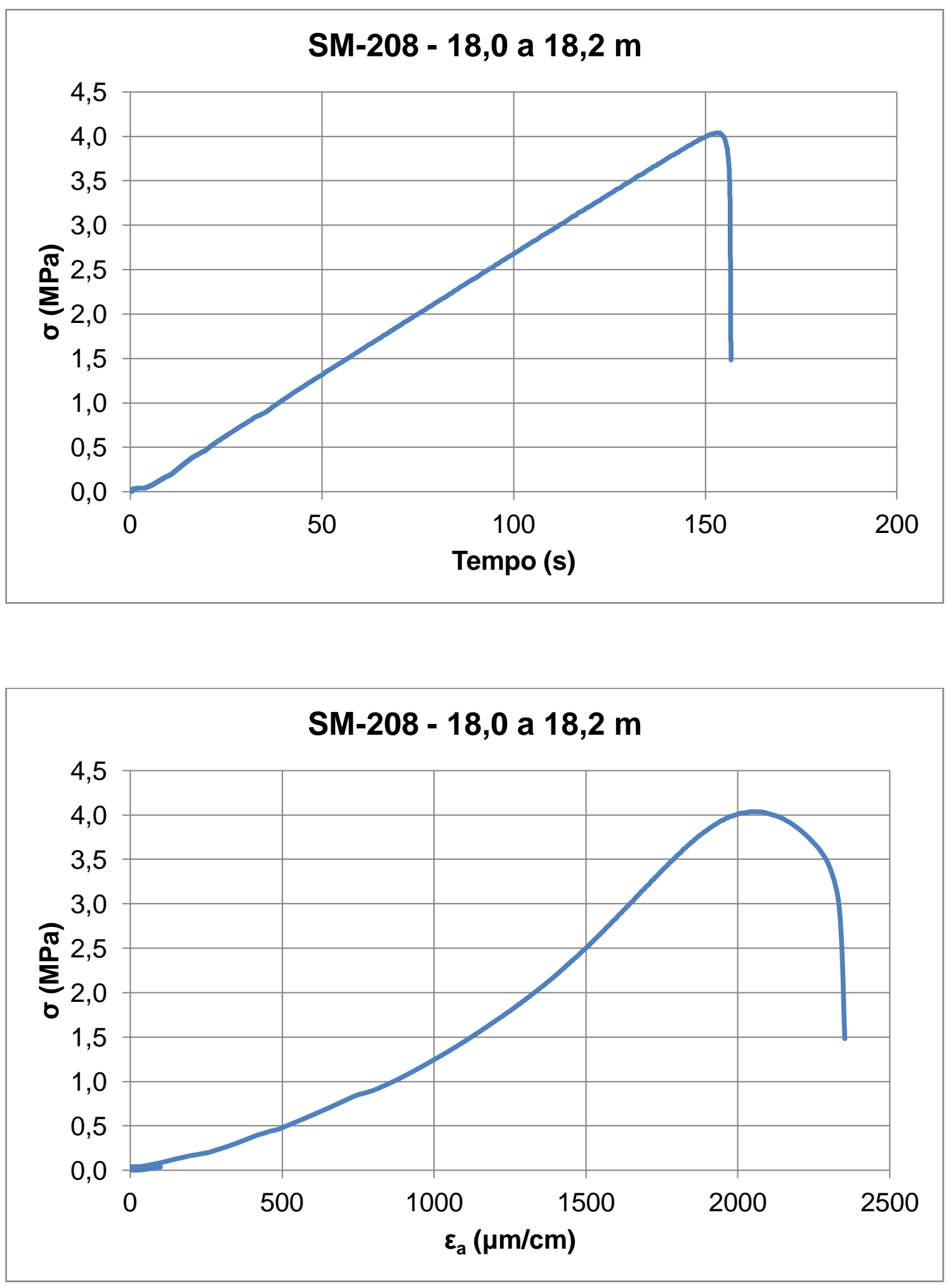

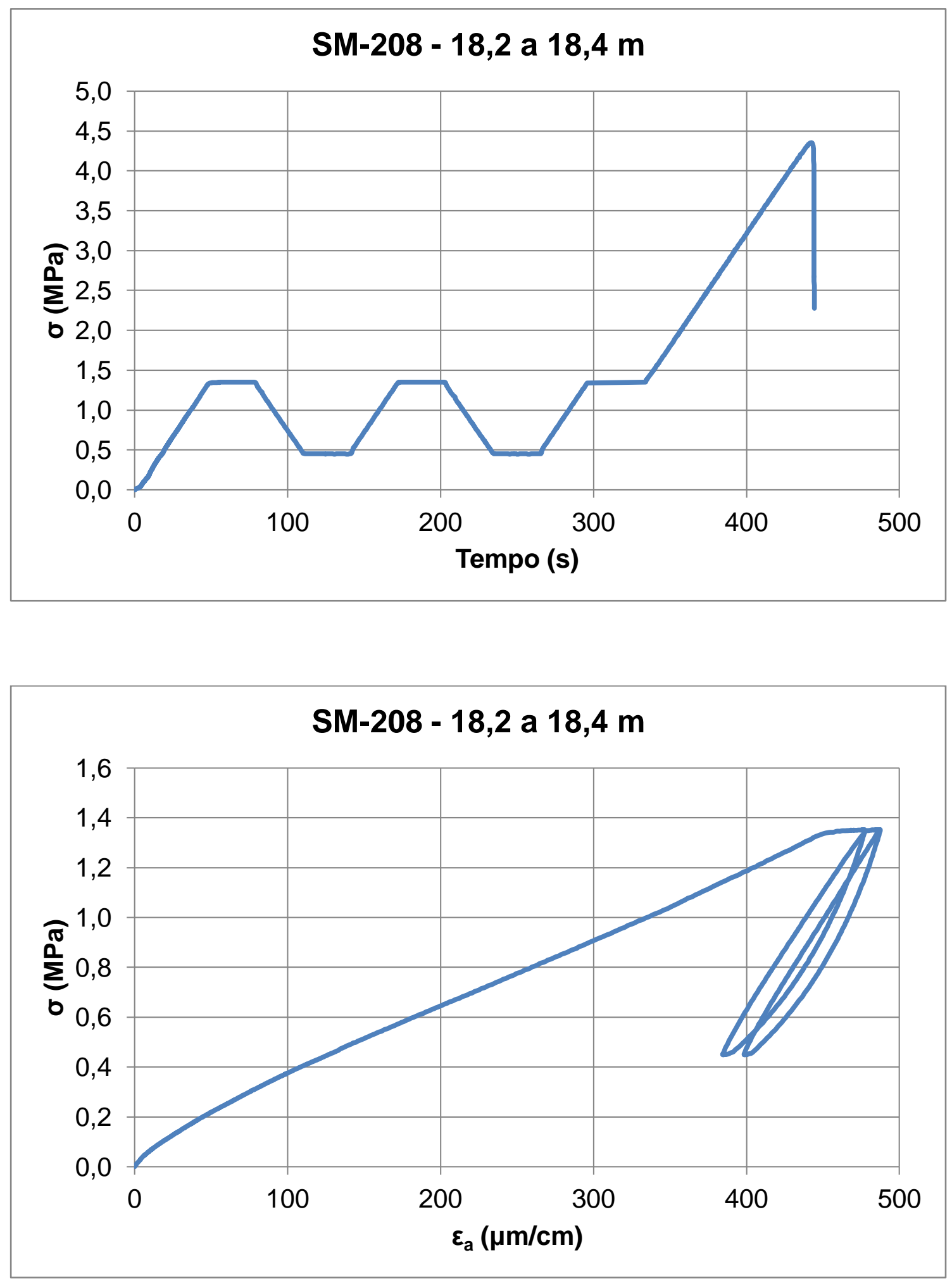

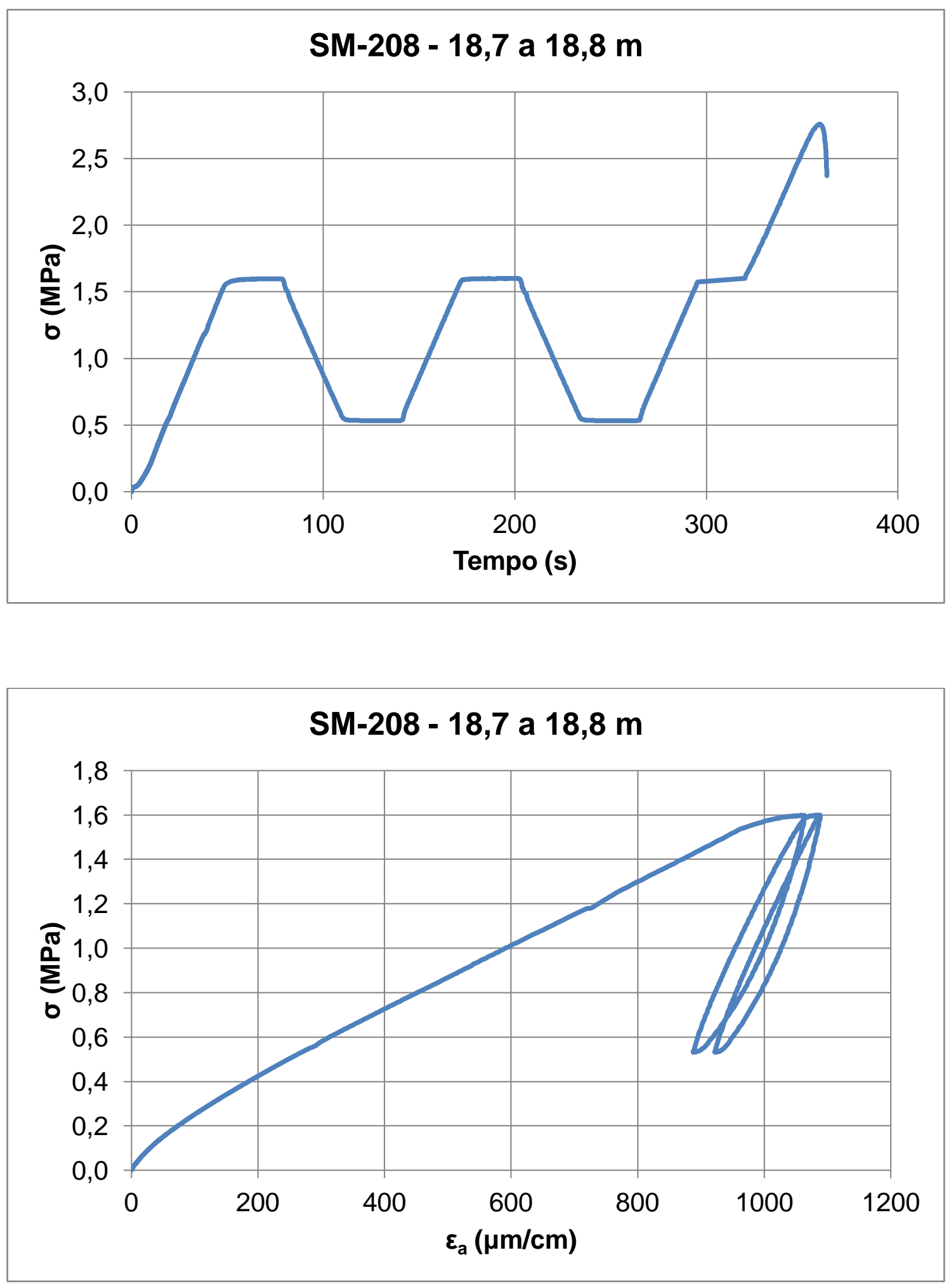

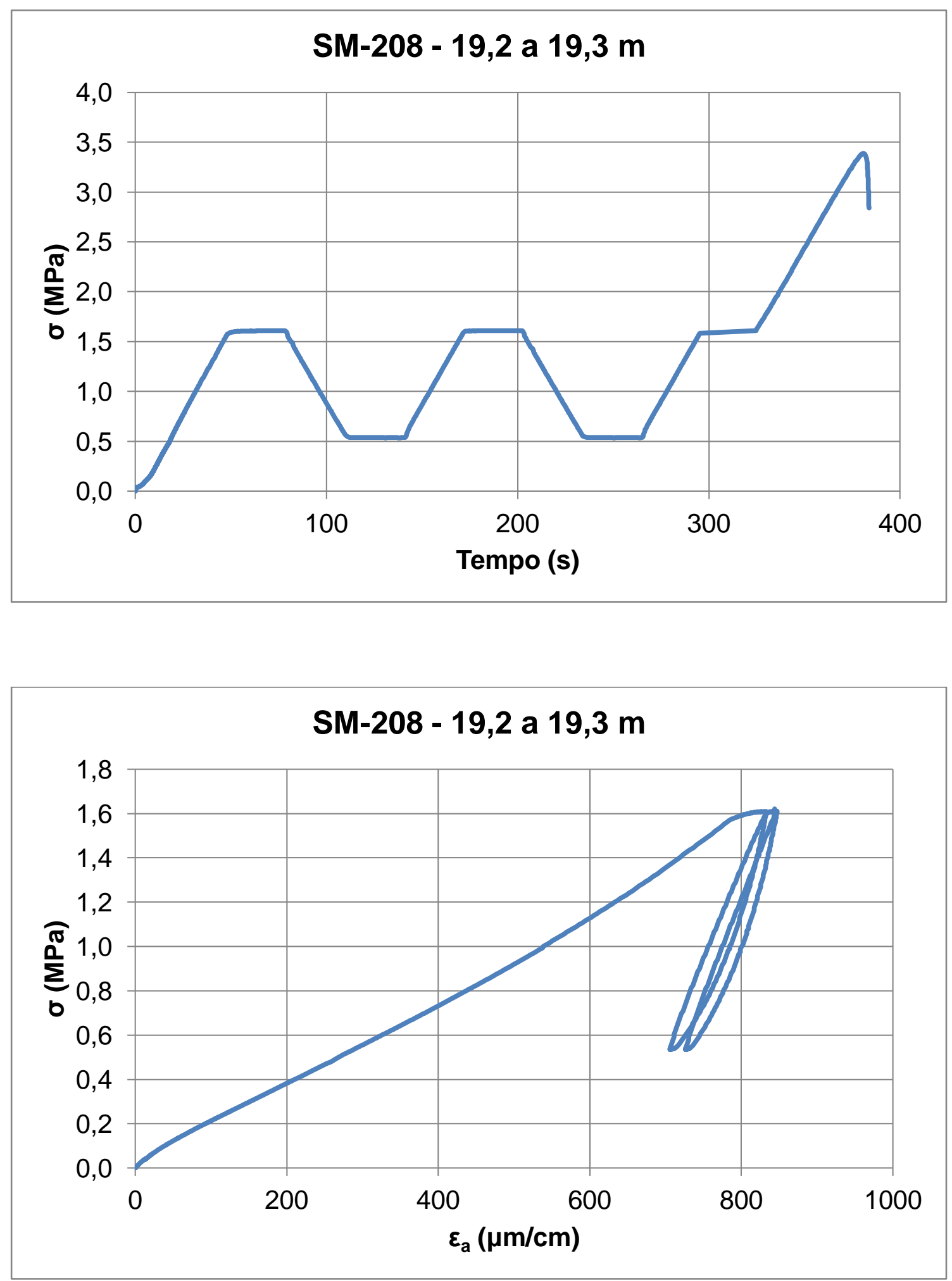

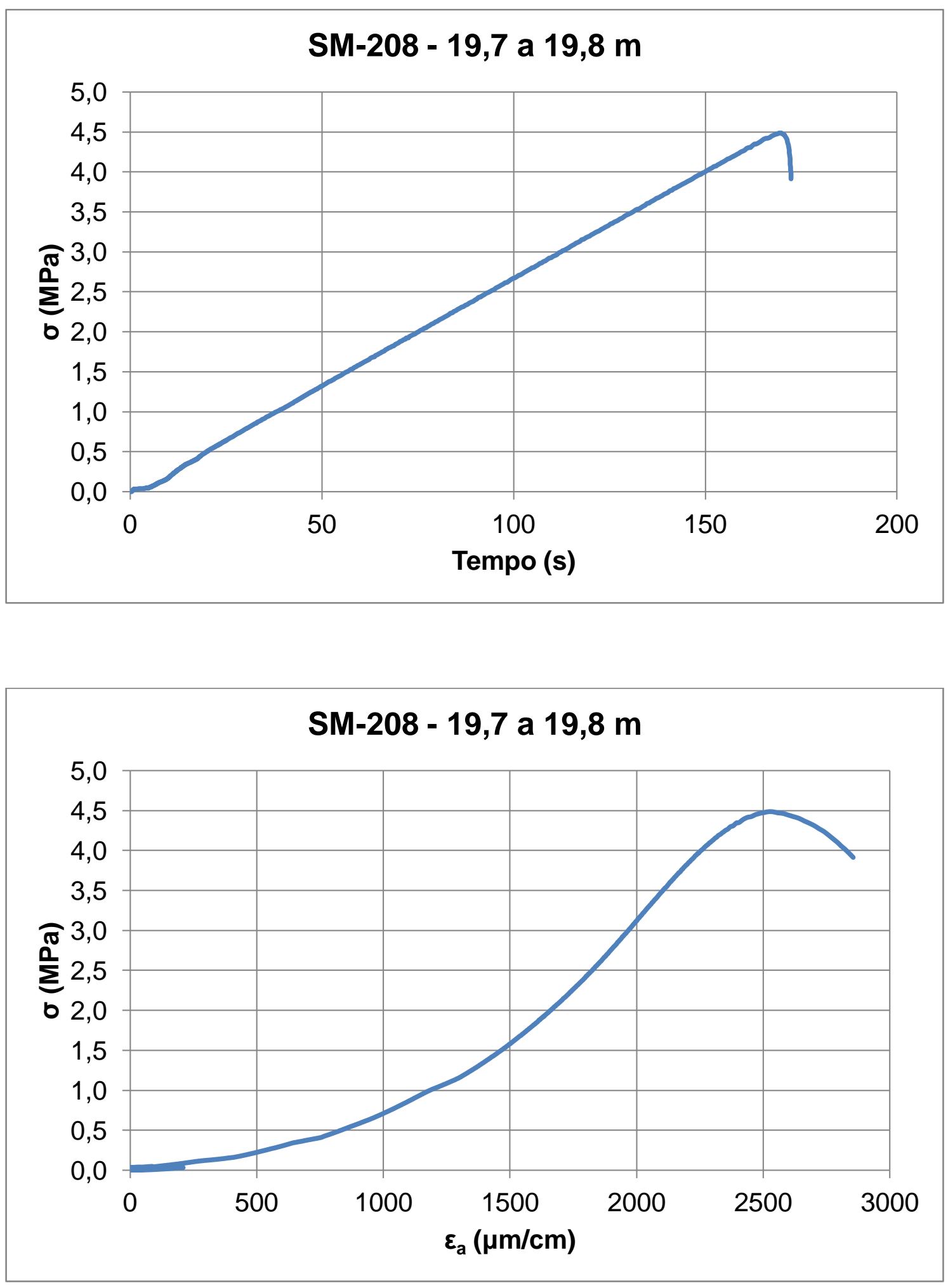

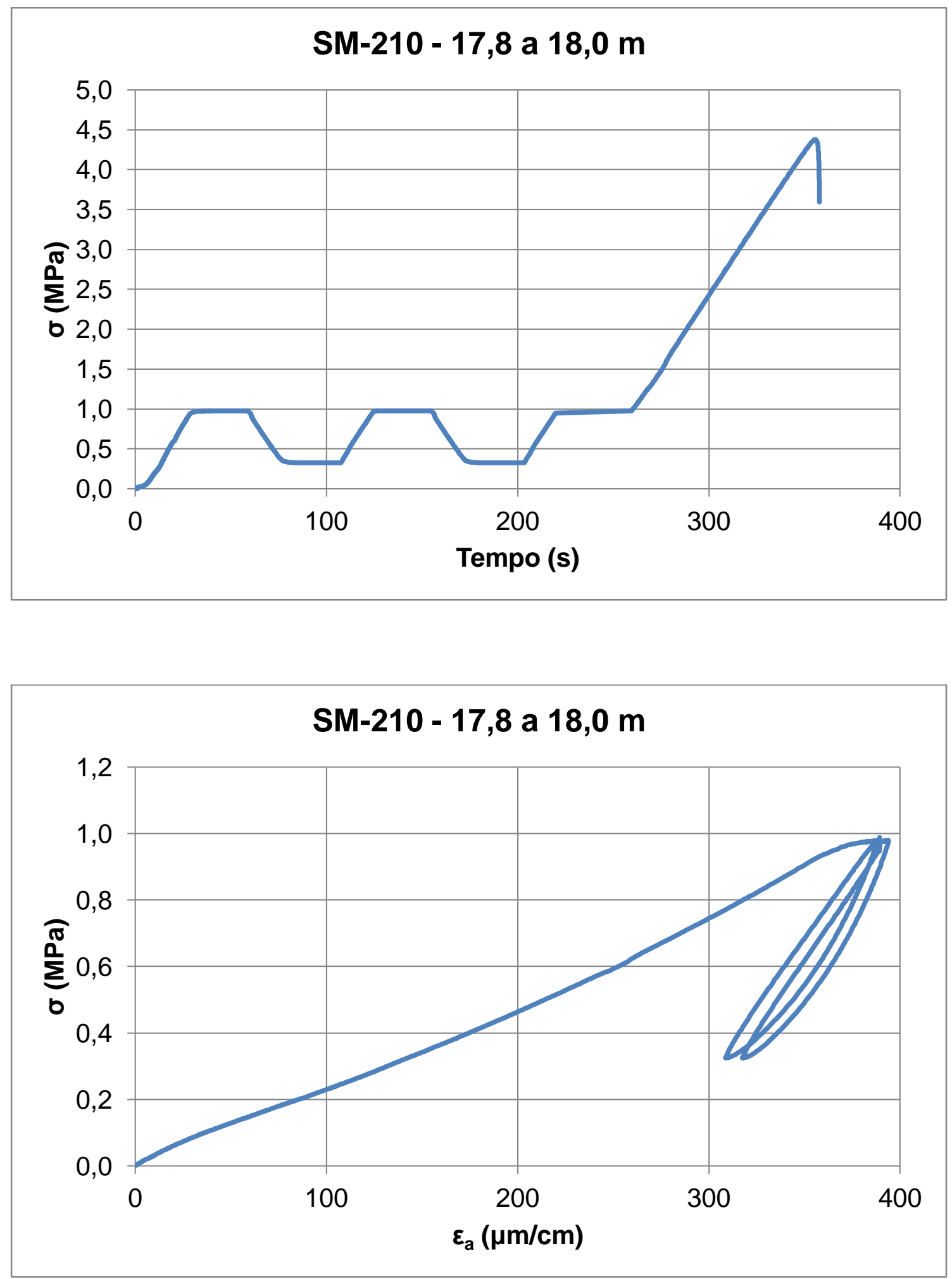

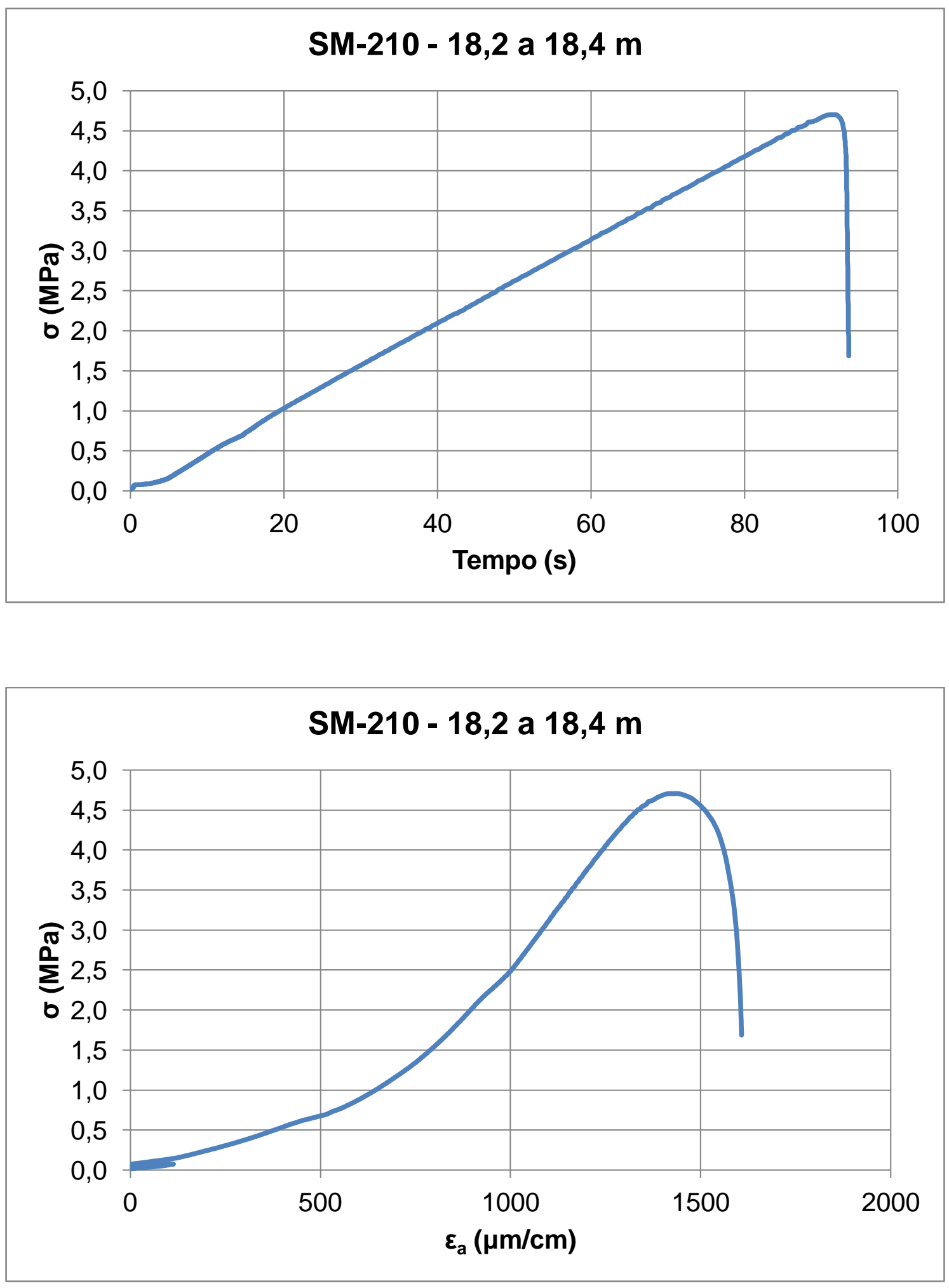

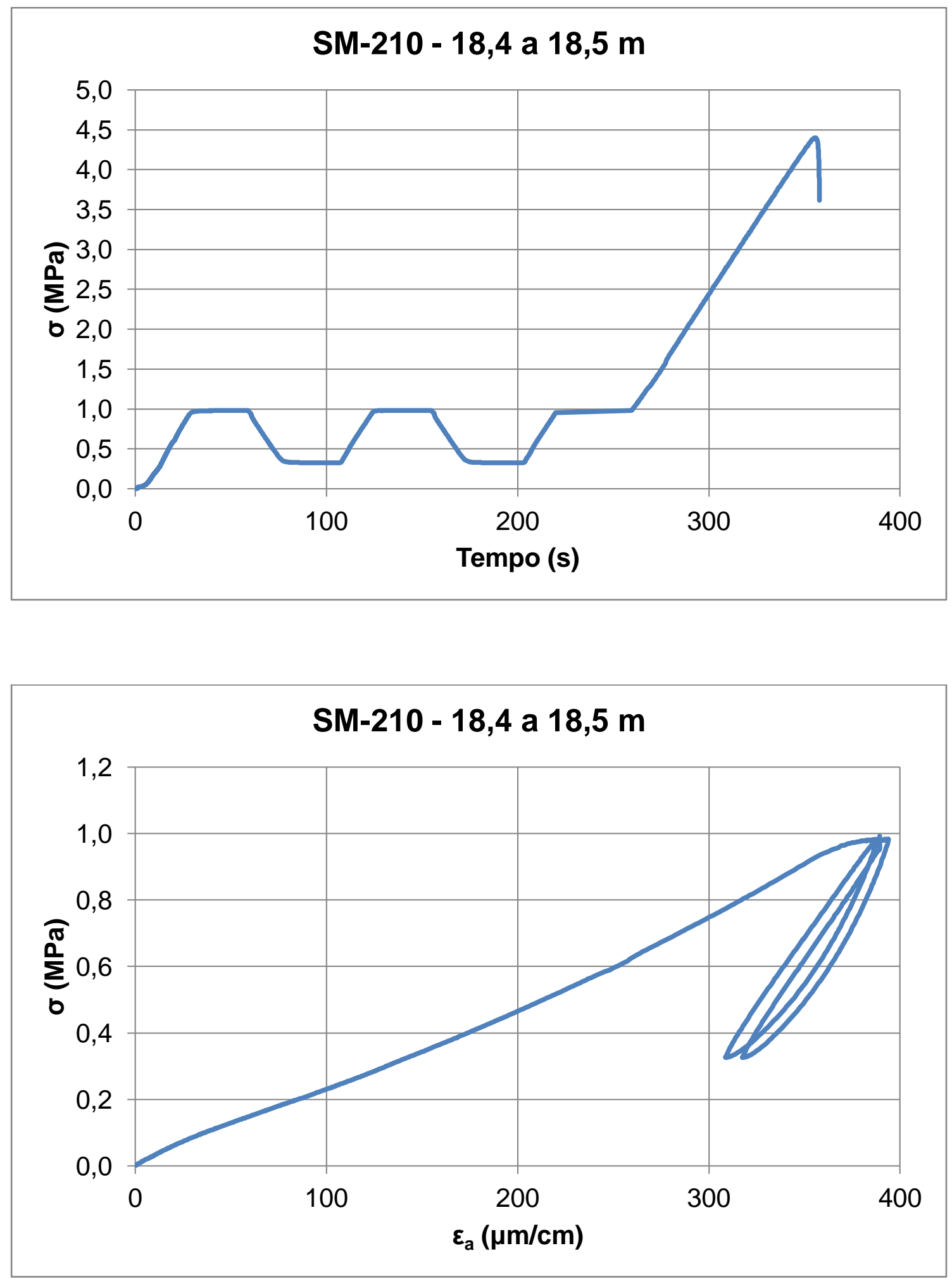

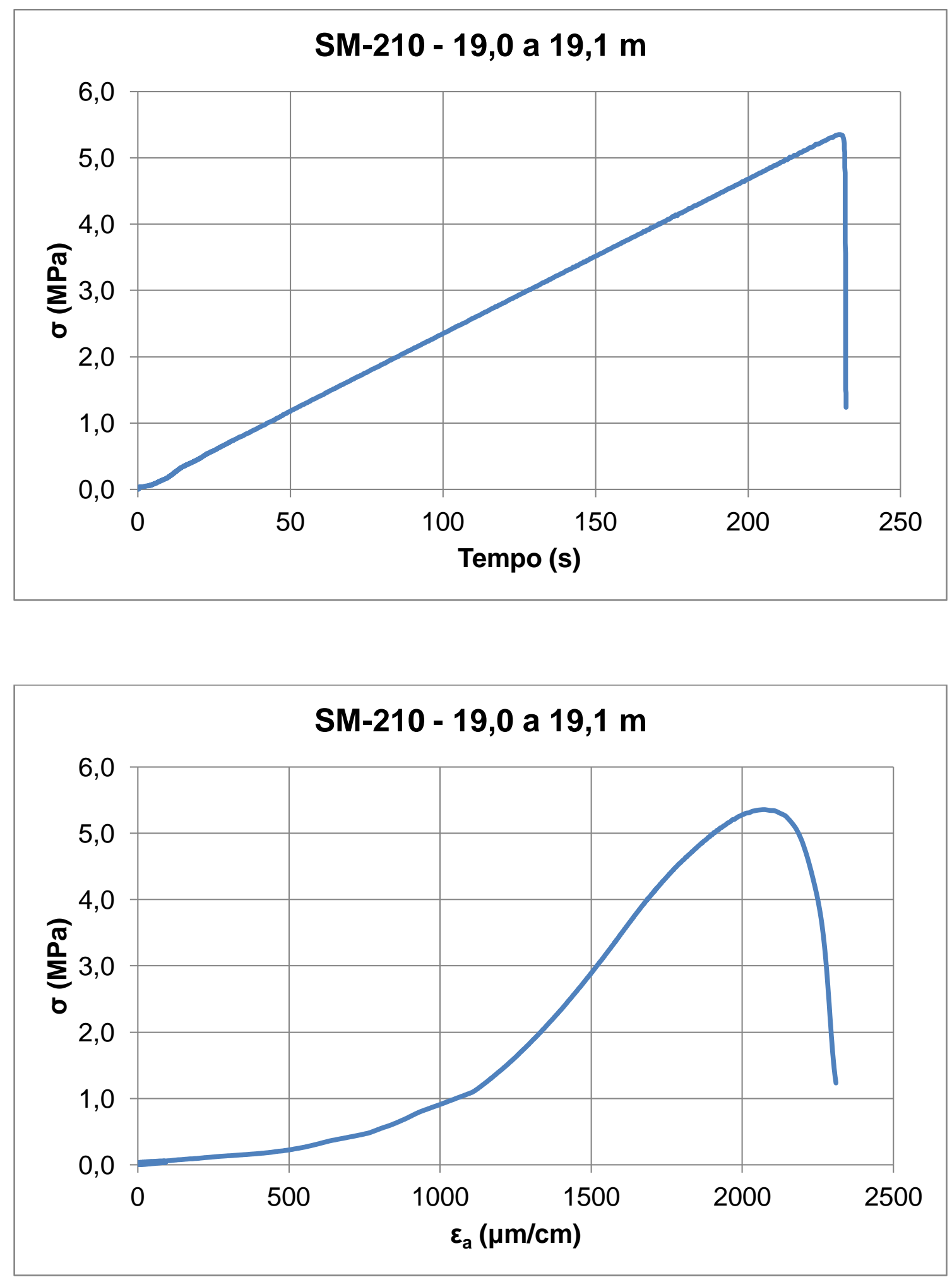

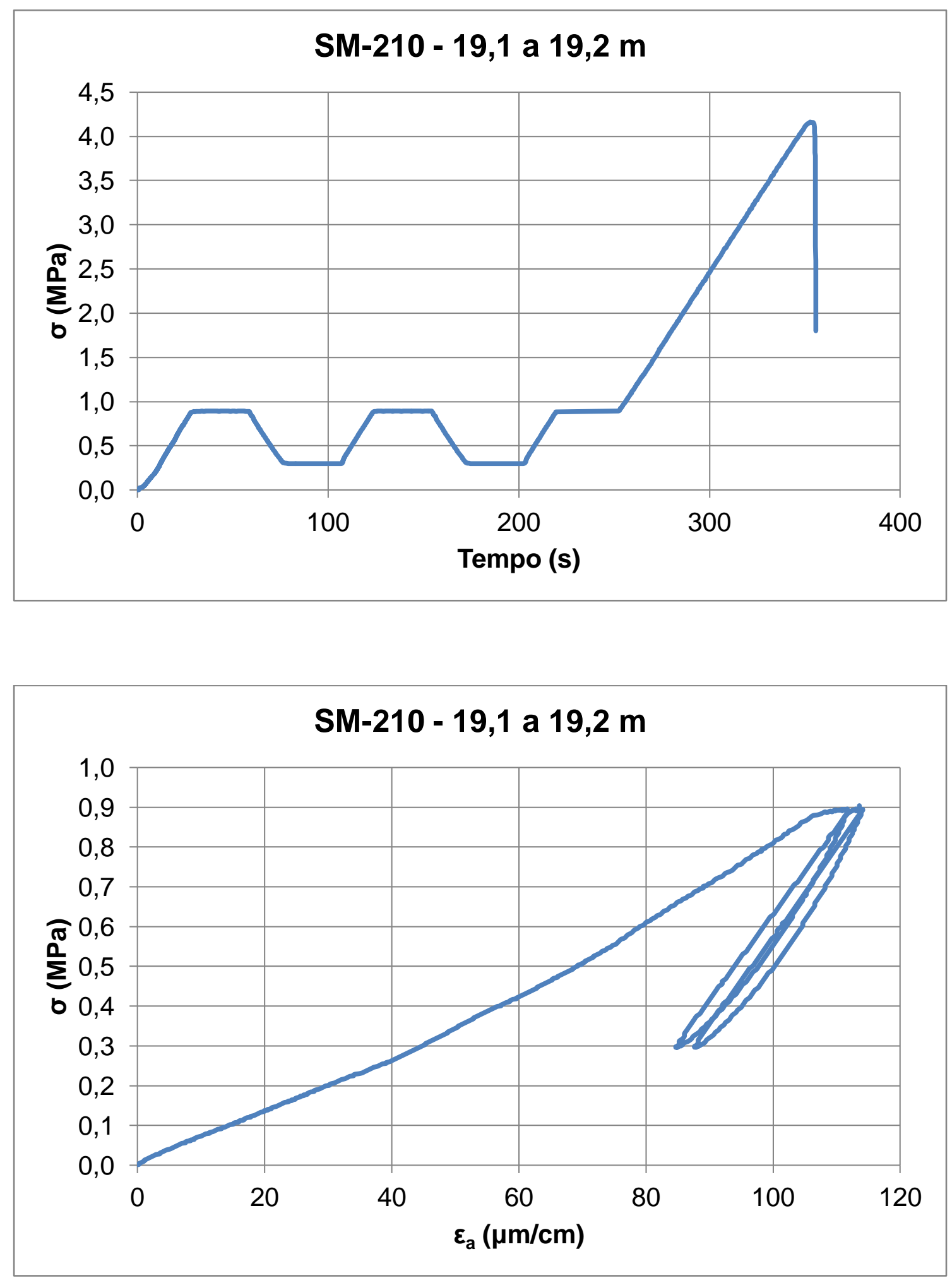

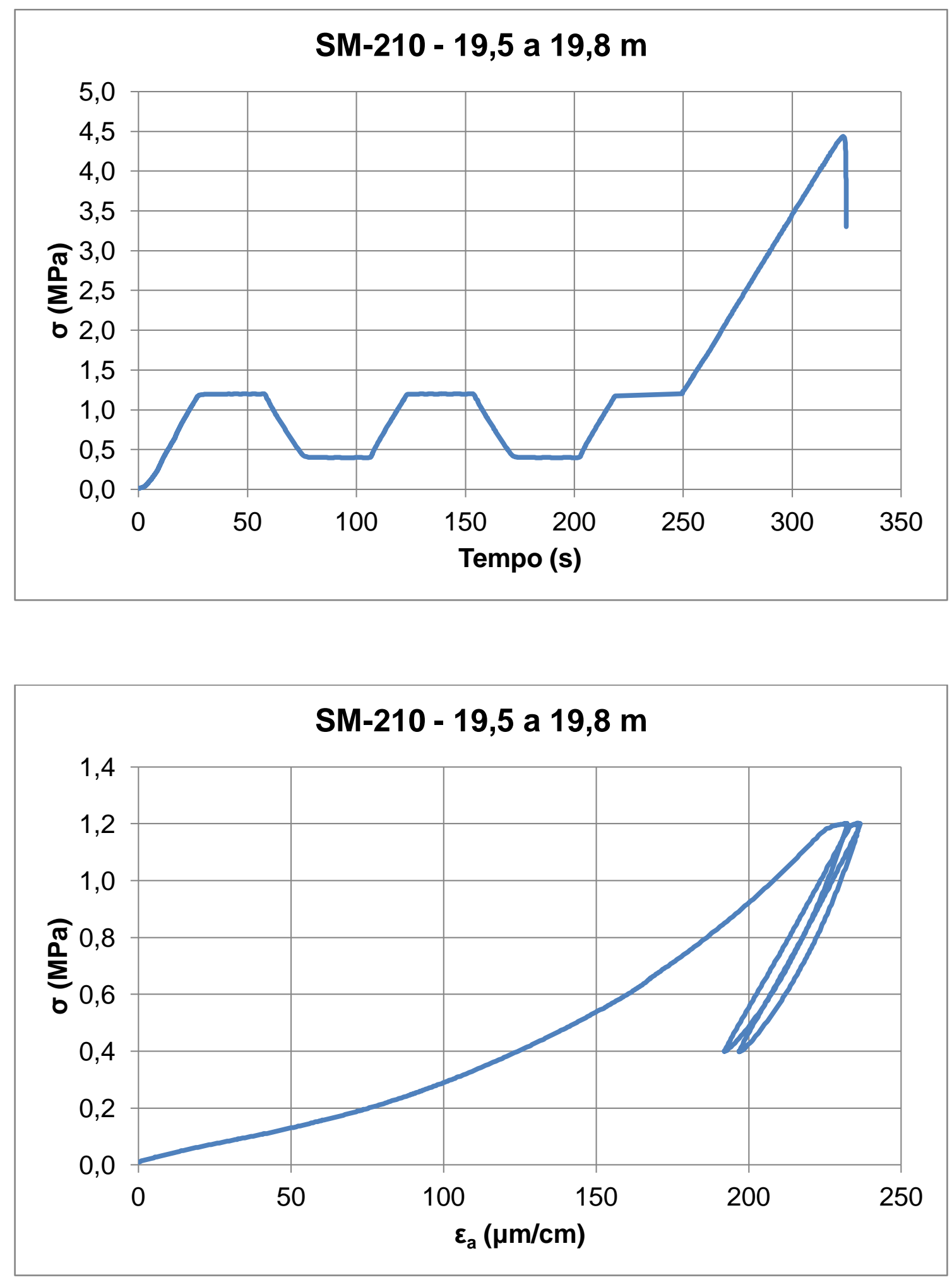

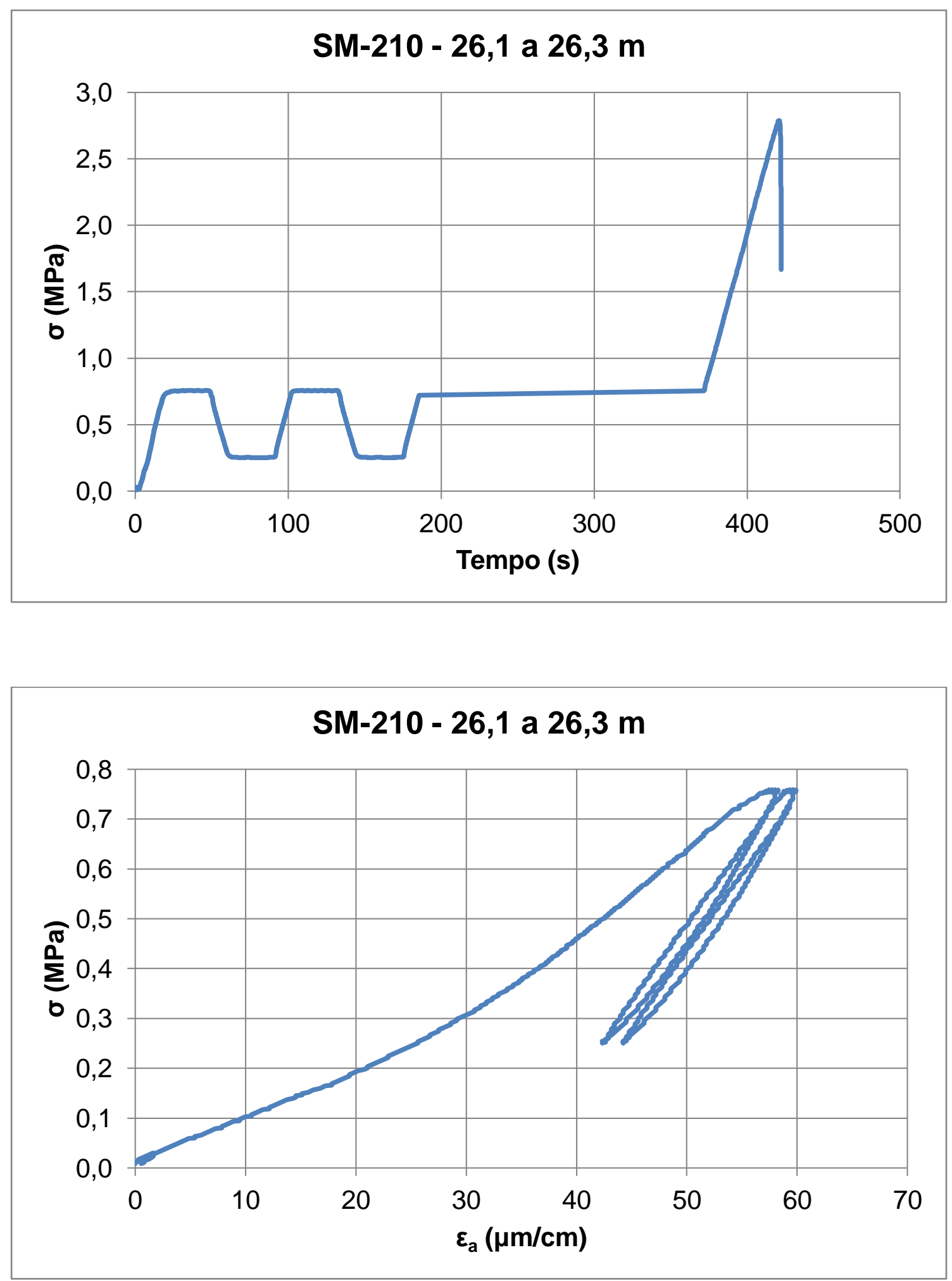

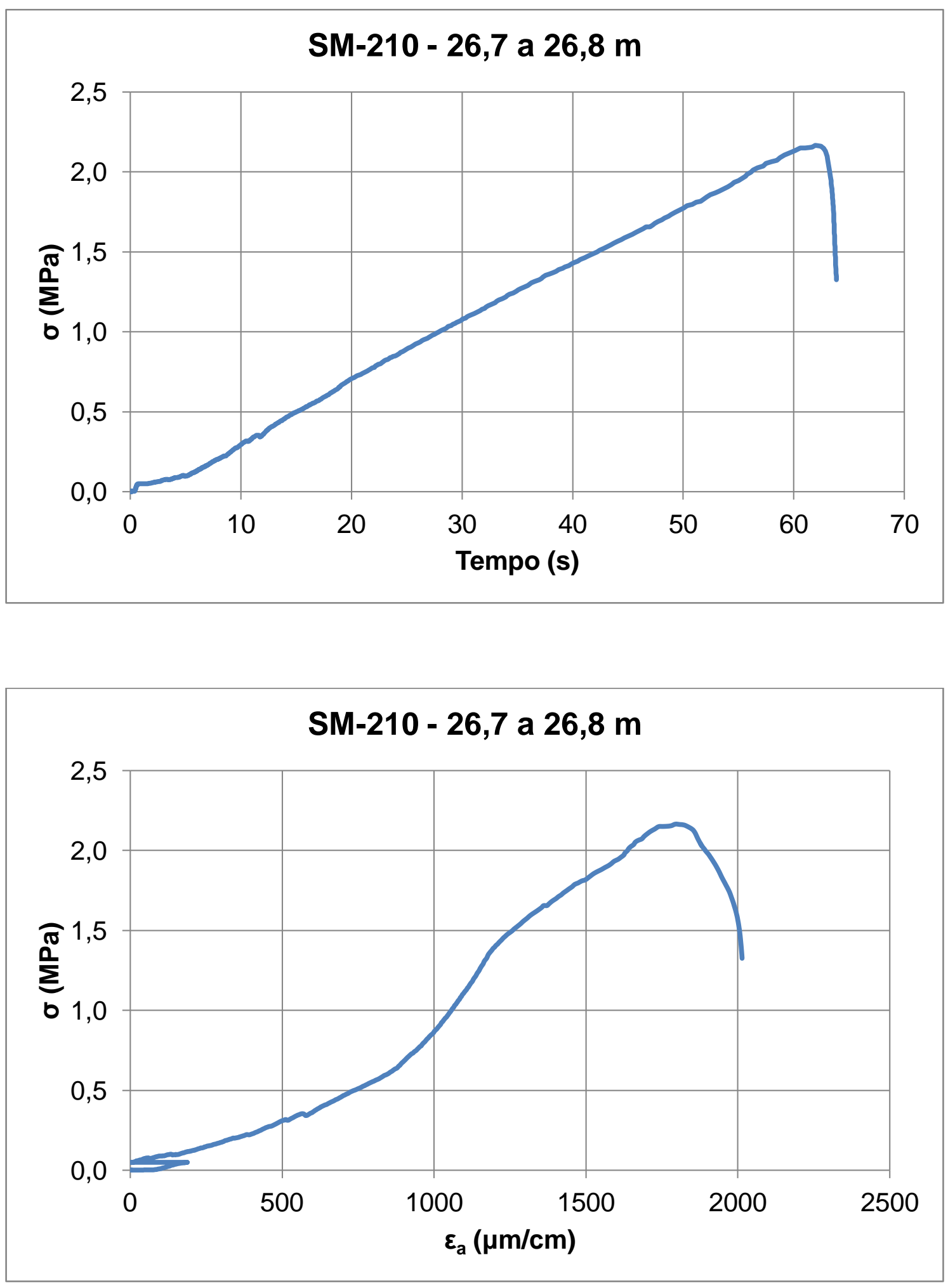

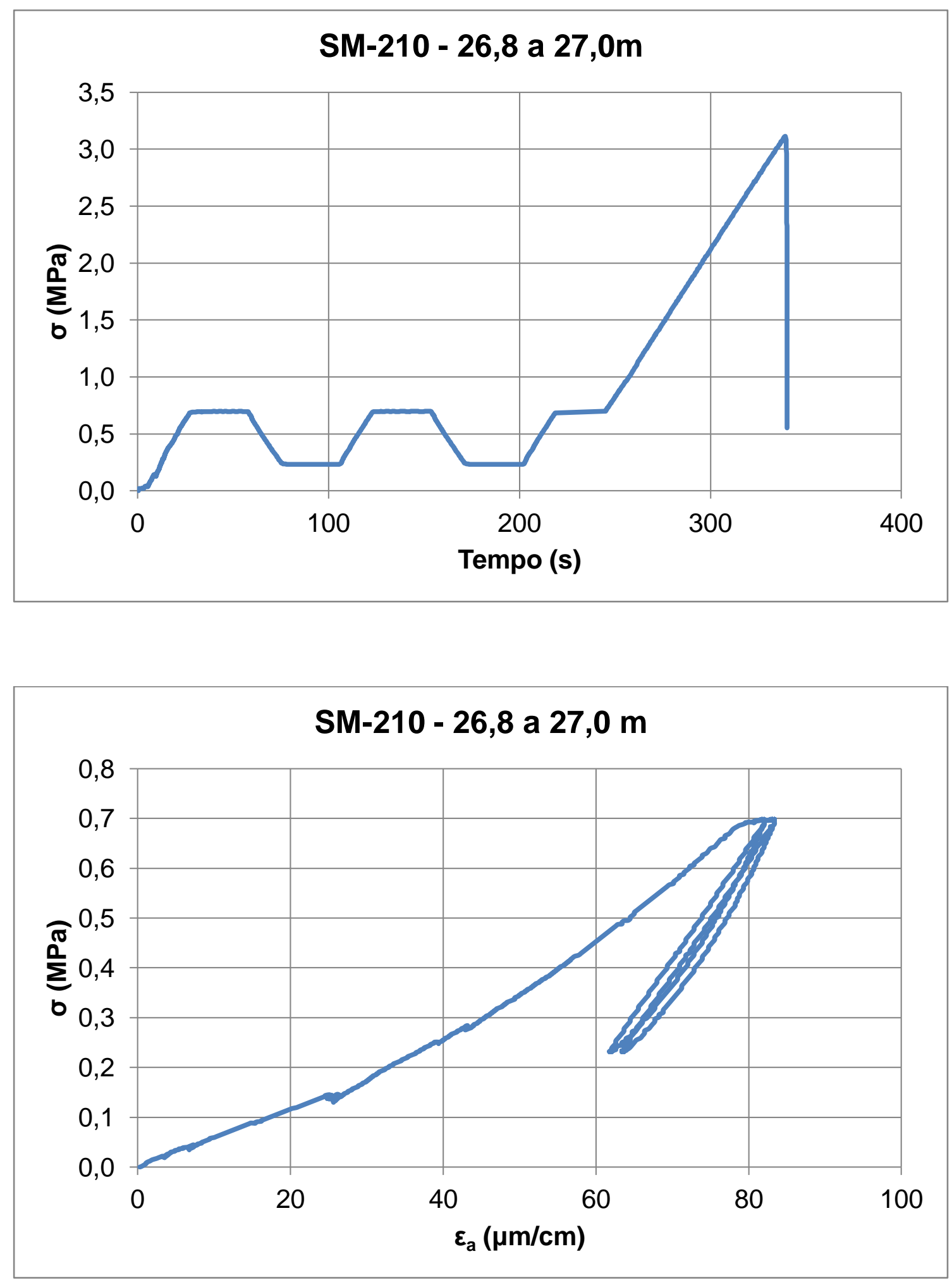

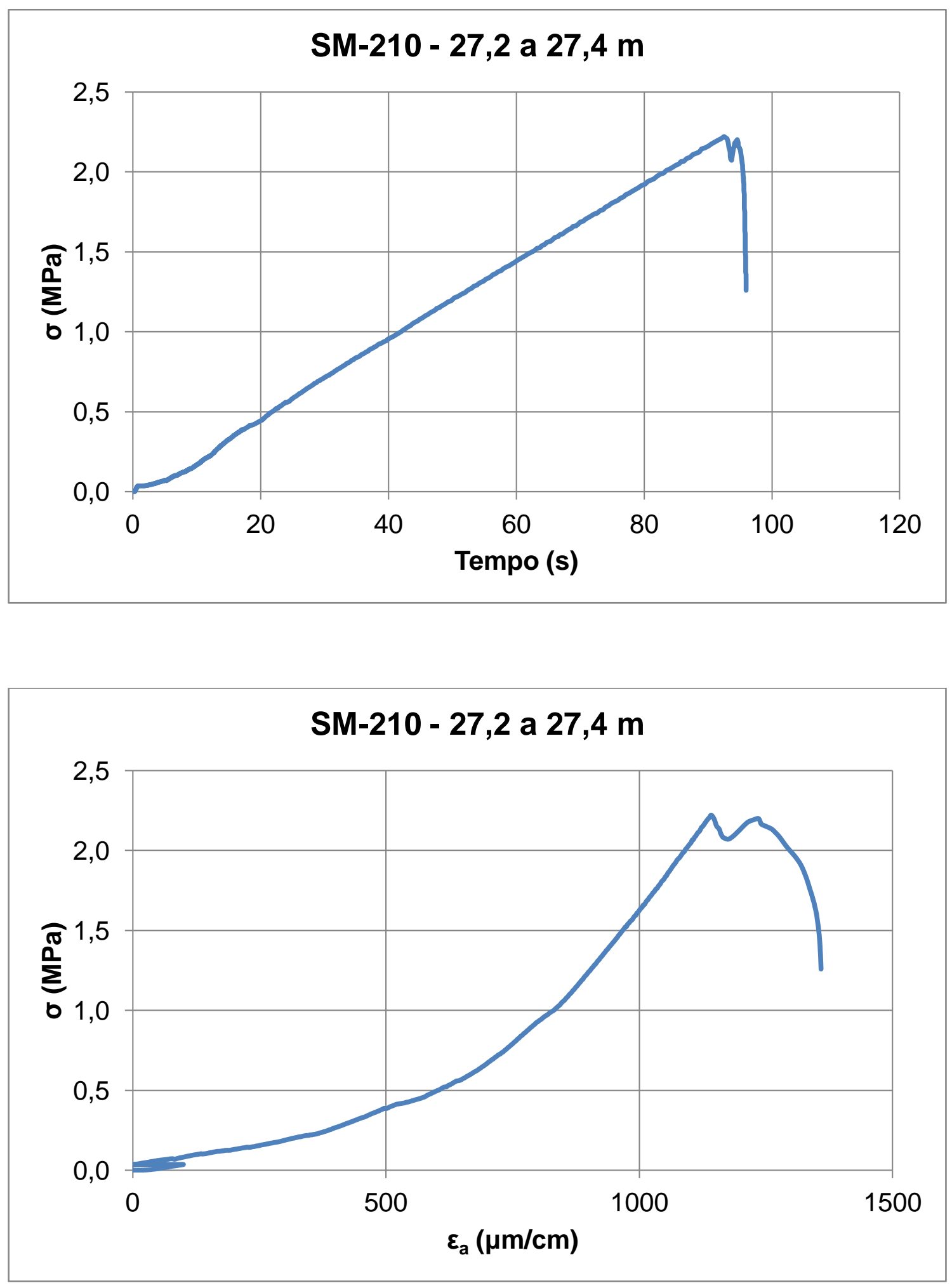

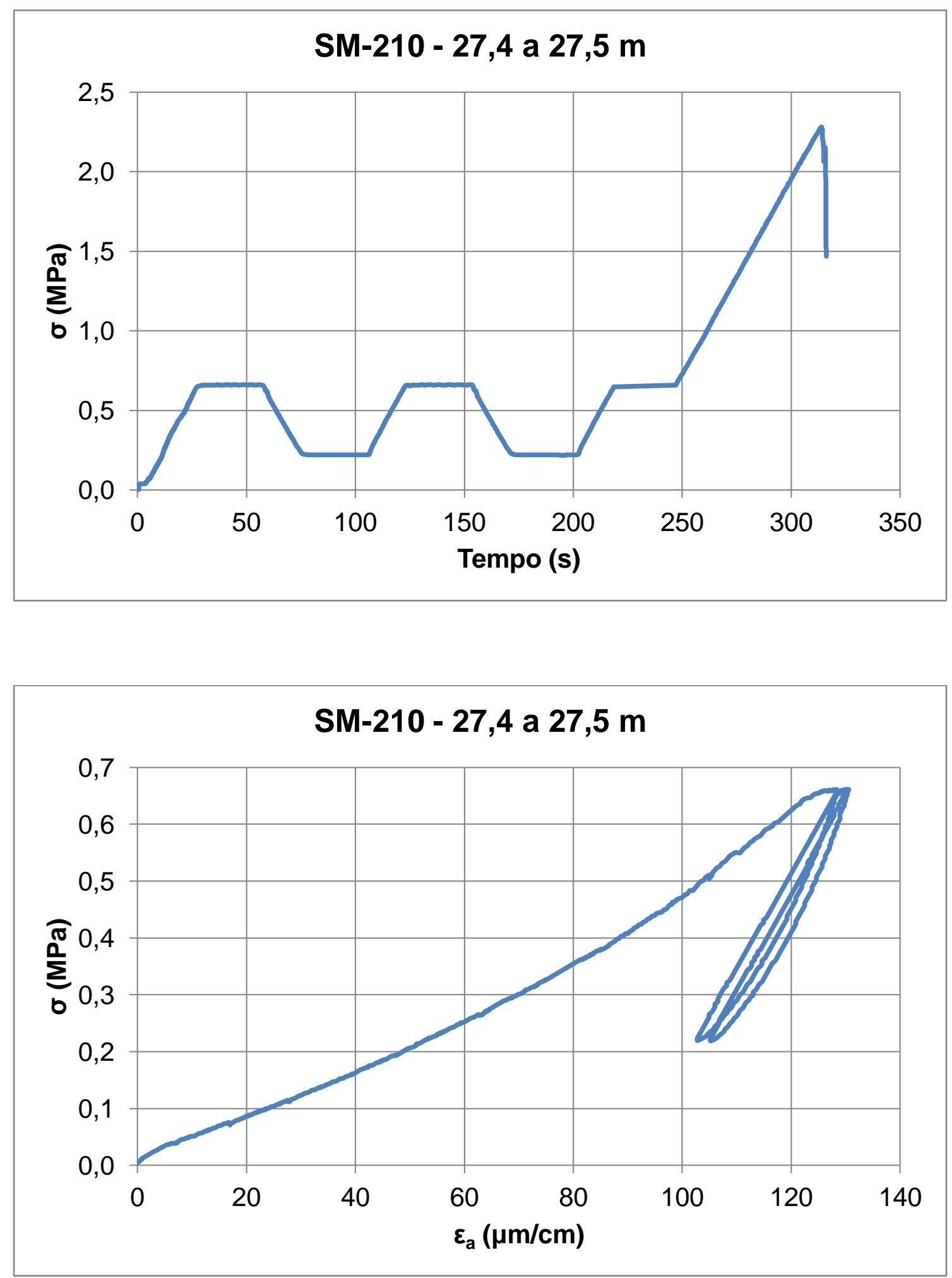

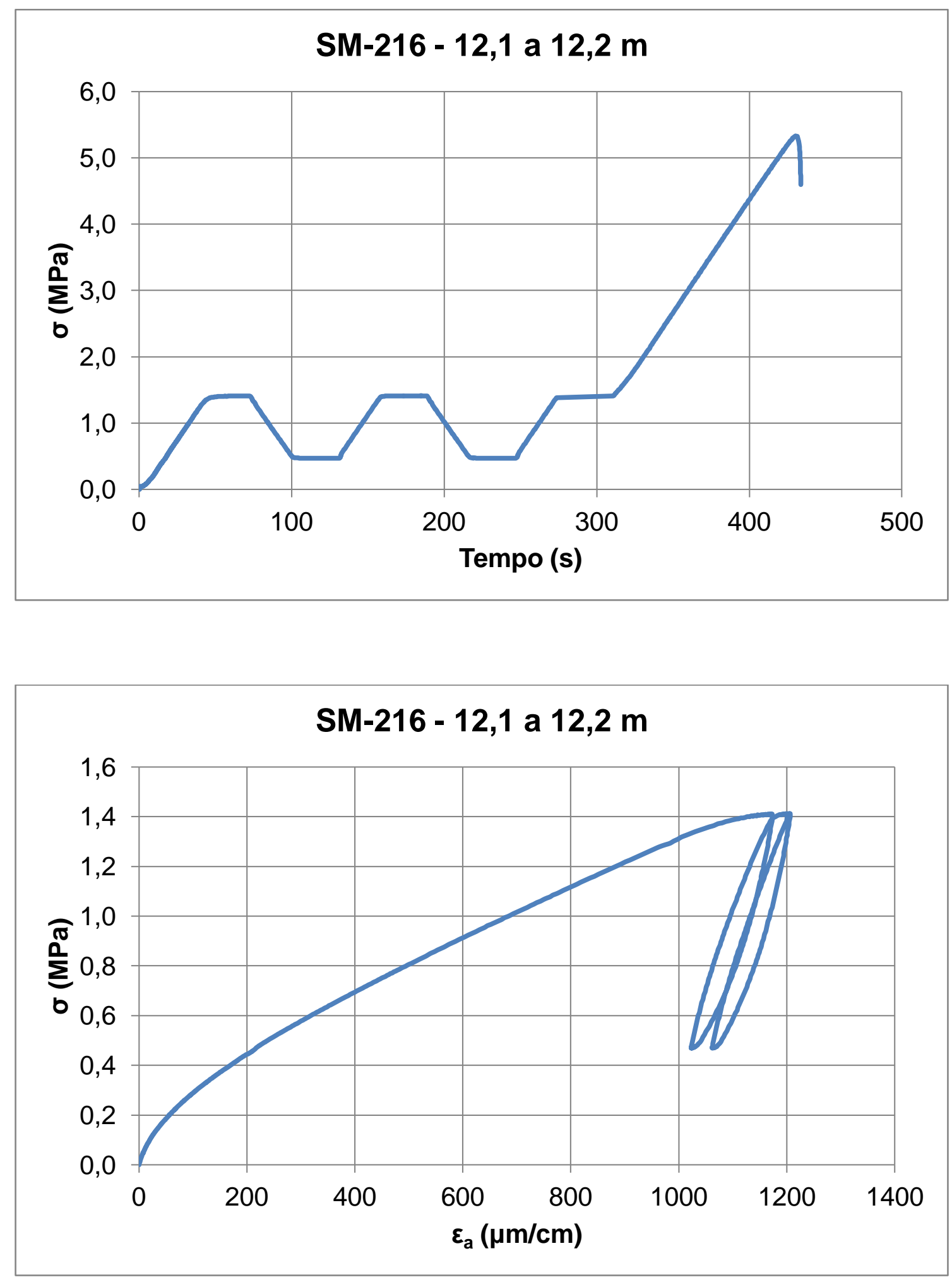

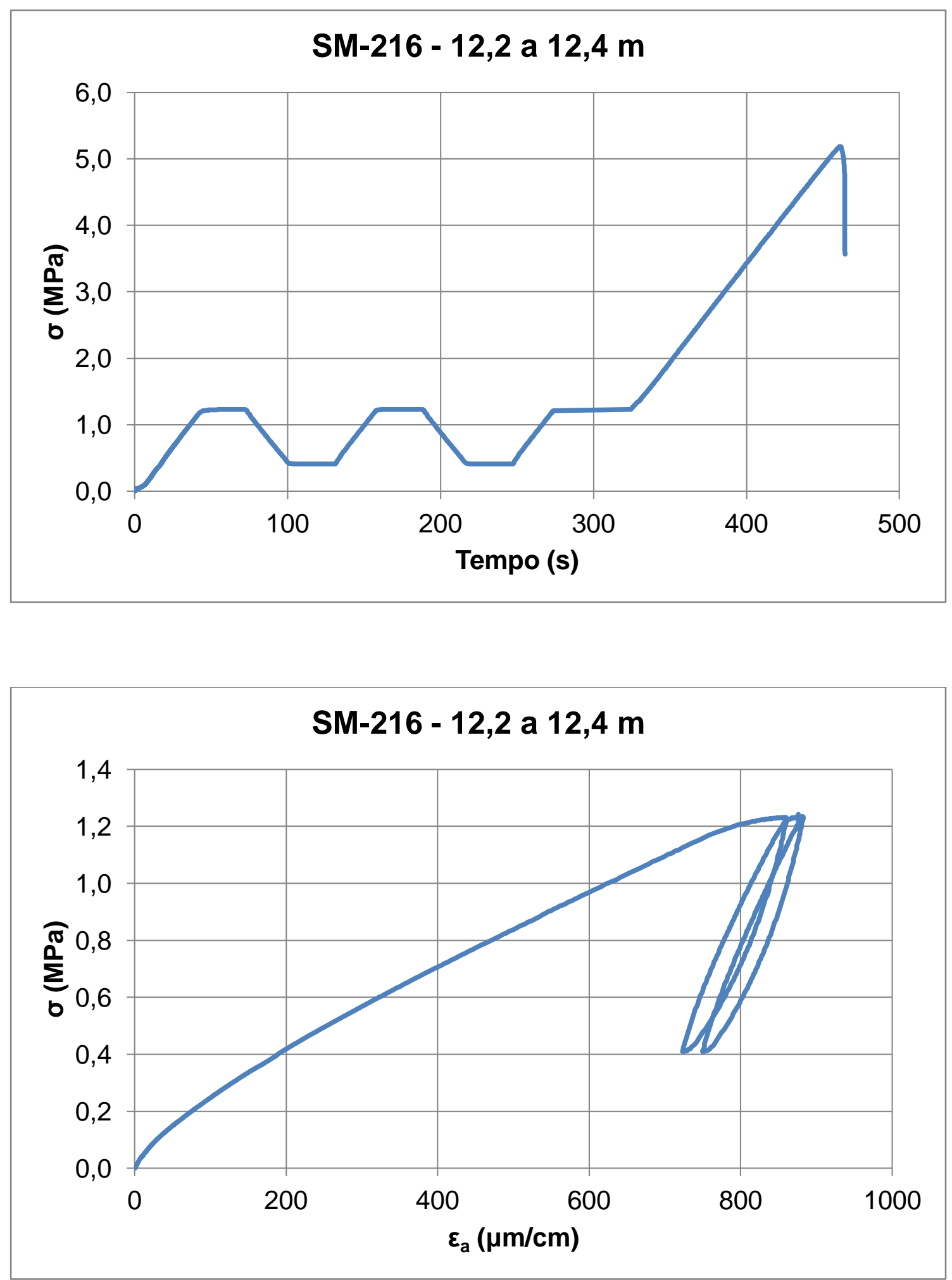

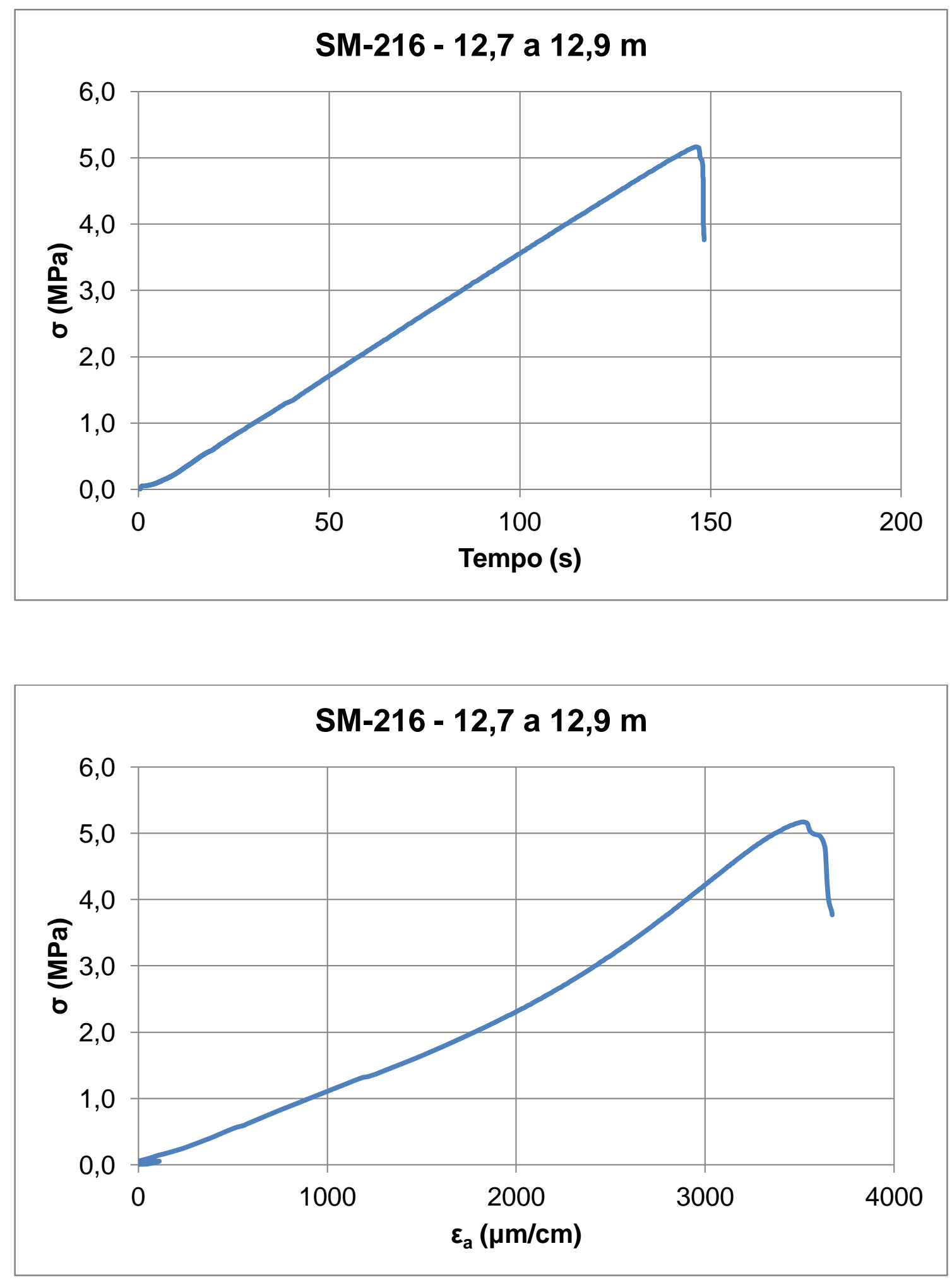

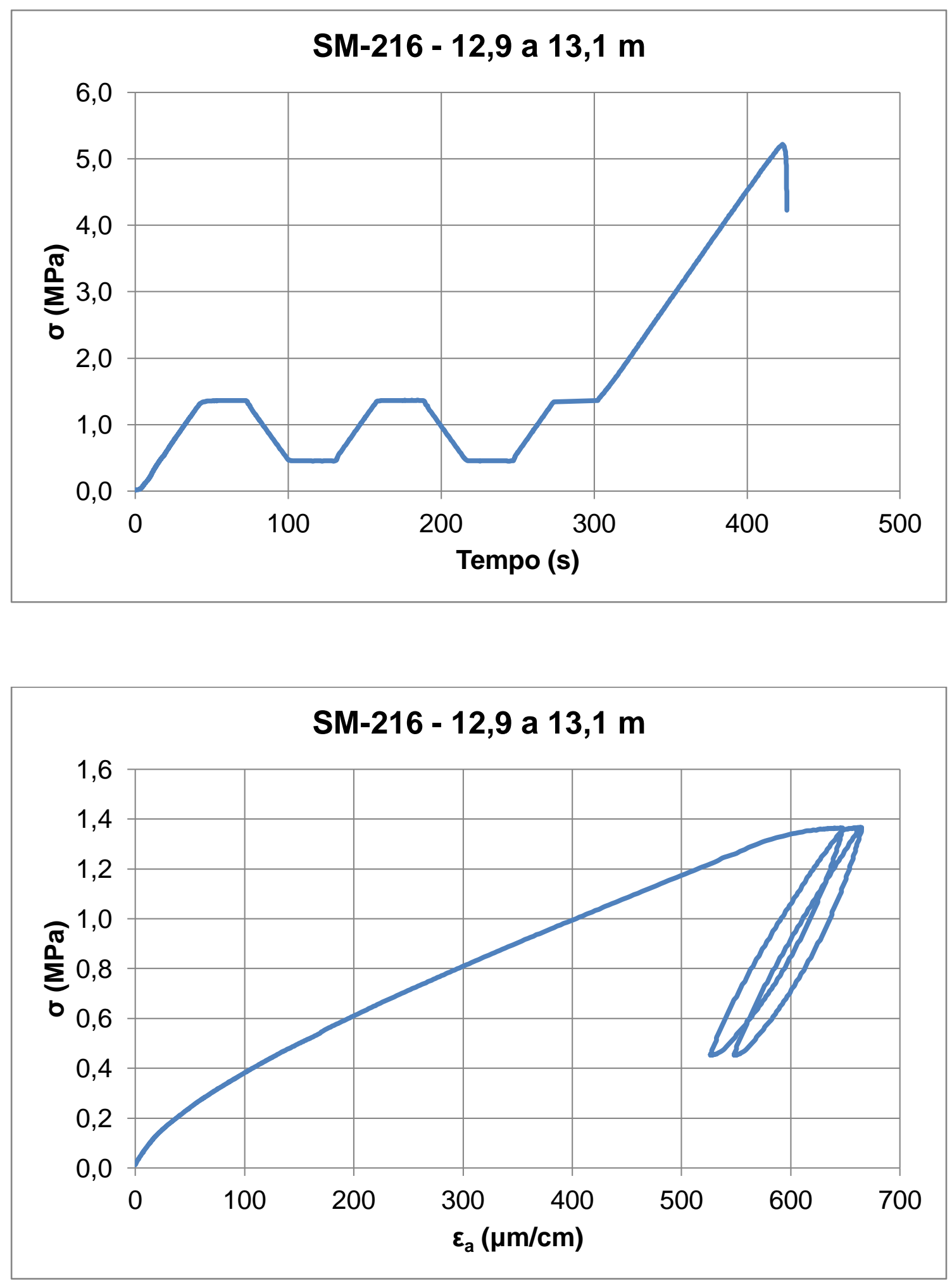

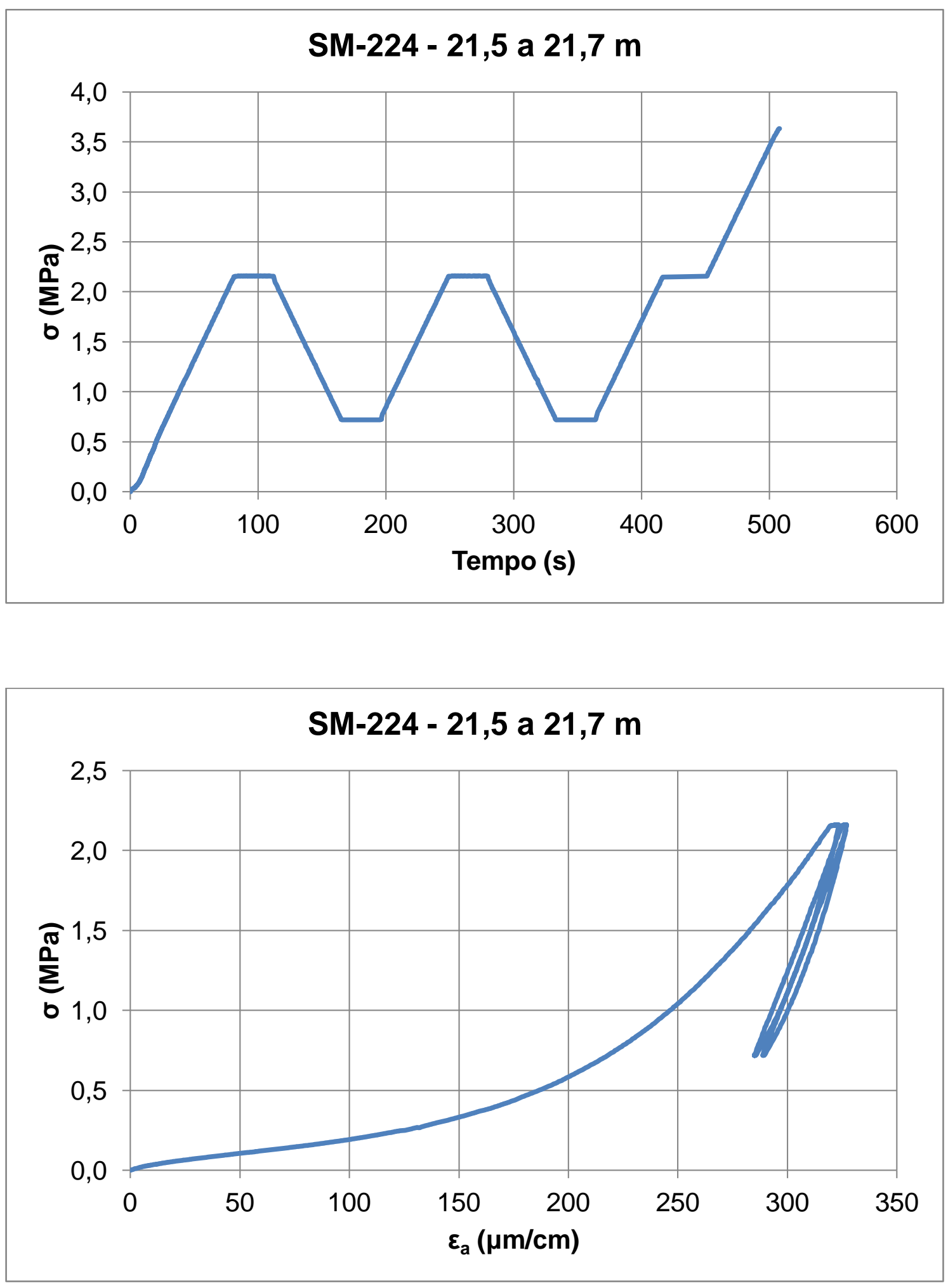

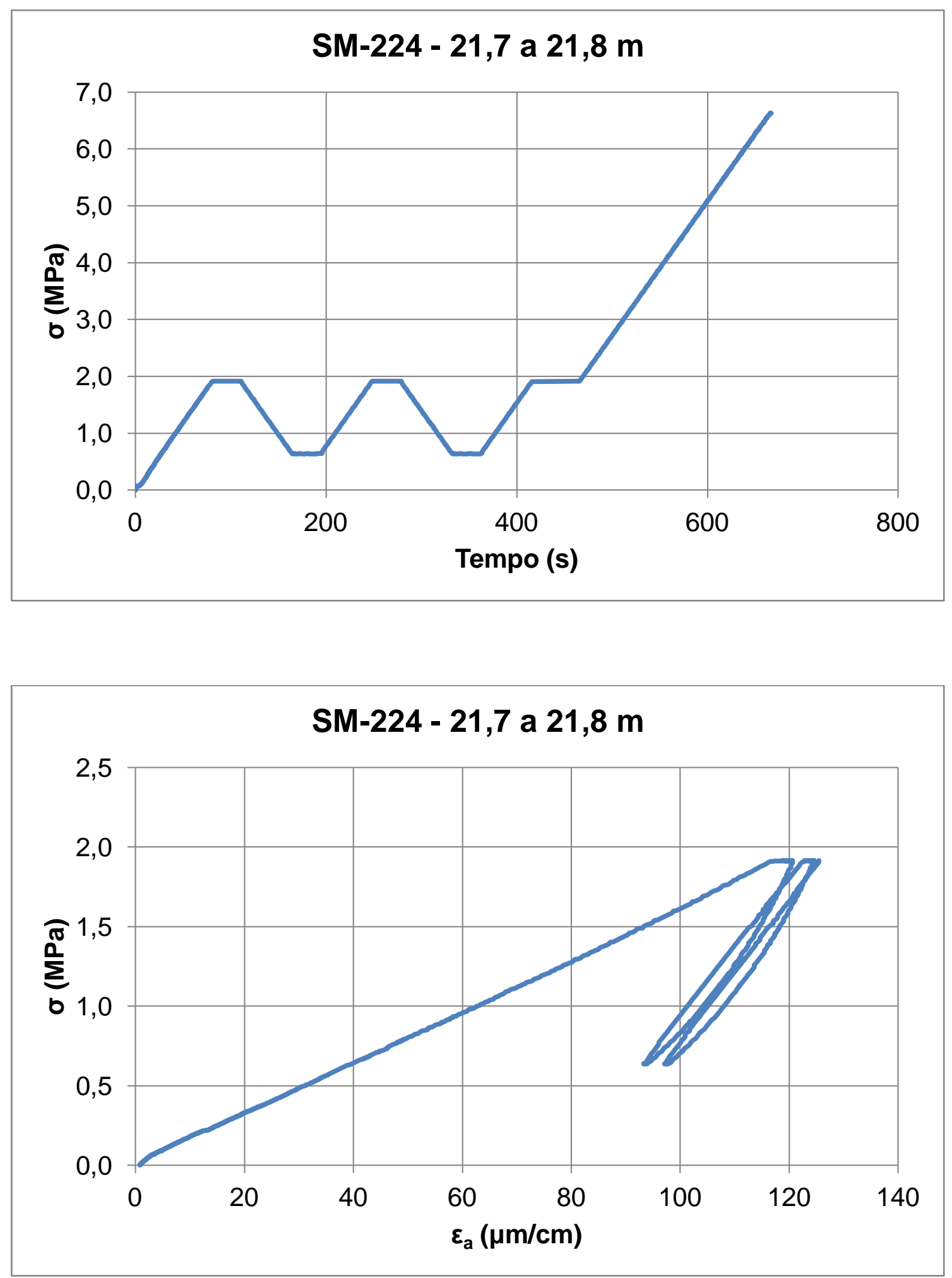

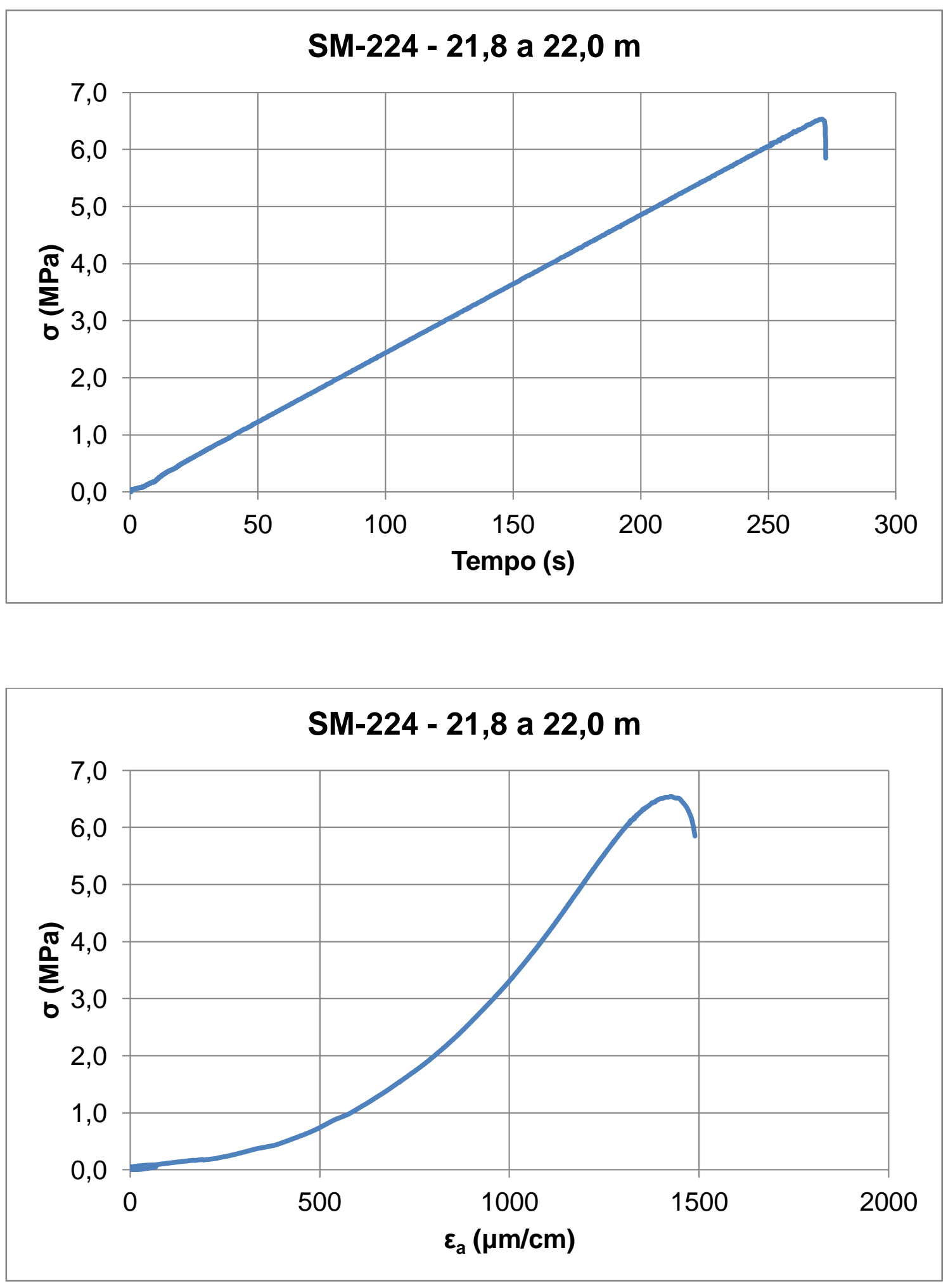

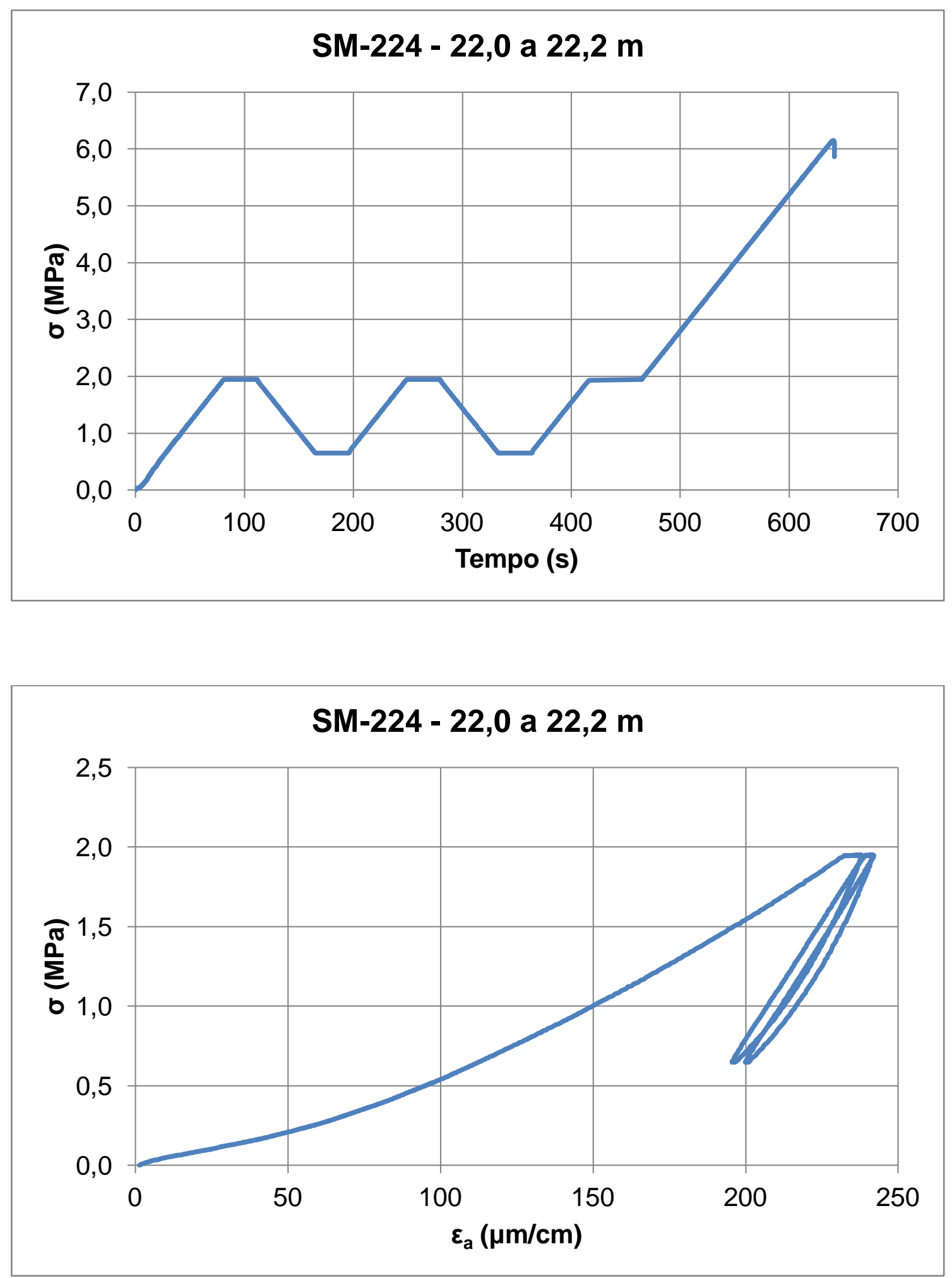

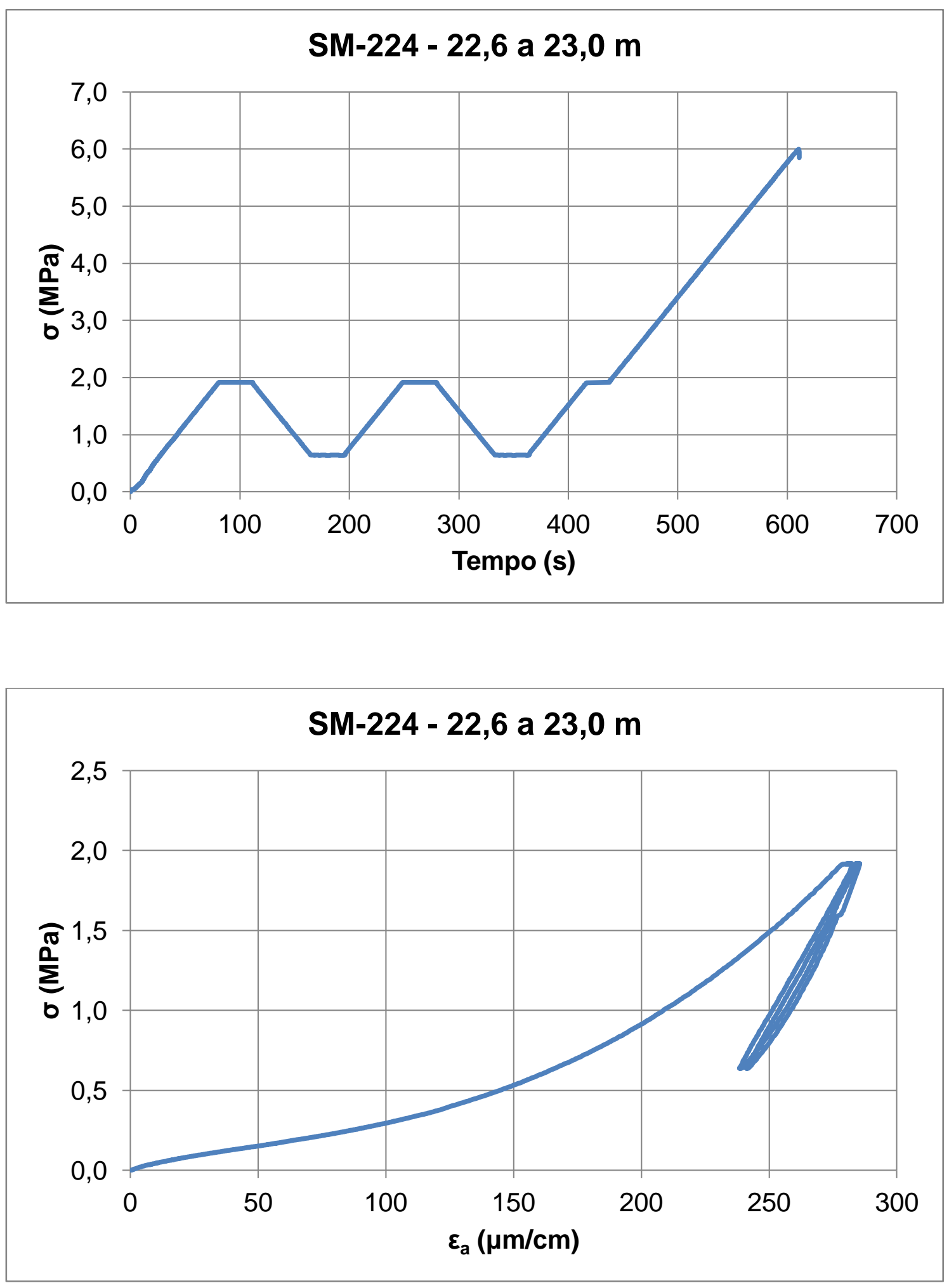

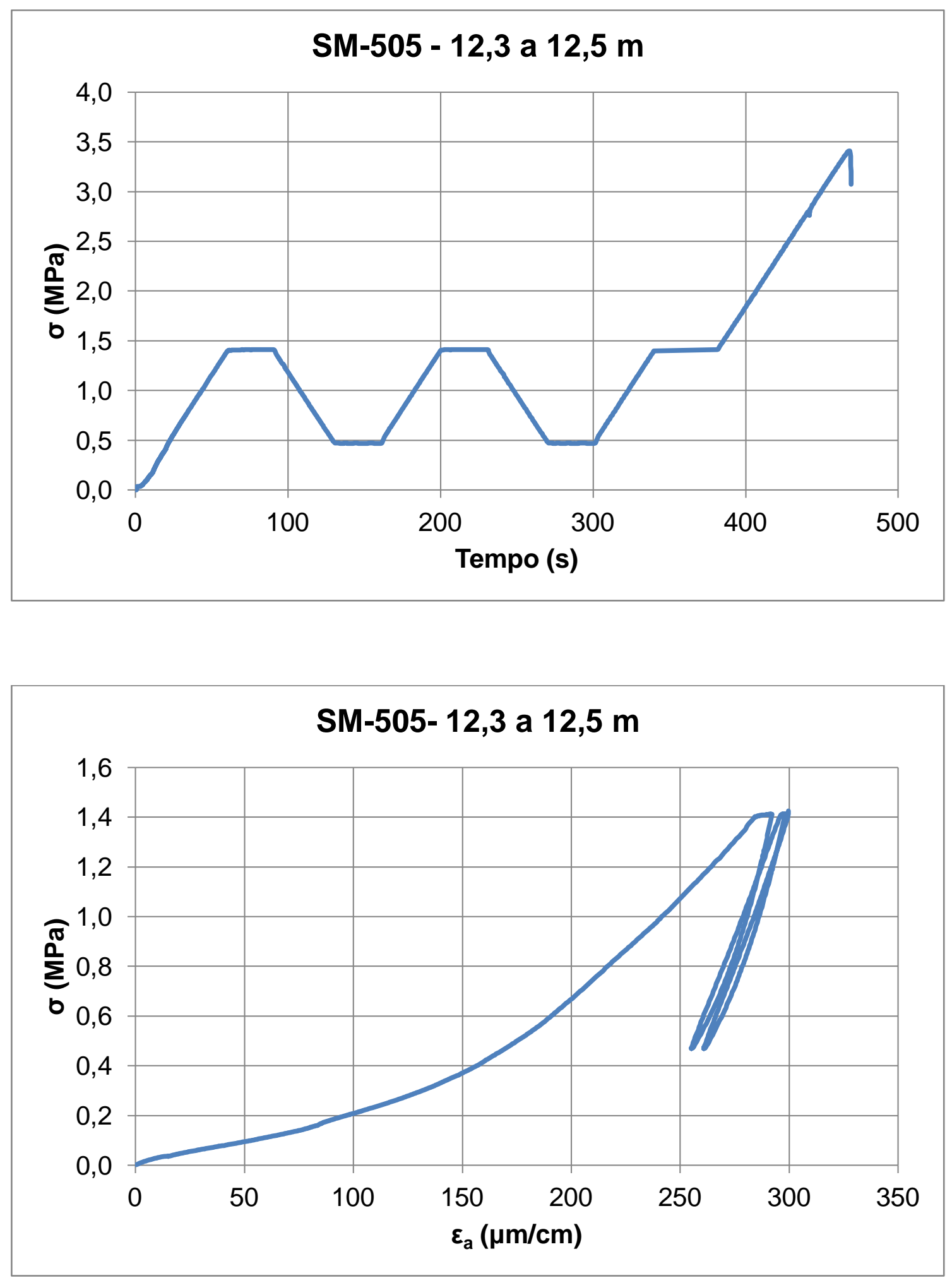

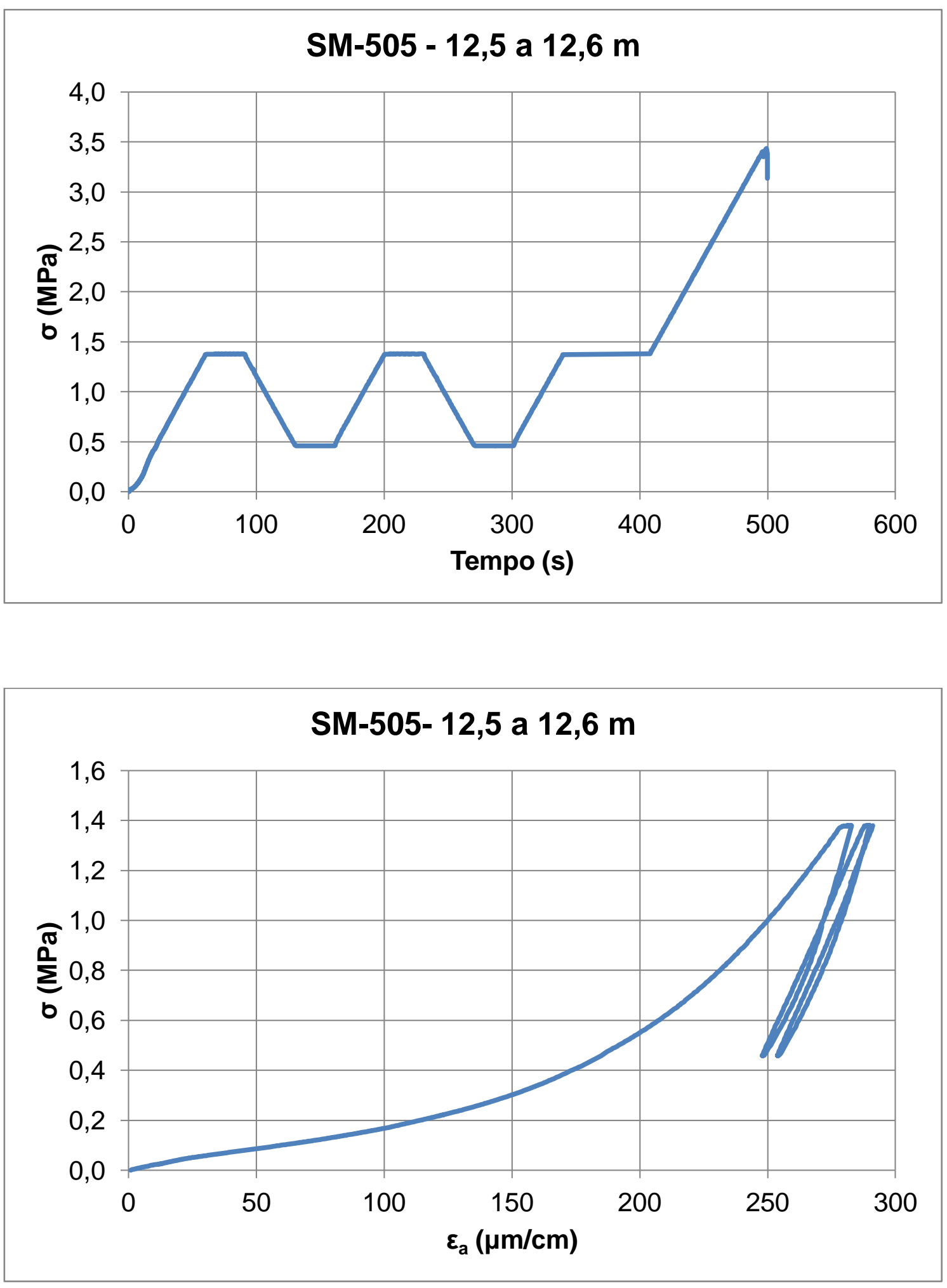

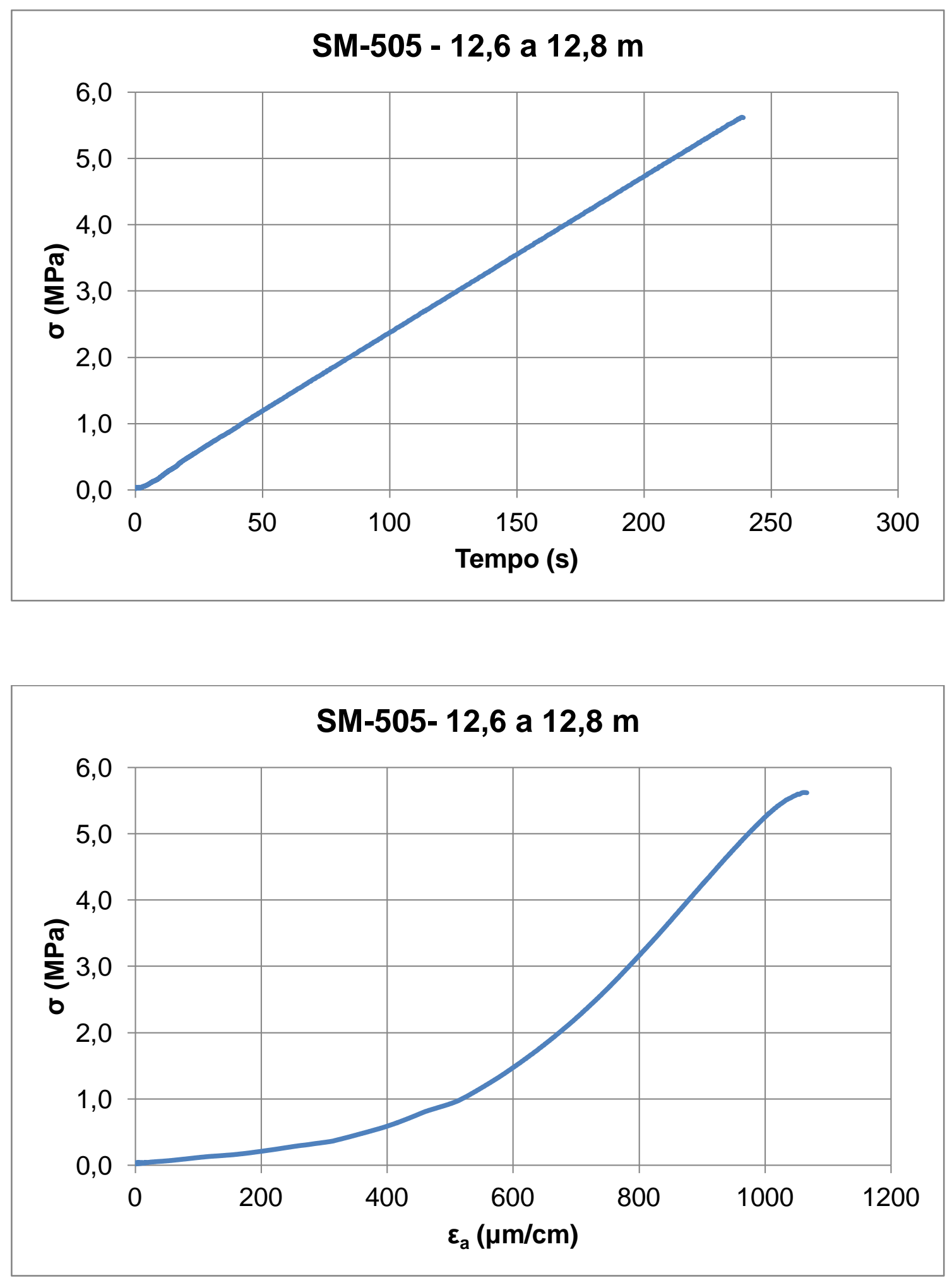

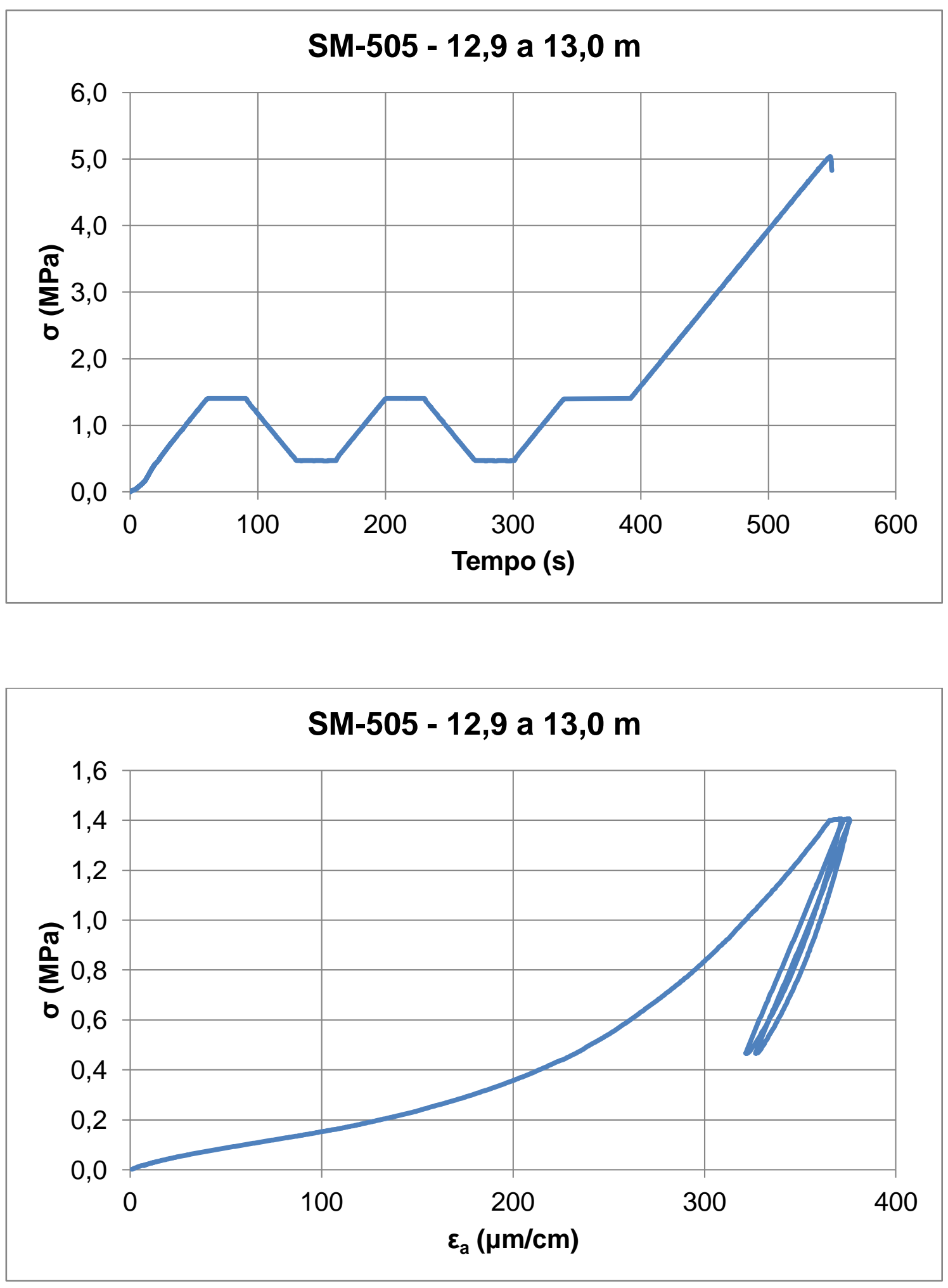

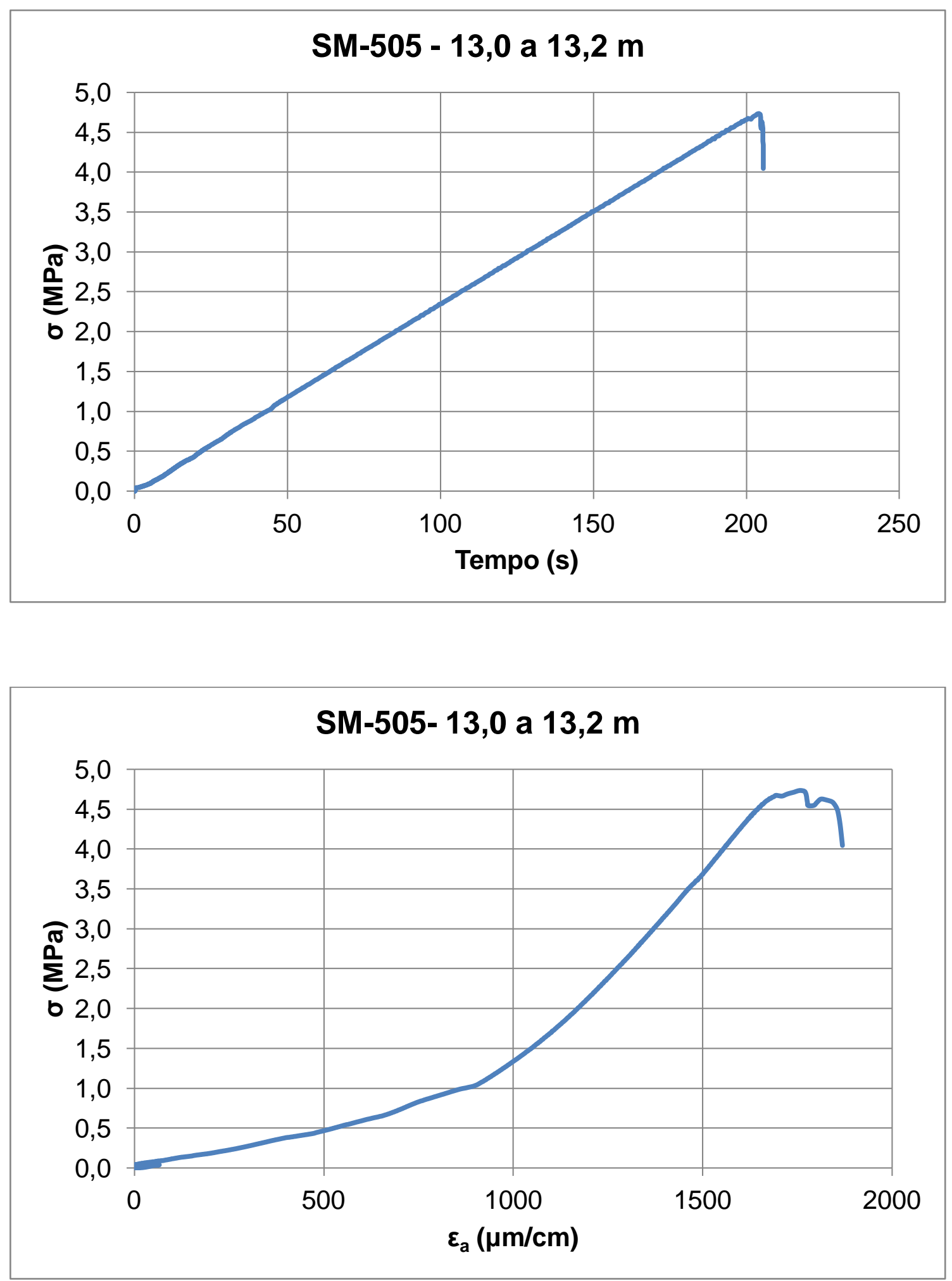

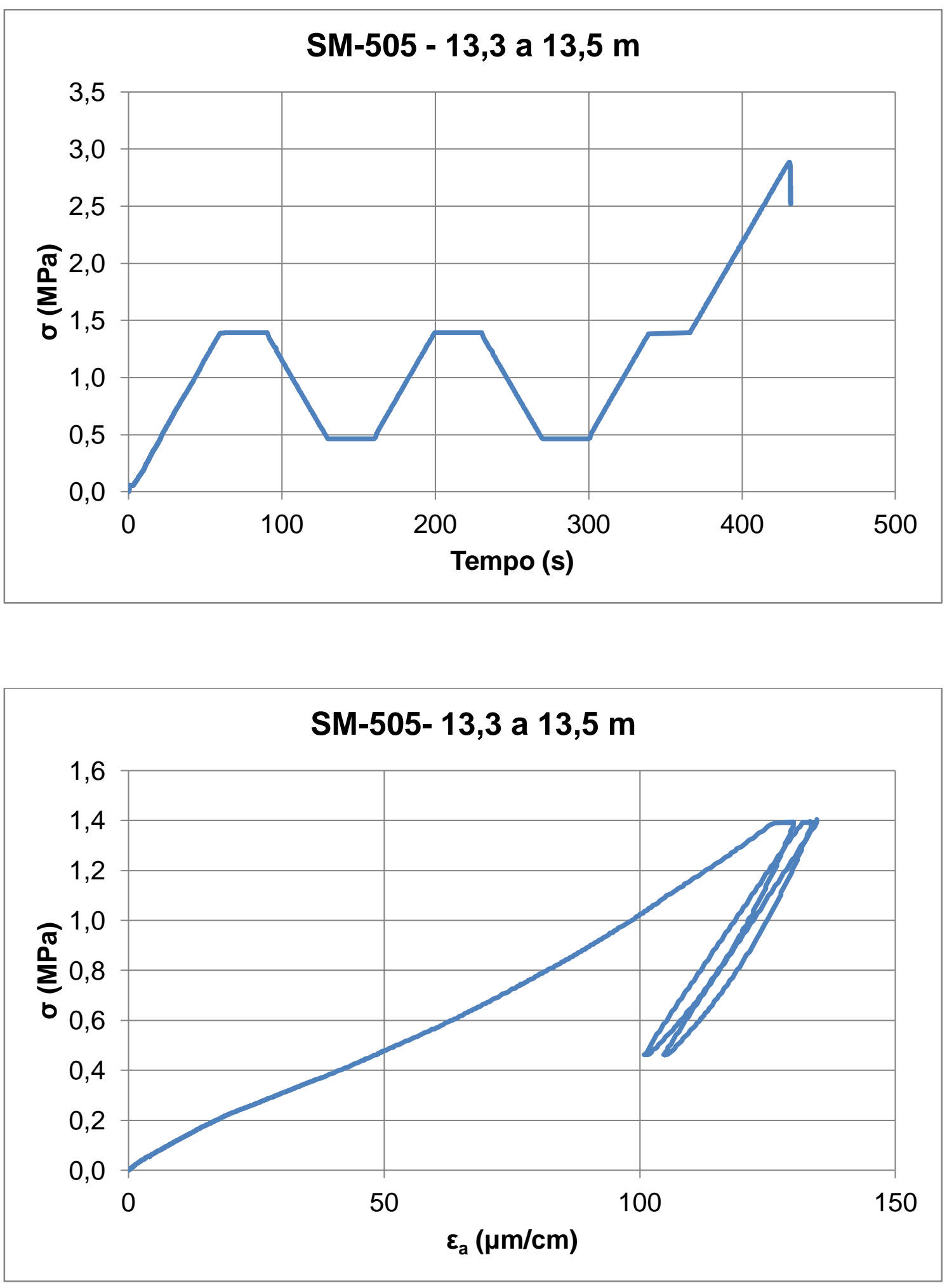

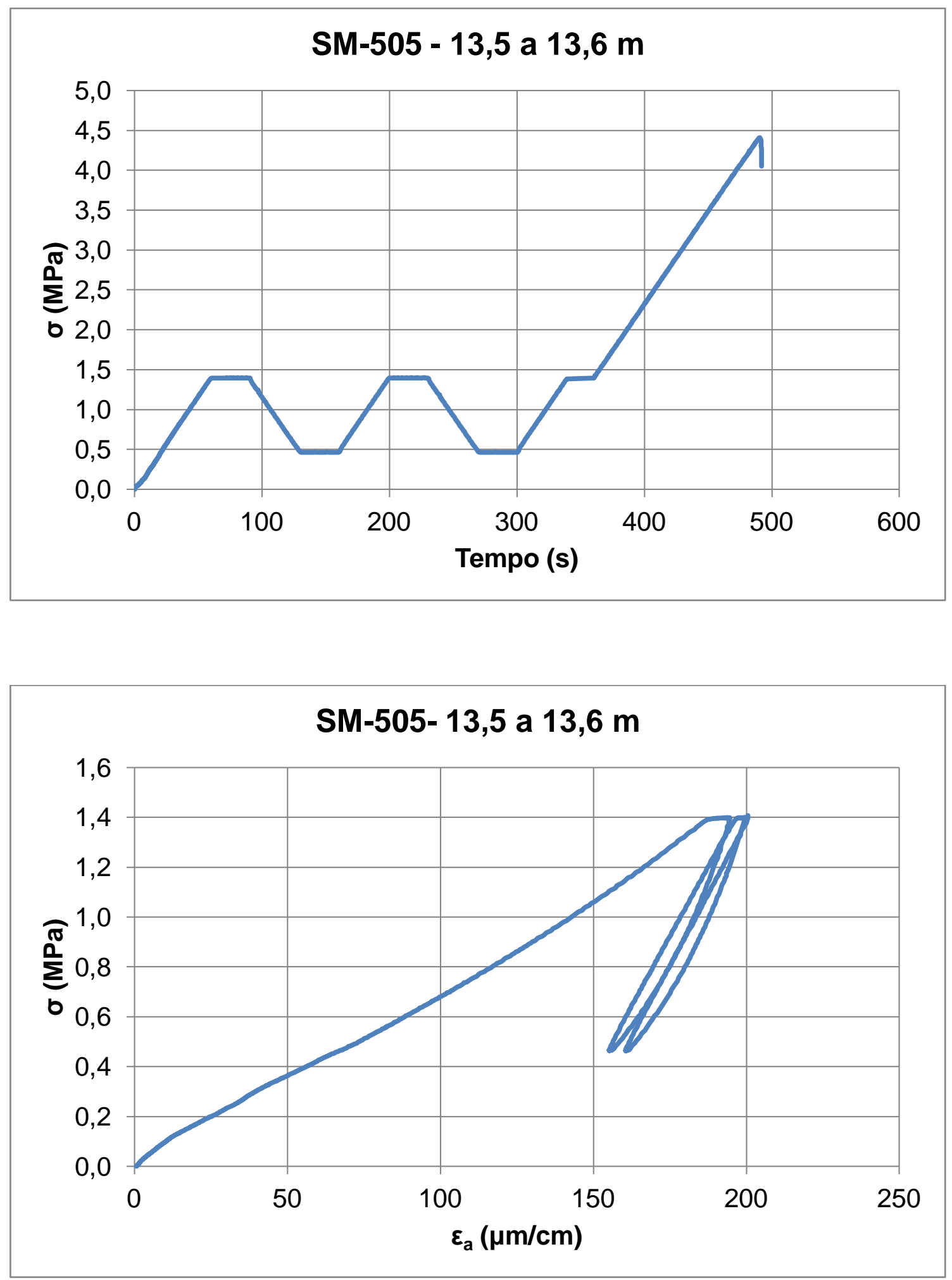

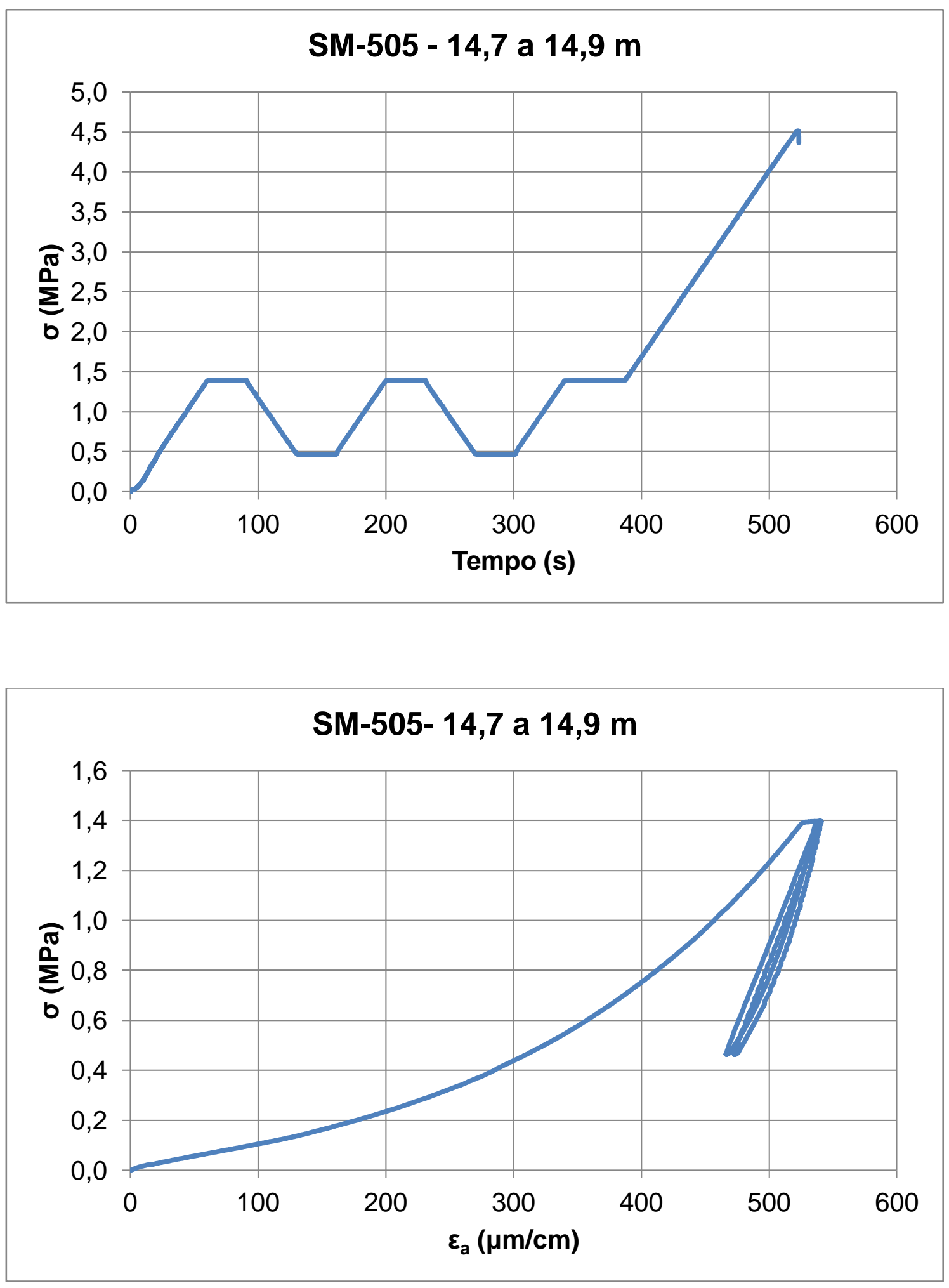


\section{APÊNDICE E}

Matrizes de coeficientes de correlação e valores $p$

Tabela 1 - Matriz com os valores $p$

Tabela 2 - Matriz com os coeficientes de correlação linear

Quadro 1 - Legenda de siglas e símbolos 
As Tabelas 1 e 2 a seguir apresentam as matrizes com os coeficientes de correlação e valores $p$ entre as propriedades petrográficas, físicas e mecânicas dos arenitos selecionados, avaliadas nesta dissertação.

Para obtenção dos coeficientes de correlação e valores $p$ entre a maioria das propriedades, foi utilizado número de amostras $N=27$, com exceção da densidade aparente $\left(\rho_{\mathrm{a}}\right)$, porosidade aparente $\left(\eta_{\mathrm{a}}\right)$, resistência à compressão uniaxial corrigida conforme Turk \& Dearman (1986) $\left(\sigma_{50}\right)$ e módulo de deformabilidade $\left(E_{s}\right)$. Estes coeficientes de correlação e valores $p$ estão hachurados em tons de cinza nas matrizes.

Para obtenção dos coeficientes de correlação e valores $p$ entre densidade e porosidade aparentes e demais propriedades, o número de amostras utilizado foi de $\mathrm{N}=24$.

Para obtenção dos coeficientes de correlação e valores $p$ entre as demais propriedades e resistência à compressão uniaxial corrigida conforme Turk \& Dearman (1986) e módulo de deformabilidade, foi utilizado número de amostras $\mathrm{N}=$ 7.

Na matriz com valores $p$, valores considerados significativos estatísticamente, ou seja, menores ou iguais a 0,05 , estão grafados em negrito e hachurados em verde.

$\mathrm{Na}$ matriz de coeficientes de correlação, os coeficientes positivos avaliados como significativos estão grafados em negrito e hachurados em verde, ao passo que os coeficientes negativos avaliados como significativos estão grafados em negrito e hachurados em vermelho.

O Quadro 1 apresenta uma legenda com o significado das siglas e símbolos utilizados nas tabelas 1 e 2 . 
APÊNDICE E - Tabela 1 - Matriz com os valores $p$.

(continua)

\begin{tabular}{|c|c|c|c|c|c|c|c|c|c|c|}
\hline & prof & $\operatorname{arc}$ & $\mathrm{cim}$ & n_mod & n2_mod & $n 2 \_m \_f$ & n_las & $q$ & $f$ & 1 \\
\hline prof & NA & 0,006 & 0,008 & 0,132 & 0,037 & 0,044 & 0,440 & 0,742 & 0,623 & 0,724 \\
\hline $\operatorname{arc}$ & 0,006 & NA & 0,000 & 0,090 & 0,082 & 0,016 & 0,380 & 0,469 & 0,132 & 0,113 \\
\hline $\mathrm{cim}$ & 0,008 & 0,000 & NA & 0,000 & 0,038 & 0,000 & 0,007 & 0,506 & 0,167 & 0,145 \\
\hline n_mod & 0,132 & 0,090 & 0,000 & NA & 0,090 & 0,000 & 0,000 & 0,638 & 0,451 & 0,548 \\
\hline n2_mod & 0,037 & 0,082 & 0,038 & 0,090 & NA & 0,000 & 0,766 & 0,354 & 0,161 & 0,320 \\
\hline$n 2 \_m \_f$ & 0,044 & 0,016 & 0,000 & 0,000 & 0,000 & NA & 0,034 & 0,052 & 0,035 & 0,633 \\
\hline n_las & 0,440 & 0,380 & 0,007 & 0,000 & 0,766 & 0,034 & NA & 0,477 & 0,816 & 0,392 \\
\hline$q$ & 0,742 & 0,469 & 0,506 & 0,638 & 0,354 & 0,052 & 0,477 & NA & 0,000 & 0,425 \\
\hline$f$ & 0,623 & 0,132 & 0,167 & 0,451 & 0,161 & 0,035 & 0,816 & 0,000 & NA & 0,064 \\
\hline I & 0,724 & 0,113 & 0,145 & 0,548 & 0,320 & 0,633 & 0,392 & 0,425 & 0,064 & NA \\
\hline$q m$ & 0,013 & 0,000 & 0,000 & 0,069 & 0,087 & 0,012 & 0,346 & 0,173 & 0,038 & 0,148 \\
\hline$q p$ & 0,064 & 0,016 & 0,066 & 0,524 & 0,070 & 0,045 & 0,385 & 0,409 & 0,104 & 0,105 \\
\hline$f d$ & 0,022 & 0,056 & 0,155 & 0,735 & 0,841 & 0,732 & 0,709 & 0,000 & 0,000 & 0,401 \\
\hline$a g l$ & 0,000 & 0,000 & 0,000 & 0,002 & 0,218 & 0,004 & 0,002 & 0,994 & 0,896 & 0,809 \\
\hline esm & 0,019 & 0,044 & 0,254 & 0,922 & 0,615 & 0,665 & 0,056 & 0,426 & 0,115 & 0,115 \\
\hline$o x$ & 0,002 & 0,000 & 0,000 & 0,004 & 0,065 & 0,010 & 0,024 & 0,205 & 0,356 & 0,605 \\
\hline tm & 0,000 & 0,000 & 0,000 & 0,002 & 0,045 & 0,008 & 0,190 & 0,737 & 0,189 & 0,048 \\
\hline$d p$ & 0,225 & 0,001 & 0,033 & 0,793 & 0,788 & 0,355 & 0,803 & 0,113 & 0,172 & 0,812 \\
\hline$t m \_m / v$ & 0,001 & 0,001 & 0,000 & 0,001 & 0,014 & 0,005 & 0,053 & 0,989 & 0,328 & 0,053 \\
\hline$d p \_m / v$ & 0,758 & 0,656 & 0,949 & 0,529 & 0,664 & 0,958 & 0,919 & 0,258 & 0,074 & 0,181 \\
\hline pel & 0,000 & 0,000 & 0,000 & 0,000 & 0,020 & 0,000 & 0,011 & 0,378 & 0,183 & 0,342 \\
\hline ang & 0,376 & 0,229 & 0,489 & 0,941 & 0,908 & 0,859 & 0,063 & 0,574 & 0,725 & 0,729 \\
\hline subang & 0,923 & 0,801 & 0,722 & 0,722 & 0,619 & 0,369 & 0,187 & 0,019 & 0,028 & 0,980 \\
\hline subarr & 0,867 & 0,831 & 0,769 & 0,448 & 0,364 & 0,588 & 0,028 & 0,868 & 0,998 & 0,763 \\
\hline arr & 0,996 & 0,816 & 0,762 & 0,425 & 0,285 & 0,257 & 0,776 & 0,024 & 0,031 & 0,941 \\
\hline esf & 0,277 & 0,467 & 0,357 & 0,429 & 0,091 & 0,069 & 0,718 & 0,631 & 0,499 & 0,020 \\
\hline$P_{d}$ & 0,002 & 0,001 & 0,002 & 0,080 & 0,162 & 0,061 & 0,647 & 0,641 & 0,418 & 0,474 \\
\hline$P_{p}$ & 0,794 & 0,120 & 0,208 & 0,603 & 0,071 & 0,733 & 0,297 & 0,297 & 0,879 & 0,099 \\
\hline$g g t$ & 0,111 & 0,446 & 0,415 & 0,473 & 0,837 & 0,589 & 0,461 & 0,281 & 0,775 & 0,007 \\
\hline$g g r$ & 0,246 & 0,231 & 0,415 & 0,930 & 0,021 & 0,384 & 0,389 & 0,484 & 0,853 & 0,353 \\
\hline$g g c c$ & 0,360 & 0,016 & 0,048 & 0,533 & 0,157 & 0,682 & 0,484 & 0,989 & 0,279 & 0,031 \\
\hline$g c$ & 0,485 & 0,004 & 0,000 & 0,000 & 0,181 & 0,004 & 0,009 & 0,219 & 0,143 & 0,571 \\
\hline$g v$ & 0,480 & 0,011 & 0,000 & 0,000 & 0,038 & 0,001 & 0,012 & 0,315 & 0,127 & 0,277 \\
\hline$\rho_{a}$ & 0,310 & 0,899 & 0,988 & 0,805 & 0,439 & 0,442 & 0,083 & 0,298 & 0,638 & 0,317 \\
\hline$\eta_{a}$ & 0,075 & 0,222 & 0,486 & 0,966 & 0,786 & 0,383 & 0,192 & 0,535 & 0,708 & 0,677 \\
\hline$\sigma_{50}$ & 0,614 & 0,585 & 0,294 & 0,189 & 0,892 & 0,651 & 0,786 & 0,972 & 0,769 & 0,028 \\
\hline$E_{s}$ & 0,057 & 0,090 & 0,188 & 0,513 & 0,328 & 0,190 & 0,844 & 0,044 & 0,072 & 0,977 \\
\hline
\end{tabular}


APÊNDICE E - Tabela 1 - Matriz com os valores $p$.

(continuação)

\begin{tabular}{|c|c|c|c|c|c|c|c|c|c|c|}
\hline & $q m$ & $q p$ & $f d$ & $a g l$ & esm & $o x$ & $t m$ & $d p$ & $t m \_m / v$ & $d p \_m / v$ \\
\hline prof & 0,013 & 0,064 & 0,022 & 0,000 & 0,019 & 0,002 & 0,000 & 0,225 & 0,001 & 0,758 \\
\hline arc & 0,000 & 0,016 & 0,056 & 0,000 & 0,044 & 0,000 & 0,000 & 0,001 & 0,001 & 0,656 \\
\hline $\mathrm{cim}$ & 0,000 & 0,066 & 0,155 & 0,000 & 0,254 & 0,000 & 0,000 & 0,033 & 0,000 & 0,949 \\
\hline n_mod & 0,069 & 0,524 & 0,735 & 0,002 & 0,922 & 0,004 & 0,002 & 0,793 & 0,001 & 0,529 \\
\hline n2_mod & 0,087 & 0,070 & 0,841 & 0,218 & 0,615 & 0,065 & 0,045 & 0,788 & 0,014 & 0,664 \\
\hline$n 2 \_m \_f$ & 0,012 & 0,045 & 0,732 & 0,004 & 0,665 & 0,010 & 0,008 & 0,355 & 0,005 & 0,958 \\
\hline n_las & 0,346 & 0,385 & 0,709 & 0,002 & 0,056 & 0,024 & 0,190 & 0,803 & 0,053 & 0,919 \\
\hline$q$ & 0,173 & 0,409 & 0,000 & 0,994 & 0,426 & 0,205 & 0,737 & 0,113 & 0,989 & 0,258 \\
\hline$f$ & 0,038 & 0,104 & 0,000 & 0,896 & 0,115 & 0,356 & 0,189 & 0,172 & 0,328 & 0,074 \\
\hline I & 0,148 & 0,105 & 0,401 & 0,809 & 0,115 & 0,605 & 0,048 & 0,812 & 0,053 & 0,181 \\
\hline$q m$ & NA & 0,052 & 0,190 & 0,000 & 0,105 & 0,001 & 0,000 & 0,000 & 0,001 & 0,708 \\
\hline$q p$ & 0,052 & NA & 0,994 & 0,028 & 0,160 & 0,143 & 0,026 & 0,602 & 0,087 & 0,034 \\
\hline$f d$ & 0,190 & 0,994 & NA & 0,005 & 0,002 & 0,000 & 0,357 & 0,551 & 0,302 & 0,155 \\
\hline$a g l$ & 0,000 & 0,028 & 0,005 & NA & 0,000 & 0,000 & 0,000 & 0,023 & 0,001 & 0,786 \\
\hline esm & 0,105 & 0,160 & 0,002 & 0,000 & NA & 0,009 & 0,839 & 0,191 & 0,970 & 0,649 \\
\hline$o x$ & 0,001 & 0,143 & 0,000 & 0,000 & 0,009 & NA & 0,002 & 0,256 & 0,001 & 0,403 \\
\hline$t m$ & 0,000 & 0,026 & 0,357 & 0,000 & 0,839 & 0,002 & NA & 0,261 & 0,000 & 0,895 \\
\hline$d p$ & 0,000 & 0,602 & 0,551 & 0,023 & 0,191 & 0,256 & 0,261 & NA & 0,691 & 0,583 \\
\hline$t m \_m / v$ & 0,001 & 0,087 & 0,302 & 0,001 & 0,970 & 0,001 & 0,000 & 0,691 & NA & 0,783 \\
\hline$d p \_m / v$ & 0,708 & 0,034 & 0,155 & 0,786 & 0,649 & 0,403 & 0,895 & 0,583 & 0,783 & NA \\
\hline pel & 0,000 & 0,026 & 0,128 & 0,000 & 0,057 & 0,000 & 0,000 & 0,071 & 0,000 & 0,828 \\
\hline ang & 0,297 & 0,558 & 0,270 & 0,146 & 0,051 & 0,089 & 0,736 & 0,395 & 0,805 & 0,909 \\
\hline subang & 0,483 & 0,357 & 0,067 & 0,332 & 0,004 & 0,291 & 0,337 & 0,540 & 0,541 & 0,984 \\
\hline subarr & 0,852 & 0,697 & 0,815 & 0,759 & 0,904 & 0,877 & 0,273 & 0,342 & 0,191 & 0,821 \\
\hline arr & 0,806 & 0,464 & 0,026 & 0,266 & 0,001 & 0,169 & 0,080 & 0,774 & 0,131 & 0,962 \\
\hline esf & 0,579 & 0,123 & 0,860 & 0,736 & 0,253 & 0,589 & 0,048 & 0,445 & 0,028 & 0,778 \\
\hline$P_{d}$ & 0,001 & 0,366 & 0,266 & 0,004 & 0,339 & 0,013 & 0,001 & 0,131 & 0,017 & 0,581 \\
\hline$P_{p}$ & 0,086 & 0,738 & 0,377 & 0,037 & 0,041 & 0,600 & 0,901 & 0,190 & 0,967 & 0,500 \\
\hline$g g t$ & 0,369 & 0,661 & 0,409 & 0,134 & 0,187 & 0,651 & 0,848 & 0,621 & 0,772 & 0,515 \\
\hline$g g r$ & 0,193 & 0,829 & 0,538 & 0,137 & 0,072 & 0,914 & 0,654 & 0,181 & 0,567 & 0,528 \\
\hline$g g c c$ & 0,013 & 0,668 & 0,670 & 0,055 & 0,332 & 0,155 & 0,030 & 0,379 & 0,195 & 0,572 \\
\hline$g c$ & 0,002 & 0,526 & 0,727 & 0,002 & 0,765 & 0,010 & 0,014 & 0,203 & 0,008 & 0,633 \\
\hline$g v$ & 0,006 & 0,433 & 0,908 & 0,010 & 0,355 & 0,008 & 0,008 & 0,324 & 0,003 & 0,732 \\
\hline$\rho_{a}$ & 0,920 & 0,905 & 0,629 & 0,890 & 0,955 & 0,346 & 0,323 & 0,183 & 0,066 & 0,902 \\
\hline$\eta_{a}$ & 0,208 & 0,523 & 0,651 & 0,154 & 0,176 & 0,039 & 0,094 & 0,785 & 0,033 & 0,514 \\
\hline$\sigma_{50}$ & 0,514 & 0,452 & 0,951 & 0,658 & 0,515 & 0,553 & 0,314 & 0,212 & 0,270 & 0,509 \\
\hline$E_{s}$ & 0,061 & 0,324 & 0,309 & 0,287 & 0,831 & 0,331 & 0,138 & 0,777 & 0,234 & 0,187 \\
\hline
\end{tabular}


APÊNDICE E - Tabela 1 - Matriz com os valores $p$.

(continuação)

\begin{tabular}{|c|c|c|c|c|c|c|c|c|c|}
\hline & pel & ang & subang & subarr & arr & esf & $P_{d}$ & $P_{p}$ & $g g t$ \\
\hline prof & 0,000 & 0,376 & 0,923 & 0,867 & 0,996 & 0,277 & 0,002 & 0,794 & 0,111 \\
\hline $\operatorname{arc}$ & 0,000 & 0,229 & 0,801 & 0,831 & 0,816 & 0,467 & 0,001 & 0,120 & 0,446 \\
\hline $\mathrm{cim}$ & 0,000 & 0,489 & 0,722 & 0,769 & 0,762 & 0,357 & 0,002 & 0,208 & 0,415 \\
\hline n_mod & 0,000 & 0,941 & 0,722 & 0,448 & 0,425 & 0,429 & 0,080 & 0,603 & 0,473 \\
\hline n2_mod & 0,020 & 0,908 & 0,619 & 0,364 & 0,285 & 0,091 & 0,162 & 0,071 & 0,837 \\
\hline$n 2 \_m \_f$ & 0,000 & 0,859 & 0,369 & 0,588 & 0,257 & 0,069 & 0,061 & 0,733 & 0,589 \\
\hline n_las & 0,011 & 0,063 & 0,187 & 0,028 & 0,776 & 0,718 & 0,647 & 0,297 & 0,461 \\
\hline$q$ & 0,378 & 0,574 & 0,019 & 0,868 & 0,024 & 0,631 & 0,641 & 0,297 & 0,281 \\
\hline$f$ & 0,183 & 0,725 & 0,028 & 0,998 & 0,031 & 0,499 & 0,418 & 0,879 & 0,775 \\
\hline I & 0,342 & 0,729 & 0,980 & 0,763 & 0,941 & 0,020 & 0,474 & 0,099 & 0,007 \\
\hline$q m$ & 0,000 & 0,297 & 0,483 & 0,852 & 0,806 & 0,579 & 0,001 & 0,086 & 0,369 \\
\hline$q p$ & 0,026 & 0,558 & 0,357 & 0,697 & 0,464 & 0,123 & 0,366 & 0,738 & 0,661 \\
\hline$f d$ & 0,128 & 0,270 & 0,067 & 0,815 & 0,026 & 0,860 & 0,266 & 0,377 & 0,409 \\
\hline agl & 0,000 & 0,146 & 0,332 & 0,759 & 0,266 & 0,736 & 0,004 & 0,037 & 0,134 \\
\hline esm & 0,057 & 0,051 & 0,004 & 0,904 & 0,001 & 0,253 & 0,339 & 0,041 & 0,187 \\
\hline$o x$ & 0,000 & 0,089 & 0,291 & 0,877 & 0,169 & 0,589 & 0,013 & 0,600 & 0,651 \\
\hline $\mathrm{tm}$ & 0,000 & 0,736 & 0,337 & 0,273 & 0,080 & 0,048 & 0,001 & 0,901 & 0,848 \\
\hline$d p$ & 0,071 & 0,395 & 0,540 & 0,342 & 0,774 & 0,445 & 0,131 & 0,190 & 0,621 \\
\hline$t m \_m l v$ & 0,000 & 0,805 & 0,541 & 0,191 & 0,131 & 0,028 & 0,017 & 0,967 & 0,772 \\
\hline$d p \_m / v$ & 0,828 & 0,909 & 0,984 & 0,821 & 0,962 & 0,778 & 0,581 & 0,500 & 0,515 \\
\hline pel & NA & 0,515 & 0,807 & 0,809 & 0,862 & 0,439 & 0,001 & 0,095 & 0,129 \\
\hline ang & 0,515 & NA & 0,039 & 0,013 & 0,105 & 0,920 & 0,147 & 0,615 & 0,599 \\
\hline subang & 0,807 & 0,039 & NA & 0,074 & 0,000 & 0,250 & 0,245 & 0,823 & 0,195 \\
\hline subarr & 0,809 & 0,013 & 0,074 & NA & 0,257 & 0,448 & 0,029 & 0,314 & 0,299 \\
\hline$a r r$ & 0,862 & 0,105 & 0,000 & 0,257 & NA & 0,099 & 0,990 & 0,532 & 0,553 \\
\hline esf & 0,439 & 0,920 & 0,250 & 0,448 & 0,099 & NA & 0,908 & 0,197 & 0,796 \\
\hline$P_{d}$ & 0,001 & 0,147 & 0,245 & 0,029 & 0,990 & 0,908 & NA & 0,209 & 0,271 \\
\hline$P_{p}$ & 0,095 & 0,615 & 0,823 & 0,314 & 0,532 & 0,197 & 0,209 & NA & 0,000 \\
\hline$g g t$ & 0,129 & 0,599 & 0,195 & 0,299 & 0,553 & 0,796 & 0,271 & 0,000 & NA \\
\hline$g g r$ & 0,333 & 0,259 & 0,363 & 0,639 & 0,133 & 0,046 & 0,443 & 0,000 & 0,059 \\
\hline$g g c c$ & 0,137 & 0,708 & 0,652 & 0,491 & 0,921 & 0,588 & 0,217 & 0,268 & 0,645 \\
\hline$g c$ & 0,000 & 0,939 & 0,227 & 0,829 & 0,348 & 0,876 & 0,039 & 0,037 & 0,070 \\
\hline$g v$ & 0,000 & 0,820 & 0,212 & 0,913 & 0,212 & 0,565 & 0,073 & 0,553 & 0,471 \\
\hline$\rho_{a}$ & 0,528 & 0,577 & 0,355 & 0,015 & 0,025 & 0,440 & 0,453 & 0,721 & 0,587 \\
\hline$\eta_{a}$ & 0,093 & 0,201 & 0,587 & 0,182 & 0,311 & 0,443 & 0,803 & 0,576 & 0,485 \\
\hline$\sigma_{50}$ & 0,606 & 0,226 & 0,154 & 0,343 & 0,268 & 0,211 & 0,747 & 0,954 & 0,955 \\
\hline$E_{s}$ & 0,088 & 0,539 & 0,838 & 0,680 & 0,920 & 0,470 & 0,022 & 0,197 & 0,095 \\
\hline
\end{tabular}


APÊNDICE E - Tabela 1- Matriz com os valores $p$.

(conclusão)

\begin{tabular}{|c|c|c|c|c|c|c|c|c|}
\hline & $g g r$ & $g g c c$ & $g c$ & $g v$ & $\rho_{a}$ & $\eta_{a}$ & $\sigma_{50}$ & $E_{s}$ \\
\hline prof & 0,246 & 0,360 & 0,485 & 0,480 & 0,310 & 0,075 & 0,614 & 0,057 \\
\hline arc & 0,231 & 0,016 & 0,004 & 0,011 & 0,899 & 0,222 & 0,585 & 0,090 \\
\hline $\mathrm{cim}$ & 0,415 & 0,048 & 0,000 & 0,000 & 0,988 & 0,486 & 0,294 & 0,188 \\
\hline$n \_\bmod$ & 0,930 & 0,533 & 0,000 & 0,000 & 0,805 & 0,966 & 0,189 & 0,513 \\
\hline$n 2 \mathrm{mod}$ & 0,021 & 0,157 & 0,181 & 0,038 & 0,439 & 0,786 & 0,892 & 0,328 \\
\hline$n \overline{2} m_{-} f$ & 0,384 & 0,682 & 0,004 & 0,001 & 0,442 & 0,383 & 0,651 & 0,190 \\
\hline n_las & 0,389 & 0,484 & 0,009 & 0,012 & 0,083 & 0,192 & 0,786 & 0,844 \\
\hline$q$ & 0,484 & 0,989 & 0,219 & 0,315 & 0,298 & 0,535 & 0,972 & 0,044 \\
\hline$f$ & 0,853 & 0,279 & 0,143 & 0,127 & 0,638 & 0,708 & 0,769 & 0,072 \\
\hline I & 0,353 & 0,031 & 0,571 & 0,277 & 0,317 & 0,677 & 0,028 & 0,977 \\
\hline$q m$ & 0,193 & 0,013 & 0,002 & 0,006 & 0,920 & 0,208 & 0,514 & 0,061 \\
\hline$q p$ & 0,829 & 0,668 & 0,526 & 0,433 & 0,905 & 0,523 & 0,452 & 0,324 \\
\hline$f d$ & 0,538 & 0,670 & 0,727 & 0,908 & 0,629 & 0,651 & 0,951 & 0,309 \\
\hline agl & 0,137 & 0,055 & 0,002 & 0,010 & 0,890 & 0,154 & 0,658 & 0,287 \\
\hline esm & 0,072 & 0,332 & 0,765 & 0,355 & 0,955 & 0,176 & 0,515 & 0,831 \\
\hline$O x$ & 0,914 & 0,155 & 0,010 & 0,008 & 0,346 & 0,039 & 0,553 & 0,331 \\
\hline $\mathrm{tm}$ & 0,654 & 0,030 & 0,014 & 0,008 & 0,323 & 0,094 & 0,314 & 0,138 \\
\hline$d p$ & 0,181 & 0,379 & 0,203 & 0,324 & 0,183 & 0,785 & 0,212 & 0,777 \\
\hline$t m \_m / v$ & 0,567 & 0,195 & 0,008 & 0,003 & 0,066 & 0,033 & 0,270 & 0,234 \\
\hline$d p m / v$ & 0,528 & 0,572 & 0,633 & 0,732 & 0,902 & 0,514 & 0,509 & 0,187 \\
\hline pel & 0,333 & 0,137 & 0,000 & 0,000 & 0,528 & 0,093 & 0,606 & 0,088 \\
\hline ang & 0,259 & 0,708 & 0,939 & 0,820 & 0,577 & 0,201 & 0,226 & 0,539 \\
\hline subang & 0,363 & 0,652 & 0,227 & 0,212 & 0,355 & 0,587 & 0,154 & 0,838 \\
\hline subarr & 0,639 & 0,491 & 0,829 & 0,913 & 0,015 & 0,182 & 0,343 & 0,680 \\
\hline arr & 0,133 & 0,921 & 0,348 & 0,212 & 0,025 & 0,311 & 0,268 & 0,920 \\
\hline esf & 0,046 & 0,588 & 0,876 & 0,565 & 0,440 & 0,443 & 0,211 & 0,470 \\
\hline$P_{d}$ & 0,443 & 0,217 & 0,039 & 0,073 & 0,453 & 0,803 & 0,747 & 0,022 \\
\hline$P_{p}$ & 0,000 & 0,268 & 0,037 & 0,553 & 0,721 & 0,576 & 0,954 & 0,197 \\
\hline$g g t$ & 0,059 & 0,645 & 0,070 & 0,471 & 0,587 & 0,485 & 0,955 & 0,095 \\
\hline$g g r$ & NA & 0,419 & 0,149 & 0,870 & 0,287 & 0,920 & 0,965 & 0,344 \\
\hline$g g c c$ & 0,419 & NA & 0,342 & 0,498 & 0,933 & 0,328 & 0,603 & 0,353 \\
\hline$g c$ & 0,149 & 0,342 & NA & 0,000 & 0,969 & 0,917 & 0,393 & 0,108 \\
\hline$g v$ & 0,870 & 0,498 & 0,000 & NA & 0,901 & 0,800 & 0,243 & 0,187 \\
\hline$\rho_{2}$ & 0,287 & 0,933 & 0,969 & 0,901 & NA & 0,000 & 0,009 & 0,515 \\
\hline$\eta_{a}$ & 0,920 & 0,328 & 0,917 & 0,800 & 0,000 & NA & 0,137 & 0,401 \\
\hline$\sigma_{50}$ & 0,965 & 0,603 & 0,393 & 0,243 & 0,009 & 0,137 & NA & 0,538 \\
\hline$E_{s}$ & 0,344 & 0,353 & 0,108 & 0,187 & 0,515 & 0,401 & 0,538 & NA \\
\hline
\end{tabular}


APÊNDICE E - Tabela 2 - Matriz com os coeficientes de correlação linear.

(continua)

\begin{tabular}{|c|c|c|c|c|c|c|c|c|c|c|}
\hline & prof & $\operatorname{arc}$ & $\mathrm{cim}$ & n_mod & n2_mod & $n 2 \_m \_f$ & n_las & $q$ & $f$ & 1 \\
\hline prof & 1 & 0,515 & $-0,499$ & 0,298 & $-0,402$ & $-0,390$ & 0,155 & $-0,066$ & 0,099 & $-0,071$ \\
\hline $\operatorname{arc}$ & 0,515 & 1 & $-0,835$ & 0,333 & $-0,340$ & $-0,461$ & 0,176 & 0,145 & $-0,297$ & 0,312 \\
\hline cim & $-0,499$ & $-0,835$ & 1 & $-0,795$ & 0,401 & 0,650 & $-0,506$ & $-0,134$ & 0,274 & $-0,288$ \\
\hline n_mod & 0,298 & 0,333 & $-0,795$ & 1 & $-0,333$ & $-0,635$ & 0,693 & 0,095 & $-0,152$ & 0,121 \\
\hline n2_mod & $-0,402$ & $-0,340$ & 0,401 & $-0,333$ & 1 & 0,795 & $-0,060$ & $-0,186$ & 0,277 & $-0,199$ \\
\hline$n 2 \_m \_f$ & $-0,390$ & $-0,461$ & 0,650 & $-0,635$ & 0,795 & 1 & $-0,409$ & $-0,378$ & 0,406 & $-0,096$ \\
\hline n_las & 0,155 & 0,176 & $-0,506$ & 0,693 & $-0,060$ & $-0,409$ & 1 & 0,143 & $-0,047$ & $-0,172$ \\
\hline$q$ & $-0,066$ & 0,145 & $-0,134$ & 0,095 & $-0,186$ & $-0,378$ & 0,143 & 1 & $-0,863$ & $-0,160$ \\
\hline$f$ & 0,099 & $-0,297$ & 0,274 & $-0,152$ & 0,277 & 0,406 & $-0,047$ & $-0,863$ & 1 & $-0,361$ \\
\hline I & $-0,071$ & 0,312 & $-0,288$ & 0,121 & $-0,199$ & $-0,096$ & $-0,172$ & $-0,160$ & $-0,361$ & 1 \\
\hline$q m$ & 0,470 & 0,985 & $-0,839$ & 0,356 & $-0,336$ & $-0,478$ & 0,188 & 0,270 & $-0,402$ & 0,286 \\
\hline$q p$ & 0,361 & 0,461 & $-0,359$ & 0,128 & $-0,354$ & $-0,390$ & 0,174 & 0,166 & $-0,320$ & 0,319 \\
\hline$f d$ & 0,438 & 0,372 & $-0,282$ & 0,068 & 0,041 & 0,069 & 0,075 & $-0,726$ & 0,772 & $-0,168$ \\
\hline agl & $-0,646$ & $-0,819$ & 0,857 & $-0,580$ & 0,245 & 0,539 & $-0,561$ & $-0,001$ & 0,026 & $-0,049$ \\
\hline esm & 0,450 & 0,390 & $-0,227$ & $-0,020$ & 0,101 & $-0,087$ & 0,373 & $-0,160$ & 0,310 & $-0,310$ \\
\hline$o x$ & $-0,573$ & $-0,675$ & 0,743 & $-0,537$ & 0,360 & 0,489 & $-0,434$ & 0,252 & $-0,185$ & $-0,104$ \\
\hline$t m$ & $-0,685$ & $-0,676$ & 0,775 & $-0,577$ & 0,389 & 0,497 & $-0,260$ & $-0,068$ & 0,261 & $-0,384$ \\
\hline$d p$ & $-0,241$ & $-0,594$ & 0,412 & $-0,053$ & 0,054 & 0,185 & 0,050 & $-0,312$ & 0,270 & 0,048 \\
\hline$t m \_m / v$ & $-0,619$ & $-0,608$ & 0,753 & $-0,621$ & 0,467 & 0,527 & $-0,376$ & $-0,003$ & 0,196 & $-0,377$ \\
\hline$d p \_m / v$ & $-0,062$ & 0,090 & 0,013 & $-0,127$ & $-0,088$ & $-0,011$ & 0,021 & 0,226 & $-0,349$ & 0,265 \\
\hline pel & $-0,646$ & $-0,828$ & 0,912 & $-0,666$ & 0,444 & 0,665 & $-0,484$ & $-0,177$ & 0,264 & $-0,190$ \\
\hline ang & $-0,177$ & 0,239 & $-0,139$ & $-0,015$ & 0,023 & $-0,036$ & 0,363 & $-0,113$ & 0,071 & 0,070 \\
\hline subang & 0,019 & $-0,051$ & 0,072 & $-0,072$ & 0,100 & 0,180 & 0,262 & $-0,449$ & 0,422 & 0,005 \\
\hline subarr & 0,034 & 0,043 & 0,059 & $-0,152$ & 0,182 & 0,109 & $-0,424$ & 0,034 & 0,000 & $-0,061$ \\
\hline arr & 0,001 & $-0,047$ & $-0,061$ & 0,160 & $-0,213$ & $-0,226$ & $-0,058$ & 0,432 & $-0,416$ & 0,015 \\
\hline esf & 0,217 & 0,146 & $-0,185$ & 0,159 & $-0,332$ & $-0,355$ & $-0,073$ & $-0,097$ & $-0,136$ & 0,444 \\
\hline$P_{d}$ & 0,570 & 0,582 & $-0,577$ & 0,343 & $-0,277$ & $-0,365$ & $-0,092$ & 0,094 & $-0,162$ & 0,144 \\
\hline$P_{p}$ & 0,053 & 0,306 & $-0,250$ & 0,105 & 0,353 & 0,069 & 0,208 & 0,209 & $-0,031$ & $-0,324$ \\
\hline$g g t$ & 0,314 & 0,153 & $-0,164$ & 0,144 & 0,042 & $-0,109$ & 0,148 & 0,215 & 0,058 & $-0,509$ \\
\hline$g g r$ & $-0,231$ & 0,238 & $-0,164$ & 0,018 & 0,443 & 0,174 & 0,173 & 0,141 & $-0,037$ & $-0,186$ \\
\hline$g g c c$ & 0,183 & 0,459 & $-0,384$ & 0,125 & 0,280 & 0,083 & 0,141 & 0,003 & $-0,216$ & 0,416 \\
\hline$g c$ & $-0,140$ & $-0,534$ & 0,810 & $-0,810$ & 0,265 & 0,530 & $-0,494$ & $-0,245$ & 0,289 & $-0,114$ \\
\hline$g v$ & 0,142 & 0,482 & $-0,800$ & 0,846 & $-0,402$ & $-0,600$ & 0,476 & 0,201 & $-0,301$ & 0,217 \\
\hline$\rho_{a}$ & 0,216 & $-0,027$ & $-0,003$ & 0,053 & $-0,166$ & $-0,165$ & 0,361 & 0,222 & $-0,101$ & $-0,213$ \\
\hline$\eta_{a}$ & $-0,370$ & $-0,259$ & 0,149 & $-0,009$ & 0,059 & 0,186 & $-0,276$ & $-0,133$ & 0,081 & 0,090 \\
\hline$\sigma_{50}$ & $-0,234$ & $-0,252$ & 0,464 & $-0,562$ & $-0,064$ & 0,210 & 0,127 & 0,017 & 0,137 & $-0,808$ \\
\hline$E_{s}$ & 0,740 & 0,685 & $-0,564$ & 0,300 & $-0,436$ & $-0,562$ & 0,092 & 0,767 & $-0,714$ & 0,014 \\
\hline
\end{tabular}


APÊNDICE E - Tabela 2- Matriz com os coeficientes de correlação linear.

(continuação)

\begin{tabular}{|c|c|c|c|c|c|c|c|c|c|c|}
\hline & $q m$ & $q p$ & $f d$ & agl & esm & $O x$ & $\mathrm{tm}$ & $d p$ & $t m \_m / v$ & $d p \_m / v$ \\
\hline prof & 0,470 & 0,361 & 0,438 & $-0,646$ & 0,450 & $-0,573$ & $-0,685$ & $-0,241$ & $-0,619$ & $-0,062$ \\
\hline $\operatorname{arc}$ & 0,985 & 0,461 & 0,372 & $-0,819$ & 0,390 & $-0,675$ & $-0,676$ & $-0,594$ & $-0,608$ & 0,090 \\
\hline $\mathrm{cim}$ & $-0,839$ & $-0,359$ & $-0,282$ & 0,857 & $-0,227$ & 0,743 & 0,775 & 0,412 & 0,753 & 0,013 \\
\hline n_mod & 0,356 & 0,128 & 0,068 & $-0,580$ & $-0,020$ & $-0,537$ & $-0,577$ & $-0,053$ & $-0,621$ & $-0,127$ \\
\hline n2_mod & $-0,336$ & $-0,354$ & 0,041 & 0,245 & 0,101 & 0,360 & 0,389 & 0,054 & 0,467 & $-0,088$ \\
\hline$n 2 \_m \_f$ & $-0,478$ & $-0,390$ & 0,069 & 0,539 & $-0,087$ & 0,489 & 0,497 & 0,185 & 0,527 & $-0,011$ \\
\hline n_las & 0,188 & 0,174 & 0,075 & $-0,561$ & 0,373 & $-0,434$ & $-0,260$ & 0,050 & $-0,376$ & 0,021 \\
\hline$q$ & 0,270 & 0,166 & $-0,726$ & $-0,001$ & $-0,160$ & 0,252 & $-0,068$ & $-0,312$ & $-0,003$ & 0,226 \\
\hline$f$ & $-0,402$ & $-0,320$ & 0,772 & 0,026 & 0,310 & $-0,185$ & 0,261 & 0,270 & 0,196 & $-0,349$ \\
\hline I & 0,286 & 0,319 & $-0,168$ & $-0,049$ & $-0,310$ & $-0,104$ & $-0,384$ & 0,048 & $-0,377$ & 0,265 \\
\hline$q m$ & 1 & 0,378 & 0,260 & $-0,781$ & 0,319 & $-0,616$ & $-0,668$ & $-0,625$ & $-0,600$ & 0,076 \\
\hline$q p$ & 0,378 & 1 & $-0,001$ & $-0,423$ & 0,278 & $-0,289$ & $-0,427$ & $-0,105$ & $-0,335$ & 0,409 \\
\hline$f d$ & 0,260 & $-0,001$ & 1 & $-0,520$ & 0,570 & $-0,626$ & $-0,184$ & $-0,120$ & $-0,206$ & $-0,281$ \\
\hline$a g l$ & $-0,781$ & $-0,423$ & $-0,520$ & 1 & $-0,676$ & 0,798 & 0,648 & 0,435 & 0,602 & 0,055 \\
\hline esm & 0,319 & 0,278 & 0,570 & $-0,676$ & 1 & $-0,491$ & $-0,041$ & $-0,259$ & $-0,008$ & $-0,092$ \\
\hline$o x$ & $-0,616$ & $-0,289$ & $-0,626$ & 0,798 & $-0,491$ & 1 & 0,568 & 0,227 & 0,602 & 0,168 \\
\hline$t m$ & $-0,668$ & $-0,427$ & $-0,184$ & 0,648 & $-0,041$ & 0,568 & 1 & 0,224 & 0,888 & $-0,027$ \\
\hline$d p$ & $-0,625$ & $-0,105$ & $-0,120$ & 0,435 & $-0,259$ & 0,227 & 0,224 & 1 & 0,080 & 0,111 \\
\hline$t m \_m / v$ & $-0,600$ & $-0,335$ & $-0,206$ & 0,602 & $-0,008$ & 0,602 & 0,888 & 0,080 & 1 & $-0,056$ \\
\hline$d p \_m / v$ & 0,076 & 0,409 & $-0,281$ & 0,055 & $-0,092$ & 0,168 & $-0,027$ & 0,111 & $-0,056$ & 1 \\
\hline pel & $-0,821$ & $-0,428$ & $-0,301$ & 0,894 & $-0,371$ & 0,725 & 0,779 & 0,353 & 0,800 & $-0,044$ \\
\hline ang & 0,208 & 0,118 & 0,220 & $-0,288$ & 0,379 & $-0,334$ & 0,068 & $-0,171$ & 0,050 & $-0,023$ \\
\hline subang & $-0,141$ & 0,184 & 0,358 & $-0,194$ & 0,535 & $-0,211$ & 0,192 & 0,123 & 0,123 & $-0,004$ \\
\hline subarr & 0,038 & $-0,078$ & 0,047 & 0,062 & 0,024 & 0,031 & 0,219 & $-0,190$ & 0,259 & 0,046 \\
\hline$a r r$ & 0,050 & $-0,147$ & $-0,428$ & 0,222 & $-0,618$ & 0,273 & $-0,342$ & 0,058 & $-0,298$ & $-0,010$ \\
\hline esf & 0,112 & 0,304 & $-0,036$ & $-0,068$ & $-0,228$ & $-0,109$ & $-0,384$ & 0,153 & $-0,424$ & 0,057 \\
\hline$P_{d}$ & 0,581 & 0,181 & 0,222 & $-0,539$ & 0,192 & $-0,473$ & $-0,584$ & $-0,298$ & $-0,454$ & $-0,111$ \\
\hline$P_{p}$ & 0,337 & $-0,067$ & 0,177 & $-0,404$ & 0,395 & $-0,106$ & $-0,025$ & $-0,260$ & 0,008 & $-0,136$ \\
\hline$g g t$ & 0,180 & $-0,088$ & 0,166 & $-0,296$ & 0,262 & $-0,091$ & $-0,039$ & $-0,100$ & $-0,058$ & $-0,131$ \\
\hline$g g r$ & 0,258 & $-0,044$ & 0,124 & $-0,294$ & 0,352 & $-0,022$ & 0,090 & $-0,265$ & 0,115 & $-0,127$ \\
\hline$g g c c$ & 0,474 & 0,086 & 0,086 & $-0,373$ & 0,194 & $-0,282$ & $-0,418$ & $-0,176$ & $-0,257$ & 0,114 \\
\hline$g c$ & $-0,577$ & $-0,128$ & $-0,070$ & 0,566 & 0,060 & 0,489 & 0,467 & 0,253 & 0,498 & 0,096 \\
\hline$g v$ & 0,519 & 0,157 & 0,023 & $-0,489$ & $-0,185$ & $-0,501$ & $-0,499$ & $-0,197$ & $-0,543$ & $-0,069$ \\
\hline$\rho_{a}$ & 0,022 & $-0,026$ & $-0,104$ & $-0,030$ & 0,012 & $-0,201$ & $-0,211$ & 0,281 & $-0,381$ & $-0,027$ \\
\hline$\eta_{a}$ & $-0,266$ & $-0,137$ & $-0,097$ & 0,300 & $-0,286$ & 0,423 & 0,349 & $-0,059$ & 0,436 & 0,140 \\
\hline$\sigma_{50}$ & $-0,300$ & 0,342 & 0,029 & 0,206 & 0,299 & $-0,273$ & 0,448 & 0,539 & 0,485 & $-0,303$ \\
\hline$E_{s}$ & 0,733 & 0,439 & $-0,452$ & $-0,471$ & 0,100 & $-0,434$ & $-0,619$ & $-0,133$ & $-0,518$ & 0,564 \\
\hline
\end{tabular}


APÊNDICE E - Tabela 2 - Matriz com os coeficientes de correlação linear.

(continuação)

\begin{tabular}{|c|c|c|c|c|c|c|c|c|c|}
\hline & pel & ang & subang & subarr & arr & esf & $P_{d}$ & $P_{p}$ & $g g t$ \\
\hline prof & $-0,646$ & $-0,177$ & 0,019 & 0,034 & 0,001 & 0,217 & 0,570 & 0,053 & 0,314 \\
\hline $\operatorname{arc}$ & $-0,828$ & 0,239 & $-0,051$ & 0,043 & $-0,047$ & 0,146 & 0,582 & 0,306 & 0,153 \\
\hline $\mathrm{cim}$ & 0,912 & $-0,139$ & 0,072 & 0,059 & $-0,061$ & $-0,185$ & $-0,577$ & $-0,250$ & $-0,164$ \\
\hline$n \_$mod & $-0,666$ & $-0,015$ & $-0,072$ & $-0,152$ & 0,160 & 0,159 & 0,343 & 0,105 & 0,144 \\
\hline n2_mod & 0,444 & 0,023 & 0,100 & 0,182 & $-0,213$ & $-0,332$ & $-0,277$ & 0,353 & 0,042 \\
\hline$n 2 \_m \_f$ & 0,665 & $-0,036$ & 0,180 & 0,109 & $-0,226$ & $-0,355$ & $-0,365$ & 0,069 & $-0,109$ \\
\hline n_las & $-0,484$ & 0,363 & 0,262 & $-0,424$ & $-0,058$ & $-0,073$ & $-0,092$ & 0,208 & 0,148 \\
\hline$q$ & $-0,177$ & $-0,113$ & $-0,449$ & 0,034 & 0,432 & $-0,097$ & 0,094 & 0,209 & 0,215 \\
\hline$f$ & 0,264 & 0,071 & 0,422 & 0,000 & $-0,416$ & $-0,136$ & $-0,162$ & $-0,031$ & 0,058 \\
\hline 1 & $-0,190$ & 0,070 & 0,005 & $-0,061$ & 0,015 & 0,444 & 0,144 & $-0,324$ & $-0,509$ \\
\hline$q m$ & $-0,821$ & 0,208 & $-0,141$ & 0,038 & 0,050 & 0,112 & 0,581 & 0,337 & 0,180 \\
\hline$q p$ & $-0,428$ & 0,118 & 0,184 & $-0,078$ & $-0,147$ & 0,304 & 0,181 & $-0,067$ & $-0,088$ \\
\hline$f d$ & $-0,301$ & 0,220 & 0,358 & 0,047 & $-0,428$ & $-0,036$ & 0,222 & 0,177 & 0,166 \\
\hline agl & 0,894 & $-0,288$ & $-0,194$ & 0,062 & 0,222 & $-0,068$ & $-0,539$ & $-0,404$ & $-0,296$ \\
\hline esm & $-0,371$ & 0,379 & 0,535 & 0,024 & $-0,618$ & $-0,228$ & 0,192 & 0,395 & 0,262 \\
\hline$o x$ & 0,725 & $-0,334$ & $-0,211$ & 0,031 & 0,273 & $-0,109$ & $-0,473$ & $-0,106$ & $-0,091$ \\
\hline$t m$ & 0,779 & 0,068 & 0,192 & 0,219 & $-0,342$ & $-0,384$ & $-0,584$ & $-0,025$ & $-0,039$ \\
\hline$d p$ & 0,353 & $-0,171$ & 0,123 & $-0,190$ & 0,058 & 0,153 & $-0,298$ & $-0,260$ & $-0,100$ \\
\hline$t m \_m / v$ & 0,800 & 0,050 & 0,123 & 0,259 & $-0,298$ & $-0,424$ & $-0,454$ & 0,008 & $-0,058$ \\
\hline$d p \_m / v$ & $-0,044$ & $-0,023$ & $-0,004$ & 0,046 & $-0,010$ & 0,057 & $-0,111$ & $-0,136$ & $-0,131$ \\
\hline pel & 1 & $-0,131$ & 0,049 & 0,049 & $-0,035$ & $-0,155$ & $-0,618$ & $-0,328$ & $-0,299$ \\
\hline ang & $-0,131$ & 1 & 0,400 & $-0,472$ & $-0,319$ & $-0,020$ & $-0,287$ & 0,101 & $-0,106$ \\
\hline subang & 0,049 & 0,400 & 1 & $-0,349$ & $-0,809$ & $-0,229$ & $-0,231$ & $-0,045$ & $-0,257$ \\
\hline subarr & 0,049 & $-0,472$ & $-0,349$ & 1 & $-0,226$ & $-0,152$ & 0,421 & 0,202 & 0,207 \\
\hline arr & $-0,035$ & $-0,319$ & $-0,809$ & $-0,226$ & 1 & 0,324 & $-0,003$ & $-0,126$ & 0,119 \\
\hline esf & $-0,155$ & $-0,020$ & $-0,229$ & $-0,152$ & 0,324 & 1 & 0,023 & $-0,256$ & $-0,052$ \\
\hline$P_{d}$ & $-0,618$ & $-0,287$ & $-0,231$ & 0,421 & $-0,003$ & 0,023 & 1 & 0,250 & 0,220 \\
\hline$P_{p}$ & $-0,328$ & 0,101 & $-0,045$ & 0,202 & $-0,126$ & $-0,256$ & 0,250 & 1 & 0,768 \\
\hline$g g t$ & $-0,299$ & $-0,106$ & $-0,257$ & 0,207 & 0,119 & $-0,052$ & 0,220 & 0,768 & 1 \\
\hline$g g r$ & $-0,194$ & 0,225 & 0,182 & 0,095 & $-0,296$ & $-0,387$ & 0,154 & 0,857 & 0,369 \\
\hline$g g c c$ & $-0,294$ & 0,076 & $-0,091$ & 0,138 & $-0,020$ & 0,109 & 0,246 & 0,221 & $-0,093$ \\
\hline$g c$ & 0,674 & 0,016 & 0,241 & $-0,044$ & $-0,188$ & $-0,031$ & $-0,400$ & $-0,403$ & $-0,354$ \\
\hline$g v$ & $-0,626$ & $-0,046$ & $-0,248$ & $-0,022$ & 0,248 & 0,116 & 0,350 & 0,119 & 0,145 \\
\hline$\rho_{a}$ & $-0,135$ & 0,120 & $-0,197$ & $-0,490$ & 0,455 & 0,165 & $-0,161$ & $-0,077$ & 0,117 \\
\hline$\eta_{a}$ & 0,351 & $-0,270$ & 0,117 & 0,282 & $-0,216$ & $-0,164$ & $-0,054$ & $-0,120$ & $-0,150$ \\
\hline$\sigma_{50}$ & 0,239 & 0,525 & 0,600 & $-0,424$ & $-0,487$ & $-0,540$ & $-0,151$ & $-0,027$ & $-0,026$ \\
\hline$E_{s}$ & $-0,688$ & $-0,283$ & 0,096 & 0,192 & $-0,047$ & $-0,330$ & 0,826 & 0,554 & 0,676 \\
\hline
\end{tabular}


APÊNDICE E - Tabela 2 - Matriz com os coeficientes de correlação linear.

(conclusão)

\begin{tabular}{|c|c|c|c|c|c|c|c|c|}
\hline & $g g r$ & $g g c c$ & $g c$ & $g v$ & $\rho_{a}$ & $\eta_{a}$ & $\sigma_{50}$ & $E_{s}$ \\
\hline prof & $-0,231$ & 0,183 & $-0,140$ & 0,142 & 0,216 & $-0,370$ & $-0,234$ & 0,740 \\
\hline $\operatorname{arc}$ & 0,238 & 0,459 & $-0,534$ & 0,482 & $-0,027$ & $-0,259$ & $-0,252$ & 0,685 \\
\hline cim & $-0,164$ & $-0,384$ & 0,810 & $-0,800$ & $-0,003$ & 0,149 & 0,464 & $-0,564$ \\
\hline n_mod & 0,018 & 0,125 & $-0,810$ & 0,846 & 0,053 & $-0,009$ & $-0,562$ & 0,300 \\
\hline n2_mod & 0,443 & 0,280 & 0,265 & $-0,402$ & $-0,166$ & 0,059 & $-0,064$ & $-0,436$ \\
\hline$n 2 \_m \_f$ & 0,174 & 0,083 & 0,530 & $-0,600$ & $-0,165$ & 0,186 & 0,210 & $-0,562$ \\
\hline n_las & 0,173 & 0,141 & $-0,494$ & 0,476 & 0,361 & $-0,276$ & 0,127 & 0,092 \\
\hline$q$ & 0,141 & 0,003 & $-0,245$ & 0,201 & 0,222 & $-0,133$ & 0,017 & 0,767 \\
\hline$f$ & $-0,037$ & $-0,216$ & 0,289 & $-0,301$ & $-0,101$ & 0,081 & 0,137 & $-0,714$ \\
\hline I & $-0,186$ & 0,416 & $-0,114$ & 0,217 & $-0,213$ & 0,090 & $-0,808$ & 0,014 \\
\hline$q m$ & 0,258 & 0,474 & $-0,577$ & 0,519 & 0,022 & $-0,266$ & $-0,300$ & 0,733 \\
\hline$q p$ & $-0,044$ & 0,086 & $-0,128$ & 0,157 & $-0,026$ & $-0,137$ & 0,342 & 0,439 \\
\hline$f d$ & 0,124 & 0,086 & $-0,070$ & 0,023 & $-0,104$ & $-0,097$ & 0,029 & $-0,452$ \\
\hline$a g l$ & $-0,294$ & $-0,373$ & 0,566 & $-0,489$ & $-0,030$ & 0,300 & 0,206 & $-0,471$ \\
\hline esm & 0,352 & 0,194 & 0,060 & $-0,185$ & 0,012 & $-0,286$ & 0,299 & 0,100 \\
\hline$o x$ & $-0,022$ & $-0,282$ & 0,489 & $-0,501$ & $-0,201$ & 0,423 & $-0,273$ & $-0,434$ \\
\hline$t m$ & 0,090 & $-0,418$ & 0,467 & $-0,499$ & $-0,211$ & 0,349 & 0,448 & $-0,619$ \\
\hline$d p$ & $-0,265$ & $-0,176$ & 0,253 & $-0,197$ & 0,281 & $-0,059$ & 0,539 & $-0,133$ \\
\hline$t m \_m / v$ & 0,115 & $-0,257$ & 0,498 & $-0,543$ & $-0,381$ & 0,436 & 0,485 & $-0,518$ \\
\hline$d p \_m / v$ & $-0,127$ & 0,114 & 0,096 & $-0,069$ & $-0,027$ & 0,140 & $-0,303$ & 0,564 \\
\hline finos & $-0,194$ & $-0,294$ & 0,674 & $-0,626$ & $-0,135$ & 0,351 & 0,239 & $-0,688$ \\
\hline ang & 0,225 & 0,076 & 0,016 & $-0,046$ & 0,120 & $-0,270$ & 0,525 & $-0,283$ \\
\hline subang & 0,182 & $-0,091$ & 0,241 & $-0,248$ & $-0,197$ & 0,117 & 0,600 & 0,096 \\
\hline subarr & 0,095 & 0,138 & $-0,044$ & $-0,022$ & $-0,490$ & 0,282 & $-0,424$ & 0,192 \\
\hline arr & $-0,296$ & $-0,020$ & $-0,188$ & 0,248 & 0,455 & $-0,216$ & $-0,487$ & $-0,047$ \\
\hline esf & $-0,387$ & 0,109 & $-0,031$ & 0,116 & 0,165 & $-0,164$ & $-0,540$ & $-0,330$ \\
\hline$P_{d}$ & 0,154 & 0,246 & $-0,400$ & 0,350 & $-0,161$ & $-0,054$ & $-0,151$ & 0,826 \\
\hline$P_{p}$ & 0,857 & 0,221 & $-0,403$ & 0,119 & $-0,077$ & $-0,120$ & $-0,027$ & 0,554 \\
\hline$g g t$ & 0,369 & $-0,093$ & $-0,354$ & 0,145 & 0,117 & $-0,150$ & $-0,026$ & 0,676 \\
\hline$g g r$ & 1 & 0,162 & $-0,285$ & 0,033 & $-0,227$ & $-0,022$ & 0,020 & 0,424 \\
\hline$g g c c$ & 0,162 & 1 & $-0,190$ & 0,136 & 0,018 & $-0,209$ & $-0,241$ & 0,417 \\
\hline$g c$ & $-0,285$ & $-0,190$ & 1 & $-0,957$ & 0,008 & $-0,022$ & 0,386 & $-0,658$ \\
\hline$g v$ & 0,033 & 0,136 & $-0,957$ & 1 & 0,027 & 0,054 & $-0,509$ & 0,564 \\
\hline$\rho_{a}$ & $-0,227$ & 0,018 & 0,008 & 0,027 & 1 & $-0,84$ & 0,882 & 0,299 \\
\hline$\eta_{a}$ & $-0,022$ & $-0,209$ & $-0,022$ & 0,054 & $-0,84$ & 1 & $-0,621$ & $-0,379$ \\
\hline$\sigma_{50}$ & 0,020 & $-0,241$ & 0,386 & $-0,509$ & 0,882 & $-0,621$ & 1 & 0,284 \\
\hline$E_{s}$ & 0,424 & 0,417 & $-0,658$ & 0,564 & 0,299 & $-0,379$ & 0,284 & 1 \\
\hline
\end{tabular}


APÊNDICE E - Quadro 1 - Legenda de siglas utilizadas nas tabelas 1 e 2 deste apêndice.

\begin{tabular}{|c|c|}
\hline $\begin{array}{l}\text { Sigla ou } \\
\text { símbolo }\end{array}$ & Significado \\
\hline $\operatorname{arc}$ & Arcabouço modal (\%) \\
\hline $\operatorname{cim}$ & Cimento modal (\%) \\
\hline n_mod & Porosidade modal (\%) \\
\hline n2_mod & Porosidade intragranular modal (\%) no total \\
\hline$n 2 \_m \_f$ & Porosidade intragranular modal (\%) na fração porosidade modal \\
\hline n_las & Porosidade obtida por meio de software analisador de imagens digitais (\%) \\
\hline$q$ & Porcentagem modal de quartzo normalizada para QFL \\
\hline$f$ & Porcentagem modal de feldspato normalizada para QFL \\
\hline I & Porcentagem modal de fragmentos líticos normalizada para QFL \\
\hline$q m$ & Quartzo monocristalino modal (\%) \\
\hline$q p$ & Quartzo policristalino modal (\%) \\
\hline$f d$ & Feldspato modal (\%) \\
\hline$a g l$ & Cimento argilo ferruginoso modal (\%) \\
\hline esm & Cimento esmectítico modal (\%) \\
\hline$o x$ & Cimento de óxido/hidróxido metálico modal \\
\hline $\operatorname{tm}$ & Tamanho médio dos grãos de areia em $\varphi$, avaliado por análise petrográfica \\
\hline$d p$ & Desvio padrão do tamanho dos grãos de areia em $\varphi$, avaliado por análise petrográfica \\
\hline$t m \_m / v$ & $\begin{array}{l}\text { Tamanho médio dos grãos de areia em } \varphi \text {, avaliado por meio do analisador de } \\
\text { partículas Malvern Mastersizer } 2000\end{array}$ \\
\hline$d p \_m / v$ & $\begin{array}{l}\text { Desvio padrão do tamanho dos grãos de areia em } \varphi \text {, avaliado por meio do analisador } \\
\text { de partículas Malvern Mastersizer } 2000\end{array}$ \\
\hline pel & Massa de teor de pelíticos (silte e argila) em porcentagem na amostra total \\
\hline ang & Grãos angulosos (\%) \\
\hline subang & Grãos subangulosos (\%) \\
\hline subarr & Grãos subarredondados (\%) \\
\hline arr & Grãos arredondados (\%) \\
\hline esf & Razão entre os eixos menor e maior dos grãos \\
\hline$P_{d}$ & Densidade de empacotamento de Kahn (1956) \\
\hline$P_{p}$ & Proximidade de empacotamento de Kahn (1956) \\
\hline ggt & Contatos intergranulares tangenciais (\%) \\
\hline$g g r$ & Contatos intergranulares retos $(\%)$ \\
\hline$g g c c$ & Contatos intergranulares côncavo-convexos (\%) \\
\hline$g c$ & Contatos grão-cimento (\%) \\
\hline$g v$ & Contatos grão-vazio (\%) \\
\hline coer & Grau de coerência \\
\hline$\rho_{a}$ & Densidade aparente \\
\hline$\eta_{a}$ & Porosidade aparente \\
\hline$\sigma_{50}$ & Resistência à compressão uniaxial corrigida conforme Turk \& Dearman (1986) \\
\hline$E_{s}$ & Módulo de deformabilidade secante \\
\hline
\end{tabular}




\section{APÊNDICE F}

\section{Testes estatísticos}

Tabelas 1 e 2 - Testes de normalidade de Shapiro-Wilk Tabelas 3 e 4 - Testes de homocedasticidade de Levene Tabelas 5 e 6 - Análises de variância Tabela 7 - Testes de Kruskal-Wallis 
APÊNDICE F - Tabela 1 - Teste de normalidade de Shapiro-Wilk, por grau de coerência. $p<0,05$ indica que os dados não se distribuem normalmente.

\begin{tabular}{|c|c|c|}
\hline Variável & $\mathbf{W}$ & $p$ \\
\hline Profundidade $(\mathrm{m})$ & 0,97 & 0,719 \\
\hline Tamanho médio $(\varphi)$ - petrografia & 0,96 & 0,441 \\
\hline Tamanho médio $(\varphi)$ - Malvern & 0,97 & 0,577 \\
\hline Desvio padrão $(\varphi)$ - petrografia & 0,97 & 0,727 \\
\hline Desvio padrão $(\varphi)$ - Malvern & 0,99 & 0,988 \\
\hline Teor de pelíticos (\% em peso) & 0,89 & 0,008 \\
\hline Porosidade LAS (\%) & 0,99 & 0,978 \\
\hline Porosidade intragranular (\%) & 0,92 & 0,049 \\
\hline$\rho_{\mathrm{a}}\left(\mathrm{g} / \mathrm{cm}^{3}\right)$ & 0,94 & 0,199 \\
\hline$\eta_{a}\left(\mathrm{~g} / \mathrm{cm}^{3}\right)$ & 0,97 & 0,656 \\
\hline$P_{d}$ & 0,97 & 0,733 \\
\hline$P_{p}$ & 0,96 & 0,445 \\
\hline Contatos tangenciais (\%) & 0,95 & 0,162 \\
\hline Contatos retos $(\%)$ & 0,99 & 0,966 \\
\hline Contatos côncavo-convexos (\%) & 0,90 & 0,012 \\
\hline Contatos grão-cimento (\%) & 0,98 & 0,793 \\
\hline Contatos grão-vazio (\%) & 0,97 & 0,494 \\
\hline Grãos subangulares (\%) & 0,98 & 0,820 \\
\hline Grãos subarredondados (\%) & 0,98 & 0,936 \\
\hline Grãos arredondados (\%) & 0,96 & 0,381 \\
\hline Razão eixo menor/eixo maior & 0,97 & 0,729 \\
\hline Arcabouço (\%) & 0,95 & 0,172 \\
\hline Cimento (\%) & 0,95 & 0,168 \\
\hline Feldspato (\%) & 0,98 & 0,929 \\
\hline$F(\%)$ & 0,95 & 0,205 \\
\hline Esmectita (\%) & 0,98 & 0,883 \\
\hline Oxi-hidróxido metálico (\%) & 0,97 & 0,555 \\
\hline$\sigma_{50}(\mathrm{MPa})$ & 0,95 & 0,056 \\
\hline $\mathrm{E}_{\mathrm{s}}(\mathrm{GPa})$ & 0,90 & 0,016 \\
\hline
\end{tabular}

APÊNDICE F - Tabela 2 - Teste de normalidade de Shapiro-Wilk para profundidade por petrofácies. $p<0,05$ indica que os dados não se distribuem normalmente.

\begin{tabular}{ccc}
\hline Variável & W & $\boldsymbol{p}$ \\
\hline Profundidade $(\mathrm{m})$ & 0,96 & 0,470 \\
\hline
\end{tabular}


APÊNDICE F - Tabela 3 - Teste de homocedasticidade de Levene, por grau de coerência (centro = mediana). GLT e GLR referem-se a graus de liberdade dos tratamentos e resíduos, respectivamente. $p<0,05$ indica heterocedasticidade.

\begin{tabular}{|c|c|c|c|c|}
\hline Variável & GLT & GLR & $\mathbf{F}$ & $p$ \\
\hline Profundidade $(\mathrm{m})$ & 4 & 22 & 0,77 & 0,554 \\
\hline Tamanho médio $(\varphi)$ petrografia & 4 & 22 & 0,56 & 0,695 \\
\hline Tamanho médio $(\varphi)$ Malvern & 4 & 22 & 0,40 & 0,805 \\
\hline Desvio padrão $(\varphi)$ petrografia & 4 & 22 & 1,45 & 0,251 \\
\hline Desvio padrão $(\varphi)$ Malvern & 4 & 22 & 0,62 & 0,652 \\
\hline Teor de pelíticos (\% em peso) & 4 & 22 & 0,84 & 0,512 \\
\hline Porosidade LAS (\%) & 4 & 22 & 0,34 & 0,851 \\
\hline Porosidade intragranular (\%) & 4 & 22 & 1,890 & 0,148 \\
\hline$\rho_{\mathrm{a}}\left(\mathrm{g} / \mathrm{cm}^{3}\right)$ & 4 & 19 & 1,01 & 0,427 \\
\hline$\eta_{a}\left(g / \mathrm{cm}^{3}\right)$ & 4 & 19 & 1,70 & 0,191 \\
\hline$P_{d}$ & 4 & 22 & 0,91 & 0,474 \\
\hline$P_{p}$ & 4 & 22 & 0,90 & 0,479 \\
\hline Contatos tangenciais (\%) & 4 & 22 & 0,23 & 0,919 \\
\hline Contatos retos $(\%)$ & 4 & 22 & 1,01 & 0,424 \\
\hline Contatos côncavo-convexos (\%) & 4 & 22 & 0,58 & 0,679 \\
\hline Contatos grão-cimento (\%) & 4 & 22 & 0,81 & 0,532 \\
\hline Contatos grão-vazio (\%) & 4 & 22 & 0,67 & 0,622 \\
\hline Grãos subangulares (\%) & 4 & 22 & 0,31 & 0,868 \\
\hline Grãos subarredondados (\%) & 4 & 22 & 2,96 & 0,043 \\
\hline Grãos arredondados (\%) & 4 & 22 & 1,80 & 0,165 \\
\hline Razão eixo menor/eixo maior & 4 & 22 & 1,02 & 0,417 \\
\hline Arcabouço (\%) & 4 & 22 & 1,48 & 0,241 \\
\hline Cimento (\%) & 4 & 22 & 0,89 & 0,489 \\
\hline Feldspato (\%) & 4 & 22 & 0,94 & 0,461 \\
\hline$F(\%)$ & 4 & 22 & 0,17 & 0,949 \\
\hline Esmectita (\%) & 4 & 22 & 0,25 & 0,907 \\
\hline Oxi-hidróxido metálico (\%) & 4 & 22 & 1,93 & 0,142 \\
\hline$\sigma_{50}(\mathrm{Mpa})$ & 2 & 36 & 1,40 & 0,260 \\
\hline$E_{s}(G P a)$ & 2 & 24 & 2,97 & 0,070 \\
\hline
\end{tabular}

APÊNDICE F - Tabela 4 - Teste de homocedasticidade de Levene para profundidade, por petrofácies (centro = mediana). GLT e GLR referem-se a graus de liberdade dos tratamentos e resíduos, respectivamente. $p<0,05$ indica heterocedasticidade.

\begin{tabular}{ccccc}
\hline Variável & GLT & GLR & F & $\boldsymbol{p}$ \\
\hline Profundidade $(m)$ & 4 & 22 & 1,64 & 0,200 \\
\hline
\end{tabular}


APÊNDICE F - Tabela 5 - ANOVA por grau de coerência. GL: graus de liberdade; T: tratamentos; R: resíduos; $\mathrm{SQ}$ : soma de quadrados; $\mathrm{QM}$ : quadrado médio. $p<0,05$, indica que pelo menos um grau de coerência exibe valores significativamente diferentes.

\begin{tabular}{|c|c|c|c|c|c|c|}
\hline Variável & & GL & SQ & QM & $\mathbf{F}$ & $p$ \\
\hline \multirow{2}{*}{ Profundidade $(\mathrm{m})$} & $T$ & 4 & 626,5 & 156,62 & 6 & 0,003 \\
\hline & $\mathrm{R}$ & 22 & 623,8 & 28,35 & & \\
\hline \multirow{2}{*}{$\begin{array}{c}\text { Tamanho médio }(\varphi) \\
\text { petrografia }\end{array}$} & $\mathrm{T}$ & 4 & 1.068 & 0,2671 & 1 & 0,422 \\
\hline & $\mathrm{R}$ & 22 & 5.800 & 0,2636 & & \\
\hline \multirow{2}{*}{ Tamanho médio $(\varphi)$ Malvern } & $\mathrm{T}$ & 4 & 0,478 & 0,1195 & 0,726 & 0,584 \\
\hline & $\mathrm{R}$ & 22 & 4 & 0,1646 & & \\
\hline \multirow{2}{*}{ Desvio padrão $(\varphi)$ petrografia } & $\mathrm{T}$ & 4 & 0,03861 & 0,009652 & 1,5 & 0,236 \\
\hline & $\mathrm{R}$ & 22 & 0,14153 & 0,006433 & & \\
\hline \multirow{2}{*}{ Desvio padrão $(\varphi)$ Malvern } & $\mathrm{T}$ & 4 & 0,06043 & 0,01511 & 1.285 & 0,306 \\
\hline & $\mathrm{R}$ & 22 & 0,25869 & 0,01176 & & \\
\hline \multirow{2}{*}{ Porosidade LAS (\%) } & $\mathrm{T}$ & 4 & 38,7 & 10 & 0,327 & 0,857 \\
\hline & $\mathrm{R}$ & 22 & 651,8 & 30 & & \\
\hline \multirow{2}{*}{$\rho_{a}\left(g / \mathrm{cm}^{3}\right)$} & $\mathrm{T}$ & 4 & 0,03625 & 0,009063 & 0,896 & 0,486 \\
\hline & $\mathrm{R}$ & 19 & 0,19214 & 0,010113 & & \\
\hline \multirow{2}{*}{$\eta_{a}\left(\mathrm{~g} / \mathrm{cm}^{3}\right)$} & $\mathrm{T}$ & 4 & 65,15 & 16,29 & 1,348 & 0,289 \\
\hline & $\mathrm{R}$ & 19 & 229,52 & 12,08 & & \\
\hline \multirow{2}{*}{$P_{d}$} & $\mathrm{~T}$ & 4 & 135,3 & 33,82 & 1 & 0,298 \\
\hline & $\mathrm{R}$ & 22 & 569,2 & 25,87 & & \\
\hline \multirow{2}{*}{$P_{p}$} & $\mathrm{~T}$ & 4 & 108,5 & 27,12 & 0,809 & 0,533 \\
\hline & $\mathrm{R}$ & 22 & 737,8 & 33,54 & & \\
\hline \multirow{2}{*}{ Contatos tangenciais (\%) } & $\mathrm{T}$ & 4 & 0,007483 & 0,0018706 & 2,281 & 0,093 \\
\hline & $\mathrm{R}$ & 22 & 0,018046 & 0,0008203 & & \\
\hline \multirow{2}{*}{ Contatos retos (\%) } & $\mathrm{T}$ & 4 & 0,009999 & 0,0025 & 2,396 & 0,081 \\
\hline & $\mathrm{R}$ & 22 & 0,022948 & 0,001043 & & \\
\hline \multirow{2}{*}{ Contatos grão-cimento (\%) } & $\mathrm{T}$ & 4 & 0,1116 & 0,02791 & 0,729 & 0,582 \\
\hline & $\mathrm{R}$ & 22 & 0,8422 & 0,03828 & & \\
\hline \multirow{2}{*}{ Contatos grão-vazio (\%) } & $T$ & 4 & 0,1862 & 0,04655 & 1,648 & 0,198 \\
\hline & $\mathrm{R}$ & 22 & 0,6215 & 0,02825 & & \\
\hline \multirow{2}{*}{ Grãos subangulares (\%) } & $\mathrm{T}$ & 4 & 444,4 & 111,1 & 2,71 & 0,057 \\
\hline & $\mathrm{R}$ & 22 & 902,1 & 41 & & \\
\hline \multirow{2}{*}{ Grãos arredondados (\%) } & $\mathrm{T}$ & 4 & 308 & 77 & 1,437 & 0,255 \\
\hline & $\mathrm{R}$ & 22 & 1179 & 53,59 & & \\
\hline \multirow{2}{*}{ Razão eixo menor/eixo maior } & $\mathrm{T}$ & 4 & 0,003289 & 0,0008222 & 3,115 & 0,036 \\
\hline & $\mathrm{R}$ & 22 & 0,005807 & 0,000264 & & \\
\hline \multirow{2}{*}{ Arcabouço (\%) } & $\mathrm{T}$ & 4 & 98,1 & 24,53 & 0,437 & 0,780 \\
\hline & $\mathrm{R}$ & 22 & 1234,2 & 56,1 & & \\
\hline \multirow{2}{*}{ Cimento (\%) } & $\mathrm{T}$ & 4 & 269,2 & 67,29 & 0,491 & 0,743 \\
\hline & $\mathrm{R}$ & 22 & 3017,8 & 137,17 & & \\
\hline \multirow{2}{*}{ Feldspato (\%) } & $\mathrm{T}$ & 4 & 10,93 & 2,7328 & 2,875 & 0,047 \\
\hline & $\mathrm{R}$ & 22 & 20,91 & 0,9504 & & \\
\hline \multirow{2}{*}{$F(\%)$} & $\mathrm{T}$ & 4 & 23,97 & 5,993 & 2,907 & 0,045 \\
\hline & $\mathrm{R}$ & 22 & 45,35 & 2,061 & & \\
\hline Fsmectita (\%) & $\mathrm{T}$ & 4 & 428,3 & 107,1 & 2,051 & 0,122 \\
\hline Esmecuta (\%) & $\mathrm{R}$ & 22 & 1148,4 & 52,2 & & \\
\hline Oxi-hidróxidn metálico (\%) & $\mathrm{T}$ & 4 & 9,443 & 2,361 & 1,672 & 0,192 \\
\hline UXI-niaroxiao metallco (\%) & $\mathrm{R}$ & 22 & 31,067 & 1,412 & & \\
\hline & $\mathrm{T}$ & 2 & 6,01 & 3,005 & 1,91 & 0,163 \\
\hline$\sigma_{50}(\mathrm{Mpa})$ & $\mathrm{R}$ & 36 & 56,64 & 1,573 & & \\
\hline
\end{tabular}


APÊNDICE F - Tabela 6 - ANOVA da profundidade por petrofácies. GL: graus de liberdade; T: tratamentos; R: resíduos; SQ: soma de quadrados; QM: quadrado médio. $p<0,05$ indica que pelo menos uma das petrofácies exibe valores significativamente diferentes.

\begin{tabular}{ccccccc}
\hline Variável & & GL & SQ & QM & F & $\boldsymbol{p}$ \\
\hline \multirow{2}{*}{ Profundidade $(\mathrm{m})$} & $\mathrm{T}$ & 4 & 812,1 & 203,02 & 10,19 & $\mathbf{0 , 0 0 0}$ \\
& $\mathrm{R}$ & 22 & 438,2 & 19,92 & & \\
\hline
\end{tabular}

APÊNDICE F - Tabela 7 - Testes de Kruskal-Wallis, por grau de coerência. GL: graus de liberdade. $p$ $<0,05$ indica que pelo menos um grau de coerência exibe valores significativamente diferentes.

\begin{tabular}{lccc}
\hline \multicolumn{1}{c}{ Variável } & Qui-quadrado & GL & $\boldsymbol{p}$ \\
\hline Subarredondados (\%) & 0,98 & 4 & 0,913 \\
Teor de pelíticos (\% em peso) & 2,94 & 4 & 0,569 \\
Porosidade intragranular (\%) & 3,51 & 4 & 0,476 \\
Contatos côncavo-convexos & 3,02 & 4 & 0,554 \\
Coerência vs $\mathrm{E}_{\mathrm{s}}$ & 6,30 & 2 & $\mathbf{0 , 0 4 3}$ \\
\hline
\end{tabular}

